
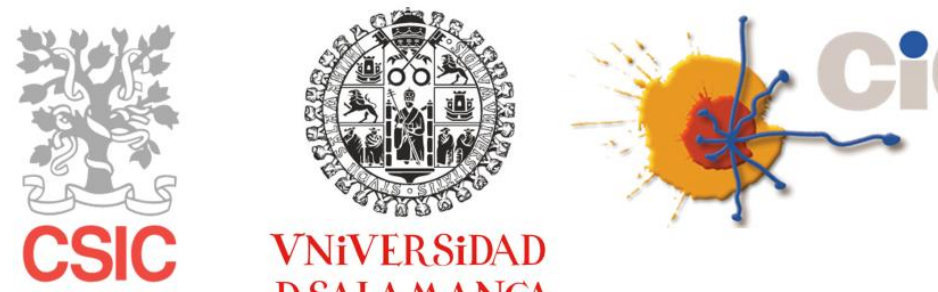

VNIVERSIDAD

DSALAMANCA

INSTITUTO DE BIOLOGÍA MOLECULAR Y CELULAR DEL CÁNCER / CENTRO DE INVESTIGACIÓN DEL CÁNCER

Inhibición de las rutas de ubiquitinación de proteínas dependientes de complejos Cullin-RING Ligasa en Sarcoma de Ewing: Validación preclínica y caracterización de mecanismos moleculares

TESIS DOCTORAL

Daniel José García Domínguez

Salamanca, Julio de 2013 
D. ENRIQUE DE ÁlAVA CASADO, Doctor en Medicina y Cirugía y Jefe de Servicio de Anatomía Patológica, Hospital Universitario Virgen del Rocío/Instituto de Biomedicina de Sevilla,

\section{CERTIFICA:}

Que el trabajo realizado bajo mi dirección por el licenciado en Biología DANIEL JOSÉ GARCÍA DOMÍNGUEZ titulado “Inhibición de las rutas de ubiquitinación de proteínas dependientes de complejos Cullin-RING Ligasa en Sarcoma de Ewing: Validación preclínica y caracterización de mecanismos moleculares", reúne las condiciones de originalidad y contenido requeridas para ser presentado ante el tribunal correspondiente y optar al grado de doctor por la Universidad de Salamanca.

Y para que conste a los efectos oportunos, expido y firmo el presente certificado mediante el cual autorizo la presentación de dicha tesis.

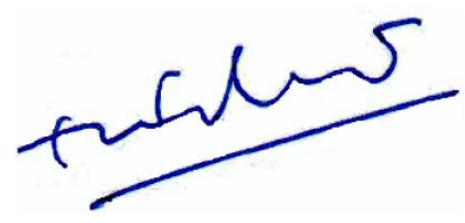

Fdo. Dr. Enrique de Álava Casado 
D. CARLOS JESÚS MACKINTOSH GINEL, Doctor en Biología e Investigador Posdoctoral en la Universidad de California (UCSD), San Diego,

\section{CERTIFICA:}

Que el trabajo realizado bajo mi co-dirección por el licenciado en Biología DANIEL JOSÉ GARCÍA DOMÍNGUEZ titulado “Inhibición de las rutas de ubiquitinación de proteínas dependientes de complejos Cullin-RING Ligasa en Sarcoma de Ewing: Validación preclínica y caracterización de mecanismos moleculares", reúne las condiciones de originalidad y contenido requeridas para ser presentado ante el tribunal correspondiente y optar al grado de doctor por la Universidad de Salamanca.

Y para que conste a los efectos oportunos, expido y firmo el presente certificado mediante el cual autorizo la presentación de dicha tesis.

Salamanca, a 04 de Julio de 2013.

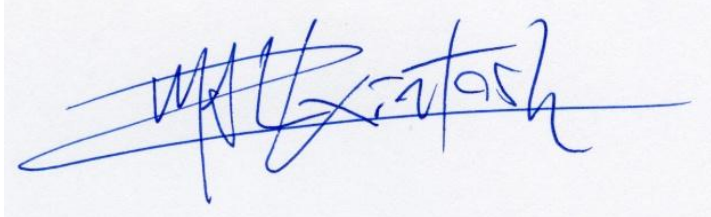

Fdo. Dr. Carlos Jesús Mackintosh Ginel 
Dra. ROCío I. RODRÍGUEZ MACÍAS, Doctora en Farmacia y Profesora Titular del Departamento de Fisiología y Farmacología, Universidad de Salamanca,

\section{CERTIFICA:}

Que el trabajo realizado bajo mi tutoría por el licenciado en Biología DANIEL JOSÉ GARCÍA DOMÍNGUEZ titulado “Inhibición de las rutas de ubiquitinación de proteínas dependientes de complejos Cullin-RING Ligasa en Sarcoma de Ewing: Validación preclínica y caracterización de mecanismos moleculares", reúne las condiciones de originalidad y contenido requeridas para ser presentado ante el tribunal correspondiente y optar al grado de doctor por la Universidad de Salamanca.

Y para que conste a los efectos oportunos, expido y firmo el presente certificado mediante el cual autorizo la presentación de dicha tesis.

Salamanca, a 04 de Julio de 2013.

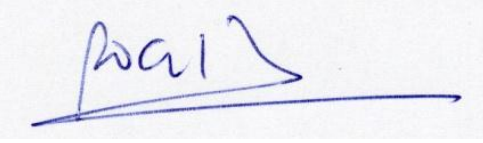

Fdo. Dra. Rocío I. Rodríguez Macías 
Este proyecto de tesis ha sido financiado por:

- La Fundación María García Estrada

- La Red de Excelencia de la Comunidad Europea EUROBONET, con el Proyecto Europeo "Molecular Pathology of Bone Tumors" (FP6-2004-Lifescihealth-5, 018814).

- European Clinical trials in Rare Sarcomas within an integrated translational trial network (EUROSARC) FP7-HEALTH-2011-two-stage, Project ID 278742 Comisión Europea. 2012-201

- El Ministerio de Ciencia e Innovación, a través del Instituto de Salud Carlos III (RD12/0036/0017, RD06/0020/0059, PI1203102, PI1100018

PI081828, PI052524) 


\section{TABLA DE CONTENIDOS}

1. INTRODUCCIÓN

1.1 SARCOMA DE EWING 3

1.1.1 La fusión quimérica EWSR1-FLI1 y otras alteraciones citogenéticas en SE $\quad 4$

1.1.1.1 Funciones nativas de los genes implicados $\quad 5$ EWSR1 FLI1 6

$\begin{array}{ll}\text { 1.1.1.2 EWSR1-FLI1 } & 6\end{array}$

1.1.1.3 Otras alteraciones citogenéticas en SE $\quad 8$

$\begin{array}{ll}\text { 1.1.2 Origen celular } & 9\end{array}$

$\begin{array}{ll}\text { 1.1.3 Presentación clínica } & 10\end{array}$

1.1.4 Histología $\quad 11$

$\begin{array}{ll}\text { 1.1.5 Factores con valor pronóstico } & 13\end{array}$

$\begin{array}{ll}\text { 1.1.6 Tratamiento } & 15\end{array}$

1.2 CICLO CELULAR: EN CÉLULAS EUCARIOTAS 19

1.2.1 Regulación del ciclo celular: Checkpoints 19

$\begin{array}{ll}\text { 1.2.2 Proteínas CDK } & 20\end{array}$

1.2.2.1 Reguladores CDKs: Ciclinas y CIKs $\quad 21$

Ciclinas $\quad 21$

Proteínas inhibidoras de CDKs (CKIs)

1.2.3 Regulación en la entrada y salida de Mitosis $\quad 22$

1.2.3.1 Regulación de la entrada en Mitosis $\quad 22$

Regulación de la entrada en mitosis por los complejos CDK 22

Regulación de la entrada en mitosis por otras quinasas

1.2.3.2 Regulación de la salida de Mitosis $\quad 26$

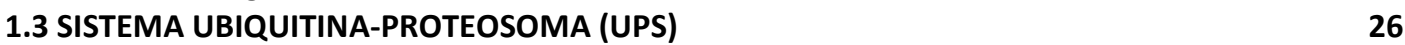

1.3.1 Complejos Ubiquitina Ligasas $\quad 26$

1.3.1.1 Clasificación de las Ubiquitina Ligasas E3 28

1.3.2 Principales complejos con dominio RING-finger: SCF Y APC/C 30

$\begin{array}{ll}\text { 1.3.2.1 SCF } & 30\end{array}$

1.3.2.2 APC/C 30

1.3.3 Regulación de los complejos Cullin Ring Ligasas (CRL) 32

$\begin{array}{ll}\text { 1.3.4 Proteosoma 26S } & 34\end{array}$

$\begin{array}{ll}\text { 1.3.4.1 Inhibidores del proteosoma } & 35\end{array}$

2. HIPÓTESIS Y OBJETIVOS

2.1 HIPÓTESIS

2.2 OBJETIVOS

$\begin{array}{ll}\text { 2.2.1 Objetivos específicos } & 39\end{array}$

3. MATERIAL Y MÉTODOS

3.1. LÍNEAS CELULARES

3.2 FÁRMACOS

3.3 ENSAYOS DE PROLIFERACIÓN

$\begin{array}{ll}\text { 3.3.1 MTT } & 44\end{array}$

3.3.2 ATPlite $^{\text {TM }}$ LUMINESCENCE ASSAY SYSTEM $\quad 45$

3.3.3 Cálculo de ICs de fármacos $\quad 45$

3.3.4 Cálculo del índice de combinación entre dos fármacos: MLN4924 y DXR 46

3.4 ESTUDIOS IN VIVO: XENOTRASPLANTES EN RATÓN 46

3.4.1 Procesamiento de muestras tumorales del ensayo in vivo para estudios 47

histopatológicos

3.4.1.1 Análisis de muestras histopatológicas $\quad 48$

3.5 CITOMETRÍA DE FLUJO

3.5.1 Análisis de ciclo celular por citometría de flujo 49

3.5.2 Análisis de muerte celular por citometría de flujo: Cleaved Caspase $3 \quad 50$ 
3.5.3 Análisis de ciclo celular con discriminación de mitosis: Fosforilación S10 de Histona $\mathrm{H3}$

3.5.4 Análisis de ciclo celular de fase $S$

3.6 EXTRACCIÓN DE PROTEÍNAS Y WESTERN BLOT

3.6.1 WB en condiciones no "denedilantes": OPT

3.7 SINCRONIZACIÓN DE CULTIVOS CELULARES

3.7.1 Protocolo de doble sincronización con nocodazol: sincronización en mitosis temprana

3.7.2 Protocolo de sincronización con timidina: Sincronización en la transición G1/S

3.8 INMUNOFLUORESCENCIA DE CÉLULAS CRECIDAS SOBRE PLACAS DE CULTIVO DE 35mm DE DIÁMETRO

3.9 TRANSDUCCIÓN LENTIVIRAL DE LÍNEAS CELULARES DE SE

3.11.1 Elementos del sistema "Retro-X-Tet-On Advanced" de Clontech

3.11.2 Establecimiento el sistema inducible en líneas celulares de SE

3.11.3 Evaluación de la transducción y actividad del vector transactivador del sistema inducible: ensayo luciferasa para selección de clones

3.11.4 Evaluación de la transducción del vector de respuesta y de la actividad del sistema

"Retro-X-Tet-On Advanced" estable en la línea celular diana: ensayo WB para selección de clones

3.12 TRANSDUCCIÓN RETROVIRAL DE LÍNEAS CELULARES DE SE

3.13 CLONAJE PARA LA SOBREEXPRESIÓN DE CDT1

3.13.1 Clonación de Ciclina A y Ciclina E en vectores de respuesta inducibles 79

3.14 ENSAYO DE LA FUNCIONALIDAD DEL CHECKPOINT DE G2/M POR DAÑO EN EL DNA: CAFEÍNA

3.15 ENSAYO DE SENESCENCIA

4.1.1 Estudio de combinación de los fármacos MLN4924 y Doxorrubicina

4.2 EVALUACIÓN DE LA EFICACIA DE MLN4924 IN VIVO MEDIANTE XENOINJERTOS EN RATONES CB17/SCID

4.2.1 Alteración de la piel

4.2.2 Estudio histopatológico

4.3 CARACTERIZACIÓN DEL PAPEL DEL FÁRMACO EN LA PROGRESIÓN DEL CICLO CELULAR Y EN LA VIABILIDAD DE LAS LÍNEAS CELULARES DE SE TRATADAS CON MLN4924

4.3.1 Alteración de la progresión del ciclo celular por la aplicación de MLN4924

4.3.2 Estudio de apoptosis en líneas celulares de SE tratadas con MLN4924

4.3.3 Evaluación de daño en el DNA por la aplicación de MLN4924

4.3.4 Estudio de senescencia

4.4 DETERMINACIÓN DE LAS DIANAS DIRECTAS DEL FÁRMACO MLN4924

4.4.1 Sobreexpresión de CDT1

4.4.2 Determinación de dianas directas de los complejos CRL acumuladas tras el tratamiento con el fármaco MLN4924 en líneas celulares de SE

4.5 IDENTIFICACIÓN DE MECANISMOS MOLECULARES DE RESPUESTA AL FÁRMACO MLN4924 EN LÍNEAS CELULARES DE SE

4.5.1 Mecanismo molecular causante del retraso en la progresión G2/M

4.5.1.1 Sincronización en mitosis temprana

4.5.1.2 Evaluación de p27 como posible inductor del retraso en la transición G2/M en líneas celulares de SE tratadas con concentraciones medias (hasta IC $\mathrm{C}_{75}$ ) de MLN4924

4.5.1.3 Retraso en la transición G2/M inducido por MLN4924 y el checkpoint de daño en el DNA 
células de SE tratadas con concentraciones intermedias (hasta IC $\mathrm{C}_{75}$ ) de MLN4924

Rescate de la transición G2/M mediante inhibición de la actividad de WEE1

Rescate de la transición G2/M mediante el silenciamiento de la expresión de WEE1

4.5.2 Mecanismo molecular causante del retraso en fase $S$

4.5.2.1 Efecto fisiológico-molecular del posible desplazamiento de Ciclina A por Ciclina E en la unión a CDK2 a altas dosis del fármaco $\left(\geq I_{95}\right)$ MLN4924 en líneas celulares de SE

4.5.2.2 Sobreexpresión de Ciclina E en líneas celulares de SE

4.5.2.3 Intento de rescate del retraso en fase S provocado por MLN4924 (IC 95 ) mediante la sobreexpresión inducible de Ciclina A

5.1 LAS LÍNEAS CELULARES DE SE SON ALTAMENTE SENSIBLES AL FÁRMACO MLN4924 135

5.2 AUSENCIA DE DIFERENCIA DE RESPUESTA A MLN4924 ENTRE LÍNEAS CELULARES DE SE CON 1qG Y 1qN

5.3 SENSIBILIDAD AL FÁRMACO MLN4924 DE LAS CÉLULAS DE SE IN VIVO, MEDIANTE EL EMPLEO DE XENOTRANSPLANTES EN RATONES CB17/SCID

5.4 MLN4924 PROVOCA ALTERACIÓN DUAL DOSIS-DEPENDIENTE DE LA PROGRESIÓN DEL CICLO CELULAR

5.5 MLN4924 INDUCE APOPTOSIS DOSIS-DEPENDIENTE EN LÍNEAS CELULARES DE SE

5.6.1 Propuesta de marcadores fármacodinámicos de MLN4924 en SE

5.7.1 Mecanismo molecular del retraso en $\mathbf{G 2}$

5.7.1.1 Evaluación de p27 como principal efector del retraso en G2 ejercido por MLN4924

5.7.1.2 Evaluación de daño al DNA como principal efector del retraso en G2 ejercido por MLN4924

5.7.1.3 Evaluación de WEE1 como principal efector del retraso en G2 en respuesta a MLN4924

5.7.2 Mecanismo molecular de retraso de fase $\mathbf{S}$ tardía

5.7.2.1 Evaluación de WEE1 como principal efector del retraso en fase $\mathrm{S}$ tardía ejercida por MLN4924

5.7.2.2 Evaluación de Ciclina E como principal efector del retraso en fase $\mathrm{S}$ tardía ejercida por MLN4924: alteración de la localización subcelular de CDC6

5.7.3 Acúmulo de CDC25A inactivo

5.8 MLN4924, UN FÁRMACO ALTAMENTE ESPECÍFICO QUE PROVOCA RESPUESTAS DISPARES

5.9 ENSAYOS CLÍNICOS CON EL FÁRMACO MLN4924 Y FUTURO DEL TRATAMIENTO CLÍNICO DE PACIENTES CON SE

"WEE1 accumulation and deregulation of S-phase proteins mediate MLN4924 potent inhibitory effect on Ewing sarcoma cells" 


\section{INDICE DE FIGURAS}

Figura 1: Localización del SE y distribución por edad y sexo

Figura 2: Esquema de la proteína de fusión EWSR1-FLI1 y tipos de fusiones EWSR1-FLI1 descritos

Figura 3: IHQ en Sarcoma de Ewing

Figura 4: Impacto del PGA, ganancia del brazo q del cromosoma 1 y la firma 1qGSig en la supervivencia total de los pacientes de SE

Figura 5: Ejemplo de SE localizado en el fémur y de tratamiento local quirúrgico

Figura 6: Actividad de los complejos CDK-Ciclina en las distintas fases del ciclo celular en células eucariotas.

Figura 7: Sistema Ubiquitina-Proteosoma (UPS)

Figura 8: El Sistema Ubiquitin-Proteosoma (UPS) regula el ciclo celular

Figura 9: Regulación de la actividad de los complejos CRL

Figura 10: Esquema montaje del "sandwich" para la trasferencia en WB

Figura 11: WB de CUL1 en condiciones no "denedilantes" en la línea celular de SE, RDES

Figura 12: Esquema del protocolo para ensayos de sincronización en mitosis temprana con nocodazol

Figura 13: Esquema del protocolo para ensayos de sincronización en la transición G1/S con timidina

Figura 14: Sistema de expresión inducible Retro-XTM Tet-On Advanced de Clontech

Figura 15: Electroforesis en gel agarosa al 1\% en TAE de (1) pOTB7-CDT1 (EcoRI+Xhol+Clal) y (2) pBABEpuro (EcoRI+Sall)

Figura 16: Electroforesis de clones preseleccionados pBABEpuro-CDT1

Figura 18: Relación entre la IC50 de las líneas celulares de SE frente al fármaco MLN4924 y el número de copia del brazo " $q$ " del cromosoma 1 (1qN vs. 1qG)

Figura 19: Combinación de los fármacos MLN4924 y Doxorrubicina en líneas celulares de SE, RDES y RM82

Figura 20: Ensayo in vivo del fármaco MLN4924 con xenoinjertos a partir de líneas celulares de SE

Figura 21: Progresión del desarrollo tumoral en estudios in vivo en ratones CB17/SCID tratados con el fármaco MLN4924

Figura 22: Progresión del desarrollo tumoral en estudios in vivo en ratones CB17/SCID tratados con el fármaco MLN4924

Figura 23: Preparaciones de H\&E de cortes histológicos de piel de ratones utilizados en el ensayo in vivo con el fármaco MLN4924

Figura 24: Preparaciones de H\&E de tumores del ensayo in vivo del fármaco MLN4924 con la línea celular RDES

Figura 25: Estudio de citometría de flujo mediante marcaje de DNA con ioduro de propidio en líneas celulares de SE tratadas con MLN4924

Figura 26: Porcentaje de células positivas para Caspasa 3 procesada en líneas celulares de SE tratadas durante $48 \mathrm{~h}$ con MLN4924

Figura 27: Diagrama donde se representa el marcaje DNA (IP) en el eje $Y$ frente al marcaje de apoptosis (Caspasa 3 procesada) en el eje $\mathrm{X}$, de la línea celular RDES tratada con el fármaco MLN4924

Figura 28: Inmunofluorescencia anti $\mathrm{\gamma}-\mathrm{H} 2 \mathrm{AX}$ (daño en el DNA) en línea celular RDES de SE tratada con el fármaco MLN4924

Figura 29: Estudio de senescencia en las líneas celulares de SE, RDES y RM82 tratadas con el fármaco MLN924

Figura 30: Estudio de inhibición de la nedilación de culinas con el fármaco MLN4924 en líneas celulares de SE y colorrectal

Figura 31: Estudio de los niveles proteicos de las dianas de los complejos CRL en respuesta a MLN4924 en células de SE

Figura 32: Histogramas de contenido en DNA (marcaje con ioduro de propidio) en el ensayo de sincronización en mitosis en la línea celular de SE RDES, con y sin tratamiento con el fármaco MLN4924 
Figura 33: WB de extractos proteicos del ensayo de sincronización en mitosis y tratamiento con MLN4924 (IC75) en células RDES

Figura 34: Ensayo de inhibición de p27 mediante shRNA en células RDES tratadas con el fármaco MLN4924 ( $\approx$ IC75)

Figura 35: Inmunofluorescencia de células RDES tratadas con MLN4924 y marcaje de la proteína p27

Figura 36: Ensayo de rescate del retraso en la transición G2/M utilizando cafeína (20mM) en la línea celular RDES tratada con el fármaco MLN4924

Figura 37: Esquema de empleo secuencial de fármacos en ensayos de rescate del retraso en la transición G2/M provocado por MLN4924 en líneas celulares de SE mediante la inhibición de la actividad de WEE1 aplicando el fármaco PD0166285

Figura 38: WB del tratamiento de la línea RDES con los fármacos MLN4924 y PD0166285

Figura 39: Rescate del retraso en la transición G2/M inducido por el fármaco MLN4924 mediante la inhibición de la actividad de WEE1 con el fármaco PD0166285 en la línea celular RDES

Figura 40: Análisis de ciclo celular con discriminación de mitosis en células RDES tratadas con MLN4924 y rescate con PD0166285

Figura 41: WB del tratamiento de la línea celular RDES con el fármaco MLN4924 (IC75) en condiciones de silenciamiento de WEE1 mediante shRNA

Figura 42: Histogramas de marcaje de DNA con ioduro de propidio en células RDES tratadas con MLN4924, en el estudio de rescate mediante el silenciamiento de WEE1 con shRNAs

Figura 43: Estudio de proliferación/apoptosis en células RDES tratadas con MLN4924 y transducidas con shRNAs-WEE1/NTC

Figura 44: Mecanismo de acción de MLN4924 en RM82 y rescate mediante la inhibición o el silenciamiento de WEE1

Figura 45: Sincronización en la transición G1/S, liberación y seguimiento del progreso del ciclo en células RDES tratadas con MLN4924 (IC95) frente al control (DMSO)

Figura 46: Disminución de la incorporación de BrdU a 12h tras la liberación de la timidina de las células tratadas con MLN4924 (IC95) con respecto a células control (DMSO)

Figura 47: WB de extractos proteicos del ensayo de sincronización en la transición G1/S y tratamiento con MLN4924 (IC95) en células RDES

Figura 48: Inmunoprecipitación de CDK2 en células RDES tratadas con el fármaco MLN4924 (IC95) sincronizadas con timidina

Figura 49: Estudio de localización subcelular de CDC6 mediante inmunofluorescencia en células RDES tratadas con MLN4924 (IC95) sincronizadas con timidina

Figura 50: Ensayo de sobreexpresión inducible de Ciclina E en células RDES

Figura 51: Selección y evaluación del sistema de sobreexpresión inducible de Ciclina A en células RDES para revertir el retraso en fase S provocado por el tratamiento MLN4924 (IC95)

Figura 52: Resultados del ensayo in vivo de silenciamiento de CDT2 en líneas celulares de SE inoculadas a ratones inmunodeprimidos NOD/SCID

Figura 53: Perfiles de citometría de flujo con marcaje de DNA mediante IP en células HCT116 tratadas con UBA3 siRNA o con $0.3 \mu \mathrm{M}$ de MLN4924

Figura 54: Retraso en G2 en líneas celulares de SE tratadas con MLN4924 ( $\leq$ IC75)

Figura 55: Retraso en G2 en líneas celulares de SE tratadas con MLN4924 (sIC75) y silenciamiento de p27

Figura 56: Rescate del retraso en G2 en líneas celulares de SE tratadas con MLN4924 ( $\leq$ IC75) mediante el silenciamiento o inhibición de WEE1

Figura 57: Retraso en fase S tardía en líneas celulares de SE tratadas con MLN4924 ( $\geq$ IC95)

Figura 58: MLN4924 es un inhibidor potente y altamente selectivo de la enzima NAE

Figura 59: Esquema de diferentes respuestas moleculares al fármaco MLN4924 descritas en estudios preclínicos de diversas neoplasias 


\section{INDICE DE TABLAS}

Tabla 1: Frecuencia de las fusiones génicas más comunes en SE $\quad \mathbf{5}$

Tabla 2: Clasificación de las Ubiquitina Ligasas E3 $\quad 29$

Tabla 3: Procedimiento de inclusión de muestras tumorales en parafina $\quad 48$

Tabla 4: Procedimiento de tinción de muestras tumorales con H\&E $\quad 49$

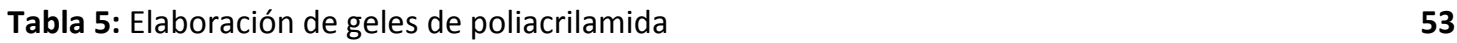

Tabla 6: Anticuerpos primarios utilizados en WB $\quad \mathbf{5 5}$

Tabla 7: Anticuerpos utilizados para Inmunofluorescencia sobre placas de 35mm de diámetro $\quad 63$

Tabla 8: Construcciones shRNA frente a los transcritos de los genes $p 27$ y WEE1 64

Tabla 9: Cebadores diseñados para la secuenciación de clones pBABEpuro-CDT1 78

Tabla 10: Tabla de referencias $\quad 82$

Tabla 11: Taba de anticuerpos $\quad \mathbf{8 4}$

Tabla 12: Valores de IC50 de seis líneas celulares de SE tratadas durante 72h con los fármacos 89 DXR o VCR

Tabla 13: Valores de $I C_{s}$ de 14 líneas celulares de SE tratadas durante $72 \mathrm{~h}$ con el fármaco MLN4924

Tabla 14: Valores de índice de combinación entre los fármacos DXR y MLN4924 en las líneas celulares de SE, RDES y RM82

Tabla 15: Resumen bibliográfico de ensayos preclínicos con MLN4924 en líneas celulares de diversas neoplasias. 


\section{INTRODUCCIÓN}




\subsection{SARCOMA DE EWING}

El Sarcoma de Ewing (SE) es una entidad neoplásica con diversas presentaciones clínicas localizadas en hueso, tejidos blandos y, menos frecuentemente, en localizaciones viscerales, que afecta fundamentalmente a niños y adultos jóvenes. La clasificación de estas presentaciones clínicas ha variado a lo largo del tiempo de acuerdo a los avances en investigación y estudios clínicos y patológicos.

Hasta hace poco, el SE óseo era considerado como la principal neoplasia dentro de un conjunto mayor de tumores denominados Tumores de la Familia del Sarcoma de Ewing (ESFT). Esta familia englobaba a un grupo de presentaciones clínicas con rasgos morfológicos e histológicos diversos, que fueron definidos originalmente como neoplasias diferentes: tumor de Askin, tumor neuroectodérmico primitivo periférico (PNET), sarcoma de Ewing extraesquelético y el propio SE óseo. Éste último era el grupo más representativo, con el $60 \%$ del total de los sarcomas de esta familia ${ }^{1}$. Posteriormente, a la luz de los descubrimientos en el campo de la biología molecular de los diferentes tumores, la clasificación de la OMS 2013 de los tumores mesenquimales recoge esta neoplasia como una única entidad clínico-patológica: Sarcoma de Ewing. El proceso de descubrimiento y clasificación ha sido el siguiente:

En 1918 se describió el caso de un tumor compuesto por células indiferenciadas, redondas localizado en el nervio cubital de un paciente, al que se le definió como tumor neuroectodérmico primitivo periférico o PNET de tejido blando ${ }^{2}$. Se caracterizó por células que se agrupaban en nidos y trabéculas formando rosetas variables con lumen central generalmente mal definido.

En 1921 un tumor primario de células pequeñas y redondas localizado en el hueso radial de una niña de 14 años fue definido como "endotelioma difuso de hueso". La designación de esta entidad quedó sin embargo vinculada al nombre de su descubridor, James Ewing, conociéndose a partir de ese momento como SE óseo.

En 1975 se describió el primer caso de SE extraesquelético ${ }^{3}$, desarrollado en un tejido blando.

En 1979 se definió el tumor de Askin ${ }^{4}$, con característicos histológicas similares al PNET, como un tumor maligno de células pequeñas de la región torácico pulmonar.

En 1984 se describe el primer PNET localizado en hueso, una vez más definido por células pequeñas y redondas, al que se le denominó PNET de hueso ${ }^{5}$.

En el mismo año, se identificó un evento a nivel molecular presente prácticamente en la totalidad de todas las entidades descritas anteriormente, la translocación cromosómica $\mathrm{t}(11 ; 22)(\mathrm{q} 24 ; \mathrm{q} 21)^{6-8}$. En 1992 se caracterizó el gen quimérico EWSR1-FLI1 derivado de la mencionada translocación ${ }^{9}$, tras lo cual se postuló el papel central que dicha alteración tiene en la oncogénesis de estos sarcomas. Ello permitió englobar a las anteriores entidades bajo la categoría de $\mathrm{ESFT}^{10}$, que abarcó un grupo de tumores con un espectro de diferenciación neuroectodérmica que fluctuó desde los casos más indiferenciados (SE) hasta los tumores con evidente diferenciación neuroectodérmica (PNET) ${ }^{11-12}$. 
Para ajustarnos a la clasificación actual de la OMS de tumores de hueso y partes blandas utilizaremos el término Sarcoma de Ewing (SE) para referirnos a todas las entidades descritas anteriormente.

Dado que el $90 \%$ de los casos aparece en pacientes cuya edad se sitúa entre los 5 y los 25 años, el SE es considerado un cáncer de niños o adultos jóvenes. La media de edad de los pacientes afectados por SE es de 15 años, comprendiendo alrededor del $4 \%$ del total de tumores de niños y adolescentes; es infrecuente en menores de 5 años y raro en mayores de $45^{11}$. La incidencia anual es de 1-3 casos por millón de habitantes en los países del hemisferio Norte, siendo el segundo sarcoma de hueso más frecuente en pacientes menores de 20 años $^{13}$. Se localiza fundamentalmente en las extremidades distales y proximales, pelvis, tórax, cabeza y cuello. La incidencia en varones es ligeramente superior, en una proporción 1.3-1.5:1 respecto a mujeres ${ }^{14}$ (Figura 1). Por grupos étnicos, la patología es más frecuente en caucásicos que en asiáticos, mientras que africanos y afro-americanos raramente la padecen ${ }^{15}$. Estas diferencias se mantienen constantes en cualquier área geográfica.
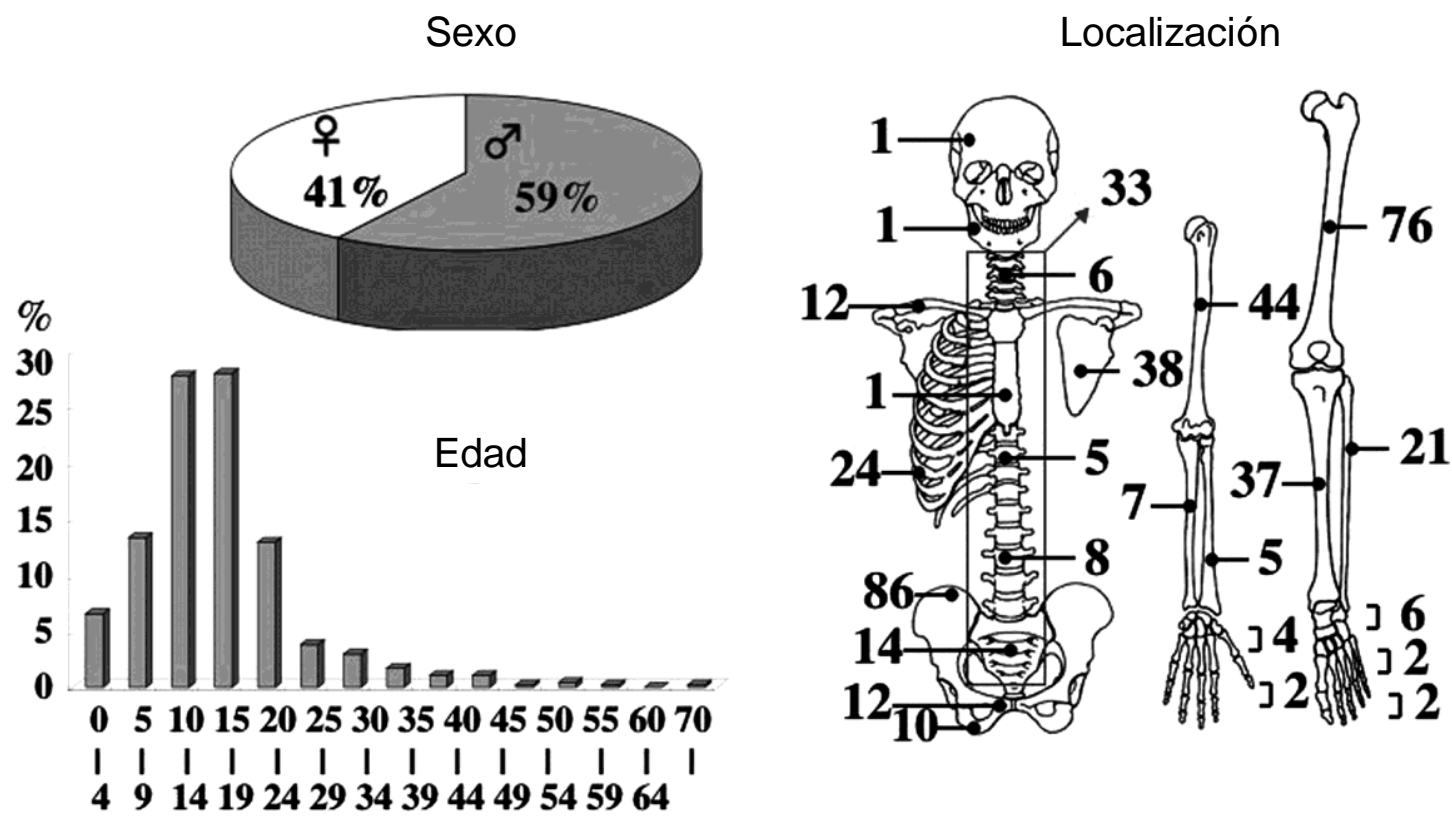

Figura 1: Localización del SE y distribución por edad y sexo. Adaptado de Iwamoto, Y. (2007). Diagnosis and treatment of Ewing's sarcoma. Jpn J Clin Oncol 37, 79-89) ${ }^{16}$.

\subsubsection{La fusión quimérica EWSR1-FLI1 y otras alteraciones citogenéticas en SE}

Estudios citogenéticos del SE han permitido detectar una alteración sistemática del locus del gen EWSR1 en la localización cromosómica 22 q12 que da lugar a la fusión del extremo Nterminal del gen EWSR1 con el término C-terminal de otro gen de la familia ETS. La combinación génica EWSR1-ETS claramente mayoritaria y más estudiada es la EWSR1-FLI1. Producto de la translocación $\mathrm{t}(11 ; 22)$ (q24;q12), supone el $85 \%$ de los casos e implica al gen FLI1 (11q24), un miembro de la familia de factores de transcripción ETS. Existen otras combinaciones génicas que involucran al gen EWSR1 y a otros genes de la familia ETS, pero su frecuencia es notablemente menor (por orden de frecuencia): $E R G$, ubicado en el cromosoma 
21; ETV1, ubicado en el cromosoma 7; E1AF, ubicado en el cromosoma 17 y FEV, ubicado en el

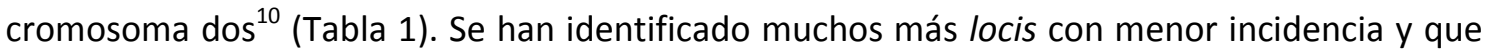
están recogidos en la clasificación de fusiones génicas en SE de la OMS.

\begin{tabular}{|ccc|}
\hline Translocación & Fusión Génica & Frecuencia \\
\hline $\mathrm{t}(11 ; 22)(q 24 ; q 12)$ & EWSR1-FLI1 & $85 \%$ \\
$\mathrm{t}(21 ; 22)(q 22 ; q 12)$ & EWSR1-ERG & $10 \%$ \\
$\mathrm{t}(7 ; 22)(\mathrm{p} 22 ; q 12)$ & EWSR1-ETV1 & $<5 \%$ \\
$\mathrm{t}(17 ; 22)(q 12 ; q 12)$ & EWSR1-E1AF & $<5 \%$ \\
\hline
\end{tabular}

Tabla 1: Frecuencia de las fusiones génicas más comunes en SE. Adaptado de Burchill, S. A. (2003). Ewing's sarcoma: diagnostic, prognostic, and therapeutic implications of molecular abnormalities. J Clin Pathol 56, 96-102).

Son muy raros los casos de SE con la fusión FUS-ERG, $\mathrm{t}(16 ; 21)(\mathrm{p} 11 ; \mathrm{q} 22)^{17}$, presente así mismo en algunas leucemias mieloides agudas. Este descubrimiento puso de manifiesto que los dominios de transactivación de los miembros de la familia TET, como EWSR1 y FUS, se pueden intercambiar.

\subsubsection{Funciones nativas de los genes implicados}

EWSR1

El gen EWSR1 consta de 18 exones distribuidos a lo largo de $40 \mathrm{~kb}$ y se localiza en el cromosoma 22q12.2. La proteína a la que da lugar está compuesta por 656 aminoácidos y posee un peso molecular de $68 \mathrm{kDa}^{18-19}$. La proteína codificada por el locus EWSR1 pertenece a la familia de proteínas TET, caracterizada por la presencia de un dominio carboxiterminal de 87 aminoácidos que comprende un número variable de repeticiones RGG (arginina-glicina-glicina) a través del cual es capaz de unirse a complejos RNA-proteínas ${ }^{20}$. Los siete primeros exones de EWSR1 codifican para la región aminoterminal en la que se sitúa el dominio RRM/RNP-CS, que consiste en la repetición de un polipéptido degenerado de entre 7 y 12 residuos ricos en tirosina, serina, tirosina, glicina y glutamina. Este dominio actúa como activador transcripcional siendo la tirosina el residuo clave ${ }^{21-22}$. La expresión de EWSR1 es ubicua y elevada, lo que hace pensar que es un gen de expresión constitutiva; además el alelo no involucrado en la translocación se expresa de manera normal en los tumores ${ }^{23}$. La localización habitual de la proteína es nuclear aunque su distribución subcelular puede verse alterada por diversos estímulos y por modificaciones post-traduccionales ${ }^{24}$.

Aunque las funciones de EWSR1 no son aún bien conocidas sus características estructurales y su capacidad de unión al RNA, junto con las conclusiones obtenidas de diversas experiencias realizadas, sugieren su participación en procesos de transcripción y procesamiento del RNA $^{20,25}$. La región perteneciente a EWSR1 involucrada en las fusiones EWSR1-ETS es indispensable para la acción oncogénica de esta ya que su sustitución por otros dominios proteicos elimina su potencial transformador ${ }^{26}$. 
FLI1

El gen FLI1 (Friend leukemia integration site 1) está localizado en el cromosoma 11q23-24, y cuenta con 118kb. La proteína a la que da lugar consta de 452 aminoácidos y un peso molecular de $51 \mathrm{kDa}^{27}$. El locus de FLI1 fue inicialmente identificado como un lugar de integración frecuente de retrovirus inductores de leucemias murinas ${ }^{28-29}$. Su producto proteico pertenece a la familia de factores de transcripción ETS, caracterizada por la presencia de un domino de unión al DNA (dominio ETS) de 85 aminoácidos altamente conservado. Este dominio media la unión a secuencias ricas en purinas con una estructura central consenso, $\mathrm{GGA}(\mathrm{A} / \mathrm{T})$, localizada en el promotor del gen diana ${ }^{30}$.

La expresión de FLI1 es elevada durante el desarrollo embrionario en células hematopoyéticas, endoteliales y en las células mesenquimales derivadas de la cresta neural ${ }^{31-32}$. En tejidos adultos su expresión está restringida al tejido hematopoyético, timo e hígado. En estos últimos la detección de su expresión se debe a la presencia de precursores de linfocitos, eritrocitos y megacariocitos $^{33}$. De hecho FLI1 activa la expresión de diversos genes específicos de megacariocitos y es capaz de inducir la diferenciación a este tipo celular ${ }^{34-36}$.

El papel de FLI1 como transformador oncogénico per se, especialmente en leucemias eritrocíticas, está mediado por el incremento de la supervivencia celular, inducción de factores anti-apoptóticos y la promoción de la progresión del ciclo celular ${ }^{37-40}$.

\subsubsection{EWSR1-FLI1}

La proteína quimérica EWSR1-FLI1 es el resultado de la unión del dominio $\mathrm{N}$-terminal de EWSR1 con el dominio C-terminal de FLI1 (que engloba al dominio ETS de unión al DNA), como consecuencia de la translocación $\mathrm{t}(11 ; 22)(\mathrm{q} 24 ; \mathrm{q} 12)$ (Figura 2). Se han descrito hasta 10 variantes diferentes de EWSR1-FLI1, según los puntos de ruptura y unión en los diversos intrones de ambos genes en la translocación ${ }^{41}$. La forma mayoritaria es la conocida como tipo 1, cuyo transcrito incluye la porción 5' del mRNA de EWSR1 hasta el exón 7 y la porción 3' del de FLI1 desde el exón 6 hasta la 3' UTR. De manera análoga la fusión de tipo 2 comprende hasta el exón 7 de EWSR1 y desde el exón 5 de $F L I 1$, mientras que la fusión de tipo 3 llega hasta el exón 10 de EWSR1 e incluye desde el exón 6 de FLI1. La prevalencia del resto de variantes de fusiones quiméricas es inferior a las tres anteriores.
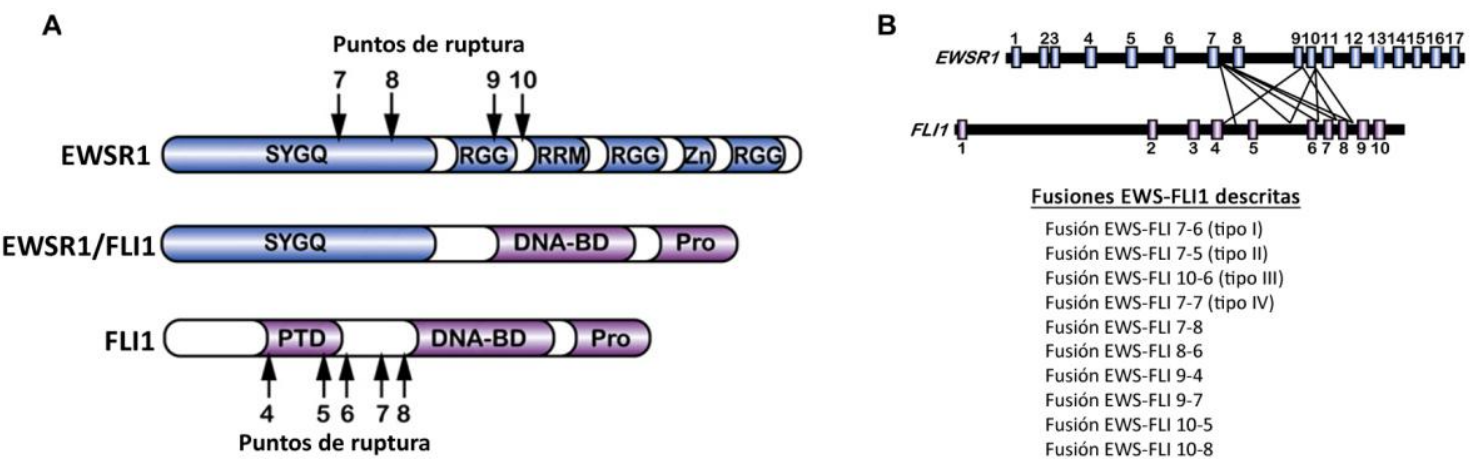

Figura 2: Esquema de la proteína de fusión EWSR1-FLI1 y tipos de fusiones EWSR1-FLI1 descritos: A Dominios estructurales de las proteínas nativas EWSR1 y FLI1 y de la quimera EWSR1-FLI1: SYGQ, dominio de transactivación 
rico en serina-tirosina-glicina-glutamina; RGG, dominio rico en arginina-glicina-glicina; RRM, dominio de reconocimiento de RNA; Zn, dominio "dedos de zinc"; PTD, dominio puntiagudo; DNA-BD, dominio de unión al DNA; Pro, dominio de activación rico en prolina. Las flechas indican los principales puntos de ruptura. B Puntos de ruptura (siempre en intrones) y combinaciones que originan los diferentes tipos de fusiones EWSR1-FLI1. Adaptado de Sankar, S., and Lessnick, S.L. (2011). Promiscuous partnerships in Ewing's sarcoma. Cancer Genet 204, 351-365 ${ }^{41}$.

Existen evidencias que demuestran que el dominio aminoterminal aportado por EWSR1 posee un potencial de transactivación superior al del dominio equivalente nativo de FLI1, que es reemplazado por el primero. De este modo, a pesar de que la fusión EWSR1-FLI1 comparte con la proteína FLI1 nativa la especificidad de unión al DNA, la proteína quimérica tiene funciones de activador/represor transcripcional alteradas ${ }^{42-45}$. En consecuencia, la sobreexpresión exógena de FLI1 no es capaz de recapitular los efectos producidos por la fusión, tales como el crecimiento en agar blando o la formación de tumores en ratones inmunodeprimidos ${ }^{26}$.

Existen diferentes aspectos mecanísticos de la proteína de fusión esenciales para el desarrollo de su función biológica:

Primero, la necesidad de la presencia de ambos dominios. Los mutantes de EWSR1-FLI1 deficientes tanto en la región correspondiente a EWSR1 como en la de FLI1 carecen de capacidad de transformación, lo cual demuestra la importancia de ambos elementos para la acción oncogénica de la fusión quimérica ${ }^{44}$.

Segundo, EWSR1-FLI1 es capaz de interaccionar con las proteínas nativas EWSR1 y FLI1 formando heterodímeros. A su vez EWSR1 (pero no FLI1) es capaz de formar homodímeros ${ }^{46}$. La mayor parte de las proteínas de la familia ETS, como por ejemplo FLI1, reconocen el DNA en forma de monómeros ${ }^{47}$. Se ha comprobado mediante ensayos de movilidad electroforética en geles de retardo que la fusión EWSR1-FLI1 se puede unir al DNA como monómero al promotor del gen TGF- $\beta^{48}$. Sin embargo, también es capaz de formar complejos multiméricos que le permiten unirse a regiones de baja afinidad para los dominios ETS, ampliando de esta forma el espectro de posibles dianas de la fusión. La oligomerización de EWSR1-FLI1 o la formación de heterodímeros con EWSR1 son aspectos importantes en la capacidad tumorigénica de la fusió $n^{46} y$ tienen incidencia en la heterogeneidad del SE ${ }^{49}$.

Tercero, la fusión per se no es capaz de transformar líneas celulares primarias murinas o humanas, induciendo parada del ciclo celular y/o muerte celular ${ }^{50}$. La translocación es necesaria pero no suficiente por sí sola como generar el fenotipo tumoral, se hace necesaria la colaboración de otras alteraciones genéticas secundarias (mutación y/o sobreexpresión de otros genes).

Los genes desregulados por EWSR1-FLI1 mejor caracterizados son CDKN1A (p21), CCND1 (Ciclina D1), MYC e ID2, que sufren un fuerte aumento de expresión y $p 57$, el cual es reprimido. La acción directa de la fusión sobre los promotores de estos genes ha sido demostrada ${ }^{51-53}$. Además, EWSR1-FLI1 afecta a componentes de distintas vías de señalización, principalmente la de TGF $\beta R \|^{48}$ y la de IGF1R. El efecto sobre esta última es especialmente relevante en la biología del $\mathrm{SE}^{54-55}$; se ejerce mediante la represión de IGFBP3, un importante regulador de esta vía ${ }^{56}$ y la activación de IGF1R ${ }^{57}$. Otros genes relevantes recientemente descritos como dianas de EWSR1-FLI1 son DAX1/NROB1 $1^{58}, P T P L 1^{59}, P L D 2^{60}, N K X 2.2^{61}, R X R^{62}, V E G F^{63}$ y GLI1 ${ }^{64}$. 
Aparte de los hallazgos relativos a la acción de EWSR1-FLI1 sobre genes puntuales, los estudios realizados por el grupo de Kaue ${ }^{65}$ han puesto de manifiesto las consecuencias de la actividad desreguladora sobre las principales funciones celulares, integrando los datos transcriptómicos de diversas líneas celulares de SE (antes y después del silenciamiento de la fusión mediante técnicas de siRNA o shRNA) con los de 59 tumores primarios de SE. Según los resultados de este estudio los genes afectados positivamente por la proteína quimérica desarrollan funciones de regulación del ciclo celular (siendo esta la función más afectada de todas), proliferación y respuesta a daño en el DNA, mientras que los genes reprimidos están principalmente involucrados en funciones de diferenciación y comunicación celular.

\subsubsection{Otras alteraciones citogenéticas en SE}

La gran mayoría de la investigaciones desarrolladas en el ámbito de la biología molecular del SE se han centrado en las implicaciones moleculares de la fusión EWSR1-ETS, de sus acciones aberrantes (directas o indirectas) sobre la transcripción de los llamados "genes diana de la fusión" y en la relevancia de estos. Mientras tanto, la presencia y contribución de otras alteraciones, que llamaremos secundarias por considerarse EWSR1-ETS el evento primario, casi no han sido abordadas. La relevancia de dichas alteraciones secundarias estriba en su potencialidad en la estratificación clínica de la enfermedad ya que la fusión quimérica carece de valor pronóstico al estar presente en todos los tumores de esta entidad y debido a que, tal y como recientemente se ha demostrado ${ }^{66-67}$, no existen diferencias clínicas debidas a las diversas combinaciones génicas o a las variantes exónicas de cada una de ellas. En este escenario, las alteraciones secundarias emergen como candidatos prometedores para explicar las evoluciones clínicas más adversas de la enfermedad y podrían asimismo suponer nuevas dianas para terapia dirigida.

A través de estudios de citogenética se han descrito aberraciones numéricas y estructurales en los $\mathrm{SE}$, como por ejemplo ganancias de los cromosomas $2,5,7,8,9$ y $12^{68}$, la translocación no recíproca $\mathrm{t}(1 ; 16)(q 12 ; q 11.2)^{69}$ y la pérdida del brazo corto del cromosoma 1 y $6^{70}$. La adquisición por parte de algunos tumores de estos eventos secundarios tiene consecuencias en el pronóstico de los mismos ${ }^{71-74}$.

Una de las alteraciones más comunes es la pérdida de expresión del gen $p 21^{\text {WAF1/CIP1 }}$ que, sin embargo, no está relacionada con el estatus del supresor tumoral p53 en la mayoría de SE. p53 está mutado en aproximadamente un $11 \%$ de los casos de $\mathrm{SE}^{75}$. Aquellos pacientes con pérdida de $p 21^{\text {WAF1/CIP1 }}$ y mutaciones de $p 53$ debidas a deleciones homozigóticas de la región 9p21 constituyen un subgrupo de peor pronóstico ${ }^{76}$. El locus INK4A que codifica para el inhibidor de CDKs p16 y el regulador positivo de la vía de $\mathrm{p} 53, \mathrm{p} 14^{\mathrm{ARF}}$ ( $\mathrm{p} 19$ en ratones) está perdido en algunos de estos tumores ${ }^{77}$. En un estudio a partir de muestras de 60 pacientes se concluyó que existían un $15 \%$ y un $13 \%$ de deleciones homocigóticas del locus CDKN2A y p53 respectivamente ${ }^{78}$.

Recientemente nuestro grupo ha descrito el valor pronóstico de una alteración secundaria mediante estudios de CGH arrays, la ganancia del brazo q del cromosoma 1 (1qG), presente en el 30\% de una serie de 25 muestras tumorales. En el mismo trabajo se realizó un estudio transcriptómico con 38 muestras donde se describió la firma 1qGSig, que corresponde a la 
expresión de una serie de 74 genes del brazo $1 q$ alterados con respecto a $1 q$ normal (1qN). Aquellos casos que presentaban la firma se relacionaron con desregulación de ciclo celular, recaída y peor supervivencia ${ }^{71}$.

\subsubsection{Origen celular}

La heterogeneidad morfológica e histológica del SE, unida a la diversidad de localizaciones que presenta, ha dificultado la determinación de su origen y ha suscitado todo un abanico de teorías respecto a este punto, abarcando propuestas tan dispares como un inicio a partir de células madre de gran potencialidad o la existencia de diferentes células de origen.

Las características neurales de los PNET, el subgrupo que más controversias plantea y que apunta a un origen celular neural distinto al resto de tumores de ESFT, se deben más bien a la acción de la proteína quimérica EWSR1-ETS que a ser una reminiscencia del "background" celular de origen ${ }^{79}$. En contraposición, un trabajo reciente indica que las células madre de la cresta neural hNCSC (diferenciadas a partir de células madre embrionarias humanas, hESCS) son permisivas a la expresión ectópica de EWSR1-FLI1. La proteína de fusión altera la expresión de genes como el de la proteína BMI-1 (integrante de complejos polycomb) y provoca el silenciamiento epigenético reversible de $\mathrm{p} 16$, lo que se asocia a evitar senescencia ${ }^{80}$. Estas células, que evitan la senescencia, son capaces de generar neuroesferas no adherentes pero no forman colonias en agar blando ni tumores subcutáneos en ratones inmunodeprimidos.

En paralelo otros estudios demuestran la permisividad diferencial de las células madre mesenquimales (MSC) y sus progenitores a la expresión exógena de EWSR1-FLI1 respecto a la refractariedad manifiesta de otros tipos celulares ${ }^{50,81-82}$. La facilidad de las MSC para migrar desde la médula ósea a localizaciones extraesqueléticas explicaría todo el abanico de entidades y localizaciones del SE. Proponen por tanto que las MSCs sean las principales candidatas para explicar el origen celular del SE.

Por otra parte, los resultados y conclusiones de los trabajos que han pretendido desvelar el origen celular del SE han generado multitud de evidencias útiles para resolver otra cuestión importante: la del requerimiento o no de alteraciones moleculares secundarias. Aceptando la necesidad esencial que el SE tiene de la fusión quimérica EWSR1-ETS para su oncogénesis ${ }^{83}$, cabe plantearse si este evento molecular es suficiente para establecer y desarrollar la neoplasia. Para intentar responder a esta pregunta repasemos los resultados obtenidos en algunos de los trabajos más importantes de la investigación relativa a la célula de origen del SE:

- La expresión exógena de EWSR1-FLI1 en fibroblastos embrionarios murinos (MEFs) induce parada de ciclo celular y apoptosis. En MEFs carentes de p16 ${ }^{\text {INK4a }}$, p19 ${ }^{\text {ARF }}$ o p53 (procedentes de ratones knockout para estas funciones génicas) EWSR1-FLI1 es capaz de mantener su expresión pero no es capaz de lograr la transformación celular, la cual sólo se produce al cointroducir el antígeno T del virus SV-40 ${ }^{84}$.

- En fibroblastos humanos primarios, inmortalizados mediante expresión exógena de hTERT, la introducción de EWSR1-FLI1 provoca igualmente una rápida parada del ciclo celular mediada 
por p53, así como inducción de apoptosis. La introducción de EWSR1-FLI1 junto con la expresión exógena de la proteína E6 del HPV o de una forma de p53 dominante negativa consigue anular esta parada de ciclo inicial pero no libera a las células de sistemas de regulación ulteriores, puesto que el cultivo detiene de nuevo su crecimiento al cabo de unos días. Lo más interesante es que la expresión de EWSR1-FLI1 no consigue transformar estos fibroblastos ni siquiera ante la presencia conjunta de las proteínas E6 y E7 del HPV, del antígeno $T$ del virus SV40 y del oncogén RAS ${ }^{\mathrm{V} 12}$. De hecho, estos oncogenes son capaces de inducir per se la formación de colonias en agar blando, pero dicha capacidad es anulada al añadir al cóctel oncogénico la expresión de EWSR1-FLI1 ${ }^{50}$.

- La introducción de EWSR1-FLI1 en la línea celular C2C12 (una línea mioblástica murina que retiene la potencialidad para diferenciar no sólo a tejido muscular, sino también a óseo y adiposo), induce una parada en el curso de la diferenciación miogénica. Cabe destacar que esta línea mioblástica sí resultó ser permisiva a la expresión exógena de la fusión quimérica ${ }^{79}$.

- Por otra parte la introducción de EWSR1-FLI1 en células progenitoras mesenquimales primarias (MPC) de ratón demostró la capacidad de estas células no sólo de mantener la expresión de EWSR1-FLI1 sino también de ser transformadas por su acción. Estas células conservaron intactos los loci de $p 53$ y de $p 16^{\mathrm{INK} 4 \mathrm{~A}} / p 19^{\mathrm{ARF}}$ y mantuvieron una ruta funcional de p53 tras la introducción de la fusión quimérica ${ }^{81}$. Un estudio paralelo con un planteamiento similar confirmó estos resultados y concluyó que los tumores generados en ausencia de p53 eran más agresivos ${ }^{85}$. De manera análoga, otro estudio en el que se introdujo EWSR1-FLI1 en MPC, esta vez carentes de p19 ${ }^{A R F}$, demostró un bloqueo de los programas de diferenciación adipogénico y osteogénico característicos de estas células, debido a los efectos moleculares de la proteína quimérica ${ }^{86}$.

- La introducción de la fusión EWSR1-FLI1 en células madre mesenquimales humanas (hMSC) ha producido resultados notablemente distintos a los obtenidos con las MPC de ratón: aunque permiten y mantienen la expresión de la proteína quimérica, ésta no consigue incrementar la baja tasa proliferativa y la viabilidad de las hMSC, ni tampoco es capaz de transformarlas (no producen tumores en xenotransplantes en ratón) o de retrasar su senescencia.

Tomadas en conjunto, todas estas evidencias sugieren que se requieren otras alteraciones moleculares para el establecimiento o al menos para el desarrollo del SE ya que, incluso en modelos celulares humanos permisivos a la presencia de la fusión quimérica (como hNCSC y hMSC), ésta no es capaz de inducir transformación por sí sola. Además, los resultados obtenidos en hMSC podrían simplemente estar reflejando la mayor permisividad de los entornos celulares pluripotentes debido a la ausencia en ellos de algunas de las restricciones moleculares que se oponen a la acción transformadora de EWSR1-ETS, como la ruta de p53 o la expresión de $\mathrm{p} 16^{\mathrm{INK} 4 \mathrm{a}}$, que de hecho anulan la reprogramación celular inducida ${ }^{86-90}$.

\subsubsection{Presentación clínica}

El SE puede pasar inadvertido durante largo tiempo o diagnosticarse erróneamente como "dolores de crecimiento" o como una lesión deportiva debido a la similitud de la sintomatología. Es frecuente experimentar dolor e inflamación en la región afectada. El dolor 
puede aumentar al hacer ejercicio físico o durante la noche. Alrededor del $25 \%$ de los pacientes refiere fiebre y/o pérdida de peso. También son comunes el incremento de la velocidad de sedimentación globular, la leucocitosis y la anemia. En los tumores localizados en la diáfisis de los huesos largos se observa mediante examen radiológico una progresiva reacción formadora de hueso en el periostio que es definida como "reacción en capas de cebolla" (Figura 5, página 18). En ocasiones el tumor debilita la estructura del hueso y provoca fracturas patológicas.

Como hemos comentado anteriormente, el SE es un tumor que aparece en hueso y en partes blandas. La localización en hueso es la más frecuente (85\%) repartiéndose anatómicamente como sigue: extremidades distales (27\%), proximales (25\%), pelvis $(20 \%)$, tórax (20\%), columna vertebral y cráneo (9\%). Los SE extraesqueléticos o de partes blandas ( $15 \%$ de los casos) se distribuyen de la siguiente manera: tronco (32\%), extremidades (26\%), cabeza y cuello (18\%), retroperitoneo $(16 \%)$ y otras localizaciones $(8 \%)^{91}$.

El SE tiene una gran tendencia a la metástasis, principalmente hacia hueso y pulmón; de hecho se considera una enfermedad sistémica desde el inicio, cualquiera que sea su estadio clínico. Más del $10 \%$ de pacientes presentan múltiples metástasis óseas. La metástasis a hueso, pulmón y médula ósea es detectable al diagnóstico en un $25 \%$ de los pacientes, mientras que la metástasis a ganglios linfáticos es rara ${ }^{92}$.

El diagnóstico anatomopatológico es complejo debido a la variabilidad fenotípica, heterogeneidad histológica y la ausencia de marcadores inmunohistoquímicos patognomónicos. De este modo, la detección molecular de la translocación específica t(11;22)(q24;q12) y/o de la fusión génica asociada a ella (EWSR1-ETS) ayudan a diferenciar a esta entidad de otras como el neuroblastoma, el rabdomiosarcoma, el linfoma no Hodgkin, el tumor desmoplásico de células pequeñas o el sarcoma sinovial ${ }^{93-94}$.

\subsubsection{Histología}

EI SE se caracteriza por presentar células pequeñas y redondas con núcleos redondos $u$ ovalados prominentes, nucléolo ausente y cromatina fina y dispersa, así como bajo índice mitótico. En ocasiones se aprecian células con núcleos hipercromáticos, probablemente degenerativas, que conforman un patrón que alterna células claras con células oscuras. El citoplasma suele ser escaso, claro y rico en glucógeno, por lo que las células son positivas para la tinción del ácido periódico de Schiff (PAS). También presentan uniones intercelulares tipo hemidesmosomas ${ }^{12}$. La disposición celular es densa, sin apenas matriz extracelular mientras que el patrón de crecimiento carece de una organización clara (Figura 3).

Numerosos estudios han demostrado que la inmunohistoquímica (IHQ) es de gran ayuda en la identificación de este grupo de neoplasias, y sobre todo en el diagnóstico diferencial con otros tumores de células redondas y pequeñas (TCRP) de hueso o extraóseos. Entre los marcadores antigénicos empleados en el diagnóstico de SE se encuentran el CD99 (presente en el $90 \%$ de los tumores), el propio FLI1, HNK-1(CD57), la Enolasa Específica Neuronal (NSE), S-100 y Sinaptofisina ${ }^{11,95-98}$. En un $20 \%$ de casos hay también presencia de citoqueratinas y 
neurofilamentos ${ }^{99}$. Recientemente se ha descrito la Caveolina-1 (CAV-1) como un marcador que puede ser útil en el diagnóstico de $\mathrm{SE}^{11,100}$.
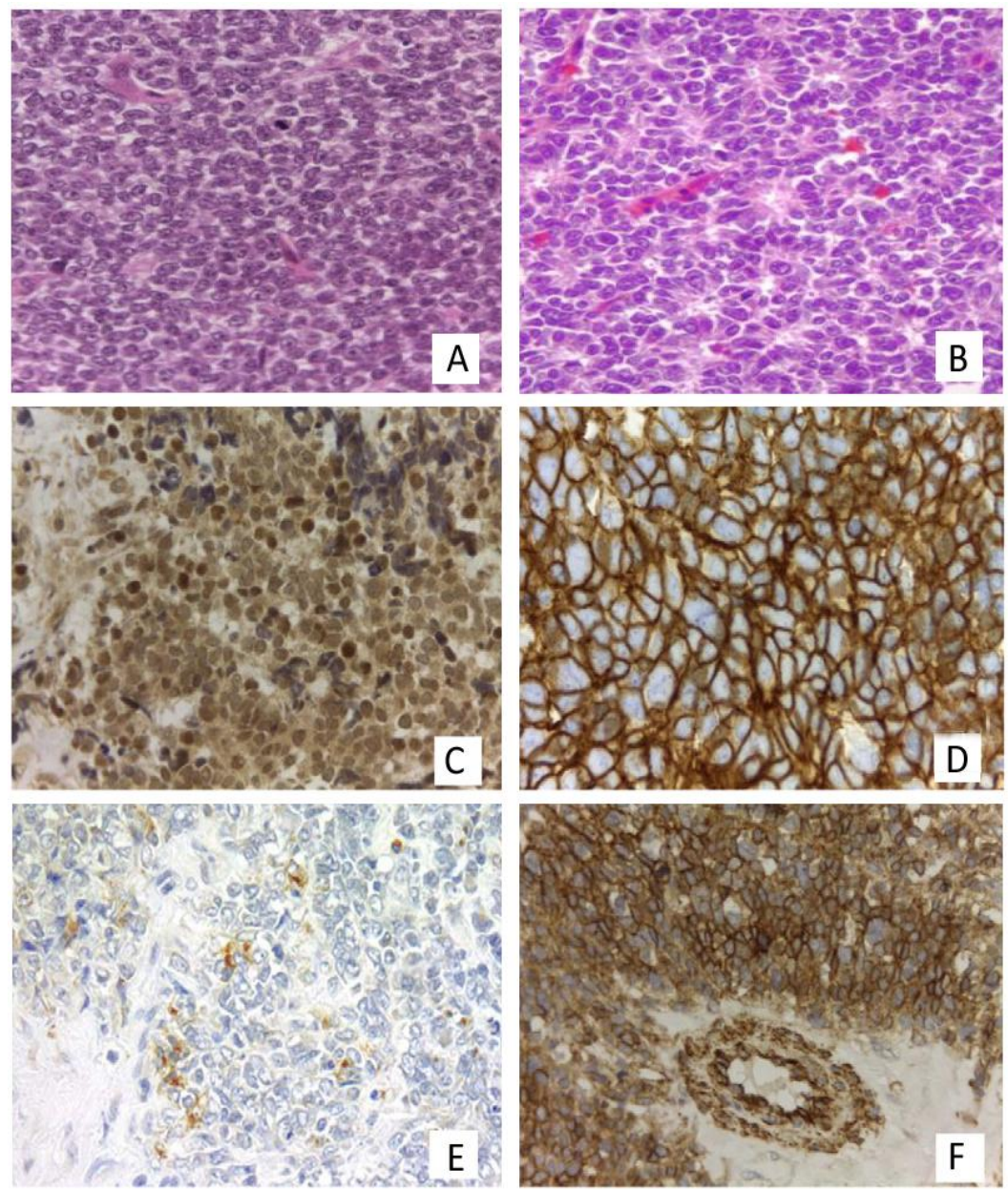

Figura 3: IHQ en Sarcoma de Ewing: A Sarcoma de Ewing, hematoxilina y eosina (H\&E), X20. B PNET con presencia de abundantes rosetas, H\&E, x40. C SE con tinción nuclear positiva para FLI1, x40. D Tinción de membrana intensamente positiva para CD99 en SE, x100. E Inmunotinción débil positiva para HNK-1(CD57) con patrón paranuclear en SE, x40. F SE que muestra positividad intensa para Caveolina-1; se observa también un marcaje positivo en pared de vasos sanguíneos, x40. Adaptado de Machado, I., Navarro, S. y Llombart-Bosch, A. (2012). Pautas en el diagnóstico morfológico, inmunohistoquímico y genético de los tumores de células redondas y pequeñas con especial referencia al sarcoma de Ewing/PNET. Patología 45(3), $145-153^{101}$.

La expresión IHQ del CD99 es de membrana y/o citoplasmática generalmente es moderada $(++)$ o intensamente positiva (+++) en SE. No obstante, la especificidad del CD99 no es exclusiva para SE debido a que este anticuerpo puede ser expresado en otros TCRP como por ejemplo el osteosarcoma de células pequeñas (OCP), rabdomiosarcoma, linfoma, carcinoma indiferenciado, etc. Inicialmente se pensó que la inmunotinción con FLI1 sería de gran apoyo en el diagnóstico de SE, pero todos los autores coinciden en que este marcador carece de especificidad, y además su sensibilidad es bastante variable $e^{11,96,102}$. HNK-1 es un marcador con especificidad y sensibilidad similar al FLI1 ${ }^{11}$. La CAV-1 está sobreexpresada en una alta proporción de casos con diagnóstico de SE, y por tanto se considera como un marcador que ayuda en el diagnóstico en estas neoplasias. Cuando se combinan los 4 anticuerpos descritos anteriormente (CD99, FLI1, HNK-1 y CAV-1) (Figura 3) prácticamente cubren el diagnóstico de 
más del 99\% de los SE genéticamente confirmados, por lo que el empleo de estos anticuerpos es de gran apoyo en el diagnóstico IHQ de estas neoplasias, independientemente del subtipo histológico o del estadio clínico.

En contraposición a este aspecto difuso típico del SE, las células del PNET se agrupan en nidos, trabéculas o rosetas, aunque en ocasiones también son apreciables grupos de células semejantes a la histología anteriormente descrita para el SE (Figura 3). Además, aunque los PNET presentan también inmunoreactividad para CD99, NSE y/o $\beta-2$ Microglobulina, se distinguen por su positividad para marcadores neurales tales como LEU-7, Sinaptofisina, neurofilamento, y S100. De hecho, la presencia de gránulos neurosecretores, proyecciones celulares de tipo neural con neurotúbulos y material de lámina basal son sus principales elementos distintivos ${ }^{103-105}$.

\subsubsection{Factores con valor pronóstico}

Podemos distinguir dos tipos principales de factores pronósticos para los pacientes de ES: factores clínicos y factores moleculares.

Los principales factores clínicos con valor pronóstico en SE son:

- Metástasis: la presencia de metástasis al diagnóstico es el factor con mayor impacto en la mala supervivencia de los pacientes. Entre un 15 y un 25\% de los pacientes presentan metástasis en el momento de ser diagnosticados. Se ha descrito una mejor supervivencia en aquellos pacientes con metástasis a pulmón respecto a los que presentan metástasis en hueso o médula ósea ${ }^{106}$; cuando es posible, la extirpación de las metástasis pulmonares debe realizarse porque se ha demostrado que prolonga la supervivencia ${ }^{107}$.

- Localización del tumor primario: los pacientes que tienen el tumor en las extremidades distales tienen mejor pronóstico que aquellos que lo presentan en las proximales. Las localizaciones centrales o pélvicas son las que peor pronóstico poseen ${ }^{108-110}$.

- Tamaño del tumor primario: en la mayoría de los estudios el tamaño del tumor ha demostrado ser un factor pronóstico importante. Para definir los tumores más grandes se usa un límite de 100 o $200 \mathrm{ml}$. Los tumores mayores tienden a presentarse en zonas de localización desfavorable ${ }^{111}$.

- Edad del paciente: los niños menores de 10 años tienen un mejor pronóstico que los adolescentes, los adultos jóvenes o los adultos ${ }^{108,110}$.

- Sexo del paciente: las mujeres afectadas de SE tienen un mejor pronóstico que los varones ${ }^{108}$.

- Deshidrogenasa láctica: altos niveles de la enzima Deshidrogenasa Láctica (DHL) previos al tratamiento correlacionan con un mal pronóstico. Los tumores primarios grandes y los metastásicos presentan una elevada concentración de $\mathrm{DHL}^{108}$.

Los factores moleculares con valor pronóstico descrito son: 
- Detección del transcrito de la fusión EWSR1-ETS en muestras de médula ósea: la detección de pequeñas poblaciones de células tumorales en médula ósea mediante Real Time RT-qPCR se ha asociado a un mayor riesgo de recidiva ${ }^{112}$.

- Deleción de CDKN2A y mutaciones en TP53: consideradas por separado, cada una de estas alteraciones afecta a menos del $15 \%$ de los pacientes de SE. Sin embargo, aunque infrecuentes, se ha demostrado el peor pronóstico que confieren en varios estudios retrospectivos, el más completo de ellos el elaborado a partir de 60 muestras tumorales ${ }^{78}$.

- Pérdida del brazo corto del cromosoma $16^{113}$ y aumento de la actividad de la telomerasa ${ }^{114}$ : son sugeridos como factores pronósticos adversos.

- Porcentaje del genoma alterado (PGA): recientemente nuestro grupo ha propuesto este indicador por su valor pronóstico en pacientes con $\mathrm{SE}^{71}$. Es un indicador fiable del total del genoma afectado por alteraciones de número de copia (ANC) y guarda una relación inversa con la supervivencia total del paciente. En nuestro estudio se detalla cómo el grupo de pacientes cuyas muestras tumorales carecían de ANC (PGA<0.1\%) presentó una supervivencia extraordinariamente favorable, cercana al $85 \%$ a 5 años ${ }^{71}$. Figura 4 , A.

A

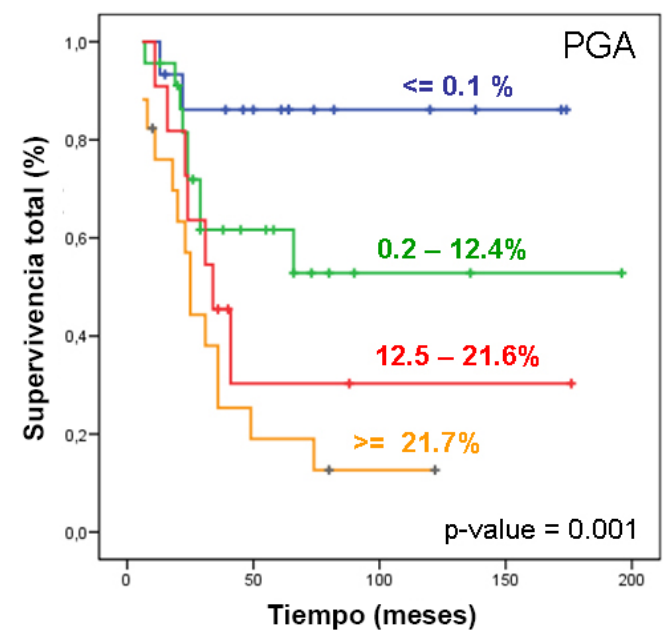

B
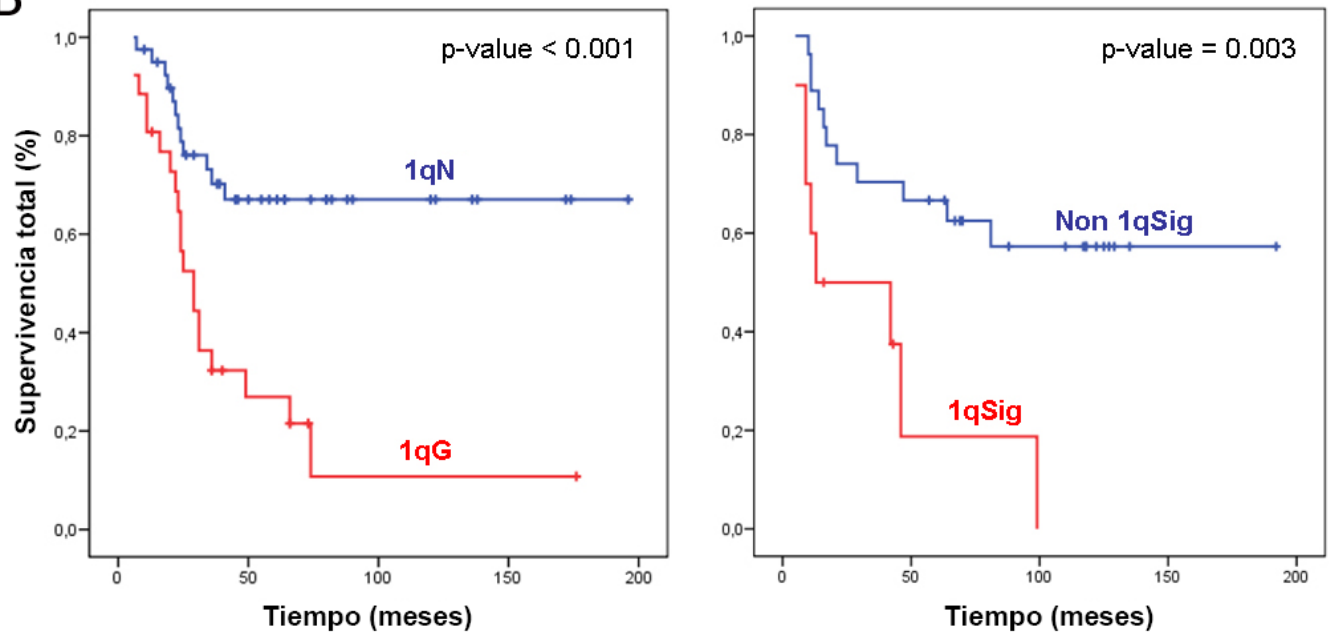

Figura 4: Impacto del PGA, ganancia del brazo q del cromosoma 1 y la firma 1qGSig en la supervivencia total de 
los pacientes de SE. A Resultados del test Kaplan-Meier log rango de los parámetros PGA organizados en intervalos (denotados sobre la correspondiente curva de supervivencia). B Resultados del test Kaplan-Meier log rango de los parámetros 1qG (panel izquierdo) y 1qGSig (panel derecho). Adaptado de Mackintosh, C., Ordonez, J.L., GarciaDominguez, et al. (2012). 1q gain and CDT2 overexpression underlie an aggressive and highly proliferative form of Ewing sarcoma. Oncogene $31,1287-1298^{71}$.

- Ganancia del brazo q del cromosoma 1 (1qG) y firma 1qGSig: este mismo trabajo de nuestro grupo, en un estudio retrospectivo multicéntrico de hibridación genómica comparativa sobre microarray (aCGH) de 67 muestras de tumores de pacientes con $\mathrm{SE}$, ha puesto de manifiesto que el $30 \%$ de los tumores presentan ganancia de número de copia del brazo largo del cromosoma $1(1 q G)$. Los resultados evidenciaron además una correlación entre la presencia de 1qG y una peor supervivencia de los pacientes (Figura 4, B). En un estudio transcriptómico de 38 muestras de tumores (grupo de muestras independiente del anterior), se validó el valor pronóstico de 1qG y se definió la firma de expresión local (genes en 1q) asociada a esta aberración cromosómica, la 1qGSig. (Figura 4, B $)^{71}$.

- Sobreexpresión del gen CDT2: la proteína CDT2 es un componente de los complejos CRL (Cullin RING-Ligasa) que reconocen sustratos específicos (proteínas) y los marcan con residuos de ubiquitina para que sean degradados en el proteosoma. En el estudio transcriptómico descrito anteriormente, se puso de manifiesto que CDT2 era el gen sobreexpresado con mayor relevancia en los tumores con 1qG, formando además parte de la fima 1qGSig. Además la función de este gen (que fue validado como oncogén tanto in vitro como in vivo) se ajustaba la desregulación de ciclo celular predicha por los estudios bioinformáticos in silico que encontraron un enriquecimiento estadístico de las funciones génicas reguladoras de la transición de la fase $\mathrm{G} 1$ a la fase $\mathrm{S}$ del ciclo celular ${ }^{71}$.

La potencialidad de los factores con valor pronóstico puede ser reconsiderada con el avance en el conocimiento en la biología del SE, así como con el análisis retrospectivo y/o prospectivo de un número mayor de pacientes por estudio. Un ejemplo relevante es el impacto pronóstico de las variantes moleculares del gen de fusión EWSR1-FLI1: aunque en estudios retrospectivos las distintas variantes de la fusión EWSR1-FLI1 parecían tener diferencias en el pronóstico clínico ${ }^{115}$, dos trabajos, recientes y prospectivos con sendas series independientes de más de 700 pacientes han descartado este punto ${ }^{66-67}$.

\subsubsection{Tratamiento}

El SE es una neoplasia agresiva con tendencia a recidivar (reaparición en el punto donde se originó) y a metastatizar (diseminación a otra zona del organismo). El tratamiento del SE ha evolucionado a la luz de nuevos conocimientos en la biología del tumor así como de las alternativas clínicas. Antes del uso de quimioterapia múltiple la supervivencia de los pacientes de SE era inferior al $10 \%$. El uso de terapias multimodales ha conseguido mejorarla, incrementándola hasta alcanzar la tasa actual del 70\%. Sin embargo, el pronóstico de supervivencia de aquellos pacientes con enfermedad primaria diseminada o recaída se mantienen aún por debajo del $20 \%{ }^{107}$. Desafortunadamente un $15-25 \%$ de los pacientes presentan enfermedad diseminada al momento del diagnóstico. 
El tratamiento del SE combina quimioterapia sistémica multimodal con tratamiento local (cirugía, radioterapia o ambas) $^{116-119}$. Los agentes quimioterápicos que han demostrado mayor efectividad son doxorubicina (DXR), ciclofosfamida (CPA), vincristina (VCR), actinomicina-D (ACT), ifosfamida (IFM) y etopósido (VP16). Históricamente destacan en la evolución del tratamiento frente al SE los siguientes avances:

- En 1968 se usó por primera vez una combinación de quimioterápicos y tratamiento local en SE. Dicha combinación incluía CPA, VCR y radioterapia. Era el inicio de la aplicación de la terapia multimodal en esta neoplasia ${ }^{120}$. A partir de entonces se han ensayado diversas combinaciones que han incidido en un aumento paulatino de la supervivencia de los pacientes.

- VACD (VCR, ACT, CPA y DXR) y radioterapia: la inclusión de DXR en el esquema compuesto por 3 agentes quimioterápicos demostró ser muy beneficiosa, incrementando la supervivencia libre de recaída del 24 al $60 \%{ }^{121}$. Además, se demostró una ulterior mejora en este factor al aumentar la dosis de DXR respecto a la usada inicialmente, alcanzando una tasa del $74 \%$ para los SE libres de metástasis ${ }^{122}$. Estos ensayos se hicieron en el seno de los estudios estadounidense IESS-I e IESS-II y en el europeo CESS-81, y establecieron el esquema VACD como terapia estándar en $\mathrm{SE}^{123}$.

- En Europa, el estudio CESS-86 ensayó la sustitución de DXR en el esquema VACD por IFM para el tratamiento de los pacientes con tumores con volúmenes superiores a $100 \mathrm{ml}$. El resultado fue satisfactorio ${ }^{118}$.

- La implementación de IFM y VP16 (IE) en el esquema VACD (VACD-IE) en ensayos de fase 2 del estudio INT-0091 consiguió un notable incremento en la supervivencia libre de recaída $(54 \% \text { a } 69 \%)^{124}$, lo que supuso la adopción del esquema VACD-IE como nuevo estándar en el tratamiento del $\mathrm{SE}^{125}$.

Posteriormente, y con el fin de aumentar el periodo libre de enfermedad y mejorar la supervivencia, algunos investigadores han valorado el uso de regímenes quimioterápicos intensivos. La intensificación puede hacerse aumentando la cantidad de fármaco o acortando los intervalos de administración; emplearon para los ensayos la combinación habitual de 5 fármacos (VCR, DXR, CPA, IFM y VP16) ${ }^{126}$. En un primer abordaje analizaron el aumento de las dosis de los medicamentos sin modificar la duración del intervalo entre dosis. Este ensayo no demostró una mejoría en la supervivencia de los pacientes ${ }^{127}$. Un ensayo clínico posterior ha demostrado que el protocolo intensivo aplicando los fármacos en intervalos de tiempo inferiores a lo habitual (tratar cada dos semanas en vez de cada tres, lo habitual), favorece la duración del periodo libre de enfermedad así como la supervivencia global: $76 \%$ frente al $65 \%$ en el periodo libre de enfermedad a los cuatro años ( $p=0.029$ ), y $91 \%$ frente al $85 \%$ en la supervivencia global a los cuatro años $(p=0.026)$. Además comprobaron que este régimen intensivo no incrementaba la toxicidad con respecto al régimen habitual de suministro de fármaco ${ }^{128}$.

Actualmente se evalúan nuevos compuestos dirigidos a diferentes dianas: 
- Derivados de camptotecina (Topotecán e Irinotecán): estabilizan la Topoisomerasa I provocando daño al DNA y muerte celular ${ }^{129}$. Se ha demostrado ser útiles contra el SE utilizándose solos y en combinación con CPA o temozolamida ${ }^{130-131}$. En un estudio los datos de expresión génica, número de copia cromosómica y de secuenciación se cruzaron con las referencias de 24 agentes farmacológicos utilizados en 479 líneas celulares de cáncer humano. Las líneas celulares de SE se encontraban entre las más sensibles a camptotecina y se relacionó con SLFN11, un gen que fue definido como factor de predicción de sensibilidad a camptotecina $^{132}$. No obstante, se describieron efectos secundarios como mielosupresión al utilizar topotecán ${ }^{133}$ e irinotecán ${ }^{134}$.

- ET-743 (Ecteinascidina 743, Trabectedina, Yondelis ${ }^{T M}$ ) informes preclínicos han demostrado que las células de SE son sensibles al fármaco in vitro con $\mathrm{IC}_{50}$ en rango de concentración picomolar ${ }^{135-136}$. Se ha sugerido que el fármaco interfiere con dianas de la actividad de EWSR1FLI1 a nivel de mRNA y de promotor ${ }^{137}$. Existe controversia acerca del potencial del fármaco en ensayos clínicos. Se propone como estrategia la combinación con otros compuestos y el desarrollo de nuevos análogos de ET-743 como Zalipsys ${ }^{\text {TM }}$ y PM001183 (más potentes y menos tóxicos).

- Inhibidores de PARP. Varios estudios han evaluado las consecuencias de inhibir la poli ADP ribosa polimerasa (PARP) en células de SE. En un primer estudio, se determinó la relación de sensibilidad entre 639 líneas celulares y 130 diferentes fármacos focalizando el impacto en una lista de 64 genes analizados mediante su secuenciación. Entre las relaciones más significativas destacó la expresión de EWSR1-FLI1 y la sensibilidad al inhibidor de PARP AZD2281 (Olaparib) $^{138}$. La alta sensibilidad no se produce en todas las líneas de SE, por lo que es imperativo describir los factores predictivos de sensibilidad a la inhibición de PARP. No parece haber una gran actividad en la inhibición del crecimiento de xenotrasplantes de células de SE al utilizar exclusivamente inhibidores de PARP. Si bien, la reducción de los tumores es drástica cuando se combinan con temozolamida ${ }^{139}$.

- Inhibidores de la vía de señalización IGF. Estudios preclínicos han establecido la alta sensibilidad de las células de SE a la inhibición de la ruta IGF tanto in vitro como in vivo ${ }^{54,140}$. Anticuerpos dirigidos a los receptores, moléculas pequeñas inhibidoras de la quinasa del receptor y dianas aguas abajo tales como mTOR inhiben la proliferación de las líneas celulares de $\mathrm{SE}^{141-149}$. Además, estos agentes se relacionaron con el bloqueo de procesos biológicos críticos tales como el desarrollo de vasos sanguíneos en el tumor en crecimiento, e incluso inhibición de metástasis en los modelos experimentales utilizados ${ }^{147,150-151}$. Sin embargo estudios clínicos realizados con amplios grupos de pacientes solo dieron resultado positivo entre 10 y el $17 \%$ de casos (datos de dos estudios independientes) ${ }^{130,152}$. Las tasas de respuesta relativamente bajas sugieren la necesidad de establecer mejores marcadores predictivos de respuesta.

En último lugar, con respecto al manejo local del SE, existe aún cierta controversia: aunque varios estudios muestran la eficacia de la resección del tumor reduciendo la tasa de recaída local (hasta niveles inferiores al 10\%) e incrementando la supervivencia total, no existen ensayos aleatorizados comparando cirugía y radioterapia. En consecuencia, cuando es posible 
la resección del tumor con márgenes amplios normalmente prevalece la cirugía sin radioterapia, mientras que si no está claro que se pueda resecar completamente el tumor con márgenes negativos se aplica radiación pre-operatoria y/o quimioterapia neoadjuvante. Además, si tras la cirugía los márgenes quirúrgicos están afectados por tumor se puede hacer uso de radioterapia postoperatoria. En el caso de los tumores de extremidades en los que no es posible una resección quirúrgica la amputación puede ser la única opción para el manejo de la enfermedad local (Figura 5). Finalmente, los tumores inoperables (debido normalmente a su localización central y/o tamaño masivo) son tratados localmente sólo con radioterapia ${ }^{153-154}$.

A
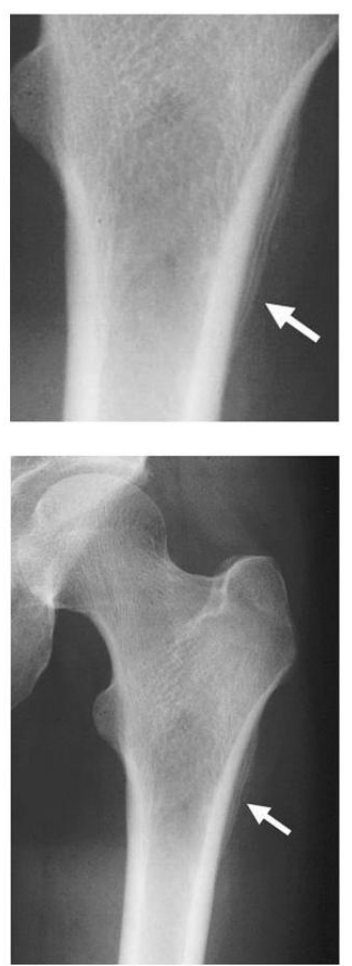

B

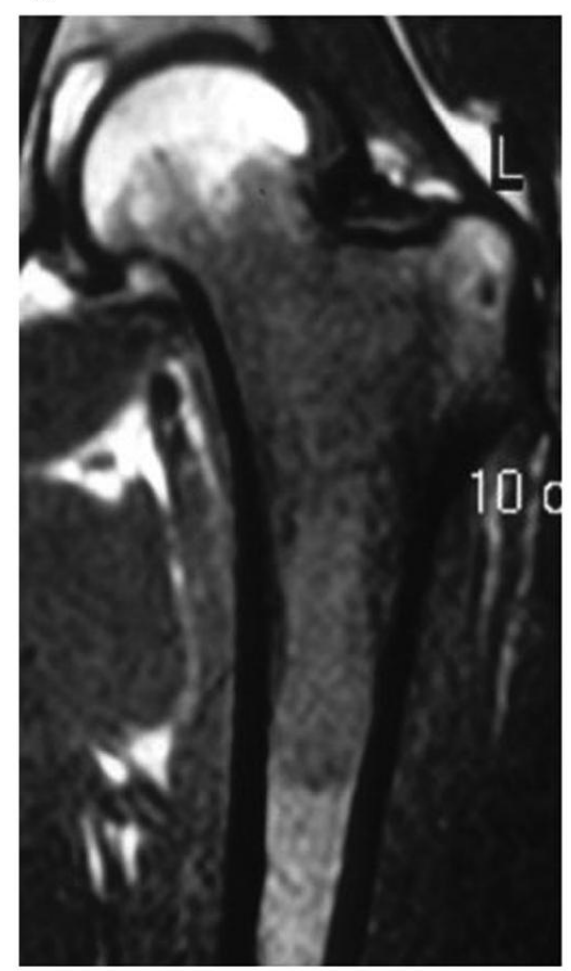

C

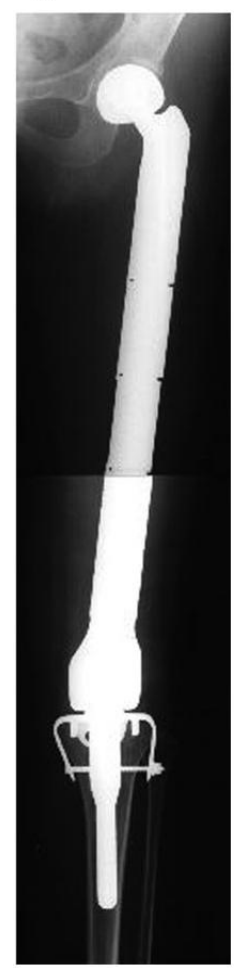

Figura 5: Ejemplo de SE localizado en el fémur y de tratamiento local quirúrgico. A Radiografía mostrando una lesión invasiva metafiso-diafisaria femoral con una reacción perióstica en capas de cebolla. La imagen superior es una ampliación de la zona marcada en la inferior (Flecha). B Imagen de resonancia magnética mostrando un tumor intramedular expandiéndose desde el segmento largo de la diáfisis hasta el cuello femoral. C Reconstrucción de la extremidad afectada con una endoprótesis tras la resección. Reproducido de Iwamoto, Y. (2007). Diagnosis and treatment of Ewing's sarcoma. Jpn J Clin Oncol 37, 79-89 ${ }^{16}$.

A pesar de la evolución en el manejo clínico y su notable contribución a la supervivencia de los pacientes de $\mathrm{SE}$, el tratamiento actual es insuficiente para un subgrupo de pacientes que o bien presenta enfermedad diseminada al diagnóstico o sufre recaída posterior. Estos pacientes muestran una buena respuesta inicial al tratamiento pero en la mayoría de los casos sólo se consigue controlar la enfermedad parcialmente y ésta acaba reapareciendo ${ }^{118,155-156}$. Asimismo, no existe aún una clara estratificación clínica del SE mediante parámetros moleculares pronósticos ya que el conocimiento de estos es deficiente en esta enfermedad. En consecuencia, es necesaria la búsqueda de nuevos factores pronósticos moleculares, así como de nuevas dianas terapéuticas que incidan en un mejor manejo clínico de subtipos agresivos de SE. 


\subsection{CICLO CELULAR: EN CÉLULAS EUCARIOTAS}

El ciclo celular es un proceso altamente conservado caracterizado por un conjunto ordenado de eventos que culminan con el crecimiento y la división celular. Asegura la propagación de la vida desde seres unicelulares a los organismos multicelulares. Con el fin de generar dos células hijas, la célula parental tiene que someterse a varios cambios entre los cuales están: crecimiento de la masa, duplicación de los orgánulos y duplicación y separación igual del DNA entre las dos células hijas. Estos procesos tienen lugar en fases bien definidas del ciclo. De forma general, el ciclo celular puede ser desglosado en interfase y en división o fase mitótica. Durante la interfase, la célula cumple todos aquellos requisitos necesarios para iniciar la división. Específicamente el ciclo celular se divide en cuatro etapas que, ordenadas cronológicamente, se denominan:

- $\quad$ G1 (Gap 1): primera fase del nuevo ciclo celular.

- $\quad$ Fase $\mathbf{S}$ (Síntesis): período de replicación del DNA.

- $\mathbf{G 2}$ (Gap 2): período previo a la mitosis.

- Mitosis: consiste en la descomposición de la envoltura nuclear, segregación de los cromosomas por el huso mitótico y la separación física de las células hijas o citocinesis.

Durante G1 y G2 la célula crece y, antes de pasar a la siguiente fase, comprueba que los procesos ocurridos en la fase anterior se han producido correctamente (transiciones G1/S y $\mathrm{G} 2 / \mathrm{M}$ respectivamente). Al conjunto de fases $\mathrm{G} 1$, S y $\mathrm{G} 2$ se le denomina interfase.

La entrada de las células en un nuevo ciclo de división está determinada por señales externas y por la propia información interna de la célula. Las señales externas afectan a la progresión del ciclo hasta un determinado momento de G1, conocido como punto de restricción ${ }^{157}$, a partir del cual el control lo ejerce únicamente la maquinaria del ciclo celular. Antes de superar el punto de restricción las células pueden abandonar el ciclo, temporal o permanentemente, y entrar en una fase de arresto o fase quiescente, $\mathbf{G}_{\mathbf{0}}$. La regulación del ciclo celular es fundamental para el desarrollo normal de los organismos; la pérdida de control podría llevar a la muerte celular o la aparición de cáncer ${ }^{158}$.

\subsubsection{Regulación del ciclo celular: Checkpoints}

Los controles de comprobación del ciclo celular o checkpoints son vías de señalización que aseguran la homeostasis, la estabilidad, la correcta replicación y la distribución adecuada del material genético en las células por medio de la regulación de la progresión del ciclo. Estos controles se ejercen principalmente en dos puntos del ciclo celular: la transición G2/M y la transición metafase/anafase. En el primero, el bloqueo o retraso (que afecta a la entrada de las células en mitosis) ocurre en respuesta a daño al DNA, a una replicación anómala o incompleta y por activación del checkpoint de antefase. La transición metafase/anafase puede ser interrumpida, por activación del checkpoint de huso mitótico, para impedir la segregación irregular de los cromosomas.

A continuación, se muestran los principales tipos de checkpoint descritos en células humanas: 
- Checkpoint de daño al DNA: se activa cuando se detectan roturas o alteraciones de la estructura normal de la cadena de DNA, con el fin de parar el ciclo celular y reparar el DNA si es posible. Este checkpoint evita la transmisión de mutaciones a las células hijas, y por ende, contribuye al mantenimiento de su estabilidad genómica.

- Checkpoint de replicación o de estrés replicativo: regula el programa temporal de los distintos orígenes de replicación, así como la tasa de elongación de las horquillas de replicación. Se activa en respuesta a problemas que afectan a la replicación en ausencia de daño directo al DNA, pudiendo inducir incluso su parada.

- Checkpoint de antefase: este checkpoint promueve la parada de las células en un punto concreto de la transición $\mathrm{G} 2 / \mathrm{M}$, la antefase, en respuesta a problemas en el ensamblaje del huso mitótico, a cambios en la topología de la cromatina, o a un estrés de tipo térmico u osmótico. Antefase, es un concepto clásico con el que se designó el periodo al final de la fase G2 inmediatamente anterior a los signos visibles de condensación cromosómica, durante el cual células normales pueden sufrir un retraso reversible a causa de diferentes tipos de estrés. En el checkpoint de antefase pueden participar diversas proteínas de tipo sensor en función de la naturaleza de la perturbación, pero todas ellas inducen la activación de la quinasa de tipo MAPK p38, que a su vez promueve la inhibición de proteínas reguladoras del ciclo celular como CDC25B y/o la activación de p53, importante supresor tumoral ${ }^{159}$.

- Checkpoint de huso mitótico: es el mecanismo de control que asegura la correcta segregación cromosómica en mitosis, evitando así la aparición de aneuploidías. Este checkpoint se mantiene activo desde la ruptura de la envoltura nuclear hasta la metafase tardía, asegurando que todos los cromosomas estén correctamente anclados al huso mitótico y alineados en la placa metafásica ${ }^{160-161}$. Sólo con que exista una cromátida no unida al huso mitótico, este checkpoint provoca la parada del ciclo celular inhibiendo APC/C mediante la fosforilación de su complejo F-box, CDC20, ejercida por BUB1 ${ }^{162}$.

\subsubsection{Proteínas CDK}

En células eucariotas, el control de la progresión por las distintas fases del ciclo celular se fundamenta en la actividad de unas proteínas denominadas CDKs. Las CDKs presentan actividad quinasa sobre residuos serina o treonina, siendo capaces de fosforilar diversas proteínas en dichos residuos. Estas quinasas constituyen una familia muy conservada evolutivamente en los organismos eucariotas. En células de mamíferos varias CDKs participan en la regulación del ciclo, de modo que CDK4 y CDK6 están implicadas en la regulación de G1, CDK2 regula principalmente la entrada y progresión por la fase $\mathrm{S}$, y por último, CDK1 (también denominada $\mathrm{CDC2}$ ) es necesaria para la entrada y la progresión por las primeras etapas de la mitosis ${ }^{163-164}$. Sin embargo, estudios recientes han puesto de manifiesto la existencia de redundancia funcional entre las distintas CDKs en células de ratón, ya que sólo CDK1 parece esencial para la regulación del ciclo celular ${ }^{165}$.

Las quinasas CDK están sometidas a una regulación muy estricta que, pese a mantener su nivel de expresión proteica constante, hace que su actividad fluctúe a lo largo del ciclo celular. Esta 
oscilación en la actividad depende de: asociación con distintas proteínas activadoras de tipo ciclina (que les confieren especificidad de sustrato) (Figura 6), procesos de fosforilación/desfosforilación y de la presencia de proteínas inhibidoras de tipo CKI.

\subsubsection{Reguladores CDKs: Ciclinas y CIKs}

\section{Ciclinas}

Las ciclinas son una familia de proteínas involucradas en la regulación del ciclo celular. Forman complejos con las CDKs activando en estas últimas su actividad quinasa. Inicialmente, las ciclinas fueron identificadas en embriones de invertebrados marinos como proteínas que oscilaban periódicamente durante el ciclo celular, debido a su regulación transcripcional y degradación ${ }^{166}$. Se conocen ciclinas en todos los organismos eucariotas estudiados, aunque la conservación evolutiva no es muy grande, estando limitada al dominio de interacción con CDKs. Se pueden distinguir cuatro tipos distintos de ciclinas en función de la fase del ciclo en la que aparecen y a la CDK a la que se asocian (Figura 6), aunque no todos los tipos están presentes en todos los organismos eucariotas:

- Ciclinas de G1: promueven la superación del punto de restricción, lo que conlleva a la entrada de la célula en un nuevo ciclo celular. Ciclinas D son las que se asocian a CDK4 y CDK6 durante G1.

- Ciclinas G1/S: requeridas para el inicio de la replicación del DNA. La Ciclina E asociada a CDK2 parece ser la encargada de esta función.

- Ciclinas de fase S: permiten la progresión por la fase S. Con este fin Ciclina A se asocia a CDK2 y CDK1 durante la fase $S$.

- Ciclinas mitóticas: su función es necesaria en mitosis. La desempeña inicialmente Ciclina A, y sobre todo, las Ciclinas B (que la sustituyen) formando complejos con CDK1.

\begin{tabular}{ccl}
\hline CDKs de G1 & CDKs de Fase S & \multicolumn{1}{c}{ CDKs de Mitosis } \\
CycD1,CycD2,CycD3+Cdk4,Cdk6 & CycE+Cdk2 (?) & CycB1,CycB2,CycB3+Cdk1 \\
CycE+Cdk2 & CycA+Cdk2/Cdk1 & CycA+Cdk2/Cdk1 \\
\hline
\end{tabular}

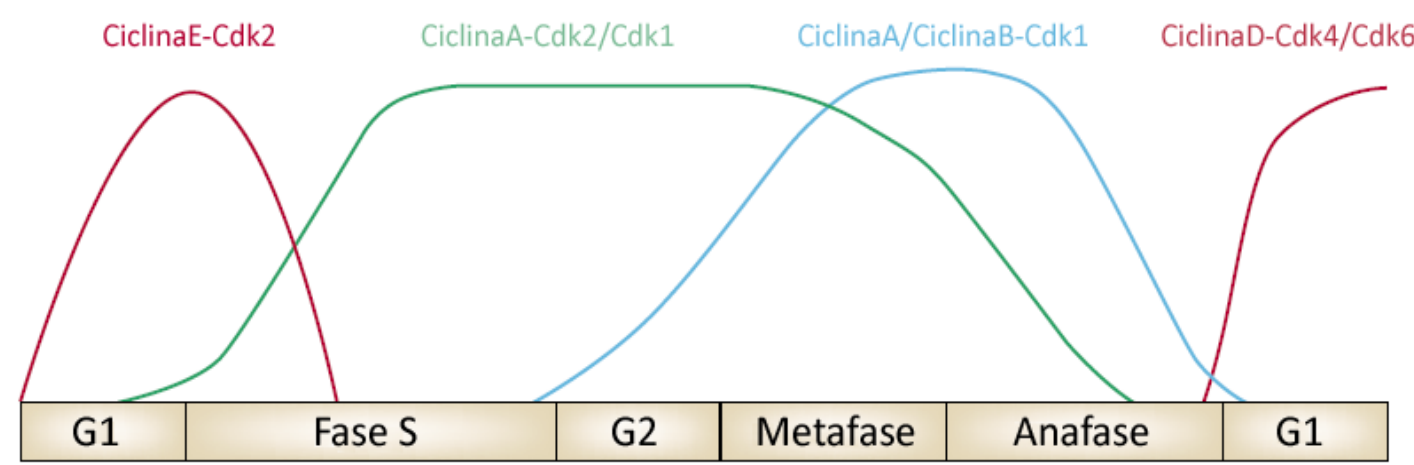

Figura 6: Actividad de los complejos CDK-Ciclina en las distintas fases del ciclo celular en células eucariotas. En el esquema se observa como fluctúa la actividad de los distintos complejos CDK-Ciclina a lo largo del ciclo celular. En la parte superior se detallan las distintas holoenzimas que se forman en cada punto del ciclo. El símbolo (?) indica que CDK2-CiclinaE es sugerido como participante en la regulación del inicio de la replicación. Modificado de Bardin, A.J., and Amon, A. (2001). Men and sin: what's the difference? Nat Rev Mol Cell Biol 2, 815-826 ${ }^{167}$. 
Las ciclinas modulan positivamente la actividad de las diferentes CDKs a lo largo del ciclo, para lo cual deben expresarse y unirse a ellas en el momento del ciclo idóneo y desaparecer cuando son prescindibles (Figura 6). Las células eucariotas poseen un sistema que ayuda a la regulación de la degradación de las mismas, este sistema es el de ubiquitinación y proteólisis en el proteosoma ${ }^{168}$.

Se ha identificado otra familia de proteínas que pueden unirse y regular positivamente a las CDKs, tanto en oocitos de Xenopus, como en células de mamíferos. Estas proteínas se denominan RINGO/Speedy ${ }^{169}$.

Proteínas inhibidoras de CDKs (CKIs)

Las proteínas CKIs participan en la parada del ciclo celular en respuesta a señales intrínsecas y/o extrínsecas al propio ciclo, como las relacionadas con procesos de senescencia, inhibición por contacto, señales antiproliferativas, o activación de un checkpoint ${ }^{170-171}$. En células de mamíferos se han distinguido dos familias de CKIs: la familia CIP/KIP que incluye a p21, p27 y p57 y la familia INK4 cuyos miembros comprenden a p15, p16, p18 y p19. Los miembros de la familia INK4 son específicos de CDKs de G1 (inhiben a CDK4 y CDK6 imposibilitando que se unan a las ciclinas o, cuando se han unido previamente, inhiben al complejo). Las proteínas de la familia KIP bloquean la actividad quinasa al unirse a diferentes complejos CDK-Ciclina (CDK2Ciclina E, CDK2-Ciclina A, CDK1-Ciclina A, CDK1-Ciclina B y, posiblemente, CDK4-Ciclina D y CDK6-Ciclina D) $)^{171-172}$.

\subsubsection{Regulación en la entrada y salida de Mitosis}

Debido a los resultados obtenidos en este trabajo haremos especial mención a la regulación de la entrada y salida de mitosis durante el ciclo celular, así como el papel que juegan las CDKs mitóticas y otras enzimas que regulan a éstas, y al conjunto del proceso.

\subsubsection{Regulación de la entrada en Mitosis}

\section{Regulación de la entrada en mitosis por los complejos CDK}

La entrada en mitosis corresponde al periodo del ciclo celular comprendido desde el final de G2 hasta prometafase (incluida), y se caracteriza por numerosas modificaciones a nivel molecular y morfológico: ruptura de la membrana nuclear, separación de centrosomas y ensamblaje del huso mitótico, condensación cromosómica, fragmentación del aparato de Golgi, etc. Los complejos CDK-Ciclinas durante la fase de mitosis tienen como subunidad catalítica a CDK1 que se une inicialmente a Ciclina A y, con gran relevancia, a Ciclina B. Existen diferentes sistemas que se complementan para regular las CDKs mitóticas: localización subcelular de los complejos, procesos de fosforilación/desfosforilación, auto-amplificación de la actividad CDK mitótica y participación de otras enzimas como las CKIs.

- Localización subcelular de los complejos: la localización subcelular de Ciclina A es predominantemente nuclear, donde se acumula desde la fase $S$ hasta el final de prometafase, 
siendo esencial para la transición $\mathrm{G} 2 / \mathrm{M}^{173-174}$. Con la entrada de Ciclina $\mathrm{B}$ en el núcleo al final de la profase, Ciclina A es dispensable y degradada antes del desglose de la envoltura nuclear ${ }^{173,175}$. El complejo CDK1-Ciclina A regula procesos tempranos como la condensación cromosómica, acúmulo de Ciclina B, regulación positiva de CDC25B y CDC25C ${ }^{173,176}$, inhibición de WEE ${ }^{177}$ e inhibición de $A P C^{\text {Cdh1 }}$ que provoca el acúmulo de sus sustratos PLK1 y Ciclina $B 1^{178-179}$.

Los complejos CDK1-Ciclina B son fundamentales en la transición G2/M pues son capaces de inducir la mitosis en células de vertebrados, por ello se denominan Factor Promotor de Mitosis (MPF). La activación de los complejos CDK1-Ciclina B se inicia al final de G2 en los centrosomas (esta localización es favorecida por la quinasa Aurora A) y se completa posteriormente en el núcleo al inicio de mitosis ${ }^{180-181}$. El mecanismo por el cual se produce el acúmulo de Ciclina $B$ en el núcleo durante las transición $\mathrm{G} 2 / \mathrm{M}$ no se ha esclarecido totalmente, se sugiere la necesidad de la fosforilación del residuo de señal de retención citoplasmática (CRS), interacción con la Ciclina F, o la disociación del complejo SCF ${ }^{\mathrm{NIPA}}$ durante esta etapa (ya que este complejo induce la ubiquitinación y degradación nuclear de la Ciclina B durante el resto del ciclo) ${ }^{182}$.

- Procesos de fosforilación y desfosforilación: durante la fase G2, los complejos CDK mitóticos requieren la fosforilación activadora del residuo T161 situado en la región T-loop de CDK1. Esta

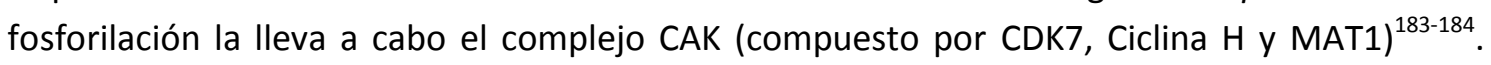
CAK puede ser inhibida por p21 en respuesta a daño al DNA ${ }^{185}$.

La fosforilación de los residuos T14 y Y15 de CDK1, situados en la región de unión al ATP, tiene un efecto inhibidor sobre la actividad de los complejos CDK mitóticos, al contrario que su desfosforilación. Las quinasas encargadas de la fosforilación inhibidora en células humanas son WEE1 (fosforila el residuo Y15) y MYT1 (fosforila los residuos T14 y Y15) ${ }^{186-187}$. WEE1 lleva a cabo su función en el núcleo y MYT1 se encuentra asociada a la membrana citoplasmática. Ambas quinasas son activas durante interfase y se inhiben en la transición G2/M. Para su inactivación, WEE1 es poliubiquitinada por complejos $\operatorname{SCF}^{188}$ y MYT1 es hiperfosforilada durante la fase M por la quinasa PLK1 ${ }^{189}$.

WEE1 en coordinación con la quinasa CHK1, participa en el control de la replicación del DNA, la condensación de los cromosomas, y la entrada anafase. El papel de WEE1 es la ralentización y/o bloqueo de estos procesos para afianzar la estabilidad e integridad del DNA ${ }^{190}$. La inhibición de WEE1 conduce a estrés en replicación y pérdida de la integridad genómica ${ }^{191-}$ ${ }^{192}$.La capacidad de WEE1 para regular la progresión del ciclo celular ha llevado al estudio clínico para el tratamiento de diversos tumores: se ha descrito la efectividad de combinar la inhibición de WEE1 con agentes que provocan daño al DNA (químicos o radiación), principalmente en aquellos casos donde p53 estuviera mutado ${ }^{193-197}$. Los agentes químicos para la inhibición de WEE1 utilizados en los anteriores estudios fueron PD0166285 ${ }^{198}$ y MK$1775^{199}$. Con respecto a la relación de WEE1 con CHK1, se ha demostrado que la inhibición de ambos componentes causa un efecto sinérgico ${ }^{200}$.

Las proteínas de la Familia CDC25 son fosfatasas activadoras que desfosforilan los residuos T14 y Y15 de CDK1 a la entrada en mitosis ${ }^{201}$. Existen tres isoformas de CDC25 en las células 
humanas: CDC25A, CDC25B y CDC25C. Los distintos componentes de la familia no solo juegan un papel regulador en la transición $\mathrm{G} 2 / \mathrm{M}$, sino también en la de $\mathrm{G} 1 / \mathrm{S}$. Se ha descrito la implicación de CDC25B y CDC25C en la regulación de la entrada en fase $S^{202-203}$. CDC25B participa en la activación de complejos CDK-Ciclina $A$ en el núcleo durante $\mathrm{G}^{204}$ y ya durante la transición $\mathrm{G} 2 / \mathrm{M}$, tiene un papel importante como iniciador de la activación de los complejos CDK1-Ciclina B1 en centrosomas ${ }^{180-181,205}$. Se cree que CDC25A está implicada en la regulación de los complejos CDK1-Ciclina B1 a la entrada en mitosis induciendo la condensación de los cromosomas $^{206}$.

La inhibición de las fosfatasas CDC25, de WEE1 y MYT1 impide la correcta activación CDK1Ciclina B1 y, por ende, la fosforilación de sus sustratos, lo que conduce al colapso mitótico ${ }^{207}$.

- Mecanismo de auto-amplificación de la actividad CDK mitótica: auto-amplificación consiste, tanto en la regulación positiva de las fosfatasas activadoras de los complejos CDK mitóticos (CDC25A, CDC25B y CDC25C), como en la regulación negativa de la quinasa que los inhiben, WEE1 (a través de su fosforilación por parte de los propios complejos CDK1-Ciclina B1 a la entrada en mitosis). Todo ello conduce a un sistema de retroalimentación positiva de la actividad CDK1-Ciclina B1.

- Regulación de los complejos CDK mitóticos por parte de CKIs: los inhibidores de quinasas dependientes de ciclinas (CKIs) son proteínas que generalmente se unen a los centros catalíticos de los complejos CDKs inhibiéndolos de esta manera. Se han descrito números miembros que perteneces a esta clase de proteínas: p16, p15p18, p19, p21, p27, p57. Debido a la relevancia en los resultados de la tesis destacamos los CKIs p21 y p27. Se ha descrito que la proteína p21 ejerce una función reguladora sobre los complejos CDK mitóticos durante la transición G2/M en un ciclo celular normal o en respuesta a la activación de un checkpoint. En respuesta a daño al DNA, p21 tiene un efecto inhibidor sobre CDK1 que puede ocurrir por diversos mecanismos: a través del bloqueo de la fosforilación activadora en el residuo T161 ${ }^{185}$. O bien a través de la inhibición del mecanismo de auto-amplificación de la actividad de los complejos, al impedir la activación de CDC25C por parte de CDK1 ${ }^{208}$. En cuanto a p27, se ha demostrado ampliamente su acción inhibitoria sobre los complejos CDK-Ciclina que forman CDK2 y CDK4 participando en la regulación de la fase del ciclo celular G1; de hecho su sobreexpresión provoca el bloqueo en dicha fase ${ }^{209}$. Mediante ensayos in vitro, se ha puesto de manifiesto la capacidad de p27 de inhibir la actividad de CDK1 participando en la regulación de la transición $\mathrm{G} 2 / \mathrm{M}^{209-210}$.

Regulación de la entrada en mitosis por otras quinasas

En la regulación de la entrada en mitosis participan otras proteínas diferentes a las CDK mitóticas. Estas proteínas participan en la regulación directa de estos complejos (como se ha explicado en varios puntos anteriormente), de manera indirecta o independientemente.

- PLK1: se trata de un quinasas de tipo serina/treonina perteneciente a la familia Polo. En la transición $\mathrm{G} 2 / \mathrm{M}$, se localiza en los centrosomas y participa en su maduración favoreciendo la formación del huso mitótico ${ }^{211}$. Durante la mitosis, PLK1 juega un papel importante al nivel de 
los cinetocoros, a los que han de unirse los microtúbulos durante el ensamblaje del huso mitótico para garantizar una correcta segregación cromosómica ${ }^{212-213}$. En vertebrados, PLK1 fosforila la subunidad SCC1 de las cohesinas (proteínas que mantienen la cohesión entre cromátidas hermanas), lo que permite la disociación entre las cromátidas ${ }^{214}$. También participa en la activación de los complejos CDK mitóticos: favoreciendo el acúmulo de CDK1-Ciclina B en el núcleo al fosforilar el residuo CRS $^{215}$, promoviendo la degradación de WEE1 (PLK1 y CDK1 fosforilan los residuos S53 y S153, respectivamente lo que provoca su degradación por SCF) ${ }^{216-}$ ${ }^{217}$, fosforila e inactiva a MYT1 a la entrada de mitosis ${ }^{189}$ e induce la activación y entrada en el núcleo de CDC25C (previamente fosforilado por CDK1) 216,218-219. Por otra parte, las quinasas PLK1 también están implicadas en rutas de checkpoint, ya que son inactivadas en presencia de daño al DNA $220-221$.

- Furry: durante la mitosis temprana, Furry (FRY) se une a PLK1 junto a Aurora A y promueve la fosforilación del residuo T210 de PLK1. Ello activa a PLK1 y permite la organización del centrosoma así como el establecimiento del patrón bipolar del huso mitótico ${ }^{222}$.

- Aurora A: La proteína Aurora A desempeña un papel esencial en la transición G2/M a través de la regulación de los centrosomas, el ensamblaje del huso mitótico y la activación de los complejos CDK mitóticos ${ }^{223-224}$. Al final de G2, participa en la maduración de centrosomas mediante el reclutamiento y/o fosforilación de proteínas como la $\gamma$-Tubulina favoreciendo la nucleación de los microtúbulos. Además, está implicada en la separación de los centrosomas durante $\mathrm{G} 2 / \mathrm{M}^{225}$. También participa en la activación de los complejos CDK1-Ciclina B1 en la transición $\mathrm{G} 2 / \mathrm{M}$, promoviendo su localización en centrosomas y la activación de CDC25B localizada en los mismos ${ }^{226-227}$. La regulación y posterior degradación de Aurora $A$ es orquestada por los complejos SCF mediante poliubiquitinación ${ }^{228-229}$.

-Aurora B: está implicada en modificaciones de cromatina relacionadas con el inicio de la condensación cromosómica, en la regulación de la unión de los cromosomas al huso mitótico y, ya a la salida de mitosis, en el checkpoint del huso mitótico y en la citocinesis ${ }^{223}$. Respecto a su efecto sobre la condensación cromosómica, Aurora B es la principal quinasa encargada de la fosforilación de la Histona H3 en el residuo Ser10, condición necesaria para que se inicie la condensación ${ }^{230}$. Por último, Aurora B, al igual que PLK1, también participa al inicio de mitosis en la fosforilación de una subunidad de las cohesinas en los brazos de los cromosomas, promoviendo su disociación de los mismos ${ }^{214,231}$.

- CHK1: En las células de vertebrados, la proteína CHK1 es un componente esencial en la activación de muchos tipos de checkpoints. Sin embargo, esta quinasa también parece desempeñar funciones importantes en la regulación del ciclo celular independiente a estos puntos de control ${ }^{232}$. En este sentido, se ha demostrado que durante interfase $\mathrm{CHK} 1$ se localiza en los centrosomas, donde previene la activación prematura de CDK1-Ciclina B1 a través de la fosforilación de $C D C 25 B^{233-234}$. CHK1 también parece inhibir la actividad de CDC25A sobre los complejos CDK1-Ciclina B1, lo que conlleva a la inhibición de las CDK mitótica e impide una prematura entrada en mitosis ${ }^{235}$. Para la correcta organización de los cinetocoros y establecimiento del patrón bipolar del huso, CHK1 regula a Aurora $\mathrm{B}^{232}$. Por último, conviene recordar el papel que puede jugar junto a WEE1 en la ralentización de la replicación del DNA, condensación cromosómica y entrada en anafase ${ }^{190}$. 


\subsubsection{Regulación de la salida de Mitosis}

Si bien una elevada actividad CDK mitótica ha sido necesaria para la entrada en mitosis y la progresión por sus primeras fases (hasta alcanzar metafase), la salida de mitosis se caracteriza por una bajada drástica de esta actividad CDK. Existen dos mecanismos principales que gobiernan la progresión a través de estas últimas etapas de la mitosis: la desfosforilación ordenada de sustratos fosforilados principalmente por CDK1 (aunque también por otras quinasas mitóticas) y la destrucción también ordenada de proteínas por el complejo $\mathrm{APC} / \mathrm{C}^{236}$ (Figura 8, página 31). Las fosfatasas encargadas de desfosforilar a los distintos sustratos de CDK1 a la salida de mitosis pueden ser fosfatasas generales (como PP1 o PP2A) o específicas (como las proteínas CDC14). La degradación ordenada de diversas proteínas por el proteasoma parece esencial para que tenga lugar la correcta salida de mitosis en células eucariotas. La degradación de proteínas durante la mitosis parece estar regulada principalmente por el complejo APC/C, que poliubiquitina proteínas, marcándolas de este modo para su destrucción por parte del proteosoma 26S. La importancia de la función desempeñada por APC/C en mitosis se pone de manifiesto al demostrarse que su inactivación genética es letal en todas las especies en las que se ha investigado ${ }^{237}$.

\subsection{SISTEMA UBIQUITINA-PROTEOSOMA (UPS)}

A lo largo del capítulo anterior hemos visto el papel central que juega la actividad CDK en la progresión del ciclo celular y cómo se regula mediante procesos de fosforilación y desfosforilación (WEE1, MYT1 y CDC25), así como unión de cofactores (ciclinas) y acción de otras proteínas que participan en control de la actividad (CKIs, PLK1, etc). También hemos visto que la degradación de los reguladores es un mecanismo que permite alcanzar la homeostasis celular y una correcta progresión del ciclo celular en su conjunto y en cada una de sus etapas. La proteólisis es un mecanismo útil pues se trata de un proceso irreversible que fuerza al ciclo hacia una única dirección; por lo que cada ciclo requiere la síntesis de nuevo de cada regulador. La degradación proteica debe ser un mecanismo perfectamente coordinado, eficiente y rápido en su ejecución para asegurar que ocurre en el punto de tiempo exacto del ciclo. Para ello, las células eucariotas poseen una maquinaria que permite controlar la degradación proteica de manera eficiente, el Sistema Ubiquitina-Proteosoma (UPS): las ubiquitinas ligasas regulan qué proteína debe ser degrada y en qué momento, y el proteosoma es el brazo ejecutor de la proteólisis (Figura 7). La desregulación de este sistema provoca inestabilidad genómica, descontrol del ciclo celular y cáncer ${ }^{238}$.

\subsubsection{Complejos Ubiquitina Ligasas}

Las enzimas ubiquitina ligasas tienen como función principal marcar a las proteínas con la unión covalente de varias moléculas de ubiquitina. La poliubiquitinación conduce a las proteínas al proteosoma $26 \mathrm{~S}$ para su proteólisis. El hallazgo y explicación del modelo sirvió para el reconocimiento con el Nobel de Química del 2004 a Aaron Ciechanover, Avram Hershko e Irwin Rose.

La ubiquitina es un polipéptido muy conservado de 76 aminoácidos de aproximadamente 8.5KDa. Es el resultado de varios genes con distinta localización en el genoma (UBA, UBB y 
$U B C)$ y un conjunto de modificaciones postraducionales que generan una ubiquitina libre ${ }^{239}$ (Figura 7). Esta proteína se caracteriza por siete residuos de lisina (K6, K11, K27, K29, K33, K48 y K63) y una glicina (G76) situada en la cola C-terminal. Estos residuos están altamente conservados y juegan un papel esencial en la unión al sustrato y en la generación de cadenas poliubiquitinadas ${ }^{240-241}$.

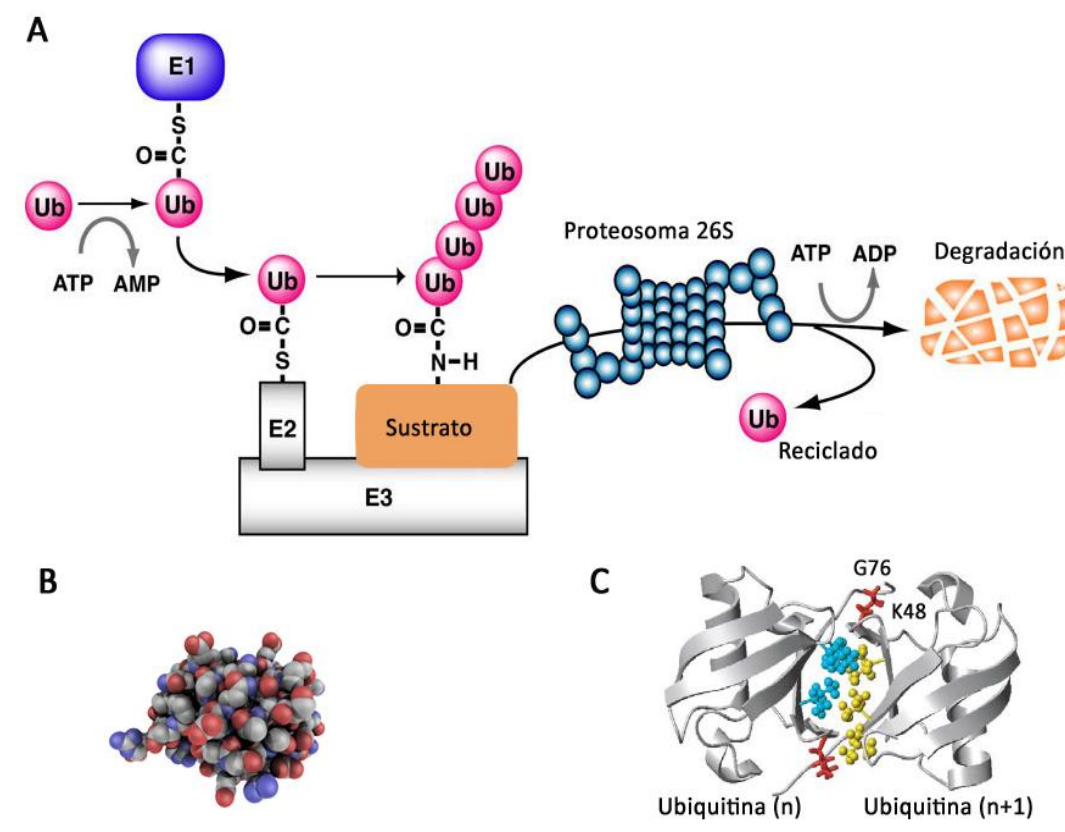

Figura 7: Sistema Ubiquitina-Proteosoma (UPS). A Esquema de la vía UPS: activación de la ubiquitina por la enzima E1, trasmisión de ubiquitina al sustrato (mediante E2 y E3), formación de la cadena poliubiquitinada y traspaso al proteosoma para la degradación del sustrato. Las ubiquitinas liberadas al proceso son recicladas para un nuevo ciclo. B Estructura tridimensional de la molécula de ubiquitina: en gris átomos de carbono, rojo los de oxígeno y azul los de nitrógeno. C Enlace isopeptídico entre dos moléculas de ubiquitina, la lisina48 (k48) de la segunda molécula " $n+1$ " se une a la glicina76 (G76) de la primera molécula de ubiquitina " $n$ ". Modificadas de Nakayama, K.I. \& Nakayama, K. (2006) Ubiquitin ligases: cell cycle control and cáncer. Nat Rev Cancer 6, 369-381 y Pickart, C.M. \& Fushman, D. (2004) Polyubiquitin chains: polymeric protein signal. Curr Opin Chem Biol 8, 610-616 $238,241$.

La adición de residuos de ubiquitina a la proteína diana, ubiquitinación, es un proceso postraducional altamente específico que requiere la actividad de tres clases de enzimas: una enzima activadora de ubiquitina (E1), una ubiquitina conjugante (E2) y una ubiquitina ligasa (E3).

La proteína E1 activa la molécula de ubiquitina al formar un enlace tioéster entre un residuo de cisteína de su centro activo y el residuo de glicina (G76) del extremo carboxilo terminal de la ubiquitina, consumiendo ATP. Normalmente, cada organismo eucariótico presenta un solo tipo de $E 1$, sin embargo existen excepciones en plantas ${ }^{240}$. A continuación, la ubiquitina activada se transfiere a un residuo de cisteína del sitio activo de la enzima E2, formándose un nuevo enlace tioéster. Las E2 actúan de puente entre E1 y E3. El mecanismo de acción de E2 depende del tipo de E3 con el que interaccionen: si E3 es de tipo HECT, E2 recibe la ubiquitina de E1 y luego la cede a E3. Si E3 es de tipo RING, E2 transfiere la ubiquitina directamente al sustrato (los tipos de proteínas E3 serán explicados posteriormente). En mamíferos existen entre $30 \mathrm{y}$ 40 E2 diferentes y cada uno de ellos interacciona con varios E3. E2 interviene, en cierto grado, en la especificidad de la ligación de ubiquitina al sustrato ${ }^{242-243}$. Por último, la ubiquitina se 
acopla al grupo $\varepsilon$-amino de un residuo de lisina de la proteína a marcar, a través de un enlace isopeptídico, gracias a la actividad conjunta de E2 y la ubiquitina ligasa E3, quien confiere especificidad de sustrato (Figura 7).

La elongación de las cadenas de poliubiquitina se consigue mediante el establecimiento de un enlace isopeptídico entre el residuo G76 carboxilo terminal de la ubiquitina " $n+1$ " con el grupo $\varepsilon$-amino de un residuo de lisina de la ubiquitina anterior "n" (Figura 7, C). Dado que cada molécula de ubiquitina contiene siete residuos de lisina, se puede generar una gran variedad de cadenas de poliubiquitina desde el punto de vista morfológico, con distintas funciones celulares. La degradación por el proteosoma depende, principalmente, de cadenas unidas a través de $K 48^{244}$. Para que el proteosoma pueda reconocer las cadenas de poliubiquitina, éstas deben tener una longitud mínima de cuatro moléculas, aunque algunos sustratos presentan cadenas mucho más largas ${ }^{245}$. Esto implica que la E3 debe permanecer unida al sustrato el tiempo suficiente para procesarlo varias veces, o bien, necesita varios encuentros sucesivos con éste antes de marcarlo para su destrucción. Por ello, tanto la actividad de la E3 como su capacidad para reconocer sustratos resultan factores limitantes del proceso de poliubiquitinación, aunque no son los únicos, pues también influye la actividad de las enzimas des-ubiquitinantes (DUBs), las cuales revierten el efecto de las E3 ${ }^{246}$.

\subsubsection{Clasificación de las Ubiquitina Ligasas E3}

Las E3 se clasifican en cuatro clases principales, en función del motivo estructural que las caracteriza: tipo HECT, tipo RING-finger, tipo U-box y tipo PHD-finger (Tabla 2):

- Ligasas con dominios HECT ("homologous to E6-AP carboxy terminus") ) $^{247}$ conjugan directamente la ubiquitina activada con el sustrato formando un enlace tioéster con ella.

- Ligasas con dominios de dedos RING ("really interesting new gene") poseen un dominio formado por 40-100 aminoácidos con 8 residuos de cisteína e histidina muy conservados que coordinan dos átomos de $\mathrm{Zn}$ en una estructura de abrazaderas cruzadas ${ }^{248}$. Este subtipo de E3 ligasas no transfieren directamente la ubiquitina al sustrato sino que lo hacen de manera indirecta, activando de forma alostérica a la E2, de modo que, junto con otras proteínas como la culina, conforman un armazón sobre el cual la ubiquitina activada se transfiere de la E2 directamente al sustrato. Dentro de este grupo existen dos subclases: las que contienen en un mismo polipéptido los dominios de dedos RING y los dominios de unión al sustrato, y las de tipo ligasas RING-finger con culina (CRL, "Cullin-containing RING-finger E3 ligases") en las que el sustrato se une a una proteína intermedia, llamada culina, por medio de diversos adaptadores.

Cada subtipo de complejo CRL se compone de un núcleo del que forman parte un miembro de la familia culina (CUL1, 2, 3, 4A, 4B, 5 o 7 en humanos, cada uno codificado por un locus distinto) estrechamente unido a la proteína RING-finger, RBX1 (también llamada ROC1) o RNF7 (también llamada RBX2 o ROC2). Esta base estructural conforma un armazón alargado cuya finalidad es hacer de ensamblaje de las actividades enzimáticas y el sustrato. El extremo Cterminal de la proteína RING-finger (RBX1 o RNF7) se une a la E2 conjugada con una ubiquitina activada, mientras que su extremo $\mathrm{N}$-terminal permanece unido a un complejo multiproteico al que, a través de la culina y de diversos adaptadores, se une el sustrato ${ }^{249}$.Los complejos CRL 
comprenden una amplia variedad de posibilidades de ensamblaje, que se diferencian principalmente en la culina que forma la base del armazón y, especialmente, en el receptor de sustrato, que es el elemento que determina la "elección" de la proteína que será marcada con ubiquitina para ser degradada. Esto último se traduce en una enorme variedad de sustratos que serán regulados de manera específica ${ }^{250}$.

\begin{tabular}{cccc}
\hline Tipos de E3 ligasas & $\begin{array}{c}\text { Subtipos=RING- } \\
\text { finger+Scaffold+ } \\
\text { Adaptador }\end{array}$ & $\begin{array}{c}\text { Proteínas } \\
\text { box } \\
\text { (receptores) }\end{array}$ & Sustratos descritos \\
\hline
\end{tabular}

$>$ Con dominio HECT

Con dominio RING-finger

Con dominio U-box

Con dominio PHD-finger

Tabla 2: Clasificación de las Ubiquitina Ligasas E3. Se especifica los cuatro subtipos principales, detallando aquellos que más nos interesan para explicar los resultados de la tesis, E3 RING-finger. Dentro de las cuales, podemos establecer una subdivisión que diferencia las CRL (SCF, EVC, CUL3, CUL4, ECS y CUL7) que jugaran un papel central en nuestra investigación, y el resto de las RING-finger (APC/C).

- Ligasas con dominios U-box ${ }^{251}$, componen una familia menor de complejos de estructura similar a las E3 ligasas RING-finger pero que carecen de los residuos quelantes de metal típicos de los dominios de dedos RING. 
- Ligasas con dominio PHD-finger que se caracterizan por tener un dominio de unión con dos átomos de $\mathrm{Zn}$ similar al de las RING ligasas. Median junto a las E2 la ubiquitinación de los sustratos $^{252}$. Un ejemplo de estas ligasas es PHF9, cuya deficiencia juega un papel importante en la Anemia de Fanconi ${ }^{253}$.

\subsubsection{Principales complejos con dominio RING-finger: SCF Y APC/C}

Los principales y más estudiados complejos E3 RING-finger son SKP1/CUL1/F-box (SCF) y el Complejo Promotor de la Anafase o Ciclosoma (APC/C), ambos son esenciales en la destrucción de componentes de la maquinaria del ciclo celular ${ }^{238}$. Se considera que SCF permanece activo a lo largo de todo el ciclo celular ${ }^{254}$, mientras que APC/C lo está desde prometafase hasta el final de $\mathrm{G}^{255}$ ya que se encuentra inhibido por EMI1 en el resto del ciclo (Figura 8).

\subsubsection{1 $\underline{\mathrm{SCF}}$}

El complejo SCF está formado por tres componentes invariables: RBX1 (proteína con estructura RING-finger), CUL1 (proteína de andamiaje) y SKP1 (proteína pre-adaptadora), además de un componente variable, conocido como proteína F-box (proteína adaptadora). El componente variable se une a SKP1 y es responsable del reconocimiento de sustratos. Cabe destacar que la interacción entre la proteína F-box y los sustratos depende del estado de estos últimos (fosforilación, glicosilación, acetilación, hidroxilación, etc), de manera que para la proteólisis mediada por SCF resultan críticos tanto la disponibilidad de proteínas F-box, como las modificaciones de los sustratos ${ }^{238}$. En humanos, se han identificado aproximadamente 70 proteínas F-box, que se clasifican en tres categorías: FBXW (presentan repeticiones WD40), FBXL (presentan repeticiones ricas en leucina) y FBXO (con otros dominios estructurales diferentes). Destacan tres proteínas F-box involucradas en el control del ciclo celular:

- SKP2 ("S-phase kinase-associated protein 2") (FBXL1): marca para su degradación algunos reguladores negativos del ciclo celular, como p27, p21 y p57, promoviendo así la progresión del ciclo durante las fases $S$ y $\mathrm{G} 2$.

- FBW7 ("F-box and WD40 domain protein 7") (FBXW7): induce la degradación de reguladores positivos del ciclo celular, como MYC, JUN, Ciclina E y Notch.

- $\beta$-TRCP (" $\beta$-transducin repeat-containing protein") (FBXW1/11): es una proteína F-box versátil, pues reconoce algunos reguladores del ciclo celular como WEE1, EMI1/2 y CDC25A/B, además de sus sustratos clásicos $\beta$-Catenina e Іқß $\alpha$.

\subsubsection{2 $\underline{\mathrm{APC} / \mathrm{C}}$}

En la mayoría de eucariotas el complejo APC/C está formado por 13 proteínas diferentes, en general altamente conservadas. El núcleo se compone de las subunidades APC2 y el dominio RING-finger APC11, análogos de la culina y Rbx1 de los complejos SCF. El dominio C-terminal de APC2 está unido a APC11 y ambos catalizan la ubiquitinación, si bien este núcleo está desprovisto de selectividad de sustrato. Otro componente importante es la subunidad CAP1 que sirve da andamiaje para el complejo y contiene repeticiones en tándem, repeticiones que comparten las subunidades RPN1 y RPN2 del proteosoma. Todas ellas conforman las 
denominadas repeticiones proteosoma/ciclosoma que permiten la relación entre el complejo $\mathrm{APC} / \mathrm{C}$ y el proteosoma ${ }^{256-257}$.

Además de las E2, la actividad de APC/C en las células depende estrictamente de sus proteínas F-box (adaptadores), que se unen durante periodos específicos del ciclo celular. Los más conocidos son $\underline{\mathrm{CDC} 20}$ y $\underline{\mathrm{CDH} 1}$, aunque también se han identificado otros adaptadores específicos de meiosis. Estas proteínas se caracterizan por presentar tres elementos en su secuencia ${ }^{258}$ : La cola IR (dipéptido isoleucina-arginina) en el extremo C-terminal, que media la unión con $\mathrm{APC} / \mathrm{C}^{259}$. La secuencia C-box situada en el extremo N-terminal. En humanos, a diferencia de levaduras, no se necesita la C-box para la asociación de los activadores con $A P C / C$, pero se sugiere que interviene en el reconocimiento de sustratos ${ }^{260}$. $Y$ el dominio WD40, situado en el extremo C-terminal, está compuesto por repeticiones de 40 aminoácidos que contienen residuos de triptófano y aspártico en posiciones conservadas ${ }^{261}$. Generalmente, siete repeticiones WD40 se pliegan en una estructura con forma de hélice en la que cada repetición constituye un aspa. Se sugiere que este dominio reconoce a los sustratos de APC/C al interaccionar con unas secuencias consenso presentes en ellos denominadas D-box y KENbox $^{258,262}$.

La actividad de APC/C oscila a lo largo del ciclo celular, siendo baja en las fases S y G2, y elevada durante mitosis y G1. Estas oscilaciones son responsables, en gran medida, de la progresión del ciclo celular, desempeñando un papel crucial en la transición metafase-anafase y en la subsecuente fase G1 (Figura 8).

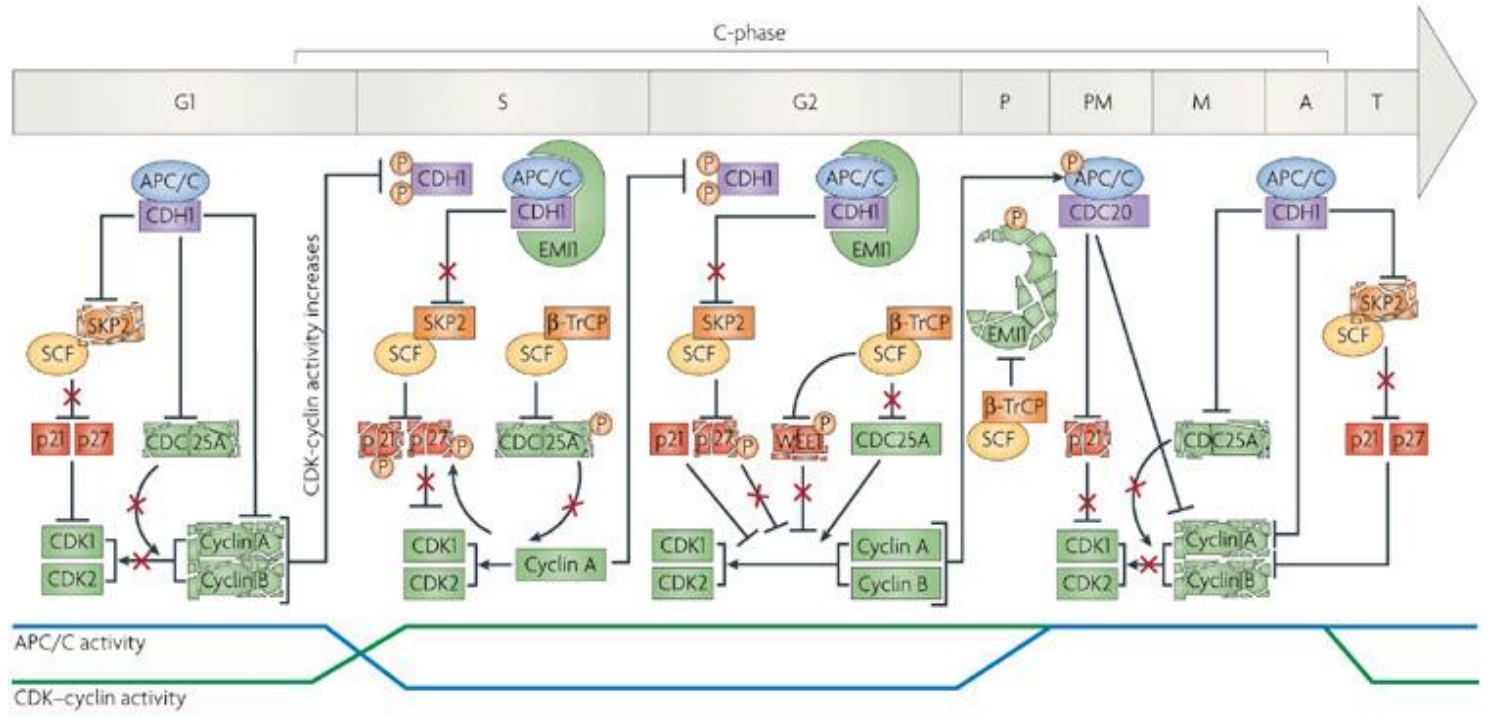

Figura 8: El Sistema Ubiquitin-Proteosoma (UPS) regula el ciclo celular. Descripción de las diferentes fases del ciclo celular en las que interviene los complejos E3 RING-finger SCF y APC/C. Se detalla la oscilación de los niveles de actividad de CDK-Ciclinas frente a los niveles de actividad de los complejos APC/C. Reproducido de Frescas, D., and Pagano, M. (2008). Deregulated proteolysis by the F-box proteins SKP2 and beta-TrCP: tipping the scales of cancer. Nat Rev Cancer 8, 438-449 $9^{263}$. 


\subsubsection{Regulación de los complejos Cullin Ring Ligasas (CRL)}

En la regulación de los complejos CRL participa un amplio conjunto de variables que actúan a varios niveles: la unión específica al sustrato y el estado del propio sustrato, síntesis y disposición de cada uno de los componentes del complejo (proteínas de andamiaje, preadaptadores, adaptadores, proteínas RING...) varios de ellos relacionados y sometidos a degradación por otros complejos de UPS, etc. Además, la regulación de los CRL es modulada y específica en cada fase del ciclo celular. Por todo ello sería demasiado ambicioso querer explicar en este apartado todo el organigrama de su regulación. No obstante, se resumirán los factores más relevantes para la formación y regulación del macro-complejo proteico CRL:

- Nedilación (unión reversible de la proteína NEDD8): todas las culinas estudiadas son susceptibles de ser nediladas, es decir, que se les una covalentemente NEDD8 (una proteína de tipo ubiquitina). La unión tiene lugar en una lisina (K) de una región homóloga entre las diferentes culinas y la glicina 76 (G76) del extremo C-terminal de NEDD8. El sistema de nedilación parte de la maduración del precursor NEDD8. Tras la traducción, la Gly76 no se encuentra accesible de modo que una C-terminal hidrolasa, $\mathrm{UCH}-\mathrm{L}^{264}$ entre otras, cortará la proteína y expondrá el residuo. Tras la maduración, NEDD8 es activado por una E1 con gasto de $\mathrm{ATP}^{265}$. Específicamente la proteína $\mathrm{E} 1$ es un heterodímero formado por las subunidades UBA3 y APPBP $1^{266}$ que se denomina enzima activadora de NEDD8 (NAE). Este complejo carga la NEDD8 activada a una E2 específica, Ubc12 ${ }^{267}$. Finalmente con la participación de una E3 ligasa se trasfiere el NEDD8 activado al sustrato final, la culina a activar. La E3 que realiza esta función no es específica como E2, existe cierta controversia entre cuales de las E3 descritas pueden llevar a cabo la función (Figura 9, A).

Se ha demostrado que la nedilación potencia la actividad ubiquitin-ligasa in vitro, e in vivo se ha demostrado que es esencial desde levaduras hasta ratones (con la excepción de $S$. Cerevisiae $)^{268}$. In vivo, se ha detectado que sólo una fracción del conjunto total de las culinas está nedilada, lo que indica que tal vez sólo un subconjunto de las moléculas está en plena actividad. La unión de NEDD8 a las culinas es reversible, la liberación se realiza mediante un proceso denominado denedilación. La denedilación la lleva a cabo el signalosoma COP9 $(\mathrm{CSN})^{269-270}$. CSN también regula las CRL mediante el reclutamiento de la enzima desubiquitinante UBP12, que inactiva al complejo CRL y favorece la renovación de sus componentes $^{271}$. La denedilación de las culinas disminuye el reclutamiento y la activación de las proteínas que constituyen los complejos CRL (Figura 9, B).

Actualmente existe un inhibidor del proceso de nedilación, el fármaco MLN4924 de Millennium Pharmaceuticals, Inc (Takeda Oncology Company, Cambridge, MA, USA) ${ }^{272}$. Se interpone entre NEDD8 y la NAE, impidiendo la acción de esta segunda para que active al primero. MLN4924 inhibe la acción de UBA3 al bloquearlo específicamente por su similitud a la molécula de $A M P$, lo que inactiva el núcleo catalítico de $N A E^{272}$. Consecuentemente es interrumpida la ruta de nedilación, la activación de las culinas y, por consiguiente, la activación de los complejos $\mathrm{CRL}^{273}$. Otros autores defienden que además se une covalentemente con NEDD8 ${ }^{274}$ imposibilitando su activación por el complejo NAE. Se está evaluando en numerosos ensayos preclínicos ${ }^{272-273,275-286} \mathrm{y}$, según el portal "web" clinicaltrials.gov (service of the U.S. 
National Institutes of Health), en varios ensayos clínicos de este fármaco frente a diversas neoplasias se están hallando resultados favorables.

- Secuestro de las culinas denediladas: CAND1 (también conocido como TIP120A) fue identificado recientemente como una proteína que interactúa con CUL1 ${ }^{287-288}$. Existe controversia sobre la especificidad de CAND1 ya que se ha descrito la unión con todas las culinas excepto CUL7. CAND1 compite con SKP1 para la unión a CUL1, y sólo se une a ésta cuando CUL1 no tiene conjugada NEDD8. Destacamos que la unión de NEDD8 a la culina o la presencia de SKP1 complementada con altas concentraciones de ATP ${ }^{288}$ pueden provocar la disociación de CAND1 y la culina (Figura 9, B).

A

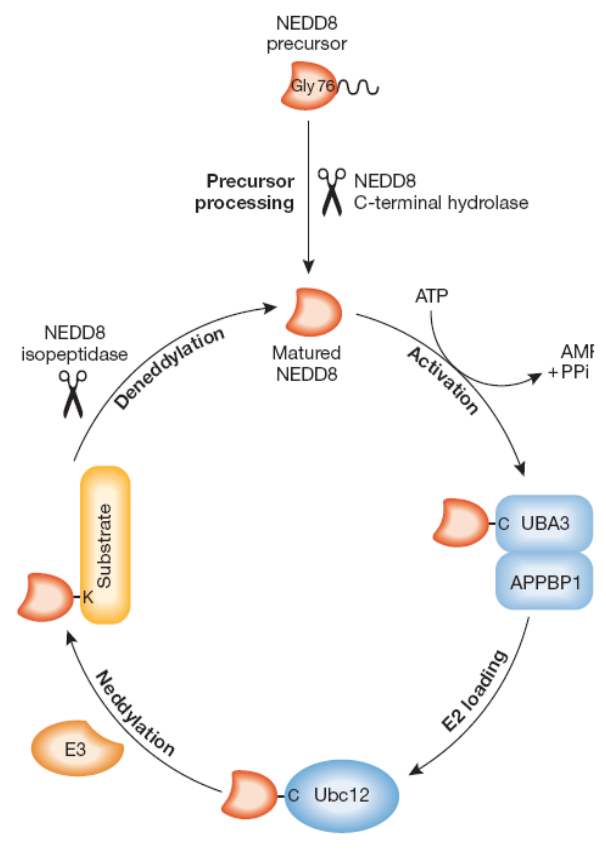

B

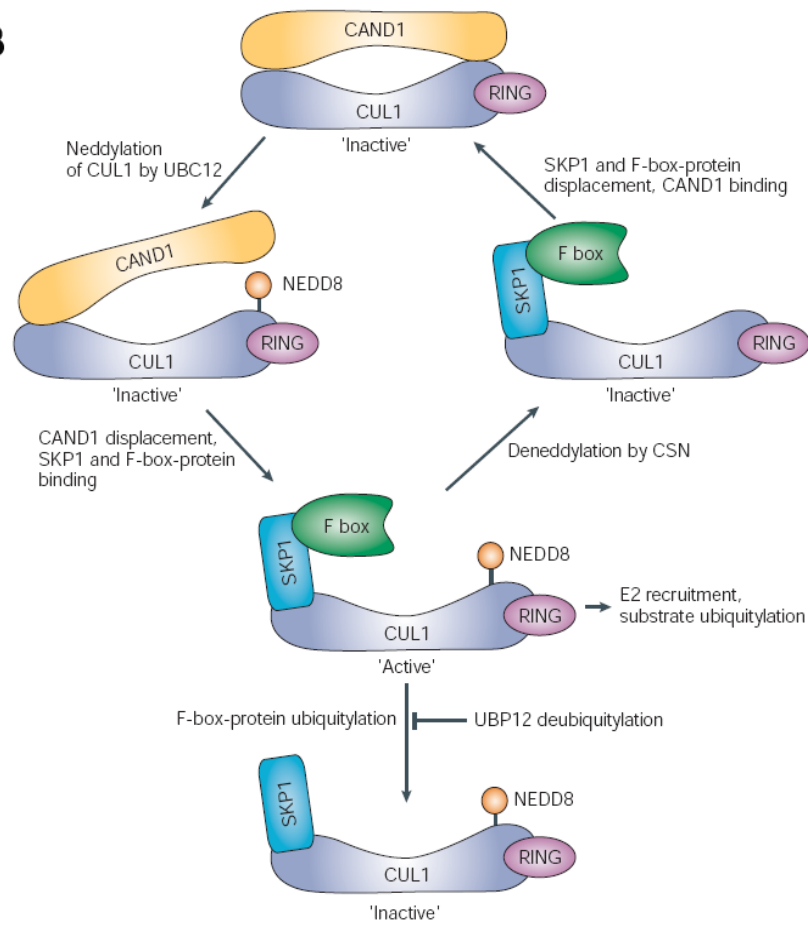

Figura 9: Regulación de la actividad de los complejos CRL. A Vía de la nedilación, la enzima NAE (heterodímero compuesto por las subunidades UBA3 y APPBP1) activa NEDD8. Reproducido de Rabut, G., and Peter, M. (2008). Function and regulation of protein neddylation. 'Protein modifications: beyond the usual suspects' review series. EMBO Rep 9, 969-976 ${ }^{289}$. B Regulación de complejos CRL mediante nedilación/denedilación y la participación de las proteínas CAND1, CNS y UBP12. Reproducido de Petroski, M.D., and Deshaies, R.J. (2005). Function and regulation of cullin-RING ubiquitin ligases. Nat Rev Mol Cell Biol 6, 9-20 ${ }^{268}$.

- Dimerización de las proteínas F-box (adaptadores): las proteínas que reconocen al sustrato pueden formar dímeros que incrementa el abanico de sustratos a los que ligarse o modular la unión a ellos. Las F-box forman dímeros a través de un pequeño dominio llamado D-domain, situado en el extremo $\mathrm{N}$-terminal formado por aproximadamente 40 aminoácidos capaces de crear una estructura tridimensional de tres $\alpha$-hélices que permiten la unión dimérica. Un factor importante en la regulación del reconocimiento de sustratos por parte de los CRLs es la orientación espacial del dímero que forman, fruto de la unión de sus dominios F-box ${ }^{290-291}$.

- Pseudosustratos que pueden regular la función de CRL: en mamíferos, se identificó la proteína nuclear heterogénea ribonuclear-U (hnRNP-U) como pieza clave en la regulación de la función los CRL con la F-box $\beta$-TrCP ${ }^{292}$. En el núcleo hnRNP-U compite con IkB fosforilada para 
unirse al complejo SFC ${ }^{\beta-T r C P}$. IKB es un sustrato de este complejo pero tiene menor afinidad con él que hnRNP-U. hnRNP-U no es ubiquitinada cuando se une al complejo SFC ${ }^{\beta-T r C P}$, además no interfiere en la unión de éste con otros sustratos con los que tiene mayor afinidad. Por lo que se sugiere que hnRNP-U puede jugar un rol de regulador de la ubiquitinación basándose en la competencia por afinidad con los sustratos hacia el complejo SFC ${ }^{\beta-T r C P}$, como mínimo en el caso de IKB.

\subsubsection{Proteosoma 26S}

El proteosoma o proteasoma $26 \mathrm{~S}$ es un complejo multimérico extraordinariamente complejo cuya función primaria es la degradación de proteínas marcadas con cadenas de ubiquitina unidas a la K48, como ya se ha señalado. Esta degradación proteica es llevada a cabo de manera específica y eficiente mediante el consumo de ATP. La degradación mediada por el sistema UPS afecta a la mayoría de proteínas celulares, entre ellas, gran cantidad de proteínas reguladoras y aquellas mal sintetizadas o cuyas modificiones postraducionales son erróneas. Por ello, el proteosoma participa en la homeostasis, modulación del ciclo celular, apoptosis, diferenciación, respuesta inmune y metabolismo celular. ${ }^{293-294}$.

El proteosoma está formado por dos subcomplejos multiprotéicos con diferente funcionalidad, denominados 195 y $20 S$ según su coeficiente de sedimentación en centrifugación en gradiente de densidad. El núcleo catalítico con actividad proteasa es el 20S, su masa molecular aproximada es de $750 \mathrm{kDa}$ y presenta forma cilíndrica. El subcomplejo regulador es el 19S, con una masa aproximada de $700 \mathrm{kDa}$. El $20 \mathrm{~S}$ se une por sus extremos a uno o dos subcomplejos 195 , formando el proteosoma $26 \mathrm{~S}$ que desarrolla la actividad proteasa dentro del sistema UPS $^{293-294}$ (Figura 7).

La estructura cilíndrica del núcleo catalítico 20 S está formada por cuatro anillos, dos externos formados por siete subunidades $\alpha$ distintas, y dos internos con siete subunidades $\beta$, también distintas, quedando una estructura $\alpha 1-7 \beta 1-7 \beta 1-7 \alpha 1-7$. La partícula 20 s presenta capacidad proteolítica homogénea en todos los eucariotas, y la estructura y función de las subunidades que integran el cilindro también está conservada en la mayoría de eucariotas. La actividad hidrolítica reside en un residuo treonina de la parte $N$-terminal en las subunidades $\beta 1, \beta 2$, y $\beta 5$ de los dos anillos internos. $\beta 1, \beta 2$, y $\beta 5$ presentan actividad caspasa proteasa que capacita para corte en C-terminal de aminoácidos ácidos, tripsina proteasa que corta en C-terminal de aminoácidos básicos y quimiotripsina proteasa que corta en C-terminal de aminoácidos hidrofóbicos. El acceso a estos sitios catalíticos de los anillos $\beta$ esta ocluido por las colas $\mathrm{N}$ terminal de las subunidades $\alpha$ de los anillos externos, cuya apertura in vivo probablemente depende de la acción de las partículas reguladoras 19S. No obstante, se ha observado que in vitro el núcleo catalítico 205 tiene actividad proteolítica por sí solo, y es capaz de generar oligopepétidos de entre 3 y 15 aminoácidos ${ }^{294}$.

La partícula reguladora $19 \mathrm{~S}$ reconoce las proteínas diana marcadas con poliubiquitina, libera la marca de ubiquitina, cataliza el despliegue de la proteína diana, abre el anillo de subunidades a y transfiere la proteína desplegada dentro del núcleo 20S. Para ello, el 195 se vale de un conjunto de al menos 19 subunidades, algunas con capacidad ATPasa, RPT (regulatory particle of triple-ATPase) y otras no ATPasa, RPN (regulatory particle non-ATPase) que se distribuyen en dos subcomplejos: la Tapa (Lid) y la Base. La tapa tiene los sitios de unión de los sustratos 
poliubiquitinados y presenta la actividad deubiquitinasa que libera la marca de la proteína diana permitiendo su degradación ${ }^{294}$. La Base está compuesta por seis ATPasas (RPT1-RPT6) que interaccionan con los anillos $\alpha$ externos de núcleo catalítico 20S, son necesarias para desplegar las proteínas sustrato e introducirlas dentro del canal catalítico del 205 abriendo el anillo $\alpha$.

\subsubsection{Inhibidores del proteosoma}

Como estrategia terapéutica frente a diversas neoplasias se han desarrollado fármacos que inhiben el proteosoma. Tienen gran efectividad sobre líneas celulares tumorales al inducir apoptosis por la disrupción de la degradación de proteínas clave para la regulación del ciclo celular. Existen varios inhibidores del proteosoma que nombraremos a continuación:

- Bortezomib (Velcade, Millenium Pharmaceuticals): fue el primer inhibidor proteosómico en alcanzar el uso clínico como agente quimioterapéutico, en concreto frente a mieloma múltiple. En esta enfermedad se describió la sobreexpresión de complejos 265 que disminuían el éxito de otras quimioterapias convencionales. Existen diversos estudios preclínicos y clínicos que demuestran que bortezomib sería útil frente a cáncer pancreático, otras neoplasias relacionadas con células B, cáncer de mama, cáncer de próstata, linfoma no-Hodgkin, etc ${ }^{295-296}$.

- Disulfiran: descubierto en 1920, se utilizaba para tratar a pacientes alcohólicos crónicos. Posteriormente se ha descubierto que inhibe el proteosoma en combinación con gluconatos de metales como el zinc o el cobre. Con la primera combinación se curó un paciente con melanoma ocular ${ }^{297}$ y con el segundo, gluconato de cobre, se están realizando ensayos clínicos.

- Ritonavir (Norvir, Abbott Laboratories): fue desarrollado como un anti-retroviral en la lucha contra el VIH. Sin embargo, diferentes estudios concluyeron que inhibía la actividad del proteosoma ${ }^{298}$ al margen de otras proteasas libres, específicamente a aquellos sistemas con función quimiotripsina. Se está estudiando la utilidad frente a gliomas.

- Lactacystin: es un derivado natural sintetizado por la bacteria Streptomyces. Inhibe al proteosoma y fue estudiado como alternativa clínica frente a líneas celulares de neuroblastoma ${ }^{299}$. 


\section{HIPÓTESIS Y OBJETIVOS}




\subsection{HIPÓTESIS}

La hipótesis principal del presente estudio consiste en que las alteraciones moleculares secundarias tienen un papel biológico relevante en la oncogénesis, desarrollo tumoral y estratificación clínica del SE, como por ejemplo la firma 1qGSig (relacionada con peor pronóstico en pacientes con $\mathrm{SE})^{71}$. Dado que el evento molecular primario (generalmente EWSETS) carece de valor pronóstico ${ }^{66-67}$, estas alteraciones moleculares secundarias son objeto de ser consideradas como dianas terapéuticas.

Esta hipótesis general comprende la asunción de tres hipótesis menores:

1. Aquellas células de SE que presenten la firma 1qGSig, así como la sobreexpresión del gen más relevante en cuanto al mal pronóstico asociado a la firma, $C D T 2^{71}$, responderán al tratamiento con el inhibidor de la enzima NAE, MLN4924 de Millennium Pharmaceuticals, Inc (Takeda Oncology Company, Cambridge, MA, USA) ${ }^{272}$. Lo cual supondría una estrategia terapéutica focalizada para este subgrupo de pacientes de SE.

2. El fármaco MLN4924 puede ser efectivo frente al resto de células de SE, al margen de las definidas por la firma 1qGSig. El tratamiento es extensible al global de pacientes con SE.

3. Profundizar en la biología del SE para detectar factores predictivos y marcadores fármacodinámicos de respuesta a MLN4924, permitirá la comprensión de los mecanismos moleculares y celulares de respuesta al fármaco que nos servirán de base para extrapolaciones a otros subgrupos de pacientes con sarcomas, así como a otros tipos de neoplasias que compartan con el SE determinados mecanismos biológicos.

\subsection{OBJETIVOS}

El trabajo presentado en esta tesis pretende desarrollar el estudio preclínico del fármaco MLN4924 en líneas celulares de SE a través de experimentos in vitro, así como en ensayos in vivo mediante xenotrasplantes en ratones inmunodeprimidos CB17/SCID. Lo cual permitirá el desarrollo de estrategias terapéuticas para aquellos pacientes de SE con peor pronóstico, concretamente aquellos que presentan la firma 1qGSig. De esta manera podremos aportar terapias focalizadas en la inhibición específica de complejos CRL en detrimento de otras estrategias de bloqueo de la degradación total de proteínas mediante la inhibición del proteosoma (por ejemplo mediante la aplicación de Bortezomib) y sus consecuentes efectos secundarios.

\subsubsection{Objetivos específicos}

Para lograr el objetivo general antes descrito se propusieron los siguientes objetivos específicos:

1. Calcular la sensibilidad de las líneas celulares de SE al fármaco MLN4924 mediantes ensayos de proliferación y de apoptosis.

2. Comprobar si existe respuesta diferencial frente al fármaco MLN4924 entre las líneas celulares $1 q G$ y $1 q N$. 
3. Evaluar la eficacia de MLN4924 in vivo mediante xenoinjertos de líneas celulares de SE en ratones CB17/SCID, es decir, valorar la capacidad antitumoral del fármaco.

4. Caracterizar el papel del fármaco en la progresión del ciclo celular y en la viabilidad de las líneas celulares de SE tratadas.

5. Determinar las dianas directas del fármaco y proponer posibles marcadores fármacodinámicos a tener en cuenta en futuros ensayos clínicos.

6. Identificar mecanismos moleculares de respuesta al fármaco que aporten información para futuras estrategias terapéuticas a partir de los conocimientos en biología del SE obtenidos con la inhibición de los complejos CRL mediante el fármaco MLN4924. 
MATERIAL Y MÉTODOS 
Las referencias de cada producto así como la casa comercial que las distribuye están incluidas en una tabla al final del capítulo "Material y Métodos", ordenados alfabéticamente según el nombre del producto. De igual forma se detallan los anticuerpos utilizados para la realización de la tesis, en otra tabla independiente, discriminando entre anticuerpos primarios, secundarios y la técnica en la que se emplearon.

\subsection{LÍNEAS CELULARES}

Las líneas celulares de SE utilizadas fueron A4573, A673, CADO-ES, RDES, RM82, SKES1, SKNMC, STA-ET1, STA-ET2.1, STA-ET10, TC32, TC71, TTC466, y WE68, obtenidas a través de la Heinrich-Heine-Universität (HHU) de Düsseldorf, que las mantiene y caracteriza ${ }^{300}$ como repositorio central de líneas celulares de la red de investigación europea EuroBoNet. Todas ellas fueron cultivadas en medio RPMI al $10-20 \%$ de FBS inactivado (56\%C durante una hora) y 100 unidades $-\mu \mathrm{g} / \mathrm{ml}$ de Penicilina-Estreptomicina $(P / S)$, sobre placas de cultivo previamente tratadas con gelatina porcina tipo $\mathrm{A}$ al $0.1 \%$ en agua Milli-Q autoclavada.

La línea celular HEK-293T se empleó para la producción viral en los ensayos de transducción lenti y retroviral, crecida en DMEM adicionado con $2 \mathrm{mM}$ de glutamina, $10 \%$ de FBS y 100 unidades- $\mu \mathrm{g} / \mathrm{ml}$ de $\mathrm{P} / \mathrm{S}$.

La línea celular HCT116, de carcinoma de colon, se utilizó como control en determinados ensayos para contrastar resultados de bibliografía ya publicados con nuestros datos experimentales. Crecida en DMEM adicionado con $2 \mathrm{mM}$ de glutamina, $10 \%$ de FBS y 100 unidades- $\mu \mathrm{g} / \mathrm{ml}$ de $\mathrm{P} / \mathrm{S}$.

Todas las líneas celulares fueron crecidas en un incubador a $37 \circ \mathrm{C}$ y $5 \% \mathrm{CO}_{2}$. En todas las líneas celulares, para revertir la adhesión a la placa e individualizar las células en sucesivos pases o ensayos, se utilizó Tripsina-EDTA al $0.25 \%$. Para congelar líneas celulares, resuspendimos el pellet de células tras la centrifugación en un mililitro de medio suplementado más DMSO (en una proporción 9:1 volumen/volumen), bajamos su temperatura introduciéndolas en hielo y posteriormente trasferimos el vial a un "mister-frosty" $48-72 \mathrm{~h}$ a $-80 \circ \mathrm{C}$; finalmente lo trasladamos a nitrógeno líquido a $-195,8$ ㄷ․

\subsection{FÁRMACOS}

Las líneas celulares de SE fueron tratadas con diversos fármacos. Estos o bien se compraron a las casas comerciales que se indican, o bien fue cedido por la farmacéutica que lo distribuye, como en el caso del fármaco MLN4924. Todos ellos llegaron liofilizados y se resuspendieron con diferentes disolventes:

- MLN4924 Millennium Pharmaceuticals, Inc (Takeda Oncology Company, Cambridge, MA, USA): es un inhibidor de la enzima NAE encargada de activar a NEDD8 en el proceso de nedilación de las culinas. Su efecto bloquea la actividad de los complejos $\mathrm{CRL}^{272}$. Para los ensayos in vitro, fue disuelto con DMSO específico para cultivo celular. Para los experimentos in vivo, se utilizó como vehículo 2-Hidroxipropil- $\beta$-Ciclodextrina. 
- Doxorrubicina (Adriamicina; SIGMA-Aldrich): es un agente que se intercala en la molécula de DNA e inhibe el metabolismo del DNA y RNA ${ }^{301}$, además impide el avance de la Topoisomerasa ${ }{ }^{302}$ que queda fijada y bloquea la replicación. Disuelto en DMSO específico para cultivo celular.

- Vincristina (Oncovina; SIGMA-Aldrich): es un alcaloide que interrumpe la mitosis en la etapa de metafase al inhibir la polimerización de los microtúbulos ${ }^{303} \mathrm{y}$, por tanto, impide la formación del huso mitótico. Disuelto en DMSO específico para cultivo celular.

- PD0166285 (Tocris Bioscience): es un inhibidor de la actividad tirosina quinasa ${ }^{304}$ de WEE1 y MYT1, suprimiendo las fosforilaciones que ejercen sobre los residuos Y15 y T14 de CDK1, acelerando la transición G2/M y anulando el checkpoint de esta fase. Disuelto en DMSO específico para cultivo celular.

- MK-1775 (Axon): es un inhibidor de WEE1 ${ }^{199,305}$, suprimiendo la fosforilación que ejerce sobre el residuo Y15 de CDK1. Disuelto en DMSO específico para cultivo celular.

\subsection{ENSAYOS DE PROLIFERACIÓN}

\subsubsection{MTT}

Este ensayo evaluó la proliferación celular haciendo uso del reactivo MTT o sal de tetrazolio, que reaccionó en las mitocondrias de las células metabólicamente activas y viables, siendo reducida por éstas y transformándose en formazán. En este proceso el reactivo cambió de color (de amarillo pasó a azul) y se volvió hidrofóbico, quedando capturado en la célula. Posteriormente se pudo solubilizar con DMSO y cuantificar por colorimetría.

Para el ensayo de MTT se trabajó en formato de placa de 24 pocillos, cada condición ensayada por triplicado (tres pocillos). Las células fueron sembradas a diferentes concentraciones (según la capacidad proliferativa intrínseca de cada línea celular) para que no alcanzasen confluencia en ningún momento del periodo de ensayo (5 días). Sembramos tres placas (réplicas biológicas) cuyas etapas del ensayo se realizaron en tres días correlativos. Podemos estratificar el ensayo en: 1.- Siembra de células. Al día siguiente tras la correcta adhesión de las células a la placa, se sustituye el medio de cultivo celular por medio suplementado con las distintas condiciones del experimento $\rightarrow$ diferentes concentraciones de fármaco, controles (disolvente del fármaco, por ej. DMSO) y "blanco", es decir, únicamente el medio suplementado. 2.Periodo de incubación de $72 \mathrm{~h}$ (a partir del inicio del tratamiento), durante el cual las diferentes condiciones afectan a la proliferación de las líneas celulares. 3.- Al cumplir las $72 \mathrm{~h}$ de tratamiento, adquisición de resultados.

Para adquirir los resultados se retiró el medio y se añadió por cada pocillo una mezcla de $270 \mu \mathrm{l}$ de medio suplementado más $30 \mu \mathrm{l}$ de la solución de MTT ( $5 \mu \mathrm{g} / \mu \mathrm{l}$ en PBS). La placa se incubó a $37{ }^{\circ} \mathrm{C}$ una hora en el incubador de cultivos celulares, tras lo cual se retiró el medio, se añadió $500 \mu \mathrm{l}$ de DMSO y se agitó la placa suavemente durante 5 minutos protegida de la luz. Finalmente se midió la absorbancia a 570nm en el lector de placas "Ultra Evolution Microplate Reader" (TECAN). 


\subsubsection{ATPlite $^{\mathrm{TM}}$ Luminescence Assay System}

Este ensayo evaluó la proliferación celular haciendo uso del kit "ATP-lite one-step" de Perkin Elmer. Este sistema monitoriza el ATP basándose en la cuantificación de luz proveniente de la actividad de la molécula luciferasa (de la luciérnaga Photinus pyralis), que es añadida como parte del reactivo "ATP-lite". El ATP marca células viables porque está presente en infinidad de procesos metabólicos. La concentración de ATP disminuye rápidamente durante la apoptosis y/o necrosis. Por lo tanto, el ATP es un indicador del tamaño de la población celular (más células viables, más ATP). La reacción química que relaciona el ATP con la luciferasa para la monitorización de células vivas es:

$$
\mathrm{ATP}+\mathrm{D} \text {-Luciferina }+\mathrm{O}_{2} \underset{\mathrm{Mg}^{2+}}{\stackrel{\text { LUCIFERASA }}{\longrightarrow}} \text { Oxiluciferina }+\mathrm{AMP}+\mathrm{PPi}+\mathrm{CO}_{2}+\mathrm{Luz}
$$

El protocolo del ensayo de proliferación con este kit fue análogo al del MTT pero cambió las placas donde se llevaron a cabo los ensayos y el modo de adquisición de resultados, el resto de variables se mantuvieron. Las placas que se utilizaron en este protocolo fueron de 96 pocillos. El fondo de la placa era transparente, lo que permitió ver la distribución de las células adheridas, si bien las paredes eran opacas pues como hemos explicado anteriormente la señal que medimos fue luz por lo que se debió evitar la "contaminación" entre pocillos (captura de luz proveniente de los pocillos anexos). Las placas usadas fueron del modelo Isoplate-96 TC (Perkin-Elmer). Al realizar los ensayos sobre placas de 96 pocillos, sembramos 3000 células por pocillo, concentración optimizada para no alcanzar el estado de confluencia durante el periodo del ensayo.

Para la adquisición, se retiró el medio y se añadieron $100 \mu$ l de sustrato (D-Luciferina) por pocillo, previamente equilibrado con el buffer del kit (según las instrucciones del fabricante). Sellamos los pocillos con parafilm para evitar que el contenido de cada pocillo se escapase y agitamos durante un minuto. A continuación dimos un pulso de centrifugación para llevar al fondo del pocillo la solución, retiramos el parafilm y medimos luminiscencia en el lector de placas "Ultra Evolution Microplate Reader" (TECAN) con la plantilla predeterminada de placa GRE96wt.

\subsubsection{Cálculo de ICs de fármacos}

El IC es un parámetro que nos indica la concentración de fármaco necesaria para provocar una determinada disminución de la proliferación de una línea celular. Este parámetro es acompañado de un subíndice que indica la proporción de esta inhibición. Por ejemplo: $I_{50}$ (concentración del fármaco con la que se reduce a la mitad la proliferación de una determinada línea celular), $I_{75}$ (concentración del fármaco con la que se reduce un $75 \%$ la capacidad de proliferación de una determinada línea celular), etc. Para realizar el cálculo de estos factores mantuvimos las células en cultivo siempre en crecimiento exponencial (nunca en confluencia, lo cual conduciría a una subestimación del parámetro IC) y delimitamos un periodo de tiempo en el que el fármaco llevó a cabo su función. En nuestros estudios se estableció un periodo de incubación de $72 \mathrm{~h}$ (tiempo habitual descrito en bibliografía). Establecimos un patrón de concentraciones crecientes de fármaco abarcando 5 escalas 
logarítmicas con dos concentraciones en cada escala: $0,0.001,0.003,0.01,0.03,0.1,0.3,1,3$ y $10 \mu \mathrm{M}$. Al final del periodo adquirimos los resultados mediante una de las dos técnicas explicadas anteriormente (MTT o "ATP-lite one-step"). Los datos obtenidos en una hoja "excel" fueron procesados con el programa informático OriginPro8 (Originlabs) que tenía implementados algoritmos que nos permitieron determinar las ICs.

\subsubsection{Cálculo del índice de combinación entre dos fármacos: MLN4924 y DXR}

El índice de combinación es un parámetro que nos indica si la acción conjunta de varios fármacos sobre la proliferación de una determinada línea celular es sinérgica (índice de combinación <0.9), aditiva (índice de combinación= 0.9-1.1) o antagónica (índice de combinación $>1.1$ ).

Además de los estudios in vitro con un único fármaco, realizamos experimentos de combinación de DXR junto con MLN4924 sobre las líneas celulares de SE RDES y RM82. Para ello aplicamos diferentes concentraciones de DXR (DMSO (0), 10, 50, 100, 150, 200, 250, 300, 400, 500, 600, 700, 800900 y 1000nM) junto con una determinada concentración de MLN4924 (la $\mathrm{IC}_{75}$ específica de cada línea celular o $1 \mu \mathrm{M}$ ). Tras $72 \mathrm{~h}$ de tratamiento se evaluó la viabilidad de las células mediante la aplicación del kit "ATP-lite one-step". Por último, utilizando el programa informático CalcuSyn Versión 2.1 (Biosoft), teniendo en cuenta la dosis-efecto de la aplicación de cada fármaco por separado así como el de la combinación de ambos, se calculó el índice de combinación.

\subsection{ESTUDIOS IN VIVO: XENOTRANSPLANTES EN RATÓN}

Para los ensayos in vivo utilizamos células en crecimiento exponencial, en ningún caso confluentes, y además evaluamos el porcentaje de células viables utilizando "Trypan blue solution $0.4 \% "$. Tras tripsinizar las células, aislamos una muestra representativa y le añadimos el mismo volumen de trypan blue (considerando un factor de dilución $2 \mathrm{X}$ ) que marcó a aquellas células cuyas membranas estaban desorganizadas y no pudieron mantener el químico fuera del citoplasma (células muertas). Utilizando la cámara de Neubauer cuantificamos el porcentaje de células muertas (azules), el cual no debió superar el 5\% para considerar el cultivo como viable y apto para el ensayo in vivo.

Cuantificamos el número de células, y se prepararon suspensiones de $4 \times 10^{6}$ células en un volumen de medio sin suplementar ( $\sin$ suero y $\sin \mathrm{P} / \mathrm{S}$ ) de $100 \mu \mathrm{l}$. Este volumen lo trasferimos a un microtubo de $1.5 \mathrm{ml}$ en hielo con $100 \mu \mathrm{l}$ de "Matrigel ${ }^{\mathrm{TM}}$ " (BD). El Matrigel $\mathrm{I}^{\mathrm{TM}}$ es una matriz que se mantiene en estado líquido a una temperatura de $4 \stackrel{\circ}{ } \mathrm{C}$ y se solidifica conformando una malla estructural donde establecerse las células al aumentar la temperatura. Esta malla evita que las células se dispersen tras la inyección en el ratón, así permite el seguimiento del desarrollo de una única masa tumoral localizada. Estas suspensiones (células + Matrigel $^{\mathrm{TM}}=$ $200 \mu l)$ se inyectaron de forma subcutánea en el flanco izquierdo de ratones hembra CB17/SCID de 4 semanas de edad, concretamente ratones CB17/IcrHanHsd-Prkdc-scid (Harlan Indianapolis, IN, USA). Se utilizaron jeringas con agujas hipodérmicas de calibre 27G. Los ratones se encontraron en jaulas con sistemas estancos e individuales de renovación del aire que los mantuvieron libres de patógenos. El agua, comida y serrín se conservaron en 
condiciones asépticas. Los ratones se mantuvieron ad libitum en cuanto al acceso a agua y comida.

Las líneas celulares de SE utilizadas para nuestros experimentos con el fármaco MLN4924 fueron RDES y RM82. Se establecieron, mediante distribución aleatoria, tres grupos de ratones para cada línea, dos semanas después de la inyección de células más "Matrigel ${ }^{\mathrm{TM}}$ " (BD), y antes del tratamiento, cuando se apreció un tamaño de tumor cuantificable con el calibre de un volumen aproximado de $400 \mathrm{~mm}^{3}$. Dada la variabilidad estocástica del tamaño de los tumores, los grupos se hicieron de forma que mantuvieran una distribución intragrupo y media de volumen de tumor $\left(\approx 400 \mathrm{~mm}^{3}\right)$ equivalente. Una vez distribuidos en estos tres grupos equivalentes, se inició el tratamiento de los animales, inyectando subcutáneamente cada una de las tres condiciones: un grupo control donde inyectamos el vehículo del fármaco (2Hidroxipropil- $\beta$-Ciclodextrina al $10 \%$ ), un segundo grupo tratado con una concentración de MLN4924 de 30mg/Kg-ratón y un tercer grupo tratado con 60mg/Kg-ratón. La inyección del fármaco y del control fue bidiaria (con una diferencia de 8 horas entre cada inyección) durante 5 días seguidos y dos días de descanso. El punto de inyección varió por todo el área del flanco y se alternó cada flanco para evitar dañar la piel y la región tratada. En ningún caso se inyectó en el propio tumor en desarrollo. El cálculo del volumen a inyectar se hizo tras cuantificar el peso de cada animal.

Se usaron 8 ratones por cada condición, 24 en total, para el estudio con la línea celular RM82; 9 y 27 en el caso de RDES. Durante el periodo de tratamiento se realizaron mediciones periódicas de los tumores en desarrollo. Utilizando el calibre, se medían los diámetros mayor "a" y menor "b" (perpendiculares entre sí) y, mediante la fórmula $a b^{2} / 6$, se estimaba el volumen en $\mathrm{mm}^{3}$. Tras 16 (RDES) y 21 (RM82) días de tratamiento, los tumores alcanzaron el límite de tamaño éticamente aceptable por lo que los animales fueron sacrificados mediante eutanasia consistente en sobredosis del anestésico Isoflurano. Los tumores se extrajeron y se pesaron. La mitad de cada pieza tumoral se congeló incluyéndose en resina O.C.T. dentro de criomoldes y la otra mitad se fijó en formol al 10\% para estudios de análisis histopatológico.

El estudio fue previamente aprobado por el comité de bioética de la Institución Universidad de Salamanca y se realizó de acuerdo con la normativa vigente Española y Europea (RD 1201/05 y 86/609/CEE, respectivamente).

\subsubsection{Procesamiento de muestras tumorales del ensayo in vivo para estudios histopatológicos}

La elaboración y procesamiento de las muestras fue llevado a cabo por el Banco de Tumores del Centro de Investigación del Cáncer $(\mathrm{CIC})$ siguiendo los protocolos de inclusión en parafina y tinción con H\&E detallados a continuación.

Las muestras, para el estudio histopatológico, requirieron la inclusión en un medio sólido como la parafina. Ésta confirió a los tejidos una dureza que permitió el tallado e impidió su fragmentación durante el corte. Además mantuvo la estructura y la relación arquitectural entre los distintos elementos y aseguró la obtención de cortes muy finos, regulares y homogéneos. 
Los tumores, una vez extraídos del animal, se fijaron en formol al 10\% durante 24 horas y, posteriormente, se mantuvieron en etanol al 70\% a 4 으 (con el fin de evitar una fijación excesiva del tejido) hasta ser enviados al Banco de Tumores (Servicio del CIC). El citado Servicio procesó las muestras mediante un sistema automático que realizó una serie de pasos sucesivos detallados en la Tabla 3. Básicamente, el proceso consistió en la fijación con formol, seguida de deshidratación con alcoholes de concentraciones progresivas crecientes y aclarado con xilol (con el fin de sustituir el agente deshidratante, etanol, por una sustancia miscible con el medio de inclusión que se utilizó, la parafina).

\begin{tabular}{|c|c|c|}
\hline PROCEDIMIENTO & MATERIAL & \multicolumn{1}{|c|}{ TIEMPO } \\
\hline FIJACIÓN & $\begin{array}{c}\text { formol } \\
\text { formol }\end{array}$ & $\begin{array}{l}1 \text { hora } \\
1 \text { hora }\end{array}$ \\
\hline \multirow{2}{*}{ DESHIDRATACIÓN } & alcohol $60 \%$ & 1 hora \\
& alcohol $80 \%$ & 1 hora \\
& alcohol $100 \%$ & 1 hora \\
\hline \multirow{2}{*}{ ACLARAMIENTO } & xilol & 1 hora \\
& xilol & 1 hora \\
& xilol & 1 hora \\
\hline INCLUSIÓN & parafina & 1 hora \\
& parafina & 1 hora \\
& parafina & 1 hora \\
\hline
\end{tabular}

Tabla 3: Procedimiento de inclusión de muestras tumorales en parafina. Cada fila detalla el proceso automatizado y el tiempo empleado para su realización. Cada periodo descrito corresponde al empleo de una vasija independiente, con el correspondiente material nuevo en su interior, donde se sumergen las muestras durante el tiempo señalado.

Una vez que terminó el procesado, se sacaron las piezas aún en parafina líquida y se hicieron los bloques definitivos con un molde adecuado al tamaño del tejido. Para ello, se empleó una "estación de inclusión en parafina" que consiste en un tanque de parafina liquida con un grifo dispensador. Una vez hecho el bloque, se enfrió para que se solidificase. Con el micrótomo tipo Minot o de rotación (Microm) se realizaron cortes de tres micras de grosor. Se pasaron a un baño de agua caliente en el cual se estiraron $y$, finalmente, se trasfirieron totalmente extendidos a un portaobjetos.

A continuación la muestras sobre los portas fueron sometidas a la tinción con $\mathrm{H} \& \mathrm{E}$, que se realizó en un teñidor automático que incluyó el paso por una estufa para la desecación de los tejidos durante 20 minutos. Tras lo cual se realizó la tinción H\&E siguiendo las etapas indicadas en la Tabla 4. Una vez terminado el proceso, las muestras se montaron con el medio de montaje "Eukitt" y un cubreobjetos de $50 \mathrm{~mm}$.

\subsubsection{Análisis de muestras histopatológicas}

Tras obtener las muestras montadas por el servicio del Banco de Tumores del $\mathrm{CIC}$, las analizamos a través del microscopio de campo claro "BX51" (Olympus). Observamos a diferentes aumentos y utilizamos aceite de inmersión con el objetivo de 100X aumentos. 
Obtuvimos fotos representativas de las muestras con el programa "DP Controller" (Olympus) específico de la cámara "DP70" y del microscopio referido anteriormente.

\begin{tabular}{|c|c|c|}
\hline PROCEDIMIENTO & MATERIAL & TIEMPO \\
\hline \multirow{2}{*}{ DESPARAFINADO } & Xilol & 5 minutos \\
& Xilol & 5 minutos \\
& Xilol & 5 minutos \\
\hline \multirow{2}{*}{ REHIDRATACIÓN } & alcohol $100 \%$ & 5 minutos \\
& alcohol $75 \%$ & 5 minutos \\
alcohol $50 \%$ & 5 minutos \\
\hline \multirow{2}{*}{ TINCIÓN } & hematoxilina & 4 minutos \\
& agua corriente & 5 minutos \\
& eosina & 2 minutos \\
\hline \multirow{2}{*}{ DESHIDRATACIÓN } & alcohol $50 \%$ & 2 minutos \\
& alcohol 75\% & 2 minutos \\
\hline \multirow{2}{*}{ ACLARADO } & alcohol 100\% & 2 minutos \\
\hline & Xilol & 2 minutos \\
& Xilol & 2 minutos \\
\hline & Xilol & 2 minutos \\
\hline
\end{tabular}

Tabla 4: Procedimiento de tinción de muestras tumorales con H\&E. Cada fila detalla el proceso automatizado y el tiempo empleado para su realización. Cada periodo descrito corresponde al empleo de una vasija independiente, con el correspondiente material nuevo en su interior, donde se sumergen las muestras durante el tiempo señalado.

\subsection{CITOMETRÍA DE FLUJO}

\subsubsection{Análisis de ciclo celular por citometría de flujo}

Para este análisis las células fueron marcadas con ioduro de propidio (IP), que se unió al DNA de manera proporcional a la cantidad de éste, intercalándose entre los pares de bases nitrogenadas. La cantidad celular de DNA, y por tanto la señal debida al marcaje con IP, varía en las diferentes fases del ciclo celular, siendo el doble en la fase G2/M respecto a la fase G0/G1 y presentando todo el rango de valores intermedios en la fase $\mathrm{S}$ o de replicación del DNA.

Los cultivos celulares analizados estuvieron siempre en crecimiento activo, evitando la confluencia y sub-confluencia, que distorsionan la distribución de la población celular en los distintos estadíos del ciclo celular. El número óptimo de células sembradas por pocillo de placa de 6 pocillos, para las líneas celulares utilizadas en este estudio, fue de $3 \times 10^{5}-4 \times 10^{5}$. En primer lugar, se aspiró el medio y se tripsinizaron las células durante el tiempo suficiente para que éstas se despegasen y se separasen bien entre sí, pero acortándolo en lo posible para que no hubiera inducción de apoptosis (tiempo óptimo que depende de la línea celular). La reacción de la tripsina se detuvo añadiendo un volumen de medio de cultivo suplementado igual al usado de tripsina (unos 200-300 $\mu \mathrm{l}$ por pocillo). Se transfirieron las células despegadas a tubos de citometría y éstos se centrifugaron a 1200 rpm durante tres minutos. Se aspiró el 
sobrenadante y se lavaron las células con PBS (con una nueva centrifugación y aspiración). Tras lo cual se añadieron $700 \mu \mathrm{l}$ de etanol al $70 \%$ frío (mantenido en congelador $-20{ }^{\circ} \mathrm{C}$ ), se sellaron los tubos cubriéndolos con "parafilm" y se incubaron a 4 ํㅡ (en un rango desde 45 minutos a varias horas).

A continuación se realizaron dos lavados con PBS (centrifugando y aspirando el sobrenadante) y se añadió $200 \mu \mathrm{l}$ de la siguiente mezcla: $1 \mathrm{ml}$ de PBS $+5 \mu \mathrm{l}$ de RNAsa A $(50 \mathrm{mg} / \mathrm{ml})+5 \mu \mathrm{l}$ de IP $(1 \mathrm{mg} / \mathrm{ml}$ en PBS con $0.1 \%$ azida sódica).

Se incubaron los tubos durante una o dos horas, a temperatura ambiente y en agitación suave (tubos protegidos de la luz en posición horizontal). La RNAsa A elimina rápidamente todo el RNA de las muestras y el IP se une estequiométricamente al DNA. Finalmente, las muestras fueron adquiridas en el citómetro de flujo "FACScalibur" (Becton Dickinson, BD) utilizando el programa "CellQuest" (BD). Se adquirieron alrededor de $2 \times 10^{5}$ células a una velocidad no superior a mil eventos por segundo. Las poblaciones se seleccionaron descartando los dobletes y restos celulares ("debris"). El cálculo del reparto poblacional en cada fase del ciclo se realizó usando los algoritmos implementados en el programa informático "FlowJo 7.6" (Treestar).

\subsubsection{Análisis de muerte celular por citometría de flujo: Cleaved Caspase 3}

Para éste tipo de análisis estudiamos en paralelo el ciclo celular (siguiendo las pautas descritas en el apartado anterior) y el marcaje de las células con Caspasa 3 procesada.

La Caspasa 3 es una cisteína-ácido aspártico proteasa (caspasa efectora) que interactúa con las Caspasas 8 y 9 (caspasas activadoras). Juega un papel dominante en la ejecución de la apoptosis celular tanto por vía intrínseca como por vía extrínseca. La Caspasa 3, al igual que otras caspasas, se encuentra inactiva como zimógeno. Cuando la señal intrínseca o extrínseca activa la cascada de las caspasas, los zimógenos son procesados y comienzan su actividad. En el caso de la Caspasa 3 reconoce tetrámeros de aminoácidos con secuencias Asp-X-X-Asp y los hidroliza. Junto con el resto de caspasas efectoras, Caspasa 3 provoca condensación cromosómica, fragmentación nuclear, "blebbing" de la membrana plasmática, restructuración del citoesqueleto, etc ${ }^{306}$. Consideramos pues que aquellas células marcadas con Caspasa 3 procesada ("cleaved Caspase 3") se encuentran irreversiblemente en vía de apoptosis y por tanto es útil para estimar mediante citometría de flujo el tamaño de la población celular en proceso de muerte programada ${ }^{307}$.

Para llevar a cabo el análisis de muerte celular mediante citometría de flujo en células de SE, sembramos dos pocillos de placa de 6 pocillos con $4-5 \times 10^{5}$ células en cada uno por cada condición a analizar. Tras completarse las $48 \mathrm{~h}$ de tratamiento, recogimos el sobrenadante y lo transferimos a un tubo de citometría. Tripsinizamos las células adheridas y bloqueamos con el medio del sobrenadante aislado en el paso anterior. Unificado todo en un único tubo de citometría, lavamos con PBS y fijamos con etanol al 70\% frío (almacenado a -20ㄷ) durante toda la noche a 4 ํㅡ. Al día siguiente se aspiró el etanol y se lavó con PBS; tras lo cual se bloqueó, es decir, retiramos el PBS y añadimos $50 \mu \mathrm{l}$ de solución de incubación (0.5\% BSA en PBS) e incubamos 30 minutos a temperatura ambiente. 
A continuación incubamos con el anticuerpo primario: añadimos por cada tubo $50 \mu$ de anticuerpo primario en solución de incubación, calculando una dilución final de 1:200. Incubamos a temperatura ambiente durante 60 minutos. Incluimos un control negativo, es decir, un tubo al que no se añadió el anticuerpo primario y al que sí se añadió posteriormente el secundario. Tras la incubación, lavamos el exceso de anticuerpo primario; añadimos $1 \mathrm{ml} \mathrm{de}$ solución de incubación por tubo, centrifugamos y aspiramos el sobrenadante.

En este punto iniciamos la incubación con el anticuerpo secundario: añadimos $100 \mu l$ por tubo de solución de incubación más anticuerpo secundario en dilución 1:200. Incubamos 30 minutos en oscuridad. Tras lo cual, lavamos el exceso de anticuerpo secundario; añadimos $1 \mathrm{ml}$ de solución de incubación por tubo, centrifugamos y aspiramos (dos lavados).

Por último procedimos al marcaje del DNA: añadimos a cada tubo $200 \mu l$ de solución de marcaje del DNA que contenía por cada $\mathrm{ml}$ de PBS, $5 \mu \mathrm{l}$ de loduro de propidio $(1 \mathrm{mg} / \mathrm{ml}$ en PBS con $0.1 \%$ azida sódica) y $5 \mu l$ de RNAsa A $(50 \mathrm{mg} / \mathrm{ml})$. Sellamos los tubos con parafilm y cubrimos el rack con papel de aluminio de modo que los tubos quedaron protegidos de la luz. Colocamos el rack con los tubos en horizontal sobre el agitador, aseguramos con cinta aislante e incubamos 1.5-4 horas en agitación horizontal (80 rpm).

Para la adquisición utilizamos el citómetro "FACScalibur" (BD). Ajustamos el pico de G1 a 200 en el histograma y centramos la nube del dotplot FL2 vs FL1 en el mismo sitio (creando un "Gate"), para facilitar posteriormente la superposición de muestras. El citómetro fue compensado para trabajar con el marcaje de cl. Caspase 3 en el canal FL1 (verde) y el marcaje de DNA en el FL2. Tras la adquisición, el cálculo del reparto poblacional en cada fase del ciclo se realizó usando los algoritmos implementados en el programa informático "FlowJo 7.6" (Treestar). Además se discriminó el porcentaje de células cl. Caspase 3 positivas (apoptóticas) en cada etapa del ciclo (G1, sase $S$ y G2/M).

Nota: Preparación de la RNAsa A libre de DNAsa (la RNAsa de páncreas bovino incluye trazas de DNasa) $\rightarrow$ hervimos el stock de $55.56 \mathrm{mg} / \mathrm{ml}$ (en Acetato Sódico $10 \mathrm{mM}, \mathrm{pH} 5.2$ ) a 100ㄷ durante 15 minutos (la RNAsa A es una de las enzimas más estables conocidas mientras que la DNAsa I es de las más lábiles) y dejamos enfriar paulatinamente hasta alcanzar temperatura ambiente. Ajustamos el pH a 7.4 añadiendo 0.1 del volumen de $1 \mathrm{M}$ Tris- $\mathrm{HCl}$, pH 7.4.

\subsubsection{Análisis de ciclo celular con discriminación de mitosis: Fosforilación S10 de Histona H3}

Este ensayo es análogo al anterior. Se realizó con el mismo protocolo pero en este caso se utilizó como anticuerpo primario un anti Fosfo Histona H3 (Ser10) (Clon D2C8, Cell Signalling) a una dilución 1:1500. La fosforilación en S10, S28 y T11 de la Histona H3 está estrechamente relacionada con la condensación de cromosomas durante la mitosis y la meiosis ${ }^{308}$. En células de mamíferos, la fosforilación en S10 de la Histona H3 se inicia en la profase, alcanza su máximo en metafase, disminuye en anafase y es perdida en telofase ${ }^{309}$. Debido a que el marcaje por fosfo-S10 de la H3 se encuentra prácticamente en la totalidad de las etapas de mitosis, se utilizó para discriminar el porcentaje de células que se hallaron en mitosis en el momento de la captura de la muestra. 


\subsubsection{Análisis de ciclo celular de fase $S$}

En este caso monitorizamos la incorporación de BrdU, un análogo sintético de la base nitrogenada timidina. Se trata de un nucleótido halogenado (por el grupo bromuro incorporado en el quinto carbono) formado por una base pirimídica y el monosacárido ribosa, cuya analogía con la timidina permite su sustitución casi total (99.8-100\%) durante la replicación en la fase de síntesis ${ }^{310}$ o fase S. A diferencia de los dos procesos descritos anteriormente, basados en la detección de componentes endógenos de la célula (Caspasa 3 procesada o fosfo-S10 Histona $\mathrm{H} 3$ ), aquí dirigimos los anticuerpos contra un componente exógeno, BrdU. Para ello debimos añadir BrdU al medio de cultivo de las células a una concentración de $10 \mu \mathrm{M}$ una hora antes de ser procesadas. En ese periodo aquellas células en fase $S$ (que por tanto estaban replicando el DNA) incorporaron diferentes nucleótidos, entre ellos el análogo de la timidina BrdU, permitiendo su detección posterior a través de citometría de flujo mediante un anticuerpo específico anti-BrdU.

Más en detalle, al medio de cultivo de las células que fueron procesadas de este modo, le añadimos $\mathrm{BrdU}$ a una concentración final de $10 \mu \mathrm{M}$ durante la hora previa a ser tripsinizadas. Partimos de un stock de BrdU a 3mM, luego para un pocillo de placa de 6 pocillos (con $1.5 \mathrm{ml}$ de medio) equivalió a añadir $5 \mu \mathrm{l}$ por pocillo. Se tripsinizaron, lavaron, pasaron a tubo de citometría y permeabilizaron las células con etanol al 70\%. Para evitar agregados celulares, dejamos caer el etanol lentamente por las paredes del tubo e, inmediatamente después, agitamos dando golpes con el dedo hasta que todo el pellet se resuspendió y homogenizó. El etanol debió estar frío en todo momento, luego realizamos el ensayo con los tubos inmersos en hielo e incubados durante toda la noche a 4 으.

Al día siguiente se centrifugaron las células, se lavaron con agua Milli-Q, se centrifugaron de nuevo y se resuspendieron con $200 \mu$ l de solución desnaturalizante de DNA $(2 \mathrm{~N} \mathrm{HCl})$, la cual añadimos lentamente gota a gota con el tubo de citometría agitándose en el vórtex a 1400rpm., e incubamos 30 minutos a temperatura ambiente. Lavamos con agua, centrifugamos y añadimos $500 \mu \mathrm{l}$ de solución de tetraborato sódico para recuperar el pH neutro en las muestras. Incubamos dos minutos y lavamos con PBS. Centrifugamos y resuspendimos con la solución de anticuerpo primario (por cada tubo: $45 \mu$ l de solución del anticuerpo primario $+5 \mu$ de anti-BrdU-FITC, es decir, dilución 1:10). Incubamos durante una hora a temperatura ambiente en oscuridad. Lavamos una vez con PBS y añadimos la solución de marcaje del DNA (para $1 \mathrm{ml}$ de PBS: $5 \mu$ l de solución de RNAsa A y $5 \mu l$ de solución de IP). Incubamos un par de horas en agitación (con los tubos en horizontal protegidos de la luz a 75 rpm.). Finalmente se adquirió en el citómetro ("FACScalibur", BD) y se procesaron los datos mediante el programa informático "FlowJo 7.6" (Treestar).

Soluciones utilizadas:

- Solución BrdU 3mM (0.92mg/ml): resuspender el contenido del bote con 100mg de BrdU liofilizada en $108.54 \mathrm{ml}$ de PBS autoclavado, homogeneizar bien y filtrar a través de filtro de $0.22 \mu \mathrm{m}$ de poro y almacenar a $-20{ }^{\circ} \mathrm{C}$. Importante: al descongelar el $\mathrm{BrdU}$ precipita, por lo que se recomienda calentar a $37^{\circ} \mathrm{C}$ y agitar para resuspender correctamente. 
- Solución Desnaturalizante de DNA: 2M HCl, 0.5\% Tritón X-100 en agua Milli-Q

- Solución de Tetraborato sódico (Na2B4O7), 0.1M, pH 8.5: pesar 3,87gramos de Sodium tetraborate decahydrate y resuspender en $80 \mathrm{ml}$ de agua Milli-Q. Ajustar el $\mathrm{pH}$ con $\mathrm{HCl} 37 \%$ hasta pH8.5 en constante agitación. Completar con agua Milli-Q hasta 100ml.

- Solución del anticuerpo primario: 1\%BSA, 0.5 \% Tritón X-100 en PBS 1X.

\subsection{EXTRACCIÓN DE PROTEÍNAS Y WESTERN BLOT}

Para extraer proteínas de cultivos celulares retiramos el medio de cultivo y lavamos las células con PBS a 4 으, con las placas sobre hielo. Retiramos el PBS, añadimos $500 \mu \mathrm{l}$ PBS frío y despegamos las células con un raspador. El volumen se transfirió a un microtubo de $2 \mathrm{ml}$ y se precipitaron las células mediante centrifugación (1200 rpm. a 4ํㄷ durante tres minutos), tras lo cual descartamos el sobrenadante y añadimos la solución de lisis RIPA suplementada con inhibidores de proteasa y fosfatasas (el volumen dependió del número de células, en general $100 \mu$ l por cada $4-5 \times 10^{6}$ células). A continuación, determinamos la concentración proteica mediante el uso del reactivo "Bradford" (Biorad). Para ello, creamos un patrón de concentración conocido, a partir de una solución de BSA de $2 \mathrm{mg} / \mathrm{ml}$ en volúmenes finales de $800 \mu \mathrm{l}$, desde $2 \mu \mathrm{g} / \mathrm{ml}$ a $10 \mu \mathrm{g} / \mathrm{ml}$. De manera similar preparamos las muestras problema, añadiendo $1 \mu \mathrm{l}$ del extracto proteico en el mismo volumen final $(800 \mu \mathrm{l})$. Hicimos duplicados de cada muestra. Añadimos $200 \mu \mathrm{l}$ del reactivo Bradford a los $800 \mu \mathrm{l}$ de cada muestra, mezclamos adecuadamente por vórtex, incubamos 5 minutos y medimos la absorbancia en el espectrofotómetro, a $595 \mathrm{~nm}$. Las concentraciones de las muestras problema se calcularon interpolando en la recta patrón (utilizando la fórmula del modelo de regresión creado). Los extractos proteicos se sometieron entonces a electroforesis en gel de poliacrilamida en condiciones desnaturalizantes (SDS-PAGE). Para ello, la cantidad de proteína a cargar (generalmente $40 \mu \mathrm{g}$ por condición/pocillo) fue desnaturalizada añadiendo el tampón de carga $4 \mathrm{X}$ e hirviendo la muestra a 95 ㅇ C durante 5 minutos. En la preparación del gel de poliacrilamida se siguieron las siguientes recetas, para $20 \mathrm{ml}$ totales (los porcentajes usados dependieron del tamaño de la proteína o proteínas que se pretendían visualizar, usándose mayores concentraciones cuanto menor era el tamaño de la proteína de interés), Tabla 5.

\begin{tabular}{|ccccccc|}
\hline $\begin{array}{c}\text { Porcentaje de } \\
\text { poliacrilamida }\end{array}$ & $\mathrm{H}_{2} \mathrm{O}$ & Acrilamida/Bis & Tris-HCl* & $\begin{array}{c}\text { SDS } \\
(10 \%)\end{array}$ & TEMED & $\begin{array}{c}\text { APS } \\
10 \mathrm{mg} / 100 \mu \mathrm{ll}\end{array}$ \\
\hline $4 \%$ & 12.68 & 2 & 5 & 0.2 & $20 \mu \mathrm{l}$ & $100 \mu \mathrm{l}$ \\
$6 \%$ & 11.68 & 3 & 5 & 0.2 & $20 \mu \mathrm{l}$ & $100 \mu \mathrm{l}$ \\
$8 \%$ & 10.68 & 4 & 5 & 0.2 & $20 \mu \mathrm{l}$ & $100 \mu \mathrm{l}$ \\
$10 \%$ & 9.68 & 5 & 5 & 0.2 & $20 \mu \mathrm{l}$ & $100 \mu \mathrm{l}$ \\
$12 \%$ & 8.68 & 6 & 5 & 0.2 & $20 \mu \mathrm{l}$ & $100 \mu \mathrm{l}$ \\
\hline
\end{tabular}

Tabla 5: Elaboración de geles de poliacrilamida. Cantidad de los reactivos necesarios para su elaboración según el porcentaje de poliacrilamida que deseemos tener en el gel. * El Tris $\mathrm{HCl}$ varía en concentración y pH dependiendo de si el gel es el superior ("stacking gel", 0.5M, pH 6.8, conocido como "Upper Tris") o el inferior ("resolving gel", 1.5M, pH 8.8, conocido como "Lower Tris"). 
Los reactivos TEMED (Tetrametil-etilen-diamina) y APS (persulfato amónico) se añadieron justo antes de la adición a los cristales montados en los soportes, para desencadenar la reacción de polimerización. Se añadió primero el gel inferior ("resolving gel"), tras lo cual se añadió isopropanol, inmiscible con el gel, para facilitar su polimerización exenta de burbujas o imperfecciones. Una vez ésta ocurrió, se retiró el isopropanol y se añadió el gel superior ("stacking gel", al 4\% de poliacrilamida) junto con el peine que creó el espacio de los pocillos. Tras la polimerización se montó el sistema de electroforesis "Miniprotean System" (Bio-Rad), se rellenó la cubeta con solución SDS-PAGE $1 \mathrm{X}$, se depositaron las muestras en los pocillos y se conectó la fuente de alimentación, iniciándose la electroforesis a 90 voltios hasta que las muestras alcanzaron el gel inferior, momento en el que se subió el voltaje a 120-150 voltios. Una vez que las muestras se resolvieron hasta el punto deseado, se realizó una transferencia húmeda durante 2-3 horas a 330 miliamperios (amperaje constante), utilizando una membrana de trasferencia de PVDF (polifluoruro de vinilideno).

La trasferencia húmeda se realizó con el gel, membrana de trasferencia y el resto de componentes necesarios en constante inmersión en el buffer de trasferencia. El buffer de trasferencia se compuso para 1,25 litros de: $875 \mathrm{ml}$ de agua Milli-Q, $125 \mathrm{ml}$ de buffer de trasferencia (10X) y $250 \mathrm{ml}$ de metanol. Utilizamos "Miniprotean System" (Bio-Rad) con el adaptador para trasferencia. En dicho adaptador se pudo introducir dos "sandwichs", en cuyo interior ocurrió la trasferencia de proteínas desde el gel hacia la membrana de trasferencia. Fue crucial el orden de los elementos que conformaron cada "sandwich", así como la orientación que tuvieron con respecto al gradiente eléctrico al que se sometieron (Figura 10).

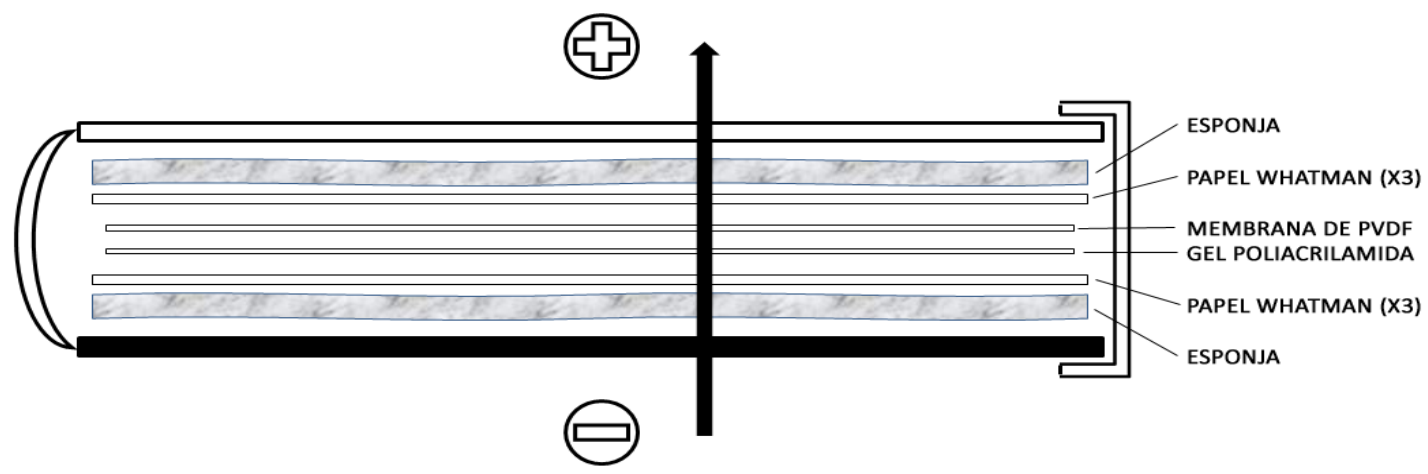

Figura 10: Esquema montaje del "sandwich" para la trasferencia en WB. Se detalla la dirección de la trasferencia determinada por las cargas.

Tras la transferencia confirmamos la correcta electroforesis y transferencia mediante tinción de la membrana con la solución Rojo Ponceau, que marcó las proteínas en la membrana. A continuación eliminamos fácilmente la tinción con sucesivos lavados con TBS-T (solución salina tamponada con Tris y Tween20). Finalmente sometimos a la membrana a la incubación con los distintos anticuerpos. En todos los casos la membrana se bloqueó primero con $5 \%$ de leche en polvo en TBS-T, durante una hora a temperatura ambiente y después se incubó el anticuerpo primario durante la noche al 1\% BSA en TBS-T, a 4ํㅡ. El anticuerpo secundario siempre se utilizó a una dilución 1:10000 al 1\% BSA en TBS-T, incubado una hora a temperatura ambiente. También en todos los casos, las incubaciones se realizaron en agitación horizontal circular a una velocidad de $70 \mathrm{rpm}$. Los lavados entre soluciones se realizaron con TBS-T. Los anticuerpos primarios usados y las diluciones de cada uno de ellos se indican en la Tabla 6. 


\begin{tabular}{|l|c|lc|}
\multicolumn{1}{|c|}{ Anticuerpo } & Dilución & \multicolumn{1}{|c|}{ Anticuerpo } & Dilución \\
\hline$\beta$-TUBULIN & $1: 10000$ & CUL1 & $1: 500$ \\
Cl. Caspase-3 & $1: 1000$ & CUL4 & $1: 2500$ \\
CDC25A & $1: 250$ & EMI1 & $1: 100$ \\
p-CDC2 (Y15) & $1: 1000$ & n-ACTIN & $1: 5000$ \\
CDC2 (SC)* & $1: 2000$ & P21 & $1: 500$ \\
CDC2 (CS)* & $1: 2000$ & P27 & $1: 1000$ \\
CDK2 & $1: 2000$ & CHK1 & $1: 1000$ \\
p-CDK (Y15) & $1: 1000$ & p-CHK1 (S345) & $1: 500$ \\
CDT1 & $1: 500$ & WEE1 & $1: 500$ \\
Cyclin A2 & $1: 500$ & p-RB (S780) & $1: 500$ \\
Cyclin B1 & $1: 500$ & RB & $1: 500$ \\
Cyclin E & $1: 500$ & & \\
\hline
\end{tabular}

Tabla 6: Anticuerpos primarios utilizados en WB. Se detalla a la derecha de cada uno a la dilución que se utilizó en 1\% BSA en TBS-T. Los asteriscos indican las abreviaturas de las casas comerciales Santa Cruz (SC) y Cell Signaling (CS).

Para aplicar un anticuerpo en una membrana sobre la que ya se ha usado y revelado un anticuerpo primario anterior se procedió incubando la membrana en la solución de "stripping" durante no más de 20 minutos a 56으, lavando la membrana posteriormente varias veces con TBS-T (lavados de 10 minutos). Tras ello, se bloqueó de nuevo la membrana con leche al $5 \%$ en TBS-T.

En aquellos casos en los que los anticuerpos primarios utilizados fueron de distinta especie, pudieron ser incubados a la vez a 4으 toda la noche. Si bien, a la hora de revelar, se reveló uno de ellos mediante el protocolo habitual con el sistema ECL. Posteriormente, se añadió azida sódica en TBS-T y se mantuvo en agitación 20-30 minutos. En ese periodo se inactivó la peroxidasa (HRP, enzima marcadora del anticuerpo secundario) y se comprobó tras un revelado que dejó de marcar la película en exposiciones suficientemente largas. Tras ello se lavó con abundante agua y además tres veces con TBS-T (lavados de 5 minutos) y se inició la incubación con el anticuerpo secundario contra el segundo anticuerpo primario que era de origen distinto al primero (combinaciones conejo-ratón, típicamente). Este sistema, cuando fue aplicable, incrementó la utilidad de la membrana, reduciendo el número de "strippings" (que conllevan una pérdida sustancial de proteínas) necesarios para obtener el elevado número de blots requeridos en experimentos como el mostrado en la Figura 31 y redujo además el tiempo empleado para obtenerlos.

Soluciones utilizadas:

- Solución de lisis RIPA (100 ml): 10mM Tris HCl pH 7.5, 1mM EDTA, 0.5gr de deoxicolato sódico, $0.1 \mathrm{M} \mathrm{NaCl}, 1 \mathrm{ml}$ de NP-40, $1 \mathrm{ml}$ de SDS $10 \%$ y agua Milli-Q hasta completar $100 \mathrm{ml}$.

A esta solución se le añadió en fresco, cada vez que iba a ser utilizada, para $1 \mathrm{ml}$ total de buffer de lisis: $900 \mu$ l de solución RIPA $+40 \mu l$ de inhibidor de proteasas $+50 \mu l$ de $\mathrm{NaF} 200 \mathrm{mM}+10 \mu \mathrm{l}$ de NaOV $200 \mathrm{mM}$.

- Tampón de carga 4X: Tris 200mM pH 6.8, 40\% glicerol, 4\% $\beta-\mathrm{ME}, 0.04 \%$ azul de bromofenol. 
- Solución de rojo Ponceau: 3gr de rojo ponceau (SIGMA) 30ml TCA (Ácido Tricloroacético al 100\%). Enrasar a un litro con agua Milli-Q.

- Solución de "stripping": 20ml SDS 10\%, 6.2ml "Upper Tris" (Tris-HCl 0.5 M) pH 6.7, 73.1ml

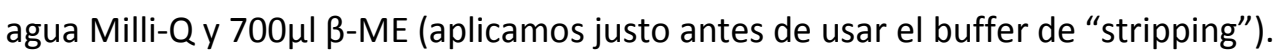

\subsubsection{WB en condiciones no "denedilantes": OPT}

Para el estudio de la actividad de las culinas (proteínas de andamiaje de los complejos CRL) realizamos un WB en condiciones no "denedilantes". Se considera que la culina está activa cuando tiene unida NEDD8, fruto del proceso de nedilación (explicado ampliamente en apartado 1.3.3 de la sección Introducción). Esta unión puede ser revertida por el complejo CNS (COP9 signalosoma). Cuando extraemos las proteínas favorecemos el contacto entre la CNS y las culinas nediladas, de tal manera que provocan la denedilación. Existe un inhibidor de CNS, el 1,10-orthophenathroline (OPT) ${ }^{270}$, que añadimos al buffer de lisis a una concentración de $2 \mathrm{mM}$, que quela los iones de $\mathrm{Zn}$ necesarios para el funcionamiento del complejo CNS. De esta manera, aquellas culinas que estaban nediladas (activas) en el momento del extracto serán capturadas así en el ensayo. Cuando revelamos el WB observamos una banda correspondiente a las culinas inactivas $y$, justo por encima, las culinas activas (mayor peso molecular al tener unida NEDD8), Figura 11.

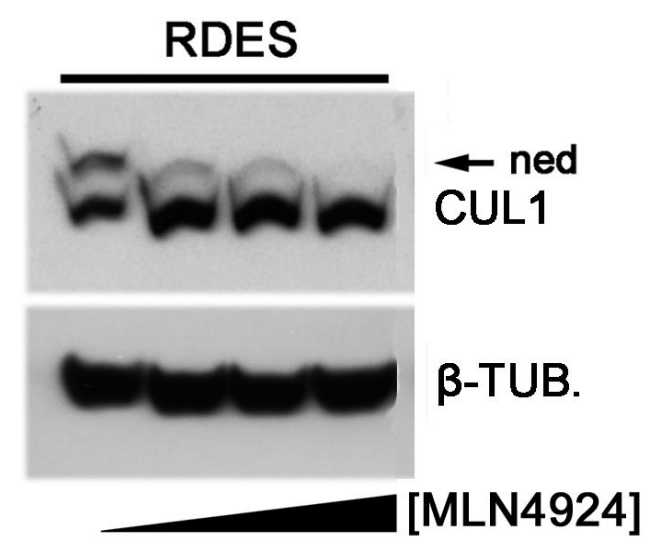

Figura 11: WB de CUL1 en condiciones no "denedilantes" en la línea celular de SE, RDES: Se observan diferentes grados de nedilación (activación) de la CUL1 debidos al tratamiento creciente con el fármaco MLN4924 (la primera calle corresponde al control sin tratar y muestra una población de CUL1 activa/nedilada de en torno al 30\%). Aquellas moléculas de CUL1 activas tienen unidas NEDD8 por lo que tienen mayor peso molecular y aparecen como una banda más alta en el WB (tienen menor migración electroforética). Vemos que, para la misma carga proteica en el WB (indicada por el blot de $\beta$-tubulina, abreviado $\beta$-tub), la cantidad de CUL1 total es igual pero se reparte entre ambos estados (nedilado/denedilado) de forma distinta, reduciéndose la población molecular activa por la inhibición ejercida por MLN4924.

\subsection{SINCRONIZACIÓN DE CULTIVOS CELULARES}

Para estudios relacionados con mecanismos reguladores del ciclo celular es útil el sincronizar las células en determinadas etapas del ciclo. Las líneas celulares están compuestas por una población celular heterogénea en lo que respecta a los diferentes estadíos del ciclo celular. Para poder estudiar fenómenos exclusivos que se dan en etapas concretas del ciclo, es muy útil tener todas las células en el mismo punto del ciclo. Para alcanzar dicho objetivo, se han desarrollado protocolos que incluyen el uso de drogas que sincronizan a las células en etapas 
concretas del ciclo celular evitando al máximo comprometer la viabilidad del cultivo. La utilidad de estos protocolos es que una vez alcanzada la sincronización, podemos liberar a las células del bloqueo y permitir que, sincronizadas, progresen hacia las posteriores etapas del ciclo. Hay que tener en cuenta que si prolongamos el estudio en el tiempo, conforme se completan ciclos celulares sucesivos, las células abandonaran estocásticamente la sincronización inicial. A continuación se describen los dos tipos de sincronización que nos permitieron realizar ensayos cruciales para la tesis. En aras de una mejor compresión se detalla las etapas de cada ensayo y la planificación temporal de cada una de ellas. Con la misma intención, al inicio de cada apartado se incluye un esquema (Figuras 12 y 13).

\subsubsection{Protocolo de doble sincronización con nocodazol: sincronización en mitosis temprana}

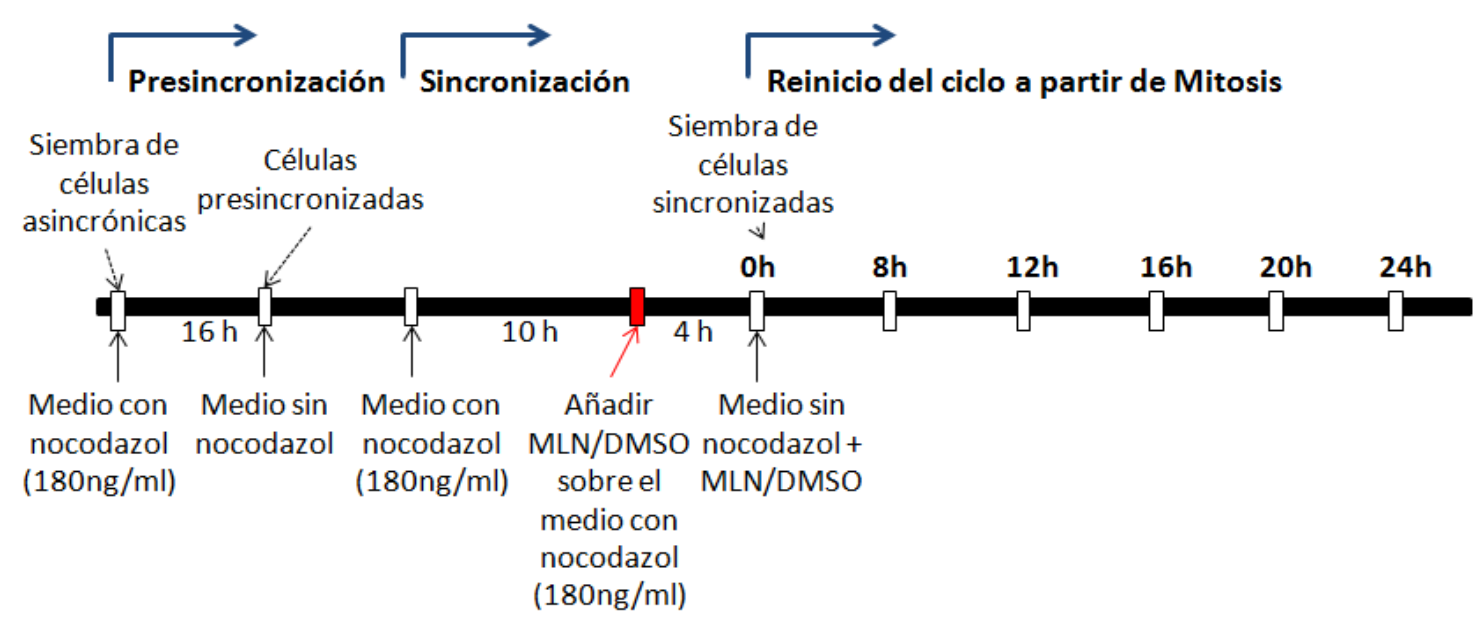

Figura 12: Esquema del protocolo para ensayos de sincronización en mitosis temprana con nocodazol. MLN= fármaco MLN4924. DMSO (control), se añade el mismo volumen utilizado para los tratamientos con el fármaco. En los puntos de tiempo $(0,8,12,16,20$ y 24 horas) se extrajo muestra para análisis de citometría de flujo y para western blot.

Pre-sincronización de células RDES (para otras líneas celulares ensayadas el tratamiento con nocodazol resultó demasiado tóxico): sembramos células en $15-20$ placas de $15 \mathrm{~cm}$ por condición. Al iniciar el tratamiento debían encontrarse en torno al $60 \%$ de confluencia y distribuidas homogéneamente por toda la placa (una confluencia excesiva limita la capacidad de sincronización del nocodazol). Incubamos $16 \mathrm{~h}$ en medio normal (RPMI más 10\% FBS y P/S) con $180 \mathrm{ng} / \mathrm{ml}$ de nocodazol. El nocodazol interfiere en la polimerización de los microtúbulos, lo que impide que las células progresen en mitosis y se quedan bloqueadas en pro-metafase. EI stock de nocodazol lo conservamos a $-20{ }^{\circ} \mathrm{C}$ en DMSO a $400 \mu \mathrm{g} / \mathrm{ml}$.

Tras las 16h, recuperamos las células golpeando las placas. Las células que se encontraron en mitosis se despegaron fácilmente de la placa debido a que perdieron adherencia durante esta breve fase del ciclo celular al adoptar una morfología esférica, con escaso contacto con la placa. Recuperamos el medio con las células mitóticas en suspensión y centrifugamos a 1200 rpm durante $5 \mathrm{~min}$. Descartamos el medio que contiene nocodazol y las resuspendimos en medio de cultivo suplementado normal. Sembramos estas células en 20 placas de $15 \mathrm{~cm}$ por condición. Dejamos proliferar hasta $60-70 \%$ de confluencia para iniciar la sincronización definitiva. 
Segunda sincronización en mitosis de células RDES: a las células pre-sincronizadas, al alcanzar el $70 \%$ de confluencia ( 20 placas de $15 \mathrm{~cm}$ por condición $\rightarrow$ aproximadamente $2.2-2.5 \times 10^{8}$ células totales), se les añadió $15 \mathrm{ml}$ de medio con $180 \mathrm{ng} / \mathrm{ml}$ de nocodazol para sincronizarlas definitivamente. Para una correcta sincronización, se requerían $14 \mathrm{~h}$ de tratamiento. Iniciamos el tratamiento con nocodazol a las 9:00h del día 1.

Para la condición que requirió la aplicación del fármaco objeto de estudio (MLN4924) se inició el tratamiento cuatro horas antes del punto de Oh, de la liberación del nocodazol (19:00h, día 1). Añadimos el fármaco directamente sobre el medio que contiene nocodazol $\rightarrow$ cada placa contenía $15 \mathrm{ml}$ de medio, por lo que hubo que calcular la concentración de fármaco requerida para una vez diluido con el resto de medio quedase a la concentración final deseada $\left(\mathrm{IC}_{75}\right.$ específico de la línea celular). Con el tratamiento previo a la liberación, conseguimos que aquellas dianas específicas de los complejos CRL estuvieran influenciadas por el fármaco (acumuladas debido a la inhibición de su degradación) antes de la liberación del arresto inducido por el nocodazol, de modo que provocasen cualquier posible efecto en la progresión en mitosis desde el punto inicial del estudio (Oh).

Reinicio del ciclo partiendo de mitosis temprana: 0 horas (23:00h, día 1$) \rightarrow$ golpeando las placas separamos las células en mitosis temprana, junto al medio las transferimos a 6 tubos falcon de $50 \mathrm{ml}$. Centrifugamos $5 \mathrm{~min}$ a $1200 \mathrm{rpm}$., recuperamos $50 \mathrm{ml}$ de medio con nocodazol sin células (que lo mantuvimos en un falcon de $50 \mathrm{ml}$ al margen). Unimos todos los pellets de células sincronizadas en mitosis en un solo falcon utilizando el medio con nocodazol que habíamos recuperado (para evitar la pérdida de sincronización durante la manipulación de las células); resuspendimos las células con $25 \mathrm{ml}$ aproximadamente. Tomamos una alícuota y contamos el número de células/ml en un contador "Z1 Coulter Particle Counter" (Beckman Coulter). De estas células sincronizadas, en medio con nocodazol, separamos las siguientes alícuotas:

- $8 \times 10^{6}$ células para el punto de tiempo 0 h destinadas a extracción de proteínas (esta alícuota se hizo en cada condición, vehículo/MLN4924, manteniéndolas en medio con nocodazol).

- $8 \times 10^{5}$ células para el punto de tiempo Oh destinadas a análisis del ciclo celular (esta alícuota se hizo en cada condición, vehículo/MLN4924, conservándolas en medio con nocodazol).

Conservamos las células apartadas del punto de oh en medio con nocodazol hasta procesar el resto de células destinadas a los posteriores puntos de tiempo $(8,12,16,20$ y $24 \mathrm{~h})$. Las células del resto de puntos de tiempo, que reanudaron posteriormente la progresión del ciclo celular, las centrifugamos, les retiramos medio con nocodazol, las lavamos con PBS (para eliminar restos de la droga), y las resuspendimos con medio suplementado normal. Cuantificamos de nuevo el número de células $/ \mathrm{ml}$ y sembramos por condición dos pocillos de placa de 6 poc. para análisis de ciclo $\left(5 \times 10^{5}\right.$ células por pocillo) y tres placas de $10 \mathrm{~cm}$ para extraer proteínas ( $3 \times 10^{6}$ células por placa, las células RDES rinden poca proteína total). El medio utilizado en la siembra debió estar exento de nocodazol y llevar el fármaco MLN4924 o el vehículo (DMSO). 
Obtención de muestras a diferentes puntos de tiempo: mientras sembramos lo detallado en el apartado anterior, mantuvimos las alícuotas de células correspondientes al punto de oh en medio con nocodazol, en hielo. Las destinadas al estudio de ciclo celular las transferimos a un tubo de citometría correctamente rotulado. Las muestras se procesaron para estudios de citometría del ciclo celular tal y como se detalla en el apartado 3.5 y para extracción proteica como se detalla en el apartado 3.6 de Material y Métodos.

Punto de extracción a 8 h (07:00, día 2) $\rightarrow$ dejamos 8 h para continuar con los puntos de tiempo de extracción de muestras porque comprobamos que las células necesitaban ese rango de tiempo para recuperarse de la sincronización y superar la mitosis, de modo que el siguiente punto tras $0 \mathrm{~h}$ fue $8 \mathrm{~h}$ y posteriormente seguimos extrayendo a intervalos de $4 \mathrm{~h}$. Para procesar las células de $8 \mathrm{~h}$ descartamos el medio (evitamos el pequeño porcentaje de células muertas que no sobrevivieron al proceso de sincronización con nocodazol). Para las células objeto de estudio de ciclo celular, tras descartar el medio con células muertas, "tripsinizamos" y bloqueamos la tripsina con medio suplementado nuevo. Continuamos el procesado de las muestras como se detalla en el apartado 3.5. La metodología para extracción proteica fue idéntico al explicado en el apartado 3.6 de la sección Material y Métodos. Tras procesar el punto de 8 h renovamos el medio del resto de puntos de tiempo, retirando las células muertas por el nocodazol, por medio nuevo (manteniendo la concentración de vehículo/fármaco). A partir del siguiente punto de tiempo, recuperamos el medio junto a las células para el estudio de ciclo celular. Repetimos las extracciones a $12,16,20$ y $24 \mathrm{~h}$.

Análisis de las muestras sincronizadas (día 3): Citometría $\rightarrow$ Las muestras que permanecieron a 4 으 se habían permeabilizado totalmente con etanol al $70 \%$. Antes de adquirir las células se trataron conforme al protocolo descrito en el apartado 3.5 de Material y Métodos (añadiendo el ioduro de propidio y RNAsa A). Analizamos los datos con el programa informático FlowJo 7.6 .

Western blot $\rightarrow$ Las muestras que permanecieron a $-20^{\circ} \mathrm{C}$, se descongelaron en hielo, se cuantificaron mediante Bradford y se realizó el WB mediante el protocolo descrito en el apartado 3.6 de Material y Métodos.

\subsubsection{Protocolo de sincronización con timidina: Sincronización en la transición G1/S}

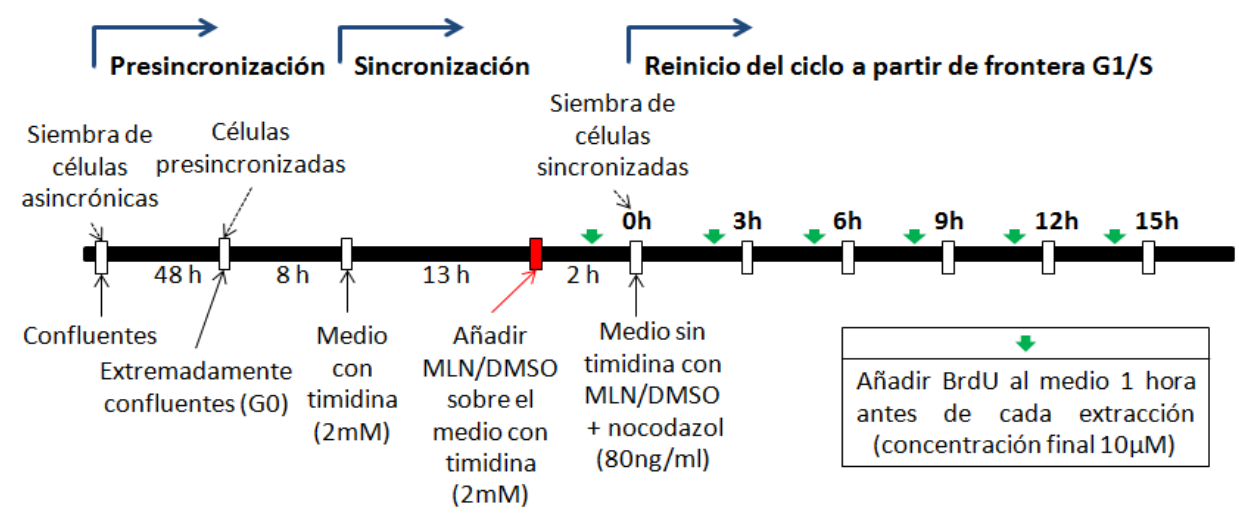

Figura 13: Esquema del protocolo para ensayos de sincronización en la transición G1/S con timidina. MLN= fármaco MLN4924. DMSO (control), se añade el mismo volumen utilizado para los tratamientos con el fármaco. En 
los puntos de tiempo $(0,3,6,9,12$ y 15 horas) se extrajo muestra para análisis de citometría de flujo y para western blot.

Pre-sincronización de la línea celular RDES de SE (para otras líneas celulares ensayadas el tratamiento de sincronización resultó tóxico): sembramos 6 placas de $10 \mathrm{~cm}$ y dejamos que alcanzaran confluencia, la cual indujo una primera sincronización en estas células que aguantan muy bien este estado. Consideramos confluente cuando toda la superficie de la placa estuvo ocupada por las células que a su vez estuvieron en contacto físico. Una vez alcanzado este nivel de confluencia mantuvimos el cultivo confluente $48 \mathrm{~h}$ más. Cambiamos todos los días el medio que fue rápidamente consumido por las células. En las últimas $24 \mathrm{~h}$ de confluencia renovamos el medio dos veces. Al final de las $48 \mathrm{~h}$ las células alcanzaron un nivel superior de confluencia, de tal manera que inhibieron por contacto la progresión de ciclo celular y se mantuvieron en $\mathrm{G}_{0}$ (esta línea celular presenta inhibición por contacto e incapacidad para crecer en multicapa). Aplicamos este protocolo en lugar de uno tradicional de doble sincronización con timidina porque éste último resultó ser demasiado tóxico para estas células (tardaban mucho tiempo en recuperarse y avanzar en ciclo de nuevo). En este punto, en cada placa de $10 \mathrm{~cm}$ hubo aproximadamente $5.0-5.2 \times 10^{7}$ células RDES. De acuerdo al dato anterior, deberíamos modificar el número de placas de partida ( 6 en este caso) para tener el número de células requeridas para el experimento que llevaríamos a cabo posteriormente.

Siembra de las células pre-sincronizadas en $\mathrm{G}_{0}$ : consideramos el día 1 al día siguiente, por la mañana, tras las $48 \mathrm{~h}$ de confluencia. Tripsinizamos las 6 placas de RDES en $\mathrm{G}_{0}$ y bloqueamos la tripsina con medio suplementado. Aseguramos bien por pipeteo la individualización celular (evitamos agrupados de células adheridas). Transferimos las células individualizadas a un solo falcon de $50 \mathrm{ml}$. Homogeneizamos y tomamos una pequeña alícuota para cuantificar en el contador "Z1 Coulter Particle Counter" (Beckman Coulter). Llevamos hasta $10 \mathrm{ml}$ con el buffer isotónico (1X) y nos dió un valor de células/ml. Multiplicamos por el factor de dilución y obtuvimos el número de células por $\mathrm{ml}$ que teníamos en el falcon de $50 \mathrm{ml}$ que mantuvimos en todo momento en la campana de cultivos. El número de células total fue de $3-3.2 \times 10^{8}(50 \times 6$ placas cultivadas en confluencia). Tras la cuantificación sembramos las células con medio normal suplementado (10:00h, día1). Sembramos $4 \times 10^{5}$ células por pocillo de placa de 6 poc. (tres pocillos para cada condición) y $2.4 \times 10^{6}$ células por placa de $10 \mathrm{~cm}$ (una placa por condición). Tras la siembra incubamos las células a 37 ํㅡ y $5 \%$ de $\mathrm{CO}_{2}$. En este periodo se recuperaron de la siembra y pusieron en marcha la maquinaria de progresión del ciclo celular.

Sincronización en la transición G1/S: 18:00h, día $1 \rightarrow$ Tras 8 h desde la siembra, las células se recuperaron de la pre-sincronización en $\mathrm{G}_{0}$. Procedimos a sincronizarlas definitivamente con timidina. Sustituimos el medio por medio normal (RPMI, 10\% FBS, P/S) con $2 \mathrm{mM}$ de timidina. El stock lo conservamos a $-20{ }^{\circ} \mathrm{C}$ en medio RPMI a $200 \mathrm{mM}$. Las células en presencia de timidina quedaron sincronizadas en el rango de ciclo celular comprendido entre G1 tardía (mayoritariamente) y fase $\mathrm{S}$ temprana, tal y como mostró la citometría de flujo posterior.

En aquella condición que requirió la aplicación del fármaco objeto de estudio (MLN4924) iniciamos el tratamiento dos horas antes del punto de $0 \mathrm{~h}$, de la liberación de la timidina. Añadimos el fármaco directamente sobre el medio que contenía timidina $\rightarrow$ cada placa contenía $9 \mathrm{ml}(10 \mathrm{~cm}$ ) y $1.5 \mathrm{ml}$ (pocillo de placa de 6 poc.) de medio, por lo que hubo que calcular la concentración de fármaco requerida para que, una vez diluido con el resto de medio, 
quedaran a la concentración final deseada (500nM de MLN4924 ||$_{95}$ ). Con el tratamiento previo a la liberación conseguimos que aquellas dianas específicas de los complejos CRL estuvieran influenciadas por el fármaco (acumuladas debido a la inhibición de su degradación) para que provocaran su efecto desde el punto inicial del estudio (Oh).

Para observar con mayor precisión el avance en fase $\mathrm{S}$ decidimos incluir un ensayo de incorporación de BrdU en cada punto de tiempo, y determinar si existieron diferencias entre el control y el tratamiento con 500nM de MLN4924. Para poder analizar esto por citometría, una hora antes de cada punto de tiempo, añadimos BrdU a cada pocillo de placa de 6 poc. para que quedase a una concentración final de $10 \mu \mathrm{M}$. Como teníamos el stock de BrdU a $3 \mathrm{mM}$, añadimos por pocillo $5 \mu$ l. Por lo tanto, el segundo día, a las 8:00h, añadimos BrdU a las placas correspondientes al punto de tiempo de 0 h.

Reinicio del ciclo partiendo de frontera G1/S: 9:00h, día 2 (punto de tiempo 0h) $\rightarrow$ separamos las placas destinadas a $0 \mathrm{~h}$ del resto de placas para los diferentes puntos de tiempo. Excepto a las de 0 h, quitamos el medio con timidina y lavamos con PBS atemperado a 37으 $\mathrm{C}$ para eliminar totalmente restos de timidina. Añadimos medio nuevo (con DMSO o 500nM de MLN4924) que además incluía $80 \mathrm{ng} / \mathrm{ml}$ de nocodazol. Utilizamos nocodazol para que, en los últimos puntos de tiempo, aquellas células que terminaron la G2 se quedaran bloqueadas en mitosis temprana y no reiniciasen un nuevo ciclo. Evitamos que dificultasen el estudio de la cantidad de células en cada punto de ciclo por superposición de células en distinto ciclo. Comprobamos empíricamente que las células sincronizadas con timidina perdían rápidamente la sincronía por lo que las células completaron el ciclo en diferentes tiempos.

Obtención de muestras a diferentes puntos de tiempo: 9:00h, día 2. Procesado de las placas de $\mathrm{Oh} \rightarrow$ las células se encontraron sincronizadas por la timidina y en el caso de las sembradas en placas de 6poc., destinadas a análisis de ciclo celular, llevaban una hora con BrdU (10 $\mu \mathrm{M})$. Las destinadas al estudio de ciclo celular, se procesaron siguiendo el protocolo habitual descrito en el apartado 3.5 de Material y Métodos, mientras que las destinadas a extracción de proteínas se procedieron siguiendo lo indicado en el apartado 3.6. Repetimos el proceso en los restantes puntos de tiempo $(3,6,9,12$ y $15 \mathrm{~h})$, añadiendo durante la hora previa $10 \mu \mathrm{M}$ de BrdU en las células destinadas a estudios de ciclo celular.

Análisis de las muestras sincronizadas (día 3): Citometría $\rightarrow$ Las muestras que permanecieron a 4 으 se habían permeabilizado totalmente con etanol al $70 \%$. Antes de adquirir las células se trataron conforme al protocolo descrito en el apartado 3.5 de Material y Métodos (añadiendo el ioduro de propidio y RNAsa A). Analizamos los datos con el programa informático FlowJo 7.6. Western blot $\rightarrow$ Las muestras que permanecieron a $-20 \circ C$, se descongelaron en hielo, se cuantificaron mediante Bradford y se realizó el WB mediante el protocolo descrito en el apartado 3.6 de Material y Métodos.

\subsection{INMUNOFLUORESCENCIA DE CÉLULAS CRECIDAS SOBRE PLACAS DE CULTIVO DE $35 \mathrm{~mm}$ DE DIÁMETRO}

De manera habitual los ensayos de marcaje con inmunofluorescencia de líneas celulares se realizan sobre un soporte de cristal, el portaobjetos. Dicho soporte en ocasiones, dependiendo del tipo celular, es tratado para facilitar la adherencia celular. Los tratamientos con polímeros 
que crean un recubrimiento que mejora la adhesión celular, tales como la poli-L-lisina o poli-Lornitina, fibronectina, gelatina al $0.1 \%$ o tratamiento con ácidos del vidrio del portaobjetos (para mejorar el recubrimiento) solucionan generalmente la dificultad de adherencia. En el caso de las líneas celulares de SE, todas estas opciones fueron ensayadas pero ninguna de ellas fue útil para la adherencia de las células sobre los portas. En consecuencia la viabilidad del cultivo fue deficiente ( $\mathrm{y}$ por tanto las células fueron extremadamente sensibles a los tratamientos) y la morfología que adquirieron sobre esta superficie distó de ser la óptima para un ensayo de microscopía como es la inmunofluorescencia, a diferencia del buen crecimiento y morfología que muestran estas células cuando son crecidas sobre el plástico de las placas de cultivo tratado con gelatina al $0.1 \%$. Consideramos por tanto que cualquier resultado obtenido sobre vidrio sería cuanto menos subóptimo, cuando no artefactual y no fiable.

Debido a lo anterior desarrollamos una estrategia de inmunofluorescencia directamente sobre el cultivo celular crecido en placas de cultivo de $35 \mathrm{~mm}$ de diámetro previamente tratadas con gelatina al $0.1 \%$. A la hora de realizar la inmunofluorescencia retiramos el medio, fijamos las células sobre la propia placa y cubrimos con cubreobjetos de $20 \times 20 \mathrm{~mm}$ el área sobre la que se pipetearon las soluciones con los anticuerpos. Debido a la superficie de la placa cabían dos cubres por cada una. Finalmente analizamos las muestras en el microscopio motorizado de inmunofluorescencia "DM6000B" (Leica) introduciendo el objetivo en la placa de manera automática y controlada (protegiéndolo del contacto con la muestra mediante el cubre, y teniendo cuidado de que no colisionara con los bordes de la placa). Aunque la refracción del plástico no es la idónea (como sí lo es la del vidrio) para microscopía, descubrimos que la calidad de las imágenes obtenidas fue más que aceptable y en compensación tanto la viabilidad del cultivo ( $\mathrm{y}$ por tanto la fiabilidad del resultado final del ensayo) como la morfología celular fueron muy superiores a las obtenidas inicialmente sobre vidrio.

Procedimiento: sembramos en cada placa de $35 \mathrm{~mm}$ (tratada con gelatina al $0.1 \%$ ) $4 \times 10^{5}$ células para condiciones de tratamiento de alta concentración del fármaco MLN4924 (IC 95 ó $1 \mu \mathrm{M}), 3.5 \times 10^{5}$ células para concentraciones de $\mathrm{IC}_{50}$ e IC $\mathrm{IC}_{75}$ específico de cada línea celular y $3 \times 10^{5}$ células para la condición control (medio con DMSO). Sembramos distinto número de células porque el fármaco inhibe la proliferación a distinto nivel según la concentración que empleamos. De este modo obtuvimos un número de células similar en cada condición tras el periodo de tratamiento con las distintas concentraciones de MLN4924. El grado de confluencia final no debió ser excesivo para facilitar la lectura de las imágenes. Aplicamos los distintos tratamientos directamente sobre el medio de cultivos de cada placa por pipeteo, agitando a continuación la placa para distribuirlo homogéneamente. Tras $24 \mathrm{~h}$ de incubación retiramos el medio, lavamos con PBS y añadimos $2 \mathrm{ml}$ de formaldehido (3.7\% en PBS) para fijar. Incubamos 5-8 minutos a temperatura ambiente; no excedimos este intervalo de tiempo en ningún caso porque comprobamos que la fijación excesiva comprometía la calidad de la inmunofluorescencia. Retiramos el formaldehido, añadimos inmediatamente $2 \mathrm{ml}$ de metanol frío (conservado a $-20 \circ \mathrm{C}$ ) para permeabilizar las membranas e incubamos tres minutos a temperatura ambiente. Lavamos con PBS para eliminar los restos de metanol y bloqueamos, es decir, añadimos $2 \mathrm{ml}$ de $1 \%$ de BSA en PBS e incubamos durante 30 minutos. A continuación aspiramos la solución de bloqueo y dejamos secar las placas. Una vez secas, procedimos a la incubación con el anticuerpo primario, es decir, añadimos la solución del anticuerpo primario 
(diluido en $1 \%$ de BSA en PBS). Los anticuerpos primarios utilizados para los ensayos de inmunofluorescencia se detallan en la Tabla 7.

\begin{tabular}{|c|c|}
\hline Anticuerpo & Dilución \\
\hline \multicolumn{2}{|l|}{ Primarios } \\
\hline Alpha tubulina & $1: 500$ \\
\hline Phospho-Histone H3 & 1:1000 \\
\hline Gamma H2AX & $1: 200$ \\
\hline P27 (KIP1) & $1: 1000$ \\
\hline CDC6 $(\mathrm{H}-304)$ & $1: 50$ \\
\hline \multicolumn{2}{|l|}{ Secundarios } \\
\hline Cy3-cabra anti-conejo IgG $(\mathrm{H}+\mathrm{L})$ & $1: 500$ \\
\hline $\begin{array}{l}\text { AlexaFluor }{ }^{\oplus} 488 \text {-cabra anti-ratón IgG } \\
(\mathrm{H}+\mathrm{L})\end{array}$ & $1: 500$ \\
\hline
\end{tabular}

Tabla 7: Anticuerpos utilizados para Inmunofluorescencia sobre placas de $35 \mathrm{~mm}$ de diámetro. Se detalla a la derecha de cada uno a la dilución que se utilizó en 1\%BSA en PBS.

Aplicamos $40 \mu \mathrm{l}$ de solución de anticuerpo primario por placa, cerca del borde. Dejamos caer lentamente (para que no se formaran burbujas de aire) un cubre sobre la solución. De esta manera se extendió la película de anticuerpo sobre las células fijadas en la placa. Repetimos el paso anterior en el extremo opuesto de la placa (para que cupieran los dos cubreobjetos de $20 \times 20 \mathrm{~mm}$ ). Marcamos con rotulador en la base de la palca el perímetro del cubre para tener localizada la zona donde se aplicó el anticuerpo primario y así poder añadir el secundario en la misma zona. El resto de superficie de la placa, no cubierta por anticuerpo primario, no fue marcada por esta técnica. Introdujimos las placas de $35 \mathrm{~mm}$ en una placa de $15 \mathrm{~cm}$ que actuó a modo de cámara húmeda. En su interior, bajo las placas de $35 \mathrm{~mm}$ dónde se estuvo incubando los anticuerpos, colocamos papel empapado de agua. Este método mantuvo el ambiente húmedo e impidió la desecación del volumen bajo el cubre. Incubamos el primario durante toda la noche a 4 으.

Al día siguiente, retiramos los cubres con cuidado. Se añadió primero PBS en el interior de las placas de $35 \mathrm{~mm}$, sobre los cubreobjetos, para poder retirarlos más fácilmente y sin despegar las muestras que estaban bajo ellos. Una vez retirados los cubres, aspiramos totalmente el PBS. Lavamos de nuevo con PBS y añadimos tras ello la solución de anticuerpo secundario (en $1 \%$ BSA-PBS) en el centro de la zona marcada con el rotulador; la dilución a la que se aplicó se detalla en la Tabla 7. Al igual que con la del anticuerpo primario, colocamos un cubreobjetos para extender la solución de anticuerpo secundario por toda la región donde el primario estaba unido a la muestra (haciéndolo coincidir en lo posible con el área marcada con rotulador). Situamos el cubre y dejamos caer lentamente, como se explica para el primario. Introdujimos las placas de $35 \mathrm{~mm}$ de nuevo en la placa de $15 \mathrm{~cm}$ (cámara húmeda) e incubamos una hora a temperatura ambiente en oscuridad. Retiramos los cubres de la misma forma que se ha detallado y completamos tres lavados con PBS. Tras lo cual, aspiramos totalmente los restos de PBS e incubamos con DAPI (Diluido 1:1000 en PBS, $2 \mathrm{ml}$ por placa; el stock estaba a $0.1 \mathrm{mg} / \mathrm{ml}$ en agua Milli-Q) durante 1-2 minutos para evitar un excesivo marcaje. DAPI, o 4',6diamidino-2-fenilindol, es un marcador fluorescente que se une a regiones ricas en AT del 
DNA. Además atraviesa fácilmente la membrana de las células fijadas e incluso vivas. Por ello, se utiliza habitualmente en microscopía de fluorescencia para marcar núcleos.

A continuación, retiramos la solución con DAPI y lavamos dos veces con PBS. Descartamos totalmente el PBS y montamos la muestra, es decir, añadimos "Vectashield" (Vector) en el centro de cada región marcada con rotulador, colocamos un cubreobjetos para que se extienda por toda la zona y sellamos con esmalte de uñas para aislar totalmente la muestra con la unión de los anticuerpos conjugados. "Vectashield" (Vector) es un medio de montaje que conserva la muestra y aumenta la vida media de emisión de los anticuerpos fluorescentes.

En último lugar, observamos por el microscopio "DM6000B" (Leica) motorizado y adquirimos imágenes con el programa informático Metamorph, generalmente a un aumento de 40x (no requirió aceite de inmersión).

\subsection{TRANSDUCCIÓN LENTIVIRAL DE LÍNEAS CELULARES DE SE}

Utilizamos una colección de shRNA ("short-hairpin RNA") compuesta de 7 y 5 construcciones (comercializadas por Openbiosystems, Thermo) cada una de ellas dirigida contra una parte distinta de los transcritos de $p 27$ y WEE1 respectivamente (Tabla 8), clonadas en el vector pLKO.1. Junto con esta colección utilizamos dos vectores control: el pLKO.1-“non-targeting control" (NTC, que contiene una construcción shRNA que no está dirigida contra ningún transcrito celular en concreto) y el pLKO.1-“turboGFP" (SIGMA), que contiene la secuencia de la proteína verde fluorescente de copépodo. Asimismo, utilizamos los vectores pCMV-dr8.91 y pMD.2G, que aportan los genes del HIV-1 gag y pol (entre otros) y la proteína de la envuelta del virus de le estomatitis vesiculosa (vsv-g), respectivamente. Este fue un sistema para la producción de virus defectivos en replicación de segunda generación: al estar los genes virales separados en dos vectores que además no son empaquetados en las partículas virales, éstas fueron incapaces de replicarse tras penetrar en la célula diana y tan sólo actuaron portando el transgén seleccionado.

\begin{tabular}{lcl} 
Construcciones shRNA & Secuencia diana del mRNA ("sense") & \multicolumn{1}{c}{ mRNA diana (RefSeq) } \\
\hline TRCN0000039928 & GTAGGATAAGTGAAATGGATA & NM_004064 (P27) \\
TRCN0000039929 & CCGACGATTCTTCTACTCAAA & NM_004064 (P27) \\
TRCN0000039930 & GCGCAAGTGGAATTTCGATTT & NM_004064 (P27) \\
TRCN0000039931 & CCTCAGAAGACGTCAAACGTA & NM_004064 (P27) \\
TRCN0000039932 & CAGCGCAAGTGGAATTTCGA & NM_004064 (P27) \\
TRCN0000039856 & AGCAATGCGCAGGAATAAGG & NM_004064 (P27) \\
TRCN0000039857 & AATGGTGATCACTCCAGGTA & NM_004064 (P27) \\
TRCN0000039858 & CACACTTGTAGGATAAGTGAA & NM_004064 (P27) \\
TRCN0000001700 & CCACCCAGAGTAATAGAACAT & NM_003390 (WEE1) \\
TRCN0000001701 & CTAGAAAGAGTGCAGAACAAT & NM_003390 (WEE1) \\
TRCN0000001702 & GCCTTGTGAATTTGCTGCTAT & NM_003390 (WEE1) \\
TRCN0000001703 & AGATGAAACAAGACCTGCTAA & NM_003390 (WEE1) \\
TRCN0000001704 & GCCAGTGATTATGAGCTTGAA & NM_003390 (WEE1)
\end{tabular}

Tabla 8: Construcciones shRNA frente a los transcritos de los genes p27 y WEE1. 
Co-transfectamos todos estos vectores en cultivos de células 293T al 80-90\% de confluencia con un protocolo típico de lipofectamina. Utilizamos estas células por tanto como células empaquetadoras o productoras virales. El día anterior a la transfección, al cultivo de células 293T le cambiamos el medio de cultivo por $12 \mathrm{ml}$ de DMEM con glutamina, 10\% FBS y una décima parte de la concentración habitual de $\mathrm{P} / \mathrm{S}$. La mezcla de transfección usada fue la siguiente (por cada placa de $10 \mathrm{~cm}$ a transfectar):

pLKO.1-shRNA $\quad 10 \mu \mathrm{g}$

pCMV-dr8.91 $\quad 10 \mu \mathrm{g}$

pMD2.G $\quad 5 \mu \mathrm{g}$

Optimem $\quad 1.5 \mathrm{ml}$

En otro tubo preparamos la mezcla de $1.5 \mathrm{ml}$ de Optimem con $60 \mu \mathrm{l}$ de Lipofectamina2000 $(1 \mathrm{mg} / \mathrm{ml})$ e incubamos 5 minutos a temperatura ambiente. Adicionamos la mezcla con la lipofectamina suavemente, por goteo, sobre el volumen de la mezcla de las construcciones plasmídicas. Homogeneizamos suavemente por pipeteo e incubamos 20 minutos a temperatura ambiente. Tras ello añadimos los $3 \mathrm{ml}$ suavemente al cultivo de 293T, por goteo, $\mathrm{y}$ distribuimos homogéneamente inclinando la placa suavemente. Incubamos la transfección durante la noche, en el incubador de cultivos celulares $\left(37 \stackrel{\circ}{ } \mathrm{C}, 5 \% \mathrm{CO}_{2}\right)$. Al día siguiente retiramos el medio de transfección y añadimos $9 \mathrm{ml}$ de medio con exceso de FBS (DMEM 40\% FBS, que mejoró la producción viral) y $0.1 \%$ de $\mathrm{P} / \mathrm{S}$. Consideramos este momento como el punto de tiempo cero de la producción viral.

Al día siguiente, 24h antes de la transducción, sembramos las células diana (las que iban a ser transducidas) en placas de 6 poc., poniendo por pocillo $4 \times 10^{5}$ células, una placa de 6 poc. por cada placa de $10 \mathrm{~cm}$ de células productoras transfectadas. Esto fue para conseguir el mayor silenciamiento posible de las proteínas p27 y WEE1 (se producirá una infección con alta multiplicidad, o moi).

48h tras la transfección, recogimos el sobrenadante de las placas de células empaquetadoras con una jeringa, lo filtramos a través de un filtro de $0.45 \mu \mathrm{m}$ de polisulfonato (de baja afinidad proteica) y añadimos $3 \mathrm{ml}$ de medio fresco (DMEM $40 \%$ FBS). Además, añadimos polibreno a una concentración final de $8 \mu \mathrm{g} / \mathrm{ml}$ ("hexadimethrine bromide"; este compuesto químico anula las cargas eléctricas que producen una repulsión entre la membrana celular y la superficie de las partículas virales). Además del sobrenadante viral sin diluir $\left(10^{\circ}\right)$, en los ensayos realizamos diluciones seriadas del sobrenadante viral de modo que obtuvimos diferentes concentraciones virales $\left(10^{-1}, 10^{-2}, 10^{-3}, 10^{-4}\right.$ y $\left.10^{-5}\right)$. En todos los casos la concentración final de polibreno fue de $8 \mu \mathrm{g} / \mathrm{ml}$. Con este paso indujimos diferentes niveles de transducción de las células dianas (diferentes moi o multiplicidades de infección, es decir, número de virus que infectan cada célula; las multiplicidades mayores causaron un mayor silenciamiento del gen diana). Añadimos los sobrenadantes virales procesados de este modo a las células diana (tras retirarles el medio), $2 \mathrm{ml}$ por pocillo. Finalmente, centrifugamos las placas a $2000 \mathrm{rpm}$., 32으, durante una hora. Tras $7 \mathrm{~h}$ de incubación en el incubador de cultivos $\left(37^{\circ} \mathrm{C}, 5 \% \mathrm{CO}_{2}\right)$, retiramos 
el medio de transducción y añadimos el medio habitual del cultivo celular (RPMI al 10\% de FBS para la mayoría de líneas celulares de SE).

Para el control de la eficiencia del proceso se transdujeron en paralelo las células diana con la construcción pLKO.1-turboGFP (en paralelo, no las mismas transducidas con las construcciones shRNA), sin diluir o diluida de forma seriada con un factor de dilución $1: 10$ (desde $10^{\circ}$ hasta $10^{-}$ ${ }^{6}-10^{-7}$, al igual que se menciona en los párrafos anteriores). Tras $48-72 \mathrm{~h}$ observamos la población celular al microscopio de fluorescencia para confirmar la expresión de proteína verde y por tanto la correcta transducción. Tras ello adquirimos las células en el citómetro. Adquirimos junto a ellas un control negativo de transducción (no transducido y/o transducido con el control NTC). Una vez delimitada la población negativa para GFP (la población control sin GFP), calculamos el porcentaje de población celular positiva para GFP para cada nivel de dilución. Seleccionamos el valor de la dilución seriada que consiguió una transducción de un 20\%-50\% de células positivas (para evitar la subestimación debida a la presencia de células con multiplicidad de infección, o moi, superior a uno) y calculamos con este porcentaje el tamaño de la población transducida, y la multiplicidad de infección, teniendo en cuenta el número de células totales transducidas (para lo cual realizamos un contaje celular de un pocillo no transducido en el momento de la transducción). Multiplicamos por el factor de dilución y dividimos el resultado por el volumen de sobrenadante aplicado por pocillo, de esa manera obtuvimos el número de partículas infectivas (diferente al número de partículas virales, ya que en la producción viral se generan multitud de partículas incompletas o sin el transgén) del sobrenadante viral por ml. Obtuvimos la moi dividiendo este valor por el número de células que fueron transducidas por cada $\mathrm{ml}$ de sobrenadante viral. Con este procedimiento conseguimos moi de más de 10 partículas infectivas (de hasta 100 en algunos casos) por célula sin necesidad de concentrar el sobrenadante.

\subsection{INMUNOPRECIPITACIÓN DE CDK2}

La inmunoprecipitación (IP) es una técnica que consiste en precipitar una proteína en una solución utilizando un anticuerpo que se une específicamente al epítopo de esa proteína en particular. Este proceso se puede utilizar para aislar y concentrar una proteína en particular o para determinar la unión física directa entre dos proteínas o grupos de ellas que forman parte de un complejo (Co-inmunoprecipitación). Se utilizó la segunda premisa para precipitar proteínas CDK2 y determinar qué ciclinas (E O A) se encontraban unidas a ella, y si la proporción de ambas unidas a CDK2 varió con la aplicación del fármaco MLN4924 (500nM). Inmunoprecipitamos CDK2 mediante anticuerpos específicos unidos a bolas magnéticas recubiertas de Proteína $A$. Estas bolas fueron atraídas por fuerzas magnéticas a un imán de manera que facilitaron cada paso del protocolo. Fueron una alternativa a las bolas de sefarosa o agarosa que debían ser aglutinadas mediante centrifugaciones, lo que producía pérdidas de bolas (y proteínas unidas a ellas) en cada paso. Al margen de las herramientas utilizadas, fue fundamental para la inmunoprecipitación realizar todo el proceso en condiciones no desnaturalizantes, es decir, que se mantuviera la estructura tridimensional y los enlaces de los dominios de las proteínas. Para ello utilizamos un buffer de extracción de proteínas diferente al RIPA descrito en el apartado 3.6 (que es capaz de desnaturalizar a ciertas proteínas). El buffer utilizado para inmunoprecipitar fue el denominado NP40 (que se describe al final del protocolo). Éste fue menos agresivo que el buffer RIPA y no comprometió la unión entre 
proteínas. Tras la inmunoprecipitación realizamos WB para determinar los resultados. En este punto, tras aislar las proteínas mediante la inmunoprecipitación, sí se desnaturalizaron mediante la adición del buffer de carga $4 \mathrm{X}$ habitual para WB y hervir.

Indicaciones útiles para el empleo de las bolas magnéticas: A) Cómo recuperar las bolas de su envase original $\rightarrow$ Las bolas deben ser mezcladas muy bien por inversión enérgica antes de coger el volumen requerido del bote en el que vienen conservadas. Para asegurarnos de que cogemos la misma cantidad de bolas, mezclar por inversión antes de cada pipeteo. B) Cómo realizar los lavados $\rightarrow$ dar primero un pulso breve de centrifugación (sin exceder de 5500rpm. para no dañar las bolas o su recubrimiento de proteínas $A / G$ ), utilizar el imán para que se mantengan las bolas aglutinadas en la pared interna del microtubo de $1.5 \mathrm{ml}$ y con una pipeta Pasteur de vidrio, y el sistema de vacío, aspirar con precaución deslizando la pipeta por la pared del tubo opuesta a las bolas. Los lavados y resuspensiones se hacen con $250 \mu \mathrm{l}$ de buffer de lisis NP40. Tras añadir los $250 \mu l$ de lavado debemos resuspender por inversión y/o dando golpes con el dedo.

Procedimiento: sembramos una placa de $15 \mathrm{~cm}$ por condición experimental (controles y las diferentes concentraciones del fármaco MLN4924). Al día siguiente aplicamos los correspondientes tratamientos e incubamos durante $18 \mathrm{~h}$. Al tercer día realizamos la extracción proteica utilizando el buffer de lisis NP40, que conservó las estructuras e interacciones proteicas pues no desnaturalizó las proteínas. El extracto fue adecuadamente aclarado (dimos un pulso largo de centrifugación antes de cuantificar las proteínas para precipitar cualquier resto celular que pudo haber quedado; repetimos lo mismo antes de tomar el volumen a usar en la IP). Cuantificamos los extractos proteicos con Bradford y transferimos a un microtubo de $1.5 \mathrm{ml}$ el volumen correspondiente a $250 \mu \mathrm{g}$ de cada extracto proteico. Mantuvimos los extractos en un volumen mínimo de buffer NP40 de $250 \mu \mathrm{l}$ durante las diferentes etapas. En paralelo apartamos $40 \mu \mathrm{g}$ de extracto sin procesar de cada condición (input).

Una vez aislado el extracto proteico equilibramos las bolas magnéticas. Para ello descartamos el buffer comercial en el que vienen sumergidas y realizamos dos lavados de las bolas con buffer de lisis NP-40. A continuación llevamos a cabo las incubaciones previas a la incubación de las bolas con anticuerpos junto al extracto proteico $\rightarrow$ Tubo1: añadimos en el microtubo de $1.5 \mathrm{ml} 7.5 \mu \mathrm{l}$ de bolas $+250 \mu \mathrm{g}$ de cada extracto proteico (en un volumen final de $250 \mu \mathrm{l}$ ) e incubamos una hora a $4 \stackrel{\circ}{ } \mathrm{C}$ en la noria. Con este paso eliminamos las proteínas que se podrían haber unido de forma inespecífica a las bolas. Tubo2: por cada muestra, añadimos en un microtubo de $1.5 \mathrm{ml} 15 \mu \mathrm{l}$ de bolas y $2 \mu \mathrm{g}$ del anticuerpo anti-CDK2 (M2). Añadimos buffer NP40 hasta completar un volumen total de $250 \mu$ l e incubamos una hora a temperatura ambiente.

Recuperamos del Tubo1 el sobrenadante, que incluyó las proteínas que no se unieron inespecíficamente a las bolas magnéticas, y descartamos las bolas. Descartamos el sobrenadante del Tubo2 que incluyó a los anticuerpos que no se unieron a las bolas y lavamos dos veces las bolas con buffer NP40 para eliminar restos de anticuerpos no unidos. Tras estos pasos, resuspendimos las bolas con anticuerpos unidos del Tubo2 en buffer NP40. El volumen empleado dependió del número de muestras, de tal manera que tras homogeneizar pudimos redistribuir el mismo número de bolas más anticuerpos a cada muestra/condición. 
En este punto procedimos a la incubación de bolas con anticuerpos junto al extracto proteico, para lo cual añadimos el volumen de buffer NP40 con bolas más anticuerpos del paso anterior a cada muestra de proteína. Completamos con buffer de lisis NP40 hasta tener un volumen final de $500 \mu \mathrm{l}$ por muestra e incubamos tres horas a 4 으 en la noria. Tras la incubación recogimos el sobrenadante que contiene el resto de proteínas no inmunoprecipitadas (output) y lo almacenamos a -20 으. Estas muestras proteicas fueron útiles, entre otras cosas, para determinar la eficiencia del proceso de inmunoprecipitación. Una vez completado el proceso de IP, si funcionó al 100\%, al revelar en el WB, debimos ver la proteína inmunoprecipitada (CDK2) en la IP, en el input y no aparecer en el output (o al menos verse reducida si el éxito fue inferior al $100 \%)$.

Completada la principal incubación de la IP, lavamos las bolas que tenían unido el inmunoprecipitado con buffer NP40 en cuatro ocasiones. Centrifugamos las bolas con el inmunoprecipitado tras el último lavado, resuspendimos cada muestra en $15 \mu \mathrm{l}$ de buffer NP40, añadimos $5 \mu \mathrm{l}$ de sample buffer $4 X$ (buffer de carga del WB) y hervimos a 95ㅇ $\mathrm{C}$ al menos durante 5 minutos en el termo-agitador de tubos "Thermomixer Compact" (Eppendorff). En estas condiciones desnaturalizantes, se produjo la separación de las bolas, el anticuerpo antiCDK2 (M2) y las proteínas inmunoprecipitadas. Tras este proceso, centrifugamos los microtubos para no perder la equidad entre los volúmenes de carga del WB. Utilizamos el imán para recupera los $20 \mu \mathrm{l}$ de inmunoprecipitado desnaturalizado y descartamos las bolas (alternativamente las pudimos conservar a $-20^{\circ} \mathrm{C}$ por si no conseguimos separar adecuadamente el inmunoprecipitado de ellas). Cargamos los $20 \mu \mathrm{l}$ del inmunoprecipitado en el gel de poliacrilamida y realizamos el WB con las condiciones habituales descritas en el apartado 3.6 de Material y Métodos.

Al teñir con rojo de Ponceau la membrana vimos la banda del anticuerpo usado para inmunoprecipitar, a 50KDa aproximadamente. Esta banda sirvió como control de que habíamos puesto la misma cantidad de bolas más anticuerpo en cada muestra a inmunoprecipitar. El resto de proteínas que arrastramos con la IP no fueron detectables mediante esta tinción debido a que la concentración de las mismas no aglutinó suficiente marcaje como para observar a simple vista una banda.

Otro aspecto a tener en cuenta en la IP, es que al incubar la membrana con un secundario anticonejo apareció una banda de 50-52 KDa correspondiente a la IgG del anticuerpo anti-CDK2 con el que inmunoprecipitamos, interfiriendo con la detección de cualquier proteína de ese tamaño para la que utilicemos un primario originado en conejo (source). Por ello fue recomendable usar en el Western blot un anticuerpo de diferente origen al usado en la IP.

- Buffer de lisis NP40: $150 \mathrm{mM} \mathrm{NaCl}, 20 \mathrm{mM}$ Tris pH 8.0, $1 \mathrm{mM}$ DTT (pesado directamente del polvo; Pm 154.25) y 0.5\% NP40.

Una vez preparado complementamos, justo antes de usar, el buffer de lisis NP40 con los siguientes inhibidores: $10 \mathrm{mM}$ Glicerofosfato, $5 \mathrm{mM} \mathrm{NaF}, 1 \mathrm{mM}$ NaOV e inhibidor de proteasa EDTA mini de Roche ( $40 \mu \mathrm{l}$ para $1 \mathrm{ml}$ final). 


\subsection{SISTEMA INDUCIBLE DE EXPRESIÓN GÉNICA}

A la hora de expresar genes exógenos y/o ectópicos en líneas celulares, los sistemas inducibles son herramientas fundamentales cada vez más empleadas en estudios científicos. Constituyen el paso siguiente a aquellos sistemas basados en promotores constitutivos cuyo control de expresión era limitado o nulo.

Para la realización de ensayos de esta tesis utilizamos el sistema inducible "Retro-X-Tet-On Advanced" de Clontech. Este sistema ofrece un alto nivel de expresión, fuertemente regulado, en un formato de vectores retrovirales altamente eficientes. El diseño del sistema de alta expresión se basa en el trabajo de Gossen y Bujard ${ }^{311}$, e incluye las mejoras del sistema que describió Urlinger ${ }^{312}$. El mecanismo retroviral nos permite trasferir el gen de interés a líneas celulares con mayor eficiencia que otros mecanismos como lipofección o electroporación. Una vez trasladado el sistema a la línea celular, éste permite la expresión controlada del gen de interés mediante el ajuste de la concentración del inductor del sistema, la doxiciclina (dox, un derivado de la tetraciclina) (Figura 14, A). El sistema inducible "Retro-X-Tet-On Advance" mantiene el sistema basal (apagado) en ausencia de dox en el medio de cultivo, mientras que la inducción se produce con la adicción de dox. Los niveles de inducción pueden ser controlados ajustando la concentración de dox añadida al medio. Los máximos niveles de inducción obtenidos con este sistema, a menudo, superan los alcanzados con otros promotores constitutivos como el pCMV. En el lado opuesto, los niveles de expresión basal (es decir, sin adición de dox y por tanto, sin inducción voluntaria del sistema) son bajos o inexistentes si se hace una correcta y minuciosa selección de clones.

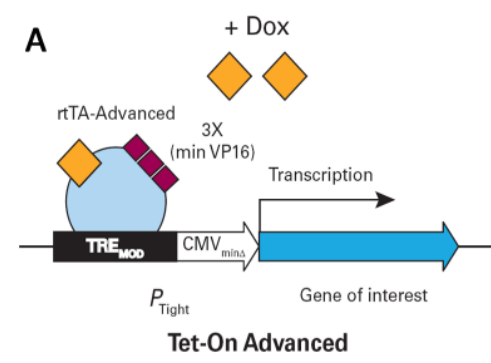

C

C Serial Infection Method
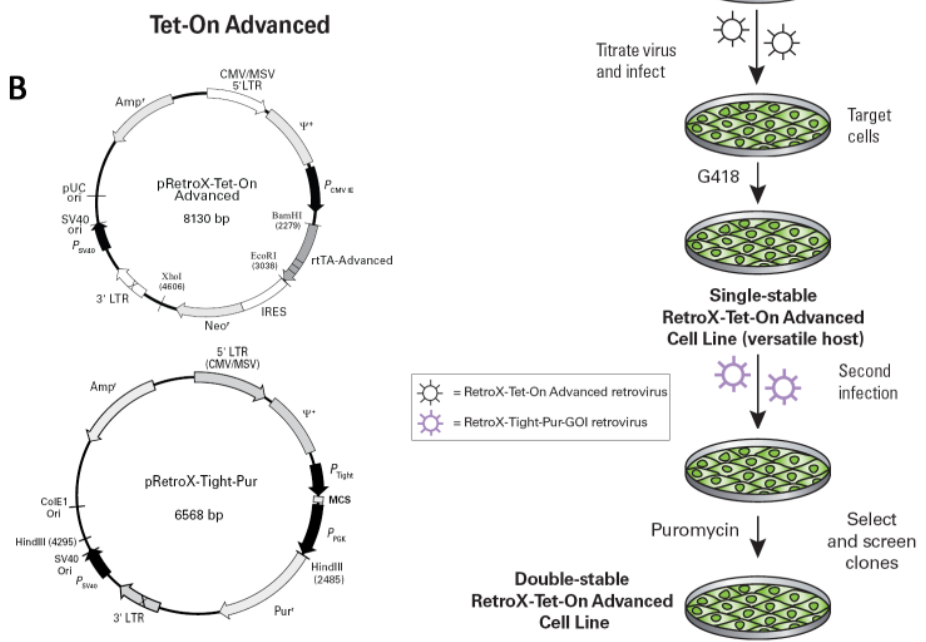

Figura 14: Sistema de expresión inducible Retro- $\mathrm{X}^{\mathrm{TM}}$ Tet-On Advanced de Clontech. A Inducción de la unión de la proteína transactivadora rtTA al promotor $\mathrm{P}_{\text {Tigth }}$ mediada por doxiciclina. B Esquemas de componentes de los vectores del sistema inducible. C Metodología secuencial para el establecimiento del sistema inducible en líneas 
celulares. En el cuadro se detalla el vector utilizado en cada etapa; GOI (del inglés, gen of interest). Reproducido del manual del Retro- $\mathrm{X}^{\mathrm{TM}}$ Tet-On ${ }^{\circledR}$ Advanced Inducible Expression System (Clontech).

\subsubsection{Elementos del sistema "Retro-X-Tet-On Advanced" de Clontech}

El sistema se compone de dos vectores: el transactivador y el vector de respuesta. Además, para establecer el sistema en las líneas celulares diana se requieren el resto de vectores necesarios para la transducción retroviral (que se explica en el apartado 3.12 de la sección Material y Métodos). Las características de los vectores del sistema inducible de Clontech se detallan a continuación:

- Vector transactivador (pRetro-X-Tet-On Advance transactivator): este vector expresa constitutivamente la proteína transactivadora rtTA-Advance. Ésta se caracteriza por tener un dominio mutante rTetR que permite la unión a sitios tetO en presencia de dox. El dominio rTetR está fusionado a regiones mínimas de transactivación " $F$ " de un dominio derivado del virus del herpex simple, VP16. Este vector porta el gen de resistencia a Neomicina (Figura 14, A y B).

- Vector de respuesta (pRetroX-Tight-Pur): contiene $\mathrm{P}_{\mathrm{Tigth}}$, que es el promotor de respuesta inducible que controla la expresión del gen de interés. El promotor se compone de siete repeticiones de una secuencia tetO modificada seguidas de un promotor $\mathrm{CMV}$ modificado $\left(P_{\text {mincmva }}\right)$. $P_{\text {tigth }}$ carece de sitios de unión para factores de transcripción endógenos de mamífero, lo que favorece la ausencia de expresión basal. Tras la inducción (por presencia de dox en el medio), rtTA-Advanced se une al promotor $P_{\text {Tigth }}$ lo que provoca el inicio de transcripción del gen de interés. Este vector porta el gen de resistencia a Puromicina (Figura $14, A$ y $B)$.

\subsubsection{Establecimiento el sistema inducible en líneas celulares de SE}

Para establecer el sistema inducible seguimos tres pasos secuenciales:

1- Clonación del cDNA del gen de interés en el vector de respuesta downstream del promotor PTigth. Utilizamos los sitios de clonaje del vector indicados en el manual (zona del plásmido con varias dianas de restricción, o "multiple cloning site").

2- Transducción retroviral del vector transactivador. Mediante el protocolo que se describe en el apartado 3.12 de Material y Métodos, introdujimos y establecimos el primer vector del sistema inducible. Aislamos clones individuales mediante la aplicación de geneticina (G418) y evaluamos como se indica a continuación. Posteriormente, aquellos clones preseleccionados pasaron a la tercera etapa (Figura 14, C).

3- Transducción retroviral del vector de respuesta con el gen de interés ("GOI") en el clon seleccionado en el paso anterior. Aislamos clones individuales mediante la aplicación de puromicina (Figura 14, C) y evaluamos como se indica en el último sub-apartado.

3.11.3 Evaluación de la transducción y actividad del vector transactivador del sistema inducible: ensayo luciferasa para selección de clones

Una vez finalizada la transducción viral (donde insertamos el vector transactivador), de acuerdo al protocolo que se describe en el apartado 3.12 de esta sección, procedimos a 
seleccionar aquellas células que recibieron la carga génica. Como realizamos diluciones seriadas del sobrenadante viral, el número de partículas infectivas por célula y por lo tanto copias génicas exógenas, fueron disminuyendo. Las diluciones utilizadas fueron $10^{0}, 10^{-1}, 10^{-2}$, $10^{-3}, 10^{-4}$ y $10^{-5}$ sobre la línea celular de SE RDES. En el rango de $10^{0}$ a $10^{-3}$ cada célula recibió más de un impacto viral con la carga completa y casi la totalidad del cultivo fue infectado y sobrevivió a la selección. Estas condiciones (especialmente la $10^{-3}$ ) son útiles para hacer un pool de clones con el que hacer un primer test de funcionalidad del sistema. Sin embargo, en las dos últimas diluciones observamos como una mínima parte de las células seleccionadas con $130 \mu \mathrm{g} / \mathrm{ml}$ de $\mathrm{G} 418$ sobrevivieron y formaron colonias suficientemente espaciadas como para ser fácilmente aisladas y crecidas individualmente. Estocásticamente alguna célula pudo tener más de una copia (evento extremadamente improbable), pero el resto (la casi totalidad) tuvo solo una. Una vez expandidos los pools de células de las diluciones menores fueron congelados por si eran requeridos para otros ensayos (testeo preliminar de funcionalidad del sistema, por ejemplo). Mientras que en las dos diluciones mayores se dejó expandir y formar clones individuales a partir de una sola célula. Una vez que alcanzaron un tamaño adecuado, los picamos y expandimos. Los clones individuales en ningún momento fueron tratados con medio más dox.

Una vez expandidos estos clones con una única copia del vector transactivador procedimos a la evaluación y selección de los mejores clones: las cualidades que buscamos fueron ausencia total de expresión basal, y dentro de este grupo de clones sin basal, seleccionamos aquellos con la máxima inducibilidad, es decir, que fueron capaces de provocar la mayor activación del promotor del vector de respuesta. En este punto, la línea RDES sólo poseía el vector transactivador por lo que para poder determinar el potencial transactivador y la basal debimos implementar la línea con un vector de respuesta. El vector utilizado era el pTight-Pur con un gen reporter, luciferasa de Firefly (pTight-Luciferase-Pur).

Mediante el uso de lipofectamina transfectamos los clones de RDES que contenían el vector de transactivación con: pTigtht-Luciferase-Pur (vector inducible con el gen de luciferasa) y otras con el vector pGL2c (contiene el gen de la luciferasa de Firefly con un promotor constitutivo). Con el primer vector comprobamos la capacidad de inducción del vector transactivador y el segundo fue un control positivo ya que expresó constitutivamente la luciferasa. En paralelo, en todos los casos, se co-transfectó un segundo vector denominado pRL-TK (contenía el gen de luciferasa pero de Renilla regulado por un promotor constitutivo; sirvió para normalizar todos los resultados frente a él puesto que la luciferina que usa como sustrato es distinta a la de la luciferasa de luciérnaga). De modo que si partimos de un distinto número de células viables en cada condición u ocurrió cualquier otro factor que pudo provocar variación técnica (ejemplo: distintas eficiencias de transfección) fue corregido con la normalización.

Procedimiento: sembramos tres pocillos de placa de 24 poc. $\left(5 \times 10^{4}\right.$ células por pocillo) por cada condición. Las condiciones por cada clon fueron: pTight-Luciferase-Pur por duplicado (ya que una fue activada con dox y la otra no) y pGL2c (que era independiente de doxiciclina). Por lo tanto, el primer día sembramos 9 pocillos por clon en medio con una décima parte de $\mathrm{P} / \mathrm{S}$ de lo habitual (para evitar apoptosis con la posterior lipofección). Al día siguiente realizamos la lipofección de las células. Por cada pocillo preparamos $0.7 \mu \mathrm{g}$ del plásmido de interés (pTightLuciferase-Pur o pGL2c) $+0.7 \mu \mathrm{g}$ del plásmido pRL-TK $+62.5 \mu$ l de Optimen. En paralelo para 
cada pocillo preparamos $2.5 \mu \mathrm{l}$ de Lipofectamina $+60 \mu \mathrm{l}$ de Optimen. Añadimos la segunda mezcla sobre la primera e incubamos durante 20 minutos. Tras los cual, añadimos por goteo sobre el medio de cultivo del pocillo de destino (volumen total $125 \mu \mathrm{l}$ ). Una vez lipofectados todos los pocillos incubamos las células en las condiciones habituales $\left(37 \circ \mathrm{C}, 5 \% \mathrm{CO}_{2}\right)$ durante 6h. Al finalizar este periodo sustituimos el medio que contenía lipofectamina (que era tóxica para las células) por medio normal suplementado.

Al día siguiente añadimos medio con $1 \mu \mathrm{g} / \mathrm{ml}$ de dox a la mitad de los pocillos que lipofectamos con pTight-Luciferase-Pur). En el resto de condiciones sustituimos el medio por medio normal suplementado. De esta manera indujimos el vector de respuesta y lo pudimos comparar frente al vector sin inducción, a su vez ambos con respecto al vector con promotor constitutivo. El periodo de inducción del sistema con dox de las muestras fue de $12 \mathrm{~h}$. Tras las $12 \mathrm{~h}$ de inducción se adquirieron los resultados de todas las condiciones mediante el uso del kit "Dual-Luciferase Reporter Assay System" (Promega). Este kit, compuesto de un buffer de lisis, que lisó las células liberando las luciferasas y manteniéndolas activas durante el revelado (a 4ㄷ y/o hielo), LARII (solución que contenía luciferina, el sustrato para la luciferasa de Firefly) y la solución Stop\&Glo (solución que inhibió la reacción de la luciferasa de Firefly y que además contenía la luciferina específica de la luciferasa de Renilla). La acción de las luciferasas de cada condición fueron cuantificadas mediante el uso del luminómetro "Lumat LB 9507" (Berthold Technologies). El protocolo de medición consistió en aplicar a $10 \mu \mathrm{l}$ de lisado $50 \mu \mathrm{l}$ de LARII y medir la actividad luciferasa (Firefly) durante 5 segundos. A continuación se añadieron $50 \mu l$ de Stop\&Glo y se midió de nuevo la actividad luciferasa (Renilla) durante 5 segundos.

En último lugar llevamos a cabo el procesamiento de los datos y la elección del clon más eficiente. Tras obtener los datos en crudo de actividad luciferasa Firefly, normalizamos cada muestra (cada pocillo) con la actividad luciferasa Renilla del mismo. Posteriormente unificamos las tres réplicas (tres pocillos) de cada condición y, finalmente, comparamos la condición inducida (con dox) con la basal (sin dox) y ambas con el constitutivo pGL2c. Para la selección del clon más idóneo realizamos una preselección de aquellos cuya basal fue mínima o nula. Dentro de esos, seleccionamos finalmente los que más inducibilidad tenían, es decir, aquellos cuya actividad luciferasa distó más con respecto a su valor basal (calculado como "fold change").

\subsubsection{Evaluación de la transducción del vector de respuesta y de la actividad del sistema "Retro-X-Tet-On Advanced" estable en la línea celular diana: ensayo WB para selección de clones}

Una vez seleccionado el clon de RDES cuyo vector transactivador no presentó expresión basal y además fue el más eficiente a la hora de la inducción, procedimos a la transducción del vector de respuesta que contenía el gen de interés sobre dicho clon: pRetroX-Tight-CiclinaA-Pur y pRetroX-Tight-CiclinaE-Pur.

La transducción se llevó a cabo mediante el protocolo detallado en el apartado 3.12 de Material y Métodos. Nuevamente establecimos pools de células y clones individuales mediante la aplicación de diluciones seriadas del sobrenadante viral. Una vez establecidos los clones individuales, evaluamos la capacidad de inducción del gen de interés mediante WB. 
Procedimiento: sembramos dos placas de $10 \mathrm{~cm}$ de cada clon a testar $\left(2.5 \times 10^{6}\right.$ células por placa) en medio normal suplementado. Al día siguiente le sustituimos a una de las placas el medio por medio nuevo con dox a una concentración final de $0.5 \mu \mathrm{g} / \mathrm{ml}$ (inducción). A la otra placa se le sustituimos el medio por medio nuevo normal (sin dox). Prolongamos el periodo de inducción durante 12-15h. Tras los cual, extrajimos proteínas y realizamos WB con ellas siguiendo el protocolo del apartado 3.6 de Material y Métodos.

Finalmente basamos la selección en descartar aquellos que tuvieron expresión basal detectable (en este caso hubo que tener en cuenta que al revelar el WB apareció una banda en los carriles de no dox que correspondieron a la expresión de Ciclina A o Ciclina E endógenas). Consideramos clones con demasiada basal aquellos casos en los que la banda de proteína en la condición sin dox superaba a la banda habitual de proteína endógena. Dentro de los preseleccionados, elegimos finalmente a aquellos cuya inducibilidad y, por tanto, capacidad de expresión de la proteína de interés fue mayor.

\subsection{TRANSDUCCIÓN RETROVIRAL DE LÍNEAS CELULARES DE SE}

El sistema utilizado se basó en la producción de retrovirus defectivos en replicación de segunda generación, y fue similar al descrito anteriormente para la generación de lentivirus (apartado 3.9). Sin embargo, a diferencia del protocolo usado para la transducción lentiviral, los vectores de producción retroviral (en este caso los genes gag-pol transfectados pertenecieron al virus de la leucemia murina de Moloney, Mo MuLV) se co-transfectaron en cultivos de células $293 \mathrm{~T}$ a baja confluencia (50-60\%) mediante un protocolo típico de transfección con fosfato cálcico utilizando el kit "CalPhos" Mammalian Transfection" (Clontech).

El día anterior a la transfección sembramos $2.5 \times 10^{6}$ células $293 \mathrm{~T}$ por placa de $10 \mathrm{~cm}$, en un volumen total de $8 \mathrm{ml}$ de DMEM suplementado con $10 \% \mathrm{FBS}$, glutamina y $\mathrm{P} / \mathrm{S}$. El día de la transfección, por la tarde, añadimos $2 \mathrm{ml}$ adicionales de medio. En paralelo, completamos en dos tubos falcon de $15 \mathrm{ml}$ las siguientes mezclas (por cada placa de $10 \mathrm{~cm}$ de $293 \mathrm{~T}$ a transfectar):

- Tubo1:

Plásmido con gen de interés o vector vacío $\quad 10 \mu \mathrm{g}$

pUMVC (genes gag-pol del Mo MuLV) $\quad 10 \mu \mathrm{g}$

pMD2.G (gen de la envuelta VSV-G) $\quad 5 \mu \mathrm{g}$

$\mathrm{CaCl}_{2} 2.5 \mathrm{M} \quad 100 \mu \mathrm{l}$

Agua Milli-Q autoclavada $\quad \Sigma=1 \mathrm{ml}$

- Tubo2:

$1 \mathrm{ml}$ de solución HBS $2 \mathrm{X}$ 
Tras mezclar debidamente el contenido del Tubo1, añadimos éste sobre el volumen del Tubo2 lentamente por goteo mientras mantuvimos el falcon de $15 \mathrm{ml}$ en agitación con el vórtex a una velocidad de 700rpm. Una vez hecho esto, incubamos la mezcla durante 5 minutos y después, tras resuspender el precipitado suavemente por pipeteo, adicionamos los $2 \mathrm{ml}$ por goteo a la placa de 293T. Finalmente homogeneizamos agitando suavemente la placa con movimientos en cruz. Confirmamos al microscopio la presencia de un fino precipitado correspondiente a las partículas de fosfato cálcico que contienen los DNA transfectados. Incubamos durante toda la noche en el incubador de cultivos (a $37 \stackrel{\circ}{\circ}, 5 \% \mathrm{CO}_{2}$ ).

Al día siguiente retiramos el medio de transfección, lavamos la placa dos veces con medio para eliminar los restos de fosfato cálcico y añadimos $9 \mathrm{ml}$ de medio fresco (de nuevo DMEM, $10 \%$ FBS más $\mathrm{P} / \mathrm{S}$ ). Los restos de fosfato cálcico deben ser eliminados porque comprometen la viabilidad celular y por tanto la producción viral de las células 293T. El instante en que añadimos los $9 \mathrm{ml}$ de medio fresco lo consideramos como tiempo cero de producción viral. Un día después, $24 \mathrm{~h}$ antes de la transducción, sembramos las células diana (las que van a ser transducidas) en placas de 6 poc., poniendo por pocillo $4 \times 10^{5}$ células y sembrando una placa de 6 poc. por cada placa de $10 \mathrm{~cm}$ de células productoras transfectadas.

48h después de la transfección, procedimos de forma idéntica a la descrita para la transducción lentiviral: filtramos el sobrenadante, añadimos $3 \mathrm{ml}$ de medio fresco (DMEM 10\% FBS) y realizamos las diluciones seriadas del sobrenadante. Tras lo cual, añadimos a todas las preparaciones polibreno a una concentración final de $8 \mu \mathrm{g} / \mathrm{ml}$. Posteriormente repartimos $2 \mathrm{ml}$ de sobrenadante viral por pocillo de las células a transducir y centrifugamos a $2000 \mathrm{rpm}$, a $32{ }^{\circ} \mathrm{C}$ durante una hora. Tras finalizar el periodo de centrifugación trasladamos las placas al incubador con las condiciones habituales de cultivo $\left(37\right.$ - $\mathrm{C}$ y $\left.5 \% \mathrm{CO}_{2}\right)$ durante $7 \mathrm{~h}$. El periodo de incubación total de la transducción con ambas fases comprendió 8h, tras lo cual, retiramos el sobrenadante viral de cada pocillo y añadimos medio normal suplementado. A partir de este momento seguimos la rutina descrita en el apartado de transducción lentiviral.

\subsection{CLONAJE PARA SOBREEXPRESIÓN DE CDT1}

Estudios preclínicos del fármaco MLN4924 en otras neoplasias, anteriores a nuestro estudio sobre líneas de SE, describieron que el fármaco provoca la inhibición de la activación de CUL1 y consecuentemente se acumula una de sus dianas de ubiquitinación, CDT1 ${ }^{272,281}$. CDT1 (chromatin licensing and DNA replication factor 1) es una proteína que participa en la replicación del DNA; su degradación controlada evita la re-replicación ${ }^{313}$. En el caso de la línea HCT116 se produce su acúmulo como resultado de la inhibición se su degradación al utilizar el fármaco MLN4924 ${ }^{272,279}$. Para nuestro estudio preclínico quisimos sobreexpresar el gen CDT1 en las líneas celulares de SE para comprobar si provoca el mismo efecto que el fármaco MLN4924.

Obtuvimos el cDNA de CDT1 en el interior del vector pOTB7, pOTB7-CDT1 (plásmido con cDNA humano completo y de secuencia confirmada obtenido de OpenBiosystems). Con la intención de poder transducir a las células de SE para sobreexpresar CDT1, debimos clonar el cDNA en un plásmido retroviral aguas abajo de un promotor constitutivo. El plásmido que reunió estas características fue el pBABE puro, cuyo promotor (la propia LTR viral) nos permitió sobreexpresar el gen de interés. 
Procedimiento: realizamos las restricciones indicadas a continuación en varias reacciones en paralelo (4-5, cada una en un microtubo independiente) para obtener gran cantidad de plásmido abierto e inserto de modo que, una vez procesados adecuadamente, tuviéramos suficiente de ambos para la ligación. En cada digestión digerimos $2 \mu \mathrm{g}$ de plásmido. Para determinar el volumen requerido de muestra para alcanzar esa cantidad utilizamos el espectrofotómetro "NanoDrop-1000". Realizamos todas las digestiones a 37으 durante toda la noche en el termociclador "MyCycler" ${ }^{\mathrm{TM}}$ thermal cycler" (Biorad).

En el caso de pOTB7-CDT1 realizamos dos digestiones secuenciales. En la primera digestión liberamos el inserto de interés (cDNA de CDT1) de 1930pb. Pero, debido al tamaño total del plásmido (3745pb), la banda que comprendió el resto del plásmido (1815pb) que queríamos descartar fue de un tamaño similar a la del inserto. Para aislar la banda específica, digerimos por segunda vez con una enzima cuya diana de restricción estuvo situada en una región intermedia de la secuencia a descartar. Para poder llevar a cabo la segunda restricción eliminamos los restos de las anteriores enzimas utilizadas así como el buffer empleado para que no interfiriesen o dificultasen en la segunda restricción. Utilizamos el "PCR purification kit" (Qiagen), que nos permitió aislar el DNA del resto de componentes: el kit atrapó por afinidad en una columna las moléculas de DNA, a continuación permitió lavar la muestra de modo que el resto de componentes que no fueron el DNA atravesaron la columna y fueron descartados. En último lugar, utilizamos un buffer de elución que disminuyó la afinidad del DNA por la columna, éste se desprendió, bajó por la columna y lo pudimos recuperar. Recolectamos la elución, comprobamos qué cantidad de DNA recuperamos midiendo con el NanoDrop y procedimos a la segunda restricción como se indica posteriormente. Tras la segunda restricción, corrimos el DNA en un gel de agarosa al 1\% en TAE y obtuvimos tres bandas de diferentes tamaños: 1930 (inserto, cDNA de CDT1) + 1079 + 736, las dos últimas eran restos del vector que contenía al cDNA de CDT1 y las descartamos.

\section{1a Restricción vector p0TB7-CDT1}

Tampón Tango 10x (Fermentas) $\quad 4 \mu \mathrm{l}$

DNA (vector)

$2 \mu \mathrm{g}$

EcoRI (Fermentas)

Xhol (Fermentas)

Agua Milli-Q 2a Restricción vector pOTB7-CDT1 (EcoRI-Xhol) Tampón Tango 10x (Fermentas) $\quad 6 \mu \mathrm{l}$ DNA (elución kit purificación) $\quad 45 \mu \mathrm{l}$ Clal (Fermentas) $\quad 6 \mu \mathrm{l}$ Agua Milli-Q $\quad \Sigma=60 \mu \mathrm{l}$

\section{Restricción vector pBABEpuro}

Tampón Orange 10x (Fermentas) $2 \mu \mathrm{l}$

DNA (vector) $2 \mu \mathrm{g}$

EcoRI (Fermentas) $\quad 1 \mu \mathrm{l}$

Sall (Fermentas) $1 \mu \mathrm{l}$

Agua Milli-Q $\quad \Sigma=20 \mu \mathrm{l}$

Tras las digestiones descritas corrimos en un gel de agarosa al 1\% en TAE alícuotas de las muestras (Figura 15) junto a un marcador de tamaños de fragmentos de DNA "1kb DNA Ladder" (Promega), así comprobamos que las bandas tenían el tamaño correcto (Figura 15, A). Tras la confirmación, corrimos en otro gel el total de las muestras digeridas para 
poder cortar las porciones del gel de agarosa que contenían las bandas de DNA de interés (Figura 15, B).

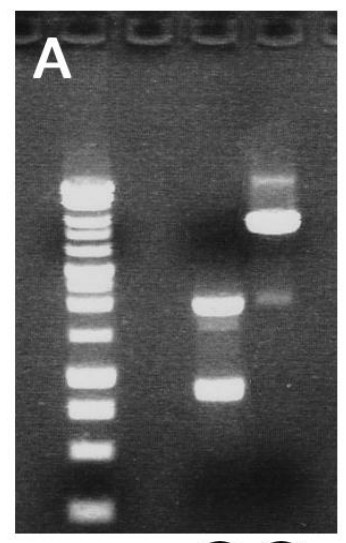

(1)(2)

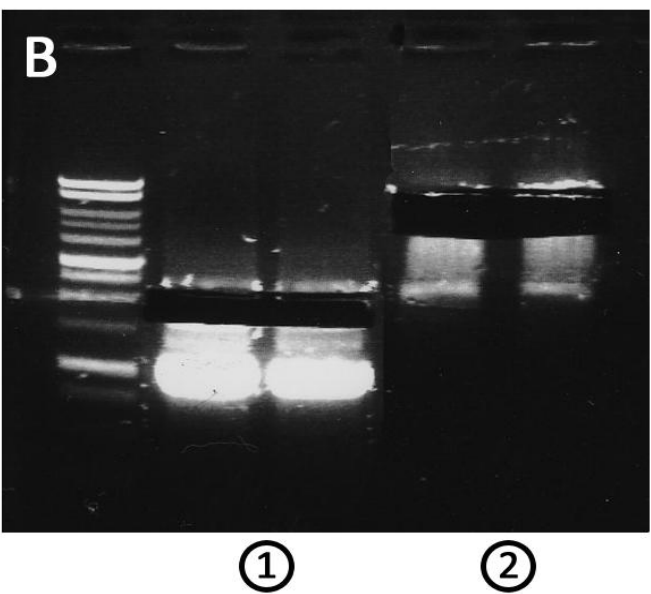

Figura 15: Electroforesis en gel agarosa al 1\% en TAE de (1) pOTB7-CDT1 (EcoRI+Xhol+Clal) y (2) pBABEpuro (EcoRI+Sall). A Digestión de los plásmidos; se observa digestión parcial por lo que aparecen bandas aún sin digerir. B Digestión completa y extracción de fragmentos de agarosa con las bandas de DNA de interés.

Una vez recuperadas las porciones del gel de agarosa utilizamos el "Gel band purification kit" (GE Healthcare) para extraer las moléculas de DNA. Primero calentamos las muestras a 65으 para fundir la agarosa (a esta temperatura las bandas de DNA son estables). Mediante un sistema de columnas de afinidad análogo al del "PCR purification kit" aislamos las moléculas de DNA, eliminamos restos de agarosa y otros componentes, y con el buffer de elución se recuperamos las muestras de interés (el inserto CDT1 y pBABEpuro abierto).

Sometimos al vector de destino abierto con las enzimas EcoRI y Sall a otro proceso, la desfosforilación. Las enzimas T4 DNA ligasas sólo pueden restablecer el enlace entre los extremos $3^{\prime}$ y $5^{\prime}$ de las moléculas de DNA cuando la desoxirribosa conserva el grupo fosfato en el extremo 5'. Mediante el empleo de ATP pueden establecer la unión con el grupo hidroxilo del otro fragmento. Desfosforilamos los extremos libres del vector que quedaron tras la digestión para dificultar que vuelvan a unirse. Esto complementó a la incompatibilidad de extremos cohesivos que quedaron tras la restricción indicada anteriormente para evitar la recircularización del plásmido. Llevamos a cabo la desfosforilación con los siguientes reactivos:

\section{Desfosforilación pBABEpuro (EcoRI-Sall)}

Vector abierto y purificado $35 \mu \mathrm{l}$

NEB buffer 3 (10X)

CIP (fosfatasa alcalina de intestino de ternera, NEB)

Agua Milli-Q

Prolongamos el proceso de desfosforilación durante toda la noche en el termociclador a 37으. Posteriormente, purificamos la muestra de nuevo mediante el uso del "PCR purification kit". Tras lo cual medimos la concentración final de plásmido y también del inserto purificado en el NanoDrop para iniciar el proceso de ligación. 
La ligación se produjo entre los extremos cohesivos compatibles del inserto y del plásmido. Además de la diana EcoRI que compartían, la unión en los extremos opuestos se realizaron entre las terminaciones cohesivas de Xhol y Sall, que pese a no compartir la misma diana de restricción generan extremos cohesivos compatibles (si bien, el resultado de su fusión provocó la pérdida del sitio de restricción de ambas). El inserto aportó los grupos fosfatos necesarios para la ligación. Para determinar la proporción de inserto y plásmido que empleamos en cada reacción seguimos la siguiente fórmula:

$$
\frac{\text { ng de vector } \mathrm{x} \text { kb de inserto }}{\mathrm{kb} \text { de vector }} \times \frac{3}{1}=n g \text { de inserto }
$$

Empleamos 20ng de vector y calculamos el número de nanogramos de inserto necesarios utilizando dos ratios, $3 / 1$ (como se indica en la fórmula) y $6 / 1$. Una vez calculada la cantidad necesaria de ambos componentes llevamos a cabo la ligación utilizando los siguientes reactivos:

\section{Ligación pBABEpuro (EcoRI-Sall) desf. + CDT1 (EcoRI-Xhol)}

$\begin{array}{lcccc} & \text { RATIOS: } & 3 / 1 & & 6 / 1 \\ \text { Vector abierto, desfosforilado y purificado } & 20 \mathrm{ng} & & 20 \mathrm{ng} \\ \text { Inserto (CDT1) } & 22.8 \mathrm{ng} & & 45.6 \mathrm{ng} \\ \text { T4 DNA ligasa } & 1 \mu \mathrm{l} & & 1 \mu \mathrm{l} \\ \text { Buffer T4 DNA ligasa } & 1 \mu \mathrm{l} & 1 \mu \mathrm{l} \\ \text { PEG4000 } & 1 \mu \mathrm{l} & & 1 \mu \mathrm{l} \\ \text { Agua Milli-Q } & \sum=10 \mu \mathrm{l} & & \Sigma=10 \mu \mathrm{l}\end{array}$

Además de las dos reacciones de ligación con diferentes ratios, incluimos un control con todos los reactivos detallados excepto el inserto. Llevamos a cabo la ligación a 16드 durante toda la noche en el termociclador.

El siguiente paso para la selección de plásmidos con el inserto de interés fue la trasformación de Escherichia coli DH5a y cribado de colonias. Para la transformación en el hospedador bacteriano, añadimos la mitad de la reacción de ligación ( $5 \mu \mathrm{l}$ ) a $100 \mu \mathrm{l}$ de bacterias $\mathrm{DH} 5 \alpha$ competentes (protocolo de competencia realizado por la Unidad de Lavado y Esterilización del $\mathrm{CIC}$ ) descongeladas en hielo. Incubamos la mezcla en hielo durante 30 minutos. Tras ello sometimos a las bacterias a un choque térmico de 45 segundos a $42^{\circ} \mathrm{C}$ seguido de un minuto en hielo. Finalmente añadimos $900 \mu$ l de medio líquido LB (Luria-Bertani), incubamos en el agitador a $37^{\circ} \mathrm{C}$ y $250 \mathrm{rpm}$ durante una hora y sembramos las bacterias en placas de agar-LBampicilina $(100 \mu \mathrm{g} / \mathrm{ml}$ de ampicilina, Unidad de Lavado y Esterilización del CIC). Distribuimos el mililitro final de LB más bacterias trasformadas en cantidades decrecientes para evitar la formación del posible césped bacteriano $(450 \mu \mathrm{l}, 150 \mu \mathrm{l}$ y $50 \mu \mathrm{l})$. Tras incubar boca abajo las placas durante aproximadamente $17 \mathrm{~h}$ en la estufa a $37{ }^{\circ} \mathrm{C}$, evitando la formación de colonias satélites, se realizó una primera evaluación del resultado comparando el número de colonias formadas en las placas del vector más inserto con las colonias de las placas control (ligaciones sólo con el vector), confirmando un mayor número de colonias en las placas con la ligación completa. Inoculamos cultivos líquidos ( $7 \mathrm{ml}$ de LB con ampicilina a $100 \mu \mathrm{g} / \mathrm{ml}$ ) a partir de 5 colonias seleccionadas al azar de cada condición, que fueron sometidos a "miniprep" 
(NucleoSpind plasmid mini) tras ser incubados durante 16 a 37으, agitación $250 \mathrm{rpm}$; y posteriormente a restricción para la selección de las construcciones positivas.

Para comprobar si los plásmidos aislados mediante "miniprep" fueron seleccionables, es decir, mantuvieron la integridad del vector y del inserto clonado en el lugar correcto, se sometieron a restricción. De tal modo que debieron dar un patrón de bandas esperado tras su ejecución. En el caso de pBABEpuro-CDT1 utilizamos una doble digestión con EcoRI y Notl. La elección de la segunda enzima fue debió a que durante el proceso de clonaje perdimos las dianas de restricción de Xhol y Sall. El patrón de banda esperado fue:

- $\quad$ BAABEpuro-CDT1 positivo (con inserto): $4.65 \mathrm{~kb}$ y $2.4 \mathrm{~kb}$

- $\quad$ BAABEpuro-CDT1 negativo (sin inserto): $2.75 \mathrm{~kb}$ y $2.4 \mathrm{~kb}$

Tras la digestión de 5 de las "minipreps" preseleccionadas durante dos horas a 37으 corrimos las digestiones en un gel de agarosa al $1 \%$ en TAE. En el primer carril añadimos el "1kb DNA Ladder" para poder determinar el tamaño de las bandas que aparecieron (Figura $16)$.

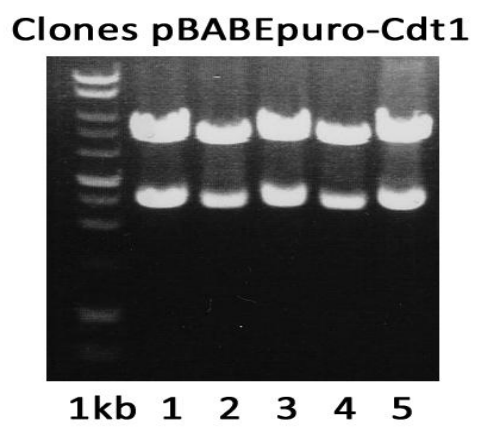

Figura 16: Electroforesis de clones preseleccionados pBABEpuro-CDT1. Tras comprobar por restricción (EcoRI + Notl) que las bandas son correctas, se procesaron para secuenciar.

Una vez que comprobamos que el tamaño de las bandas tras la digestión control fue el correcto mandamos a secuenciar los plásmidos preseleccionados. En rigor, diseñamos cebadores internos (apoyados en la propia secuencia del cDNA de CDT1) y usamos también los cebadores universales del vector, lo que permitió secuenciar completamente los insertos clonados (Tabla 9). Para cada secuenciación incluimos en un microtubo de $1.5 \mathrm{ml} 400 \mathrm{ng}$ del vector preseleccionado más un volumen de agua Milli-Q necesario para alcanzar un total de $5 \mu \mathrm{l}$, más $3 \mu \mathrm{l}$ de uno de los cebadores descritos (solución stock del cebador a $1 \mu \mathrm{M}$ ). Los $8 \mu \mathrm{l}$ se mantuvieron en todo momento en hielo y se trasladaron al Servicio de Genómica del CIC donde fueron secuenciados.

\begin{tabular}{|c|c|}
\hline Nombre & Secuencia \\
\hline pB-CDT1_Fw & 3'- CGTAGGAATTCGGCACGAGGCTC- 5' \\
\hline pB-CDT1_Rv & 3'- ATCCTCGAGAGCCCACATCTGCCTCTGGC- 5' \\
\hline CDT1_sec_Fw & 3'- CAGGTGCTGGCGGAGATG- 5' \\
\hline
\end{tabular}

Tabla 9: Cebadores diseñados para la secuenciación de clones pBABEpuro-CDT1 
Una vez obtenida la secuenciación de los clones preseleccionados, contrastamos la secuencia RefSeq del cDNA de CDT1 y del vector en la zona de "multiple cloning site" utilizando el programa informático "Clustalx" que permitió el alineamiento múltiple de secuencias ${ }^{314}$. Con este programa confirmamos el correcto ensamblaje del inserto en el vector así como la ausencia de mutaciones en la región secuenciada.

\subsubsection{Clonación de Ciclina A y Ciclina E en vectores de respuesta inducibles}

Siguiendo el protocolo de manera análoga al de clonación del cDNA de CDT1 en el vector pBABEpuro clonamos Ciclina A y Ciclina E en el vector pRetroX-Tight-Pur (más información de este vector en el apartado 3.11). A diferencia de lo explicado anteriormente, para la obtención de los insertos se realizó PCR (reacción en cadena de la polimerasa) para amplificar el cDNA de CCNA1 y CCNE1 a partir de los vectores PCKM-TOPO-Ciclina A y pOTB7-Ciclina E (colección de plásmidos con cDNAs humanos completos y de secuencias confirmadas, obtenida de OpenBiosystems).

Los cebadores para la amplificación fueron diseñados sobre las secuencias de los plásmidos de origen (desde el ATG del primer codón al codón de stop) y les incorporamos colas con las dianas de restricción adecuadas para clonar el producto de PCR en el vector pMIG. Además añadimos una secuencia codificante del "tag" HA, que permitió monitorizar la expresión de la proteína exógena que introducimos en la línea celular de destino. Tras realizar un estudio de restricción y seleccionar aquellas enzimas sin diana en el interior de las secuencias a clonar, pero sí en el sitio de clonación múltiple del vector (utilizamos para ello el programa informático "NEBcutter V2.0", New England BioLabs), diseñamos los siguientes cebadores (secuencias en sentido 5'- 3'):

- Cebador para la clonación de Ciclina A, Fw:

AT- AGATCT-GCCACC- ATGGCATACCCATACGACGTCCCAGACTACGCT -ATGTTGGGCAACTCTGCGCC

Apoyo-BgllI-Sec. Kozac Sec. codificante HA Inicio sec. codificante CiclinaA

- Cebador para la clonación de Ciclina A, Rv:

CG-GAATTC-TGTTACAGATTTAGTGTCTCTGGTGGG

Apoyo-EcoRI

- Cebador para la clonación de Ciclina E, Fw:

AT-AGATCT-GCCACC-ATGGCATACCCATACGACGTCCCAGACTACGCT-ATGAAGGAGGACGGCGG

Apoyo-BgIII-Sec. Kozac Sec. codificante HA Inicio sec. codificante CiclinaE

- Cebador para la clonación de Ciclina E, Rv: 
CG-GAATTC-TTGGTGGAGAAGGATGGGGTGG

\section{Apoyo-EcoRI}

Llevamos a cabo la amplificación utilizando una enzima DNA polimerasa termoestable de alta fidelidad (mezcla de una Taq polimerasa y de una enzima con actividad correctora de errores) y gran capacidad de extensión (hasta $5 \mathrm{~kb}$ ), incluida en el kit "Expand High Fidelity ${ }^{\text {PLus }}$ PCR System" (Roche). Los reactivos utilizados para la PCR fueron (4 reacciones de PCR por cada clonación):

DNA (vector de origen)

50ng

Tampón $5 x$ del kit

$5 \mu l$

$\mathrm{MgCl}_{2}$ del kit

$2 \mu l$

dNTPs (100mM, Eppendorf)

$0.5 \mu \mathrm{l}$

Cebador clonación Fw (20mM)

$0.4 \mu \mathrm{l}$

Cebador clonación Rv (20mM)

$0.4 \mu 1$

Enzima "High Expand Plus"

$0.5 \mu \mathrm{l}$

Agua Milli-Q

$\Sigma=25 \mu \mathrm{l}$

Condiciones de amplificación de las secuencias codificantes de ambas ciclinas:

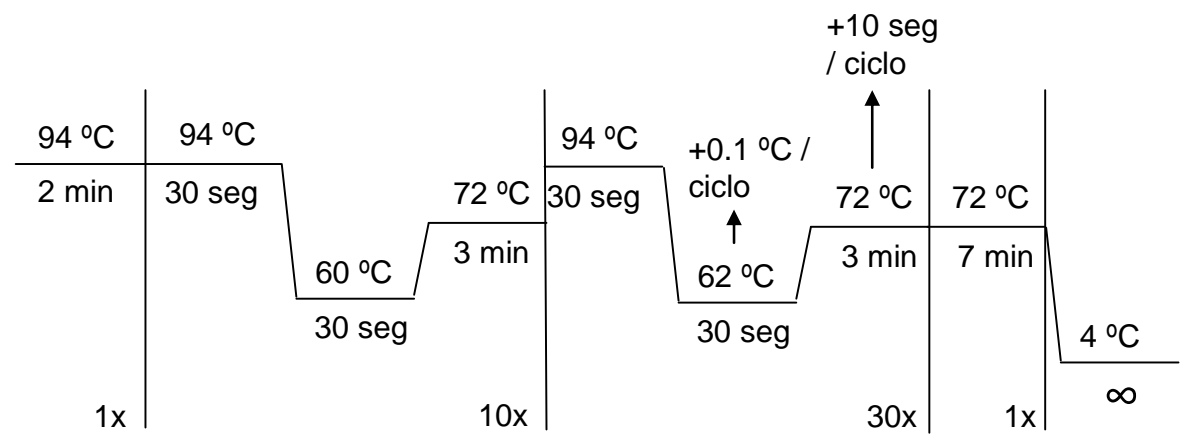

Resolvimos una alícuota de la PCR $(2 \mu \mathrm{l})$ en una electroforesis en gel de agarosa $1 \%$ en TAE para comprobar la correcta amplificación (tamaño esperado de banda según el marcador "1kb DNA ladder", cantidad de producto suficiente y ausencia de amplificación inespecífica) y conservamos el resto del volumen para la posterior restricción. Al finalizar la PCR, los insertos contenían las dianas de restricción para las enzimas Bglll y EcoRI, que digerimos para formar los extremos cohesivos necesarios para la ligación con el vector abierto pMIG.

Tras obtener los insertos, los clonamos en pMIG de manera análoga a lo descrito con CDT1, utilizando las dianas de restricción detalladas. Tras la clonación en el vector pMIG, subclonamos los cDNAs de interés en el vector inducible pRetroX-Tigtht-Pur. Para lo cual cortamos el vector de destino con las enzimas de restricción BamHI+EcoRI para abrirlo, y posteriormente lo desfosforilamos. Extrajimos a los vectores pMIG (con el cDNA de CCNA1 y el cDNA de CCNE1) cada inserto con las enzimas BgIII + EcoRI. Las dianas de restricción BamHI y BgIII son compatibles, de modo que pudimos ligar los extremos cohesivos que provocaron pero perdimos las dianas de restricción originales. 


\subsection{ENSAYO DE LA FUNCIONALIDAD DEL CHECKPOINT DE G2/M POR DAÑO EN EL DNA: CAFEÍNA}

Tras comprobar el efecto que producen determinadas concentraciones del fármaco MLN4924 sobre el ciclo celular de las líneas celulares de $\mathrm{SE}$, bloqueo en $\mathrm{G} 2 / \mathrm{M}$ (esto se explica ampliamente en el apartado 4.3 de la sección Resultados), decidimos ensayar el uso de cafeína para revertir dicho efecto. La cafeína inhibe la ruta de señalización iniciada por ATR/ATM en respuesta al daño en DNA, lo que se traduce en la inhibición directa e indirecta de la activación de los componentes de los checkpoints que bloquean el ciclo en respuesta a este daño, tales como CHK1, p53, p21 y 14-3-3 $\sigma^{315-316}$. Nuestro ensayo consistió en comprobar si el bloqueo del ciclo tras un tratamiento durante $24 \mathrm{~h}$ con MLN4924 a una concentración de 300nM, era revertido por una alta concentración de cafeína $(20 \mathrm{mM})$ aplicándola durante un periodo de $6 \mathrm{~h}$, lo cual indicaría que dicho arresto se debía a daño en DNA. Tras estas 6 h con cafeína, realizamos un estudio de ciclo celular mediante citometría de flujo siguiendo el protocolo descrito en el apartado 3.5 de Material y Métodos.

\subsection{ENSAYO DE SENESCENCIA}

Quisimos determinar si el fármaco MLN4924 provoca senescencia en las células. Para lo cual seguimos las pautas habituales de siembra de células y tratamiento con el fármaco (además de su respectivo control con DMSO). Posteriormente utilizamos el "Senescence Cells Histochemical Staining Kit" (SIGMA), evaluamos al microscopio el marcaje (células teñidas en azul) y calculamos el porcentaje de células senescentes.

Procedimiento: sembramos células RDES y RM82 en placas de 6poc. Sembramos por pocillo: $2.5 \times 10^{4}$ (para condición DMSO), $6 \times 10^{4}$ (para $I C_{25}$ ), $7 \times 10^{4}$ (para IC 50 ) y $8 \times 10^{4}$ (para $I C_{75}$ ). Al día siguiente añadimos con los $\mathrm{IC}_{\mathrm{s}}$ específicos de MLN4924 para cada línea celular y prolongamos el tratamiento durante $96 \mathrm{~h}$. Al finalizar este periodo, revelamos el porcentaje de células senescentes utilizando el "Senescence Cells Histochemical Staining Kit" (SIGMA) siguiendo las recomendaciones del fabricante: aspiramos y retiramos el medio de cultivo, lavamos con PBS y fijamos con la adición de $1.5 \mathrm{ml}$ del buffer de fijación durante 6-7 minutos a temperatura ambiente. Durante la incubación preparamos el mix de tinción $(1 \mathrm{ml}$ de solución de tinción 10X, $125 \mu$ l de reactivo $B, 125 \mu$ l de reactivo $C, 250 \mu l$ de solución X-gal y $8.5 \mathrm{ml}$ de agua Milli-Q) y lo filtramos utilizando filtros con un tamaño de poro de $0.2 \mu \mathrm{m}$.

Lavamos tres veces con PBS las células fijadas, añadimos $1 \mathrm{ml}$ del mix de tinción en cada pocillo y sellamos la placa con parafilm para impedir que penetrase $\mathrm{CO}_{2}$ y se secasen los pocillos. La tinción era sensible a cambios de $\mathrm{pH}$ por lo que fue necesario impedir que se acumulara $\mathrm{CO}_{2}$ en el interior de la placa. Incubamos a 370 o C (en una estufa normal, $\sin \mathrm{CO}_{2}$ ) durante toda la noche.

Finalmente retiramos el mix de tinción y añadimos PBS. Miramos a través del microscopio y determinamos el porcentaje de células azules (que expresaron $\beta$-galactosidasa, senescentes). Para conservar la preparación durante periodos largos sustituimos el PBS por glicerol al 70\%, sellamos con parafilm y mantuvimos las muestras a $2-8$ 으. 


\subsection{ANÁLISIS ESTADÍSTICO}

Para la estadística aplicamos el programa informático SPSS Statistics versión 17.0. Todos los test estadísticos realizados y sus resultados se exponen con detalle en los apartados correspondientes de la sección Resultados.

Para cualquier test comprobamos previamente si la distribución de los datos fue normal mediante el "test Kolmogorov-Smirnov". Posteriormente, según los resultados de dicho test, aplicamos análisis paramétricos o no dependiendo de si los datos seguían una distribución normal.

En todos los ensayos realizamos varias réplicas para confirmar estadísticamente la veracidad y reproducibilidad de los resultados. Generalmente $n=3$, excepto en los cálculos de ICs que pudo extenderse a $n=4$ o $n=5$, y en los ensayos in vivo donde la " $n$ " de cada grupo de ratones fue 80 9. En el ensayo de inmunoprecipitación de CDK2, n=2, por el coste económico y de tiempo que supuso la realización del experimento.

\subsection{TABLA DE REFERENCIAS (Tabla 10)}

\begin{tabular}{|c|c|c|}
\hline PRODUCTO & CASA COMERCIAL & REFERENCIA \\
\hline 1kb DNA Ladder & Promega & G571A \\
\hline 2-Hidroxipropil- $\beta$-Ciclodextrina & Sigma & H107 \\
\hline Ácido Tricloroacético & Merk & 100807 \\
\hline Agarose D-1 Low EEO & Pronadisa & 8012 \\
\hline Agujas hipodérmicas & $\mathrm{BD}$ & 302200 \\
\hline APS & Sigma & 248614 \\
\hline ATP-lite $^{\text {TM }} 1$ step & Perkim Elmer & 6016731 \\
\hline Azida sódica & Sigma & 438456 \\
\hline Bolas magnéticas con Proteína A & Novex & 10001D \\
\hline Bradford & Biorad & $500-0006$ \\
\hline BrdU & Sigma & B5002 \\
\hline BSA & Sigma & A47906 \\
\hline Cafeína & Sigma & C0750 \\
\hline CalPhos $^{\mathrm{TM}}$ Mammalian Transfection Kit & Clontech & 631312 \\
\hline CIP (fosfatasa alcalina de intestino de ternera, NEB) & New England Biolabs & M0290S \\
\hline Complete, Mini EDTA-free protease Inhibitor cocktail tablets & Roche & 11836170001 \\
\hline Criomoldes (para inclusión en OCT) & Tissue-Tek (Sakura) & 4557 \\
\hline Cubreobjetos 20x20mm No.1 & Marienfeld & 101040 \\
\hline DAPI & Sigma & D-9542 \\
\hline Deoxicolato sódico & Merck & 106504 \\
\hline DMSO (no específico para cultivo; para MTT) & Merck & 802912 \\
\hline DMSO específico para cultivo celular & Sigma & D2650 \\
\hline Doxiciclina (Anhydrotetracycline) & Clontech & 631310 \\
\hline Doxorrubicina & Sigma & D1515 \\
\hline DTT & Sigma & D0632 \\
\hline Dual-Luciferase Reporter Assay System & Promega & E1910 \\
\hline ECL Plus Western Blotting Detection Reagents & GE Healthcare & RPN2132 \\
\hline
\end{tabular}




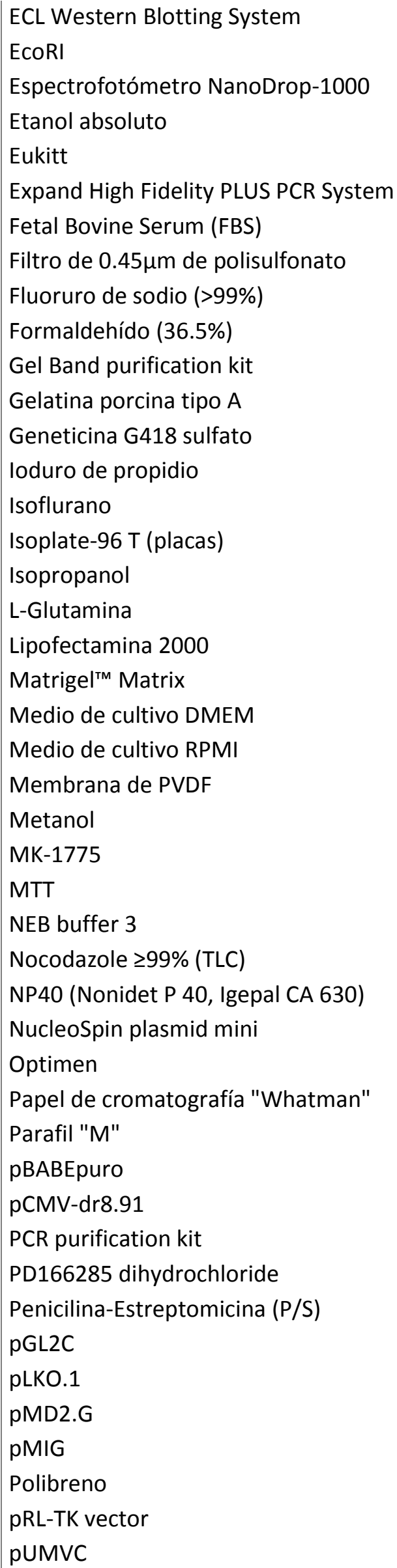

\begin{tabular}{|c|c|}
\hline GE Healthcare & RPN2108 \\
\hline Fermentas & ER0271 \\
\hline NanoDrop (Thermo) & ND-1000 \\
\hline Merck & 100986 \\
\hline Sigma & 3989 \\
\hline Roche & 3300242001 \\
\hline Gibco & $10270-106$ \\
\hline Pall & PN4184 \\
\hline Sigma & S-1504 \\
\hline Sigma & F8775 \\
\hline GE Healthcare & $28-9034-70$ \\
\hline Sigma & G2500 \\
\hline Gibco & $11811-031$ \\
\hline Sigma & P4170 \\
\hline Schering-Plough. S.A. & 3805310 \\
\hline Perkin Elmer & 6005070 \\
\hline Merck & 109634 \\
\hline Gibco & $25030-024$ \\
\hline Invitrogen & 11668019 \\
\hline BD & 356234 \\
\hline Gibco & 21969-035 \\
\hline Gibco & 21875-034 \\
\hline MilliQ & IPVH00010 \\
\hline Sigma & 32213 \\
\hline Axon & Axon 1494 \\
\hline Sigma & M2128 \\
\hline New England Biolabs & B7003S \\
\hline Sigma & M1404 \\
\hline Fluka & 56741 \\
\hline Macherey-Nagel & 740588250 \\
\hline Gibco & 11058 \\
\hline Whatman & 3030672 \\
\hline Labsco & PM996 \\
\hline Addgene & 1764 \\
\hline Addgene & No especificado \\
\hline Qiagen & 28104 \\
\hline Tocris & 3785 \\
\hline Gibco & $15140-122$ \\
\hline Promega & E1611 \\
\hline Addgene & 8453 \\
\hline Addgene & 12259 \\
\hline Addgene & 9044 \\
\hline Sigma & H9268 \\
\hline Promega & E2241 \\
\hline Addgene & 8449 \\
\hline
\end{tabular}




Puromicina
Resina O.C.T.
Retro- ${ }^{\text {TM }}$ Tet-On ${ }^{\circledR}$ Advanced Inducible Expression System
RNAsa A
Rojo Ponceau
Sall
Senescence Cells Histochemical Staining Kit
Sodio Ortovanadato (99-98\%)
Sodium tetraborate decahydrate
T4 DNA ligasa
Temed
Timidina
Tripsina/EDTA 0.25\%
Trypan blue solution $0.4 \%$
Tween 20
Vectashield
Vincristina
Xhol
$\beta$-ME 98\%

\begin{tabular}{ll|} 
Sigma & 18833 \\
Tissue-Tek (Sakura) & 4583 \\
Clontech & 632104 \\
Sigma & R4875 \\
Sigma & P3504 \\
Fermentas & ER0641 \\
Sigma & CS0030 \\
Sigma & 450243 \\
Sigma & S9640 \\
Fermentas & EL0016 \\
Sigma & T7024 \\
Sigma & T1895 \\
Gibco & $25200-056$ \\
Sigma & T8154 \\
Sigma & P7949 \\
Vector & H-1000 \\
Sigma & V8388 \\
Fermentas & ER0691 \\
Sigma & M3148 \\
\hline
\end{tabular}

\subsection{TABLA DE ANTICUERPOS (Tabla 11)}

\begin{tabular}{|c|c|c|c|}
\hline ANTICUERPOS & SOURCE & CASA COMERCIAL & REFERENCIA \\
\hline \multicolumn{4}{|l|}{ PRIMARIOS } \\
\hline \multicolumn{4}{|l|}{ Citometría } \\
\hline BrdU, FITC-Set & Ratón & $\mathrm{BD}$ & 556028 \\
\hline Cleaved-Caspase 3 (Asp175) (D3E9) & Conejo & Cell Signalling & 9603 \\
\hline Phospho-Histone H3 (Ser10) (D2C8) XРТ & Conejo & Cell Signalling & 3377 \\
\hline \multicolumn{4}{|l|}{ Inmunofluorescencia } \\
\hline Alpha tubulina & Ratón & Calbiochem & СP06 \\
\hline CDC6 (H-304) & Conejo & Santa cruz & SC-8341 \\
\hline Gamma H2AX & Conejo & Cell Signalling & 9719 \\
\hline P27 (Kip1) & Ratón & $\mathrm{BD}$ & 554069 \\
\hline Phospho-Histone H3 (Ser10) (D2C8) XРтм & Conejo & Cell Signalling & 3377 \\
\hline \multicolumn{4}{|l|}{ WB } \\
\hline CDC2 & Ratón & Santa Cruz & SC-54 \\
\hline CDC2 & Conejo & Cell Signaling & 9112 \\
\hline CDC25A & Ratón & Santa Cruz & SC-7389 \\
\hline CDK2 & Conejo & Santa Cruz & SC-163 \\
\hline CDT1 & Conejo & Abcam & ab70829 \\
\hline CHK1 & Ratón & Santa Cruz & SC-8408 \\
\hline Cl. Caspase-3 & Conejo & Cell Signaling & 9661 \\
\hline CUL1 & Conejo & Epictomics & $2436-1$ \\
\hline CUL4 & Conejo & Epictomics & $2527-1$ \\
\hline
\end{tabular}




\begin{tabular}{|c|c|c|c|}
\hline Cyclin A2 & Ratón & Sigma & C4710 \\
\hline Cyclin B1 & Conejo & Santa Cruz & SC-752 \\
\hline Cyclin E & Ratón & Santa Cruz & SC-247 \\
\hline n-ACTIN & Conejo & Sigma & A2103 \\
\hline P21 & Conejo & Santa Cruz & SC-397 \\
\hline P27 (Kip1) & Ratón & $\mathrm{BD}$ & 554069 \\
\hline p-CDC2-Y15 & Conejo & Cell Signaling & 9111 \\
\hline p-CDK (Y15) & Conejo & Santa Cruz & SC-28435 \\
\hline p-CHK1(S345) & Conejo & Cell Signaling & 2348 \\
\hline pRB (S780) & Conejo & Cell Signaling & 9307 \\
\hline $\mathrm{RB}$ & Conejo & Abcam & ab6075 \\
\hline WEE1 & Conejo & Santa Cruz & SC-9037 \\
\hline$\beta$-TUBULIN & Ratón & Sigma & T5293 \\
\hline \multicolumn{4}{|l|}{ Inmunoprecipitación } \\
\hline CDK2 (M2) & Conejo & Santa Cruz & SC-163 \\
\hline Cyclin A2 & Ratón & Sigma & C4710 \\
\hline Cyclin E & Ratón & Santa Cruz & SC-247 \\
\hline \multicolumn{4}{|l|}{ SECUNDARIOS } \\
\hline \multicolumn{4}{|l|}{ Citometría } \\
\hline Alexa Fluor ${ }^{\oplus}$ 488-cabra anti-conejo IgG $(\mathrm{H}+\mathrm{L})$ & & Invitrogen & A11008 \\
\hline \multicolumn{4}{|l|}{ Inmunofluorescencia } \\
\hline Alexa Fluor ${ }^{\circledast}$ 488-cabra anti-ratón IgG (H+L) & & Invitrogen & A11001 \\
\hline Cy3-AffiniPure F(ab')cabra anti-conejo IgG $(\mathrm{H}+\mathrm{L})$ & & Jackson ImmunoR. & 111166003 \\
\hline \multicolumn{4}{|l|}{ WB/Inmunoprecipitación } \\
\hline ECL Peroxidaselabelled anti-ratón & & GE Healthcare & NA931VS \\
\hline ECL Peroxidaselabelled anti-conejo & & GE Healthcare & NA934VS \\
\hline
\end{tabular}


RESULTADOS 


\subsection{CÁLCULO DE ICS DE DISTINTOS FÁRMACOS EN LÍNEAS CELULARES DE SE}

La IC $\mathrm{I}_{50}$ (concentración de fármaco necesaria para disminuir al 50\% la proliferación de una línea celular tratada) fue calculada tras $72 \mathrm{~h}$ de aplicación de cada fármaco. Tras el periodo de tratamiento, medimos la viabilidad de las células mediante dos sistemas (MTT y "ATP-lite one step", como se describe en el apartado 3.3 de Material y Métodos).

En primer lugar evaluamos la eficacia de dos de los fármacos utilizados en el Protocolo Eurowing 2008 (Protocolo normalizado de tratamiento de pacientes con SE en Europa), Doxorrubicina (DXR) y Vincristina (VCR). Calculamos la IC 50 mediante el protocolo de MTT:

\begin{tabular}{|lcc|}
\hline \multicolumn{1}{|c}{ Línea celular } & $\mathrm{IC}_{50}(\mathrm{nM})$ & SD \\
\hline CADOES & 227.20 & 17.61 \\
WE68 & 86.48 & 20.35 \\
STA-ET1 & 84.78 & 8.23 \\
RDES & 56.06 & 10.25 \\
SKNMC & 46.59 & 9.36 \\
RM82 & 35.16 & 10.83 \\
\hline
\end{tabular}

\begin{tabular}{|lcc|}
\hline Línea celular & $\mathrm{IC}_{50}(\mathrm{nM})$ & $\mathrm{SD}$ \\
\hline CADOES & 38.65 & 15.59 \\
WE68 & 2.96 & 0.75 \\
STA-ET1 & 2.37 & 0.22 \\
RDES & 2.03 & 0.43 \\
RM82 & 1.65 & 0.45 \\
SKNMC & 1.37 & 0.36 \\
\hline
\end{tabular}

Tabla 12: Valores de $I_{50}$ de seis líneas celulares de SE tratadas durante $72 \mathrm{~h}$ con los fármacos DXR (tabla izquierda) o VCR (tabla derecha).

Observamos para ambos fármacos una distribución similar de la resistencia, siendo la línea celular CADOES la más resistente para ambos y las líneas celulares RM82 y SKNMC las más sensibles. El resto de las líneas celulares estudiadas mostraron $\mathrm{IC}_{50}$ intermedias.

En un estudio posterior evaluamos la resistencia al fármaco MLN4924. En este caso seguimos el protocolo detallado en la sección 3.3 de Material y Métodos, aplicando el sistema "ATP-lite one step". Este segundo protocolo permitió una mejora en la eficiencia del ensayo, ahorrando reactivos, aumentando el número de concentraciones posibles a testar e incrementando la reproducibilidad y fiabilidad de los resultados. Ello nos permitió evaluar 14 líneas celulares de SE y calcular varios coeficientes de IC $\left(I C_{50}, I C_{75}\right.$ e I $\left.C_{95}\right)$ :

\begin{tabular}{|c|c|c|c|c|}
\hline Línea celular & $\begin{array}{l}\text { Número de } \\
\text { copia 1q }\end{array}$ & $\mathrm{IC}_{50}(\mathrm{nM})$ & $\mathrm{IC}_{75}(\mathrm{nM})$ & $\mathrm{IC}_{95}(\mathrm{nM})$ \\
\hline CADOES & Ganancia & $324.91 \pm 82.20$ & $467.40 \pm 184.56$ & $1009.12 \pm 731.96$ \\
\hline STA-ET10 & Ganancia & $256.73 \pm 7.60$ & $430.54 \pm 107.43$ & $2579.23 \pm 270.45$ \\
\hline TC32 & Ganancia & $152.59 \pm 35.11$ & $257.81 \pm 63.63$ & $863.85 \pm 259.65$ \\
\hline TTC466 & Normal & $150.05 \pm 2.49$ & $261.99 \pm 4.29$ & $735.36 \pm 11.63$ \\
\hline STA-ET2.1 & Normal & $103.89 \pm 53.22$ & $227.22 \pm 59.15$ & $1174.84 \pm 615.09$ \\
\hline SKES & Ganancia & $86.28 \pm 14.50$ & $118.20 \pm 21.27$ & $240.06 \pm 172.04$ \\
\hline A673 & Normal & $85.00 \pm 18.21$ & $148.09 \pm 28.64$ & $417.37 \pm 185.48$ \\
\hline TC71 & Ganancia & $76.86 \pm 2.91$ & $119.13 \pm 2.91$ & $265.62 \pm 11.82$ \\
\hline RM82 & Ganancia & $73.99 \pm 17.90$ & $135.29 \pm 24.19$ & $398.77 \pm 101.90$ \\
\hline A4573 & Ganancia & $60.52 \pm 12.21$ & $109.20 \pm 15.79$ & $406.28 \pm 112.16$ \\
\hline SKNMC & Normal & $52.60 \pm 19.58$ & $95.66 \pm 27.19$ & $327.59 \pm 113.06$ \\
\hline STA-ET1 & Normal & $42.15 \pm 11.88$ & $72.87 \pm 8.48$ & $189.00 \pm 35.39$ \\
\hline RDES & Ganancia & $36.80 \pm 14.48$ & $77.65 \pm 51.54$ & $443.71 \pm 238.83$ \\
\hline WE68 & Ganancia & $33.02 \pm 5.82$ & $85.35 \pm 4.54$ & $424.56 \pm 106.26$ \\
\hline
\end{tabular}


Tabla 13: Valores de $I_{\mathrm{s}}$ de 14 líneas celulares de SE tratadas durante $\mathbf{7 2 h}$ con el fármaco MLN4924. En la segunda columna indicamos el estatus de número de copias de 1q. En las tres últimas columnas detallamos el valor de IC \pm el valor de la desviación estándar (SD).

Los datos pusieron de manifiesto que no existió correlación entre la sensibilidad al fármaco MLN4924 y la presencia de ganancia de 1q (Figura 18). Observamos que las líneas con 1qG tenían una sensibilidad muy variable, siendo las líneas más resistentes CADOES, STA-ET10 y TC32, y las más sensibles RDES y WE68.

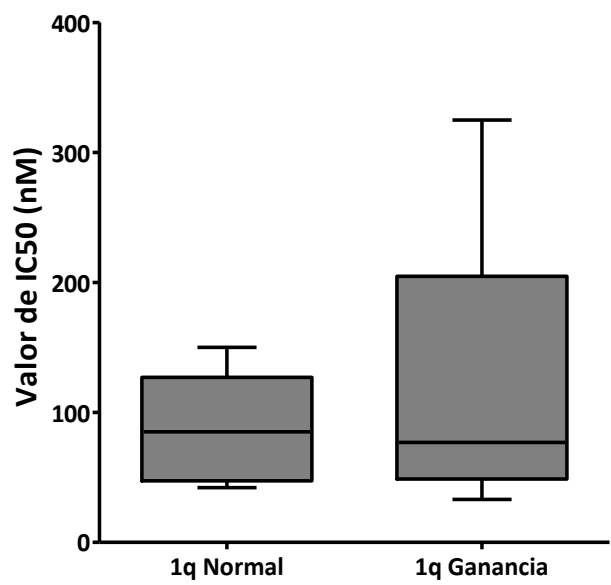

Figura 18: Relación entre la IC $\mathrm{IC}_{50}$ de las líneas celulares de SE frente al fármaco MLN4924 y el número de copia del brazo "q" del cromosoma 1 (1qN vs. 1qG). No existió diferencia significativa entre ambos grupos compuestos por las 14 líneas $(1 q N \rightarrow n=5 ; 1 q G \rightarrow n=9)$ descritas en la Tabla 13 con respecto a la sensibilidad frente al fármaco MLN4924; $p=0.1108$.

\subsubsection{Estudio de combinación de los fármacos MLN4924 y Doxorrubicina}

Posteriormente, a la luz de los resultados obtenidos (que se detallan en los apartados 4.3 y 4.5 de la sección Resultados), realizamos un ensayo de combinación entre los fármacos MLN4924 y DXR. Habíamos comprobado que el fármaco a concentraciones menores o iguales a $I_{75}$ provocó el aumento de los niveles de WEE1 y consecuentemente el bloqueo en G2/M (como se muestra más adelante). De tal manera que evaluamos si MLN4924 provocaba un efecto antagónico al aplicarse junto a un fármaco que inducía daño en el DNA. Está ampliamente descrito en bibliografía que la inactividad de CDK1 por la fosforilación en Y15 ejercida por WEE1 detiene la progresión G2/M del ciclo para lograr que todos los elementos celulares estén en condiciones óptimas para la mitosis y división celular. De hecho, mediante esta detención se revierten los posibles daños al DNA fruto de la fase $S$.

Comparamos el efecto sobre la proliferación de concentraciones crecientes de DXR (DMSO $=0$, $10,50,100,150,200,250,300,400,500,600,700,800900$ y $1000 \mathrm{nM})$, frente al efecto del mismo gradiente de concentraciones combinado con MLN4924 (administrando el IC específico de las líneas celulares RDES y RM82 o $1 \mu \mathrm{M}$ ). Calculamos la IC $\mathrm{I}_{50}$, así como la alteración del porcentaje de proliferación con respecto al control (DMSO). Figura 19.

Observamos en ambas líneas celulares que la IC $C_{50}$ del fármaco DXR fue superior a la IC $C_{50}$ de DXR junto al fármaco de MLN4924. En ambas líneas celulares y en todos los casos existió diferencia 
significativa del grupo control del ensayo (aplicación exclusiva de DXR) frente a las distintas combinaciones con el fármaco MLN4924. Figura 19, A.
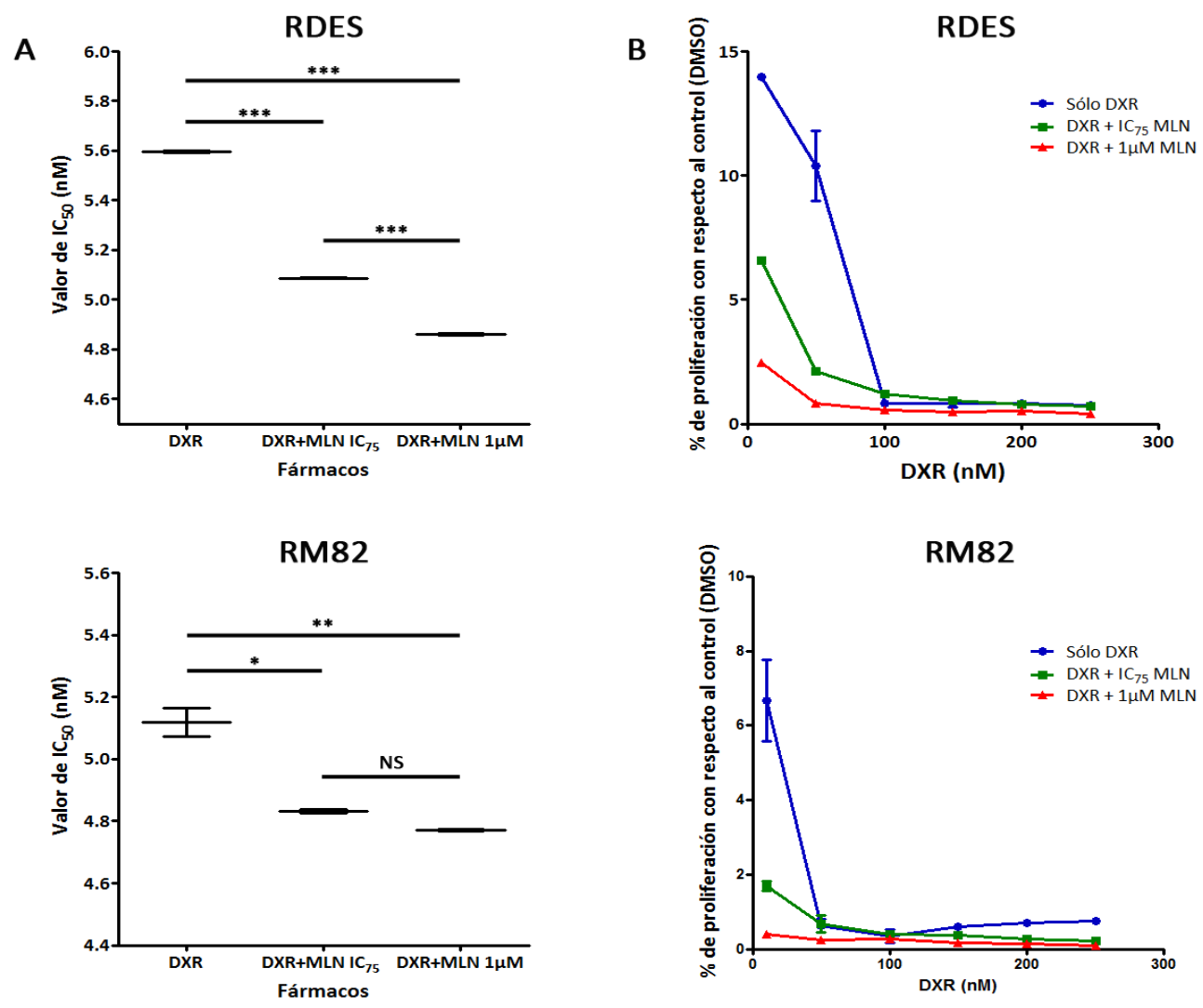

Figura 19: Combinación de los fármacos MLN4924 y Doxorrubicina en líneas celulares de SE, RDES y RM82. A Valores de $\mathrm{IC}_{50}$ con la aplicación exclusiva de DXR, DXR junto a la IC $\mathrm{C}_{75}$ de MLN4924 y DXR junto a $1 \mu \mathrm{M}$ de MLN4924 durante $72 \mathrm{~h}$ de tratamiento. B Alteración de la proliferación a 10, 50, 100, 150, 200 y $250 \mathrm{nM}$ de DXR tras $72 \mathrm{~h}$ de tratamiento sin y con la combinación con el fármaco MLN4924. Bonferroni post-hoct test $p<0.001(* * *), p<0.01(* *)$ y $p<0.05\left(^{*}\right)$; No diferencia significativa (NS).

También evaluamos si a concentraciones bajas de DXR (desde 10nM hasta 250nM) existieron comportamientos antagónicos entre ambos fármacos. Para ello comparamos el porcentaje de proliferación de cada condición de tratamiento con respecto al grupo control (sólo DMSO, donde el porcentaje de proliferación era igual a 100). Observamos en ambas líneas que la aplicación de la $I C_{75}$ de MLN4924 disminuyó el porcentaje de proliferación con respecto al tratamiento exclusivo con DXR. Además observamos que la aplicación de $1 \mu \mathrm{M}$ redujo el porcentaje por debajo de las dos condiciones anteriores (solo DXR y DXR+IC $C_{75}$ ). A partir de 250nM de DXR el porcentaje de proliferación fue mínimo e indiferente significativamente entre las tres condiciones por lo que solo se detalló hasta esa concentración (Figura 19, B).

En el mismo ensayo evaluamos la alteración de la proliferación con la aplicación individual del fármaco MLN4924 durante $72 \mathrm{~h}$ a las concentraciones indicadas. Los resultaros fueron: en la línea RDES, al aplicar la concentración de fármaco correspondiente a su $\mathrm{IC}_{75}(\approx 100 \mathrm{nM})$, la proliferación se redujo al $38.64 \% \pm 4.98$ con respecto al control (únicamente DMSO). Al aplicar $1 \mu \mathrm{M}$, la proliferación se redujo al $3.19 \% \pm 0.12$. En la línea celular RM82, al aplicar la concentración de MLN4924 correspondiente a su IC $75(\approx 150 \mathrm{nM})$ la proliferación se redujo al $25.35 \% \pm 3.88$ con respecto al control (DMSO). Al tratar con $1 \mu \mathrm{M}$ de MLN4924 se redujo al 
$1.16 \% \pm 0.2$. Además, en todos los casos, el porcentaje de proliferación al aplicar MLN4924 junto a las diferentes concentraciones de DXR fue significativamente inferior que a la aplicación individual de uno u otro fármaco (incluso con la concentración mínima de DXR, 10nM). Aseveramos lo anterior al comparar los porcentajes de proliferación con la aplicación individual del fármaco MLN4924 detallados, con respecto a la aplicación exclusiva de DXR y la combinación (Figura 19, B).

Mediante la aplicación del programa informático CalcuSyn Versión 2.1 (Biosoft), calculamos el índice de combinación entre los fármacos DXR y MLN4924 para ambas líneas celulares. Obtuvimos los valores de índice de combinación detallados en la Tabla 14:

\begin{tabular}{|c|cc|cc|}
\hline \multicolumn{2}{|c|}{ RDES } & \multicolumn{2}{c|}{ RM82 } \\
\hline Doxorrubicina & $\mathrm{IC}_{75}$ MLN4924 & $1 \mu$ M MLN4924 & $\mathrm{IC}_{75}$ MLN4924 & $1 \mu$ M MLN4924 \\
\hline $10 \mathrm{nM}$ & 0.453 & 0.309 & 0.346 & 0.066 \\
$50 \mathrm{nM}$ & 0.624 & 0.282 & 0.405 & 0.099 \\
$100 \mathrm{nM}$ & 0.728 & 0.375 & 0.390 & 0.243 \\
$150 \mathrm{nM}$ & 0.881 & 0.479 & 0.502 & 0.187 \\
$200 \mathrm{nM}$ & 0.964 & 0.672 & 0.435 & 0.163 \\
\hline
\end{tabular}

Tabla 14: Valores de índice de combinación entre los fármacos DXR y MLN4924 en las líneas celulares de SE, RDES y RM82. Cada valor corresponde al índice de combinación de la concentración especificada de uno y otro fármaco. Rangos de índices de combinación: sinergismo muy fuerte $(<0.1)$, sinergismo fuerte (0.1-0.3), sinergismo (0.3-0.7), sinergismo moderado (0.7-0.85), sinergismo leve (0.85-0.9), aditivo (0.9-1.10), antagonismo leve (1.10-1.20), antagonismo moderado (1.20-1.45), antagonismo (1.45-3.3), antagonismo fuerte (3.3-10) y antagonismo muy fuerte $(>10)$.

En ningún caso la aplicación conjunta de ambos fármacos provocó una respuesta antagónica. Consideramos pues, que la aplicación combinada de los fármacos (a las concentraciones indicadas) indujo una acción sinérgica disminuyendo la proliferación con respecto a la aplicación individual de ambos fármacos. Descartamos que a concentraciones medias $\left(I_{75}\right)$ y alta $(1 \mu \mathrm{M})$ el fármaco MLN4924 provocara un efecto de rescate frente a un fármaco inductor de daño en el DNA como es DXR.

\subsection{EVALUACIÓN DE LA EFICACIA DE MLN4924 IN VIVO MEDIANTE XENOINJERTOS EN RATONES CB17/SCID}

Tras la aplicación subcutánea de células de las líneas RDES y RM82 inmersas en la matriz

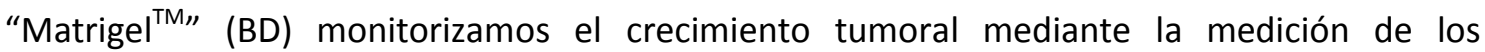
diámetros perpendiculares de cada tumor utilizando un calibre. Cuando alcanzaron un tamaño medio de alrededor de $400 \mathrm{~mm}^{3}$, realizamos una distribución aleatoria de los ratones y establecimos los diferentes grupos que fueron sometidos a las distintas condiciones de tratamiento (Control $\rightarrow$ vehículo del fármaco, $30 \mathrm{mg} / \mathrm{Kg}$ y $60 \mathrm{mg} / \mathrm{Kg}$ bidiarios). Realizamos la aplicación de los tratamientos y mantuvimos los ratones hasta que el tamaño de los tumores del grupo control (los de mayor tamaño) se aproximaron a una situación donde comprometerían las aptitudes físicas de los ratones. En ese momento los sacrificamos, tomamos el último dato de tamaño tumoral y procedimos a la extracción de muestras. Figura 20. 


\section{A}
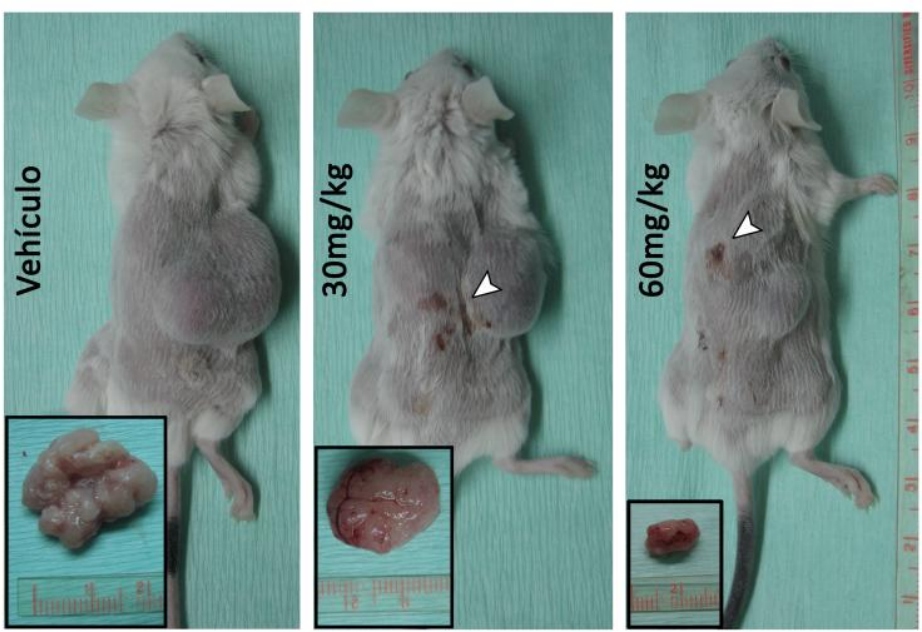

B
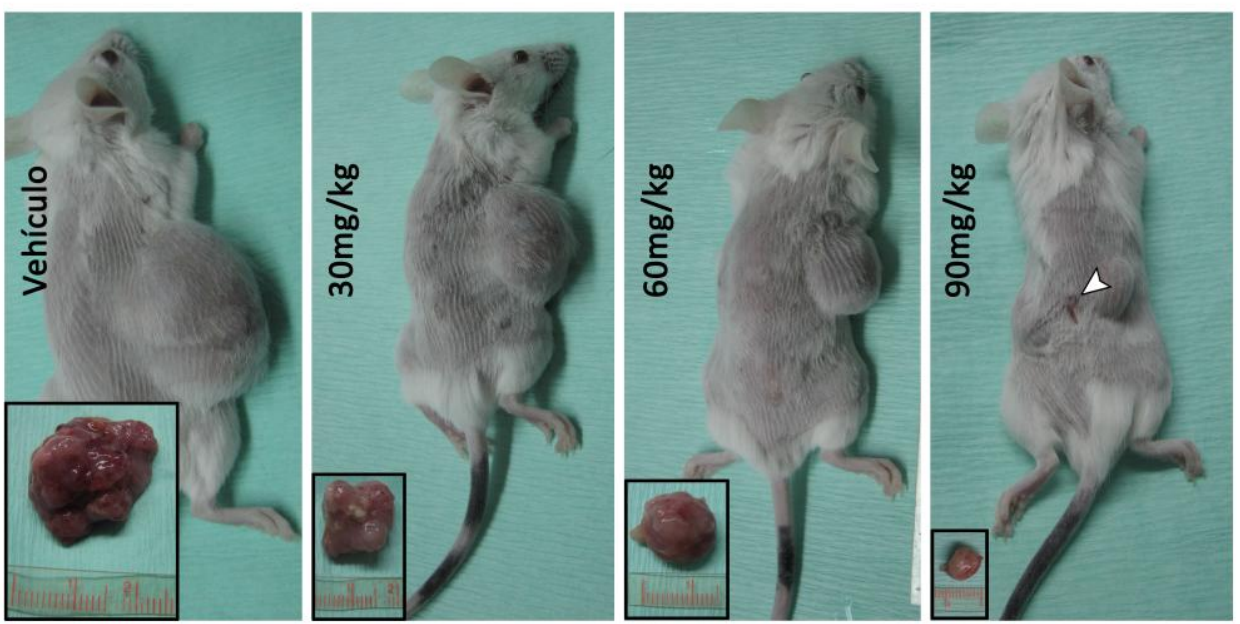

Figura 20: Ensayo in vivo del fármaco MLN4924 con xenoinjertos a partir de líneas celulares de SE. A Resultados obtenidos con la aplicación del fármaco a diferentes concentraciones en xenoinjertos desarrollados a partir de la línea celular RDES. B Resultados obtenidos con la aplicación del fármaco a diferentes concentraciones en xenoinjertos desarrollados a partir de la línea celular RM82. En la esquina inferior izquierda aparece el tumor extraído al ratón tras sacrificarlo; es posible comparar los tamaños tomando como referencia la regla fotografiada junto a los tumores. Las puntas de flecha indican las úlceras producidas por la aplicación subcutánea del fármaco MLN4924.

En cuanto a la progresión del crecimiento de los tumores (Figura 21) observamos como en los grupos control el crecimiento tumoral fue próximo a exponencial para ambas líneas. Sin embargo existieron diferencias entre las líneas celulares. En el caso de RDES, los tumores aumentaron más rápidamente de tamaño que en RM82 (RDES también prolifera más rápido cuando estudiamos su crecimiento sobre placas, in vitro), por lo que detuvimos el ensayo de RDES 16 días después del inicio del tratamiento mientras que con RM82 lo prolongamos hasta el día 21.

Con una concentración de MLN4924 de $30 \mathrm{mg} / \mathrm{kg}$, el crecimiento de los tumores de los ratones del grupo RDES tratados se detuvo, o crecieron levemente. En el grupo tratado con una concentración de $60 \mathrm{mg} / \mathrm{kg}$, observamos como el tamaño de los tumores disminuyó con respecto al tamaño medio de $400 \mathrm{~mm}^{3}$ de partida. La diferencia entre el grupo control y los dos de tratamiento con MLN4924 fue altamente significativa, y entre los dos grupos con diferente concentración de fármaco también lo fue. Figura 21, A. 
A
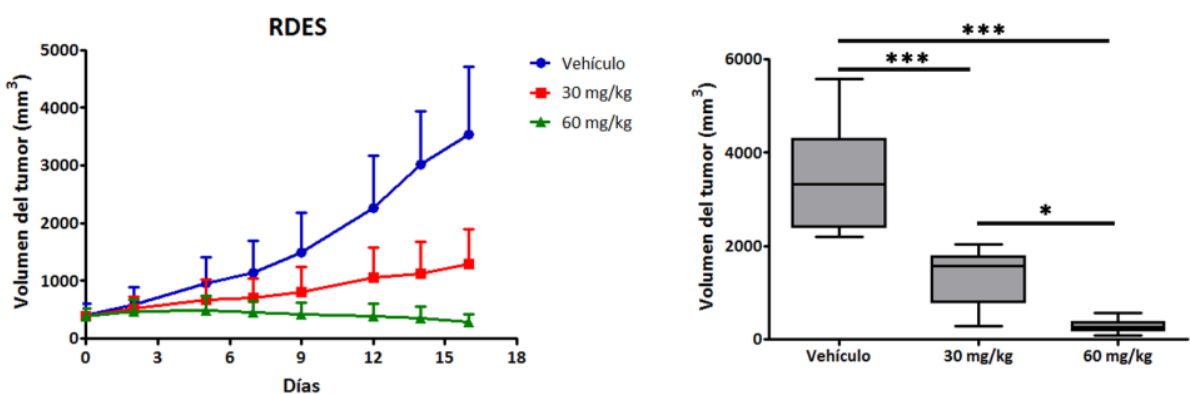

B
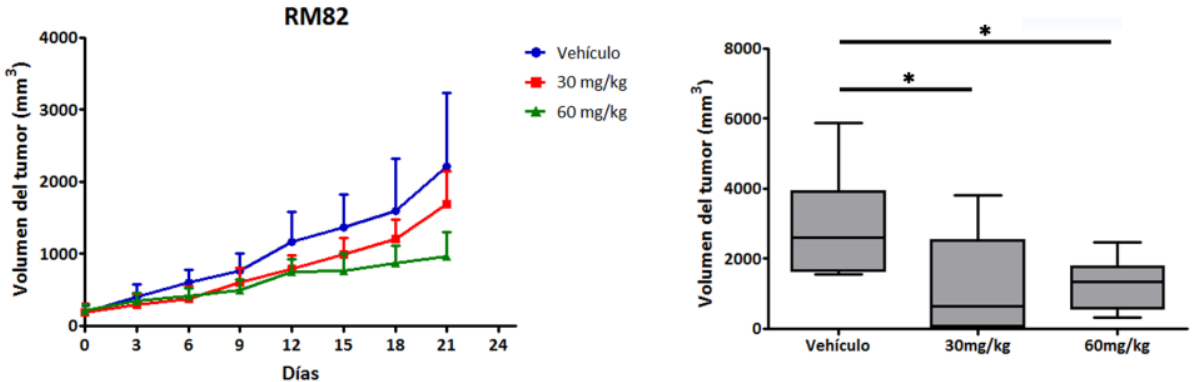

Figura 21: Progresión del desarrollo tumoral en estudios in vivo en ratones CB17/SCID tratados con el fármaco MLN4924. A Estudio en ratones con tumores desarrollados a partir de la inyección de la línea celular de SE, RDES. A la izquierda se detalla la progresión de la media de los tamaños de los tumores de los ratones ( $n=9$, en cada grupo). A la derecha, box plot del tamaño medio de los tumores el último día del ensayo (día 16). B Estudio análogo al anterior con la línea celular de SE, RM82 ( $n=8$, en cada grupo). A la derecha, box plot con los tamaños recogidos el día 21. ANOVA + Bonferroni post-hoc $t$ test $p<0.001\left({ }^{* * *}\right)$ y $p<0.05\left({ }^{*}\right)$.

En cuanto a los ratones con el inóculo de la línea celular RM82, el comportamiento del desarrollo tumoral fue distinto ante las mismas condiciones de tratamiento. El crecimiento de los tumores del grupo control fue exponencial. Sin embargo con el tratamiento de $30 \mathrm{mg} / \mathrm{kg}$ el crecimiento se ralentizó pero no se interrumpió. Presentaba diferencia significativa con el grupo control pero los tumores continuaron creciendo. En cuanto al tratamiento con $60 \mathrm{mg} / \mathrm{kg}$ se observó como la progresión del tamaño tendió a estabilizarse. Entre los grupos con diferente concentración de fármaco no hubo diferencia significativa. Figura 21, B.

Tras obtener los resultados anteriores descritos, consideramos realizar otro ensayo incrementando la concentración de fármaco empleado en el tratamiento de ratones con tumores desarrollados a partir de la línea celular RM82. Figura 22.
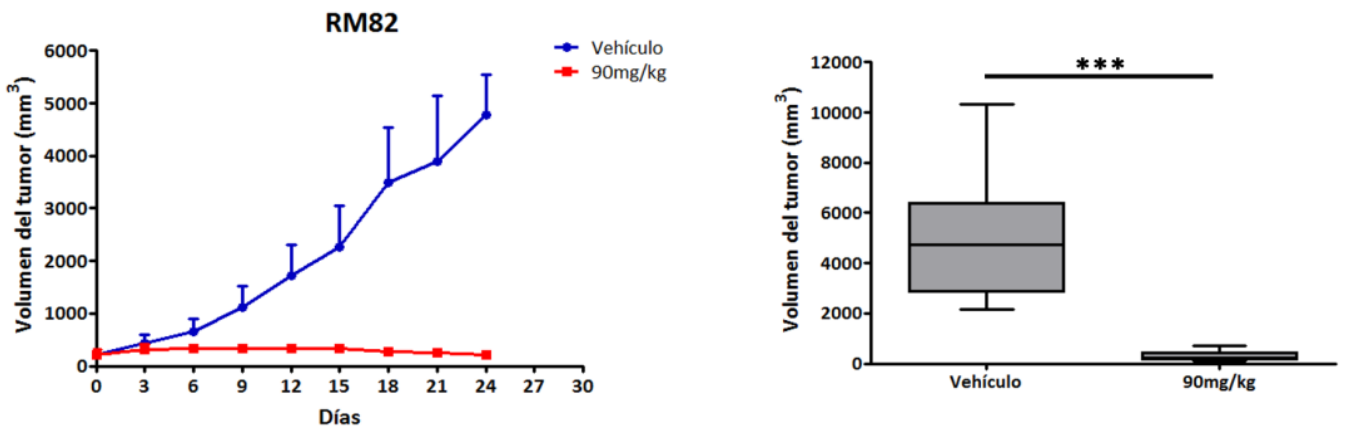

Figura 22: Progresión del desarrollo tumoral en estudios in vivo en ratones CB17/SCID tratados con el fármaco MLN4924. Estudio en ratones con tumores desarrollados a partir de la inyección de la línea celular de SE, RM82. A la 
izquierda se detalla la progresión de la media de los tamaños de los tumores de los ratones ( $n=9$, en cada grupo). A la derecha, box plot del tamaño medio de los tumores el último día del ensayo (día 24). ANOVA + Bonferroni posthoct test $p<0.001(* * *)$.

Observamos como el crecimiento de los tumores del grupo control fue ligeramente superior al del primer ensayo. A 21 días, la media del tamaño de los tumores superó ampliamente los $3000 \mathrm{~mm}^{3}$, mientras que en el primer ensayo a 21 días superó ligeramente los $2000 \mathrm{~mm}^{3}$. Esta diferencia probablemente se debió a diferencias estocásticas del crecimiento en los tumores de ambos grupos control, así como al lote distinto de ratones empleados para el ensayo. Al grupo de ratones tratados con el fármaco MLN4924 le administramos una concentración de $90 \mathrm{mg} / \mathrm{kg}$. A esa concentración el tamaño de los tumores se redujo frente al tamaño inicial $\left(\right.$ media $\left.\approx 400 \mathrm{~mm}^{3}\right)$. Demostramos que incrementando la concentración del fármaco conseguimos reducir el tamaño de los tumores. La diferencia entre el grupo control y el tratado con $90 \mathrm{mg} / \mathrm{kg}$ fue altamente significativa. Figura 22.

\subsubsection{Alteración de la piel}

Durante el trascurso del ensayo in vivo observamos como la piel de los ratones tratados con MLN4924 se alteró. En el caso de los ratones control, a los cuales inyectamos exclusivamente el vehículo del fármaco, la piel no se vio afectada y presentó las características habituales. También apreciamos como el nivel de daño que se produjo en los ratones tratados aumentó al incrementar la concentración de fármaco aplicado. La piel de los ratones tratados con el fármaco se irritó, adquirió un tacto coriáceo y el espacio subcutáneo se vio drásticamente comprometido ("la piel permaneció adherida al cuerpo" del ratón). En ciertas regiones, más abundantes y con mayor superficie conforme la concentración de fármaco empleado fue mayor, aparecieron úlceras. En la Figura 20 se aprecian algunas de estas lesiones en los ratones tratados con MLN4924.

En la Figura 23 se enfrentan preparaciones histológicas de piel de los ratones control y de los ratones tratados con el fármaco.
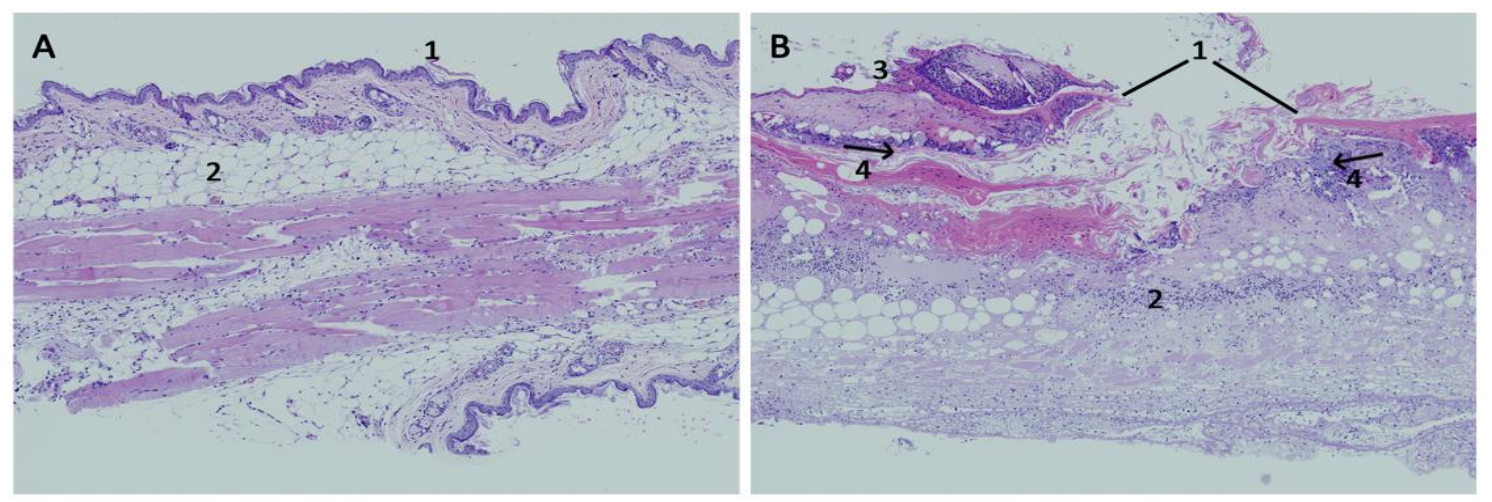

Figura 23: Preparaciones de H\&E de cortes histológicos de piel de ratones utilizados en el ensayo in vivo con el fármaco MLN4924, 10X aumentos. A Piel correspondiente a un ratón del grupo control. B Piel correspondiente a un ratón del grupo tratado con $90 \mathrm{mg} / \mathrm{kg}$ de MLN4924. 1 Se aprecia continuidad del epitelio en el control y la solución de la misma en el tratado. $\mathbf{2}$ Tejido graso subcutáneo en el control y sustitución en el tratado por un absceso. $\mathbf{3}$ Costra fibrino-purulenta. 4 Franjas de células epiteliales con función de regeneración.

Apreciamos como la irritación provocada por el fármaco MLN4924 dañó la estructura de la piel y alteró otras capas más profundas. Se perdió la continuidad del epitelio (Figura 23, 1) y de la 
capa de tejido graso subcutáneo, el cual, fue sustituido por un proceso inflamatorio que implica los planos profundos. (Figura 23, 2). Debido a lo anterior no pudimos pellizcar la piel y "despegarla" del cuerpo del ratón tratado. En los ratones de los grupos control, la capa ininterrumpida de tejido graso subcutáneo sí permitió pellizcar y "despegar" la piel.

En las regiones adyacentes a la úlcera apareció tejido altamente irritado y necrosis (Figura 23, 3) debido a la acción del fármaco y probablemente también debido a que el ratón rascó la zona alterada al causarle molestias. Observamos franjas de células epiteliales con alta tasa de proliferación (Figura 23,4), probablemente intentando proporcionar nuevas células para regenerar el tejido dañado circundante.

\subsubsection{Estudio histopatológico}

Tras el sacrificio de los ratones extrajimos los tumores y mediante el protocolo detallado en el apartado 3.4 de la sección Material y Métodos el personal del servicio del Banco de Tumores del CIC realizó los montajes de H\&E para estudios de histopatología.

Macroscópicamente, observamos que los tumores de los distintos grupo control (los de mayor tamaño) presentaron zonas necróticas localizadas en el núcleo de la masa tumoral total. Probablemente, el motivo de estas regiones necróticas fue que el alto ritmo de proliferación de las células que conforman cada tumor impidió la neo-vascularización. De tal manera que ciertas regiones del tumor no tuvieron la irrigación óptima para la afluencia de nutrientes y oxígeno. En los tumores tratados con MLN4924, cuyo crecimiento fue inferior a los del grupo control, no se detectaron regiones tan amplias de necrosis. Además en aquellos casos donde el tamaño del tumor se redujo notablemente, por la acción del fármaco a altas dosis, no existió necrosis.

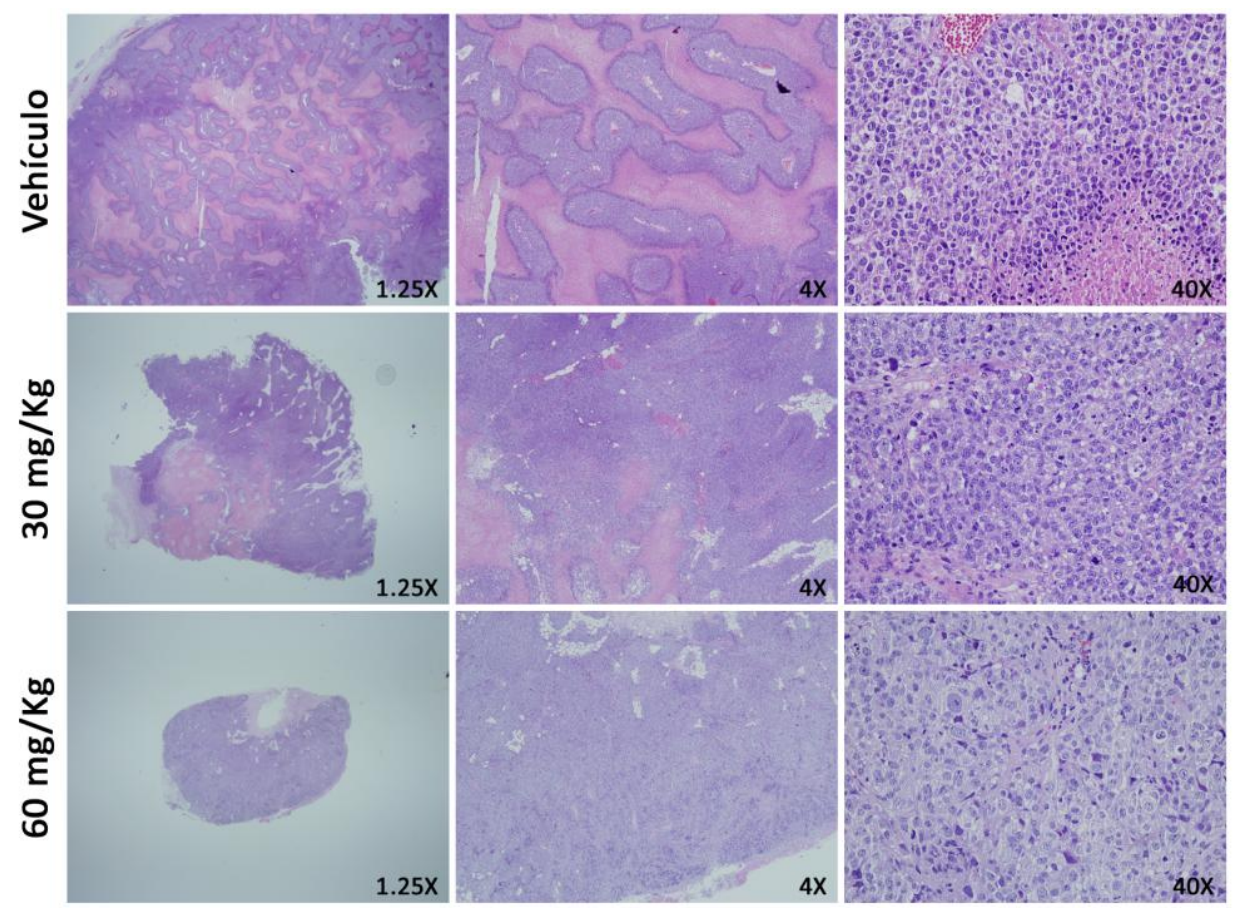

Figura 24: Preparaciones de H\&E de tumores del ensayo in vivo del fármaco MLN4924 con la línea celular RDES. A 1.25x aumentos observamos como el tamaño del tumor es inversamente proporcional a la dosis de fármaco administrada. Además apreciamos como las regiones necróticas (teñidas de color rosa) fueron más extensas en los 
tumores de mayor tamaño. A 4x aumentos distinguimos zonas necróticas (rosas) y zonas con células vivas (de color violeta principalmente por la tinción de los núcleos celulares). Además observamos como en estas regiones de células viables existen vasos sanguíneos. A 40x distinguimos como la morfología de las células de regiones viables (no necróticas) se vio alterada por la acción del fármaco. De tal manera que en el caso control la población era homogénea, mientras que al aplicar MLN4924 observamos heterogeneidad en morfología celular y tamaño del núcleo. Esta alteración fue más acusada a concentraciones mayores del fármaco.

En cuanto al estudio histopatológico microscópico (Figura 24), en cortes establecidos a partir de tumores en parafina, observamos la estructura habitual de los tumores de SE humanos. Apreciamos células pequeñas y redondas, donde el núcleo ocupó la mayor parte de la célula, y el citoplasma era muy escaso. En las regiones no necróticas, observamos la formación de vasos con eritrocitos en su interior (angiogénesis). Los tumores no presentaron estroma. En las regiones periféricas del tumor observamos infiltración de los tejidos sanos del ratón (paquetes musculares y tejido conectivo). Existió diferencia entre las células de tumor de los controles con respecto a las de los tratados: los núcleos y tamaños celulares eran homogéneos en los controles. Sin embargo en los tratados existió heterogeneidad en el tamaño y forma nucleares y ésta aumentó al incrementar la dosis de fármaco (Figura 24, 40x).

\subsection{CARACTERIZACIÓN DEL PAPEL DEL FÁRMACO EN LA PROGRESIÓN DEL CICLO CELULAR Y EN LA VIABILIDAD DE LAS LÍNEAS CELULARES DE SE TRATADAS CON MLN4924}

Para determinar el efecto de MLN4924 en la progresión del ciclo celular tratamos las células durante $24 \mathrm{~h}$ con distintas concentraciones del fármaco y evaluamos por citrometría de flujo el perfil de ciclo mediante el marcaje del DNA con ioduro de propidio (IP). El estudio de viabilidad se basó en la presencia de marcaje de Caspasa 3 procesada, que se utilizó para considerar células apoptóticas (se llevó a cabo mediante citometría de flujo siguiendo el protocolo del apartado 3.5 de Material y Métodos).

\subsubsection{Alteración de la progresión del ciclo celular por la aplicación de MLN4924}

Realizamos el ensayo sobre 10 líneas celulares de SE. En todas ellas el comportamiento ante el fármaco fue igual. Todas ellas presentaron el perfil de ciclo habitual con marcaje del DNA con IP en la condición control (DMSO), excepto SKNMC que presentó una sub-población aneuploide por lo que observamos dos perfiles de ciclo superpuestos. Con concentraciones crecientes del fármaco hasta $\mathrm{IC}_{75}$, observamos un incremento del porcentaje de la población, un acúmulo, en $\mathrm{G} 2 / \mathrm{M}$. Sin embargo con concentraciones iguales o superiores a $\mathrm{IC}_{95}$, se produjo un acúmulo de células en fase S. Figura 25.

Consideramos que existió una respuesta dual dosis-dependiente de las líneas celulares de SE frente al tratamiento con el fármaco MLN4924: a concentraciones bajas-medias (hasta $\mathrm{IC}_{75}$ ) produjo acúmulo en $\mathrm{G} 2 / \mathrm{M}$ y en concentraciones altas del fármaco ( $\mathrm{IC}_{95}$ o superior) produjo acúmulo en fase S. Mediante este ensayo descartamos una respuesta diferencial frente a MLN4924 entre las líneas celulares de SE con o sin ganancia de 1q.

\subsubsection{Estudio de apoptosis en líneas celulares de SE tratadas con MLN4924}

Llevamos a cabo el estudio en 6 líneas celulares de SE, que tratamos con diferentes concentraciones del fármaco MLN4924 durante 48h. Tras lo cual evaluamos por citometría de 
flujo el marcaje de Caspasa 3 procesada siguiendo el protocolo descrito en el apartado 3.5 de la sección Material y Métodos.
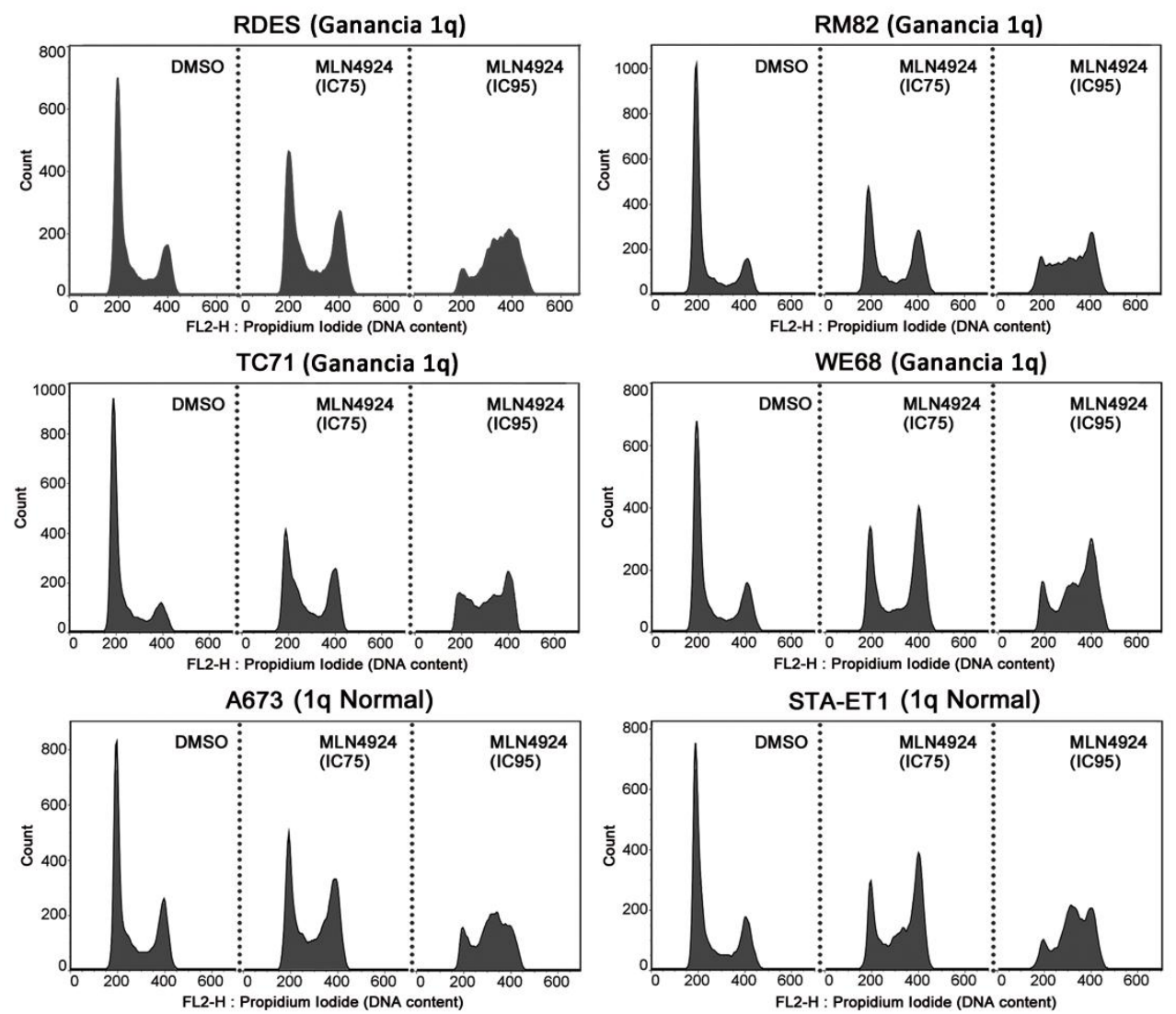

Figura 25: Estudio de citometría de flujo mediante marcaje de DNA con ioduro de propidio en líneas celulares de SE tratadas con MLN4924. Se indica si la línea celular tiene ganancia o no del brazo " $q$ " del cromosoma 1.

En primer lugar evaluamos el porcentaje total de células apoptóticas de cada línea celular en tres condiciones: control (DMSO) y concentraciones IC $C_{75}$ e IC I $_{95}$ de MLN4924 específicas de cada línea celular (Figura 26, A). Determinamos que hubo una respuesta dosis-dependiente, a $\mathrm{IC}_{75}$ la apoptosis fue baja (porcentaje medio de 6 líneas analizadas $=8.29 \pm 2.89$ ) y a concentracines de $I C_{95}$ la apoptosis se disparó (porcentaje medio de 6 líneas analizadas= 26.83 \pm 10.89 ). Figura 26, B.

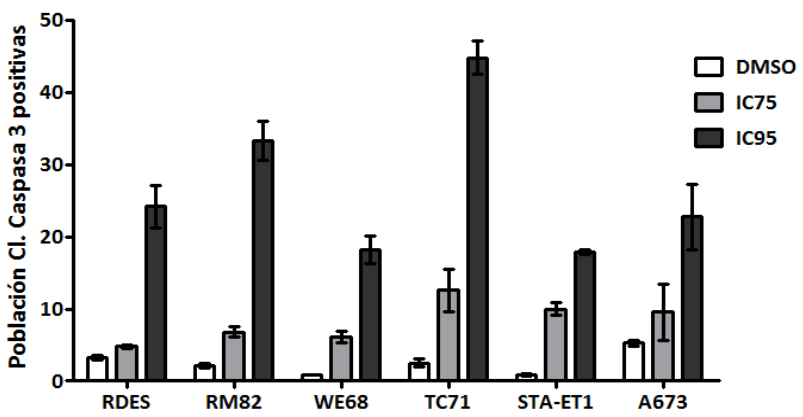

B

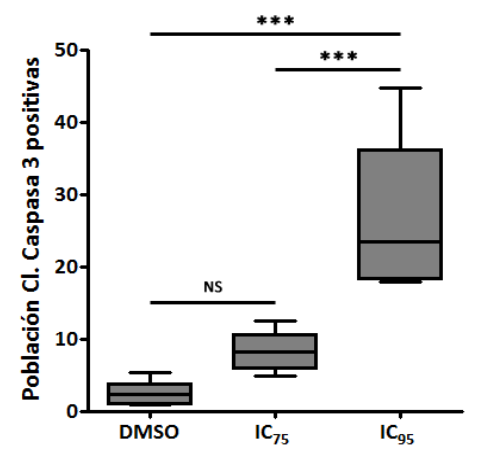

Figura 26: Porcentaje de células positivas para Caspasa 3 procesada en líneas celulares de SE tratadas durante 48h con MLN4924. A Porcentaje de población celular positiva para Caspasa 3 procesada en líneas celulares de SE en las condiciones control (DMSO), $I C_{75}$ e $I C_{95}$ específica de cada línea. B Diferencia de las medias del porcentaje de 
población positiva para C aspasa3 procesada entre las distintas concentraciones de MLN4924. ANOVA + Bonferroni post-hoct test $<0.001\left({ }^{* * *}\right)$, diferencia no significativa (NS). Cl. Caspasa 3: Caspasa 3 procesada o activa.

Establecimos que existió una diferencia altamente significativa entre el grupo de células tratadas con $I C_{75}$ e IC $C_{95}$ y que el nivel de apoptosis fue considerable a altas concentraciones del fármaco. No existió diferencia significativa en el porcentaje medio de células en apoptosis entre el grupo control y de la aplicación del fármaco a $\mathrm{IC}_{75}$.

Diseñamos un ensayo que nos permitió monitorizar los niveles de apoptosis a través de las fases del ciclo celular, y situarlos en la fase de ciclo donde se inició. Utilizamos la línea celular RDES para el ensayo, aplicamos una concentración de MLN4924 de IC 95 y extrajimos las muestras para citometría a distintos puntos de tiempo (8, 16 y $24 \mathrm{~h})$. Utilizando el protocolo ya descrito contrastamos en un plot el marcaje de DNA con IP frente a marcaje de Caspasa 3 procesada, de tal manera que posibilitó ver en qué fase del ciclo se inició la apoptosis. Figura 27.

Los datos obtenidos mostraron que existió diferencia significativa del porcentaje de células en apoptosis a $24 \mathrm{~h}$ entre el control (DMSO) con un $2.33 \%$ de células positivas para Caspasa 3 procesada y las tratadas con $\mathrm{IC}_{95}$, con un $25.7 \%$. En el caso de las células control el inicio de la apoptosis se repartió homogéneamente por todas las fases del ciclo. Sin embargo en las células tratadas con la IC ${ }_{95}$ de MLN4924, la población apoptótica se concentró en fase S-G2/M (24\% del total de las células adquiridas). Al observar el perfil de ciclo de las células tratadas con el fármaco a distintos tiempos, a $8 \mathrm{~h}$ aún no se apreció un acúmulo destacable de apoptosis en ninguna fase del ciclo en las células tratadas. A $16 \mathrm{~h}$ detectamos un acúmulo en fase $\mathrm{S}$ (7.78\%) exclusivamente, mientras que a $24 \mathrm{~h}$ la población de células apoptóticas aumentó considerablemente $(25.7 \%)$ y se desplazó ligeramente hacia $G 2 / M$, aunque la mayoría continuó en fase $\mathrm{S}$ tardía.
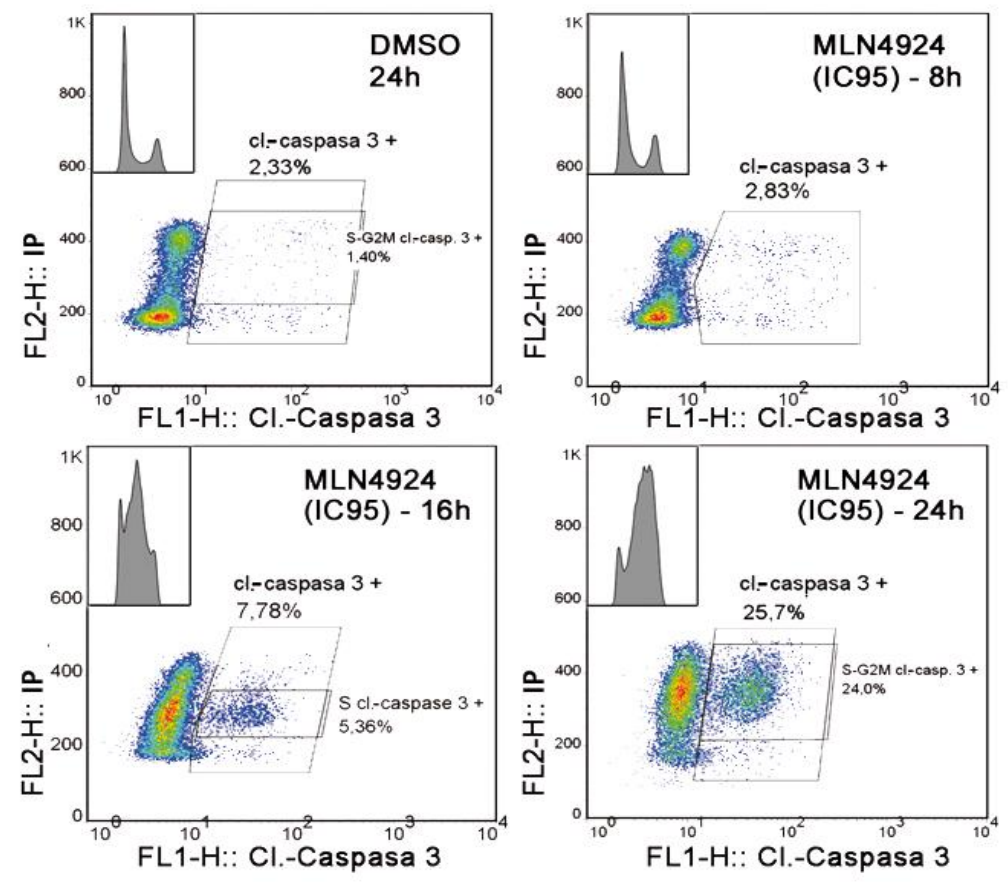

Figura 27: Diagrama donde se representa el marcaje DNA (IP) en el eje $Y$ frente al marcaje de apoptosis (Caspasa 3 procesada) en el eje X, de la línea celular RDES tratada con el fármaco MLN4924. Se muestra la aparición de 
células apoptóticas principalmente en la fase $\mathrm{S}$ del ciclo en aquellas células tratadas con el fármaco $\left(\mathrm{IC}_{95}\right)$, a diferencia del marcaje homogéneo y muy inferior en el control (DMSO). Cl. Caspasa 3: Caspasa 3 procesada o activa.

Consideramos que existió una respuesta dual dosis-dependiente de las líneas celulares de SE frente al tratamiento con el fármaco MLN4924: a concentraciones bajas-medias (hasta $\mathrm{IC}_{75}$ ) se produjo un acúmulo en $\mathrm{G} 2 / \mathrm{M}$ y el nivel de apoptosis fue bajo ( $\approx 8.29 \%)$. A concentraciones altas del fármaco ( $\mathrm{IC}_{95}$ o superior) se produjo un retraso en la progresión de la fase $\mathrm{S}$ y la apoptosis fue notablemente mayor ( $\approx 26.83 \%)$. Además la apoptosis se concentró en la fase $S$, sugiriendo que el retraso de la progresión en esta fase del ciclo celular, que el fármaco causó a concentraciones altas, fue la causa de la apoptosis.

\subsubsection{Evaluación de daño en el DNA por la aplicación de MLN4924}

Tras determinar que el fármaco provoca apoptosis quisimos evaluar si una de las causas que provocó la muerte celular fue el daño en el DNA. La acumulación de daño en las cadenas de DNA habitualmente provoca una alteración en la fase de replicación, lo que explica la relación entre apoptosis y ralentización de la progresión de la fase $\mathrm{S}$ registrada por el tratamiento a altas dosis de MLN4924. Mediante inmunofluorescencia evaluamos la presencia del marcador de daño en DNA, $\mathrm{p}$-H2AX (Figura 28).

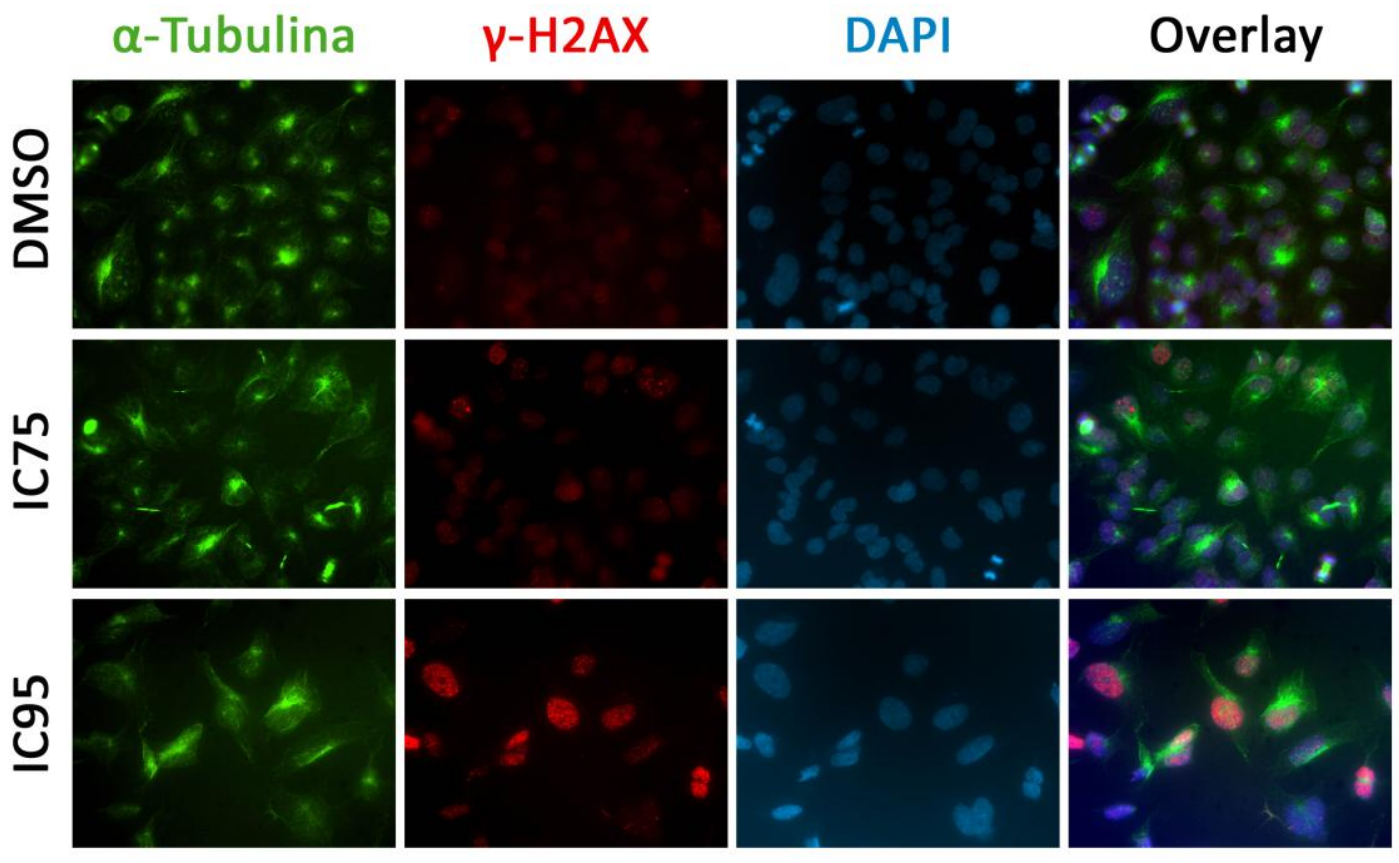

Figura 28: Inmunofluorescencia anti $\boldsymbol{\gamma}$-H2AX (daño en el DNA) en línea celular RDES de SE tratada con el fármaco MLN4924, 40x aumentos. La figura muestra los distintos niveles de daño en DNA (representado por el marcador $\gamma$ H2AX (Cy3, en rojo) a distintas concentraciones del fármaco MLN4924. El marcaje de $\alpha$-Tubulina (Alexa-488, en verde) se utilizó para visualizar la extensión de los citoplasmas, mientras que el marcaje de DAPI (azul) marcó los núcleos. Como fue esperable, el marcaje de daño en DNA se limitó al núcleo, indicando la especificidad del anticuerpo usado.

Observamos que en las células control (DMSO) no existió marcaje para $\gamma-\mathrm{H} 2 \mathrm{AX}$. Hasta la concentración IC $\mathrm{C}_{75}$ de MLN4924 aparecieron focos dispersos de marcaje. A concentración alta (IC $C_{95}$ de MLN4924) todas las células presentaron un elevado nivel de marcaje; este fuerte marcaje también ocurrió a concentración de $1 \mu \mathrm{M}$. De este modo pudimos concluir que sólo a 
altas concentraciones del fármaco se produjo daño en el DNA de las células, coincidiendo con el retraso en la fase $S$ mostrado en el apartado anterior.

\subsubsection{Estudio de senescencia}

Con este ensayo determinamos si el fármaco MLN4924 indujo senescencia a concentraciones bajas-medias $\left(\mathrm{IC}_{25}, \mathrm{IC}_{50}\right.$ e IC $\left.\mathrm{IC}_{75}\right)$ en las líneas celulares de SE RDES y RM82 tras $96 \mathrm{~h}$ de aplicación del fármaco. Finalizado el periodo de tratamiento, aplicamos el protocolo de tinción de senescencia especificado en el apartado 3.15 de Material y Métodos, tras lo cual cuantificamos el número de células senescentes marcadas (en color azul). Figura 29.
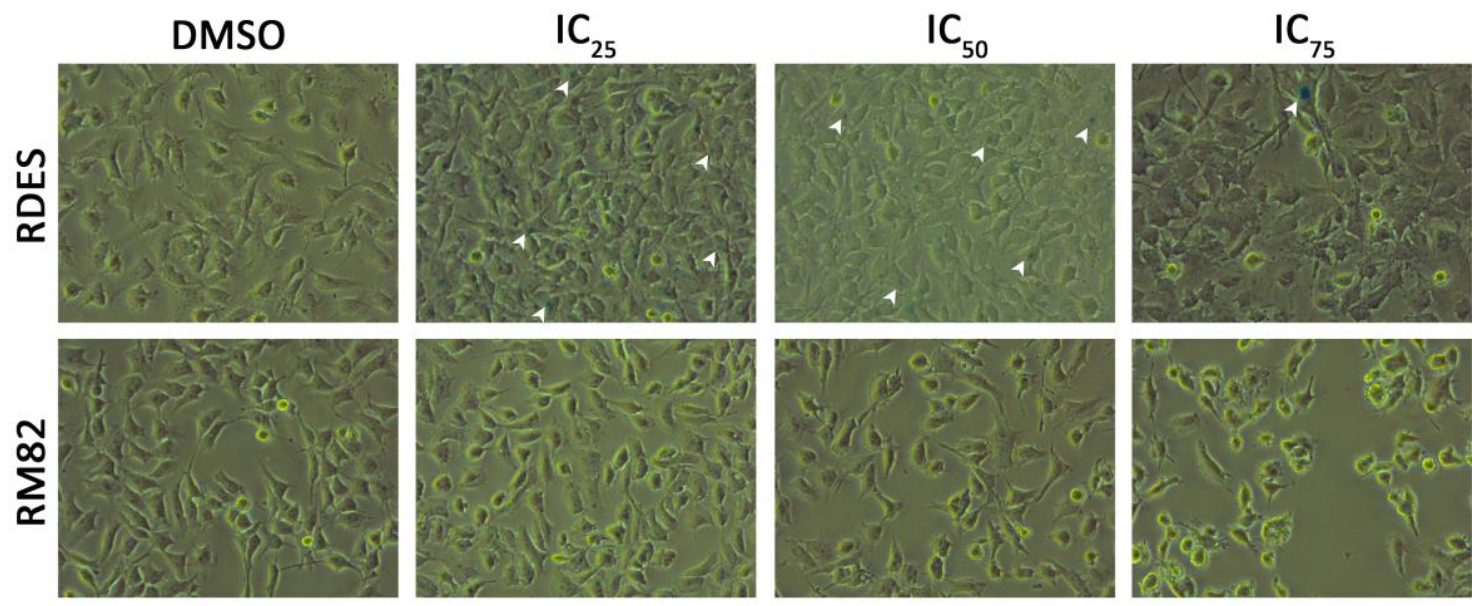

Figura 29: Estudio de senescencia en las líneas celulares de SE, RDES y RM82 tratadas con el fármaco MLN924, 20x aumentos. El marcaje de senescencia por $\beta$-galactosidasa consiste en acúmulo de tinción azul en el citoplasma celular. Las puntas de flechas señalan mínimos focos de este marcaje.

Los resultados de este ensayo evidenciaron que el tratamiento con el fármaco MLN4924 no provocó entrada en senescencia a las líneas celulares estudiadas. En todos los casos, la mayoría de las células observadas no presentaron marcaje. No obstante, apreciamos diferencias entre las líneas celulares de SE sometidas al estudio. La línea celular RM82 no presentó marcaje en ninguna de las condiciones de tratamiento. Sin embargo en RDES, vimos como existió un mínimo marcaje en las condiciones de $\mathrm{IC}_{25}$ e $\mathrm{IC}_{50}$. La población en ambos casos no fue significativa y el marcaje prácticamente inapreciable (en otros ensayos realizados en el laboratorio con este mismo kit el marcaje azul fue mucho más intenso y se extendió por todo el citoplasma de la célula, que además presentó alteración en su morfología).

\subsection{DETERMINACIÓN DE LAS DIANAS DIRECTAS DEL FÁRMACO MLN4924}

En primer lugar evaluamos el efecto directo del fármaco MLN4924, es decir, la disminución de la nedilación de las culinas fruto de la inhibición de la enzima NAE. Realizamos WB con extractos proteicos obtenidos en condiciones "no denedilantes" (aplicando OPT) de tal manera que vimos como las diferentes concentraciones de MLN4924 comprometieron el porcentaje de culinas nediladas. La culina nedilada está unida a la proteína NEDD8, de tal manera que su tamaño y peso molecular se incrementa, disminuyéndose su movilidad electroforética en condiciones desnaturalizantes (SDS-PAGE). Cuando realizamos un WB en condiciones "no denedilantes" esta unión se conservó, de tal manera que aquella sub-población de culinas activas (nediladas) apareció como una banda superior a la de las culinas inactivas (no 
nediladas) pese a utilizar el mismo anticuerpo anti-culina específico. Las culinas más estudiadas son CUL1, CUL4A y CUL4B; de las cuales se conocen múltiples complejos cullin-RING ligasa, resultado de las distintas combinaciones posibles de los elementos que los integran y los sustratos que pueden ubiquitinar ${ }^{270}$. Para este estudio se utilizaron las líneas celulares de $\mathrm{SE}, \mathrm{RDES}$ y RM82. Además, en paralelo, se realizó el ensayo con la línea celular de carcinoma colorrectal HCT116, cuyos resultados se habían publicado anteriormente ${ }^{272,281}$. Figura 30.

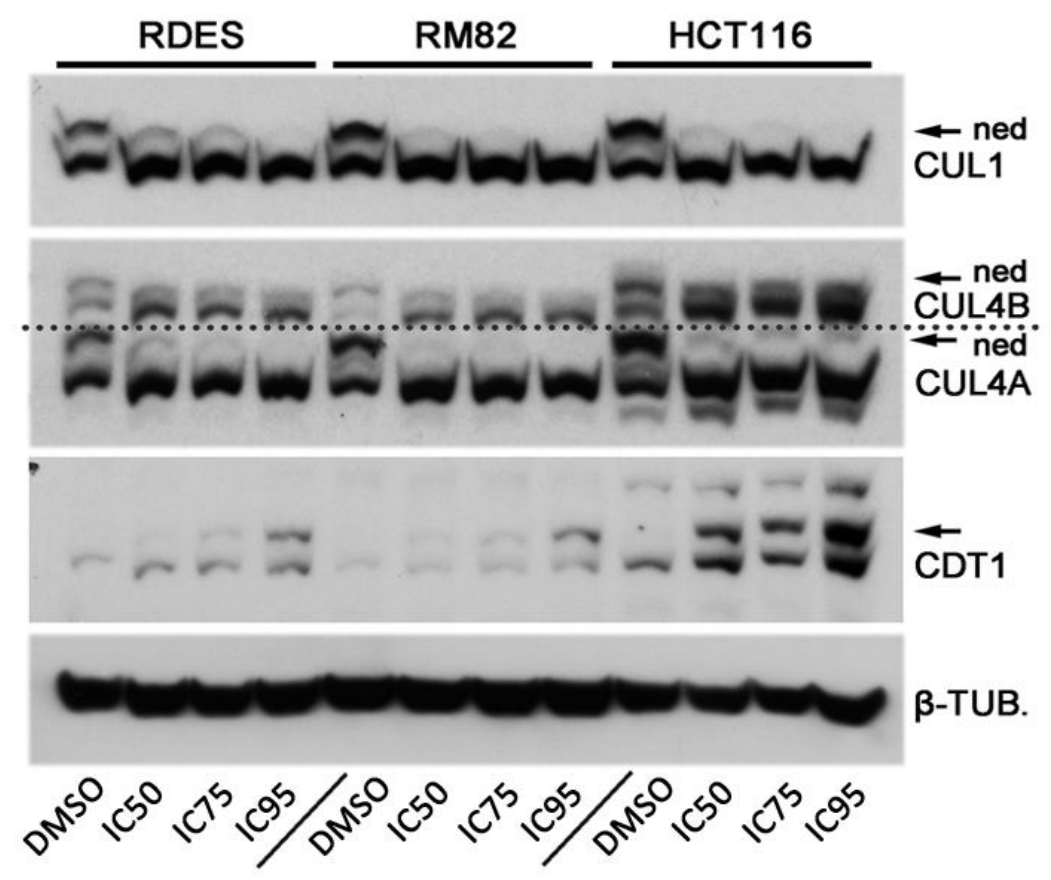

Figura 30: Estudio de inhibición de la nedilación de culinas con el fármaco MLN4924 en líneas celulares de SE y colorrectal. Las culinas nediladas ( $\leftarrow$ ned) aparecen en el WB como una banda justo por encima del tamaño de las culinas sin nedilar. Se incluye el WB de la proteína CDT1, diana de los complejos CRL ensamblados sobre CUL1. $\beta$ TUB: $\beta$-tubulina, control de carga.

En todas las líneas celulares, la banda correspondiente a los tres tipos de culinas nediladas disminuyó al aplicar el fármaco MLN4924. Además el grado de inhibición aumentó al incrementar la concentración de fármaco. Figura 30.

Se evaluó una diana de determinados complejos CRL que se establecen en torno a CUL1, CDT1 (chromatin licensing and DNA replication factor 1). En la línea celular HCT116, a medida que aumentó la concentración del fármaco aplicado, este sustrato se fue acumulando de manera creciente, como resultado lógico de la inhibición de los complejos CRL que lo ubiquitinan. En el caso de las líneas celulares de SE, pese a que la inhibición de las culinas (incluida CUL1) fue similar al de la línea celular HCT116, CDT1 se acumuló levemente y a concentraciones siempre inferiores que en la línea de carcinoma colorrectal. Los niveles de CDT1 en las líneas celulares de SE aumentaron al aplicar las mayores dosis del fármaco, y solo se detectó un acúmulo notable al utilizar la IC $C_{95}$. Figura 30.

\subsubsection{Sobreexpresión de CDT1}

En cuanto a la sobreexpresión de CDT1, este ensayo se pensó inicialmente para comprobar si su sobreexpresión inducía re-replicación en las células de SE, a pesar que el acúmulo de células 
en fase $S$ en dichas células no implicó un aumento de la población con contenido de DNA $>4 n$, como si pasa en las células de cáncer colorrectal, HCT116 ${ }^{272,281}$. Desarrollamos la construcción pBABEpuro-CDT1, con la intención de introducirla en las líneas célulares de SE mediante infección retroviral. En esta ocasión la eficiencia de transducción se redujo notablemente; en torno a un $20.32 \%$ de la población recibió la nueva carga génica. Probablemente se debió a la cola Poly A del cDNA (presente en el vector original del que CDT1 fue subclonado) que impidió el correcto empaquetamiento viral y la posterior infección. Esto imposibilitó el ensayo donde intentamos reproducir el fenotipo que genera el fármaco MLN4924 al aumentar el nivel de la proteína CDT1 (en nuestro caso por transcripción constitutiva del gen mediante el LTR viral que contiene el plásmido pBABEpuro). No obstante, iniciamos la selección con puromicina de la población que había recibido la transducción viral (el 20.32\%). Observamos que las células crecieron tras la selección, y que la sobreexpresión de CDT1 no interrumpió la proliferación.

No se prosiguió con el ensayo pues en paralelo confirmamos, mediante WB, que el acúmulo de CDT1 por el fármaco MLN4924 en las líneas de SE era mínimo (Figura 30) y en los estudios de citometría de flujo con marcaje de DNA no se detectó re-replicación (fenotipo que sí induce el acúmulo de CDT1 en la línea celular HCT116 $6^{272,281}$ ).

\subsubsection{Determinación de dianas directas de los complejos CRL acumuladas tras el tratamiento con el fármaco MLN4924 en líneas celulares de SE}

Tras descartar CDT1 como agente efector de MLN4924 en las células de SE, y ante la sorpresa de que a pesar de ser un sustrato de los complejos CRL no se estuviera acumulando significativamente al tratar con MLN4924, decidimos comprobar cuáles de los sustratos de CRL descritos en literatura y relacionados con el control del ciclo celular estaban realmente acumulándose en las células de SE. Incluimos dos tiempos de tratamiento en el estudio: 4 y 24h. Consideramos que aquellas proteínas que halláramos acumuladas en el tiempo más corto (4h) lo hacían como un efecto directo de la inhibición de los complejos CRL por MLN4924, pues en un tiempo de tratamiento tan corto es improbable que un aumento de la transcripción cause el acúmulo proteico detectado (Figura 31). El tiempo de $24 \mathrm{~h}$ fue introducido para comprobar la estabilidad de cualquier acumulación proteica detectada.

A la luz de los resultados, pudimos establecer dos grupos de respuesta al fármaco dentro de las proteínas analizadas. Un primer grupo formado por las proteínas WEE1, p27, CDC25A y Ciclina $E$, que se caracterizó por el incremento de proteína total a $4 \mathrm{~h}$ independiente de la concentración del fármaco. Y un segundo grupo de proteínas, p21 y fosfo S345-CHK1 que también se acumulan a tiempos cortos pero principalmente cuando se aplicaron concentraciones altas de MLN4924 (IC 95 , fundamentalmente).

En cuanto al primer grupo, las proteínas son reguladas por diferentes complejos CRL y están involucradas en regulación de la progresión del ciclo celular ${ }^{217,317-321}$ : en cuanto a WEE1 y CDC25A sus funciones son antagónicas, fosforilando y desfosforilando a CDK1 respectivamente; p27 inhibe la acción de las CDKs con independencia de las ciclinas a la que estén unidas; Ciclina E se une a CDK2 al inicio de la fase S, activándola. El acúmulo de estas proteínas es por tanto un efecto directo de la inhibición de los complejos CRL y podría ser clave para explicar los efectos en ciclo celular y apoptosis que induce en las células de SE el fármaco 
MLN4924 (bloqueo en G2/M y retraso de fase S a mayor concentración), como se confirmará más adelante.

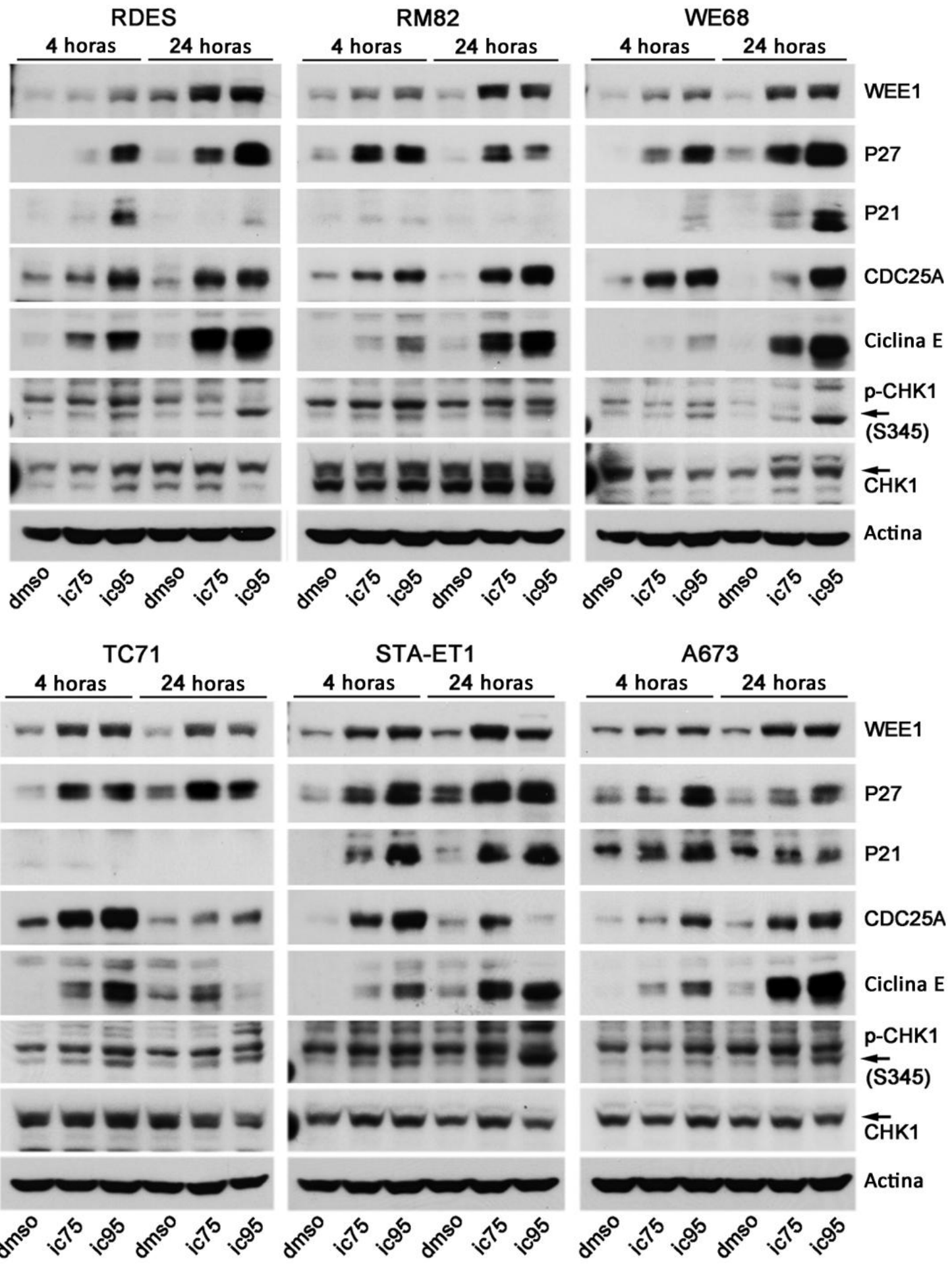

Figura 31: Estudio de los niveles proteicos de las dianas de los complejos CRL en respuesta a MLN4924 en células de SE. Paneles de WB donde se analiza el acúmulo de las dianas directas descritas en literatura de los complejos CRL, a diferentes concentraciones del fármaco MLN4924 en 6 líneas celulares de SE y a dos tiempos distintos de tratamiento (4 y $24 \mathrm{~h}$ ).

En cuanto al primer grupo, las proteínas son reguladas por diferentes complejos CRL y están involucradas en regulación de la progresión del ciclo celular ${ }^{217,317-321}$ : en cuanto a WEE1 y 
CDC25A sus funciones son antagónicas, fosforilando y desfosforilando a CDK1 respectivamente; p27 inhibe la acción de las CDKs con independencia de las ciclinas a la que estén unidas; Ciclina E se une a CDK2 al inicio de la fase $\mathrm{S}$, activándola. El acúmulo de estas proteínas es por tanto un efecto directo de la inhibición de los complejos CRL y podría ser clave para explicar los efectos en ciclo celular y apoptosis que induce en las células de SE el fármaco MLN4924 (bloqueo en G2/M y retraso de fase $S$ a mayor concentración), como se confirmará más adelante.

Centrándonos en el segundo grupo, las proteínas $\mathrm{p} 21^{277}$ y fosfo $\$ 345-\mathrm{CHK} 1$ se acumularon de manera notable a concentraciones altas del fármaco. A dichas concentraciones hemos descrito en apartados anteriores la producción de daño en el DNA. Cuando se produce daño en el DNA se desencadenan cascadas de señales moleculares que interrumpen la progresión del ciclo y facilitan la gestión de la reparación del daño (es decir, se activa el checkpoint de daño al DNA). En el checkpoint de daño en DNA participa la ruta de $\mathrm{p} 53$ y p $21^{322}$. Por tanto, probablemente el incremento de p21 fue por daño en el DNA ya que se produjo fundamentalmente con altas concentraciones del fármaco. Además el mayor acúmulo de sus niveles se produjo tras $24 \mathrm{~h}$ de tratamiento, tiempo en los que sabemos que altas concentraciones del fármaco inducen daño en DNA y apoptosis. Por tanto la acumulación de p21 pareció ser más bien un efecto indirecto del tratamiento con MLN4924 en estas células. En cuanto a CHK1, no observamos su acumulación a pesar de haber sido descrita como diana de los complejos CRL en condiciones de estrés genotóxico ${ }^{323}$. Sin embargo la fosforilación que se produce en respuesta al daño en DNA, fosforilación en $\mathrm{S} 345^{324}$, sí se acumuló de manera análoga a p21. Parece por tanto que la acumulación de este segundo grupo de proteínas no responde de manera directa al fármaco si no que lo hace en respuesta al daño en el DNA. En cuanto a las líneas RM82 y TC71, son defectivas para $\mathrm{p} 53^{300}$, lo que explica que veamos el panel de WB correspondiente a p21 en blanco.

\subsection{IDENTIFICACIÓN DE MECANISMOS MOLECULARES DE RESPUESTA AL FÁRMACO MLN4924 EN LÍNEAS CELULARES DE SE}

Una vez validada la acumulación de varios de los principales sustratos de los complejos CRL, nos decidimos a definir en lo posible el mecanismo molecular de acción del fármaco en nuestro sistema biológico. Identificar los mecanismos moleculares de respuesta de las células de SE frente a MLN4924 tiene varias finalidades importantes: determinar el mecanismo de acción del fármaco para conocer alternativas terapéuticas frente al SE (establecer rutas o moléculas diana antes no exploradas terapéuticamente); comprobar si otros fármacos son más efectivos y/o menos tóxicos para desencadenar el mismo mecanismo de respuesta; establecer posibles alternativas de combinación de fármacos, plantear estrategias ante la previsible recidiva, y extrapolar posibles resultados de aplicación del fármaco MLN4924 a otras neoplasias que tengan cierta similitud de comportamiento molecular.

Debido al comportamiento dual de respuesta al fármaco dosis-dependiente de las líneas celulares de $\mathrm{SE}$, hemos dividido los resultados en dos grandes bloques:

Mecanismo molecular de retraso en la progresión en G2/M

$>$ Mecanismo molecular de retraso en fase $\mathrm{S}$ 


\subsubsection{Mecanismo molecular causante del retraso en la progresión G2/M}

\subsubsection{Sincronización en mitosis temprana}

La sincronización al inicio de mitosis mediante la aplicación de nocodazol nos permitió monitorizar la cinética de los niveles de las proteínas clave durante la progresión del ciclo celular. Como la mayor parte de las células del cultivo se encontraron sincronizadas pudimos determinar qué proteínas y a qué niveles se expresaron a lo largo del ciclo celular.

Como se detalló en el apartado 3.7 de Material y Métodos, sincronizamos células de la línea celular RDES suficientes para llevar a cabo estudios de citometría mediante marcaje de DNA con IP y extracción de proteínas para analizar la cinética proteica durante el ciclo celular. Los tiempos analizados fueron $0,8,12,16,20$ y $24 \mathrm{~h}$ tras la liberación del nocodazol, y las condiciones fueron DMSO (control) e $\mathrm{IC}_{75}$ (concentración que provocó un notable retraso en la progresión G2/M sin apenas acúmulo en fase S). Mediante este análisis quisimos determinar posibles candidatos para explicar el mecanismo de respuesta y situar con mayor precisión el punto exacto del retraso en G2/M (discernir si ocurría en $\mathrm{G} 2$, en mitosis o en la transición entre ambas fases).

En la condición control, el perfil de ciclo del punto de tiempo Oh indicó que partimos de la fase de mitosis con el $100 \%$ de las células situadas en el pico de citometría G2/M. Las células salieron de mitosis inmediatamente, como esperábamos, y posteriormente se desplazaron por las fases G1, S y de nuevo G2/M. En el último punto de tiempo (24h) se pudo comprobar como la mayoría de las células se encontraron en G1, aunque ya existió una cierta desincronización porque una subpoblación aún se encontró en G2/M. Cuando comprobamos la progresión en el ciclo de las células tratadas con MLN4924 (IC $\left.\mathrm{C}_{75}\right)$, observamos que todas las células completaron la fase de mitosis tras el bloqueo con nocodazol sin retraso aparente con respecto a las células control, descartando un efecto del fármaco en esta fase. Esta primera observación fue de gran relevancia porque indicó que el fármaco bloquea el ciclo en la fase G2 o en una etapa muy inicial de mitosis (el nocodazol sincroniza en pro-metafase y las células llevaban tratadas 4h con MLN4924 antes de ser liberadas). Tras superar esta fase, las células tratadas entraron al mismo tiempo que las control en fase $\mathrm{S}$ y la superaron a la vez (los perfiles de los tiempo 0-12h son prácticamente superponibles, iguales). Esto nos indicó que el paso por $\mathrm{G} 1$ y fase $\mathrm{S}$ no se vio tampoco alterado por la aplicación del fármaco MLN4924 a IC 75 . Sin embargo en el último punto de tiempo comprobamos de nuevo un retraso en las células con contenido de DNA G2/M, con un pico de G1 menor en comparación con las células control (las cuales continuaban su progresión normal del ciclo). Figura 32.

En cuanto a la cinética de las principales proteínas implicadas en el control del ciclo celular dianas de los complejos CRL, detectamos cambios en la aparición/desaparición normal de éstas (reflejadas en el control de la forma esperada) por la acción del fármaco MLN4924. En cuanto a las proteínas independientes de degradación reguladas por complejos $C R L$, como Ciclina B1, observamos que el fármaco no alteró sus niveles: vimos como se encontró acumulada en fase $\mathrm{M}(\mathrm{Oh})$; cuando las células superaron esta fase y se encontraron en $\mathrm{G} 1(8 \mathrm{~h})$ sus niveles fueron mínimos y, sólo cuando las células se aproximaron y se hallaron en la siguiente fase de mitosis, volvió a acumularse. 


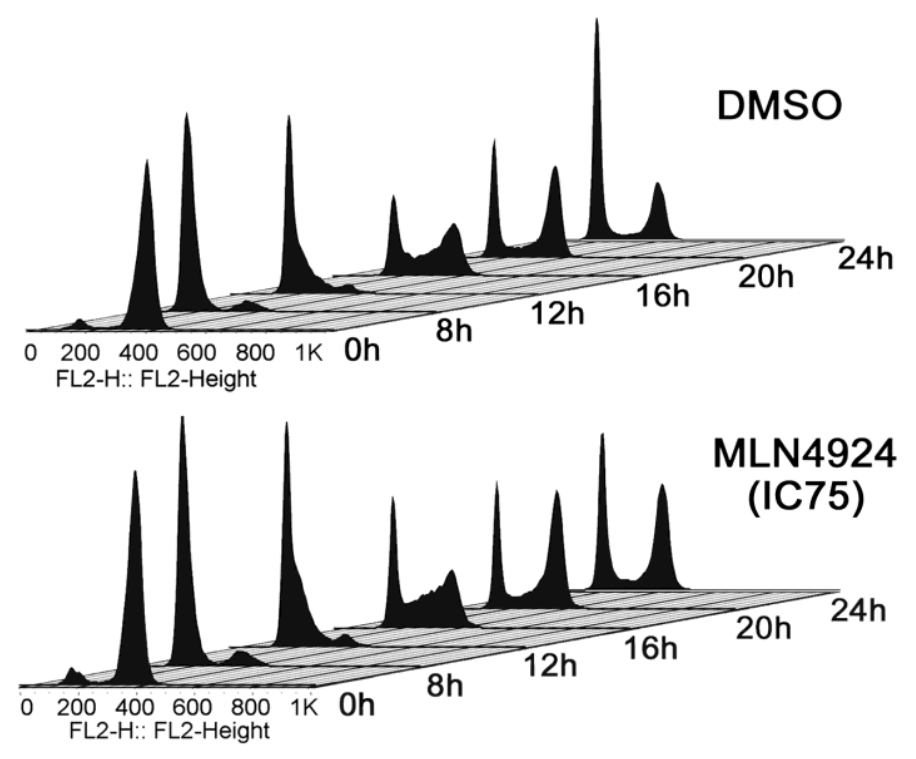

Figura 32: Histogramas de contenido en DNA (marcaje con ioduro de propidio) en el ensayo de sincronización en mitosis en la línea celular de SE RDES, con y sin tratamiento con el fármaco MLN4924. Se detallan los puntos de tiempo tras la liberación del nocodazol y la concentración de fármaco empleada (IC 75$)$.

Apreciamos una reducción de sus niveles (en los puntos de tiempo finales) $\mathrm{n}$ las células tratadas con MLN4924 que se debió seguramente al retraso de la entrada en mitosis. En el caso de CDK1, también independiente de complejos CRL, se mantuvo constante en el ciclo y no sufrió acumulación o disminución por la acción del fármaco. Sin embargo en proteínas que son dependientes de complejos CRL (p27 $7^{319-320}$, WEE1 $1^{217}$, CDC25A ${ }^{317-318}$ y Ciclina $E^{321}$ ) observamos cómo el fármaco MLN4924 provocó la acumulación de sus niveles (por la inhibición de su ubiquitinación y por tanto de su degradación vía proteosoma) mientras que las células control siguieron las cinéticas de acumulación/degradación esperables según la masiva literatura que las ha descrito. Es fundamental señalar que la aparición de estas proteínas se produjo en el mismo punto de tiempo que en las células control, variando sólo el momento de su desaparición y su consecuente acumulación. Esto fue una muestra más de que el fármaco MLN4924 no alteró la transcripción de estas proteínas. Las proteínas diana se acumularon a partir del momento de su degradación programada, indicando el efecto específico del fármaco MLN4924 inactivando a los complejos CRL encargados de ubiquitinarlas. Figura 33.

P27 se acumuló desde el primer punto de tiempo y mantuvo alta concentración de proteína a lo largo de todo el ciclo (Figura 33). Consideramos p27 como posible candidato a inductor del retraso en G2/M por el fármaco MLN4924 puesto que es una CKi capaz de inhibir a CDK2 (responsable de la transición por la fase S y S-G2). Además se ha defendido su capacidad de inhibir la actividad de CDK1 $1^{209-210,319}$.

WEE1 no estuvo presente en la fase de mitosis (Oh) en la condición control, apareció a 8h tras la liberación del nocodazol, incrementaron sus niveles durante los siguientes puntos de tiempo y después se redujeron. En las células tratadas tampoco estuvo presente en el punto de 0 h, apareció también a 8 h pero a partir de ahí se acumuló, en mayor proporción en este punto de tiempo, y mantuvo niveles altos el resto del ciclo. En consonancia con la función descrita en literatura para WEE $1^{325}$, se detectó un notable incremento de la fosforilación en el 
residuo de Y15 de CDK1. En las células control vimos como en el punto de tiempo donde la mayoría de las células se encuentran en la transición G2/M (16h) coinciden los niveles altos de WEE1 y la fosforilación Y15 de CDK1, pero disminuye a continuación a la vez que las células entran en mitosis, como ha sido descrito ${ }^{326}$. En las células tratadas, la fosforilación en Y15 de CDK1 coincidió en el patrón de aparición de WEE1 pero tuvo lugar a un mayor nivel y se mantuvo en todos los tiempos posteriores a la aparición (incluido 24h), de nuevo sustentando la idea de que el retraso observado sucedió en la fase G2 tardía o en la transición G2/M. Consideramos tras estos resultados la acumulación de WEE1 como otro posible candidato para explicar el retraso en la transición G2/M. Figura 33.

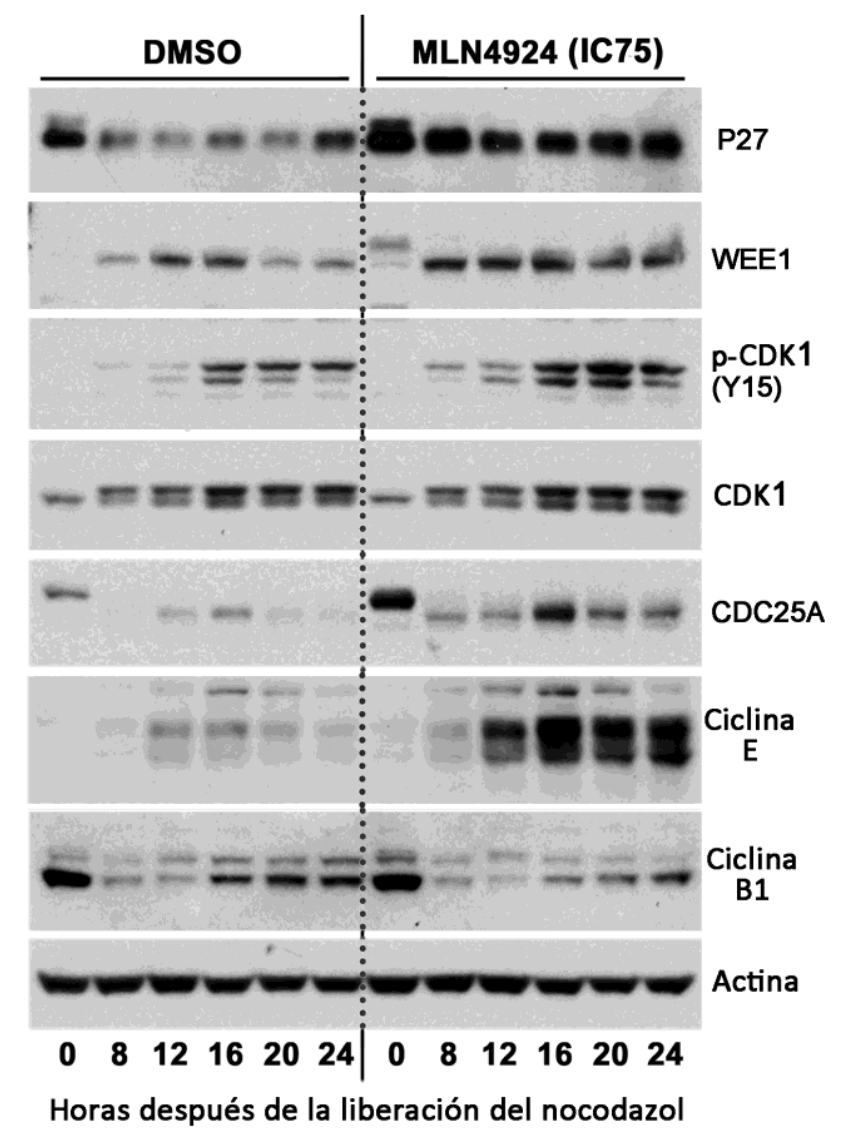

Figura 33: WB de extractos proteicos del ensayo de sincronización en mitosis y tratamiento con MLN4924 (IC 75 ) en células RDES. Se distinguen los extractos obtenidos de células tratadas con el fármaco y de las células control (DMSO), así como los puntos de tiempo en los que se realizaron los extractos tras la liberación del nocodazol. Se aprecia el acúmulo de las proteínas p27, WEE1, CDC25A y Ciclina E como resultado de la inhibición de los complejos CRL ejercida por la acción de MLN4924. Se observa el incremento de la fosforilación en Y15 de CDK1, efecto del acúmulo de WEE1, su efector. No se alteraron los niveles de las proteínas cuya degradación es independiente de los complejos CRL, CDK1 y Ciclina B1.

La siguiente proteína analizada fue CDC25A, que en las células tratadas siguió el mismo patrón que en las células control aunque su acúmulo fue mayor y se mantuvo a lo largo del ciclo (Figura 33). En contraposición al posible papel de p27 y/o WEE1, CDC25A debió facilitar e incluso acelerar el progreso del ciclo celular, lo cual no fue observado.

Por último se comprobó Ciclina $\mathrm{E}$, que al igual que los casos anteriores apareció en el mismo punto del ciclo tanto en células control como en tratadas con MLN4924, al inicio de la fase S (12h). En el caso de las células tratadas a partir del momento en el que apareció, y por acción 
de MLN4924, se acumuló gran cantidad de proteína que además no se degradó tras la entrada en fase $\mathrm{S}$, como era de esperar al estar impedida su ubiquitinación.

4.5.1.2 Evaluación de p27 como posible inductor del retraso en la transición G2/M en líneas celulares de SE tratadas con concentraciones medias (hasta IC ${ }_{75}$ ) de MLN4924

Tras los resultados descritos en el anterior apartado, evaluamos el rol que jugó p27 en el retraso en la transición $\mathrm{G} 2 / \mathrm{M}$. Una alternativa para afrontar este reto consistió en inhibir a p27 para observar si el efecto del fármaco descrito desaparecía o disminuía. Para lo cual, planteamos un ensayo de inhibición de la expresión de p27 mediante el uso de shRNA. En primer lugar evaluamos la capacidad de inhibición del sistema mediante WB (Figura 34, A). Como se aprecia en el panel izquierdo de la Figura 34, comprobamos que en el control (shRNA con una secuencia aleatoria, "NTC") el fármaco aplicado a concentraciones medias provocó el acúmulo ya observado de p27. Incluimos en el análisis a CDK1, que no varió por la acción del fármaco, al igual que WEE1 y su sustrato (fosforilación en Y15 de CDK1). En contraste, en las células a las que se silenció p27 mediante shRNA, observamos como el tratamiento con MLN4924 no indujo casi acúmulo de esta proteína (existe un acúmulo nimio probablemente porque el sistema shRNA no inhibió al 100\% la expresión de p27). En cuanto al acúmulo de WEE1 y la fosforilación de Y-15 de CDK1 no se detectaron cambios, tampoco en la expresión de CDK1. Por tanto el sistema de interferencia mediante shRNA fue específico contra p27, no afectando a WEE1.

Una vez validado el sistema de silenciamiento realizamos un ensayo de citometría con marcaje de DNA mediante IP para analizar los perfiles de ciclo sobre las mismas células de las que se extrajo proteína para el WB de la Figura 34. Tras comparar dichos perfiles en la condición control (DMSO) con respecto al fármaco, observamos cómo no hubo alteración en las células con p27 silenciado. Figura 34, B.

A

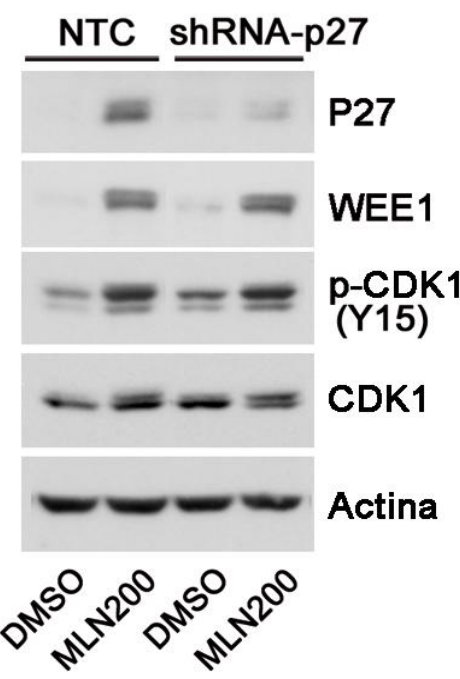

B

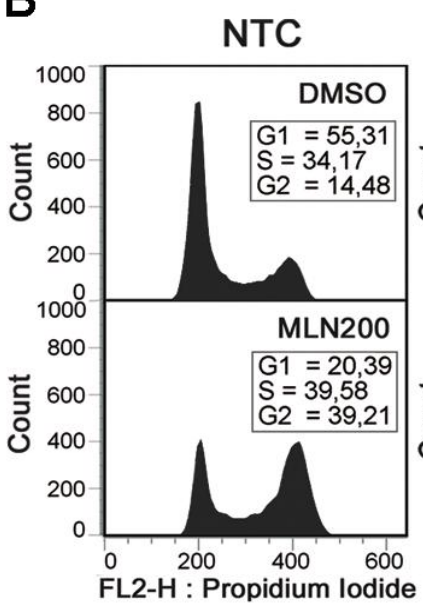

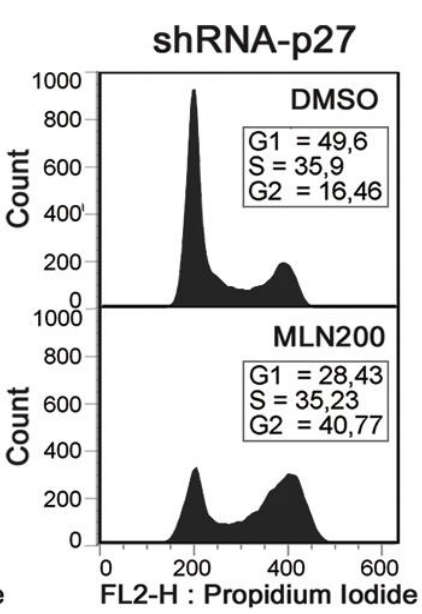

Figura 34: Ensayo de inhibición de p27 mediante shRNA en células RDES tratadas con el fármaco MLN4924 $\left(\approx C_{75}\right)$. A Panel de WB de células no tratadas y tratadas con MLN4924, validando el silenciamiento de p27 mediante shRNA. B Perfil de ciclo celular (marcaje de DNA con IP adquirido por citometría de flujo) en células tratadas o no con el fármaco MLN4924, con p27 silenciado (shRNA-p27) o control (NTC). NTC: control de inespecificidad, "non-targeting control". MLN200: 200nM de MLN4924 ( $\left.\approx 1 C_{75}\right)$. 
Si el acúmulo de p27 jugara un papel fundamental en el retraso en G2/M, su inhibición mediante shRNA permitiría a la célula evadir el retraso en esta transición del ciclo, al menos parcialmente. Sin embargo observamos como el perfil de ciclo de las células con silenciamiento de p27 tratadas con $\mathrm{IC}_{75}$ de MLN4924 conservaron el retraso en la transición G2/M (Figura 34, B). Consideramos pues que p27 no fue el efector principal del retraso en la transición G2/M de la línea celular de SE tratada con el fármaco MLN4924 a concentraciones medias $\left(\mathrm{IC}_{75}\right)$.

En este punto, tras comprobar que p27 se acumuló a altos niveles por la acción de MLN4924 pero que no jugó un papel relevante en el mecanismo de respuesta, quisimos evaluar si se produjo algún mecanismo de gestión de la actividad de p27 que impidió su acción pese al acúmulo de la proteína. Mediante inmunofluorescencia, determinamos la localización subcelular y el acúmulo de p27 inducido por el fármaco. Está descrita la translocación al citoplasma de p27 (propiciada mediante diferentes fosforilaciones de p27), normalmente en circunstancias oncogénicas, lo que impide su acción en el núcleo como $\mathrm{CKi}^{327}$. Confirmamos el acúmulo de p27 por la acción del fármaco, y además comprobamos que el aumento de la proteína también fue nuclear (luego potencialmente activo). Figura 35.

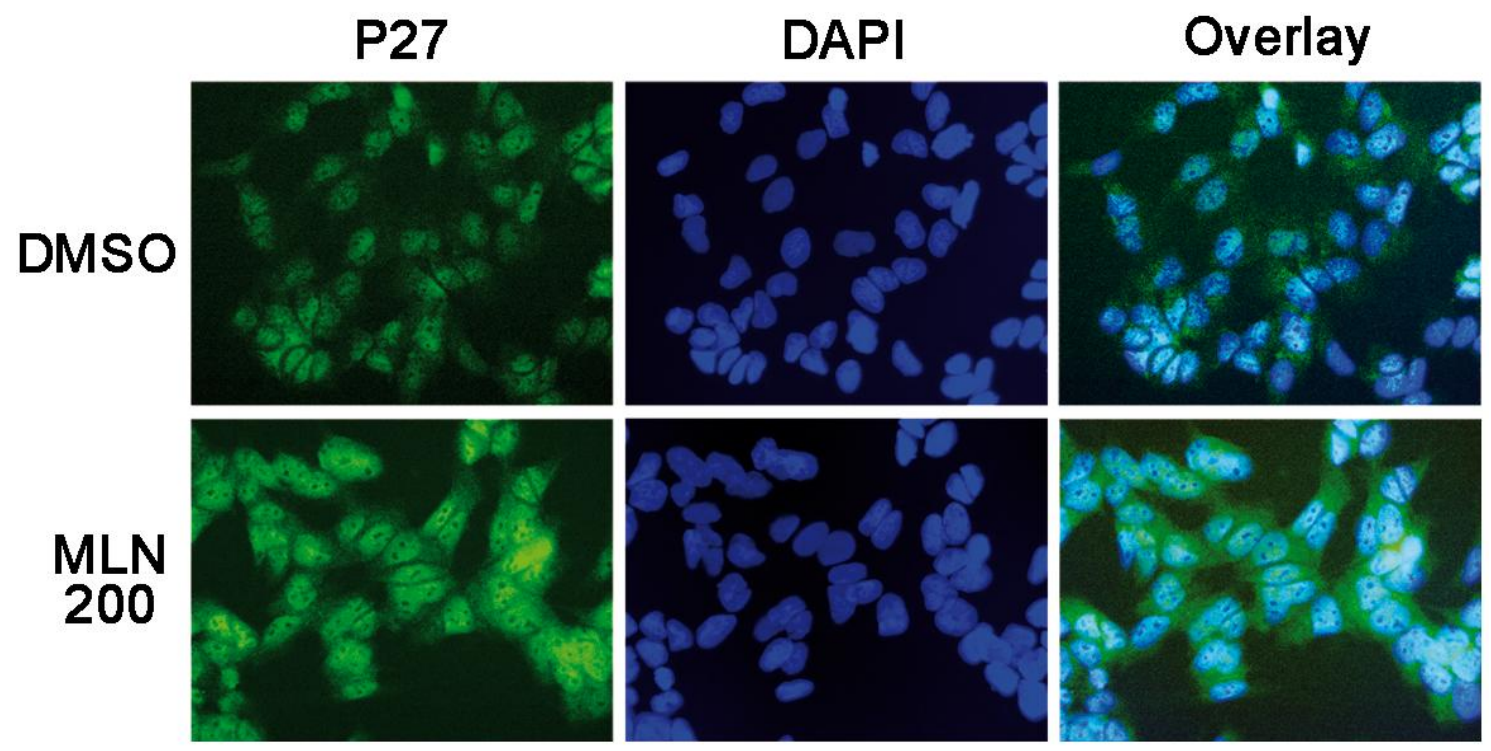

Figura 35: Inmunofluorescencia de células RDES tratadas con MLN4924 y marcaje de la proteína p27, 40x aumentos. Se observa el incremento de p27 (Alexa-488, en verde) por la acción del fármaco y que el incremento de la proteína se da en el núcleo principalmente. El marcaje de DAPI (azul) marcó los núcleos. MLN200: 200nM de MLN4924.

4.5.1.3 Retraso en la transición G2/M inducido por MLN4924 y el checkpoint de daño en el DNA

Anteriormente hemos detallado la aparición de daño en el DNA tras el tratamiento con MLN4924, abarcando desde focos aislados a concentración $\mathrm{IC}_{75}$ a un marcaje de la práctica totalidad de los núcleos a concentraciones de $\mathrm{IC}_{95}$ O superiores (Figura 28, página 100). El daño en el DNA activa el checkpoint de daño al DNA que desencadena cascadas de señales moleculares que retrasan la progresión del ciclo en en la transición G2/M, con el objetivo de dar un tiempo extra a la célula para reparar los daños antes de iniciar la etapa de mitosis. Este 
punto de control podría explicar la parada que produce MLN4924 a concentraciones bajasmedias. De nuevo diseñamos un ensayo de rescate; en este caso nos basamos en la aplicación de altas concentraciones de cafeína $(20 \mathrm{mM})$, la cual inhibe la ruta de señalización de daño en DNA ATM/ATR. Para llevar a cabo este ensayo aplicamos al fármaco a una concentración situada entre la $I C_{75}$ y la $I C_{95}$, más próxima a la primera (300nM). Con ello incrementamos el daño en el DNA sin desencadenar totalmente el fuerte retraso en la fase $\mathrm{S}$ que tiene lugar a mayores concentraciones del fármaco. Dichas concentraciones se mantuvieron durante $24 \mathrm{~h}$, tiempo en el que las células se acumularon fundamentalmente en $G 2 / M$, tras lo cual añadimos al medio la cafeína durante $12 \mathrm{~h}$ para comprobar si tenía lugar una reversión del bloqueo. Figura 36.
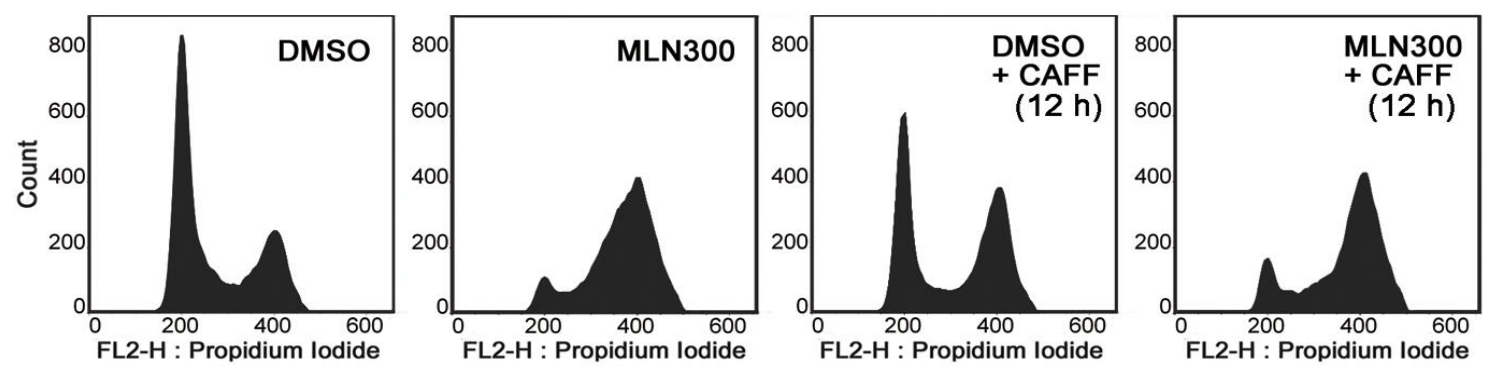

Figura 36: Ensayo de rescate del retraso en la transición G2/M utilizando cafeína $(20 \mathrm{mM})$ en la línea celular RDES tratada con el fármaco MLN4924. Histogramas de contenido de DNA por citometría de flujo de todas las combinaciones ensayadas evidenciando la ausencia de reversión del perfil de ciclo celular inducido por MLN4924 tras el tratamiento con cafeína. Experimento representativo de tres réplicas independientes. MLN300: 300nM de MLN4924. +CAFF: 20mM de cafeína.

Observamos el perfil de ciclo habitual de RDES en la condición control (DMSO) y el retraso en la transición G2/M (y cierto retraso en fase S) al aplicar 300nM de MLN4924 durante 24h. Cuando aplicamos cafeína en células control (DMSO) observamos como las células entraron más rápido en $\mathrm{G} 2 / \mathrm{M}$ al tener inhibido el checkpoint de esta fase (que también puede ser activado en células que han sufrido algún tipo de daño durante la replicación normal del DNA), causando un incremento del pico G2/M. Al aplicar cafeína en las células tratadas con MLN4924 observamos una leve disminución del acúmulo en fase $S$ pero continuó el retraso en la transición G2/M (el pico de G1 es mínimo, al igual que en la condición de aplicación exclusiva de MLN4924).

Concluimos que la contribución del checkpoint de daño en el DNA al retraso en la transición G2/M, resultado de la aplicación de MLN4924 a concentraciones intermedias, fue escasa o inapreciable.

4.5.1.4 Evaluación de WEE1 como inductor del retraso en la transición G2/M en células de SE tratadas con concentraciones intermedias (hasta $\mathrm{IC}_{75}$ ) de MLN4924

WEE1 inhibe la progresión del ciclo celular por la fosforilación Y15 de CDK1, lo que reduce drásticamente la actividad enzimática del complejo CDK1-Ciclina B que se traduce en retraso del progreso de G2 a mitosis ${ }^{328}$. Para comprobar si el acúmulo de WEE1 inducido por MLN4924 era la causa del retraso en la transición G2/M el planteamiento experimental fue similar al descrito para p27. En este caso intentamos rescatar el perfil de ciclo bloqueando la acción de WEE1 (fosforilación de Y15 de CDK1) mediante el uso del fármaco PD0166285 (un 
inhibidor de la actividad quinasa de WEE1 ${ }^{198}$ ) o silenciando la expresión de WEE1 mediante el uso de shRNAs.

Rescate de la transición G2/M mediante inhibición de la actividad de WEE1

En primer lugar utilizamos el fármaco MK-1775, teóricamente más específico que PD0166285 en la inhibición de la quinasa WEE1 ${ }^{198-199}$. Empíricamente observamos que la acción del fármaco no fue constante ni reproducible. Utilizando exactamente las mismas condiciones en las diferentes réplicas, los resultados obtenidos diferían. En muchas de las réplicas no se observó ningún efecto en la fosforilación de CDK1 en el resiudo Y15. Probablemente se debió a que el lote de fármaco recibido fue defectuoso, pues en literatura se ha descrito su eficiencia ${ }^{199}$. De todos modos, decidimos probar PD0166285 (otro inhibidor de WEE1 que también lo es de MYT1 aunque a mayores concentraciones ${ }^{198}$ ) para inhibir la actividad de WEE1 en sucesivos ensayos.

LLevamos a cabo una titulación del fármaco PD0166285 con el fin de determinar a qué concentración el fármaco era efectivo y no resultara tóxico para las células durante los ensayos. Establecimos que la manera más eficiente de evaluar los efectos de PD0166285 sobre la actividad de WEE1, así como su relación con la respuesta molecular de las líneas de SE frente al fármaco MLN4924, fue mediante un esquema de aplicación secuencial (Figura 37):

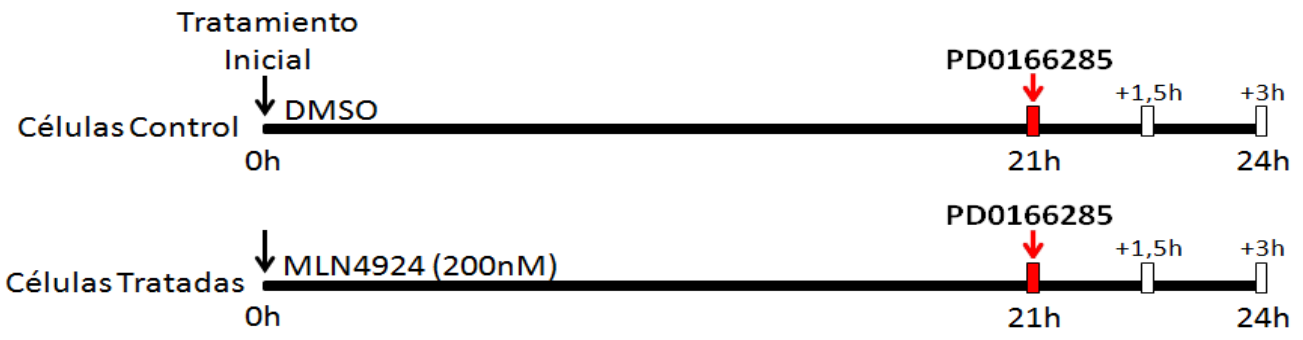

Figura 37: Esquema de empleo secuencial de fármacos en ensayos de rescate del retraso en la transición G2/M provocado por MLN4924 en líneas celulares de SE mediante la inhibición de la actividad de WEE1 aplicando el fármaco PD0166285. Se indican los tiempos a los que los fármacos fueron aplicados y los puntos de tiempo a los que se hicieron los estudios de ciclo (recuadros blancos sobre la línea temporal).

Se concluyó que el rango de concentración del fármaco PD0166285 idónea para los ensayos fue 250-500nM y, para evitar toxicidad, no debió prolongarse excesivamente la exposición de las células al fármaco. Para comprobar su efectividad evaluamos por WB (Figura 38) el efecto sobre los niveles de fosforilación en Y15 de CDK1, sustrato específico de la quinasa WEE1.En las células control (DMSO) vimos niveles relativos bajos de WEE1 y fosforilación de CDK1. Al aplicar 200nM de MLN4924, los niveles de ambos se incrementaron notablemente, como era esperable. Sin embargo, cuando se combinó el fármaco MLN4924 y el PD0166285 (a 250nM) observamos cómo, a pesar de la acumulación de los niveles de WEE1 (ligeramente superiores incluso a los niveles alcanzados en la condición donde solo se aplicó MLN4924), los niveles de fosforilación de Y15 de CDK1 fueron similares a los del control sin tratar. Esto nos indicó que efectivamente PD0166285 inhibió la actividad de WEE1 pese a que los niveles de proteína fueron altos debido a la acción de MLN4924. Al incrementar la concentración de PD0166285 a 500nM, los niveles de WEE1 se mantuvieron con respecto al caso anterior y los niveles de fosforilación de Y15 de CDK1 cayeron por debajo incluso de los de las células control (DMSO). 
Esto nos indicó que la acción del fármaco PD0166285 fue efectiva sobre la quinasa WEE1. Por último, el fármaco inhibidor de WEE1 aplicado individualmente en células control (DMSO, no tratadas con MLN4924) indujo un ligero aumento de WEE1 (posiblemente parte de algún circuito de "feedback" en respuesta a la disminución de su actividad) a la vez que disminuía su actividad (fosforilación Y15 de CDK1, que lógicamente se encontró por debajo de la situación control sin ningún tratamiento). Figura 38.

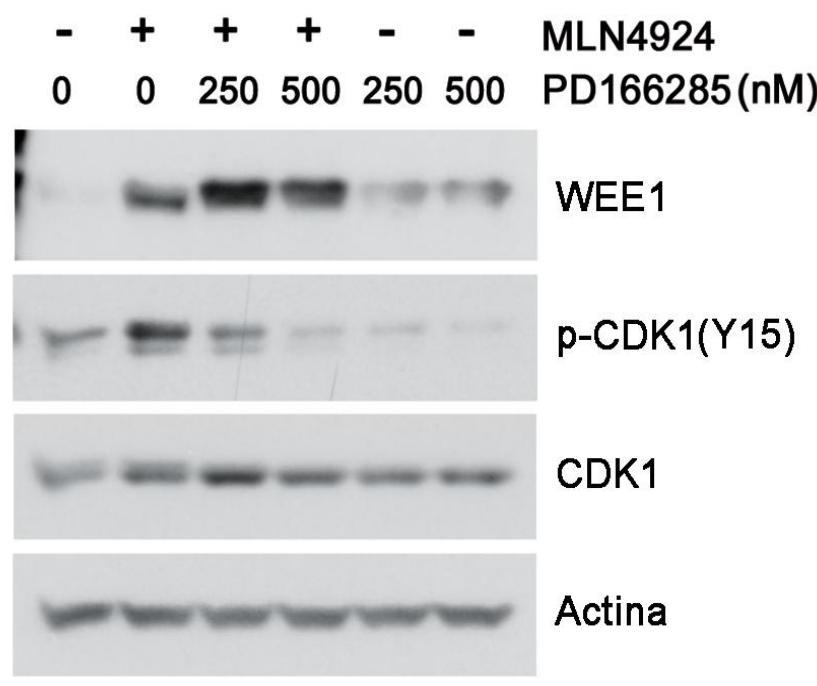

Figura 38: WB del tratamiento de la línea RDES con los fármacos MLN4924 y PD0166285. Tal y como se describe en el texto, el inhibidor de WEE1 (PD0166285) fue capaz de bloquear el aumento de la fosforilación en Y15 de CDK1, causado por MLN4924 (concentración IC 75 ), tras tan sólo tres horas de tratamiento con PD0166285 a las concentraciones que se indican en el rótulo superior de la figura.

Analizando los perfiles de ciclo obtenidos mediante marcaje del DNA con IP, observamos el perfil habitual de una línea celular en crecimiento en la condición control (DMSO). El perfil cuando aplicamos 200nM de MLN4924 mostró el retraso en la transición G2/M ya descrito. Cuando utilizamos exclusivamente el fármaco PD0166285 (250 o 500nM) observamos que la fase $S$ fue igual a la del control, pero aumentó el pico de G1 y disminuyó el de G2/M. Esto ocurrió porque quitamos el bloqueo que provoca la acción de WEE1 en un ciclo celular normal y las células pasaron más rápido hacia G1. En la combinación de los dos fármacos, aplicados de manera secuencial (tres horas del inhibidor de WEE1 en presencia de MLN4924, tras casi un día de tratamiento con éste último solamente), observamos como el pico de G2/M disminuyó en comparación con la aplicación exclusiva de MLN4924 (pasando de una población G2/M del $38 \%$ a otra del $17.7-18.6 \%$, valor muy similar al del control sin tratar, $19.5 \%)$ y se recuperó un perfil de ciclo similar al de las células control. Figura 39, A.

Con respecto a la aplicación única de este fármaco a 250nM o a $500 \mathrm{nM}$, no existió diferencia significativa en cuanto a los porcentajes de los perfiles de ciclo. En referencia al rescate (MLN4924 frente a PD0166285+MLN4924), las diferencias detectadas fueron estadísticamente significativas (tanto a 250nM como a 500nM de PD0166285). Figura 39, B.

Para hacer más evidente el efecto de rescate de la inhibición de WEE1, decidimos repetir el ensayo diferenciando ahora entre fase G2 y mitosis. Una aproximación similar se hizo al estudiar el efecto del fármaco en células sincronizadas con nocodazol ("Sincronización en 
mitosis temprana" del apartado del 4.5.1.1 de Resultados), experimento que ya nos indicó que el retraso sucedía en la transición G2/M: las células tratadas con MLN4924 liberadas del nocodazol salieron de mitosis y reanudaron la progresión del ciclo al mismo tiempo que las células control (DMSO), sin encontrar por tanto obstáculo alguno en mitosis.

A

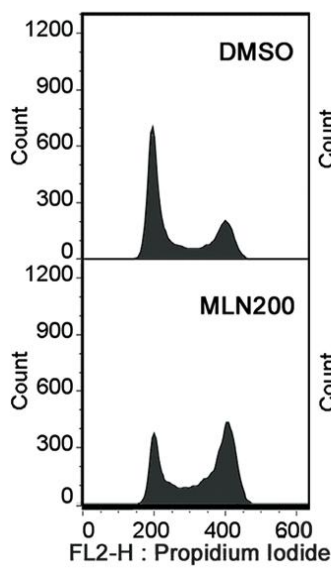

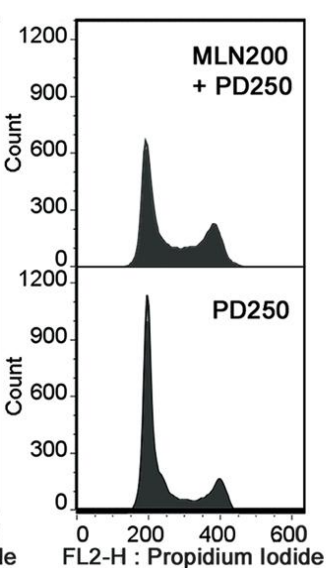

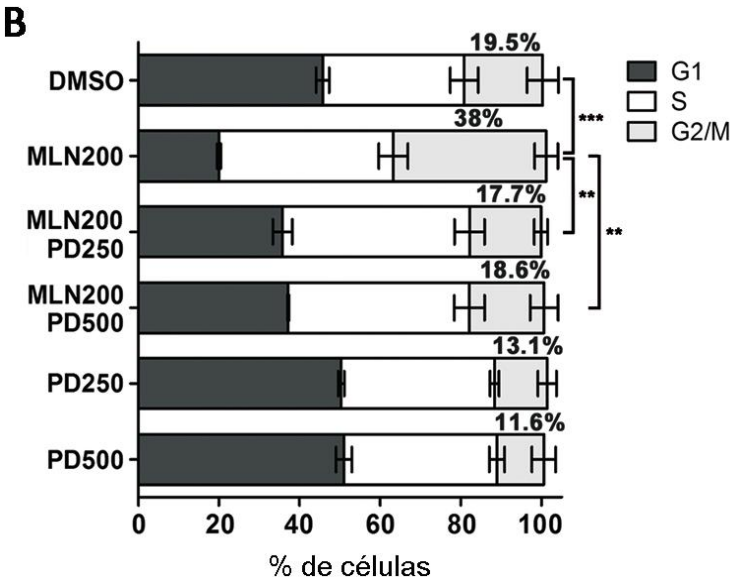

Figura 39: Rescate del retraso en la transición G2/M inducido por el fármaco MLN4924 mediante la inhibición de la actividad de WEE1 con el fármaco PD0166285 en la línea celular RDES. A Perfiles de citometría de flujo obtenidos mediante marcaje de DNA con IP. B Porcentajes de las distintas fases del ciclo en cada una de las condiciones de tratamiento indicadas; se indica numéricamente el porcentaje correspondiente al pico G2/M. Bonferroni post-hoct test $p<0.001(* * *)$ y $p<0.01(* *)$.

Para hacer más evidente el efecto de rescate de la inhibición de WEE1, decidimos repetir el ensayo diferenciando ahora entre fase G2 y mitosis. Una aproximación similar se hizo al estudiar el efecto del fármaco en células sincronizadas con nocodazol ("Sincronización en mitosis temprana" del apartado del 4.5.1.1 de Resultados), experimento que ya nos indicó que el retraso sucedía en la transición G2/M: las células tratadas con MLN4924 liberadas del nocodazol salieron de mitosis y reanudaron la progresión del ciclo al mismo tiempo que las células control (DMSO), sin encontrar por tanto obstáculo alguno en mitosis.

En esta ocasión, para visualizar las células en mitosis y diferenciarlas de las que están en G2 (que en un ensayo de marcaje de DNA con ioduro de propidio son indiscernibles por tener ambas el mismo contenido de DNA) mediante citometría de flujo, marcamos las células mitóticas con un anticuerpo anti-fosfo-histona H3, Ser10 (pH3). Comprobamos primero como el marcaje $\mathrm{pH} 3$ estuvo presente en todas las etapas de la fase de mitosis en las células de SE mediante inmunofluorescencia (Figura 40, C), y nunca estuvo presente en interfase. Una vez comprobada la especificidad del anticuerpo, se repitió el tratamiento secuencial de las células (Figura 37, página 112). Esta vez las células fueron recogidas y procesadas para el ensayo de citometría de flujo, marcándolas con IP (contenido en DNA) y pH3 (marcaje de células en mitosis; protocolo detallado en el apartado 3.5 de la sección Material y Métodos). Los dotplots de ambos factores mostraron como las células tratadas con MLN4924 durante 21h se encontraron bloqueadas en $\mathrm{G} 2$, mostrando un incremento de la población en esta fase y una respectiva disminución de la población mitótica, pH3 positiva (reducida de un $2.97 \%$ a un 1.26\%; Figura 40, A y B), de acuerdo con el resultado observado en el ensayo de sincronización con nocodazol. La adición simultánea en este mismo punto de tiempo del 
fármaco PD0166285, inhibidor de WEE1, conllevó la liberación de la células acumuladas en G2: $1.5 \mathrm{~h}$ tras su adición al medio se produjo una masiva entrada en mitosis de las células bloqueadas en $\mathrm{G} 2$ (pasando las células pH3 positivas del 1.26\% al 18\% de la población total). Tras $3 \mathrm{~h}$ de aplicación la práctica totalidad de esas células habían pasado a $\mathrm{G} 1$, dejando la población mitótica en valores cercanos al del control sin tratar (células pH3 positivas $=4.71 \%$, frente a las $2.97 \%$ del control). Figura $40, \mathrm{~A}$.

La aplicación exclusiva del fármaco PD0166285 durante una 1,5h también supuso un aumento (ligero comparativamente, $5.13 \%$ frente a $2.97 \%$ del control) de las células mitóticas, que estaban evitando el bloqueo fisiológico en la transición G2/M ejercido por WEE1. La prolongación del tratamiento único con PD0166285 a 3h supuso igualmente una reducción de ésta población, que progresó a G1 (pasando las células mitóticas del 5.13\% a 1.5h, al $3.90 \%$ tras $3 h)$.

A

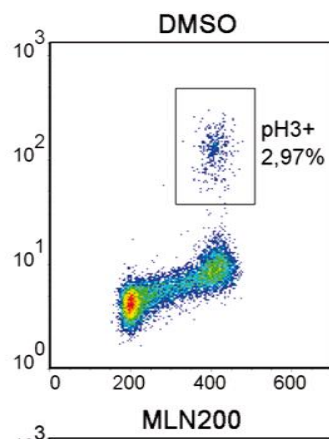

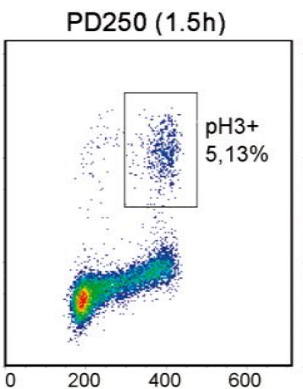
MLN200 + PD250 (1.5h) MLN200 + PD250 (3h)

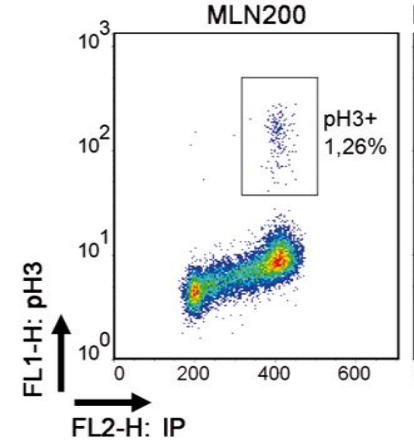
PD250 (3h)
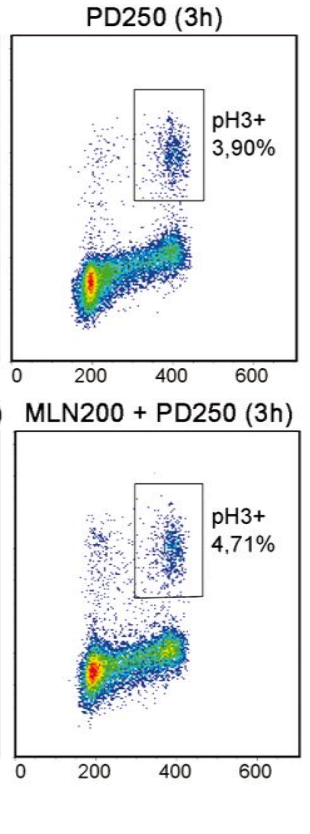

B

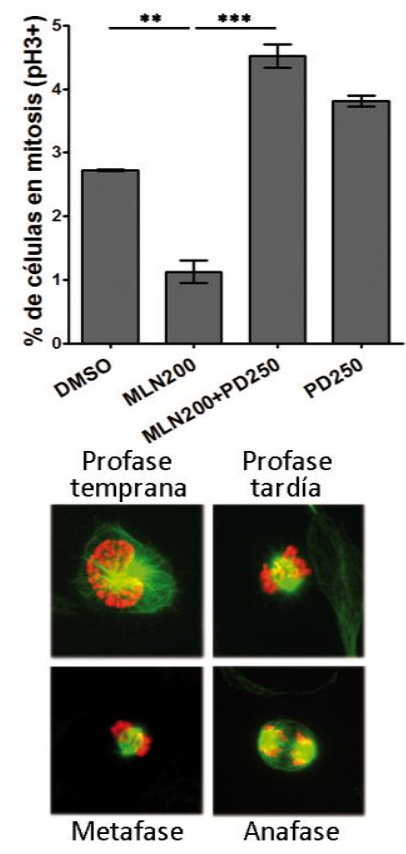

Figura 40: Análisis de ciclo celular con discriminación de mitosis en células RDES tratadas con MLN4924 y rescate con PD0166285. A Dotplot mostrando el marcaje de DNA (representado en el eje X) frente al marcaje con pH3 (eje Y). La población mitótica ha sido recuadrada y el tamaño porcentual de dicha población se representa junto a los recuadros. B Porcentajes de células pH3 positivas (en mitosis) en el estudio de rescate con PD0166285 (tras 3h de aplicación; datos de 3 réplicas independientes). ANOVA + Bonferroni post-hoc test $p<0.001(* * *)$ y $p<0.01\left({ }^{* *}\right)$. C Inmunofluorescencia anti-pH3 ( $\mathrm{Cy} 3$ en rojo, muestra el marcaje de los cromosomas en proceso de condensación o condensados) y anti- $\alpha$-actina (Alexa-488 en verde, muestra el marcaje de los microtúbulos) en células de SE, 40x aumentos.

Tras realizar tres réplicas del ensayo, y teniendo en cuenta los datos estadísticamente significativos de la aplicación de PD0166286 en combinación con MLN4924 frente a la aplicación exclusiva del MLN4924, confirmamos el efecto de rescate del fármaco PD0166285 (Figura 40, B). Concluimos por tanto que la inhibición de WEE1 mediante la aplicación del fármaco PD0166285 rescata del retraso en la transición G2/M que MLN4924 induce en células de SE tratadas con concentraciones medias (hasta $I_{C_{75}}$ ). Este ensayo confirmó además que el 
retraso se produce en $\mathrm{G} 2$ o en la transición G2/M, en cualquier caso antes de la propia fase de mitosis, momento en el que WEE1 ejerce su papel inhibitorio sobre CDK1.

Rescate de la transición G2/M mediante el silenciamiento de la expresión de WEE1

Para silenciar la expresión de WEE1 utilizamos dos construcciones shRNAs diferentes contra WEE1 disponibles comercialmente que trasferimos a las células diana mediante transducción lentiviral, que denominamos shWEE1-1 y shWEE1-2. En primer lugar evaluamos la capacidad de inhibición de los diferentes constructos comerciales mediante WB. Utilizamos un control con secuencia al azar (NTC) y valoramos su acción en células control (DMSO) y tratadas con MLN4924 (200nM e IC 95 ). Observamos como la transducción de las células de SE con el constructo control no alteró la respuesta habitual al fármaco MLN4924 (incremento de los niveles de WEE1 y su actividad, fosforilación Y15 de CDK1). Por el contrario, los shRNA específicos WEE1-1 y WEE1-2 disminuyeron la expresión de la proteína WEE1 y su actividad quinasa (el segundo constructo lo hizo de manera más intensa). El silenciamiento no fue total, lo cual fue de utilidad pues se ha descrito que la inhibición total de WEE1 conduce a catástrofe mitótica y apoptosis ${ }^{207,329}$, lo cual hubiera dificultado la obtención de resultados. Los resultados de WB confirmaron que el silenciamiento de WEE1 disminuyó la acumulación proteica inducida por MLN4924, así como la de su sustrato (fosfo-CDK1 en el residuo Y15). Figura 41.

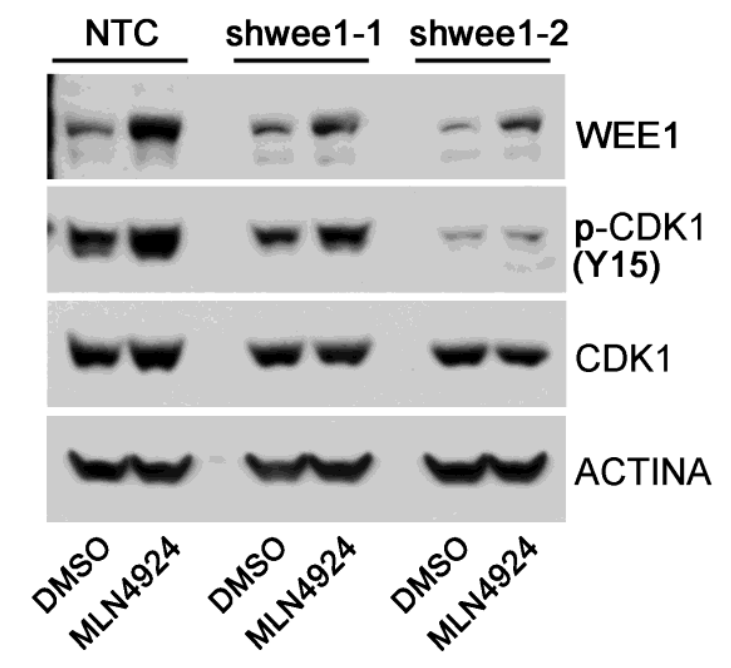

Figura 41: WB del tratamiento de la línea celular RDES con el fármaco MLN4924 (IC 75 ) en condiciones de silenciamiento de WEE1 mediante shRNA. El silenciamiento de WEE1 disminuyó su acumulación proteica tras el tratamiento con MLN4924, así como la de su sustrato específico fosfo CDK1 en el residuo Y15 (p-CDK1 (Y15)) con dos construcciones shRNA específicas distintas (WEE1-1, WEE1-2). NTC: control de inespecificidad, "non-targeting control".

Una vez comprobada la eficiencia de los constructos realizamos un estudio de citometría de flujo con marcaje del DNA mediante IP para evaluar los perfiles de ciclo. Los perfiles de ciclo obtenidos con el tratamiento con MLN4924 en células transducidas con el constructo NTC fueron los habituales y ya descritos previamente: a concentraciones medias $\left(\leq I C_{75}\right)$ bloqueo y acúmulo en $\mathrm{G} 2 / \mathrm{M}$, y a concentraciones altas ( $\geq \mathrm{IC}_{95}$ ) acúmulo en fase $\mathrm{S}$. Incluimos $I \mathrm{C}_{95}$ en este estudio para comprobar si WEE1 podía tener un papel efector importante también en el retraso en fase $\mathrm{S}$. Cuando silenciamos parcialmente la expresión de WEE1 mediante los constructos shRNA específicos contra WEE1, observamos como el perfil de ciclo de las células 
tratadas con MLN4924 200nM $\left(\approx 1 C_{75}\right)$ fue muy similar al de la condición sin tratamiento (DMSO), Figura 42. Por lo tanto confirmamos los resultados obtenidos en el anterior apartado con la inhibición de la actividad de WEE1 mediante el uso del fármaco PD0133285, indicando de manera aún más inequívoca que la acumulación de WEE1 es el principal efector funcional del retraso en la transición G2/M inducido por MLN4924.

Con respecto a la implicación de WEE1 en el incremento de células en fase $\mathrm{S}$ al tratar con altas concentraciones de MLN4924, podemos observar los resultados en el recuadro derecho de los tres paneles de la Figura 42. Vimos como el silenciamiento parcial de WEE1 no rescató totalmente del acúmulo en esta fase del ciclo, aunque sí observamos un ligero descenso de la población en fase $\mathrm{S}$ con respecto a la condición NTC, y un aumento de G1 en los shRNA con respecto a ésta. Esto nos indicó que la población de células que a concentraciones intermedias de MLN4924 estuvo retenida por la fosforilación Y15 de CDK1 ejercida por WEE1 fue rescatada y progresó hacia G1. Sin embargo, la población retrasada en fase S se mantuvo bloqueada por otro/s efector/es de manera predominante. WEE1 pudo participar directamente en este bloqueo, fosforilando quizá a CDK2 $2^{325}$.
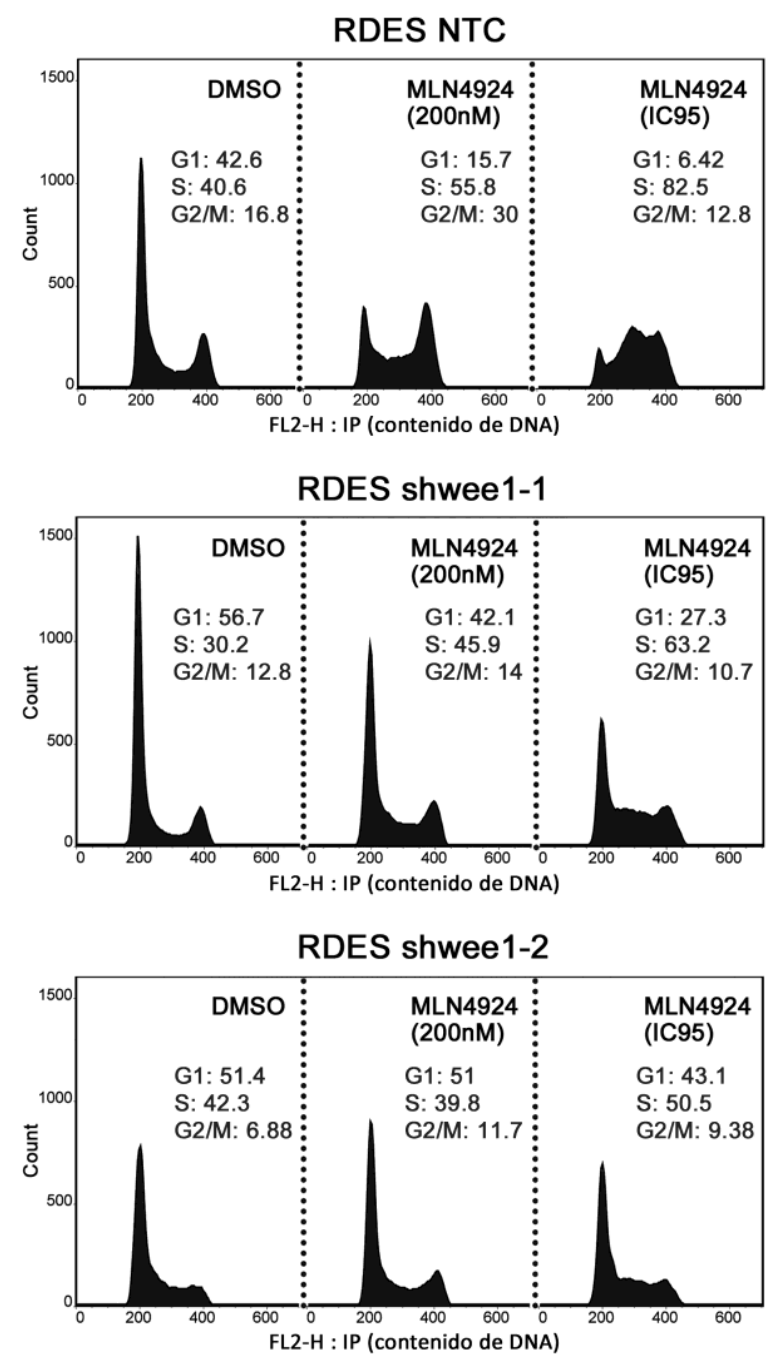

Figura 42: Histogramas de marcaje de DNA con ioduro de propidio en células RDES tratadas con MLN4924, en el estudio de rescate mediante el silenciamiento de WEE1 con shRNAs. Se muestran tres paneles con las distintas condiciones con respecto al silenciamiento de WEE1 (control $\rightarrow$ NTC y los dos constructos que silencian la quinasa). 
Podemos diferenciar en las columnas verticales las tres condiciones con respecto a la aplicación de MLN4924 (control $\rightarrow$ DMSO y las concentraciones $200 \mathrm{nM}\left(\approx \mathrm{IC}_{75}\right)$ e $\mathrm{IC}_{95}$ del fármaco). En cada histograma se detalla el porcentaje de eventos en cada fase del ciclo. NTC: control de inespecificidad, "non-targeting control".

En último lugar, el silenciamiento de WEE1 mediante shRNAs nos permitió evaluar si los niveles de apoptosis (bajos a concentraciones $\leq I C_{75}$, y altos a concentraciones $\geq I_{95}$ ) estaban relacionados con el acúmulo de WEE1 por MLN4924. Realizamos estudios de proliferación (siguiendo el protocolo descrito en el apartado 3.3 de la sección Material y Métodos adquiriendo los resultados con el kit "ATP-lite one-step") y de apoptosis (mediante marcaje con Caspasa-3 procesada). Figura 43.

A

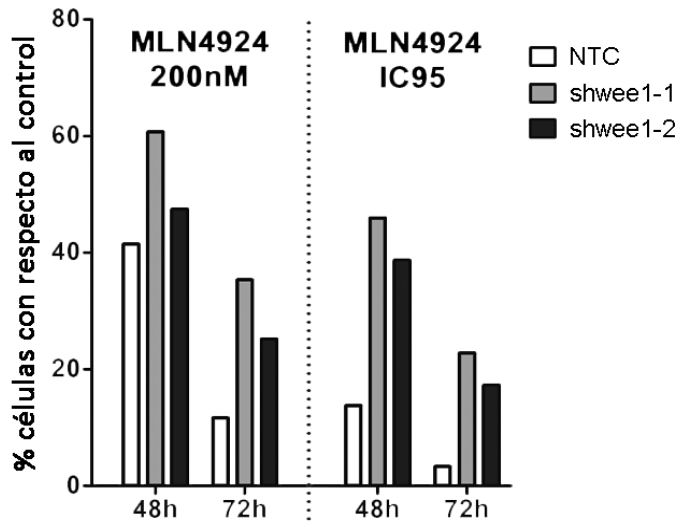

B

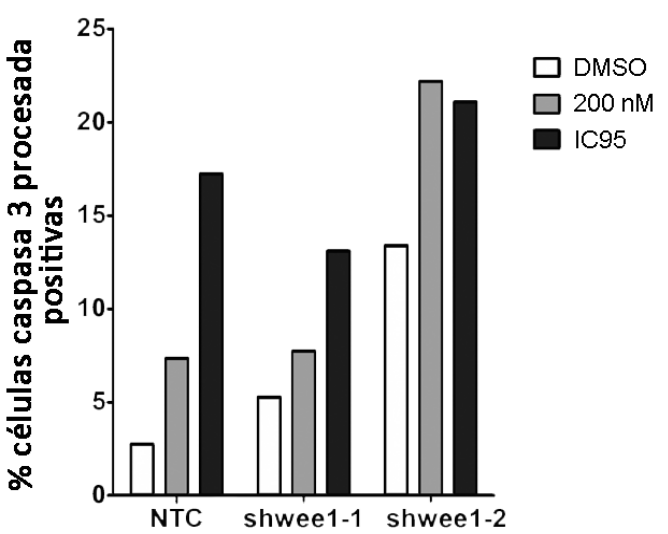

Figura 43: Estudio de proliferación/apoptosis en células RDES tratadas con MLN4924 y transducidas con shRNAsWEE1/NTC. A Ensayo de proliferación: porcentaje de células tras 48 y $72 \mathrm{~h}$ de tratamiento con respecto al control (células tratadas con MLN4924/células tratadas con DMSO, expresado como porcentaje). B Porcentaje de células apoptóticas (Caspasa 3 procesada positivas). Experimento representativo de duplicados independientes.

Los resultados evidenciaron que la inhibición de WEE1 rescató la proliferación de las células tratadas con el fármaco MLN4924 (Figura 43, A). A 48h de tratamiento, las diferencias de proliferación entre el NTC y los shRNAs-WEE1 fueron más atenuadas que a $72 \mathrm{~h}$ de tratamiento con MLN4924. Existieron diferencias entre los constructos ShWEE1-1 y shWEE1-2, ya que el primero consiguió una mayor protección de la proliferación frente a MLN4924, a pesar de que el segundo mostró mayor capacidad a la hora de bloquear la acumulación de WEE1. Estos datos en conjunto sugirieron que el acúmulo de WEE1 inducido por el fármaco MLN4924 bloqueó la progresión del ciclo lo cual disminuyó la proliferación de las células (independientemente de la apoptosis); la inhibición de la expresión de WEE1 por shRNAs actuó como baipás de esta interrupción y rescató parcialmente la proliferación de las células de SE tratadas con MLN4924.

Con respecto a la apoptosis, si observamos la condición control (DMSO) los niveles de apoptosis incrementaron por la inhibición de la expresión de WEE1 mediante shRNAs (Figura 43, B). La eliminación de WEE1 per se provocó por tanto muerte celular, y observamos que aquel constructo que inhibió más intensamente WEE1, shWEE1-2 (Figura 41), provocó un mayor aumento de apoptosis. Al inducir apoptosis el silenciamiento de WEE1 per se era esperable que no se produjera rescate de la apoptosis (tal y como se observa en la Figura 43, B), de hecho no hubo tal rescate. Esto pudo explicar también las diferencias en el rescate de proliferación entre ambos constructos, donde la proliferación de la condición tratada silenciada con shWEE1-2 fue inferior a la de shWEE1-1 (Figura 43, A). Como se ha comentado 
anteriormente, ha sido descrito que la inhibición de WEE1 conduce a la célula a catástrofe mitótica y muerte celular ${ }^{207,329-330}$, aunque no comprobamos si este punto fue la causa de la apoptosis en nuestro caso particular.

Los ensayos para dilucidar el mecanismo subyacente al retraso en la transición G2/M en respuesta al fármaco MLN4924 fueron realizados en la línea celular de SE, RM82 además de en la línea RDES. Cualitativamente los resultados obtenidos fueron iguales a los obtenidos con la línea RDES detallados anteriormente. En la Figura 44 se detalla los resultados obtenidos con la línea RM82.

A
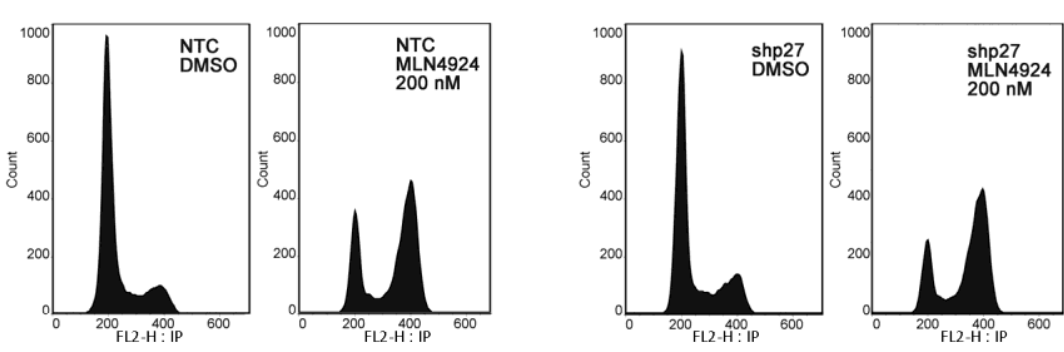

B
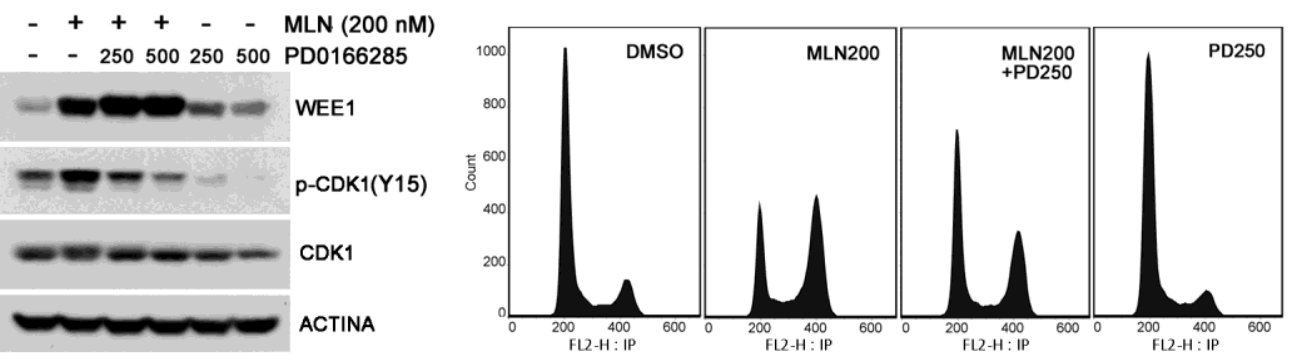

C NTC shwee1-1 shwee1-2
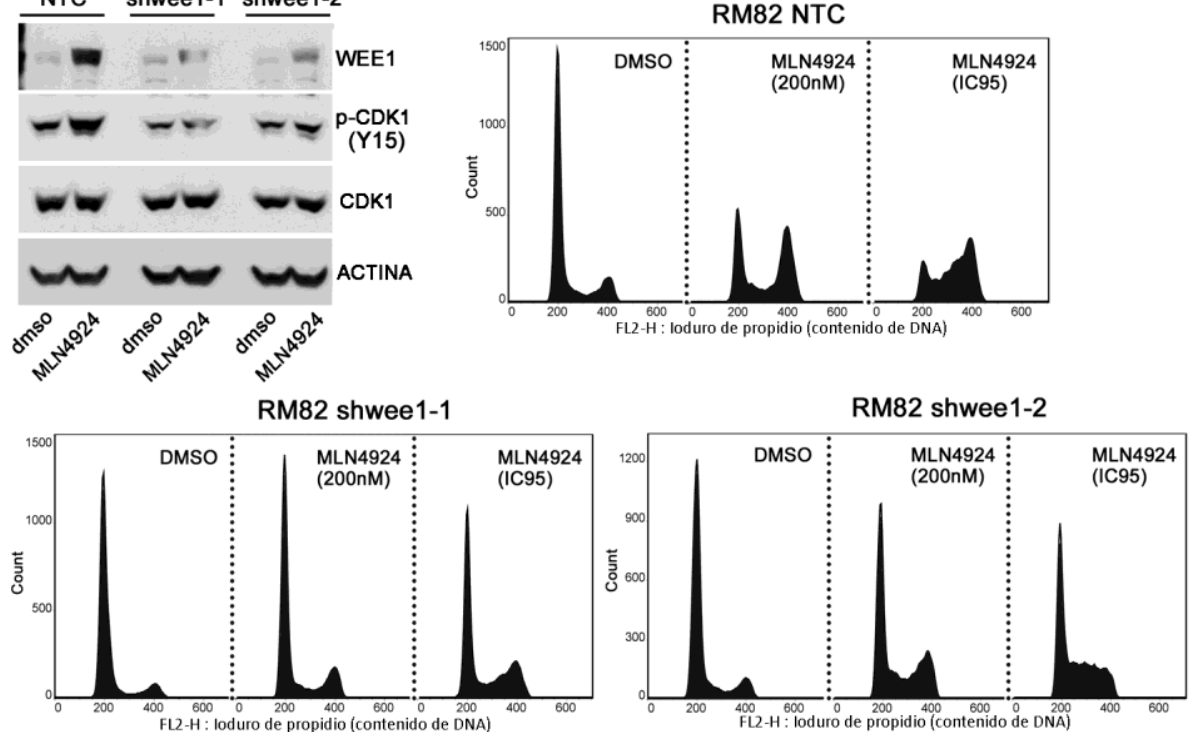

Figura 44: Mecanismo de acción de MLN4924 en RM82 y rescate mediante la inhibición o el silenciamiento de WEE1. A El silenciamiento de p27 en células tratadas con MLN4924 ( $\left.\approx \mathrm{C}_{75}\right)$ no rescata el retraso en G2/M. B Rescate del retraso en la transición G2/M inducido por MLN4924 mediante inhibición de la actividad de WEE1 (fosforilación en Y15 de CDK1) empleando el fármaco PD0166285; WB análogo al ya descrito para RDES en la Figura 38 y estudio de perfil de ciclo a través de citometría de flujo con marcaje de DNA (derecha) mostrando la reversión del pico en G2/M. C Rescate del retraso en la transición G2/M inducido por MLN4924 mediante el silenciamiento de WEE1 empleando shRNAs; WB similar al descrito para RDES en la Figura 41 y estudio de perfil de ciclo a través de 
citometría de flujo con marcaje de DNA (derecha y abajo). NTC: control de inespecificidad, "non-targeting control"; shp27: constructo shRNA para silenciar p27; shWEE1-1 y shWEE1-2: constructos shRNAs para el silenciamiento WEE1.

Los resultados confirmaron que el silenciamiento de p27 no rescató del retraso en la transición G2/M (Figura 44, A). También se comprobó cómo la inhibición de la actividad (mediante la aplicación del fármaco PD0166285) o la expresión de WEE1 (mediante los constructos shRNA: shWEE1-1 y shWEE1-2) sí fueron capaces de revertir dicho retraso, inducido por el fármaco MLN4924 a la concentración $\leq I_{75}$ específica para esta línea celular (Figura 44, B y C). Cuando aplicamos el fármaco a concentraciones altas $\left(\geq I_{95}\right)$ se produjo el retraso en fase $S$, el cual se revertió ligeramente al utilizar shWEE1-1 y absolutamente nada con el constructo shWEE1-2; Figura 44, C).

Con estos datos confirmamos que los resultados no fueron el fruto de utilizar una línea celular concreta de SE o que se debieron a las características intrínsecas de la propia línea celular. Además vimos que los efectos del fármaco MLN4924 y el rescate del mismo mediante la intervención sobre WEE1 fueron específicos. Por último, sugerimos que los resultados son extrapolables al resto de líneas celulares de SE objeto de estudio en esta tesis, dado que la respuesta a MLN4924 a nivel de perfil de ciclo celular y apoptosis fueron prácticamente idénticos en todas las líneas celulares estudiadas.

\subsubsection{Mecanismo molecular causante del retraso en fase $S$}

Tras demostrar el papel fundamental que desempeña la acumulación de WEE1 en el efecto del fármaco MLN4924 induciendo retraso en la transición G2/M, y comprobar que el posible papel de esta quinasa en el retraso en fase $S$ que tiene lugar a altas concentraciones del fármaco MLN4924 era mínimo, quisimos demostrar cuál era el mecanismo molecular que desencadenaba este segundo fenotipo de respuesta al fármaco.

Para hacer este ensayo lo más concluyente posible realizamos una sincronización en la transición G1/S mediante el uso de confluencia y altas concentraciones de timidina (protocolo detallado en el apartado 3.7 de la sección Material y Métodos), y además se marcó las células con BrdU para analizar en detalle la actividad replicadora del DNA. A partir de la liberación de la parada sincrónica que este agente impuso, las células progresaron por fase $\mathrm{S}$, permitiéndonos observar las alteraciones inducidas por MLN4924 (IC $\left.C_{95}\right)$ específicamente en esta fase del ciclo celular. En las células control (DMSO) observamos a tiempo Oh (aún en presencia de timidina) como las células se encontraron perfectamente sincronizadas en G1, justo al borde de la entrada en fase $\mathrm{S}$. Seis horas después de la liberación de timidina observamos las primeras células incorporando $\mathrm{BrdU}$ (iniciando por tanto la replicación del DNA), 48,6\% del total. A $12 \mathrm{~h}$ la progresión en el ciclo continuó, con prácticamente todas las células con contenido de DNA de fase $\mathrm{S}$ e incorporación muy activa de BrdU, mientras que a $15 \mathrm{~h}$ el porcentaje de células BrdU+ se redujo al $34.8 \%$ ya que la mayoría de las población alcanzó el contenido de DNA de G2 (59.3\%). Las células no pasaron de mitosis temprana porque el medio contenía nocodazol. Figura 45. 

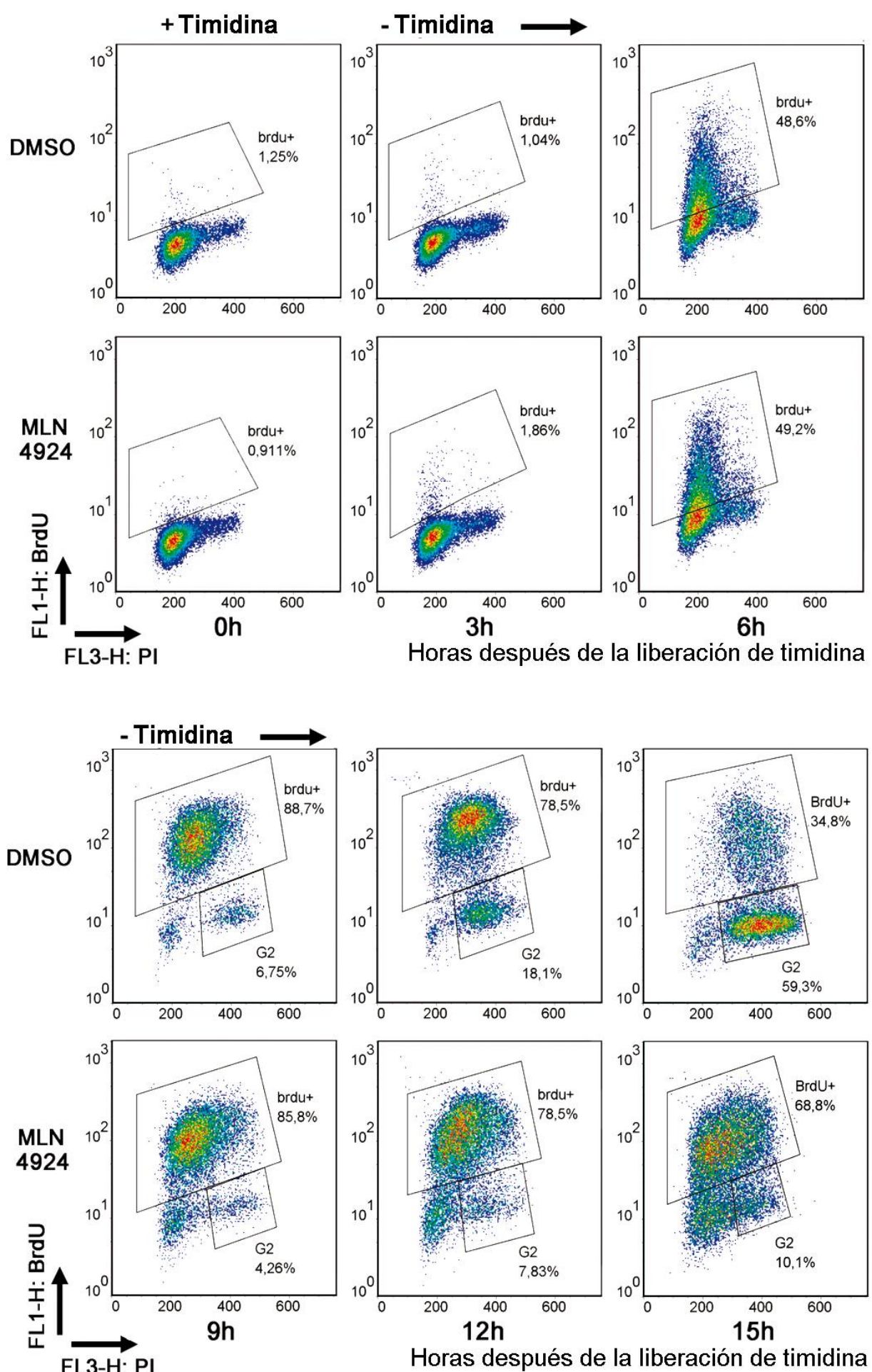

Figura 45: Sincronización en la transición G1/S, liberación y seguimiento del progreso del ciclo en células RDES tratadas con MLN4924 (IC I5 $_{\text {}}$ frente al control (DMSO). Dotplot mostrando el marcaje de DNA (representado en el eje X) frente al marcaje de BrdU (eje Y). La población celular en replicación activa (BrdU positivas) ha sido recuadrada en todos los puntos de tiempo y el tamaño porcentual de dicha población se representa junto a los recuadros; a partir del punto de tiempo $9 \mathrm{~h}$, de manera análoga se recuadra la población de células con contenido de DNA G2 (recuadros situados debajo de la mitad inferior derecha de los recuadros de BrdU). Se detalla los puntos de tiempo del ensayo tras la liberación de la timidina. Se aprecia en los dos últimos puntos de tiempo el retraso en la progresión de fase S inducido por MLN4924 a IC 95 . 
En las células tratadas con $\mathrm{IC}_{95}$ de MLN4924, la entrada en fase $\mathrm{S}$ se produjo al mismo tiempo que en las células control, siendo los porcentajes de células BrdU+ a 6 y $9 \mathrm{~h}$ prácticamente coincidentes. Por tanto, el fármaco no aceleró ni ralentizó la entrada ni la progresión inicial de la fase $\mathrm{S}$. A $12 \mathrm{~h}$ sin embargo apreciamos una disminución en el porcentaje de células en G2/M con respecto al control, $7.83 \%$ y $18.1 \%$ respectivamente. Además la incorporación de BrdU en este punto de tiempo disminuyó drásticamente con respecto al control (Figura 46). En el último punto de tiempo, $15 \mathrm{~h}$, se apreció la diferencia más significativa: en el control la población BrdU positiva (finalizando la síntesis de DNA) fue de tan sólo un 35\%, mientras la que había llegado a G2 fue de un 60\%. En fuerte contraste, en las células tratadas con el fármaco MLN4924, la población BrdU positiva fue mayoritaria (68.8\%) mientras que la población que había alcanzado G2 fue de tan sólo un $10.1 \%$, evidenciando el claro retraso en fase S tardía. Figura 45.

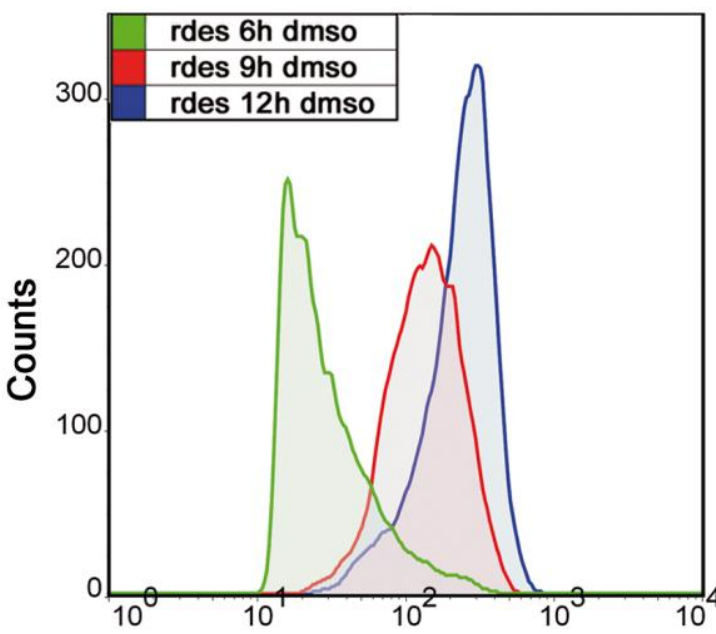

FL1-H: BrdU+

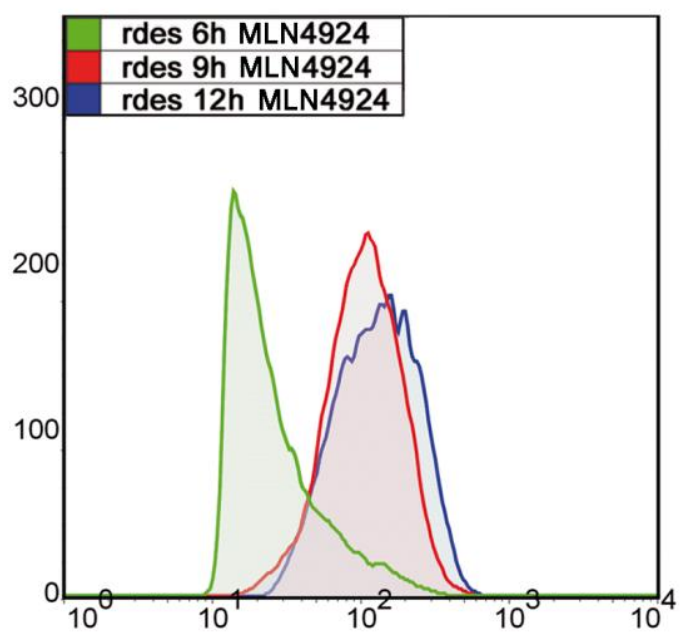

FL1-H: BrdU+

Figura 46: Disminución de la incorporación de $\mathrm{BrdU}$ a $12 \mathrm{~h}$ tras la liberación de la timidina de las células tratadas con MLN4924 (IC 95$)$ con respecto a células control (DMSO). Los histogramas pertenecen a las regiones recuadradas indicadas en la Figura 45 que correspondían a la población de células BrdU positivas (células en replicación activa) en los puntos de tiempo 6, 9 y 12h, tanto en células tratadas con MLN4924 (IC ${ }_{95}$ ) como en células control (DMSO). Dotplot mostrando el nivel de incorporación de BrdU (en el eje X) frente al número de eventos que están incorporando (eje $\mathrm{Y}$ ). Se aprecia como el nivel de BrdU que incorporaron las células tratadas con MLN4924 en el punto de $12 \mathrm{~h}$ fue inferior al de las células control.

Cuando prolongamos el ensayo a $24 \mathrm{~h}$, el $100 \%$ de las células control alcanzaron el contenido de DNA G2/M; sin embargo las tratadas con $\mathrm{IC}_{95}$ del fármaco siguieron retrasadas en fase $\mathrm{S}$ y además se disparó la apoptosis (datos no mostrados). Esto sugiere que las células tratadas con MLN4924, a pesar de estar replicando el DNA (tal y como mostró la aún masiva incorporación de $\mathrm{BrdU}$ a 15h) fueron incapaces en su mayoría de completar la fase $\mathrm{S}$ y progresar a G2. Demostramos aquí por tanto que el fármaco MLN4924 a alta concentración $\left(\mathrm{IC}_{95}\right)$ provocó una ralentización de la etapa final de la fase $\mathrm{S}$, mientras que la entrada y progreso inicial en esta fase no se vieron alteradas por la acción del fármaco.

En paralelo a la obtención de muestras para llevar a cabo el estudio de citometría con discriminación de células en replicación activa (BrdU positivas), destinamos células de cada punto de tiempo y de cada condición para extracción de proteínas. Esto nos permitió evaluar la cinética de las diferentes proteínas reguladoras de la fase $\mathrm{S}$ (y sustratos de CRL) durante el 
progreso de dicha fase. Al igual que en el ensayo de sincronización en mitosis, los niveles y la cinética de aquellas proteínas independientes de complejos CRL (CDK2, Ciclina A, Ciclina B y Retinoblastoma o RB), no se vieron alterados por el tratamiento con MLN4924. Es decir, la aparición y degradación de dichas proteínas tuvo lugar en el mismo punto de tiempo en la situación control y en las células tratadas ( $\mathrm{IC}_{95}$ de MLN4924). Sin embargo, en el caso de las proteínas clientes de los complejos CRL, a partir del momento programado para su degradación (degradación que sí sucedió en ese exacto punto de tiempo en las células control), observamos una acumulación de sus niveles en las células tratadas con MLN4924. Figura 47.

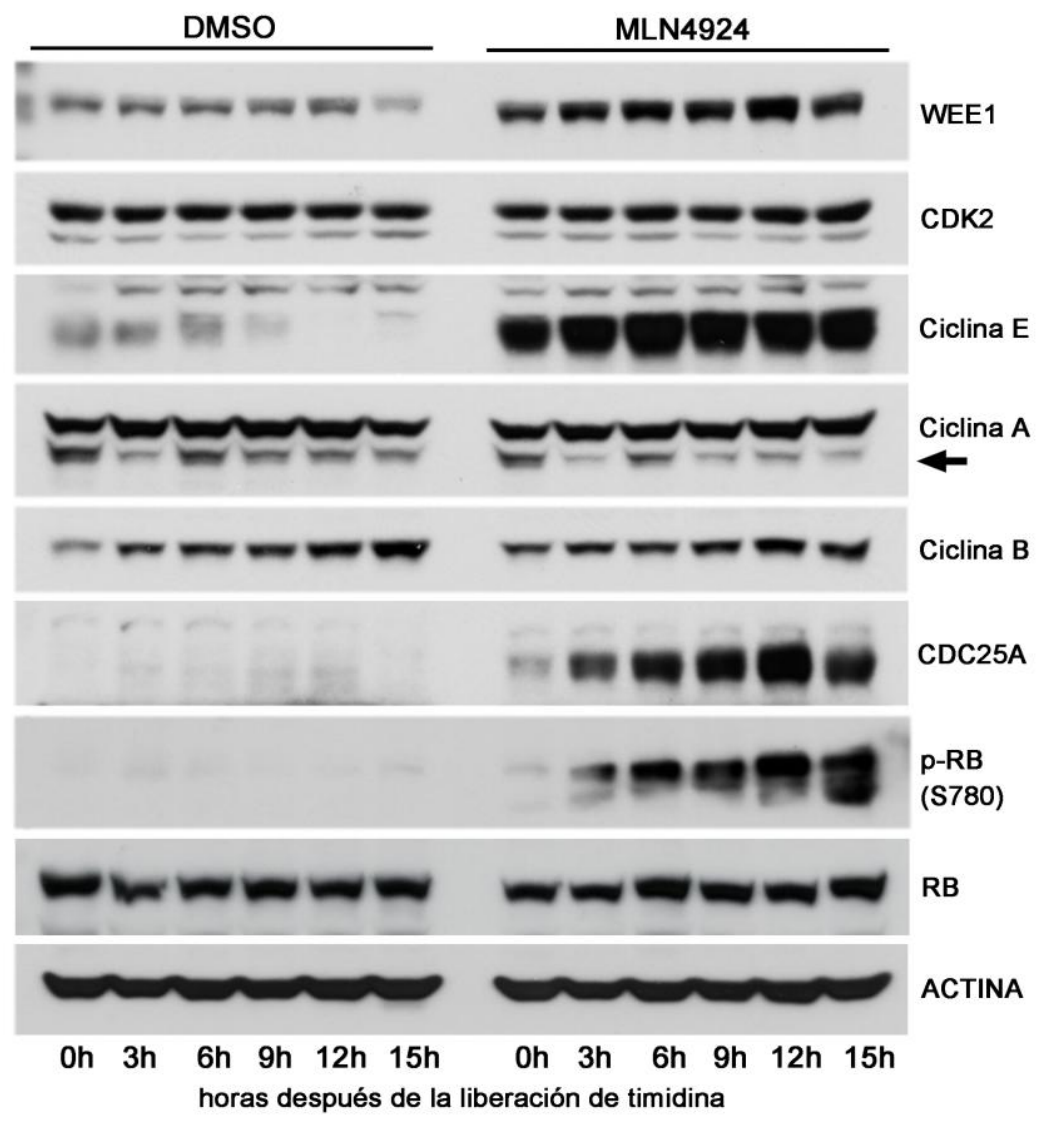

Figura 47: WB de extractos proteicos del ensayo de sincronización en la transición G1/S y tratamiento con MLN4924 ( $\left(\mathrm{IC}_{95}\right.$ ) en células RDES. Se distinguen los extractos obtenidos de células tratadas con el fármaco y de las células control (DMSO), así como los puntos de tiempo en los que se realizaron los extractos tras la liberación de la timidina. Se aprecia el acúmulo de las proteínas WEE1, Ciclina E y CDC25A como resultado de la inhibición de los complejos CRL ejercida por la acción de MLN4924. No se alteran los niveles de las proteínas cuya degradación es independiente de los complejos CRL: CDK2, Ciclina A, CiclinaB y RB. Destaca el enorme y progresivo acúmulo de la fosforilación en S780 de RB en células tratadas con IC ${ }_{95}$ de MLN4924.

Más en detalle, WEE1 se acumuló en las células tratadas en todos los puntos de tiempo. Ciclina $E$ en el control apareció al inicio de la de la fase $S$, desde 0 h hasta 6 h, y posteriormente fue degradada, como era de esperar puesto que induce uniéndose a CDK2 la entrada en la fase S. En contraste, en las células tratadas con MLN4924 (IC $\left.\mathrm{C}_{95}\right)$, Ciclina E se acumuló en gran cantidad en esta etapa inicial de fase $S$ y se mantuvo durante el resto del ensayo. CDC25A se acumuló a altas concentraciones desde el punto de tiempo de $3 \mathrm{~h}$ hasta el último punto de tiempo. Fosfo-S780 Retinoblastoma, una de las fosforilaciones inhibidoras de RB que 
permiten la liberación de E2F1 y la entrada en fase S, también se acumuló a altas concentraciones.

RB se encuentra habitualmente fosforilado en S780 en la transición G1/S por la acción de CDK4-6/Ciclina D y posteriormente por CDK2/Ciclina $\mathrm{E}^{331}$. El hecho de que detectáramos unos niveles tan elevados de RB fosforilado en este residuo tras el punto de $3 \mathrm{~h}$ nos indicó que los también altos niveles de Ciclina $\mathrm{E}$ se combinaron con CDK2 y conformaron complejos activos. De hecho, la acumulación conjunta de Ciclina E, fosfo-RB (S780) y CDC25A debería implicar una fuerte activación de la entrada en fase $S$, de acuerdo con la literatura ${ }^{332}$. Sin embargo, al igual que ya pasó en la sincronización con nocodazol, no se observó una aceleración en la entrada a fase $S$ (probablemente porque CDC25A era inactivo).

En el transcurso de un ciclo celular normal, Ciclina E se une a CDK2 en la frontera G1/S y está presente en la primera etapa de la fase $\mathrm{S}$. Posteriormente es degradado y es Ciclina A (que se va acumulando durante la fase S) la que se une a CDK2 hasta el final de esta fase del ciclo. Los resultados anteriores nos sugirieron que existía la posibilidad de que el acúmulo excesivo de Ciclina $\mathrm{E}$ y su presencia a destiempo (en momentos de la fase $\mathrm{S}$ en los que no debería de estar) por la acción de MLN4924 estuviera desplazando a Ciclina A en su unión a CDK2 entorpeciendo o impidiendo el transcurso de los momentos finales de la fase S. Para comprobar si esta hipótesis era cierta realizamos un ensayo de inmunoprecipitación de CDK2 en los puntos de tiempo en los que detectamos el retraso en fase $S$ de las células tratadas: 9 , 12 y 15 h. Figura 48.

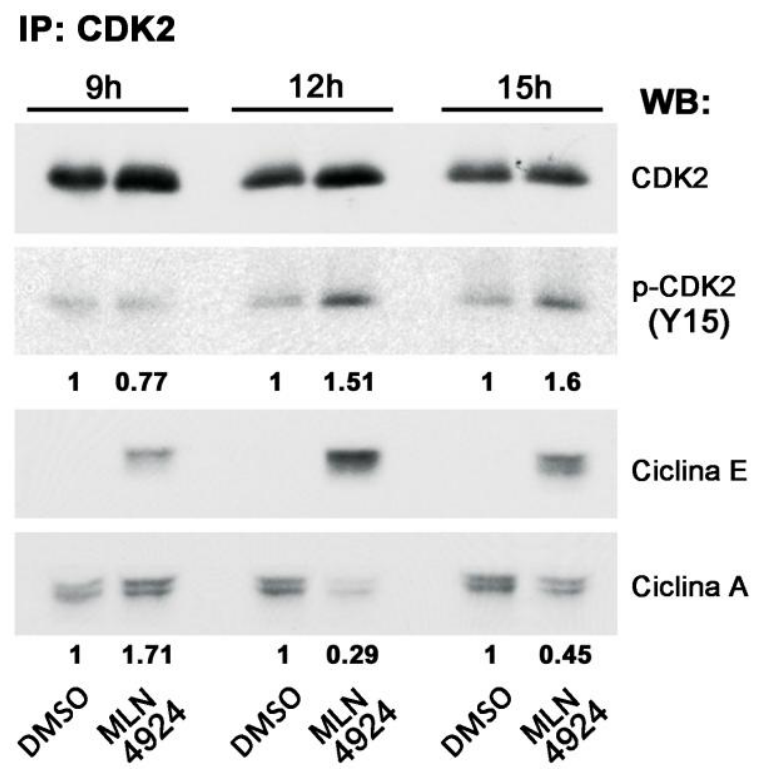

Figura 48: Inmunoprecipitación de CDK2 en células RDES tratadas con el fármaco MLN4924 (IC ${ }_{95}$ ) sincronizadas con timidina. Se observa mediante WB las proteínas coinmunoprecipitadas con CDK2 (Ciclina E y Ciclina A) así como el nivel de fosforilación en Y15 de CDK2 en células control (DMSO) y tratadas con el fármaco MLN4924 (IC 95 ), en los tres puntos de tiempo señalados tras la sincronización (9, 12 y 15h). Los números que aparecen debajo de las bandas de WB correspondientes a p-CDK2 (Y15) y Ciclina A son cuantificaciones densiométricas de cada banda de la condición MLN4924, normalizada con respecto a CDK2 total y referida a la banda de su propio control (DMSO) en cada punto de tiempo.

De acuerdo con la hipótesis, la inmunoprecipitación de anti-CDK2 reveló la presencia de Ciclina E en los inmunoprecipitados de las células tratadas con MLN4924 en todos los puntos 
de tiempo ensayados. En las células control (DMSO), Ciclina E ya no se encontró unida a CDK2 en estos puntos de tiempo, como debería de suceder en un ciclo celular normal. De manera inversa, la cantidad de Ciclina A coinmunoprecipitada junto con CDK2 en los dos puntos de tiempo finales (12 y 15h) fue drásticamente inferior en las células tratadas que en las células control. En comparación, a $12 \mathrm{~h}$ la cantidad de Ciclina A coinmunoprecipitada fue un $70 \%$ inferior al control en este punto de tiempo y a $15 \mathrm{~h}$ un $55 \%$ (Figura 48). Estos resultados sugirieron que efectivamente el acúmulo de Ciclina $E$ a altos niveles en células tratadas con altas dosis de MLN4924 desplazó a Ciclina A en la unión con CDK2 en las etapas finales de la fase $\mathrm{S}$. Asumiendo que los complejos CDK2/Ciclina A y CDK2/Ciclina E tengan funciones diferenciales sobre sus sustratos (ver siguiente apartado), y dado que CDK2/Ciclina $A$ es la encargada de impulsar el ciclo celular en la fase $S$ final, esto podría explicar al menos parcialmente el retraso demostrado en la progresión por fase $S$ tardía al tratar las células con altas dosis de MLN4924.

Además, observamos un leve incremento de la fosforilación en el residuo Y15 de CDK2 (inhibidora de la actividad de esta CDK2) en células tratadas con MLN4924, en los últimos puntos de tiempo del ensayo (Figura 48). Este leve incremento, ejercido por WEE1 $1^{325}$, pudo estar también participando en el retraso de la progresión de la fase $\mathrm{S}$ por inactivación de CDK2. No obstante los resultados de inhibición de la expresión de WEE1 mediante shRNAs (Figuras 42 y 44, páginas 117 y 119, respectivamente) mostraron que la influencia del acúmulo de WEE1 por el fármaco MLN4924 en el retraso de la progresión de la fase S fue leve (en la línea RDES) o prácticamente nula (en la línea celular RM82).

4.5.2.1 Efecto fisiológico-molecular del posible desplazamiento de Ciclina A por Ciclina E en la unión a CDK2 a altas dosis del fármaco $\left(\geq \mathrm{IC}_{95}\right)$ MLN4924 en líneas celulares de SE

Existe controversia sobre los sustratos que fosforila CDK2 unida a Ciclina E y a Ciclina A. Se han descrito sustratos que comparten ambos complejos, sin embargo existen otros sustratos que son específicos para uno u otro complejo. Incluso en el caso de sustratos comunes, las fosforilaciones ejercidas por un complejo y otro podrían ser distintas. Un ejemplo bien caracterizado de este último caso es la proteína CDC6. El complejo CDK2/Ciclina E fosforila en S54 y S74 a CDC6, modificación esencial para la entrada en el núcleo, formación y carga del complejo pre-replicativo (pre-RC) en el ADN. Por el contrario, la fosforilación S106 ejercida específicamente por CDK2/Ciclina A desencadena su separación del DNA y su reubicación en el citoplasma. Este mecanismo asegura que la replicación del ADN se lleve a cabo sólo una vez por ciclo celular ${ }^{333-335}$.

Decidimos hacer uso de esta actividad diferencial sobre CDC6 y la diferente localización subcelular de CDC6 en fase S temprana y tardía para corroborar la hipótesis del efecto funcional del desplazamiento de Ciclina A por parte de Ciclina $E$ en los complejos CDK2/Ciclina. Para ello realizamos inmunofluorescencias de CDC6 en las células de SE sincronizadas con timidina y tratadas con el fármaco MLN4924 (IC 95 ), para confirmar si existió alteración en su localización durante la etapa final de la fase $\mathrm{S}$ como consecuencia del acúmulo de Ciclina E y el desplazamiento de Ciclina A por ésta, en su unión a CDK2. Figura 49. 


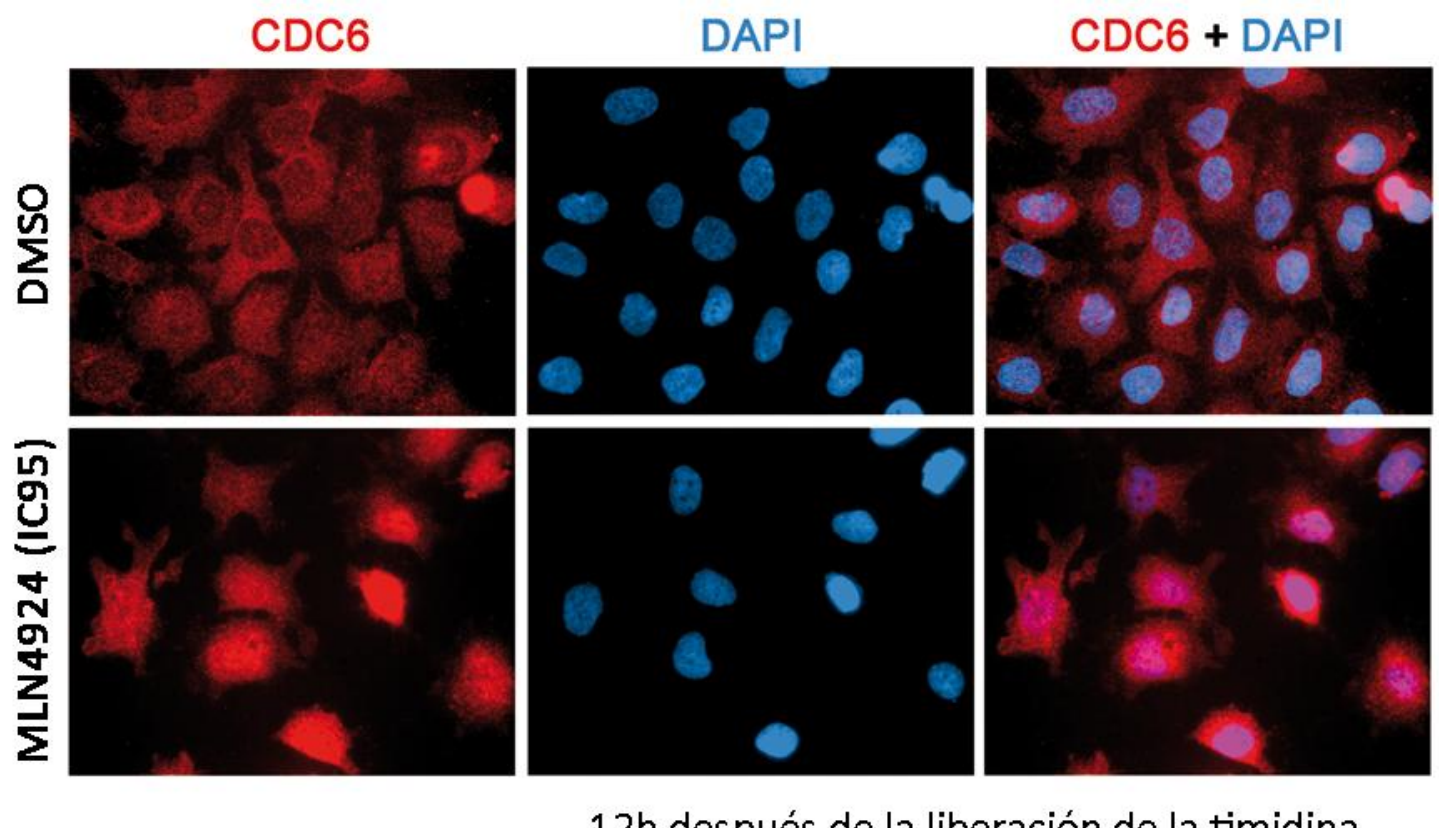

12h después de la liberación de la timidina

Figura 49: Estudio de localización subcelular de CDC6 mediante inmunofluorescencia en células RDES tratadas con MLN4924 ( $\left(\mathrm{C}_{95}\right)$ sincronizadas con timidina, 40x aumentos. Cy3 en rojo, muestra la localización subcelular de CDC6 en células control (DMSO) y tratadas con MLN4924, 12h después de la liberación de la timidina. DAPI en azul, muestra los núcleos de las células. Contrasta el marcaje predominantemente citoplasmático de las células control frente al fuerte marcaje, tanto nuclear como citoplasmático, en las células tratadas con el fármaco.

El ensayo se limitó al punto de tiempo donde se observó la mayor diferencia en los inmunoprecipitados de CDK2 (12h después de la liberación de la timidina). En este punto de tiempo las células control se encontraron en fase $S$ tardía, de tal manera que la fosforilación en S106 ejercida por el complejo CDK2/Ciclina A sobre CDC6 debió haber exportado esta proteína al citoplasma. Así se observó de hecho en las inmunofluorescencias de las células control, en las que se apreció un marcaje de CDC6 predominantemente citoplasmático, distinguiéndose perfectamente la región vacía del núcleo, con escaso o nulo marcaje en todas las células observadas. En contraposición, en las células tratadas con MLN4924 observamos como el marcaje fue tanto nuclear como citoplasmático (siendo de hecho difícil distinguir ambas regiones en la inmunofluorescencia anti-CDC6), Figura 49. Concluimos que CDC6 permaneció en gran parte en el núcleo, probablemente unido al DNA, como consecuencia del predominio de las fosforilaciones en los residuos S54 y S74 de CDC6 ejercidas por los complejos CDK2/Ciclina E aberrantes de la fase $\mathrm{S}$ tardía de las células tratadas con MLN4924, así como por la incompleta fosforilación en el residuo S106 por los escasos complejos CDK2/Ciclina A presentes en esas mismas células.

MLN4924 a altas dosis ( $\geq \mathrm{IC}_{95}$ ) induce un gran incremento de los niveles de Ciclina $\mathrm{E}$ y provoca su presencia en la célula en momentos del ciclo celular en los que debería haber sido degradado, causando a su vez el desplazamiento de Ciclina A en su unión con CDK2. En consecuencia aquellas fosforilaciones específicas de CDK2/Ciclina E que deben darse sólo en la fase $\mathrm{S}$ inicial se mantienen durante toda la fase $\mathrm{S}$. Mientras tanto, los sustratos específicos de CDK2/Ciclina A de fase $S$ tardía se ven reducidos por la falta de formación de este complejo, dando lugar al efecto opuesto respecto a sus fosforilaciones específicas. Sugerimos que esto 
desencadena, al menos en parte, el retraso en la progresión de la fases $\mathrm{S}$ tardía y el acúmulo de células en fase $S$ detectada en los ensayos de citometría de marcaje de DNA con IP, así como la apoptosis que parece derivarse de este retraso. No podemos descartar sin embargo la contribución del resto de elementos hallados desregulados a estas concentraciones de MLN4924 (acúmulo de CDC25A y daño en DNA, principalmente).

\subsubsection{Sobreexpresión de Ciclina E en líneas celulares de SE}

Una vez comprobado que los altos niveles de Ciclina E desplazaron a Ciclina A en su unión con CDK2 y que esto afectó a los sustratos de la CDK, quisimos comprobar si podríamos provocar el retraso en la fase $\mathrm{S}$ exclusivamente con el acúmulo excesivo de Ciclina E. Para ello diseñamos un constructo que portó el cDNA de CCNE1 con un promotor inducible (detalles en el apartado 3.11 de la sección Material y Métodos) de tal manera que pudimos sobreexpresar Ciclina $\mathrm{E}$ de manera controlada. A continuación establecimos clones en la línea celular RDES que incorporaron el sistema inducible evitando la expresión basal (Figura 50, A).

Posteriormente realizamos un ensayo donde comparamos el efecto de sobreexpresar Ciclina $\mathrm{E}$ con la aplicación de alta dosis de MLN4924 (IC $\left.{ }_{95}\right)$. Indujimos diferentes grados de expresión de Ciclina E utilizando distintas concentraciones de doxiciclina (inductor del sistema "Retro-X-TetOn Advanced" utilizado). Figura 50, B $\rightarrow$ panel WB.

Los resultados indicaron que la sobreexpresión exclusiva de Ciclina E produjo un acúmulo en fase S. Si comparamos las células control (DMSO sin doxiciclina) y los distintos niveles de inducción (DMSO más doxiciclina) comprobamos que G2/M se mantuvo constante, mientras que el porcentaje de células en fases $\mathrm{S}$ aumentó y en $\mathrm{G} 1$ disminuyó en las que sobreexpresan Ciclina E (Figura 50, B $\rightarrow$ gráfica de barras). Pese a que los niveles de proteína que conseguimos con las distintas concentraciones de doxiciclina diferían (Figura 50, B $\rightarrow$ panel WB), los porcentajes de las distintas fases de ciclo no variaron significativamente. No obstante, existieron diferencias entre el perfil de ciclo obtenido con la sobreexpresión exógena de Ciclina E y el que provocó la aplicación de alta concentración de MLN4924. La sobreexpresión ectópica de Ciclina E causó acúmulo de células en fase S pero conservó un alto porcentaje en $\mathrm{G1}$, sin embargo los porcentajes de $\mathrm{G} 2 / \mathrm{M}$ no se vieron alterados. En las células tratadas con el fármaco, además del aumento enorme del porcentaje de células en fase $S$ (superior al de todas las condiciones con doxiciclina), también indujo una reducción del porcentaje de células en $\mathrm{G} 1$ y G2/M. Figura 50, B.

Concluimos que el acúmulo excesivo de Ciclina E provocó retraso en la fase $\mathrm{S}$ pero el fenotipo es distinto al que provocó MLN4924 (IC $\left.C_{95}\right)$ ya que no se acumularon otras proteínas que afectan a la progresión del ciclo (WEE1 por ejemplo). Señalamos que los niveles de expresión de Ciclina $E$ obtenidos con el sistema inducible fueron inferiores a los provocados por el fármaco (Figura 50, B $\rightarrow$ WB). 
A Clon Seleccionado
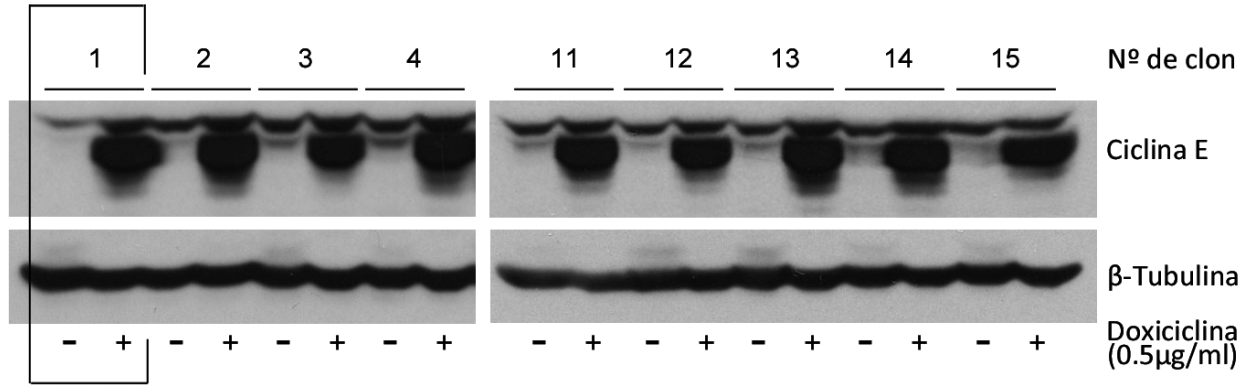

B
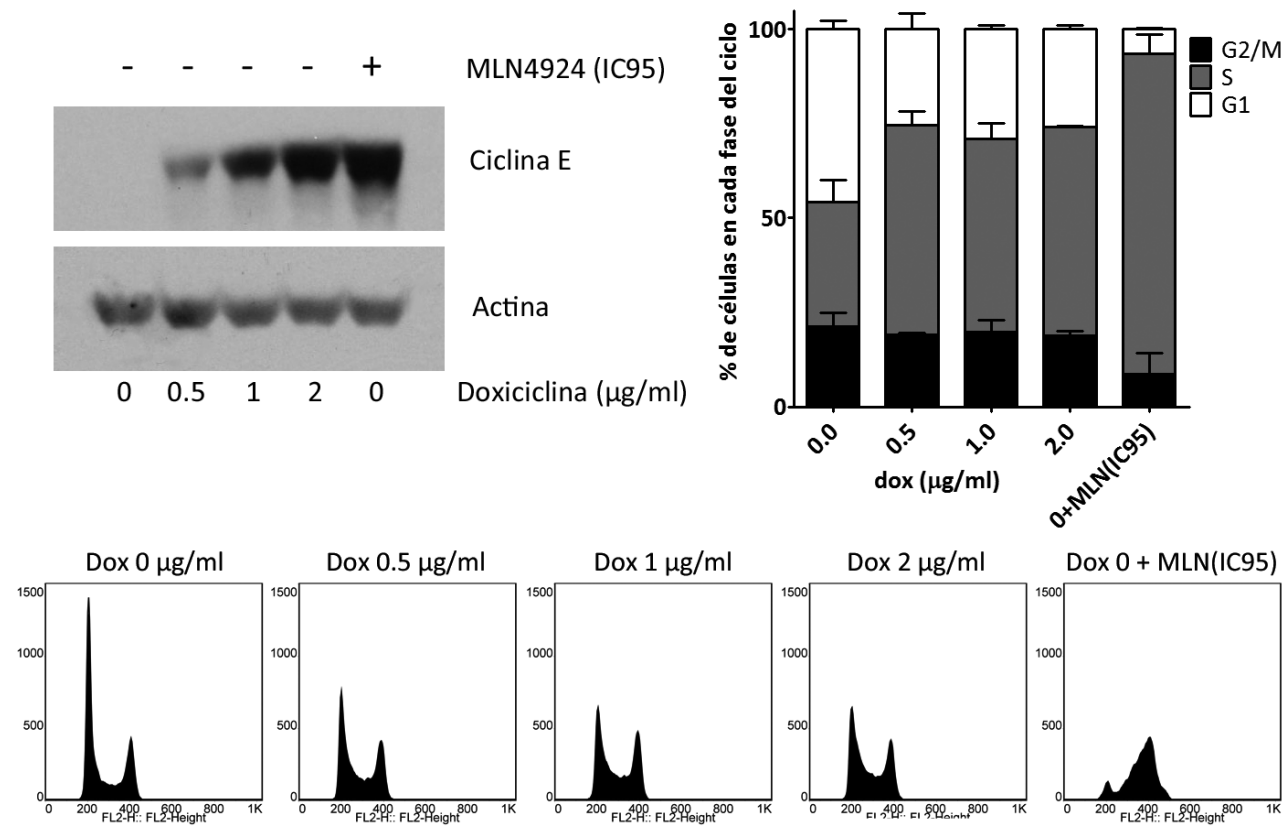

Figura 50: Ensayo de sobreexpresión inducible de Ciclina E en células RDES. A Selección del mejor clon (1) con mínima o nula expresión basal y máximo nivel de inducibilidad. B Comparación entre la sobreexpresión inducible (a diferentes niveles) de Ciclina $\mathrm{E}$ y el efecto que provoca la dosis $I C_{95}$ de MLN4924 en el clon RDES TetOn Ciclina E_1. Arriba izquierda, WB donde se muestran diferentes niveles de Ciclina E por aplicación de distintas concentraciones de doxicilina o acción del fármaco MLN4924. Abajo, perfiles de ciclo mediante marcaje de DNA con ioduro de propidio tras $15 \mathrm{~h}$ de inducción del sistema inducible o aplicación de MLN4924. Arriba derecha, cuantificación del porcentaje de células en cada fase del ciclo.

4.5.2.3 Intento de rescate del retraso en fase S provocado por MLN4924 (IC $\left.{ }_{95}\right)$ mediante la sobreexpresión inducible de Ciclina A

Para demostrar mejor las conclusiones anteriores, nos planteamos la posibilidad de rescatar las células de SE del retraso en fase S tardía provocado por altas dosis de MLN4924, mediante la sobreexpresión de Ciclina A con clones que de nuevo incorporaron el sistema inducible TetON de expresión del gen de interés (Figura 51, A). Tras comprobar que el acúmulo de Ciclina $\mathrm{E}$ afectó a los sustratos de CDK2 en la etapa final de la fase $S$ al desplazar a Ciclina $A$ (al menos en parte de ellos, como por ejemplo en (DC6), decidimos aumentar los niveles de Ciclina A exógenamente de tal manera que pudiera competir en fase $\mathrm{S}$ tardía con Ciclina $\mathrm{E}$ para unirse a CDK2, reestableciendo así el balance normal. Si tal punto se consiguiera, los sustratos específicos de CDK2/Ciclina $\mathrm{E}$ dejarían de estar fosforilados en fase $\mathrm{S}$ tardía y los específicos 
del complejo CDK2/Ciclina A serían entonces fosforilados por la CDK2, permitiendo el avance en la etapa final de fase $S$ a pesar de la presencia de MLN4924 en el medio de cultivo.

Para ello, llevamos a cabo un ensayo de sincronización en la frontera G1/S con timidina (según el protocolo detallado en el apartado 3.7 de la sección Material y Métodos). En el punto de tiempo $0 \mathrm{~h}$ (en el que retiramos la timidina) añadimos medio nuevo con $0.5 \mu \mathrm{g} / \mathrm{ml}$ doxiciclina, para iniciar la expresión inducible de Ciclina A, o sin doxiciclina (control). Figura 51, B.

A

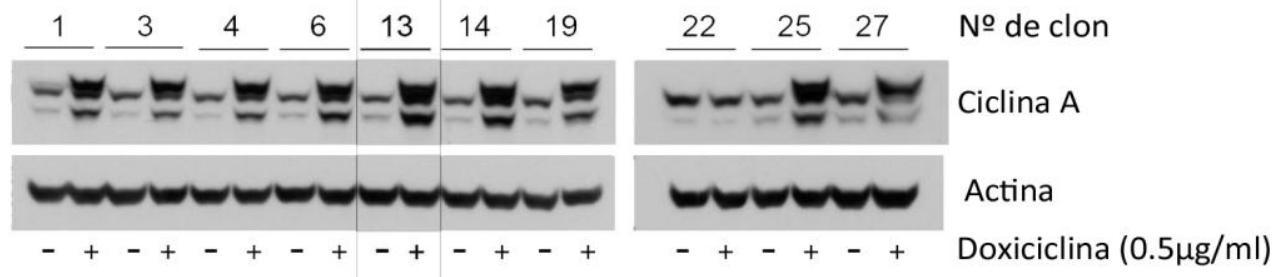

B
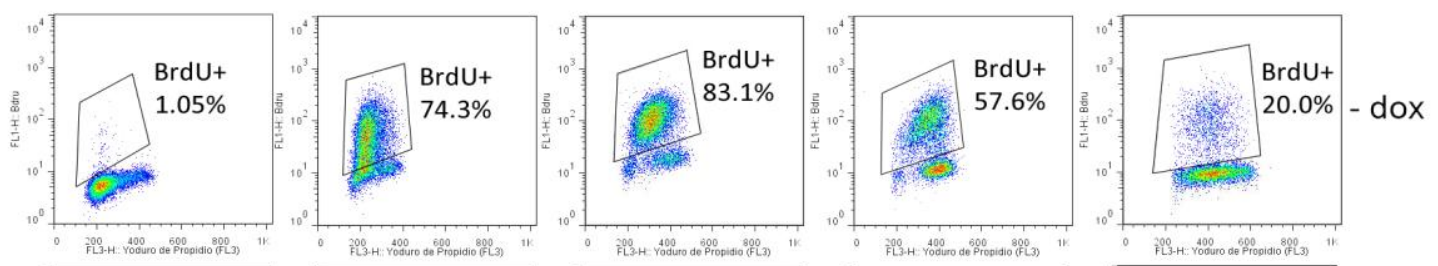

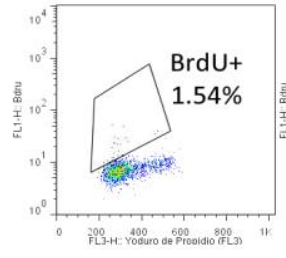

$3 \mathrm{~h}$

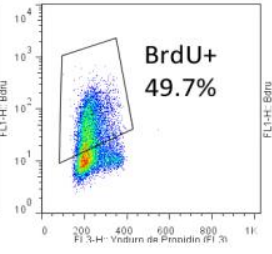

$6 \mathrm{~h}$

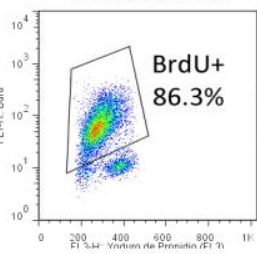

9h

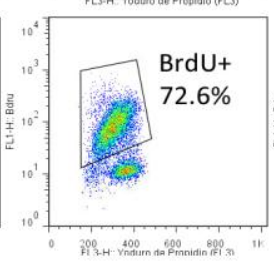

$12 \mathrm{~h}$

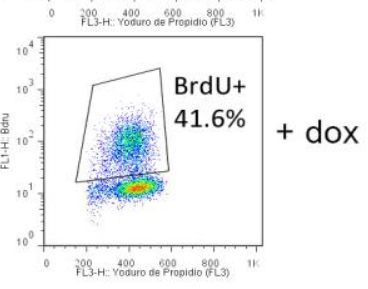

$15 \mathrm{~h}$

Horas después de la liberación de la timidina

Figura 51: Selección y evaluación del sistema de sobreexpresión inducible de Ciclina A en células RDES para revertir el retraso en fase $S$ provocado por el tratamiento MLN4924 (IC 95$)$. A Selección del mejor clon (13) con mínima o nula expresión basal y máximo nivel de inducibilidad. B Ensayo de sincronización con timidina con marcaje de BrdU e inducción (+dox) de sobreexpresión de Ciclina A con el clon RDES TetOn Ciclina A_13. Dotplot mostrando el marcaje de DNA (representado en el eje X) frente al marcaje de BrdU (eje Y). La población celular en replicación activa (BrdU positivas) ha sido recuadrada en todos los puntos de tiempo y el tamaño porcentual de dicha población se representa junto a los recuadros. Se detallan los puntos de tiempo del ensayo tras la liberación de la timidina. Se aprecia en el punto de tiempo $6 \mathrm{~h}$ un retraso en la progresión de la etapa inicial de fase $\mathrm{S}$ en las células con el sistema inducible activo por la aplicación de $0.5 \mu \mathrm{g} / \mathrm{ml}$ de doxiciclina en el medio.

Comprobamos como la sobreexpresión de Ciclina A (+dox) provocó de por sí (en ausencia de MLN4924) retardo en la progresión de la fase $S$, imposibilitando ninguna conclusión ulterior respecto a su combinación con el fármaco MLN4924. Cabe resaltar sin embargo que, en agudo contraste con lo que provocan dosis altas del fármaco MLN4924, el retraso causado por la sobreexpresión ectópica de Ciclina A se produjo en la etapa inicial de la fase S: a $6 \mathrm{~h}$ tras la liberación de timidina, el control sin inducción (-dox) presentó el $74.3 \%$ de las células BrdU positivas, mientras que en las células donde se indujo la sobreexpresión de Ciclina A el porcentaje se redujo al $49.7 \%$. A partir de ese momento se mantuvo ese lapso de retraso hasta el último punto de tiempo (15h). Por lo tanto pareció que el retardo se produjo exclusivamente en la etapa inicial de la fase S. Figura 51, B. 
Debido a este resultado no pudo concretarse el rescate del fármaco pues Ciclina A provoca un efecto análogo al que produce MLN4924 $\left(\geq I_{95}\right)$ con el acúmulo de Ciclina E (retraso en la etapa final de la fase $S$ ), pero de signo contrario (en la etapa inicial de esta misma fase). Sin embargo, este resultado sirvió para sustentar la idea de que presencia "a destiempo" de cualquiera de las ciclinas activadoras de CDK2 distorsiona el avance normal en fase $\mathrm{S}$. 


\section{DISCUSIÓN}




\subsection{LAS LÍNEAS CELULARES DE SE SON ALTAMENTE SENSIBLES AL FÁRMACO MLN4924}

En esta tesis presentamos una evaluación preclínica en profundidad del fármaco MLN4924 en SE. Nuestros resultados demuestran que existe una alta sensibilidad de las líneas celulares de esta entidad tumoral a la inhibición de los complejos Cullin RING-Ligasa consecuencia de la inactivación de la Enzima Activadora de NEDD8 (NAE) ejercida por MLN4924.

La mediana de la $\mathrm{IC}_{50}$, en torno a $81 \mathrm{nM}$, indica que el SE es una neoplasia muy sensible a MLN4924. En 2011, un estudio realizado en líneas celulares de diferentes neoplasias pediátricas (SE, Rabdomiosarcoma, Neuroblastoma, Wilms, leucemia linfoblástica...) donde se incluyó el cálculo de $\mathrm{IC}_{50}$ in vitro aplicando durante $96 \mathrm{~h}$ el tratamiento e in vivo mediante modelos con xenoinjertos, situó a las líneas celulares de SE como las más sensibles de todas las analizadas. En este estudio la mediana de $\mathrm{IC}_{50}$ de todas las líneas celulares se situó en $143 \mathrm{nM}$ y la de las líneas de SE que recogió el ensayo en $31 \mathrm{nM}^{283}$. La diferencia entre la mediana de $\mathrm{IC}_{50}$ de nuestros resultados y la de este estudio se debió a que se utilizaron diferentes líneas celulares: CHLA-9, CHLA-10, CHLA-258 y TC-71 en su caso, y las líneas celulares descritas en la Tabla 13 (página 89 de la sección Resultados), en el nuestro.

Al margen de esta publicación, se han realizado otros estudios preclínicos con MLN4924 que sitúan a las líneas de SE dentro del grupo de tumores más sensibles a este fármaco. Las líneas celulares de diferentes neoplasias como melanoma $\left(\mathrm{IC}_{25}=250 \mathrm{nM}\right)^{276}$, leucemia mieloide aguda (mediana de $\left.\mathrm{IC}_{50}=211 \mathrm{nM}\right)^{284}$, carcinoma de páncreas $\left(\mathrm{IC}_{50} \text { de dos líneas=35nM y } 117 \mathrm{nM}\right)^{285}$, cáncer de ovario (rango de $\mathrm{IC}_{50}: 0.01-10 \mu \mathrm{M}$ ) ${ }^{275}$, carcinoma escamoso de cabeza y cuello (rango de $\left.\mathrm{IC}_{50}: 50-600 \mathrm{nM}\right)^{286}$, muestran medianas superiores a las obtenidas en nuestro estudio. Dentro de las consideradas como más sensibles se sitúan las líneas celulares de linfoma difuso de células grandes $\mathrm{B}$ (mediana de $\left.\mathrm{IC}_{50}=55.45 \mathrm{nM}\right)^{282}$ y la línea $\mathrm{H} 1299$ de cáncer de pulmón $\left(\mathrm{IC}_{50}=22 \mathrm{nM}\right)^{277}$. Tabla 15.

Por tanto, teniendo en cuenta los resultados de estudios preclínicos en líneas celulares de las neoplasias ya estudiadas y comparándolas con el estudio preclínico del fármaco MLN4924 en líneas celulares de SE que aquí se detalla, podemos concluir que éstas últimas son muy sensibles al fármaco, lo que nos permite proponer este fármaco como una posible alternativa terapéutica en pacientes de SE.

\subsection{AUSENCIA DE DIFERENCIA DE RESPUESTA A MLN4924 ENTRE LíNEAS CELULARES DE SE CON 1qG Y 1qN}

Como ya se ha comentado previamente, el trabajo aquí presentado se plantea tras la obtención de resultados de un estudio europeo multicéntrico realizado en busca de alteraciones secundarias con valor pronóstico en $\mathrm{SE}^{71}$. Este estudio, que fue liderado $y$ coordinado por nuestro grupo, halló una dramática diferencia de supervivencia entre aquellos pacientes con tumores con $1 \mathrm{qN}$, respecto a los que tenían $1 q \mathrm{qG}$ (éstos con una supervivencia mucho más corta), en el estudio retrospectivo de 67 tumores de SE. Además, se definió la firma 1qGSig, como una lista de 74 genes que correlacionó con peor pronóstico. Dentro de esta lista destacó $C D T 2$, un gen cuya sobreexpresión (niveles 5 veces superiores en los tumores $1 \mathrm{qG})$ correlacionó con peor supervivencia de los pacientes con tumores $1 \mathrm{qG}^{71}$. Como se ha 
explicado ampliamente en Introducción, CDT2 es una proteína que forma parte de complejos E3 ubiquitin ligasa del tipo CRL que ubiquitinan proteínas para su degradación.

Los resultados de este estudio nos indujeron a pensar que aquellos tumores con 1qG, definidos por la sobreexpresión de CDT2 y con mayor capacidad proliferativa ${ }^{71}$ (de nuevo resultados del trabajo previo de nuestro laboratorio), presentarían una respuesta diferencial al tratamiento con MLN4924, siendo más sensibles, puesto que MLN4924 inhibe los complejos $\mathrm{CRL}$, grupo al que pertenece el complejo CRL particular en el que CDT2 actúa como receptor de sustrato (CUL4/DDB1/CDT2). Pensamos por tanto que MLN4924 sería un tratamiento específico y con alta probabilidad de éxito en pacientes con tumores 1qG. No obstante, los resultados obtenidos en estudios de proliferación y cálculo de $\mathrm{IC}_{50}$ concluyeron que no existían diferencias frente a MLN4924 entre las líneas celulares de SE 1qG y 1qN (Figura 18, página 90). Apoyando aún más esta conclusión, se constató también que no existía diferencia en el modo en que las células respondían al fármaco, en cuanto a los dos parámetros principales aquí medidos: perfil de ciclo celular y apoptosis. Tanto las líneas $1 \mathrm{qG}$ como las $1 \mathrm{qN}$ sufrían un retraso en la transición $\mathrm{G} 2 / \mathrm{M}$ a concentraciones $\leq \mathrm{IC}_{75}$ y un retraso en fase $\mathrm{S}$ tardía a concentraciones $\geq \mathrm{IC}_{95}$ (Figura 25, página 98). Ambos grupos presentaron además apoptosis sólo a las concentraciones más altas del fármaco MLN4924. Esta homogeneidad de respuesta y sensibilidad descartó cualquier tipo de tratamiento diferencial de los tumores de SE 1qG con respecto a la inhibición de los complejos CRL.

Esta falta de diferencias en la respuesta al MLN4924 entre las células de SE 1qN y 1qG es explicable: el fármaco no sólo inhibe la función del complejo CUL4/DDB1/CDT2 si no de todos los complejos CRL de la célula. Cuando buscamos un fármaco disponible que fuera capaz de tener un efecto similar al silenciamiento de CDT2, que conllevó la casi completa supresión del desarrollo tumoral in vivo en xenografts en ratón (Figura 52), MLN4924 fue el fármaco elegido pues era el que con mayor especificidad inhibiría al complejo CUL4/DDB1/CDT2 ${ }^{71}$.

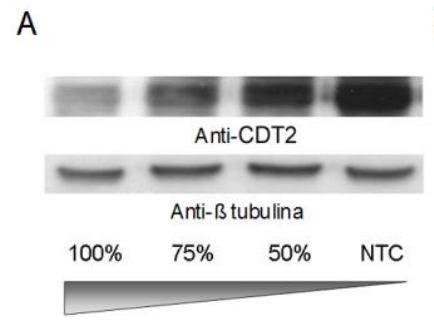

C
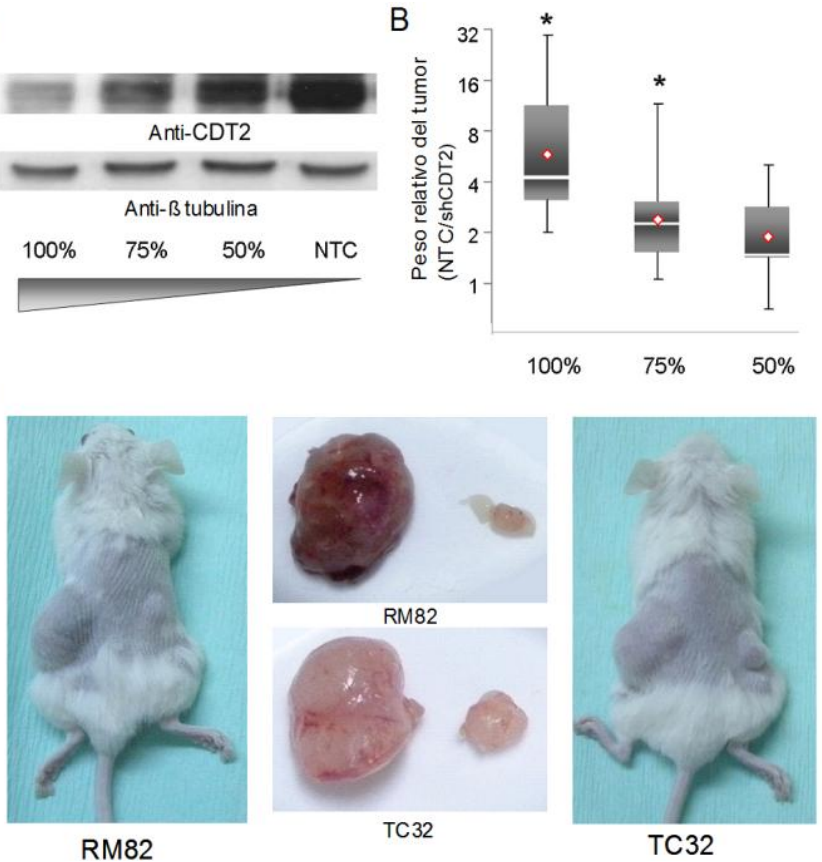

Figura 52: Resultados del ensayo in vivo de silenciamiento de CDT2 en líneas celulares de SE inoculadas a ratones inmunodeprimidos NOD/SCID, que confirma el efecto inhibidor de la proliferación. A WB del silenciamiento 
progresivo de CDT2 en RM82 obtenido mediante la aplicación de diferentes diluciones del sobrenadante viral. B "Boxplot" representando el tamaño tumoral relativo de los tumores. Los valores representados están logaritmizados (log2 ratio) pero la escala del eje $Y$ está expresada en valores naturales. Los asteriscos reflejan el resultado del t-test para una muestra $\left(\mathrm{H}_{0}=0\right)$ de cada condición de silenciamiento. C Imágenes correspondientes a los tumores de dos animales de la condición de mayor silenciamiento ( $100 \%$ de sobrenadante viral). En cada caso el tumor de la izquierda o flanco izquierdo corresponde al control NTC y el de la derecha o flanco derecho al del tumor silenciado (shRNA: sh280+sh2495). Adaptado de Mackintosh, C., Ordonez, J L., Garcia-Dominguez, D J., et al. (2012) 1q gain and CDT2 overexpression underlie an aggressive and highly proliferative form of Ewing sarcoma. Oncogene 31, $1287-1298^{71}$.

Otros fármacos como Bortezomib lo harían de una forma aún menos específica (Bortezomib interfiere con todo el "turnover" proteico mientras que MLN4924 sólo lo hace sobre un 10$20 \%$ al inhibir sólo a una subfamilia de ubiquitin ligasas, las CRL) ${ }^{272}$. Sin embargo, desde un principio fuimos conscientes de que el fármaco MLN4924 distaría de tener el mismo efecto que un shRNA contra CDT2, puesto que inhibe toda la maquinaria CRL (compuesta de decenas, si no centenas, de ensamblajes distintos de sus elementos ${ }^{270}$ ) en lugar de ser un inhibidor específico de CUL4/DDB1/CDT2. De todos modos, aunque el efecto del silenciamiento de CDT2 no pueda ser recapitulado químicamente (quizá los "Antisense Oligos" o $\mathrm{ASO}^{336}$, de gran proyección terapéutica y en varios ensayos clínicos actualmente, puedan ser la mejor alternativa para esto), consideramos que los resultados de sensibilidad de las líneas celulares de SE al MLN4924 eran suficiente motivo para ahondar más en la posible aplicación de MLN4924 a esta enfermedad. De hecho, una de las ventajas de este resultado negativo (ausencia de diferencia de sensibilidad entre células de SE $1 q N$ y $1 q G$ ) es que en potencia todos los pacientes de SE podrían beneficiarse de este fármaco, no sólo los que presenten tumores $1 \mathrm{qG}$.

\subsection{SENSIBILIDAD AL FÁRMACO MLN4924 DE LAS CÉLULAS DE SE IN VIVO, MEDIANTE EL EMPLEO DE XENOTRANSPLANTES EN RATONES CB17/SCID}

Para el ensayo in vivo, se emplearon ratones CB17/SCID y se comprobó como el fármaco MLN4924 influía sobre el crecimiento del tumor en desarrollo. MLN4924, in vivo, tiene un papel dosis-dependiente de tal manera que actúa a determinadas concentraciones deteniendo el crecimiento del tumor y a concentraciones mayores reduciéndolo. La variante de respuesta depende de cada línea celular y parece guardar relación con la IC $\mathrm{I}_{50}$. El modo de respuesta (mantenimiento o reducción del tamaño tumoral) está determinado por el nivel de sensibilidad de las líneas celulares al fármaco y conserva analogía con las diferencias de respuesta entre líneas celulares in vitro e in vivo. Ello queda de manifiesto cuando comparamos los resultados obtenidos con las líneas celulares de SE, RDES y RM82 $\left(\mathrm{IC}_{50}=\right.$ $36.8 \pm 14.48$ y $73.99 \pm 17.79 \mathrm{nM}$ respectivamente) sometidas a 30 y $60 \mathrm{mg} / \mathrm{kg}$ ratón de MLN4924 en el estudio in vivo. El resultado de la acción del fármaco a $30 \mathrm{mg} / \mathrm{kg}$ MLN4924 en la línea celular RDES fue detención del crecimiento mientras que en RM82 continuó el desarrollo tumoral. A $60 \mathrm{mg} / \mathrm{kg}$ en RDES, MLN4924 redujo en crecimiento y en RM82 se aproximó a detenerlo. Finalmente en un segundo ensayo in vivo a $90 \mathrm{mg} / \mathrm{kg}$ en RM82, los tumores disminuyeron de tamaño (Figuras 20 y 22, páginas 93 y 94, respectivamente). Sugerimos que la concentración a la que los tumores desarrollados a partir de líneas celulares de SE responden a MLN4924 guarda relación con los datos obtenidos en el ensayo de cálculos de IC $\mathrm{C}_{50}$. 


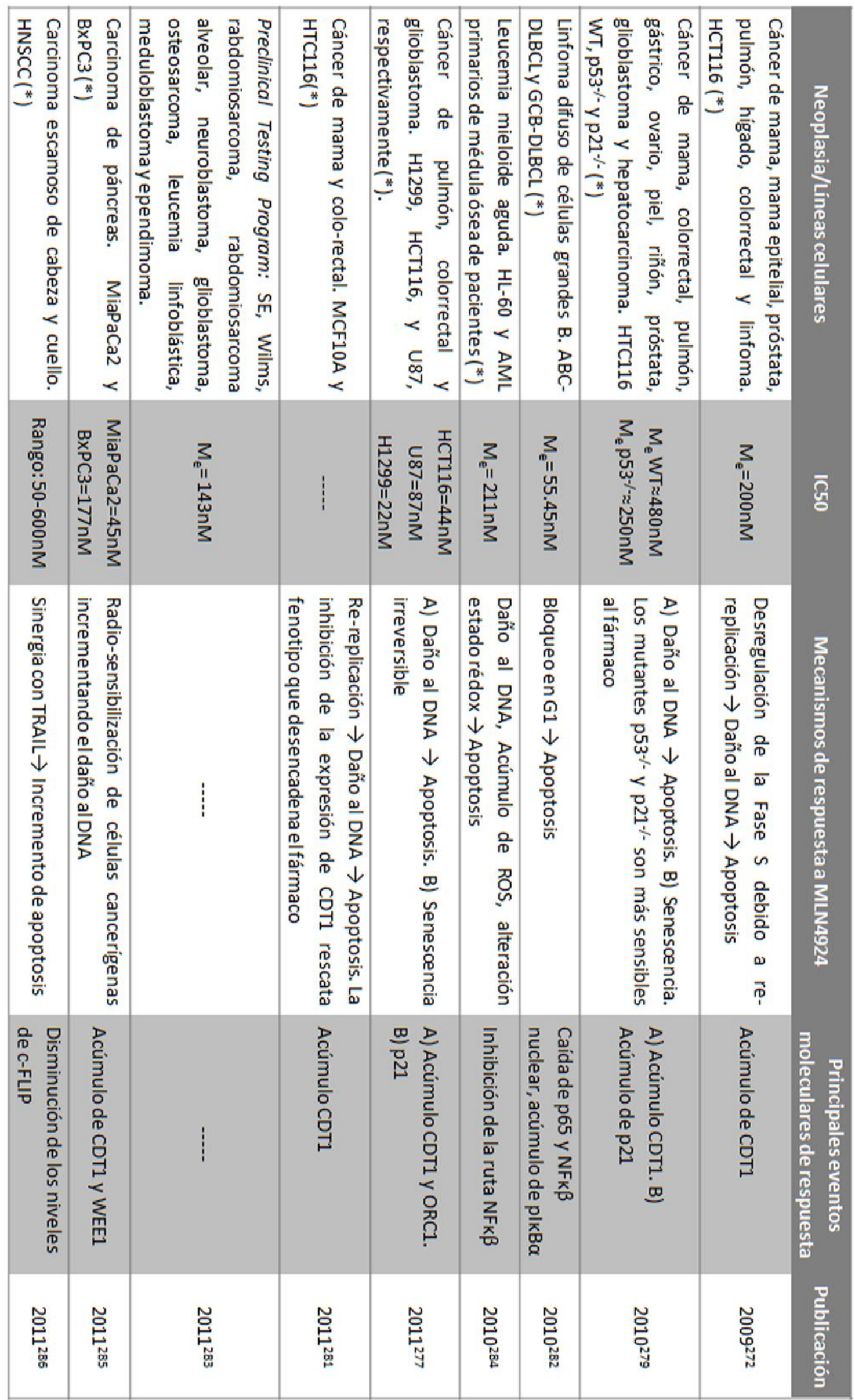




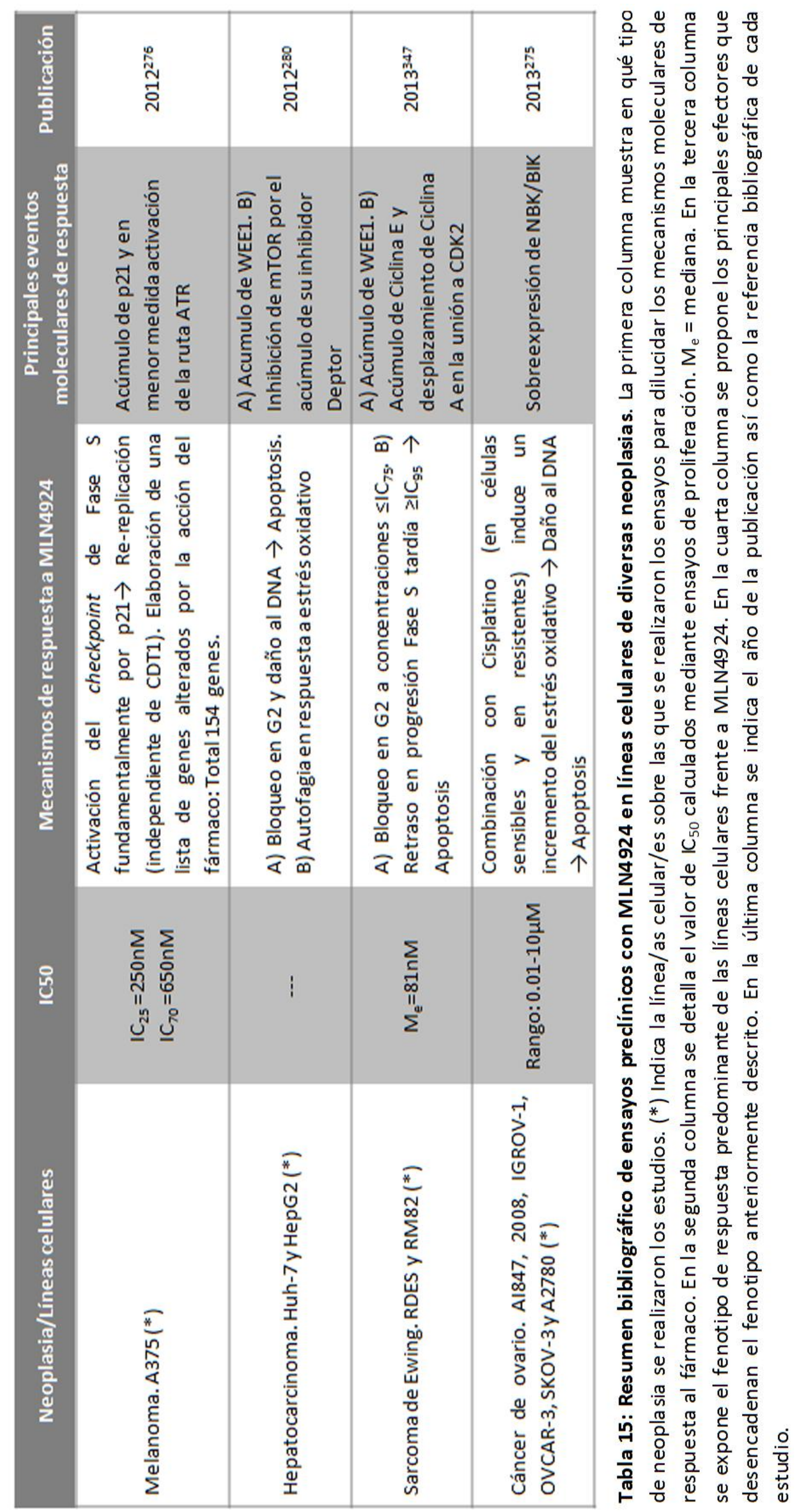


Sorprendentemente, en la publicación donde se hizo un cribado preclínico de líneas de neoplasias pediátricas y se puntualizó que las líneas celulares de SE eran las más sensibles a MLN4924, se describió que en los ensayos in vivo no se produjo una reducción significativa del tumor en ratones tratados ${ }^{283}$. La aplicación del fármaco fue bidiaria durante 5 días y dos de descanso (al igual que en nuestro ensayo) pero administraron a todos los tipos celulares una única concentración de fármaco, $100 \mathrm{mg} / \mathrm{kg}$-ratón. En el artículo señalan que tenían proyectado prolongar el ensayo durante 6 semanas pero debido al endurecimiento de la piel en la zona de inyección se redujo a tres semanas. En los resultados muestran que la progresión tumoral se detiene e incluso disminuye en etapas iniciales del ensayo y posteriormente los tumores reanudan su crecimiento de manera casi exponencial (pendiente de la curva similar a la del control $)^{283}$. Probablemente lo que ocurrió es que el daño en la piel dificultó la absorción del fármaco. A $100 \mathrm{mg} / \mathrm{kg}$, el fármaco durante los primeros días dañó la piel de los ratones tratados con MLN4924 y su alteración impidió la administración en los sucesivos días. En nuestros ensayos, variamos el flanco en la administración bidiaria, y además distribuimos el pinchazo por toda el área del flanco (evitando inyectar directamente la masa tumoral) de tal manera que redujimos al máximo el daño en la piel. Además, las concentraciones que aplicamos eran inferiores a las de su ensayo, lo que provocó un nivel menor de alteración del estado de la piel; nosotros observamos que el grado de alteración correlacionó con la concentración del fármaco (una mayor concentración provoca mayor daño). Todo lo anterior podría explicar por qué sus resultados in vivo fueron negativos pese a utilizar mayor concentración del fármaco. Nuestros ensayos, así como otros llevados a cabo por otros grupos detallados en la bibliografía expuesta en la Tabla 15, dieron resultados más que satisfactorios.

Los resultados positivos de un determinado fármaco en ensayos in vivo suponen un avance en el estudio preclínico del fármaco porque muestran la potencialidad del fármaco frente a un tumor que se está desarrollando en un nicho biológico (ratón), donde debe superar una serie de obstáculos para hacer efecto en la masa tumoral. Además se ponen de manifiesto efectos secundarios adversos (tóxicos) de la aplicación del fármaco en un organismo. Todo ello será tenido en cuenta a la hora de concluir el estudio preclínico y proponer un futuro ensayo clínico en humanos.

\subsection{MLN4924 PROVOCA ALTERACIÓN DUAL DOSIS-DEPENDIENTE DE LA PROGRESIÓN DEL CICLO CELULAR}

Tras comprobar la alta sensibilidad de las líneas celulares de SE al fármaco MLN4924 en ensayos in vitro e in vivo decidimos profundizar en su efecto sobre la progresión del ciclo celular. Nuestros resultados describieron distintas alteraciones de la progresión del ciclo celular dependiendo de la concentración de fármaco empleado. A concentraciones menores o iguales a la IC $\mathrm{IC}_{75}$ específica para cada línea celular de $\mathrm{SE}$ analizada se produjo un retraso en $\mathrm{G} 2$ que impedía la progresión hacia la fase de mitosis. Sin embargo el tratamiento con concentraciones superiores o iguales a la de $\mathrm{IC}_{95}$ específica de cada línea, provocó un retraso en la progresión de la fase $S$ en su etapa final. Ambas respuestas se reprodujeron en todas las líneas de SE que se estudiaron: RDES, RM82, STA-ET1, TC32, TC71, A673, WE68, TTC466, A4573 y SKNMC. Como se ha indicado anteriormente la variación del ciclo producida por MLN4924 fue independiente de la dosis génica o número de copia del brazo q del cromosoma 1 (1qN o $1 q G)$. 
La respuesta común de las líneas celulares de SE frente al fármaco MLN4924 difiere de la respuesta de líneas celulares de otras neoplasias. Se ha descrito como el fármaco provoca el bloqueo en $\mathrm{G} 1$ en líneas celulares de linfoma difuso de células grandes $\mathrm{B}^{282}$, en la transición G1/S en colorrectal ${ }^{281}$ o únicamente en la fase $S$ (como se detallará en profundidad en el apartado 5.7 de esta sección). Debemos señalar que en nuestro estudio se evaluó un amplio rango de concentraciones de fármaco, lo cual nos permitió establecer patrones de respuesta diferentes según la concentración de fármaco empleado. En la mayoría de los trabajos publicados, principalmente en aquellos que intentan profundizar en el mecanismo molecular de respuesta que desencadena el fármaco, las dosis empleadas son las que consideramos altas, es decir, muy superiores a la $\mathrm{IC}_{50}$ específicas de cada línea celular. No obstante ello no explica la diferencia entre los resultados de altas dosis $\left(\geq \mid C_{95}\right)$ de nuestro trabajo (con el retraso en fase $S$ tardía) y los del resto de neoplasias como se indica en la Tabla 15 . Todo ello se abordará en profundidad en el apartado 5.7). Otra modificación de la progresión normal del ciclo celular es la senescencia. La senescencia es un proceso iniciado como respuesta al estrés y/o daño ocurrido en una célula y que constituye una alternativa a la apoptosis. Se ha descrito que MLN4924 (generalmente a bajas-medias concentraciones) a través del acúmulo de p21, provoca senescencia en distintos tipos de células cancerígenas (melanoma, glioblastoma, colorrectal, pulmón) ${ }^{276-277,279}$. Nuestros resultados evidenciaron que a concentraciones bajasmedias de MLN4924 no se produce un incremento destacable de células en senescencia (Figura 29, página 101). P21 se acumula fundamentalmente a altas concentraciones del fármaco (Figura 31, página 104) probablemente participando en rutas de respuesta al daño en DNA.

Tampoco indujo senescencia el acúmulo a altos niveles de p27 detectado con cualquier concentración aplicada del fármaco (Figura 31, página 104). Se ha descrito como la sobreexpresión de p27 induce senescencia ${ }^{337-338}$. Nuestros ensayos demostraron que p27 se acumuló a altos niveles como consecuencia de la acción de MLN4924. El hecho de que no se desencadenara el proceso de senescencia nos indica (junto al ensayo de silenciamiento de p27 en el intento rescate del retraso en G2, descrito más adelante) que el p27 acumulado debe ser en una forma inactiva.

\subsection{MLN4924 INDUCE APOPTOSIS DOSIS-DEPENDIENTE EN LÍNEAS CELULARES DE SE}

MLN4924 actuó fundamentalmente como citostático a dosis menores o igual a la $I C_{75}$ específica de cada línea celular de SE como consecuencia del retraso en G2. El porcentaje de células apoptóticas (definida en nuestros ensayos como Caspasa 3 procesada positivas) supuso una media del $8.29 \%$ y no alcanzó diferencia significativa con el control (DMSO). A dosis igual o superior a $I C_{95}$ ejerció como citotóxico y aumentó el porcentaje de células Caspasa 3 precesada positivas al $26.83 \%$ alcanzando diferencia significativa los niveles de apoptosis del control y de $I C_{75}$. Además se comprobó que las células que entraron en apoptosis se concentraron en la etapa de fase $S$, concretamente en la etapa tardía de éste periodo (Figuras 26 y 27, páginas 98 y 99 , respectivamente).

Probablemente el incremento de apoptosis se debió a que las altas dosis de MLN4924 provocaron daño en el DNA, lo que conduce al retraso en la progresión de la fase $\mathrm{S}$. Demostramos que el acúmulo de daño en el DNA correlacionó con el aumento de las 
concentraciones aplicadas del fármaco y con el mecanismo de respuesta. Mediante marcaje con $\mathrm{y}$-H2AX comprobamos que en las células control (DMSO) no hubo positividad, en concentraciones hasta $\mathrm{IC}_{75}$ hubo pequeños focos aislados en el núcleo, y a concentraciones altas del fármaco $\left(\geq I C_{95}\right)$ el marcaje fue intenso y se extendió por todo el núcleo de las células (Figura 27, página 99). Sugerimos, por tanto, que la apoptosis detectada a altas dosis del fármaco probablemente se debió a daño en el DNA y, como consecuencia o como causa, se dio el retraso en fase $\mathrm{S}$. No obstante, el retraso en fase $\mathrm{S}$ se debió posiblemente a diversos factores, como el mecanismo propuesto de competición de Ciclina E y A por la unión a CDK2, con el desplazamiento de la segunda causado por la acumulación de la primera.

Quedarían por dilucidar los mecanismos moleculares que desencadenan el daño en el DNA, siendo probablemente diferentes variables las que lo desencadenan. En otros estudios con el fármaco MLN4924 sobre líneas celulares de diferentes neoplasias también se detectó daño en el DNA y alteración de la fase S. En células HCT116 (cáncer colorrectal) el motivo del daño y posterior apoptosis era el acúmulo de CDT1 que conducía a re-replicación ${ }^{272,281}$ (Figura 53).
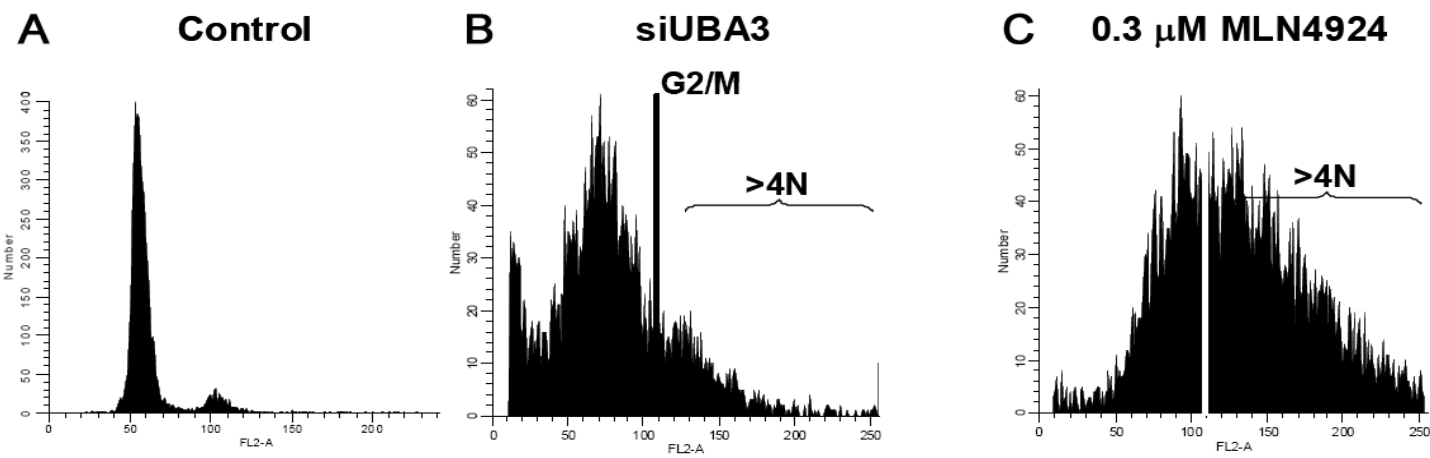

Figura 53: Perfiles de citometría de flujo con marcaje de DNA mediante IP en células HCT116 tratadas con UBA3 siRNA o con $0.3 \mu \mathrm{M}$ de MLN4924. A Control del ensayo donde se muestra el perfil de ciclo habitual de las células HCT116. B Perfil de ciclo de células HCT116 trasfectadas con siRNA (5'-CUGCCUGGAAUGACUGCUUAA-3') contra UBA3, núcleo catalítico de NAE, durante $72 \mathrm{~h}$. C Perfil de ciclo de las células HCT116 tratadas con $0.33 \mu \mathrm{M}$ de MLN4924. Se aprecia el contenido de DNA superior al $4 \mathrm{n}$ fruto del proceso de re-replicación desencadenado por la inhibición de NAE. Adaptado de Soucy, T.A., et al (2009) An inhibitor of NEDD8-activating enzyme as a new approach to treat cancer. Nature 458, 732-736 ${ }^{272}$.

La re-replicación se distingue por el marcaje de carga de DNA superior a 4n (Figura 53) debido a que se disparan nuevos procesos de replicación sin que haya existido citocinesis o división celular, lo que provoca una carga superior a $4 \mathrm{n}$. Este fenómeno es un conocido inductor de apoptosis $^{272,281}$. Nuestros ensayos, a través de estudios de marcaje de DNA con IP descartaron niveles destacables cargas de DNA superiores a 4n. Ello, junto al escaso acúmulo de CDT1 solo apreciable a concentraciones $\geq I_{95}$ (Figura 30, página 102), nos permitió considerar que el fármaco en las líneas de SE no inducía re-replicación. Consecuentemente el daño producido en el DNA detectado a altas concentraciones no era consecuencia directa del mencionado fenómeno, en contra posición de lo que ocurre con la línea celular HCT116.

Otro motivo de daño en el DNA producido por MLN4924 fue el descrito en células de leucemia mieloide aguda. En ellas el acumulo de ROS y la alteración del estado rédox como consecuencia de la alteración de la ruta de NFk $\beta$ provocaba el daño ${ }^{284}$. En líneas celulares de cáncer de ovario el daño al DNA también lo provocaba el estrés oxidativo debido a la 
sobreexpresión de NBK/BIK ${ }^{275}$. En la línea HepG2 de hepatocarcinoma, fue la inhibición de mTOR por el acúmulo de la proteína Deptor lo que provocaba daño al DNA e inducía la autofagia $^{280}$.

En las células de SE podrían estar sucediendo mecanismos similares (que no fueron comprobados). Sin embargo, la observación en la línea celular RDES de la aparición específica de las células apoptóticas en fase $S$ (Figura 27, página 99) y la presencia de apoptosis masiva tan sólo ante concentraciones altas de MLN4924 (que inducen retraso en fase S), nos parecen evidencias suficientemente significativas para buscar una causa común para ambos fenómenos. Por tanto, estos resultados nos llevan a pensar que el daño en DNA podría ser inducido por la multitud de alteraciones detectadas en los elementos fundamentales reguladores del ciclo celular durante la progresión de la fase $S$ que tienen como efecto final causar un retraso en esta fase. En concreto, destacamos el desplazamiento de Ciclina A en la unión con CDK2 en la etapa final de la fase $\mathrm{S}$ como consecuencia del acúmulo de Ciclina $\mathrm{E}$ inducido por MLN4924. Esto provocaría la fosforilación ectópica de sustratos específicos del complejo CDK2/Ciclina $\mathrm{E}$ en fase $\mathrm{S}$ tardía, y consecuentemente, la disminución de fosforilación de sustratos específicos de complejos CDK2/Ciclina A (Figura 48, página 124). Esto podría conllevar un déficit de activación de los elementos finalizadores de la etapa de síntesis del DNA y ello podría quizá generar daño en DNA por mecanismos que desconocemos. Tampoco podemos descartar la relevancia en este mecanismo de otros factores como la acumulación de CDC25A, aunque los datos recogidos parecen apuntar a una falta de funcionalidad del CDC25A acumulado en respuesta a MLN4924, como se discute más adelante.

\subsection{DIANAS DEL FÁRMACO MLN4924 EN LÍNEAS CELULARES DE SE}

Un paso fundamental para la comprensión de la acción de un fármaco sobre líneas celulares es localizar las dianas moleculares afectadas por el mismo. Ello nos permitirá posteriormente dilucidar el mecanismo global de respuesta. MLN4924 es un compuesto que actúa inhibiendo UBA3 del complejo NAE, lo que se traduce en la interrupción de la nedilación de las proteínas culinas que forman parte de los complejos E3 ligasas, CRL (Cullin RING-Ligasas). De esta forma, impide la ubiquitinación de aquellas proteínas que fisiológicamente son marcadas por estos complejos para su degradación en el proteosoma, lo que finalmente se traduce en su acumulación. Comprobamos que efectivamente el fármaco inhibió la nedilación de las principales culinas (CUL1, CUL4A y CUL4B) y que CDT1 no se acumuló a altos niveles a diferencia de lo que ocurrió en la línea celular HCT116 (Figura 30, página 102). En las células de $\mathrm{SE}$ solo se apreció un ligero incremento del nivel de CDT1 a I $\mathrm{C}_{95}$.

Tras concluir que el efecto del fármaco sobre líneas celulares de SE no se debió al acúmulo de CDT1 y el proceso de re-replicación (principal mecanismo de respuesta al fármaco MLN4924 descrito al inicio de nuestro estudio ${ }^{272}$ ), decidimos iniciar la búsqueda de sustratos de complejos CRL que se acumulasen por la acción de MLN4924 en las células de SE, con el objetivo final dilucidar el mecanismo de respuesta al fármaco de esta neoplasia.

Nuestro objetivo fue determinar cuáles de éstas proteínas reguladas por CRL, y que además participan en la regulación del ciclo celular o en mecanismos de respuesta a daño en el DNA, fueron alteradas por la acción directa del fármaco. Consideramos dianas directas a aquellas que en un periodo máximo de 4horas se encontraron afectadas, acumuladas, por la acción de 
MLN4924, asumiendo que en tan corto periodo de tiempo fue improbable que los cambios en la transcripción causaran cualquier cambio proteico detectado. Señalamos que con dianas directas, no estamos diciendo que el fármaco MLN4924 actúe directamente sobre estas proteínas (su acción de inhibición es específica contra $N A E^{272}$ ) si no que el efecto es inmediato y no es causado por otros procesos celulares como por ejemplo apoptosis o parada de ciclo. Luego la acción directa sobre las proteínas que estudiamos se debió al efecto denedilador del fármaco.

Los resultados obtenidos reflejaron dos grupos de respuesta de proteínas. Un primer grupo definido por el acúmulo a altos niveles independiente de la concentración del fármaco empleada: WEE1, p27, Ciclina E y CDC25A. Y un segundo grupo, cuyo acúmulo (a menor nivel que en el grupo anterior) se produjo fundamentalmente al aplicar dosis altas del fármaco: p21 у $\mathrm{p}$-CHK1 (S345). En ambos grupos fue detectado el incremento del nivel de proteína en células tratadas con el fármaco con respecto al control (DMSO) a $4 \mathrm{~h}$ de iniciar el tratamiento, si bien este incremento fue menor a este punto de tiempo en el segundo grupo. Figura 31, página 104.

Es factible que la respuesta del primer grupo de proteínas se debió directamente a la acción del fármaco MLN4924, por ello se acumularon a tiempos cortos y a altos niveles. Mientras que el acúmulo de proteínas del segundo grupo se debió al efecto que el fármaco provocó en las células de SE (daño en DNA probablemente), luego fue un efecto indirecto. Ello quedó postulado al observar que los niveles de proteína total de CHK1 (proteína cuya degradación es dependiente de $C R L^{323}$ ) no variaron por la acción de MLN4924, mientras que su forma fosforilada en S345 (que se produce en respuesta a daño en el DNA ${ }^{324}$ ) aumentó fundamentalmente al aplicar altas dosis del fármaco. P21, que también participa en rutas de respuesta a daño en el $D D N A^{322}$, solo se acumuló a altas concentraciones del fármaco (donde hemos demostrado que se está produciendo daño al DNA). En consecuencia, consideramos que forman parte del segundo grupo de proteínas porque sus niveles subieron en respuesta al daño en el DNA que produce el fármaco MLN4924 a dosis altas.

\subsubsection{Propuesta de marcadores fármacodinámicos de MLN4924 en SE}

La farmacodinámica es el estudio de los efectos bioquímicos/fisiológicos de los fármacos y de sus mecanismos de acción. También analiza la relación entre la concentración del fármaco y el efecto que provoca en el organismo. Tener conocimiento de estos datos es fundamental a la hora de tratar a un paciente y realizar el seguimiento de acción del fármaco y del conjunto del tratamiento. Así como poder reconsiderar la aplicación de un determinado fármaco y utilizar otras alternativas, como consecuencia de una posible presencia de efectos secundarios específicos e intolerables para el paciente.

Nuestro estudio consistió en la evaluación preclínica del fármaco MLN4924 en líneas celulares de SE, de tal manera que pudimos proponer una serie de dianas a tener en cuenta en futuros estudios fármacodinámicos y/o clínicos. Consideramos que las dianas deben reunir las siguientes características: ser diana directa y alterarse en periodos cortos (4h), ser estables (mantenerse su acumulación tras $24 \mathrm{~h}$ de tratamiento), su alteración debe ser positiva, independiente de la concentración del fármaco (detectable a dosis bajas) y que el grado de modificación provocado por el fármaco correlacione con la concentración aplicada del mismo. 
Según estos parámetros, nuestros resultados nos condujeron a proponer a WEE1, Ciclina E y p27 como futuros marcadores farmacodinámicos a considerar.

\subsection{MECANISMOS MOLECULARES DE RESPUESTA AL FÁRMACO MLN4924}

El estudio preclínico puede reducirse a la comprobación de la efectividad de un fármaco a la hora de interrumpir la proliferación celular y/o inducir apoptosis, es decir, comprobar si el fármaco es efectivo contra una determinada enfermedad. 0 , además, intentar descifrar el mecanismo molecular que induce la respuesta frente a la aplicación del fármaco. La utilidad preclínica de este segundo estudio más completo es aportar información a la investigación básica así como a la investigación clínica, ya que se pueden extrapolar resultados a otras neoplasias que mantengan analogías con la que es objeto de estudio, así como sugerir un nuevo estudio preclínico en estos otros tipos de cáncer. Además, permite definir un mecanismo molecular de respuesta, aporta sugerencias para mejorar el fármaco, permite predecir estrategias para superar resistencias, puede conducir a obtener análogos más eficientes que provoquen menos efectos adversos secundarios $y$, sobre todo, permite diseñar el mejor compañero terapéutico en terapias combinadas (muy importante ya que pocos fármacos dirigidos se utilizan en último término en régimen de monoterapia).

Los resultados obtenidos con líneas celulares de SE evidenciaron una respuesta dual dosisdependiente de manera que se intentó descifrar el mecanismo molecular de respuesta de cada uno de los rangos de concentraciones.

\subsubsection{Mecanismo molecular del retraso en G2}

A concentraciones inferiores o iguales a $I_{75}$ las células de SE tratadas con MLN4924 interrumpieron su progresión en el ciclo celular en $\mathrm{G} 2$, antes de pasar a la fase de mitosis (Figura 54). Para comprender qué proteínas reguladoras del ciclo, sustratos de los complejos CRL, pudieron estar alteradas por la acción del fármaco y provocaron el retraso en G2, realizamos un ensayo de sincronización en mitosis con nocodazol. Cuando las células que se encontraron retenidas en mitosis fueron liberadas de esta droga y progresaron en el ciclo celular de manera sincrónica. De este modo pudimos monitorizar la fase del ciclo en la que se encontraron y la alteración de los niveles de ciertas proteínas durante el trascurso del ciclo. Figuras 32 y 33, páginas 107 y 108, respectivamente).

Mediante este proceso comprobamos en primer lugar que las células tratadas superaron la fase de mitosis, continuaron hacia G1, fase $S$ y finalmente se bloquearon en la dotación génica correspondiente a G2/M. Concluimos que el retraso se producía en la transición G2/M y probablemente las células se bloquearon en G2. En segundo lugar comprobamos que aquellas proteínas independientes de ubiquitinación por CRL no se vieron alteradas por el tratamiento con MLN4924; por ejemplo Ciclina B1 que se acumuló en mitosis, desapareció y posteriormente volvió a acumularse en la siguiente etapa de mitosis. Además comprobamos que el fármaco no actuó a nivel transcripcional y no provocó la aparición prematura en el ciclo de ninguna de las proteínas que posteriormente se vieron alteradas por su efecto. Si bien, una vez que apareció la expresión de las proteínas dependientes de complejos $C R L$, instante compartido para células tratadas con MLN4924 y control (DMSO), las células tratadas 
acumularon mayores niveles y los mantuvieron durante el resto de puntos del ensayo, fruto de la inhibición de la degradación que provocó el fármaco MLN4924. Figura 33, página 108.

\section{CONCENTRACIÓN BAJA-MEDIA $\left(\leq \mathrm{IC}_{75}\right)$ MLN4924}

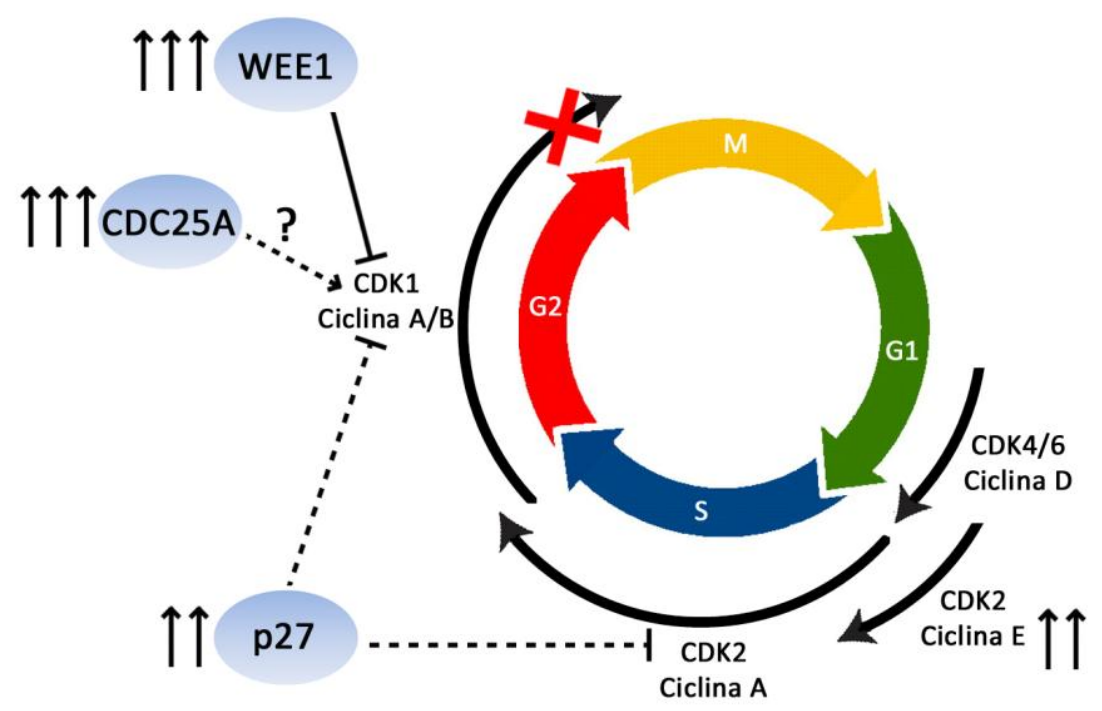

Figura 54: Retraso en G2 en líneas celulares de SE tratadas con MLN4924 ( $\leq \mathrm{IC}_{\mathbf{7 5}}$ ). Se detallan las proteínas dianas directas del fármaco que se acumulan por la inhibición de los complejos CRL: WEE1, CDC25A, p27 y Ciclina E; así como su participación en la regulación del ciclo celular.

Los resultaron mostraron que p27, WEE1, CDC25A y Ciclina E se acumularon por acción del fármaco a partir del momento fisiológico donde debieron aparecer. Además comprobamos como la principal acción de WEE1, fosforilación de Y15 de CDK1, se incrementó pese a que los niveles de CDK1 no se alteraron por la acción de MLN4924. Es decir, se debió al incremento de los niveles de proteína de WEE1. Consideramos en este punto a p27 y WEE1 como principales candidatos efectores del retraso en $\mathrm{G} 2$.

\subsubsection{Evaluación de p27 como principal efector del retraso en G2 ejercido por MLN4924}

P27 es una proteína inhibidora de CDKs que se une al núcleo catalítico e impide su función independientemente de la ciclina a la que esté unida. Juega un papel esencial en la transición $\mathrm{G} 1 / \mathrm{S}$ inhibiendo a las CDK4/6. Posteriormente complejos CRL $\left(\mathrm{SCF}^{\mathrm{SKP} 2}\right.$ ) ubiquitinan a p27 y es degradada durante la fase $S$ y $G 2$ lo que permite la actividad de $C D K 2^{263}$. También se ha descrito el papel fundamental de la degradación de p27 para completar la transición de G2 a mitosis. En ensayos con ratones knockout $\left(S K P 2^{-/}\right)$se demostró que la ausencia de SKP2, y la consecuente no degradación y acúmulo de p27 en la transición G2/M, provocaba la inactivación de CDK1 mediada por p27 e impedía la entrada en fase de mitosis ${ }^{210,319}$. También mediante ensayos in vitro se ha sugerido la capacidad de p27 de inhibir a CDK1 ${ }^{209-210}$. Por ello consideramos la posibilidad de que el retraso en la transición G2/M que provoca MLN4924 fuera ejercido por el acúmulo de p27 como consecuencia de la inhibición del complejo CRL, $\mathrm{SCF}^{\mathrm{SKP} 2}$. Para ser reconocido por el complejo $\mathrm{SCF}^{\mathrm{SKP} 2}$ para iniciar el punto de partida de su ubiquitinación y posterior degradación, es esencial la fosforilación de p27 en T187 realizada 
fundamentalmente por CDK2/Ciclina $E^{320}$, es lo que se ha denominado como fosfodegrón (marca de fosforilación de una proteína sin la cual los complejos CRL no la detectan para su ubiquitinación).

Evaluamos si el silenciamiento de p27 mediante la aplicación de shRNAs rescataba el retraso en G2 que inducía MLN4924. Tras comprobar cómo el sistema efectivamente provocó una supresión sustancial de p27, confirmamos que no redujo la población acumulada en G2/M inducida por el fármaco (Figura 35, página 110). Concluimos que p27 no era el efector principal del bloqueo en esta fase del ciclo. También comprobamos como la inhibición de p27 no afectó a la expresión de WEE1 ni a su principal acción, fosforilación en Y15 sobre CDK1. Figura 55.

\section{CONCENTRACIÓN BAJA-MEDIA $\left(\leq \mathrm{IC}_{75}\right)$ MLN4924}

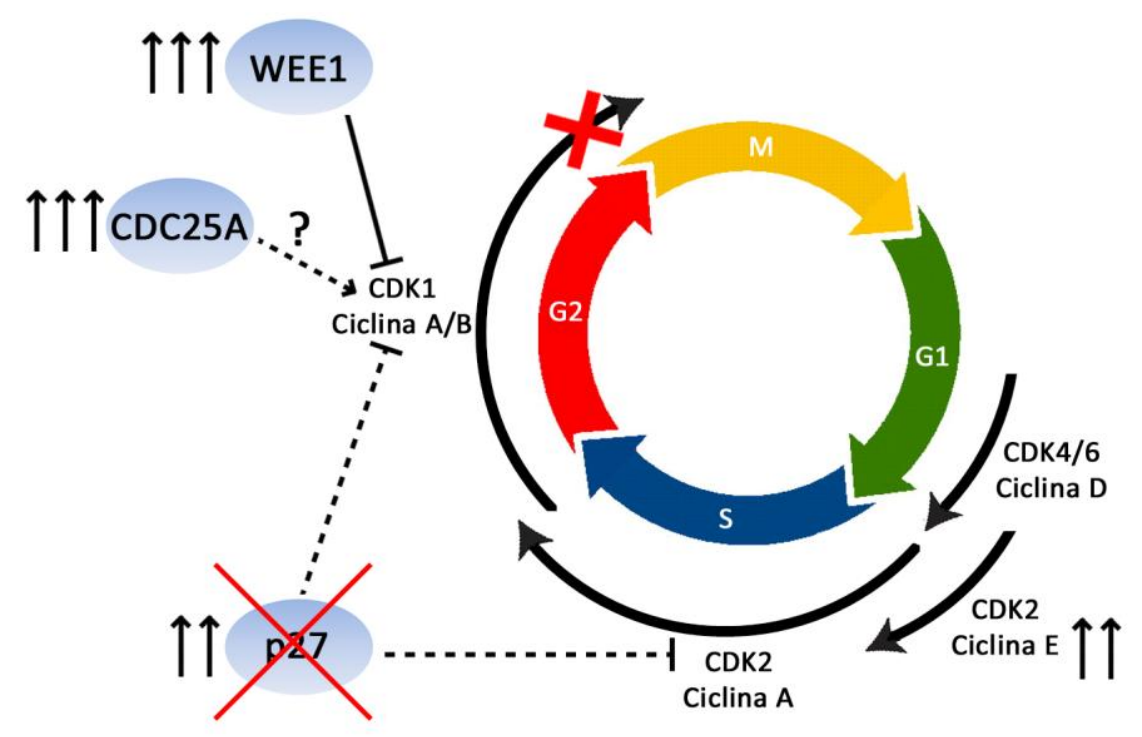

Figura 55: Retraso en G2 en líneas celulares de SE tratadas con MLN4924 ( $\left.\leq I C_{75}\right)$ y silenciamiento de p27. Se detallan las proteínas dianas directas del fármaco que se acumulan por la inhibición de los complejos CRL: WEE1, CDC25A, p27 y Ciclina E; así como su participación en la regulación del ciclo celular. El silenciamiento de p27 mediante shRNA no rescata del bloqueo. Las líneas discontinuas definen a aquellas proteínas que, pese a su enorme acúmulo producto de la acción de MLN4924, no ejercen un papel relevante en el mecanismo de respuesta.

A continuación, mediante inmunofluorescencia, corroboramos la sobreexpresión de p27 provocada por MLN4924 que habíamos detectado mediante WB. Adicionalmente esta técnica permitió comprobar la localización subcelular de la sobreexpresión de p27 tanto en el citoplasma como, mayoritariamente, en el núcleo (Figura 34, página 109). Ello adquiere relevancia porque la célula controla la actividad de p27, entre otros mecanismos, mediante la localización subcelular, principalmente en condiciones oncogénicas. Se ha descrito que diferentes tipos de fosforilaciones (como T280 ejercida por CDK4-6/Ciclina D2, o S10 ejercida por AKT) favorecen la translocación del p27 del núcleo al citoplasma para su posterior degradación, de manera que se interrumpe su función hasta ser eliminado ${ }^{327}$. Si el marcaje de p27 tras la aplicación hubiera sido principalmente citoplasmático y no nuclear nos hubiera explicado el porqué de su acumulación causada por MLN4924 pero falta de función en el retraso en $\mathrm{G} 2$. 
Al margen de su localización subcelular y la fosforilación de T187 para ser reconocida por $\mathrm{SCF}^{\text {SKP2 }}$, existen otras fosforilaciones que regulan la actividad de p27. SRC, la familia de quinasas LYN y el oncogén $B C R-A B L$ fosforilan a p27 en T88 y T74. Ambas fosforilaciones provocan que p27 sea expulsado del núcleo catalítico de CDK2, de modo que CDK2 puede recuperar su actividad ${ }^{339-341}$. Esta separación física impide la acción de p27 y es previa a su degradación, la cual, no se produce hasta que sea fosforilado en T187 (señal que permite el reconocimiento por parte de los complejos $\mathrm{CRL}$ ) y ubiquitinado por $\mathrm{SCF}^{\mathrm{KKP2}}$. Probablemente el p27 acumulado por acción del fármaco se encuentre con las fosforilaciones que impiden su actividad y no es degradado ya que los complejos CRL están inhibidos por MLN4924. Ello podría explicar que p27 no realiza un papel efector pese al gran acúmulo de proteína en las células. Es decir, según estos hallazgos previos descritos en literatura, el p27 acumulado en respuesta a MLN4924 podría ser inactivo porque es incapaz de unirse a CDK2 (por las fosforilaciones que hemos comentado). Los resultados de ausencia de inducción de senescencia por la acción de MLN4924 (descrito en el apartado 5.4 de esta sección) están consonancia con esta teoría del acúmulo de un p27 inactivo.

\subsubsection{Evaluación de daño al DNA como principal efector del retraso en G2 ejercido por MLN4924}

El checkpoint de daño al DNA juega un papel esencial para la viabilidad de la célula controlando el paso de $\mathrm{G} 2$ a mitosis. Este punto de control interrumpe la progresión del ciclo al detectar daño en el DNA, de tal manera que la célula puede reparar el daño y asegurar un estado óptimo para iniciar el crítico proceso de división celular.

Las quinasas ATM/ATR juegan un papel fundamental en este checkpoint, de modo que inician una cascada molecular de señalización en respuesta al daño. Esta cascada en última instancia inhibe la actividad enzimática de CDK1 y, consecuentemente, el inicio de la fase de mitosis ${ }^{342}$. Una de las dianas de ATM/ATR es CHK1, que como hemos visto estaba activada ( $p$-S345) en respuesta a MLN4924. Comprobamos que existían ciertos focos de daño al DNA (mediante marcaje de $\mathrm{\gamma}-\mathrm{H} 2 \mathrm{AX}$ ) al aplicar concentraciones de $\mathrm{IC}_{75}$. De tal modo que quisimos evaluar el posible papel del checkpoint de daño al DNA en el bloqueo de G2. Para comprobar si era un efector predominante quisimos rescatar el fenotipo inhibiendo la ruta de ATM/ATR mediante la aplicación a altas dosis de cafeína tras la aplicación del fármaco ${ }^{316}$. Comprobamos que en células control (DMSO) el baipás del checkpoint provocó el paso rápido por fase $S$ tardía y entrada en G2-M (evita el control y parada de la transición G2/M por el daño fisiológico del DNA producto de la replicación) lo que demostró su eficacia, y sin embargo no recuperó a las células del bloqueo en G2 inducido por MLN4924 (Figura 36, página 111). Sí se apreció la disminución del mínimo porcentaje de células que se acumularon a 300nM de MLN4924 (ligeramente superior a $\mathrm{IC}_{75}$ ) en fase $\mathrm{S}$ tardía producto del daño que provocó el fármaco a concentraciones mayores.

Los resultados obtenidos del ensayo de baipás del checkpoint de daño al DNA mediante la aplicación de altas dosis de cafeína nos indicaron que debían ser otros los factores que ejercían el bloqueo en $\mathrm{G} 2$.

\subsubsection{Evaluación de WEE1 como principal efector del retraso en G2 en respuesta a MLN4924}


WEE1 es una quinasa inhibidora de la progresión del ciclo mediante la fosforilación en Y15 de CDK1. Ello provoca la reducción drástica de la actividad enzimática del complejo CDK1-Ciclina B que conduce al retraso de la transición de G2 a mitosis ${ }^{328}$. Tras descartar los anteriores mecanismos, consideramos la posibilidad de WEE1 como principal efector del bloqueo en G2 ejercido por MLN4924 a concentraciones menores o igual a $\mathrm{IC}_{75}$.

Silenciamos parcialmente la expresión de WEE1 (mediante shRNAs) o inhibimos su actividad (aplicando el fármaco PD0166285) y comprobamos como el fenotipo de respuesta que desencadenaba MLN4924, retraso en la transición G2/M, era revertido (Figuras 39 y 42, páginas 114 y 117, respectivamente). El acúmulo de WEE1 era por tanto el mayor efector del fenotipo y su inhibición o silenciamiento eran suficientes para que las células superaran el retraso en G2/M y continuaran progresando en el ciclo celular. Figura 56.

\section{CONCENTRACIÓN BAJA-MEDIA $\left(\leq_{1 C_{75}}\right)$ MLN4924}

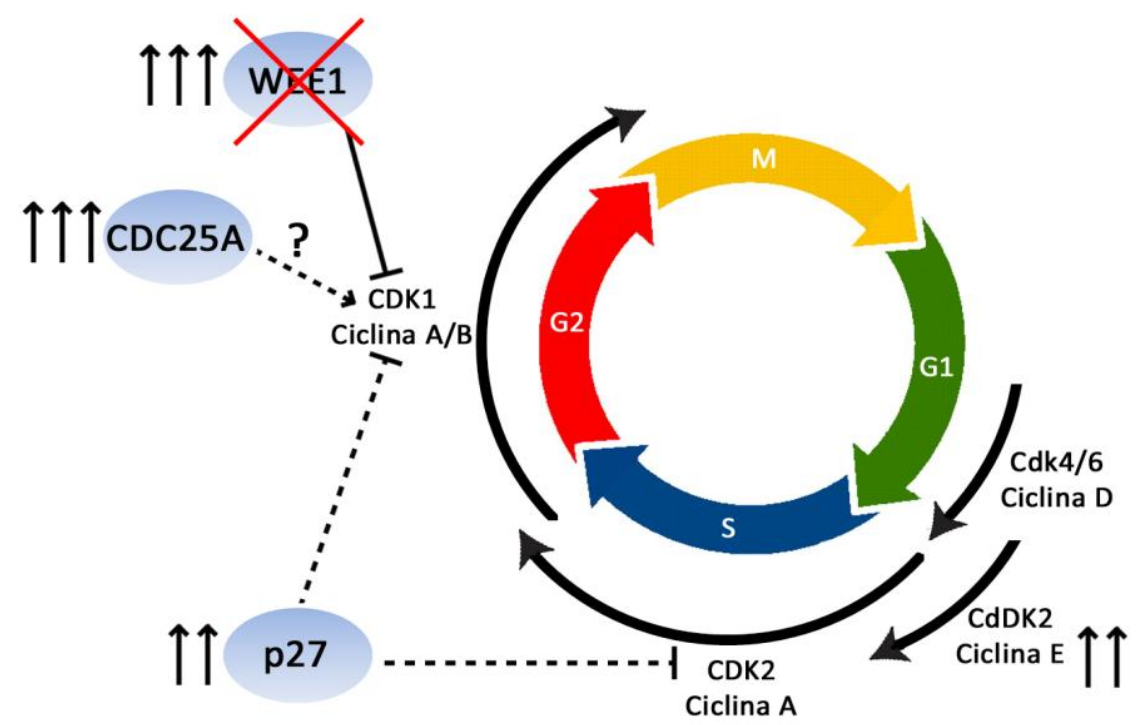

Figura 56: Rescate del retraso en G2 en líneas celulares de SE tratadas con MLN4924 ( $\left.\leq I_{75}\right)_{\text {) mediante el }}$ silenciamiento o inhibición de WEE1. Se detallan las proteínas dianas directas del fármaco que se acumulan por la inhibición de los complejos CRL: WEE1, CDC25A, p27 y Ciclina E; así como su participación en la regulación del ciclo celular. El silenciamiento de WEE1 mediante shRNA o de su actividad aplicando el fármaco PD0166285 rescata del bloqueo en G2 que induce MLN4924. Las líneas discontinuas definen a aquellas proteínas que, pese a su enorme acúmulo producto de la acción de MLN4924, no ejercen un papel relevante en el mecanismo de respuesta.

Además, comprobamos mediante ensayos secuenciales de aplicación de los fármacos MLN4924 y posteriormente PD0166285, que el bloqueo se efectuó en G2 y era previo a la entrada en mitosis. Ello se puso de manifiesto porque las células bloqueadas por MLN4924 en G2/M (según perfil de ciclo celular mediante marcaje con IP) apenas expresaban pH3. Sin embargo al aplicar a las células bloqueadas por MLN4924, PD0166285 durante 1.5h, se aumentó tremendamente la población pH3 positiva, es decir, células que habían avanzado hacia la fase de mitosis. A continuación, al prolongar en el tiempo el ensayo ( $3 \mathrm{~h}$ ), la población de nuevo disminuyó e incrementó el porcentaje de células en G1 (Figura 40, página 115); luego las células reanudaban su progresión en el ciclo. Otra prueba de que el bloqueo es previo a mitosis, en G2, es el ensayo de sincronización en fase de mitosis con nocodazol. En este 
ensayo, 4h antes de liberar de nocodazol aplicamos MLN4924, de tal modo que el efecto en sus principales dianas (incluido acúmulo de WEE1) estuvo presente en el momento de la liberación, punto de tiempo $0 \mathrm{~h}$. Cuando esto sucedió las células completaron la fase de mitosis e iniciaron un nuevo ciclo celular donde se bloquearon en la G2/M (Figura 32, página 107). Por lo tanto el fármaco MLN4924 no interrumpió la fase de mitosis (al menos no desde el instante en que el nocodazol la bloqueaba) si no que retrasó G2 o la transición G2/M. Debemos destacar que la inhibición de la expresión de WEE1 mediante sistemas shRNAs desencadena apoptosis en células de SE, independiente al uso del fármaco MLN4924 (Figura 43, página 118). La inhibición de WEE1 impide el punto de control fisiológico que ejerce la quinasa, provocando que se inicie la fase de mitosis sin que se hayan alcanzado las condiciones óptimas celulares para ello. Probablemente las células iniciaron la fase de división y se produjeron fallos letales que supusieron la muerte celular. Se ha descrito este fenómeno resultado de la supresión de WEE1 como colapso o catástrofe mitótica ${ }^{207,329-330}$.

Si mantenemos en el punto de mira en la finalidad global del estudio que realizamos, estudio preclínico del fármaco MLN4924 en SE, este último dato adquiere gran relevancia. Una de las estrategias que siguen las células de SE para defenderse de la selección negativa de un determinado factor, como por ejemplo el silenciamiento de CDT2 (ensayo realizado en un trabajo anterior del laboratorio ${ }^{71}$ ), es la de inactivar el sistema que lo induce. La mayoría de las células murieron por el silenciamiento pero excepcionalmente algunas de ellas consiguieron desactivar el sistema de silenciamiento y sobrevivieron. Si trasladamos la estrategia al tratamiento con MLN4924, las células de SE podrían intentar silenciar la expresión de WEE1 para evitar el retraso en G2 que induce su acúmulo por la acción del fármaco. En este caso la estrategia sería contraproducente pues la inhibición de WEE1 induciría el colapso o catástrofe mitótica.

\subsubsection{Mecanismo molecular de retraso de fase $\mathrm{S}$ tardía}

A concentraciones superiores o iguales a $\mathrm{IC}_{95}$ las células de SE tratadas con MLN4924 sufrían un retraso de la progresión de la fase $\mathrm{S}$. Estudios de citometría de flujo mediante marcaje de DNA con IP mostraron que las líneas de SE tratadas a altas dosis del fármaco no completaban la Fase $S$ pese a prolongar el tratamiento durante $24 \mathrm{~h}$, inherente a este retraso se producía un incremento de apoptosis.

Mediante el ensayo de sincronización en la frontera G1/S (mediante la adición de timidina al medio de cultivo y su posterior liberación) se observó como la aplicación de $\geq I_{95}$ de MLN4924 provocó un retraso en la etapa final de fase $S$ (Figura 57). La entrada en fase $S$ y el inicio de ésta tuvo lugar de manera sincrónica en células control (DMSO) y en las tratadas con el fármaco. Sin embargo quedó manifiestamente demostrado un retraso en la etapa final de la fase $S$ (puntos de tiempo 12 y 15h tras la liberación de timidina). Figura 45, página 121.

5.7.2.1 Evaluación de WEE1 como principal efector del retraso en fase $\mathrm{S}$ tardía ejercida por MLN4924

Se ha demostrado in vitro que WEE1 es una quinasa capaz de fosforilar a CDK2 en Y15 para inhibir su actividad durante el periodo de fase $S^{217}$. Debido a ello y a su predominante papel en 
el bloqueo en G2 inducido por concentraciones de MLN4924 inferiores o iguales a IC 75 , consideramos la posibilidad de que también jugara un rol relevante en el retraso en fase $\mathrm{S}$.

En primer lugar se evaluó el acúmulo de proteína y de su acción, fosforilación de Y15, sobre CDK2. Efectivamente, a dosis altas de MLN4924, WEE1 se acumuló mientras que la cantidad de proteína total de CDK2 no sufrió alteración (Figura 47, página 123). Mediante el ensayo de inmunoprecipitación detectamos cómo el porcentaje de CDK2 fosforilada en Y15 fue mayor en células tratadas con el fármaco que en las células control (DMSO), fundamentalmente en los dos últimos puntos de tiempo tras la sincronización (Figura 48, página 124). Quedó demostrado que WEE1 se acumuló, que fue activo y que ejerció su función sobre CDK2. No obstante quedó por demostrar la relevancia de este hecho con respecto al retraso en la progresión de la fase $S$ tardía. Para lo cual aplicamos una concentración de IC $C_{95}$ de MLN4924 en líneas celulares con silenciamiento parcial de la expresión de WEE1 mediante shRNAs. EI resultado obtenido fue un rescate leve mediante los dos constructos shRNA-WEE1 del porcentaje de células en fase $S$ en la línea celular RDES, y un rescate ínfimo y otro nulo en la línea RM82 (Figuras 42 y 44, páginas 117 y 119, respectivamente). En ambos casos se comprobó una cierta recuperación del porcentaje de células en G1 fruto de la liberación del retraso en $\mathrm{G} 2$ de aquellas células que superaron la fase $\mathrm{S}$ en el momento de la aplicación del fármaco a altas dosis. Aun así el gran porcentaje de células retenidas en fase $S$ por acción del fármaco se mantuvo pese al silenciamiento de la expresión de WEE1.

Los resultados anteriores nos señalaron que WEE1 no fue el principal efector del retraso en fase $\mathrm{S}$ tardía aunque pudo tener cierta implicación en el retraso del progreso de esta fase en células tratadas con concentraciones iguales o superiores a la $\mathrm{IC}_{95}$ de MLN4924.

5.7.2.2 Evaluación de Ciclina E como principal efector del retraso en fase $\mathrm{S}$ tardía ejercida por MLN4924: alteración de la localización subcelular de CDC6

Tras descartar a WEE1 como principal efector del retraso en fase $S$ tardía estudiamos otros candidatos que sufrieron alteraciones por la acción de MLN4924 y que pudieran explicar la disminución de la incorporación de BrdU a partir de $12 \mathrm{~h}$ tras la liberación de timidina (retraso en fase S, Figura 46, página 122). Entre los posibles candidatos destacó el acúmulo de Ciclina E. Apareció al inicio de fase $S$ en las células control (DMSO) y desapareció a partir del punto de tiempo de $9 \mathrm{~h}$. Sin embargo en las células tratadas con $\mathrm{IC}_{95}$ del fármaco, el acúmulo fue mucho mayor y se prolongó durante todos los puntos de tiempo. Comprobamos que el complejo CDK2/Ciclina E fue activo mediante el análisis de la fosforilación en S780 de Retinoblastoma (fosforilación ejercida por este complejo en esta etapa del ciclo celular ${ }^{331}$ ), ya que esta fosforilación se incrementó notablemente en las células tratadas y se prolongó durante todo el ensayo (Figura 47, página 123).

Durante el progreso de un ciclo celular normal, Ciclina E es sustituida por Ciclina A en su unión a CDK2 durante el transcurso de la fase $S^{167}$. Ciclina $A$ no es regulada por complejos CRL y se constató que MLN4924 no provocó su acúmulo. Como la entrada en fase $\mathrm{S}$ se produjo a la vez en células tratadas y en las células control así como el porcentaje de células BrdU positivas y células en $\mathrm{G} 2$ coincidió hasta el punto de tiempo 9h, consideramos que la entrada e inicio de la fase $\mathrm{S}$ no se vio alterado por la acción del fármaco (Figura 45, página 121). Debemos destacar que el periodo de tiempo de 0 a $9 \mathrm{~h}$ tras la liberación de timidina es el intervalo en el que 
Ciclina E estuvo presente en las células control. Posteriormente fue degradada y sustituida por Ciclina $\mathrm{A}$ en su unión a CDK2. Nos planteamos que el motivo de la alteración de la fase $\mathrm{S}$ por MLN4924 se debiera a que el acúmulo de Ciclina E desplazara a Ciclina A en su unión a CDK2 en la etapa final de esta fase del ciclo. Para comprobar si esto ocurrió realizamos una inmunoprecipitación anti-CDK2 y demostramos la veracidad de la hipótesis: observamos en los últimos puntos de tiempo (9-15h) que en las células control no se coinmunoprecipitó Ciclina $\mathrm{E}$ mientras que en las células tratadas sí. Además comprobamos como en los dos últimos puntos de tiempo (12 y $15 \mathrm{~h}$ ) el porcentaje de Ciclina $A$ unida a CDK2 era notablemente inferior en células tratadas con MLN4924 que en las células control (Figura 48, página 124).

Confirmado el desplazamiento de Ciclina A, quisimos comprobar que tenía alguna repercusión en los sustratos específicos del complejo CDK2/Ciclina A. Se ha descrito que la formación de complejos CDK2/Ciclina E o CDK2/Ciclina A afecta diferencialmente al patrón de fosforilación que ejerce CDK2 sobre sus sustratos (como se detalla a continuación). Si bien ambos complejos pueden compartir algunos de sus sustratos, otros son exclusivos de uno u otro. Un ejemplo de esta segunda asunción son las fosforilaciones ejercidas sobre la proteína CDC6. CDC6 juega un papel esencial en fase S, al inicio de la replicación mediante la fosforilación en S54 y S74 (ejercida por CDK2/Ciclina E) es trasladado al núcleo de la célula y participa en al acoplamiento del complejo pre-replicativo al DNA. En la etapa final de la fase $S$, mediante la fosforilación en S106 (ejercida por CDK2/Ciclina A) es exportado al citoplasma para asegurar que la replicación se da únicamente una vez por cada ciclo celular ${ }^{333-335}$. Mediante inmunofluorescencia y tras realizar el ensayo de sincronización, comprobamos que en el punto de tiempo de $12 \mathrm{~h}$ (fase $\mathrm{S}$ tardía, donde vimos por la inmunoprecipitación de CDK2 que la diferencia fue mayor en el porcentaje de Ciclina A unida a CDK2 entre las células tratadas con MLN4924 y las control), el marcaje de CDC6 en las células control (DMSO) fue predominantemente citoplasmático, mientras que en las células tratadas con altas dosis de MLN4924 se mostró una marcada inmunotinción nuclear (Figura 49, página 126). Comprobamos pues que el desplazamiento de Ciclina A por Ciclina E en su unión a CDK2 tuvo consecuencias en los sustratos específicos de CDK2/Cicina $A$ en la fase $S$ tardía, revelando por tanto una pérdida o disminución de las funciones específicas de CDK2/Ciclina A. Sugerimos que este hecho puede tener un importante papel efector en la respuesta de las líneas de SE al tratamiento con dosis iguales o superiores a $I_{95}$ de MLN4924. Figura 57.

Para comprobar si la sobreexpresión exclusiva de Ciclina $\mathrm{E}$ produce un retraso en fase $\mathrm{S}$ se establecieron células de SE (RDES) con un sistema de expresión inducible del gen de dicha proteína. Los resultados mostraron como efectivamente la única sobreexpresión de Ciclina $\mathrm{E}$ induce un acúmulo de células en fase $\mathrm{S}$. Sin embargo la respuesta difiere de la que desencadena la $\mathrm{IC}_{95}$ de MLN4924: la sobreexpresión exógena de Ciclina E muestra un porcentaje de G1 mayor que el de las células tratadas con el fármaco MLN4924 y un porcentaje de células en fase $S$ inferior (Figura 50, página 128). Ello se explica porque el fármaco actúa sobre otras dianas (como por ejemplo WEE1) y porque con el sistema inducible no conseguimos producir los altos niveles de Ciclina E que se acumulan por la acción de MLN4924. Además, debemos admitir la posibilidad de que el efecto en fase $\mathrm{S}$ sea más complejo y este integrado por más elementos desregulados por MLN4924. 


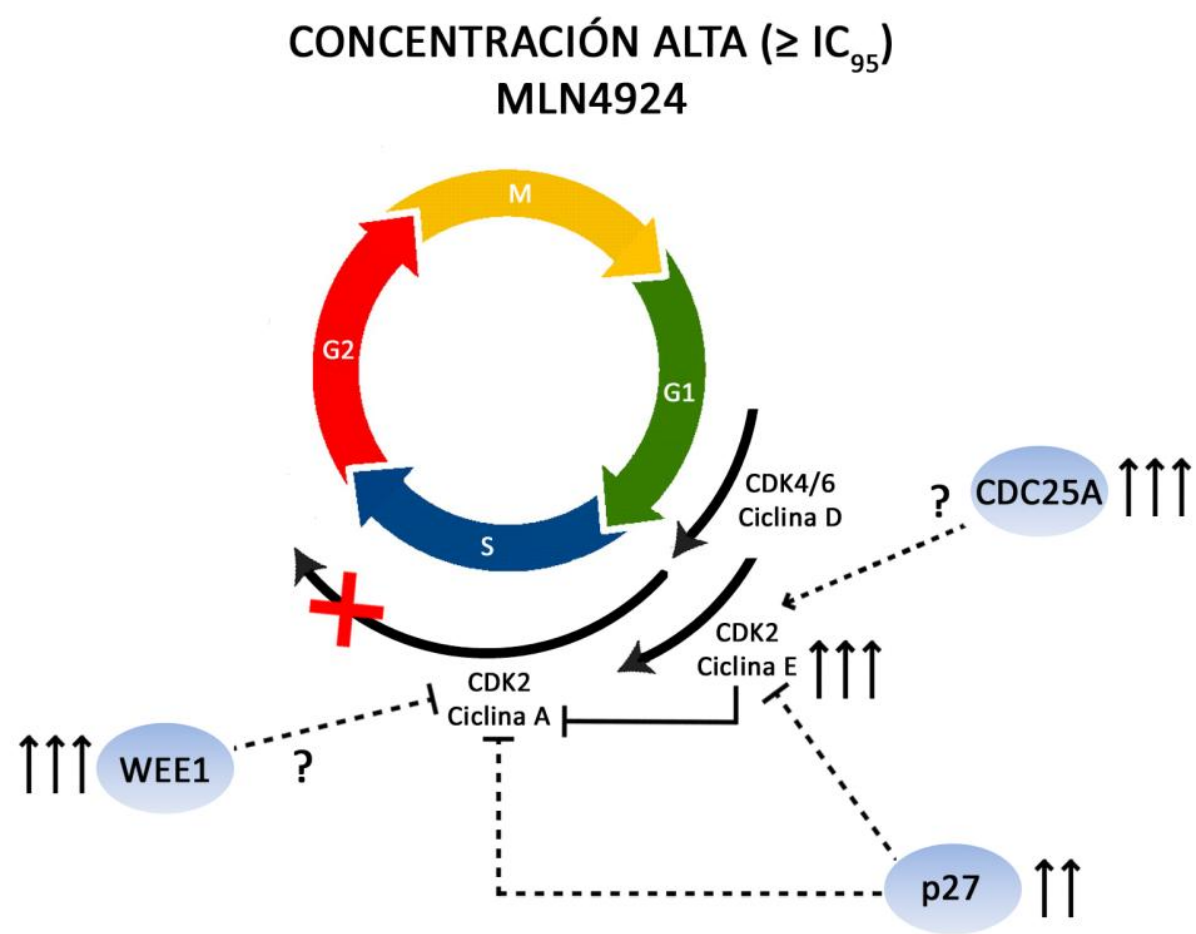

Figura 57: Retraso en fase $S$ tardía en líneas celulares de SE tratadas con MLN4924 ( $\geq I_{\text {95 }}$ ). Se detallan las proteínas dianas directas del fármaco que se acumulan por la inhibición de los complejos CRL: WEE1, CDC25A, p27 y Ciclina E; así como su participación en la regulación del ciclo celular. Se indica como el enorme acúmulo de Ciclina E desplaza a Ciclina A de la formación de complejos con CDK2. Las líneas discontinuas definen a aquellas proteínas que, pese a su enorme acúmulo producto de la acción de MLN4924, no ejercen un papel relevante en el mecanismo de respuesta.

Finalmente para intentar rescatar el fenotipo de retraso en fase $S$ tardía se sobreexpresó Ciclina A de manera inducible en la línea RDES tratadas con altas dosis de MLN4924. Nuestro objetivo fue aumentar los niveles de Ciclina $A$ en la etapa final de fase $S$ para que compitiera con Ciclina E y recuperara los niveles de unión a CDK2 necesarios para fosforilar los sustratos específicos de los complejos CDK2/Ciclina A. Sin embargo, la sobreexpresión de Ciclina A indujo retraso en la fase $S$ por sí misma, lo que impidió el ensayo de rescate. Sorprendentemente la demora en la progresión de la fase $\mathrm{S}$ se produjo al inicio de la misma, en agudo contraste con lo que provoca MLN4924 a altas dosis (Figura 51, página 129). Esto sin embargo sustenta la idea de que la sobreexpresión de las ciclinas "fuera de tiempo" en las líneas de SE induce retraso en fase $S$.

Recientemente se ha publicado que la regulación de los niveles de CDC6 es independiente de CRL y que la alteración de su actividad provoca inestabilidad genómica y daño al DNA ${ }^{343}$. Ello concuerda con el alto nivel de apoptosis que se desencadena al aplicar altas dosis de MLN4924 y que no ocurre a dosis inferior o igual a $\mathrm{IC}_{75}$ (donde no se produce el retraso en fase $\mathrm{S}$ tardía) y podría servir por tanto para dar unidad a los resultados observados de retraso en fase $S$ tardía, de inducción de daño en DNA y apoptosis. No obstante harían falta más experimentos para poder afirmar inequívocamente que CDC6 es el principal mediador de la apoptosis producida por la acción de MLN4924 a altas dosis. Como ya se ha mencionado, probablemente existan múltiples causas mecanísticas que generan el retraso en la progresión de la fase $\mathrm{S}$, daño al DNA y apoptosis. 


\subsubsection{Acúmulo de CDC25A inactivo}

CDC25A juega un papel antagónico a WEE1 y MYT1 en la regulación del ciclo celular ${ }^{344}$. Desfosforila los residuos de Y15 y T14 que ejercen ambas quinasas sobre las CDKs, ello permite superar el bloqueo de la progresión del ciclo por la reactivación de las CDKs. La regulación de $\mathrm{CDC} 25$ depende del complejo CRL SCF ${ }^{\beta-T C P}$ en fase $S / G 2$ y APC/C $C^{C D H 1}$ en mitosis ${ }^{345}$.

Durante los estudios para dilucidar el mecanismo molecular de respuesta al fármaco MLN4924 comprobamos como CDC25A se acumuló a altos niveles, a tiempos cortos de exposición al fármaco e independientemente de la concentración de fármaco empleada (Figura 31, página 104). Sin embargo, al igual que ocurrió con p27, dió la impresión de que la forma de CDC25A acumulada fue inactiva debido a que no pareció acelerar la entrada en fase $S$, ni la progresión $\mathrm{G} 2 / \mathrm{M}$, ni en respuesta a dosis bajas-medias ( $\leq \mathrm{IC}_{75} \rightarrow$ retraso en $\mathrm{G} 2$ ), ni altas ( $\geq \mathrm{I} \mathrm{C}_{95} \rightarrow$ retraso en fase $\mathrm{S}$ tardía) del fármaco.

Más en detalle, no se observó en el experimento de sincronización en la frontera G1/S con marcaje con BrdU en presencia de altas dosis de MLN4924 una entrada prematura en G1 por parte de las células tratadas con el fármaco MLN4924 (Figura 45, página 121). Sin embargo, está bien establecido que la sobreexpresión de Ciclina E y CDC25A son suficientes para inducir una entrada precoz en fase $\mathrm{S}^{332}$. Se demostró que Ciclina $\mathrm{E}$ sí fue activa y ejerció un papel relevante en el retraso en fase $S$ tardía, por lo cual queda de manifiesto que el segundo actor en la teórica entrada prematura en G1, CDC25A, estuvo inactivo. De igual modo, si nos centramos en el efecto que desencadenó MLN4924 a concentraciones iguales o inferiores a $I_{75}$, vimos como el enorme acúmulo de CDC25A no indujo una transición rápida de $\mathrm{G} 2$ a Mitosis. Ello invitó de nuevo a pensar en su inactividad. Se ha descrito que la fosforilación en S216 en humanos, S287 en xenopus, de CDC25 inactiva a la fosfatasa ${ }^{344}$.

El razonamiento para explicar la inactividad del CDC25A acumulado en respuesta a MLN4924 podría ser el mismo al de p27: las fosforilaciones que permiten su reconocimiento por parte de los complejos CRL (fosfodegrón) podrían interferir con su actividad fosfatasa. De ser así la forma acumulada en respuesta a MLN4924 (que es necesariamente la forma fosforilada para ubiquitinación) sería inactiva.

Alternativamente podemos considerar que WEE1 es la fuerza dominante al inhibir los complejos CRL a determinadas concentraciones de MLN4924, por lo que su acción frente a CDK1 se impone frente a la que podría ejecutar un CDC25A activo. No obstante esta segunda hipótesis no explicaría la falta de entrada prematura en G1 en combinación con el acúmulo de Ciclina $\mathrm{E}$ que se produce a concentraciones altas del fármaco.

\subsection{MLN4924, UN FÁRMACO ALTAMENTE ESPECÍFICO QUE PROVOCA RESPUESTAS DISPARES}

Recopilando los datos obtenidos en nuestros ensayos y contrastándolos con los publicados en una cada vez más extensa bibliografía, observamos como el fármaco MLN4924 pese a ser altamente específico y actuar exclusivamente contra su diana (la enzima activadora de NEDD8, NAE) provoca distintos tipos de respuesta en las líneas celulares de diferentes neoplasias estudiadas. 
MLN4924, molécula con similitudes estructurales a la molécula de AMP (Figura 58, A y B), fue definida como un potente inhibidor de NAE en el artículo en el cual se publicó su desarrollo farmacéutico por primera vez ${ }^{272}$. Mediante ensayos con enzimas purificadas evaluando los productos de la formación de enlaces tioéster de la E2 ligasa-UBL, se calculó la concentración media inhibitoria $\left(\mathrm{IC}_{50}=0,004 \mu \mathrm{M}\right)$ de MLN4924 sobre NAE. Se consideró altamente específica, pues la $\mathrm{IC}_{50}$ de enzimas estrechamente relacionadas como UAE, SAE, UBA6 y ATG7 fueron 1.5, 8.2, 1.8 y $>10 \mu \mathrm{M}$, respectivamente (superiores varios órdenes de magnitud). Mediante ensayos con la línea celular HCT116, se obtuvieron extractos de células tratadas con el fármaco. A continuación se evaluó la inhibición de NAE, SAE y UAE mediante análisis de inmunotransferencia y los niveles de enlaces tioéster de UBC12-NEDD8, UBC9-SUMO y UBC10$U \mathrm{~b}$, respectivamente. Se concluyó que el fármaco fue altamente específico para con la enzima NAE y que no afectó a las otras dos evaluadas (enzimas sin embargo con actividades muy similares: sumoilación y ubiquitinación). También se descartó que MLN4924 afectara a otras enzimas que utilizan ATP para llevar a cabo su función: B-RAF, PLK (dominio quinasa) y CDK1, cuyas $\mathrm{IC}_{50}>10 \mu \mathrm{M}$. Así como Aurora A, CAMKII, CHK1, CHK2, CDK2E, CKII, LCK, pKA $\alpha$ y PKC $\alpha$, cuyas $\mathrm{IC}_{50}>100 \mu \mathrm{M}$. Por último se determinó la despreciable o nula capacidad de unión de

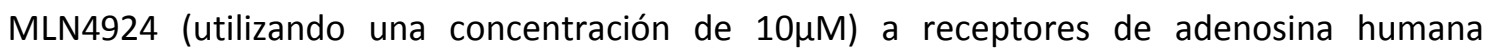
mediante ensayos in vitro ${ }^{272}$. Figura 58.

A

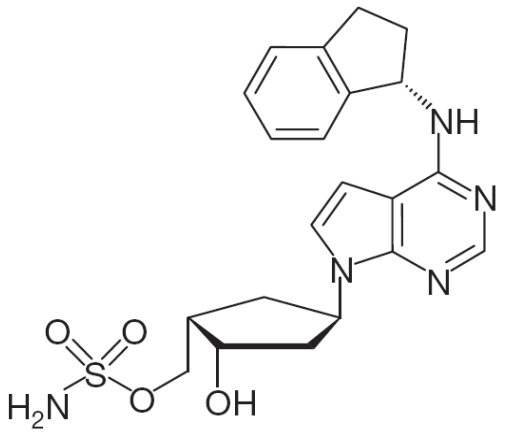

MLN4924

C

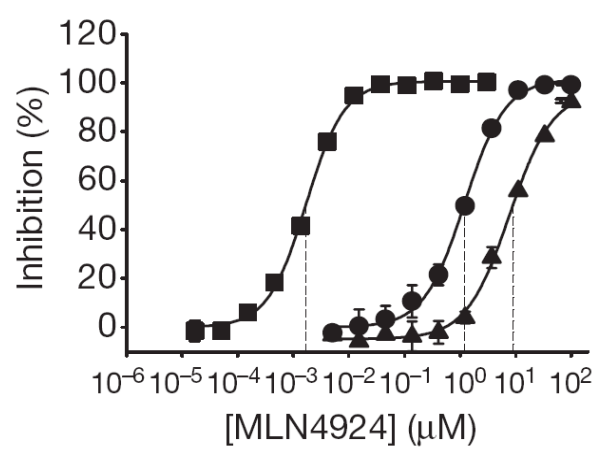

B<smiles>Nc1ncnc2c1ncn2C1OC(COP(=O)(O)O)C(O)C1O</smiles>

AMP

D

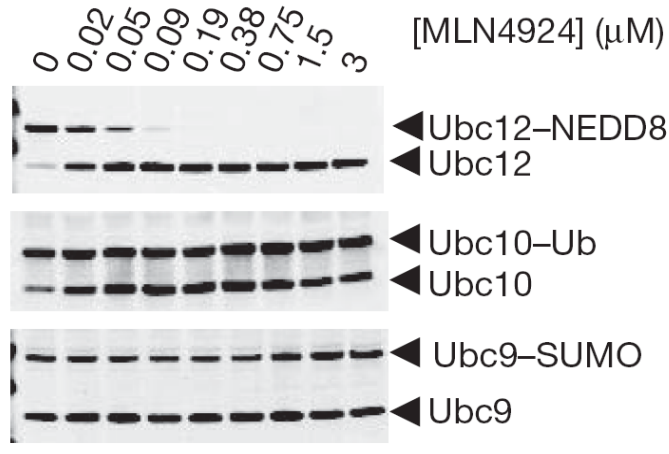

Figura 58: MLN4924 es un inhibidor potente y altamente selectivo de la enzima NAE. A Estructura química de MLN4924. B Estructura química del AMP. C MLN4924 es un potente y selectivo inhibidor de NAE (cuadrados) in vitro, en comparación con las enzimas SAE (triángulos) y UAE (círculos). D Evaluación de la inhibición de NAE, SAE y UAE mediante análisis de inmunotransferencia y los niveles de enlaces tioéster de UBC12-NEDD8, UBC9-SUMO y UBC10-Ub, respectivamente. Reproducido de Soucy, T.A., et al. (2009). An inhibitor of NEDD8-activating enzyme as a new approach to treat cancer. Nature $458,732-736^{272}$. 
En consonancia con lo descrito en el artículo del grupo de Soucy T.A. ${ }^{272}$, en todos los estudios preclínicos realizados con el fármaco MLN4924 se comprobó que el fármaco es altamente específico y conseguía disminuir el porcentaje de la población de culinas nediladas. En el mismo trabajo demostraron como MLN4924 es un fármaco con cierta ventaja frente a Bortezomib, pues éste segundo interfiere con el "turnover" proteico total mientras que MLN4924 sólo lo hace sobre el que regulan las CRL (10-20\% del total). Nuestro estudio no fue una excepción, y comprobamos que los niveles de inhibición que inducía MLN4924 sobre las culinas nediladas en las células de SE fue similar a los que provocó en la línea celular más utilizada en los ensayos preclínicos con el fármaco, HCT116 (Figura 30, página 102).

Pese a la enorme especificidad de MLN4924 descrita anteriormente, se han descrito diversos mecanismos de respuesta al fármaco MLN4924 que además difieren del que hemos definido en las líneas celulares de SE (Tabla 15 y Figura 59, páginas 138 y 159, respectivamente). Podemos clasificar los mecanismos moleculares de respuesta en:

- Desregulación de la fase S, re-replicación y daño al DNA: es el mecanismo que más prevalece en el conjunto de ensayos clínicos realizados. Se definió inicialmente en ensayos con la línea celular de cáncer colorrectal HCT116 272,279,281. La re-replicación se producía como consecuencia de la inhibición de CUL1 ${ }^{\text {SKP2 }}$, y del consiguiente acúmulo de la proteína CDT1. Su desregulación provocaba que dispararan nuevos puntos de replicación que incrementaban el contenido de DNA a niveles superiores a $4 \mathrm{n}$ lo que era fácilmente detectable en ensayos de citometría con marcaje de DNA mediante IP (Figura 53, página 142). Esta re-replicación dañaba el DNA, interrumpía la fase S y conducía a apoptosis. Durante la realización de la tesis testamos antes que nada este mecanismo como posible inductor del fenotipo en respuesta a MLN4924 en SE. Los ensayos se realizaron en paralelo con la línea celular HCTT116 y los resultados mostraron como los niveles de inhibición de CUL1, CUL4A y CUL4B fueron similares entre esta línea celular y las de SE. Pese a ello, en las líneas celulares de SE tratadas con el fármaco se produjo un mínimo acúmulo de CDT1 principalmente a concentraciones altas de MLN4924. En ningún caso se alcanzó el nivel de CDT1 que se produjo al aplicar el fármaco en la línea HTC116 (Figura 30, página 102). Tampoco se halló importantes niveles de re-replicación en las líneas celulares de SE.

Otro tipo de re-replicación, con mecanismo distinto, fue el descrito por el grupo de Blank J.L. recientemente. En este trabajo se distinguieron 154 genes alterados en respuesta a MLN4924 y se demostró que la re-replicación que se observaba era independiente de CDT1 en líneas celulares de melanoma. En estas células el principal efector del fenotipo era el acúmulo p21 y en menor medida la activación de la ruta ATR. Estas alteraciones disparaban el checkpoint de fase $S$ (en respuesta al daño al DNA) y provocaban apoptosis ${ }^{276}$.

- Entrada en estado de senescencia: otro mecanismo de respuesta al fármaco MLN4924 que comparten varias neoplasias y ha sido descrito en varios artículos es el de entrada en senescencia. A menudo, este mecanismo se desencadena junto al anterior descrito en líneas celulares tratadas con el fármaco, como en los casos de las células HCT116, U87 (línea celular de glioblastoma) y H1299 (línea celular de cáncer de pulmón) ${ }^{277,279}$. Ambos mecanismos moleculares pueden dispararse al tratar con MLN4924 las células y después uno de los dos prevalecerá sobre el otro, generalmente el de daño al DNA y apoptosis. En cuanto al 
mecanismo molecular subyacente a la entrada en senescencia, ha sido demostrado que el principal efector es el acúmulo de p21. Abundando en la variabilidad de mecanismos de respuesta, cabe destacar que aunque el principal papel del acúmulo de p21 es inducir senescencia, en el mecanismo de respuesta al fármaco MLN4924 descrito en el anterior párrafo, queda demostrada su implicación también en re-replicación.

En las ensayos realizados para la elaboración de la tesis quedó demostrado que MLN4924 no desencadenó senescencia en las líneas celulares de SE (Figura 29, página 101). Se observó un mínimo marcaje residual en la línea RDES y ausencia total en la línea RM82, que no expresa p21. RM82 pese a no expresar p21 compartió mecanismo de respuesta con el resto de líneas celulares de SE, por ello consideramos que no eran p21 ni la senescencia los principales efectores de respuesta al fármaco.

- Alteración de la ruta de NFKß: en ensayos preclínicos de MLN4924 en líneas celulares de leucemia mieloide aguda y linfoma difuso de células grandes $B$, quedó demostrado la eficacia del fármaco al encontrar entre ellas líneas con las $\mathrm{IC}_{50}$ más bajas del total de ensayos publicados con MLN4924. En este caso la diana principal alterada por el fármaco era la ruta $N F \kappa \beta$. Se constató la disminución de p65 y NFк $\beta$ en el núcleo así como el acúmulo de plкBa. La alteración de esta ruta desencadenaba bloqueo en G1 y apoptosis en las líneas de linfoma. En las líneas de leucemia por el contrario provocaba acúmulo de especies reactivas del oxígeno (ROS), alteración del estado rédox y daño al DNA, lo que desencadenaba procesos de apoptosis $^{282,284}$.

En nuestros estudios en líneas celulares de SE no profundizamos en la posible alteración de la ruta NFk $\beta$. Sin embargo sí podemos descartar el mecanismo que la alteración de esta ruta provoca en líneas celulares de linfoma, pues no se produce un acúmulo de células en G1. En cuanto al estrés oxidativo (por el acúmulo de ROS) y la alteración del estado rédox podría ser otro factor a tener en cuenta en futuros estudios para explicar la apoptosis y el daño en el DNA que se produce a dosis altas del fármaco $\left(\geq \mid C_{95}\right)$.

- Autofagia en respuesta al estrés oxidativo: en estudios en líneas celulares de hepatocarcinoma se describió que MLN4924 provocaba acúmulo en G2, daño al DNA y apoptosis, así como un proceso menos común como es la autofagia en respuesta al estrés oxidativo. En cuanto al bloqueo en G2, éste coincide con nuestros resultados al describir a WEE1 como posible inductor del fenotipo. Los autores de la publicación defienden que el mecanismo parcialmente inductor de la autofagia es la inhibición de mTOR por la acumulación de una de sus proteínas inhibidoras, Deptor ${ }^{280}$.

- Sinergia al combinarlo con otros fármacos y radio-sensibilización: este último apartado no describe respuestas específicas a MLN4924 en monoterapia, si no diferentes mecanismos desencadenados por el fármaco (algunos coincidentes con los mencionados anteriormente) que provocan una alteración sinérgica positiva del tratamiento con otro agente terapéutico.

Así, en estudios sobre líneas celulares de cáncer de páncreas se confirmó la radiosensibilización de estas células ya que MLN4924 favorece el incremento de daño al DNA. EL mecanismo molecular subyacente a esta respuesta era el acúmulo de CDT1 y WEE1. Sorprende que el acúmulo de WEE1, que fisiológicamente para el ciclo para reparar daño en el DNA, 
favorezca el daño en el DNA. Los autores lo defienden argumentando que una detención en el ciclo prolongada por WEE1 provoca daño a las moléculas de DNA ${ }^{285}$.

En cuanto a sinergia con otros fármacos, MLN4924 ha dado resultados satisfactorios en líneas cancerígenas de cabeza y cuello y en las de ovario. En las primeras se ha demostrado sinergia con TRAIL incrementando significativamente el nivel de apoptosis como consecuencia de la disminución de los niveles de c-FLIP (una forma truncada de Caspasa 8 sin capacidad enzimática que compite con la forma no truncada en la unión a FADD bloqueando la apoptosis) que induce MLN4924 ${ }^{286}$. En líneas de cáncer de ovario la sinergia se produjo al combinar con Cisplatino ${ }^{275}$. Ambos fármacos incrementaban el daño al DNA y estrés oxidativo. Los autores sugieren que este efecto se debe a la sobreexpresión de NKB/BIK ${ }^{275,286}$.

Las diferentes respuestas a la inhibición de los complejos CRL no son sorprendentes, ya que pese a la enorme selectividad de MLN4924 por su diana específica UBA3 (núcleo catalítico de NAE), su potente acción antitumoral es ejercida a través de diferentes mecanismos en respuesta al fondo genético-proteómico fisiológico celular. En concreto, por la variación intercelular en la configuración de sustratos y componentes de los complejos CRL así como los ubiquitinomas celular-específicos ${ }^{270,346}$. En el trabajo realizado por el grupo de Benett, donde desarrollaron una plataforma de proteómica cuantitativa (AQUA) para dilucidar la arquitectura de la red de los complejos CRL, observaron cómo además del fondo genético y proteíco intrínseco de la célula, la organización de dichos complejos podía sufrir modificaciones por diferentes estímulos celulares (como por ejemplo la aplicación del fármaco MLN4924 y la consecuente inhibición de la nedilación) ${ }^{270}$. Lo cual supuso añadir una nueva variable a las ya mencionadas (como son la altísima variabilidad de los complejos CRL y las diferencias específicas de cada tipo celular) con respecto al motivo de por qué se desencadenan diferentes respuestas moleculares frente al fármaco MLN4924.

Ello nos lleva a reflexionar sobre la evidente necesidad de caracterizar los mecanismos moleculares de respuesta a un determinado fármaco (en este caso MLN4924) en cada tipo de celular maligno para afrontar de una manera más eficiente su posible aplicación clínica. Esta necesidad, que debería extenderse al global de los fármacos y estudios preclínicos, se potencia si el fármaco afecta a sistemas que organizan numerosos procesos celulares $\mathrm{y} / \mathrm{o}$ rutas moleculares interconectadas, como es el caso de los complejos CRL.

\subsection{ENSAYOS CLÍNICOS CON EL FÁRMACO MLN4924 Y FUTURO DEL TRATAMIENTO CLÍNICO DE PACIENTES CON SE}

Hemos presentado una evaluación preclínica en profundidad de MLN4924 en líneas celulares de SE. Nuestros resultados apoyan un alto potencial de sensibilidad de esta entidad tumoral a la inhibición de complejos CRL y se detalla una explicación mecanicista de su actividad revelando a WEE1 como el principal efector de la acción citostática del fármaco (retraso en G2) y participación sutil en apoptosis. A mayores dosis, se ha sugerido el desplazamiento de Ciclina A por Ciclina E en su unión a CDK2 como uno de los principales efectores que conducen al efecto citotóxico de MLN4924. Además de la alta sensibilidad de las líneas de SE en ensayos in vitro, se confirmó, mediante el empleo de xenoinjertos de líneas celulares del sarcoma en ratones CB17/SCID, un notable efecto sobre el desarrollo de los tumores. El ensayo in vivo mostró como a determinadas dosis el fármaco actuó deteniendo el crecimiento tumoral, 
mientras que incrementando ligeramente éstas concentraciones se obtuvo una reducción del tamaño del tumor. Por lo tanto, independientemente del mecanismo molecular de respuesta al fármaco, observamos alta sensibilidad de las células de SE a MLN4924 y que las dosis a las que realiza su acción son fácilmente alcanzables en ensayos in vivo.

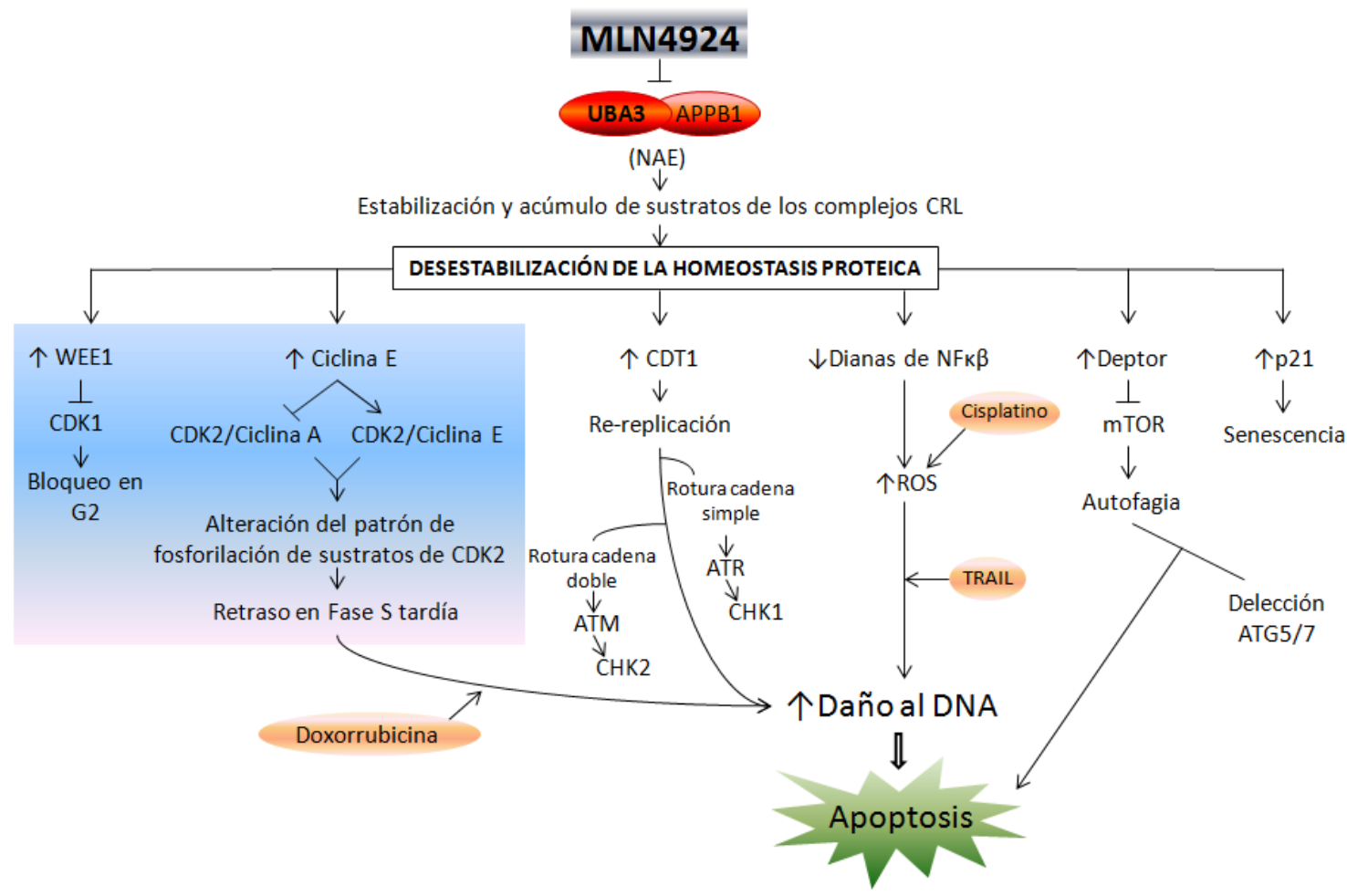

Figura 59: Esquema de diferentes respuestas moleculares al fármaco MLN4924 descritas en estudios preclínicos de diversas neoplasias. Sobre fondo azul destacan los mecanismos moleculares descritos en líneas celulares de SE. En elipses naranjas se especifican algunos fármacos con los que se han realizado estudios de combinación junto a MLN4924.

En los Estados Unidos, se han llevado o se están llevando a cabo ensayos clínicos en Fase1 con el fármaco MLN4924. A través del Instituto Nacional de la Salud de EE.UU. podemos comprobar los ensayos clínicos que se están realizando con determinados fármacos, el objetivo y si el proceso está en marcha o ha finalizado. Facilitan el acceso a esta información mediante la página web "ClinicalTrials.gov". Utilizando el mencionado servicio comprobamos como existen siete estudios clínicos registrados, de entre los cuales dos han finalizado. El primero se realizó con pacientes adultos con melanoma y se basó en el estudio de escala de dosis, calculando la Dosis Máxima Tolerable (DMT), obtener información para recomendar estudios clínicos Fase2 y evaluar actividad antitumoral del fármaco en pacientes con melanoma metastásico (Identificador ClinicalTrials= NCT01011530). El segundo ensayo finalizado fue el realizado con MLN4924 en pacientes con neoplasias no hematológicas (entendemos carcinomas y/o sarcomas). De nuevo el objetivo principal fue calcular la DMT y una primera aproximación hacia la capacidad de curar, prolongar la vida o ser alternativa cuando el tratamiento paliativo estándar no existe o no es eficaz (Identificador ClinicalTrials= NCT00677170). El resto de ensayos clínicos aún no están finalizados: a) Identificador ClinicalTrials= NCT01862328: Estudio Fase1 con MLN4924 y Docetaxel solo o en combinación (con Paclitaxel, Carboplatin o Gemcitabine) en pacientes con tumores sólidos. b) Identificador 
ClinicalTrials= NCT01814826: Estudio Fase1b con MLN4924 y Azacitidine en pacientes sin tratamiento previo con leucemia mieloide aguda mayores de 59 años que tienen pocas probabilidades de beneficiarse de la terapia estándar. c) Identificador ClinicalTrials= NCT00911066: Estudio Fase1 con MLN4924 en pacientes con leucemia mieloide aguda, síndrome mielodisplásico o leucemia linfoblástica aguda cuyos tratamientos estándar no existen o no son eficaces. d) Identificador ClinicalTrials= NCT00722488: Estudio en Fase1 con MLN4924 en pacientes adultos con linfoma o mieloma múltiple. La población de pacientes consistirá en adultos con un diagnóstico confirmado de linfoma (se permite la macroglobulinemia de Waldenstrom) o mieloma múltiple con recaída y/o refractario después de al menos dos regímenes de quimioterapia estándar anteriores y para los que no existe opción curativa. e) Identificador ClinicalTrials= NCT01415765: Estudio clínico en Fases1 y 2 con MLN4924 solo o en combinación con EPOCH-Rituximab en pacientes con linfoma difuso de células grandes B. En este estudio se calcularan las DMT en aplicación única o en combinación, y se establecerán perfiles de expresión génica así como análisis mutacional en recaída o refractario.

No se han publicado los resultados de los estudios clínicos completados. No obstante, la inclusión de la Fase2 en el último estudio clínico descrito anteriormente, así como los datos expuestos por el grupo de J. Sarantopoulos, certifican a MLN4924 como un fármaco apto para estudios clínicos posteriores a Fase1. El estudio refrenda que el fármaco provoca acúmulo de sustratos de complejos CRL en la piel y sangre periférica (CDT1 y NRF2 se acumulan en la piel a partir de la segunda administración). En cuanto a efectos citotóxicos detallan que MLN4924 provoca un incremento tolerable de las transaminasas, bilirrubina y fosfatasa alcalina. En contraposición a nuestros resultados in vivo, la administración de MLN4924 no produjo las lesiones cutáneas que describimos (apartado 4.2.1 de la sección de Resultados) en los pacientes tratados en los ensayos clínicos. Probablemente esta diferencia se debió al modo de administración: en los ensayos clínicos mencionados anteriormente la estrategia general utilizada es de 4 o 5 administraciones intravenosas durante un periodo de 21 días. Sin embargo nuestro ensayo consistió en la aplicación subcutánea bidiaria del fármaco durante 16-24 días (alternando 5 días de tratamiento y dos de descanso). Ello probablemente desencadenó la lesión local de la piel por exposición continua al fármaco MLN4924.

En cuanto al tratamiento clínico de pacientes con SE, nuestro estudio preclínico apoya el inicio de estudios clínicos con MLN4924. Contamos con información útil para planificar dichos estudios al describir dos alternativas de acción del fármaco según la dosis aplicada. A concentraciones bajas-medias MLN4924 actúa fundamentalmente como citostático y su efector principal es WEE1. WEE1 proporciona ventajas importantes a tener en cuenta cuando se considera como diana terapéutica: es una proteína reguladora clave del ciclo celular, la expresión de su gen es ubicua y está presente en cualquier célula maligna que pudiera ser considerada como potencialmente tratable con MLN4924. Además, la pérdida de WEE1 impulsa a las células a catástrofe mitótica y consecuentemente a apoptosis ${ }^{207,330}$. Por ello, las células tumorales tendrían dificultad para eliminar la expresión del gen como estrategia de supervivencia frente al fármaco. Nuestro ensayo de inhibición de la expresión de WEE1 mediante shRNA refrenda que la eliminación de WEE1, incluso parcial, incrementa la apoptosis (Figura 43, página 118). Por último se ha descrito en células de cáncer de páncreas como MLN4924 a través del acúmulo de WEE1 junto a CDT1 radio-sensibiliza a las células tratadas ${ }^{285}$. 
Aplicar radioterapia es una de las estrategias terapéuticas comunes en el tratamiento local de pacientes con $\mathrm{SE}$, principalmente en aquellos en que la posibilidad de resección está comprometida.

Nuestros resultados con la aplicación de MLN4924 a altas dosis demostraron que el fármaco induce daño al DNA y provocó apoptosis (citotóxico). En estudios preclínicos con líneas celulares de otras neoplasias la inducción de daño al DNA del fármaco es utilizado para ensayos de combinación con otros fármacos inductores de daño al DNA, como cisplatino o TRAIL, obteniendo resultados de sinergia ${ }^{275,286}$. Esto supondría una nueva focalización de la aplicación de MLN4924 en pacientes de SE como inductor de apoptosis mediante daño en el $A D N$. Este enfoque es el que plantean en el estudio clínica en Fase1 y 2 en pacientes con linfoma difuso de células grandes B, donde combinan MLN4924 con EPOCH-Rituximab para causar daño en el DNA y apoptosis en las células neoplásicas (Identificador ClinicalTrials= NCT01415765). En nuestros ensayos in vitro comprobamos como la aplicación de MLN4924 (a concentraciones de $\mathrm{IC}_{75}$ y $\left.1 \mu \mathrm{M}\right)$ en combinación con diferentes concentraciones de Doxorrubicina provocó un efecto sinérgico (Figura 19, página 91). Doxorrubicina es un agente que se intercala en la molécula de DNA que forma parte del combinado de fármacos estándar que se aplica a pacientes con SE tratados con quimioterapia. Ello nos plantea la posibilidad de utilizar el fármaco MLN4924 como un potenciador de la terapia multimodal actual frente al SE o como un fármaco candidato a actuación en segunda línea.

En consonancia con la aplicación de MLN4924 en clínica como un agente inductor de daño al DNA y posterior apoptosis en SE, existe una alternativa de combinación, con fármacos inhibidores de proteínas que participen en la reparación del DNA, como PARP1. En el estudio transcriptómico realizado en tumores de SE que permitió distinguir 74 genes diferenciales de la firma 1qGSig, donde destacó CDT2, apareció PARP1 con una tasa de cambio de "2-fold"71. Además en varios de los artículos sobre estudios preclínicos con el fármaco MLN4924 muestran que el incremento del daño al DNA induce una mayor expresión de PARP1 en respuesta a ello $277,280,286$. Por lo tanto, sería interesante combinar en modelos de SE MLN4924, debido a su papel de fármaco inductor de daño al DNA, junto con inhibidores de PARP1 debido a su capacidad de freno en la reparación del DNA.

En definitiva, la alta sensibilidad de las células de SE en ensayos in vitro, así como la reducción del tamaño de los tumores en ensayos in vivo durante la realización de nuestro estudio preclínico, nos induce a invitar a la realización de futuros ensayos clínicos de MLN4924 o agentes similares en pacientes con SE. Esperamos que la caracterización molecular desarrollada en este trabajo facilite la evaluación de este fármaco como alternativa clínica para esta enfermedad. 
CONCLUSIONES 
1. Las líneas celulares de Sarcoma de Ewing (SE) son altamente sensibles a la acción del fármaco MLN4924. Mediante ensayos in vitro se determinó que la mediana de $\mathrm{IC}_{50}$ en proliferación de las 14 líneas analizadas fue en torno a 81nM.

2. No existe diferencia significativa entre la $I_{50}$ de las líneas con ganancia de $1 \mathrm{q}$ y las $1 \mathrm{q}$ normal. De igual manera no existe un patrón de respuesta diferencial al fármaco MLN4924 entre ambos grupos. Por lo tanto podemos extender la aplicabilidad del fármaco a todos los pacientes con SE.

3. El fármaco MLN4924 tiene un efecto antitumoral en ensayos realizados en ratones inmunodeprimidos CB17/SCID con xenoinjertos de líneas celulares de SE. La acción del fármaco in vivo es dual dosis-dependiente: a determinadas concentraciones actúa como citostático, mientras que al incrementar la dosis adquiere capacidad citotóxica. Las concentraciones a emplear para un comportamiento $u$ otro guarda relación con las $\mathrm{IC}_{s}$ calculadas en el ensayo in vitro. MLN4924 provoca alteración de la estructura y daño en la piel de los ratones tratados.

4. En cuanto a la progresión del ciclo celular, MLN4924 provoca una respuesta dual dosisdependiente: $A$ concentraciones inferiores o igual a la $I_{75}$ específica de cada línea celular induce retraso en G2. A concentraciones superiores o igual a la I $\mathrm{I}_{95}$ específica de cada línea celular promueve un retraso en la fase $\mathrm{S}$ tardía.

5. En cuanto a la inducción de apoptosis, MLN4924 tiene un comportamiento próximo a citostático a concentraciones hasta $\mathrm{IC}_{75}$ donde se produce un marcaje de células cl. Caspasa 3 procesada positivas en torno al $8.3 \%$. No existe diferencia significativa entre el porcentaje de apoptosis de células tratadas hasta $\mathrm{IC}_{75}$ y células control (DMSO). Sin embargo a $\mathrm{IC}_{95}$ el fármaco actúa como citotóxico con un $26.8 \%$ de células cl. Caspasa 3 procesada positivas. La mayoría de las células positivas a dicho marcaje se concentran en fase $\mathrm{S}$ tardía y además acumulan un nivel alto de daño al DNA a diferencia de las células control o tratadas con $I_{75}$.

6. MLN4924 inhibe la nedilación de CUL1, CUL4A y CUL4B en líneas de SE. Consideramos dos grupos de proteínas dianas directas, aquellas que se acumulan por acción del fármaco en las cuatro primeras horas de tratamiento. Uno cuyos integrantes se caracterizan por acumularse a altos niveles independientemente de la concentración del fármaco y tiempo de exposición al mismo: WEE1, p27, CDC25A y Ciclina E. Un segundo grupo definido por proteínas que se acumulan a un menor nivel y fundamentalmente a concentraciones altas de MLN4924, probablemente en respuesta al daño en el DNA: p21 y fosforilación en S345 de CHK1. 
7. Descartamos la inducción de niveles considerables de re-replicación y acúmulo de CDT1, así como entrada en fase de senescencia por acúmulo de p21 o p27.

8. Cuando realizamos ensayos de sincronización en mitosis (mediante nocodazol) o en la frontera G1/S (mediante timidina) comprobamos que las proteínas diana aparecen en el instante habitual del ciclo, y posteriormente, se acumulan por la acción del fármaco. Luego MLN4924 no afecta a nivel de transcripción o traducción de proteínas.

9. El acúmulo de WEE1 y la fosforilación que ejerce sobre Y15 de CDK1, componen el principal efector del bloqueo en $\mathrm{G} 2$ a concentraciones inferiores o igual a $\mathrm{IC}_{75}$. Si inhibimos parcialmente su expresión mediante shRNAs o impedimos su actividad aplicando PD0166285 revertimos el bloqueo ejercido por MLN4924 en esta fase del ciclo.

10. El baipás del checkpoint de daño al DNA mediante la aplicación de altas dosis de cafeína así como la inhibición de la expresión de p27 mediante shRNAs no rescató del retraso en G2. P27 se acumuló por el fármaco tanto en el citoplasma como en el núcleo.

11. El acúmulo de Ciclina E, y el consecuente desplazamiento de Ciclina A por Ciclina E en la unión a CDK2 en la etapa final de la fase $S$, probablemente constituye un papel predominante en el retraso de la progresión de la fase $S$ tardía al aplicar concentraciones iguales o superiores a I C $_{95}$ de MLN4924. Este desplazamiento origina una modificación en el patrón de fosforilación de sustratos de CDK2 en la etapa final de fase S. Confirmamos esta asunción al comprobar la localización nuclear de CDC6 en fase S tardía en células de SE tratadas con MLN4924 a IC ${ }_{95}$.

12. La sobreexpresión de Ciclina E o Ciclina A en células de SE provoca un retardo en la progresión del ciclo celular en fase $\mathrm{S}$. El acúmulo de Ciclina $\mathrm{E}$ induce un retraso en fase $\mathrm{S}$ tardía mientras que la sobreexpresión de Ciclina $A$, en agudo contraste, lo desencadena al inicio de esta fase.

13. El acúmulo de las proteínas p27 y CDC25A que induce MLN4924 a concentraciones bajas y altas deben ser de formas inactivas de las mismas. P27 probablemente esté fosforilado en T88 y T74 lo que impide su unión a núcleo catalítico de las CDKs. Mientras que consideramos a CDC25A cumulado inactivo al no producirse una entrada prematura en Mitosis ni en fase $\mathrm{S}$.

14. MLN4924 en combinación con Doxorrubicina inducen un efecto sinérgico en el tratamiento de células de SE. El índice de combinación oscila entre 0.066 y 0.881 , es decir, desde valores de 
sinergia muy fuertes a moderados. A la luz de los resultados en el estudio preclínico, proponemos el uso del fármaco MLN4924 como una prometedora herramienta terapéutica en pacientes con SE. 


\section{BIBLIOGRAFÍA}


1. Hawkins, D.S., et al. Ewing Sarcoma (6th ed.). Philadelphia: Wolters Kluwer Health/Lippincott Williams \& Wilkins. (2011).

2. Stout, A. A tumor of the ulnar nerve. in Proc NY Pathol Soc, Vol. 18 (1918).

3. Angervall, L. \& Enzinger, F.M. Extraskeletal neoplasm resembling Ewing's sarcoma. Cancer 36, 240-251 (1975).

4. Askin, F.B., Rosai, J., Sibley, R.K., Dehner, L.P. \& McAlister, W.H. Malignant small cell tumor of the thoracopulmonary region in childhood: a distinctive clinicopathologic entity of uncertain histogenesis. Cancer 43, 2438-2451 (1979).

5. Jaffe, R., et al. The neuroectodermal tumor of bone. Am J Surg Pathol 8, 885-898 (1984).

6. Aurias, A., Rimbaut, C., Buffe, D., Zucker, J.M. \& Mazabraud, A. Translocation involving chromosome 22 in Ewing's sarcoma. A cytogenetic study of four fresh tumors. Cancer Genet Cytogenet 12, 21-25 (1984).

7. Turc-Carel, C., Philip, I., Berger, M.P., Philip, T. \& Lenoir, G.M. Chromosome study of Ewing's sarcoma (ES) cell lines. Consistency of a reciprocal translocation $\mathrm{t}(11 ; 22)(\mathrm{q} 24 ; \mathrm{q} 12)$. Cancer Genet Cytogenet 12, 1-19 (1984).

8. Whang-Peng, J., et al. Chromosome translocation in peripheral neuroepithelioma. $N$ Engl J Med 311, 584-585 (1984).

9. Delattre, O., et al. Gene fusion with an ETS DNA-binding domain caused by chromosome translocation in human tumours. Nature 359, 162-165 (1992).

10. Delattre, O., et al. The Ewing family of tumors--a subgroup of small-round-cell tumors defined by specific chimeric transcripts. N Engl J Med 331, 294-299 (1994).

11. Llombart-Bosch, A., et al. Histological heterogeneity of Ewing's sarcoma/PNET: an immunohistochemical analysis of 415 genetically confirmed cases with clinical support. Virchows Arch 455, 397-411 (2009).

12. Peydro-Olaya, A., Llombart-Bosch, A., Carda-Batalla, C. \& Lopez-Guerrero, J.A. Electron microscopy and other ancillary techniques in the diagnosis of small round cell tumors. Semin Diagn Pathol 20, 25-45 (2003).

13. Esiashvili, N., Goodman, M. \& Marcus, R.B., Jr. Changes in incidence and survival of Ewing sarcoma patients over the past 3 decades: Surveillance Epidemiology and End Results data. J Pediatr Hematol Oncol 30, 425-430 (2008).

14. Ginsberg, J., Woo, S., Johnson, M., Hicks, M. \& Horowitz, M. Ewing's sarcoma family of tumors: Ewing's sarcoma of bone and soft tissue and the peripheral primitive neuroectodermal tumors. Priniciples and Practice of Pediatric Oncology 4th ed, Pizzo, PA, Poplack, DG (Eds), Lippincott, Williams and Wilkins, Philadelphia (2002).

15. Dorfman, H.D. \& Czerniak, B. Bone cancers. Cancer 75, 203-210 (2006).

16. Iwamoto, Y. Diagnosis and treatment of Ewing's sarcoma. Jpn J Clin Oncol 37, 79-89 (2007).

17. Shing, D.C., et al. FUS/ERG gene fusions in Ewing's tumors. Cancer Res 63, 4568-4576 (2003).

18. Plougastel, B., Zucman, J., Peter, M., Thomas, G. \& Delattre, O. Genomic structure of the EWS gene and its relationship to EWSR1, a site of tumor-associated chromosome translocation. Genomics 18, 609-615 (1993).

19. Plougastel, B., Mattei, M.G., Thomas, G. \& Delattre, O. Cloning and chromosome localization of the mouse Ews gene. Genomics 23, 278-281 (1994).

20. Bertolotti, A., Lutz, Y., Heard, D.J., Chambon, P. \& Tora, L. hTAF(II)68, a novel RNA/ssDNA-binding protein with homology to the pro-oncoproteins TLS/FUS and EWS is associated with both TFIID and RNA polymerase II. EMBO J 15, 5022-5031 (1996).

21. Arvand, A. \& Denny, C.T. Biology of EWS/ETS fusions in Ewing's family tumors. Oncogene 20, 5747-5754 (2001). 
22. Feng, L. \& Lee, K.A. A repetitive element containing a critical tyrosine residue is required for transcriptional activation by the EWS/ATF1 oncogene. Oncogene 20, 4161-4168 (2001).

23. Aman, P., et al. Expression patterns of the human sarcoma-associated genes FUS and EWS and the genomic structure of FUS. Genomics 37, 1-8 (1996).

24. Belyanskaya, L.L., Delattre, O. \& Gehring, H. Expression and subcellular localization of Ewing sarcoma (EWS) protein is affected by the methylation process. Exp Cell Res 288, 374-381 (2003).

25. Ohno, T., et al. The EWS gene, involved in Ewing family of tumors, malignant melanoma of soft parts and desmoplastic small round cell tumors, codes for an RNA binding protein with novel regulatory domains. Oncogene 9, 3087-3097 (1994).

26. Chan, D., et al. Transformation induced by Ewing's sarcoma associated EWS/FLI-1 is suppressed by KRAB/FLI-1. Br J Cancer 88, 137-145 (2003).

27. Baud, V., Lipinski, M., Rassart, E., Poliquin, L. \& Bergeron, D. The human homolog of the mouse common viral integration region, FLI1, maps to 11q23-q24. Genomics 11, 223-224 (1991).

28. Ben-David, Y., Giddens, E.B., Letwin, K. \& Bernstein, A. Erythroleukemia induction by Friend murine leukemia virus: insertional activation of a new member of the ets gene family, Fli-1, closely linked to c-ets-1. Genes Dev 5, 908-918 (1991).

29. Bergeron, D., Poliquin, L., Kozak, C.A. \& Rassart, E. Identification of a common viral integration region in Cas-Br-E murine leukemia virus-induced non-T-, non-B-cell lymphomas. J Virol 65, 7-15 (1991).

30. Rao, V.N., Ohno, T., Prasad, D.D., Bhattacharya, G. \& Reddy, E.S. Analysis of the DNAbinding and transcriptional activation functions of human Fli-1 protein. Oncogene 8 , 2167-2173 (1993).

31. Melet, F., Motro, B., Rossi, D.J., Zhang, L. \& Bernstein, A. Generation of a novel Fli-1 protein by gene targeting leads to a defect in thymus development and a delay in Friend virus-induced erythroleukemia. Mol Cell Biol 16, 2708-2718 (1996).

32. Truong, A.H. \& Ben-David, Y. The role of Fli-1 in normal cell function and malignant transformation. Oncogene 19, 6482-6489 (2000).

33. Maroulakou, I.G. \& Bowe, D.B. Expression and function of Ets transcription factors in mammalian development: a regulatory network. Oncogene 19, 6432-6442 (2000).

34. Athanasiou, M., et al. Increased expression of the ETS-related transcription factor FLI1/ERGB correlates with and can induce the megakaryocytic phenotype. Cell Growth Differ 7, 1525-1534 (1996).

35. Bastian, L.S., Kwiatkowski, B.A., Breininger, J., Danner, S. \& Roth, G. Regulation of the megakaryocytic glycoprotein IX promoter by the oncogenic Ets transcription factor Fli1. Blood 93, 2637-2644 (1999).

36. Deveaux, S., et al. Analysis of the thrombopoietin receptor (MPL) promoter implicates GATA and Ets proteins in the coregulation of megakaryocyte-specific genes. Blood 87, 4678-4685 (1996).

37. Howard, J.C., Yousefi, S., Cheong, G., Bernstein, A. \& Ben-David, Y. Temporal order and functional analysis of mutations within the Fli- 1 and $p 53$ genes during the erythroleukemias induced by F-MuLV. Oncogene 8, $2721-2729$ (1993).

38. Lesault, I., Quang, C.T., Frampton, J. \& Ghysdael, J. Direct regulation of BCL-2 by FLI-1 is involved in the survival of FLI-1-transformed erythroblasts. EMBO J 21, 694-703 (2002).

39. Pereira, R., et al. FLI-1 inhibits differentiation and induces proliferation of primary erythroblasts. Oncogene 18, 1597-1608 (1999).

40. Tamir, A., et al. Fli-1, an Ets-related transcription factor, regulates erythropoietininduced erythroid proliferation and differentiation: evidence for direct transcriptional repression of the Rb gene during differentiation. Mol Cell Biol 19, 4452-4464 (1999). 
41. Sankar, S. \& Lessnick, S.L. Promiscuous partnerships in Ewing's sarcoma. Cancer Genet 204, 351-365 (2011).

42. Bailly, R.A., et al. DNA-binding and transcriptional activation properties of the EWS-FLI1 fusion protein resulting from the $t(11 ; 22)$ translocation in Ewing sarcoma. Mol Cell Biol 14, 3230-3241 (1994).

43. Mao, X., Miesfeldt, S., Yang, H., Leiden, J.M. \& Thompson, C.B. The FLI-1 and chimeric EWS-FLI-1 oncoproteins display similar DNA binding specificities. J Biol Chem 269, 18216-18222 (1994).

44. May, W.A., et al. The Ewing's sarcoma EWS/FLI-1 fusion gene encodes a more potent transcriptional activator and is a more powerful transforming gene than FLI-1. Mol Cell Biol 13, 7393-7398 (1993).

45. Ohno, T., Rao, V.N. \& Reddy, E.S. EWS/Fli-1 chimeric protein is a transcriptional activator. Cancer Res 53, 5859-5863 (1993).

46. Spahn, L., et al. Homotypic and heterotypic interactions of EWS, FLI1 and their oncogenic fusion protein. Oncogene 22, 6819-6829 (2003).

47. Carrere, S., Verger, A., Flourens, A., Stehelin, D. \& Duterque-Coquillaud, M. Erg proteins, transcription factors of the Ets family, form homo, heterodimers and ternary complexes via two distinct domains. Oncogene 16, 3261-3268 (1998).

48. Hahm, K.B., et al. Repression of the gene encoding the TGF-beta type II receptor is a major target of the EWS-FLI1 oncoprotein. Nat Genet 23, 222-227 (1999).

49. Lin, P.P., et al. Differential transactivation by alternative EWS-FLI1 fusion proteins correlates with clinical heterogeneity in Ewing's sarcoma. Cancer Res 59, 1428-1432 (1999).

50. Lessnick, S.L., Dacwag, C.S. \& Golub, T.R. The Ewing's sarcoma oncoprotein EWS/FLI induces a p53-dependent growth arrest in primary human fibroblasts. Cancer Cell 1, 393-401 (2002).

51. Dauphinot, L., et al. Analysis of the expression of cell cycle regulators in Ewing cell lines: EWS-FLI-1 modulates p57KIP2and c-Myc expression. Oncogene 20, 3258-3265 (2001).

52. Fukuma, M., Okita, H., Hata, J. \& Umezawa, A. Upregulation of Id2, an oncogenic helixloop-helix protein, is mediated by the chimeric EWS/ets protein in Ewing sarcoma. Oncogene 22, 1-9 (2003).

53. Nakatani, F., et al. Identification of p21WAF1/CIP1 as a direct target of EWS-Fli1 oncogenic fusion protein. J Biol Chem 278, 15105-15115 (2003).

54. Scotlandi, K., et al. Insulin-like growth factor I receptor-mediated circuit in Ewing's sarcoma/peripheral neuroectodermal tumor: a possible therapeutic target. Cancer Res 56, 4570-4574 (1996).

55. Strammiello, R., et al. Impact of IGF-I/IGF-IR circuit on the angiogenetic properties of Ewing's sarcoma cells. Horm Metab Res 35, 675-684 (2003).

56. Prieur, A., Tirode, F., Cohen, P. \& Delattre, O. EWS/FLI-1 silencing and gene profiling of Ewing cells reveal downstream oncogenic pathways and a crucial role for repression of insulin-like growth factor binding protein 3. Mol Cell Biol 24, 7275-7283 (2004).

57. Toretsky, J.A., Kalebic, T., Blakesley, V., LeRoith, D. \& Helman, L.J. The insulin-like growth factor-I receptor is required for EWS/FLI-1 transformation of fibroblasts. $J$ Biol Chem 272, 30822-30827 (1997).

58. Mendiola, M., et al. The orphan nuclear receptor DAX1 is up-regulated by the EWS/FLI1 oncoprotein and is highly expressed in Ewing tumors. Int J Cancer 118, 13811389 (2006).

59. Abaan, O.D., et al. PTPL1 is a direct transcriptional target of EWS-FLI1 and modulates Ewing's Sarcoma tumorigenesis. Oncogene 24, 2715-2722 (2005). 
60. Kikuchi, R., et al. Ewing's sarcoma fusion protein, EWS/Fli-1 and Fli-1 protein induce PLD2 but not PLD1 gene expression by binding to an ETS domain of 5' promoter. Oncogene 26, 1802-1810 (2007).

61. Smith, R., et al. Expression profiling of EWS/FLI identifies NKX2.2 as a critical target gene in Ewing's sarcoma. Cancer Cell 9, 405-416 (2006).

62. Ramakrishnan, R., et al. Role of protein-protein interactions in the antiapoptotic function of EWS-Fli-1. Oncogene 23, 7087-7094 (2004).

63. Fuchs, B., Inwards, C.Y. \& Janknecht, R. Vascular endothelial growth factor expression is up-regulated by EWS-ETS oncoproteins and Sp1 and may represent an independent predictor of survival in Ewing's sarcoma. Clin Cancer Res 10, 1344-1353 (2004).

64. Zwerner, J.P., et al. The EWS/FLI1 oncogenic transcription factor deregulates GLI1. Oncogene 27, 3282-3291 (2008).

65. Kauer, M., et al. A molecular function map of Ewing's sarcoma. PLoS One 4, e5415 (2009).

66. Le Deley, M.C., et al. Impact of EWS-ETS fusion type on disease progression in Ewing's sarcoma/peripheral primitive neuroectodermal tumor: prospective results from the cooperative Euro-E.W.I.N.G. 99 trial. J Clin Oncol 28, 1982-1988 (2010).

67. van Doorninck, J.A., et al. Current treatment protocols have eliminated the prognostic advantage of type 1 fusions in Ewing sarcoma: a report from the Children's Oncology Group. J Clin Oncol 28, 1989-1994 (2010).

68. Armengol, G., et al. Recurrent gains of $1 q, 8$ and 12 in the Ewing family of tumours by comparative genomic hybridization. Br J Cancer 75, 1403-1409 (1997).

69. Douglass, E.C., et al. A second nonrandom translocation, $\operatorname{der}(16) t(1 ; 16)(q 21 ; q 13)$, in Ewing sarcoma and peripheral neuroectodermal tumor. Cytogenet Cell Genet 53, 87-90 (1990).

70. Hattinger, C.M., et al. Prognostic impact of deletions at $1 \mathrm{p} 36$ and numerical aberrations in Ewing tumors. Genes Chromosomes Cancer 24, 243-254 (1999).

71. Mackintosh, C., et al. 1q gain and CDT2 overexpression underlie an aggressive and highly proliferative form of Ewing sarcoma. Oncogene 31, 1287-1298 (2012).

72. Kullendorff, C.M., et al. Cytogenetic aberrations in Ewing sarcoma: are secondary changes associated with clinical outcome? Med Pediatr Oncol 32, 79-83 (1999).

73. Tarkkanen, M., et al. Clinical correlations of genetic changes by comparative genomic hybridization in Ewing sarcoma and related tumors. Cancer Genet Cytogenet 114, 3541 (1999).

74. Zielenska, M., et al. Acquisition of secondary structural chromosomal changes in pediatric ewing sarcoma is a probable prognostic factor for tumor response and clinical outcome. Cancer 91, 2156-2164 (2001).

75. de Alava, E., et al. Prognostic impact of P53 status in Ewing sarcoma. Cancer 89, 783792 (2000).

76. Lopez-Guerrero, J.A., Pellin, A., Noguera, R., Carda, C. \& Llombart-Bosch, A. Molecular analysis of the 9p21 locus and p53 genes in Ewing family tumors. Lab Invest 81, 803814 (2001).

77. Kovar, H., et al. Among genes involved in the RB dependent cell cycle regulatory cascade, the p16 tumor suppressor gene is frequently lost in the Ewing family of tumors. Oncogene 15, 2225-2232 (1997).

78. Huang, H.Y., et al. Ewing sarcomas with p53 mutation or p16/p14ARF homozygous deletion: a highly lethal subset associated with poor chemoresponse. J Clin Oncol 23, 548-558 (2005).

79. Eliazer, S., Spencer, J., Ye, D., Olson, E. \& Ilaria, R.L., Jr. Alteration of mesodermal cell differentiation by EWS/FLI-1, the oncogene implicated in Ewing's sarcoma. Mol Cell Biol 23, 482-492 (2003). 
80. von Levetzow, C., et al. Modeling initiation of Ewing sarcoma in human neural crest cells. PLoS One 6, e19305 (2011).

81. Riggi, N., et al. Development of Ewing's sarcoma from primary bone marrow-derived mesenchymal progenitor cells. Cancer Res 65, 11459-11468 (2005).

82. Riggi, N., et al. EWS-FLI-1 expression triggers a Ewing's sarcoma initiation program in primary human mesenchymal stem cells. Cancer Res 68, 2176-2185 (2008).

83. Herrero-Martin, D., et al. Stable interference of EWS-FLI1 in an Ewing sarcoma cell line impairs IGF-1/IGF-1R signalling and reveals TOPK as a new target. Br J Cancer 101, 8090 (2009).

84. Deneen, B. \& Denny, C.T. Loss of p16 pathways stabilizes EWS/FLI1 expression and complements EWS/FLI1 mediated transformation. Oncogene 20, 6731-6741 (2001).

85. Castillero-Trejo, Y., Eliazer, S., Xiang, L., Richardson, J.A. \& Ilaria, R.L., Jr. Expression of the EWS/FLI-1 oncogene in murine primary bone-derived cells Results in EWS/FLI-1dependent, ewing sarcoma-like tumors. Cancer Res 65, 8698-8705 (2005).

86. Torchia, E.C., Jaishankar, S. \& Baker, S.J. Ewing tumor fusion proteins block the differentiation of pluripotent marrow stromal cells. Cancer Res 63, 3464-3468 (2003).

87. Hong, $H_{\text {., }}$ et al. Suppression of induced pluripotent stem cell generation by the p53p21 pathway. Nature 460, 1132-1135 (2009).

88. Kawamura, T., et al. Linking the p53 tumour suppressor pathway to somatic cell reprogramming. Nature 460, 1140-1144 (2009).

89. Li, H., et al. The Ink4/Arf locus is a barrier for iPS cell reprogramming. Nature 460, 1136-1139 (2009).

90. Marion, R.M., et al. A p53-mediated DNA damage response limits reprogramming to ensure iPS cell genomic integrity. Nature 460, 1149-1153 (2009).

91. Raney, R.B., et al. Ewing's sarcoma of soft tissues in childhood: a report from the Intergroup Rhabdomyosarcoma Study, 1972 to 1991. J Clin Oncol 15, 574-582 (1997).

92. McTiernan, A.M., et al. Improving Outcomes After Relapse in Ewing's Sarcoma: Analysis of 114 Patients From a Single Institution. Sarcoma 2006, 83548 (2006).

93. Meier, V.S., Kuhne, T., Jundt, G. \& Gudat, F. Molecular diagnosis of Ewing tumors: improved detection of EWS-FLI-1 and EWS-ERG chimeric transcripts and rapid determination of exon combinations. Diagn Mol Pathol 7, 29-35 (1998).

94. Dagher, R., et al. Molecular confirmation of Ewing sarcoma. J Pediatr Hematol Oncol 23, 221-224 (2001).

95. Fisher, C. Immunohistochemistry in diagnosis of soft tissue tumours. Histopathology 58, 1001-1012 (2011).

96. Folpe, A.L., et al. Morphologic and immunophenotypic diversity in Ewing family tumors: a study of 66 genetically confirmed cases. Am J Surg Pathol 29, 1025-1033 (2005).

97. Romeo, S. \& Dei Tos, A.P. Soft tissue tumors associated with EWSR1 translocation. Virchows Arch 456, 219-234 (2010).

98. Terrier, P., Llombart-Bosch, A. \& Contesso, G. Small round blue cell tumors in bone: prognostic factors correlated to Ewing's sarcoma and neuroectodermal tumors. Semin Diagn Pathol 13, 250-257 (1996).

99. Dejana, E. Endothelial cell-cell junctions: happy together. Nat Rev Mol Cell Biol 5, 261270 (2004).

100. Tirado, O.M., et al. Caveolin-1 (CAV1) is a target of EWS/FLI-1 and a key determinant of the oncogenic phenotype and tumorigenicity of Ewing's sarcoma cells. Cancer Res 66, 9937-9947 (2006).

101. Machado, I., Navarro, S. \& Llombart-Bosch, A. Pautas en el diagnóstico morfológico, inmunohistoquímico y genético de los tumores de células redondas y pequeñas con especial referencia al sarcoma de Ewing/PNET. Patología 45, 145-156 (2012). 
102. Lee, A.F., et al. FLI-1 distinguishes Ewing sarcoma from small cell osteosarcoma and mesenchymal chondrosarcoma. Appl Immunohistochem Mol Morphol 19, 233-238 (2011).

103. Banerjee, S.S., Agbamu, D.A., Eyden, B.P. \& Harris, M. Clinicopathological characteristics of peripheral primitive neuroectodermal tumour of skin and subcutaneous tissue. Histopathology 31, 355-366 (1997).

104. Ehrig, T., Billings, S.D. \& Fanburg-Smith, J.C. Superficial primitive neuroectodermal tumor/Ewing sarcoma (PN/ES): same tumor as deep PN/ES or new entity? Ann Diagn Pathol 11, 153-159 (2007).

105. Schmidt, D., Herrmann, C., Jurgens, H. \& Harms, D. Malignant peripheral neuroectodermal tumor and its necessary distinction from Ewing's sarcoma. A report from the Kiel Pediatric Tumor Registry. Cancer 68, 2251-2259 (1991).

106. Kushner, B.H. \& Meyers, P.A. How effective is dose-intensive/myeloablative therapy against Ewing's sarcoma/primitive neuroectodermal tumor metastatic to bone or bone marrow? The Memorial Sloan-Kettering experience and a literature review. J Clin Oncol 19, 870-880 (2001).

107. Haeusler, J., et al. The value of local treatment in patients with primary, disseminated, multifocal Ewing sarcoma (PDMES). Cancer 116, 443-450 (2010).

108. Bacci, G., et al. Prognostic factors in non-metastatic Ewing's sarcoma tumor of bone: an analysis of 579 patients treated at a single institution with adjuvant or neoadjuvant chemotherapy between 1972 and 1998. Acta Oncol 45, 469-475 (2006).

109. Burchill, S.A. Ewing's sarcoma: diagnostic, prognostic, and therapeutic implications of molecular abnormalities. J Clin Pathol 56, 96-102 (2003).

110. Cotterill, S.J., et al. Prognostic factors in Ewing's tumor of bone: analysis of 975 patients from the European Intergroup Cooperative Ewing's Sarcoma Study Group. $J$ Clin Oncol 18, 3108-3114 (2000).

111. Ahrens, S., et al. Evaluation of prognostic factors in a tumor volume-adapted treatment strategy for localized Ewing sarcoma of bone: the CESS 86 experience. Cooperative Ewing Sarcoma Study. Med Pediatr Oncol 32, 186-195 (1999).

112. Schleiermacher, G., et al. Increased risk of systemic relapses associated with bone marrow micrometastasis and circulating tumor cells in localized ewing tumor. $J$ Clin Oncol 21, 85-91 (2003).

113. Ozaki, T., et al. Genetic imbalances revealed by comparative genomic hybridization in Ewing tumors. Genes Chromosomes Cancer 32, 164-171 (2001).

114. Ohali, A., et al. Association between telomerase activity and outcome in patients with nonmetastatic Ewing family of tumors. J Clin Oncol 21, 3836-3843 (2003).

115. de Alava, E., et al. EWS-FLI1 fusion transcript structure is an independent determinant of prognosis in Ewing's sarcoma. J Clin Oncol 16, 1248-1255 (1998).

116. Juergens, C., et al. Safety assessment of intensive induction with vincristine, ifosfamide, doxorubicin, and etoposide (VIDE) in the treatment of Ewing tumors in the EURO-E.W.I.N.G. 99 clinical trial. Pediatr Blood Cancer 47, 22-29 (2006).

117. Klingebiel, T., et al. Treatment of children with metastatic soft tissue sarcoma with oral maintenance compared to high dose chemotherapy: report of the HD CWS-96 trial. Pediatr Blood Cancer 50, 739-745 (2008).

118. Paulussen, M., et al. Localized Ewing tumor of bone: final results of the cooperative Ewing's Sarcoma Study CESS 86. J Clin Oncol 19, 1818-1829 (2001).

119. Paulussen, M., et al. Results of the EICESS-92 Study: two randomized trials of Ewing's sarcoma treatment--cyclophosphamide compared with ifosfamide in standard-risk patients and assessment of benefit of etoposide added to standard treatment in highrisk patients. J Clin Oncol 26, 4385-4393 (2008).

120. Hustu, H.O., Holton, C., James, D., Jr. \& Pinkel, D. Treatment of Ewing's sarcoma with concurrent radiotherapy and chemotherapy. J Pediatr 73, 249-251 (1968). 
121. Nesbit, M.E., Jr., et al. Multimodal therapy for the management of primary, nonmetastatic Ewing's sarcoma of bone: a long-term follow-up of the First Intergroup study. J Clin Oncol 8, 1664-1674 (1990).

122. Burgert, E.O., Jr., et al. Multimodal therapy for the management of nonpelvic, localized Ewing's sarcoma of bone: intergroup study IESS-II. J Clin Oncol 8, 1514-1524 (1990).

123. Jurgens, H., et al. Multidisciplinary treatment of primary Ewing's sarcoma of bone. A 6year experience of a European Cooperative Trial. Cancer 61, 23-32 (1988).

124. Kung, F.H., et al. Ifosfamide/etoposide combination in the treatment of recurrent malignant solid tumors of childhood. A Pediatric Oncology Group Phase II study. Cancer 71, 1898-1903 (1993).

125. Grier, H.E., et al. Addition of ifosfamide and etoposide to standard chemotherapy for Ewing's sarcoma and primitive neuroectodermal tumor of bone. N Engl J Med 348, 694-701 (2003).

126. Ladenstein, R., et al. Primary disseminated multifocal Ewing sarcoma: results of the Euro-EWING 99 trial. J Clin Oncol 28, 3284-3291 (2010).

127. Granowetter, L., et al. Dose-intensified compared with standard chemotherapy for nonmetastatic Ewing sarcoma family of tumors: a Children's Oncology Group Study. J Clin Oncol 27, 2536-2541 (2009).

128. Womer, R.B., et al. Randomized controlled trial of interval-compressed chemotherapy for the treatment of localized Ewing sarcoma: a report from the Children's Oncology Group. J Clin Oncol 30, 4148-4154 (2012).

129. Pommier, Y. Topoisomerase I inhibitors: camptothecins and beyond. Nat Rev Cancer 6, 789-802 (2006).

130. Pappo, A.S., et al. R1507, a monoclonal antibody to the insulin-like growth factor 1 receptor, in patients with recurrent or refractory Ewing sarcoma family of tumors: results of a phase II Sarcoma Alliance for Research through Collaboration study. J Clin Oncol 29, 4541-4547 (2011).

131. Wagner, L. Camptothecin-based regimens for treatment of ewing sarcoma: past studies and future directions. Sarcoma 2011, 957957 (2011).

132. Barretina, J., et al. The Cancer Cell Line Encyclopedia enables predictive modelling of anticancer drug sensitivity. Nature 483, 603-607 (2012).

133. Saylors, R.L., 3rd, et al. Cyclophosphamide plus topotecan in children with recurrent or refractory solid tumors: a Pediatric Oncology Group phase II study. J Clin Oncol 19, 3463-3469 (2001).

134. Bisogno, G., et al. Phase II study of a protracted irinotecan schedule in children with refractory or recurrent soft tissue sarcoma. Cancer 106, 703-707 (2006).

135. Aune, G.J., et al. Von Hippel-Lindau-coupled and transcription-coupled nucleotide excision repair-dependent degradation of RNA polymerase II in response to trabectedin. Clin Cancer Res 14, 6449-6455 (2008).

136. Scotlandi, K., et al. Effectiveness of Ecteinascidin-743 against drug-sensitive and resistant bone tumor cells. Clin Cancer Res 8, 3893-3903 (2002).

137. Grohar, P.J., et al. Ecteinascidin 743 interferes with the activity of EWS-FLI1 in Ewing sarcoma cells. Neoplasia 13, 145-153 (2011).

138. Garnett, M.J., et al. Systematic identification of genomic markers of drug sensitivity in cancer cells. Nature 483, 570-575 (2012).

139. Brenner, J.C., et al. PARP-1 inhibition as a targeted strategy to treat Ewing's sarcoma. Cancer Res (2012).

140. Scotlandi, K., et al. Blockage of insulin-like growth factor-I receptor inhibits the growth of Ewing's sarcoma in athymic mice. Cancer Res 58, 4127-4131 (1998).

141. Beltran, P.J., et al. Efficacy of ganitumab (AMG 479), alone and in combination with rapamycin, in Ewing's and osteogenic sarcoma models. J Pharmacol Exp Ther 337, 644654 (2011). 
142. Houghton, P.J., et al. Initial testing of a monoclonal antibody (IMC-A12) against IGF-1R by the Pediatric Preclinical Testing Program. Pediatr Blood Cancer 54, 921-926 (2010).

143. Kang, H.G., et al. Inhibition of the insulin-like growth factor I receptor by epigallocatechin gallate blocks proliferation and induces the death of Ewing tumor cells. Mol Cancer Ther 9, 1396-1407 (2010).

144. Kolb, E.A., et al. Initial testing (stage 1) of a monoclonal antibody (SCH 717454) against the IGF-1 receptor by the pediatric preclinical testing program. Pediatr Blood Cancer 50, 1190-1197 (2008).

145. Kolb, E.A., et al. Initial testing (stage 1) of the IGF-1 receptor inhibitor BMS-754807 by the pediatric preclinical testing program. Pediatr Blood Cancer 56, 595-603 (2011).

146. Kurmasheva, R.T., et al. The insulin-like growth factor-1 receptor-targeting antibody, CP-751,871, suppresses tumor-derived VEGF and synergizes with rapamycin in models of childhood sarcoma. Cancer Res 69, 7662-7671 (2009).

147. Manara, M.C., et al. Preclinical in vivo study of new insulin-like growth factor-I receptor--specific inhibitor in Ewing's sarcoma. Clin Cancer Res 13, 1322-1330 (2007).

148. Martins, A.S., et al. Insulin-like growth factor I receptor pathway inhibition by ADW742, alone or in combination with imatinib, doxorubicin, or vincristine, is a novel therapeutic approach in Ewing tumor. Clin Cancer Res 12, 3532-3540 (2006).

149. Scotlandi, K., et al. Antitumor activity of the insulin-like growth factor-I receptor kinase inhibitor NVP-AEW541 in musculoskeletal tumors. Cancer Res 65, 3868-3876 (2005).

150. Krishnan, K., et al. Ezrin mediates growth and survival in Ewing's sarcoma through the AKT/mTOR, but not the MAPK, signaling pathway. Clin Exp Metastasis 23, 227-236 (2006).

151. Liu, L., et al. Rapamycin inhibits IGF-1 stimulated cell motility through PP2A pathway. PLoS One 5, e10578 (2010).

152. Malempati, S., et al. Phase I/II trial and pharmacokinetic study of cixutumumab in pediatric patients with refractory solid tumors and Ewing sarcoma: a report from the Children's Oncology Group. J Clin Oncol 30, 256-262 (2012).

153. Sailer, S.L., Harmon, D.C., Mankin, H.J., Truman, J.T. \& Suit, H.D. Ewing's sarcoma: surgical resection as a prognostic factor. Int J Radiat Oncol Biol Phys 15, 43-52 (1988).

154. Schuck, A., et al. Local therapy in localized Ewing tumors: results of 1058 patients treated in the CESS 81, CESS 86, and EICESS 92 trials. Int J Radiat Oncol Biol Phys 55, 168-177 (2003).

155. Bernstein, M.L., et al. Intensive therapy with growth factor support for patients with Ewing tumor metastatic at diagnosis: Pediatric Oncology Group/Children's Cancer Group Phase II Study 9457--a report from the Children's Oncology Group. J Clin Oncol 24, 152-159 (2006).

156. Pinkerton, C.R., et al. Treatment strategies for metastatic Ewing's sarcoma. Eur J Cancer 37, 1338-1344 (2001).

157. Pardee, A.B. A restriction point for control of normal animal cell proliferation. Proc Natl Acad Sci U S A 71, 1286-1290 (1974).

158. Sherr, C.J. Cancer cell cycles. Science 274, 1672-1677 (1996).

159. Mikhailov, A., Shinohara, M. \& Rieder, C.L. The p38-mediated stress-activated checkpoint. A rapid response system for delaying progression through antephase and entry into mitosis. Cell Cycle 4, 57-62 (2005).

160. Baker, D.J., Chen, J. \& van Deursen, J.M. The mitotic checkpoint in cancer and aging: what have mice taught us? Curr Opin Cell Biol 17, 583-589 (2005).

161. Musacchio, A. \& Salmon, E.D. The spindle-assembly checkpoint in space and time. Nat Rev Mol Cell Biol 8, 379-393 (2007).

162. Tang, Z., Shu, H., Oncel, D., Chen, S. \& Yu, H. Phosphorylation of Cdc20 by Bub1 provides a catalytic mechanism for APC/C inhibition by the spindle checkpoint. $\mathrm{Mol}$ Cell 16, 387-397 (2004). 
163. Lees, E. Cyclin dependent kinase regulation. Curr Opin Cell Biol 7, 773-780 (1995).

164. Morgan, D.O. Principles of CDK regulation. Nature 374, 131-134 (1995).

165. Santamaria, D., et al. Cdk1 is sufficient to drive the mammalian cell cycle. Nature $\mathbf{4 4 8 ,}$ 811-815 (2007).

166. Evans, T., Rosenthal, E.T., Youngblom, J., Distel, D. \& Hunt, T. Cyclin: a protein specified by maternal mRNA in sea urchin eggs that is destroyed at each cleavage division. Cell 33, 389-396 (1983).

167. Bardin, A.J. \& Amon, A. Men and sin: what's the difference? Nat Rev Mol Cell Biol 2, 815-826 (2001).

168. Glotzer, M., Murray, A.W. \& Kirschner, M.W. Cyclin is degraded by the ubiquitin pathway. Nature 349, 132-138 (1991).

169. Nebreda, A.R. CDK activation by non-cyclin proteins. Curr Opin Cell Biol 18, 192-198 (2006).

170. Alcorta, D.A., et al. Involvement of the cyclin-dependent kinase inhibitor p16 (INK4a) in replicative senescence of normal human fibroblasts. Proc Natl Acad Sci U S A 93, 13742-13747 (1996).

171. Harper, J.W. Cyclin dependent kinase inhibitors. Cancer Surv 29, 91-107 (1997).

172. Pavletich, N.P. Mechanisms of cyclin-dependent kinase regulation: structures of Cdks, their cyclin activators, and Cip and INK4 inhibitors. J Mol Biol 287, 821-828 (1999).

173. Minshull, J., Golsteyn, R., Hill, C.S. \& Hunt, T. The A- and B-type cyclin associated cdc2 kinases in Xenopus turn on and off at different times in the cell cycle. EMBO J 9, 28652875 (1990).

174. Pines, J. \& Hunter, T. Human cyclins A and B1 are differentially located in the cell and undergo cell cycle-dependent nuclear transport. J Cell Biol 115, 1-17 (1991).

175. Pines, J. \& Rieder, C.L. Re-staging mitosis: a contemporary view of mitotic progression. Nat Cell Biol 3, E3-6 (2001).

176. Mitra, J. \& Enders, G.H. Cyclin A/Cdk2 complexes regulate activation of Cdk1 and Cdc25 phosphatases in human cells. Oncogene 23, 3361-3367 (2004).

177. Fung, T.K., Ma, H.T. \& Poon, R.Y. Specialized roles of the two mitotic cyclins in somatic cells: cyclin A as an activator of M phase-promoting factor. Mol Biol Cell 18, 1861-1873 (2007).

178. Lukas, C., et al. Accumulation of cyclin B1 requires E2F and cyclin-A-dependent rearrangement of the anaphase-promoting complex. Nature 401, 815-818 (1999).

179. Mitra, J., Enders, G.H., Azizkhan-Clifford, J. \& Lengel, K.L. Dual regulation of the anaphase promoting complex in human cells by cyclin A-Cdk2 and cyclin A-Cdk1 complexes. Cell Cycle 5, 661-666 (2006).

180. De Souza, C.P., Ellem, K.A. \& Gabrielli, B.G. Centrosomal and cytoplasmic Cdc2/cyclin B1 activation precedes nuclear mitotic events. Exp Cell Res 257, 11-21 (2000).

181. Jackman, M., Lindon, C., Nigg, E.A. \& Pines, J. Active cyclin B1-Cdk1 first appears on centrosomes in prophase. Nat Cell Biol 5, 143-148 (2003).

182. Bassermann, F., et al. NIPA defines an SCF-type mammalian E3 ligase that regulates mitotic entry. Cell 122, 45-57 (2005).

183. Lolli, G. \& Johnson, L.N. CAK-Cyclin-dependent Activating Kinase: a key kinase in cell cycle control and a target for drugs? Cell Cycle 4, 572-577 (2005).

184. Solomon, M.J., Lee, T. \& Kirschner, M.W. Role of phosphorylation in p34cdc2 activation: identification of an activating kinase. Mol Biol Cell 3, 13-27 (1992).

185. Smits, V.A., et al. p21 inhibits Thr161 phosphorylation of Cdc2 to enforce the G2 DNA damage checkpoint. J Biol Chem 275, 30638-30643 (2000).

186. Mueller, P.R., Coleman, T.R., Kumagai, A. \& Dunphy, W.G. Myt1: a membraneassociated inhibitory kinase that phosphorylates Cdc2 on both threonine-14 and tyrosine-15. Science 270, 86-90 (1995). 
187. Parker, L.L. \& Piwnica-Worms, H. Inactivation of the p34cdc2-cyclin B complex by the human WEE1 tyrosine kinase. Science 257, 1955-1957 (1992).

188. Smith, A., Simanski, S., Fallahi, M. \& Ayad, N.G. Redundant ubiquitin ligase activities regulate wee1 degradation and mitotic entry. Cell Cycle 6, 2795-2799 (2007).

189. Nakajima, H., Toyoshima-Morimoto, F., Taniguchi, E. \& Nishida, E. Identification of a consensus motif for Plk (Polo-like kinase) phosphorylation reveals Myt1 as a Plk1 substrate. J Biol Chem 278, 25277-25280 (2003).

190. Fasulo, B., et al. Chk1 and Wee1 kinases coordinate DNA replication, chromosome condensation, and anaphase entry. Mol Biol Cell 23, 1047-1057 (2012).

191. Beck, H., et al. Cyclin-dependent kinase suppression by WEE1 kinase protects the genome through control of replication initiation and nucleotide consumption. Mol Cell Biol 32, 4226-4236 (2012).

192. Dominguez-Kelly, R., et al. Wee1 controls genomic stability during replication by regulating the Mus81-Eme1 endonuclease. J Cell Biol 194, 567-579 (2011).

193. Caretti, V., et al. WEE1 Kinase Inhibition Enhances the Radiation Response of Diffuse Intrinsic Pontine Gliomas. Mol Cancer Ther 12, 141-150 (2013).

194. Hashimoto, O., et al. Cell cycle regulation by the Wee1 inhibitor PD0166285, pyrido [2,3-d] pyimidine, in the B16 mouse melanoma cell line. BMC Cancer 6, 292 (2006).

195. Mizuarai, S., et al. Discovery of gene expression-based pharmacodynamic biomarker for a p53 context-specific anti-tumor drug Wee1 inhibitor. Mol Cancer 8, 34 (2009).

196. PosthumaDeBoer, J., et al. WEE1 inhibition sensitizes osteosarcoma to radiotherapy. BMC Cancer 11, 156 (2011).

197. Stathis, A. \& Oza, A. Targeting Wee1-like protein kinase to treat cancer. Drug News Perspect 23, 425-429 (2010).

198. Wang, Y., et al. Radiosensitization of p53 mutant cells by PD0166285, a novel G(2) checkpoint abrogator. Cancer Res 61, 8211-8217 (2001).

199. Hirai, H., et al. Small-molecule inhibition of Wee1 kinase by MK-1775 selectively sensitizes p53-deficient tumor cells to DNA-damaging agents. Mol Cancer Ther 8, 29923000 (2009).

200. Guertin, A.D., et al. Unique functions of CHK1 and WEE1 underlie synergistic antitumor activity upon pharmacologic inhibition. Cancer Cell Int 12, 45 (2012).

201. Strausfeld, U., et al. Dephosphorylation and activation of a p34cdc2/cyclin B complex in vitro by human CDC25 protein. Nature 351, 242-245 (1991).

202. Garner-Hamrick, P.A. \& Fisher, C. Antisense phosphorothioate oligonucleotides specifically down-regulate cdc25B causing S-phase delay and persistent antiproliferative effects. Int J Cancer 76, 720-728 (1998).

203. Turowski, P., et al. Functional cdc25C dual-specificity phosphatase is required for Sphase entry in human cells. Mol Biol Cell 14, 2984-2998 (2003).

204. Goldstone, S., Pavey, S., Forrest, A., Sinnamon, J. \& Gabrielli, B. Cdc25-dependent activation of cyclin A/cdk2 is blocked in $\mathrm{G} 2$ phase arrested cells independently of ATM/ATR. Oncogene 20, 921-932 (2001).

205. Lammer, C., et al. The cdc25B phosphatase is essential for the G2/M phase transition in human cells. J Cell Sci 111 ( Pt 16), 2445-2453 (1998).

206. Lindqvist, A., Kallstrom, H., Lundgren, A., Barsoum, E. \& Rosenthal, C.K. Cdc25B cooperates with $\mathrm{Cdc} 25 \mathrm{~A}$ to induce mitosis but has a unique role in activating cyclin B1Cdk1 at the centrosome. J Cell Biol 171, 35-45 (2005).

207. Potapova, T.A., Sivakumar, S., Flynn, J.N., Li, R. \& Gorbsky, G.J. Mitotic progression becomes irreversible in prometaphase and collapses when Wee1 and Cdc25 are inhibited. Mol Biol Cell 22, 1191-1206 (2011).

208. Ando, T., et al. Involvement of the interaction between p21 and proliferating cell nuclear antigen for the maintenance of G2/M arrest after DNA damage. J Biol Chem 276, 42971-42977 (2001). 
209. Toyoshima, H. \& Hunter, T. p27, a novel inhibitor of G1 cyclin-Cdk protein kinase activity, is related to p21. Cell 78, 67-74 (1994).

210. Pagano, M. Control of DNA synthesis and mitosis by the Skp2-p27-Cdk1/2 axis. Mol Cell 14, 414-416 (2004).

211. Lera, R.F. \& Burkard, M.E. High mitotic activity of Polo-like kinase 1 is required for chromosome segregation and genomic integrity in human epithelial cells. J Biol Chem 287, 42812-42825 (2012).

212. Barr, F.A., Sillje, H.H. \& Nigg, E.A. Polo-like kinases and the orchestration of cell division. Nat Rev Mol Cell Biol 5, 429-440 (2004).

213. Suijkerbuijk, S.J., Vleugel, M., Teixeira, A. \& Kops, G.J. Integration of kinase and phosphatase activities by BUBR1 ensures formation of stable kinetochore-microtubule attachments. Dev Cell 23, 745-755 (2012).

214. Hauf, S., et al. Dissociation of cohesin from chromosome arms and loss of arm cohesion during early mitosis depends on phosphorylation of SA2. PLOS Biol 3, e69 (2005).

215. Toyoshima-Morimoto, F., Taniguchi, E., Shinya, N., Iwamatsu, A. \& Nishida, E. Polo-like kinase 1 phosphorylates cyclin B1 and targets it to the nucleus during prophase. Nature 410, 215-220 (2001).

216. Elia, A.E., Cantley, L.C. \& Yaffe, M.B. Proteomic screen finds pSer/pThr-binding domain localizing Plk1 to mitotic substrates. Science 299, 1228-1231 (2003).

217. Watanabe, N., et al. M-phase kinases induce phospho-dependent ubiquitination of somatic Wee1 by SCFbeta-TrCP. Proc Natl Acad Sci U S A 101, 4419-4424 (2004).

218. Roshak, A.K., et al. The human polo-like kinase, PLK, regulates cdc2/cyclin B through phosphorylation and activation of the cdc25C phosphatase. Cell Signal 12, 405-411 (2000).

219. Toyoshima-Morimoto, F., Taniguchi, E. \& Nishida, E. Plk1 promotes nuclear translocation of human Cdc25C during prophase. EMBO Rep 3, 341-348 (2002).

220. Jang, Y.J., Ji, J.H., Choi, Y.C., Ryu, C.J. \& Ko, S.Y. Regulation of Polo-like kinase 1 by DNA damage in mitosis. Inhibition of mitotic PLK-1 by protein phosphatase 2A. J Biol Chem 282, 2473-2482 (2007).

221. van Vugt, M.A. \& Medema, R.H. Getting in and out of mitosis with Polo-like kinase-1. Oncogene 24, 2844-2859 (2005).

222. Ikeda, M., Chiba, S., Ohashi, K. \& Mizuno, K. Furry protein promotes aurora Amediated Polo-like kinase 1 activation. J Biol Chem 287, 27670-27681 (2012).

223. Fu, J., Bian, M., Jiang, Q. \& Zhang, C. Roles of Aurora kinases in mitosis and tumorigenesis. Mol Cancer Res 5, 1-10 (2007).

224. Van Horn, R.D., et al. Cdk1 activity is required for mitotic activation of aurora A during G2/M transition of human cells. J Biol Chem 285, 21849-21857 (2010).

225. Marumoto, T., et al. Aurora-A kinase maintains the fidelity of early and late mitotic events in HeLa cells. J Biol Chem 278, 51786-51795 (2003).

226. Dutertre, S., et al. Phosphorylation of CDC25B by Aurora-A at the centrosome contributes to the G2-M transition. J Cell Sci 117, 2523-2531 (2004).

227. Hirota, T., et al. Aurora-A and an interacting activator, the LIM protein Ajuba, are required for mitotic commitment in human cells. Cell 114, 585-598 (2003).

228. Chen, B.B., Glasser, J.R., Coon, T.A. \& Mallampalli, R.K. FBXL2 is a ubiquitin E3 ligase subunit that triggers mitotic arrest. Cell Cycle 10, 3487-3494 (2011).

229. Coon, T.A., Glasser, J.R., Mallampalli, R.K. \& Chen, B.B. Novel E3 ligase component FBXL7 ubiquitinates and degrades Aurora A, causing mitotic arrest. Cell Cycle 11, 721729 (2012).

230. Crosio, C., et al. Mitotic phosphorylation of histone H3: spatio-temporal regulation by mammalian Aurora kinases. Mol Cell Biol 22, 874-885 (2002). 
231. Gimenez-Abian, J.F., et al. Regulation of sister chromatid cohesion between chromosome arms. Curr Biol 14, 1187-1193 (2004).

232. Zachos, G. \& Gillespie, D.A. Exercising restraints: role of Chk1 in regulating the onset and progression of unperturbed mitosis in vertebrate cells. Cell Cycle 6, 810-813 (2007).

233. Kramer, A., et al. Centrosome-associated Chk1 prevents premature activation of cyclinB-Cdk1 kinase. Nat Cell Biol 6, 884-891 (2004).

234. Schmitt, E., et al. CHK1 phosphorylates CDC25B during the cell cycle in the absence of DNA damage. J Cell Sci 119, 4269-4275 (2006).

235. Chen, M.S., Ryan, C.E. \& Piwnica-Worms, H. Chk1 kinase negatively regulates mitotic function of Cdc25A phosphatase through 14-3-3 binding. Mol Cell Biol 23, 7488-7497 (2003).

236. Sullivan, M. \& Morgan, D.O. Finishing mitosis, one step at a time. Nat Rev Mol Cell Biol 8, 894-903 (2007).

237. Wirth, K.G., et al. Loss of the anaphase-promoting complex in quiescent cells causes unscheduled hepatocyte proliferation. Genes Dev 18, 88-98 (2004).

238. Nakayama, K.I. \& Nakayama, K. Ubiquitin ligases: cell-cycle control and cancer. Nat Rev Cancer 6, 369-381 (2006).

239. Jentsch, S., Seufert, W. \& Hauser, H.P. Genetic analysis of the ubiquitin system. Biochim Biophys Acta 1089, 127-139 (1991).

240. Pickart, C.M. \& Eddins, M.J. Ubiquitin: structures, functions, mechanisms. Biochim Biophys Acta 1695, 55-72 (2004).

241. Pickart, C.M. \& Fushman, D. Polyubiquitin chains: polymeric protein signals. Curr Opin Chem Biol 8, 610-616 (2004).

242. Glickman, M.H. \& Ciechanover, A. The ubiquitin-proteasome proteolytic pathway: destruction for the sake of construction. Physiol Rev 82, 373-428 (2002).

243. Lecker, S.H., Goldberg, A.L. \& Mitch, W.E. Protein degradation by the ubiquitinproteasome pathway in normal and disease states. J Am Soc Nephrol 17, 1807-1819 (2006).

244. Jin, L., Williamson, A., Banerjee, S., Philipp, I. \& Rape, M. Mechanism of ubiquitin-chain formation by the human anaphase-promoting complex. Cell 133, 653-665 (2008).

245. Thrower, J.S., Hoffman, L., Rechsteiner, M. \& Pickart, C.M. Recognition of the polyubiquitin proteolytic signal. EMBO J 19, 94-102 (2000).

246. Nijman, S.M., et al. A genomic and functional inventory of deubiquitinating enzymes. Cell 123, 773-786 (2005).

247. Kee, Y. \& Huibregtse, J.M. Regulation of catalytic activities of HECT ubiquitin ligases. Biochem Biophys Res Commun 354, 329-333 (2007).

248. Yi, J.J. \& Ehlers, M.D. Emerging roles for ubiquitin and protein degradation in neuronal function. Pharmacol Rev 59, 14-39 (2007).

249. Zheng, N., et al. Structure of the Cul1-Rbx1-Skp1-F boxSkp2 SCF ubiquitin ligase complex. Nature 416, 703-709 (2002).

250. Emanuele, M.J., et al. Global identification of modular cullin-RING ligase substrates. Cell 147, 459-474 (2011).

251. Hatakeyama, S. \& Nakayama, K.I. U-box proteins as a new family of ubiquitin ligases. Biochem Biophys Res Commun 302, 635-645 (2003).

252. Bienz, M. The PHD finger, a nuclear protein-interaction domain. Trends Biochem Sci 31, 35-40 (2006).

253. Meetei, A.R., et al. A novel ubiquitin ligase is deficient in Fanconi anemia. Nat Genet 35, 165-170 (2003).

254. Ang, X.L. \& Wade Harper, J. SCF-mediated protein degradation and cell cycle control. Oncogene 24, 2860-2870 (2005). 
255. van Leuken, R., Clijsters, L. \& Wolthuis, R. To cell cycle, swing the APC/C. Biochim Biophys Acta 1786, 49-59 (2008).

256. Barford, D. Structural insights into anaphase-promoting complex function and mechanism. Philos Trans R Soc Lond B Biol Sci 366, 3605-3624 (2011).

257. Lupas, A., Baumeister, W. \& Hofmann, K. A repetitive sequence in subunits of the 265 proteasome and $20 \mathrm{~S}$ cyclosome (anaphase-promoting complex). Trends Biochem Sci 22, 195-196 (1997).

258. Peters, J.M. The anaphase promoting complex/cyclosome: a machine designed to destroy. Nat Rev Mol Cell Biol 7, 644-656 (2006).

259. Vodermaier, H.C., Gieffers, C., Maurer-Stroh, S., Eisenhaber, F. \& Peters, J.M. TPR subunits of the anaphase-promoting complex mediate binding to the activator protein CDH1. Curr Biol 13, 1459-1468 (2003).

260. Schwab, M., Neutzner, M., Mocker, D. \& Seufert, W. Yeast Hct1 recognizes the mitotic cyclin Clb2 and other substrates of the ubiquitin ligase APC. EMBO J 20, 5165-5175 (2001).

261. Kraft, C., Vodermaier, H.C., Maurer-Stroh, S., Eisenhaber, F. \& Peters, J.M. The WD40 propeller domain of Cdh1 functions as a destruction box receptor for APC/C substrates. Mol Cell 18, 543-553 (2005).

262. Pfleger, C.M. \& Kirschner, M.W. The KEN box: an APC recognition signal distinct from the D box targeted by Cdh1. Genes Dev 14, 655-665 (2000).

263. Frescas, D. \& Pagano, M. Deregulated proteolysis by the F-box proteins SKP2 and betaTrCP: tipping the scales of cancer. Nat Rev Cancer 8, 438-449 (2008).

264. Wada, H., Kito, K., Caskey, L.S., Yeh, E.T. \& Kamitani, T. Cleavage of the C-terminus of NEDD8 by UCH-L3. Biochem Biophys Res Commun 251, 688-692 (1998).

265. Huang, D.T., Walden, H., Duda, D. \& Schulman, B.A. Ubiquitin-like protein activation. Oncogene 23, 1958-1971 (2004).

266. Bohnsack, R.N. \& Haas, A.L. Conservation in the mechanism of Nedd8 activation by the human AppBp1-Uba3 heterodimer. J Biol Chem 278, 26823-26830 (2003).

267. Liakopoulos, D., Doenges, G., Matuschewski, K. \& Jentsch, S. A novel protein modification pathway related to the ubiquitin system. EMBO J 17, 2208-2214 (1998).

268. Petroski, M.D. \& Deshaies, R.J. Function and regulation of cullin-RING ubiquitin ligases. Nat Rev Mol Cell Biol 6, 9-20 (2005).

269. Lyapina, S., et al. Promotion of NEDD-CUL1 conjugate cleavage by COP9 signalosome. Science 292, 1382-1385 (2001).

270. Bennett, E.J., Rush, J., Gygi, S.P. \& Harper, J.W. Dynamics of cullin-RING ubiquitin ligase network revealed by systematic quantitative proteomics. Cell 143, 951-965 (2010).

271. Zhou, C., et al. Fission yeast COP9/signalosome suppresses cullin activity through recruitment of the deubiquitylating enzyme Ubp12p. Mol Cell 11, 927-938 (2003).

272. Soucy, T.A., et al. An inhibitor of NEDD8-activating enzyme as a new approach to treat cancer. Nature 458, 732-736 (2009).

273. Soucy, T.A., Smith, P.G. \& Rolfe, M. Targeting NEDD8-activated cullin-RING ligases for the treatment of cancer. Clin Cancer Res 15, 3912-3916 (2009).

274. Brownell, J.E., et al. Substrate-assisted inhibition of ubiquitin-like protein-activating enzymes: the NEDD8 E1 inhibitor MLN4924 forms a NEDD8-AMP mimetic in situ. Mol Cell 37, 102-111 (2010).

275. Nawrocki, S.T., et al. Disrupting Protein NEDDylation with MLN4924 is a Novel Strategy to Target Cisplatin Resistance in Ovarian Cancer. Clin Cancer Res (2013).

276. Blank, J.L., et al. Novel DNA Damage Checkpoints Mediating Cell Death Induced by the NEDD8-Activating Enzyme Inhibitor MLN4924. Cancer Res (2012).

277. Jia, L., Li, H. \& Sun, Y. Induction of p21-dependent senescence by an NAE inhibitor, MLN4924, as a mechanism of growth suppression. Neoplasia 13, 561-569 (2011). 
278. Liao, H., et al. Quantitative proteomic analysis of cellular protein modulation upon inhibition of the NEDD8-activating enzyme by MLN4924. Mol Cell Proteomics (2011).

279. Lin, J.J., Milhollen, M.A., Smith, P.G., Narayanan, U. \& Dutta, A. NEDD8-targeting drug MLN4924 elicits DNA rereplication by stabilizing Cdt1 in S phase, triggering checkpoint activation, apoptosis, and senescence in cancer cells. Cancer Res 70, 10310-10320 (2010).

280. Luo, Z., et al. The Nedd8-Activating Enzyme Inhibitor MLN4924 Induces Autophagy and Apoptosis to Suppress Liver Cancer Cell Growth. Cancer Res 72, 3360-3371 (2012).

281. Milhollen, M.A., et al. Inhibition of NEDD8-activating enzyme induces rereplication and apoptosis in human tumor cells consistent with deregulating CDT1 turnover. Cancer Res 71, 3042-3051 (2011).

282. Milhollen, M.A., et al. MLN4924, a NEDD8-activating enzyme inhibitor, is active in diffuse large B-cell lymphoma models: rationale for treatment of NF-\{kappa\}Bdependent lymphoma. Blood 116, 1515-1523 (2010).

283. Smith, M.A., et al. Initial testing of the investigational NEDD8-activating enzyme inhibitor MLN4924 by the pediatric preclinical testing program. Pediatr Blood Cancer (2011).

284. Swords, R.T., et al. Inhibition of NEDD8-activating enzyme: a novel approach for the treatment of acute myeloid leukemia. Blood 115, 3796-3800 (2010).

285. Wei, D., et al. Radiosensitization of human pancreatic cancer cells by MLN4924, an investigational NEDD8-activating enzyme inhibitor. Cancer Res (2011).

286. Zhao, L., Yue, P., Lonial, S., Khuri, F.R. \& Sun, S.Y. The NEDD8-activating enzyme inhibitor, MLN4924, cooperates with TRAIL to augment apoptosis through facilitating c-FLIP degradation in head and neck cancer cells. Mol Cancer Ther (2011).

287. Liu, J., Furukawa, M., Matsumoto, T. \& Xiong, Y. NEDD8 modification of CUL1 dissociates p120(CAND1), an inhibitor of CUL1-SKP1 binding and SCF ligases. Mol Cell 10, 1511-1518 (2002).

288. Zheng, J., et al. CAND1 binds to unneddylated CUL1 and regulates the formation of SCF ubiquitin E3 ligase complex. Mol Cell 10, 1519-1526 (2002).

289. Rabut, G. \& Peter, M. Function and regulation of protein neddylation. 'Protein modifications: beyond the usual suspects' review series. EMBO Rep 9, 969-976 (2008).

290. Merlet, J., Burger, J., Gomes, J.E. \& Pintard, L. Regulation of cullin-RING E3 ubiquitinligases by neddylation and dimerization. Cell Mol Life Sci 66, 1924-1938 (2009).

291. Tang, X., et al. Suprafacial orientation of the SCFCdc4 dimer accommodates multiple geometries for substrate ubiquitination. Cell 129, 1165-1176 (2007).

292. Davis, M., et al. Pseudosubstrate regulation of the SCF(beta-TrCP) ubiquitin ligase by hnRNP-U. Genes Dev 16, 439-451 (2002).

293. Murata, S., Yashiroda, H. \& Tanaka, K. Molecular mechanisms of proteasome assembly. Nat Rev Mol Cell Biol 10, 104-115 (2009).

294. Tanaka, K. The proteasome: overview of structure and functions. Proc Jpn Acad Ser B Phys Biol Sci 85, 12-36 (2009).

295. Paramore, A. \& Frantz, S. Bortezomib. Nat Rev Drug Discov 2, 611-612 (2003).

296. Field-Smith, A., Morgan, G.J. \& Davies, F.E. Bortezomib (Velcadetrade mark) in the Treatment of Multiple Myeloma. Ther Clin Risk Manag 2, 271-279 (2006).

297. Brar, S.S., et al. Disulfiram inhibits activating transcription factor/cyclic AMPresponsive element binding protein and human melanoma growth in a metaldependent manner in vitro, in mice and in a patient with metastatic disease. Mol Cancer Ther 3, 1049-1060 (2004).

298. Nguyen, A.T., Gagnon, A., Angel, J.B. \& Sorisky, A. Ritonavir increases the level of active ADD-1/SREBP-1 protein during adipogenesis. AIDS 14, 2467-2473 (2000).

299. Omura, S., et al. Lactacystin, a novel microbial metabolite, induces neuritogenesis of neuroblastoma cells. J Antibiot (Tokyo) 44, 113-116 (1991). 
300. Ottaviano, L., et al. Molecular characterization of commonly used cell lines for bone tumor research: a trans-European EuroBoNet effort. Genes Chromosomes Cancer 49, 40-51 (2010).

301. Meriwether, W.D. \& Bachur, N.R. Inhibition of DNA and RNA metabolism by daunorubicin and adriamycin in L1210 mouse leukemia. Cancer Res 32, 1137-1142 (1972).

302. Larsen, A.K., Escargueil, A.E. \& Skladanowski, A. Catalytic topoisomerase II inhibitors in cancer therapy. Pharmacol Ther 99, 167-181 (2003).

303. Mitra, M., et al. Reversal of stathmin-mediated microtubule destabilization sensitizes retinoblastoma cells to a low dose of antimicrotubule agents: a novel synergistic therapeutic intervention. Invest Ophthalmol Vis Sci 52, 5441-5448 (2011).

304. Panek, R.L., et al. In vitro pharmacological characterization of PD 166285, a new nanomolar potent and broadly active protein tyrosine kinase inhibitor. J Pharmacol Exp Ther 283, 1433-1444 (1997).

305. Rajeshkumar, N.V., et al. MK-1775, a potent Wee1 inhibitor, synergizes with gemcitabine to achieve tumor regressions, selectively in p53-deficient pancreatic cancer xenografts. Clin Cancer Res 17, 2799-2806 (2011).

306. Ghavami, S., et al. Apoptosis and cancer: mutations within caspase genes. J Med Genet 46, 497-510 (2009).

307. Wlodkowic, D., Skommer, J. \& Darzynkiewicz, Z. Cytometry of apoptosis. Historical perspective and new advances. Exp Oncol 34, 255-262 (2012).

308. Goto, H., et al. Identification of a novel phosphorylation site on histone H3 coupled with mitotic chromosome condensation. J Biol Chem 274, 25543-25549 (1999).

309. Hendzel, M.J., et al. Mitosis-specific phosphorylation of histone $\mathrm{H} 3$ initiates primarily within pericentromeric heterochromatin during $\mathrm{G} 2$ and spreads in an ordered fashion coincident with mitotic chromosome condensation. Chromosoma 106, 348-360 (1997).

310. Bick, M.D. \& Davidson, R.L. Total substitution of bromodeoxyuridine for thymidine in the DNA of a bromodeoxyuridine-dependent cell line. Proc Natl Acad Sci U S A 71, 2082-2086 (1974).

311. Gossen, M. \& Bujard, H. Tight control of gene expression in mammalian cells by tetracycline-responsive promoters. Proc Natl Acad Sci U S A 89, 5547-5551 (1992).

312. Urlinger, S., et al. Exploring the sequence space for tetracycline-dependent transcriptional activators: novel mutations yield expanded range and sensitivity. Proc Natl Acad Sci U S A 97, 7963-7968 (2000).

313. Kim, Y. \& Kipreos, E.T. Cdt1 degradation to prevent DNA re-replication: conserved and non-conserved pathways. Cell Div 2, 18 (2007).

314. Thompson, J.D., Gibson, T.J., Plewniak, F., Jeanmougin, F. \& Higgins, D.G. The CLUSTAL_X windows interface: flexible strategies for multiple sequence alignment aided by quality analysis tools. Nucleic Acids Res 25, 4876-4882 (1997).

315. Taylor, W.R. \& Stark, G.R. Regulation of the G2/M transition by p53. Oncogene 20, 1803-1815 (2001).

316. Zhou, B.B., et al. Caffeine abolishes the mammalian G(2)/M DNA damage checkpoint by inhibiting ataxia-telangiectasia-mutated kinase activity. J Biol Chem 275, 1034210348 (2000).

317. Busino, L., et al. Degradation of Cdc25A by beta-TrCP during $S$ phase and in response to DNA damage. Nature 426, 87-91 (2003).

318. Donzelli, M., et al. Hierarchical order of phosphorylation events commits Cdc25A to betaTrCP-dependent degradation. Cell Cycle 3, 469-471 (2004).

319. Nakayama, K., et al. Skp2-mediated degradation of p27 regulates progression into mitosis. Dev Cell 6, 661-672 (2004). 
320. Tsvetkov, L.M., Yeh, K.H., Lee, S.J., Sun, H. \& Zhang, H. p27(Kip1) ubiquitination and degradation is regulated by the SCF(Skp2) complex through phosphorylated Thr187 in p27. Curr Biol 9, 661-664 (1999).

321. Koepp, D.M., et al. Phosphorylation-dependent ubiquitination of cyclin $\mathrm{E}$ by the SCFFbw7 ubiquitin ligase. Science 294, 173-177 (2001).

322. Rodriguez, R. \& Meuth, M. Chk1 and p21 cooperate to prevent apoptosis during DNA replication fork stress. Mol Biol Cell 17, 402-412 (2006).

323. Zhang, Y.W., et al. Genotoxic stress targets human Chk1 for degradation by the ubiquitin-proteasome pathway. Mol Cell 19, 607-618 (2005).

324. Zhao, H. \& Piwnica-Worms, H. ATR-mediated checkpoint pathways regulate phosphorylation and activation of human Chk1. Mol Cell Biol 21, 4129-4139 (2001).

325. Watanabe, N., Broome, M. \& Hunter, T. Regulation of the human WEE1Hu CDK tyrosine 15-kinase during the cell cycle. EMBO J 14, 1878-1891 (1995).

326. McGowan, C.H. \& Russell, P. Cell cycle regulation of human WEE1. EMBO J 14, 21662175 (1995).

327. Susaki, E. \& Nakayama, K.I. Multiple mechanisms for p27(Kip1) translocation and degradation. Cell Cycle 6, 3015-3020 (2007).

328. McGowan, C.H. \& Russell, P. Human Wee1 kinase inhibits cell division by phosphorylating p34cdc2 exclusively on Tyr15. EMBO J 12, 75-85 (1993).

329. De Witt Hamer, P.C., Mir, S.E., Noske, D., Van Noorden, C.J. \& Wurdinger, T. WEE1 kinase targeting combined with DNA-damaging cancer therapy catalyzes mitotic catastrophe. Clin Cancer Res 17, 4200-4207 (2011).

330. Mir, S.E., et al. In silico analysis of kinase expression identifies WEE1 as a gatekeeper against mitotic catastrophe in glioblastoma. Cancer Cell 18, 244-257 (2010).

331. Lundberg, A.S. \& Weinberg, R.A. Functional inactivation of the retinoblastoma protein requires sequential modification by at least two distinct cyclin-cdk complexes. Mol Cell Biol 18, 753-761 (1998).

332. Vigo, E., et al. CDC25A phosphatase is a target of E2F and is required for efficient E2Finduced S phase. Mol Cell Biol 19, 6379-6395 (1999).

333. Jiang, W., Wells, N.J. \& Hunter, T. Multistep regulation of DNA replication by Cdk phosphorylation of HsCdc6. Proc Natl Acad Sci U S A 96, 6193-6198 (1999).

334. Paolinelli, R., Mendoza-Maldonado, R., Cereseto, A. \& Giacca, M. Acetylation by GCN5 regulates CDC6 phosphorylation in the S phase of the cell cycle. Nat Struct Mol Biol 16, 412-420 (2009).

335. Petersen, B.O., Lukas, J., Sorensen, C.S., Bartek, J. \& Helin, K. Phosphorylation of mammalian CDC6 by cyclin A/CDK2 regulates its subcellular localization. EMBO J 18, 396-410 (1999).

336. Watts, J.K. \& Corey, D.R. Silencing disease genes in the laboratory and the clinic. J Pathol 226, 365-379 (2012).

337. McConnell, B.B., Starborg, M., Brookes, S. \& Peters, G. Inhibitors of cyclin-dependent kinases induce features of replicative senescence in early passage human diploid fibroblasts. Curr Biol 8, 351-354 (1998).

338. Zhu, J., Woods, D., McMahon, M. \& Bishop, J.M. Senescence of human fibroblasts induced by oncogenic Raf. Genes Dev 12, 2997-3007 (1998).

339. Chu, l., et al. p27 phosphorylation by Src regulates inhibition of cyclin E-Cdk2. Cell 128, 281-294 (2007).

340. Grimmler, M., et al. Cdk-inhibitory activity and stability of p27Kip1 are directly regulated by oncogenic tyrosine kinases. Cell 128, 269-280 (2007).

341. Russo, A.A., Jeffrey, P.D., Patten, A.K., Massague, J. \& Pavletich, N.P. Crystal structure of the p27Kip1 cyclin-dependent-kinase inhibitor bound to the cyclin A-Cdk2 complex. Nature 382, 325-331 (1996). 
342. Smith, J., Tho, L.M., Xu, N. \& Gillespie, D.A. The ATM-Chk2 and ATR-Chk1 pathways in DNA damage signaling and cancer. Adv Cancer Res 108, 73-112 (2010).

343. Tan, C.Y. \& Hagen, T. Destabilization of CDC6 upon DNA damage is dependent on neddylation but independent of Cullin E3 ligases. Int J Biochem Cell Biol (2013).

344. Perry, J.A. \& Kornbluth, S. Cdc25 and Wee1: analogous opposites? Cell Div 2, 12 (2007).

345. Busino, L., Chiesa, M., Draetta, G.F. \& Donzelli, M. Cdc25A phosphatase: combinatorial phosphorylation, ubiquitylation and proteolysis. Oncogene 23, 2050-2056 (2004).

346. Kim, W., et al. Systematic and quantitative assessment of the ubiquitin-modified proteome. Mol Cell 44, 325-340 (2011). 
APÉNDICE 


\title{
WEE1 accumulation and deregulation of S-phase proteins mediate MLN4924 potent inhibitory effect on Ewing sarcoma cells
}

\author{
C Mackintosh ${ }^{1,6}$, DJ García-Domínguez ${ }^{1,6}$, JL Ordóñez $^{1}$, A Ginel-Picardo ${ }^{2}$, PG Smith ${ }^{3}$, MP Sacristán ${ }^{4}$ and E de Álava ${ }^{1,5}$
}

Ewing sarcoma (ES) is an aggressive bone and soft tissue tumor of children and young adults in which finding effective new targeted therapies is imperative. Here, we report an in-depth preclinical study of the investigational cullin-RING ubiquitin ligase (CRL) inhibitor MLN4924 in ES, as we have recently demonstrated the implication of a CRL component in the ES pathogenesis. First, our results support a high sensitivity of ES cells to MLN4924 growth inhibition both in vitro (14 ES cell lines tested, median $\mathrm{IC} 50=81 \mathrm{~nm}$ ) and in tumor xenografts (tumor regression achieved with $60 \mathrm{mg} / \mathrm{kg} \mathrm{BID,} \mathrm{subcutaneously,} n=9$ ). Second, we report a dual mechanism of action of MLN4924 in ES cells: while a wide range of MLN4924 concentrations ( 30-300 nM) trigger a G2 arrest that can only be rescued by WEE1 kinase inhibition or depletion, saturating doses of the drug ( $>300 \mathrm{~nm}$ ) cause a delay in S-phase progression concomitant with unbalanced CDK2-Cyclin E and CDK2-Cyclin A relative levels (accumulation of the first and depletion of the latter). The aberrant presence of CDC6 in the nucleus at late S-phase cell cycle stage confirmed the loss of CDK2Cyclin A-specific functions. Remarkably, other mechanisms explored (P27 accumulation and DNA damage signaling pathways) were found unable to explain MLN4924 effects, strengthening the specificity of our findings and suggesting the absence of functionality of some CRL substrates accumulated in response to MLN4924. This study renders a rationale for clinical trials and contributes molecular mechanisms for a better understanding of this promising antitumoral agent.

Oncogene (2013) 32, 1441-1451; doi:10.1038/onc.2012.153; published online 28 May 2012

Keywords: MLN4924; Ewing sarcoma; WEE1; cyclin A; cyclin E; P27

\section{INTRODUCTION}

Ewing sarcoma (ES) is an aggressive tumor that arises from the bone or soft tissue of children and young adults, being the second most frequent bone tumor at childhood. ${ }^{1}$ Despite significant therapeutic advances in multimodal therapy, survival rates are still below $20 \%$ in patients with relapsed and/or disseminated disease. $^{2}$ Although several targeted therapies have been proposed based on preclinical studies, none has yet been agreed for the clinical routine, which makes this research an area of immediate concern.

We have recently shown that the genomic gain of an extra 1q chromosome copy strongly correlates with a poorer survival of ES patients. ${ }^{3}$ In this same study, overexpression of CDT2, a gene located at 1q32.3, was found as a major effector of this oncogenic copy number aberration. Given that CDT2 is the main substrate receptor of the cullin-RING ubiquitin ligase (CRL) complex CUL4/ $\mathrm{DDB} 1$, a rationale for a targeted therapy based on the inhibition of this CRL was proposed.

CRLs are a class of protein-ubiquitin ligases that target a wide range of proteins for degradation via proteasome 26S, being SCF (Skp, Cullin, F-box-containing complex) the best characterized CRL. ${ }^{4}$ Notwithstanding, there are dozens of different CRLs resulting from the combination of the diverse variants of each of the multiple molecular elements that constitute their structure (cullins 1 to 7, E3 ligases RBX1 and RNF7, several substrate adapters and, specially, a plethora of different substrate receptors). Each possible CRL configuration targets a particular set of proteins, ${ }^{5}$ usually through the recognition of a phospho-degron motif, a signal that triggers the degradation process. This high complexity in structure and substrate recognition patterns probably reflects the fine regulation in time and space required for the proper development of the cellular functions regulated by CRLs. It is worth noting that CRLs are essential for the correct completion of every cell cycle stage, which makes them key regulators of this cellular process. ${ }^{6}$

MLN4924 is an investigational novel antitumoral agent that inhibits the Nedd8-activating enzyme UBA3, impairing the neddylation of the cullin component of CRLs, a process required for enabling the E3 ligase enzymatic activity that ultimately performs poly-ubiquitin binding to CRL substrates. ${ }^{7-8}$ By this means, MLN4924 inhibits CRL enzymatic activity, causing an increase in the protein levels of its substrates, ${ }^{9}$ many of which have been reported as potent tumor suppressors (among others P21, P27, IKB $\alpha$ and WEE1), ${ }^{10-13}$ while others have been described as oncogenes (among others CDC25A and Cyclin E). ${ }^{14-15}$

Here, we report an in-depth preclinical evaluation of MLN4924 in ES. Our results show the potential high sensitivity of ES tumors to CRL inhibition and unveil a MLN4924 mechanism of action consisting of an induced G2 cell cycle arrest. Our data support

\footnotetext{
${ }^{1}$ Molecular Pathology Program, IBSAL-Centro de Investigación del Cáncer-IBMCC (USAL-CSIC), Campus Miguel de Unamuno S/N, Salamanca, Spain; ${ }^{2}$ Laboratory 1, Centro de

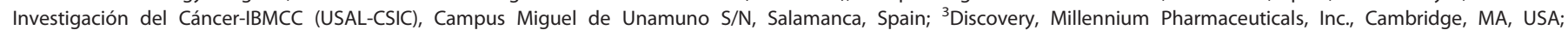

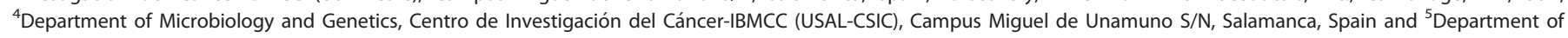

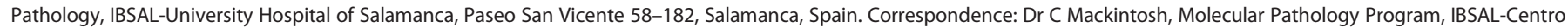

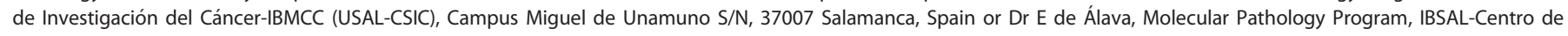
Investigación del Cáncer-IBMCC (USAL-CSIC), Campus Miguel de Unamuno S/N, 37007 Salamanca, Spain.
}

E-mail: cmackintosh@usal.es or edealava@usal.es

${ }^{6}$ These authors contributed equally to this work.

Received 5 December 2011; revised 21 February 2012; accepted 30 March 2012; published online 28 May 2012 
a major role for WEE1 mediating this new molecular mechanism. In addition, MLN4924 saturating levels induced S-phase delay paralleled by depletion and loss of function of CDK2-Cyclin A complexes.

\section{RESULTS}

ES cell lines are highly sensitive to MLN4924

A total of 14 ES cell lines were treated with MLN4924 in order to estimate its ability to impair the in vitro growth of ES cell cultures (Table 1). The median IC50 (the concentration that reduces cell population by $50 \%$ ) obtained ( $81 \mathrm{~nm}$ ) is noticeably lower than that previously obtained for 10 cell lines belonging to 7 different tumor entities $(200 \mathrm{~nm})^{7}$ and similar to that of diffuse large B-cell lymphoma cell lines, which are the most sensitive to MLN4924 treatment as reported to date $(76 \mathrm{~nm}) .^{16}$ Interestingly, a recently published study has surveyed the in vitro sensitivity of a panel of pediatric cancer cell lines to MLN4924, finding ES cells to be the most sensitive ones to this compound, among those tested. ${ }^{17}$

No differences in IC50 owing to 1q copy number were observed (Figure 1a). Although we initially foresaw a higher sensitivity of 1q gain cells to CRL inhibition, this result broadens the potential application of MLN4924 to virtually all ES patients.

MLN4924 was also able to decrease in vivo growth of RDES xenograft tumors in mice at $30 \mathrm{mg} / \mathrm{kg}$ dosed twice daily (BID), whereas $60 \mathrm{mg} / \mathrm{kg}$ BID caused regression of the initial tumor mass (Figure 1b).

MLN4924 delays G2/M- and S-phase progression and induces apoptosis in ES cells

Flow cytometry analysis of DNA content evidenced a prominent increase in $\mathrm{G} 2 / \mathrm{M}$ population $24 \mathrm{~h}$ after treatment with a broad range of MLN4924 concentrations (30-300 nM, equivalent to IC50-IC90 in most of the cell lines), while saturating doses elicited an accumulation of cells in S-phase $(\sim 300-1000 \mathrm{~nm})$ together with the aforementioned G2/M peak (Figure 1c). The effect on G2/M ranged from a delay (Figures 1c, 2c) to a severe arrest (Figure 3d) depending on MLN4924 concentration. We will refer to it here as G2/M arrest to simplify the writing. The arrest was confirmed to persist after longer treatment periods (48 and $72 \mathrm{~h}$, data not shown).

Induced apoptosis was detectable after $24 \mathrm{~h}$ of MLN4924 treatment, cleaved Caspase-3-positive population ranging from 4.7 to $10 \%$ at IC75 and from 17 to $31 \%$ at IC95 (Figure 1d). Combined flow cytometry analysis of propidium iodide and cleaved Caspase-3-labeled cells revealed a late S-G2 DNA content of apoptotic cells in RDES cell line, pointing to a common mechanism underlying both S-G2 increase and cell death (Figure 1e).

Consistent with their similar sensitivity to MLN4924, 1q gain and 1q normal cell lines did not display any difference neither in cell cycle distribution profile nor in induced apoptosis in response to MLN4924, indicating a mechanism of action independent from 1q copy number (Figures 1c and d).

Protein levels of several regulators of the G2/M transition increase shortly after MLN4924 treatment and are stable after $24 \mathrm{~h}$.

An analysis of protein increases of known CRL substrates, with special attention to G2/M regulators, was conducted. Protein extracts were harvested after 4 and $24 \mathrm{~h}$ of MLN4924 treatment in order to ensure the specificity and stability of any change detected, respectively (Figure 2a). Specific (already detectable after $4 \mathrm{~h}$ of treatment) increases of P27, WEE1, CDC25A and Cyclin E were observed both at medium (IC75) and saturating concentrations (IC95) of the drug and remained constant after $24 \mathrm{~h}$ in most of the cell lines. Increases in P21 protein levels were more difficult to detect and were absent in RM82 and TC71. This result was expected as both cell lines are known to lack functional $\mathrm{p} 53^{18}$ and discards any significant contribution of P21 to MLN4924-induced G2/M arrest in ES cell lines. EMI1 (another reported CRL substrate with functions in mitosis regulation) failed to reflect a clear pattern of accumulation.

Increases of CHK1 kinase phosphorylation at Ser345 were also detected, reflecting only mild activation of the DNA damage signaling pathway at medium drug concentrations. More intense activation of this marker was found at higher concentrations (Figure 2a). These observations were validated by $\gamma-\mathrm{H} 2 \mathrm{AX}$ immunofluorescence (Supplementary Figure S3).

Remarkably, only mild increases of CDT1 were observed (Figure 2b). However, CUL1 and CUL4 deneddylation took place in ES cell lines to a similar extent as in HCT116, a colorectal cancer cell line that responds to MLN4924 with dramatic CDT1 increases (Figure $2 \mathrm{~b}$ ) and induced re-replication. ${ }^{7,19-20}$

\section{Treatment of synchronized ES cells locates MLN4924-induced arrest in G2-early mitosis}

RDES cell line was selected to provide a mechanistic insight into MLN4924 action on ES cells. RDES can be synchronized by different methods and responds to MLN4924 treatment with pronounced and stable increases of most of the CRL substrates analyzed.

Synchronization at mitosis with nocodazole, which inhibits the polymerization of microtubules impairing the onset of metaphase,

Table 1. MLN4924 inhibitory concentrations (ICs)

\begin{tabular}{|c|c|c|c|c|}
\hline Cell line & 19 Copy number & IC50 (пм) & IC75 (пм) & IC95 (nм) \\
\hline A4573 & Gain & $60.52 \pm 12.20$ & $109.20 \pm 15.79$ & $406.28 \pm 112.16$ \\
\hline A673 & Normal & $85.00 \pm 18.21$ & $148.09 \pm 28.64$ & $417.37 \pm 185.48$ \\
\hline CADOES & Gain & $324.91 \pm 82.20$ & $467.40 \pm 184.56$ & $1009.12 \pm 731.96$ \\
\hline RDES & Gain & $36.80 \pm 14.48$ & $77.65 \pm 51.54$ & $443.71 \pm 238.83$ \\
\hline RM82 & Gain & $73.99 \pm 17.90$ & $135.29 \pm 24.19$ & $398.77 \pm 101.90$ \\
\hline SKES & Gain & $86.28 \pm 14.50$ & $118.20 \pm 21.27$ & $240.06 \pm 172.04$ \\
\hline SKNMC & Normal & $52.60 \pm 19.58$ & $95.66 \pm 27.19$ & $327.59 \pm 113.06$ \\
\hline STA-ET1 & Normal & $42.15 \pm 11.88$ & $72.87 \pm 8.48$ & $189.00 \pm 35.39$ \\
\hline STA-ET10 & Gain & $256.73 \pm 7.60$ & $430.54 \pm 107.43$ & $2579.23 \pm 270.45$ \\
\hline STA-ET2.1 & Normal & $103.89 \pm 53.22$ & $227.22 \pm 59.15$ & $1174.84 \pm 615.09$ \\
\hline TC32 & Gain & $152.59 \pm 35.11$ & $257.81 \pm 63.63$ & $863.85 \pm 259.65$ \\
\hline TC71 & Gain & $76.86 \pm 2.91$ & $119.13 \pm 2.91$ & $265.62 \pm 11.82$ \\
\hline TTC466 & Normal & $150.05 \pm 2.49$ & $261.99 \pm 4.29$ & $735.36 \pm 11.65$ \\
\hline WE68 & Gain & $33.02 \pm 5.82$ & $85.35 \pm 4.54$ & $424.56 \pm 106.256$ \\
\hline
\end{tabular}

Proliferation ICs of 14 ES cell lines assayed for MLN4924 sensitivity and measured after $72 \mathrm{~h}$ exposition to the drug. Mean \pm s.d. 

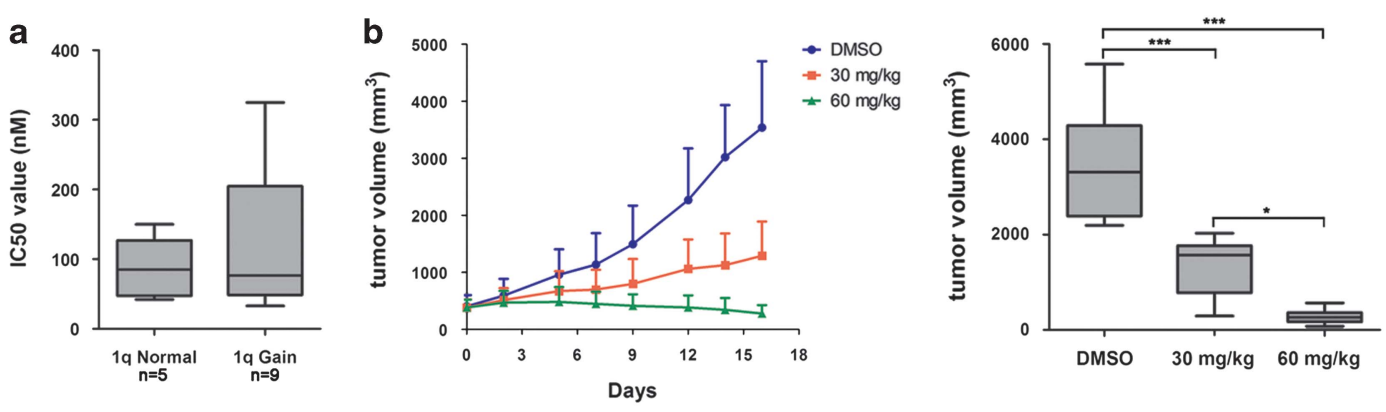

C
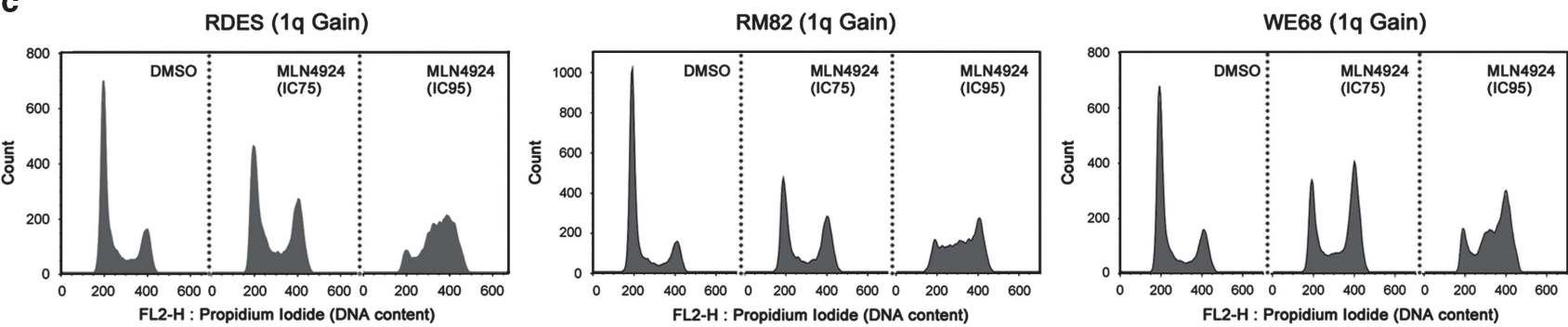

TC71 (1q Gain)
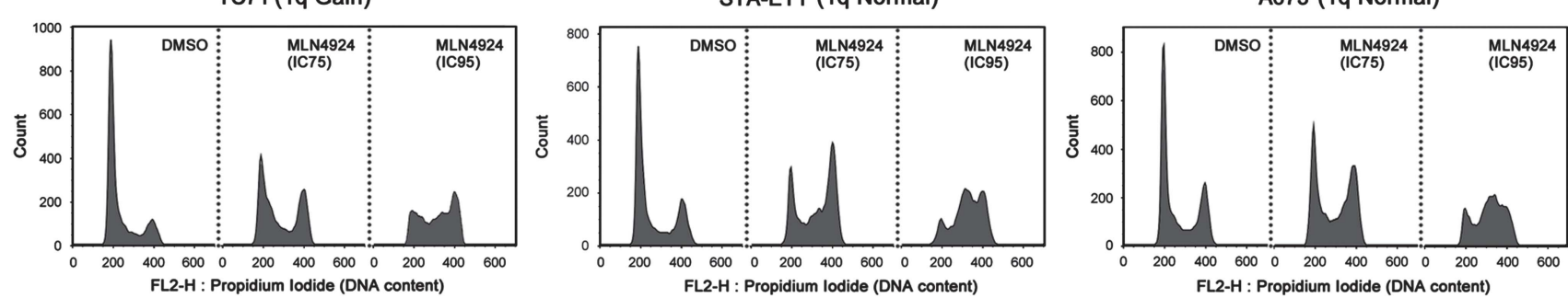

d
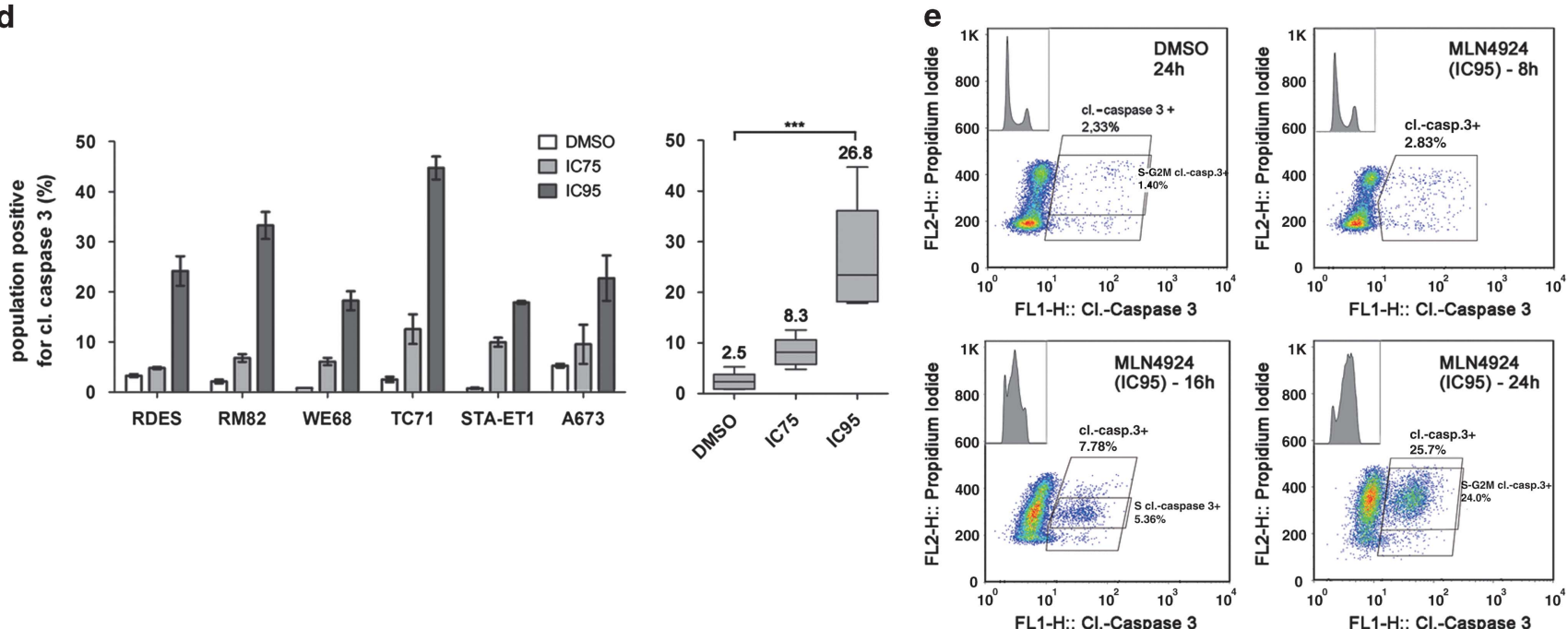

Figure 1. MLN4924 induces G2/M arrest and apoptosis in ES cell lines, which are highly sensitive to this CRL inhibitor. (a) No significant differences in IC50 were found between 1q gain and 1q normal ES cell lines. (b) Growth of RDES xenografts on mice ( $n=9$ in each treatment condition) was effectively delayed and abolished by $30 \mathrm{mg} / \mathrm{kg}$ and $60 \mathrm{mg} / \mathrm{kg}$ BID MLN4924 doses, respectively (left panel: evolution of xenograft tumor sizes; right panel: boxplots summarizing final tumor sizes). (c) Flow cytometry analysis of DNA content revealed that MLN4924 arrests ES cells in G2/M at low-medium concentrations (FL2-H histograms). SubG1 population was not conspicuous at this time point and was gated out. (d) Cleaved Caspase-3 population estimation by flow cytometry showed significant apoptosis triggered at saturating MLN4924 concentrations. Medium doses elicited apoptosis values that only reached marginal significance. Average of two independent replicates. Mean values depicted over the boxplots. (e) Combined flow cytometry analysis of Cleaved Caspase-3 and propidium iodide showed an S-phase and S-G2/M DNA content of apoptotic cells after 16 and 24h, respectively, in IC95 MLN4924-treated RDES cells. Insets: FL2-H (DNA content) histograms. In all cases: mean \pm s.d.; statistical tests: significant analysis of variance, Bonferroni post-hoc test $<0.001\left(^{* * *}\right)$ or $0.05\left(^{*}\right)$.

was used to define more precisely the arrest point within G2/M. After pre-treating RDES cultures with MLN4924 for $4 \mathrm{~h}$ (Figure 2c, bottom panel), cells were released from nocodazole and observed to enter G1 at the same time as control, dimethyl sulfoxide (DMSO) treated cells, discarding any significant contribution of late mitosis CRL substrates to the MLN4924-induced G2/M arrest. 

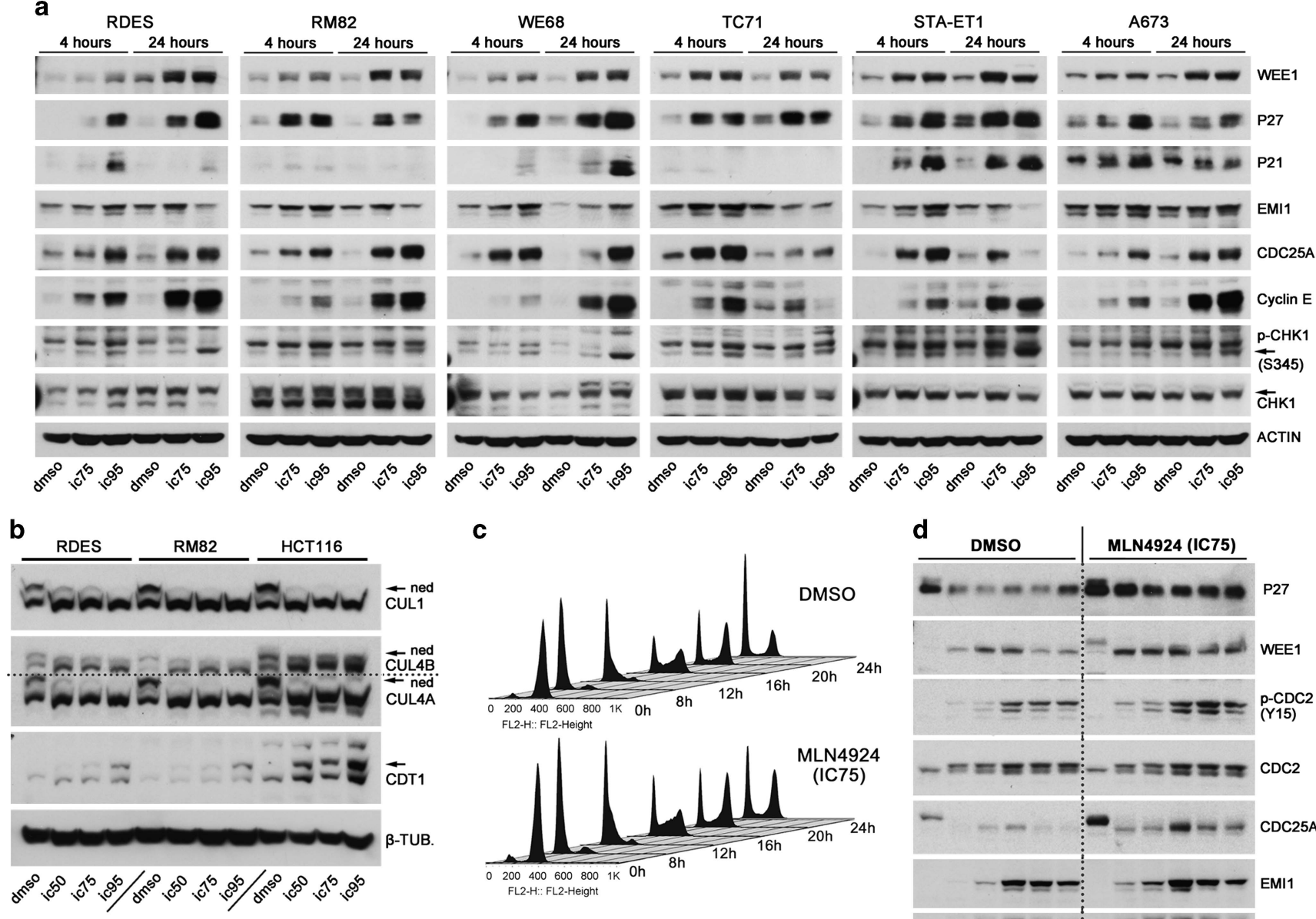

C
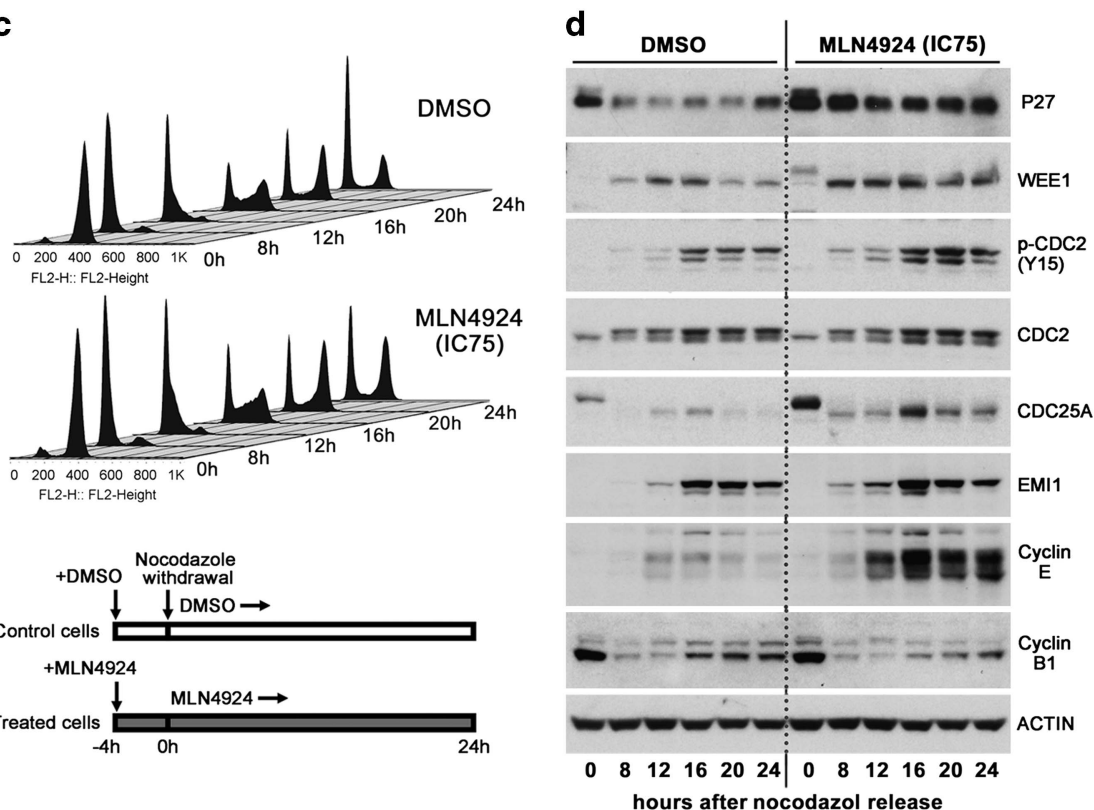

Figure 2. MLN4924 induces protein accumulation of known CRL substrates and arrests RDES cells in G2-early mitosis. (a) An analysis of CRL substrates proved the specific and stable accumulation of WEE1, P27, CDC25A and Cyclin E. Arrows: specific bands. (b) CDT1 levels increased slightly in ES cells in comparison with HCT116, although deneddylation occurred to a similar extent in both cell types. Arrows: neddylated (ned) cullins. (c) Nocodazole-synchronized RDES cells pretreated $4 \mathrm{~h}$ with MLN4924 before release were able to enter G1 normally and only showed a significant delay at G2/M (bottom panel: schematic representation of the experiment). (d) Accumulated levels of WEE1 and P27 were maintained during all cell cycle stages, in contrast to CDC25A, which decreased in G2/M in spite of CRL inhibition.

In more detail, if late mitosis CRL substrates (expected to be accumulated after MLN4924 pre-treatment) would be implicated in the G2/M arrest, treated cells should show a delayed exit from mitosis and hence MLN4924 should hamper G1 entry after removing nocodazole from the growth medium, which was not observed. In addition, treated cells progressed through undisturbed G1- and S-phases and were only delayed at G2/M (Figure 2c).

Increased WEE1 protein levels were maintained throughout the synchronized cell cycle. Remarkably, a consistent higher phosphorylation of CDC2 (CDK1) at tyrosine 15 (Y15) was also detected, evidencing the functionality of the accumulated WEE1 protein. P27 levels rose from the first time point and were maintained as well (Figure 2d). It is worth noting that CDC25A-induced levels were not constant, peaking at S-phase and decreasing thereafter and seemed to have no effect on cell cycle kinetics. Regarding other substrates analyzed, Cyclin E unscheduled accumulation was detected, whereas EMI1 accumulated only slightly and was present predominantly in mitosis, as expected. Cyclin B1 (a non-
CRL substrate) displayed the normal kinetics in both treated and untreated cells, and was used to monitor progression into mitosis.

Altogether, these results place the MLN4924-induced G2/M arrest in some point before late mitosis and offer two main candidates for a mechanistic explanation: P27 and WEE1.

P27 knockdown and caffeine treatment are unable to revert the G2/M arrest induced by MLN4924

P27 is a CDK inhibitor with a potent regulatory effect over the G1 to $S$ transition. In addition, SCF ${ }^{\text {SKP2 }}$ CRL complex targets P27 for degradation in late S-G2, rendering an additional role for P27 in the regulation of the $\mathrm{G} 2$ to $M$ progression. ${ }^{21}$

We evaluated the ability of P27 knockdown to revert MLN4924induced G2/M arrest. Despite the substantial P27 decrease obtained by short-hairpin RNA (shRNA) silencing (Figure 3a), no reduction of the population accumulated in G2/M was observed after treating P27-silenced cells with MLN4924 (Figure 3b). Other 

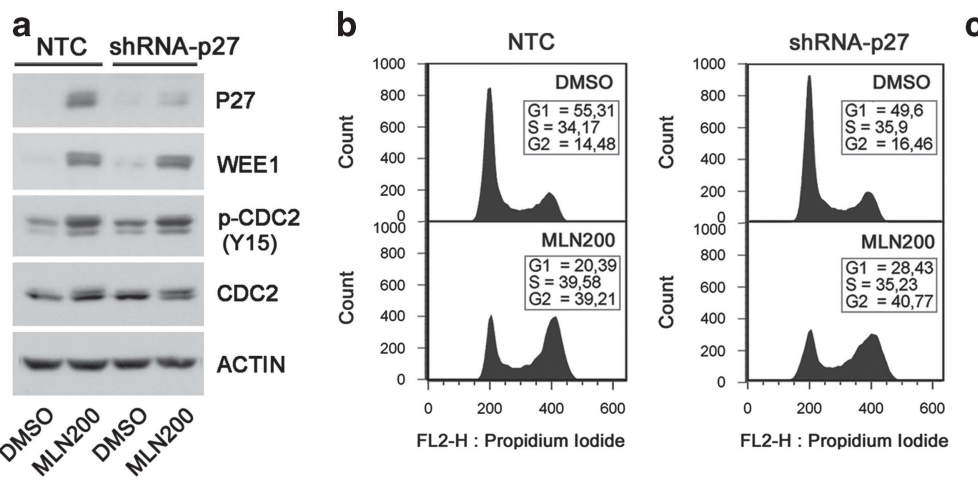

C

P27
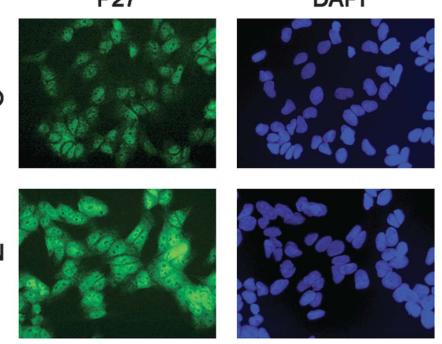

Overlay

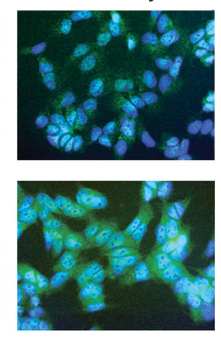

d
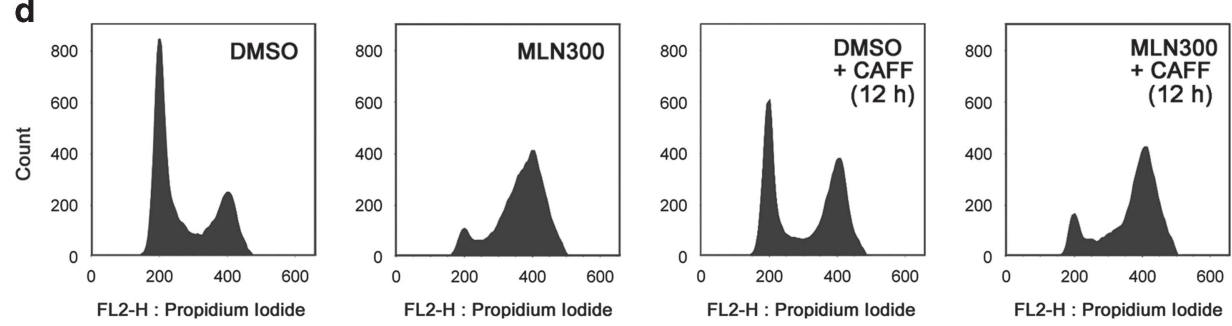

Figure 3. MLN4924-induced G2/M arrest is not reverted by P27 knockdown or caffeine. P27 knockdown efficiently impaired P27 accumulation in treated RDES cells (a) but did not impinge upon the distorted cell cycle distribution caused by MLN4924 (b), despite MLN4924 not showing any effect on P27 subcellular distribution ( $\times 20$ magnification immunofluorescence micrographs) (c). Caffeine also failed to affect the G2/M peak (d). P27 knockdown: representative experiment from two independent shRNA cell transductions with similar results. Caffeine was assayed at shorter times with identical results. caff, caffeine; MLN200/300, 200/300 nM MLN4924.

shRNA constructions against $P 27$ yielded similar results (data not shown). Remarkably, P27 knockdown did not affect WEE1 or CDC2-Y15 inhibitory phosphorylation. Silencing of $P 27$ in RM82 cell line also failed counteracting MLN4924 effects (Supplementary Figure S1A).

Moreover, $\beta$-galactosidase assay did not show senescence (a typical effect of p27 accumulation) of RDES cultures treated over 4 days with IC75 drug concentration (data not shown). Surprisingly, MLN4924 did not alter P27 subcellular location, which could have explained the unnoticeable impact of accumulated P27 levels on the cell cycle kinetics of ES cells, ${ }^{22}$ being most of the protein located inside the nucleus (Figure $3 c$ ).

The DNA damage signaling pathway has been previously shown able to arrest the cell cycle in G2. ${ }^{23-24}$ Although only mild CHK1 activation was observed at medium MLN4924 concentrations, we assessed the possible contribution of this signaling pathway to the G2/M arrest. After $24 \mathrm{~h}$ of MLN4924 treatment, caffeine (an extensively validated inhibitor of the ATRATM DNA damage signaling kinases, here used at a saturating $20 \mathrm{~mm}$ concentration) was added to the medium for $12 \mathrm{~h}$. As a result, no noticeable decrease in the MLN4924-induced G2/M peak was observed (Figure 3d).

MLN4924-induced G2/M arrest is reverted by the WEE1 kinase inhibitor PD0166285

WEE1 kinase inhibits the cell cycle progression by phosphorylating CDC2 at Y15, which reduces drastically the enzymatic activity of the CDC2-Cyclin B complex and therefore delays the $G 2$ to $M$ progression. ${ }^{25}$ Hence, and after having discarded other potential mechanisms, WEE1 role in MLN4924 action on ES cells was inquired.

The WEE1 kinase inhibitor PD0166285 was added to the medium of RDES cultures that had been treated for $21 \mathrm{~h}$ with MLN4924 (Figure 4f). PD0166285 treatment was found able to revert the inhibitory phosphorylation of CDC2 at Y15 (Figure 4a) and to release the cells from the G2/M arrest imposed by MLN4924 (Figure 4b, left panel). Cell cycle quantification showed an increase in G1 population proportional to the G2/M reduction (Figure 4b, right panel). PD0166285 treatment yielded the same results in another cell line (RM82, Supplementary Figure S1B).

Also consistent with a WEE1-imposed G2 arrest, the size of the cell population undergoing mitosis, assessed by flow cytometry analysis of phospho-histone H3-Ser10 (pH3), was found notably reduced by MLN4924 treatment. Most importantly, PD0166285 applied for $1.5 \mathrm{~h}$ released MLN4924 G2-arrested cells into mitosis (increasing $\mathrm{pH} 3$-positive population from 1 to $18 \%$ ) and after $3 \mathrm{~h}$ the size of the mitotic population reached a value close to that of control cells, indicating the restoration of the normal cell cycle kinetics accomplished by WEE 1 inhibition (Figures $4 c$ and d). The anti-pH3 antibody used was confirmed to specifically label mitotic cells and to recognize every stage of mitosis (Supplementary Figure $\mathrm{S} 2$ and Figure 4e, respectively).

WEE1 knockdown substantially restores the proliferation and normal cell cycle distribution of MLN4924-treated ES cells.

WEE1 protein levels were depleted to further explore its role mediating MLN4924 action, as PD0166285 could not be maintained in culture at high concentrations and/or long expositions due to toxicity.

Two levels of WEE1 knockdown were obtained by different shRNA constructions with medium (shwee1-1) and high (shwee1-2) silencing efficiencies, respectively. Each construction reduced CDC2-Y15 phosphorylation in clear correlation with its WEE1 reduction ability (Figure 5 a).

Next, WEE1-silenced RDES cells were treated with two different MLN4924 concentrations and proliferation was assessed after 48 and $72 \mathrm{~h}$. As a result, both constructions were able to substantially rescue RDES proliferation, with shwee1-1 being the most efficient (Figure 5b). However, no substantial reduction of apoptosis was 
a

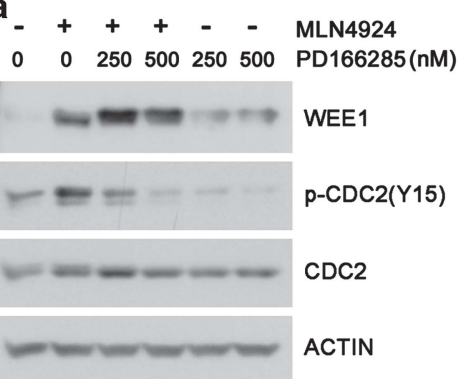

b

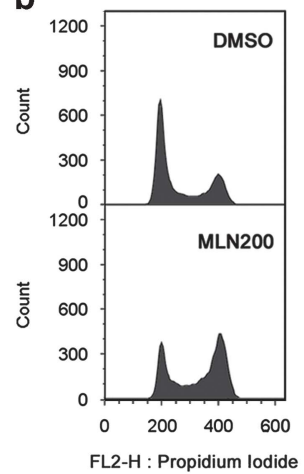

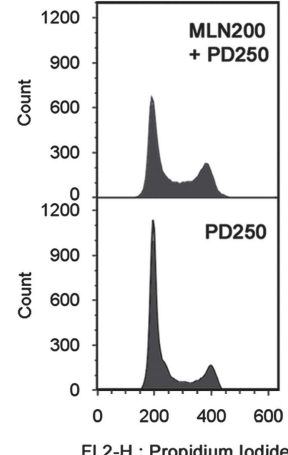

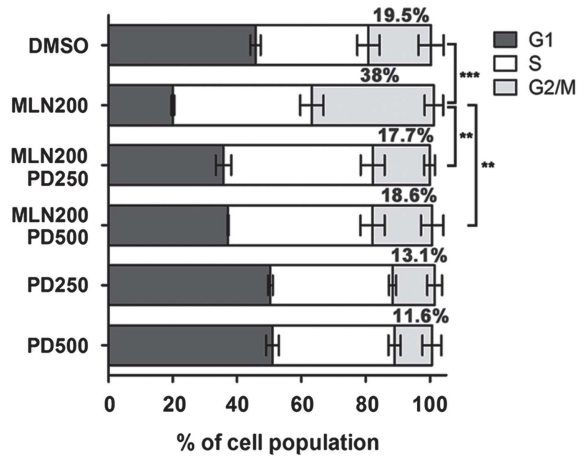

C

DMSO

MLN200

MLN200 + PD250 (1.5h) MLN200 + PD250 (3h)

PD250 (1.5h)

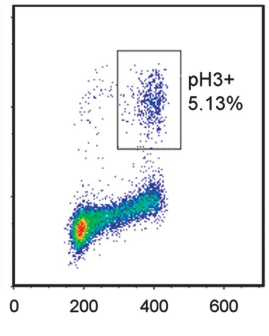

PD250 (3h)
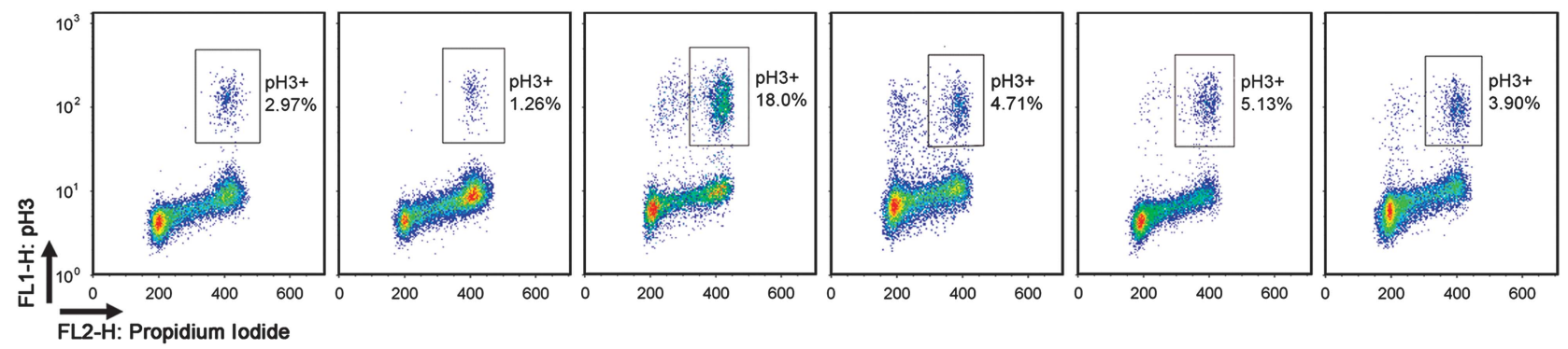

d

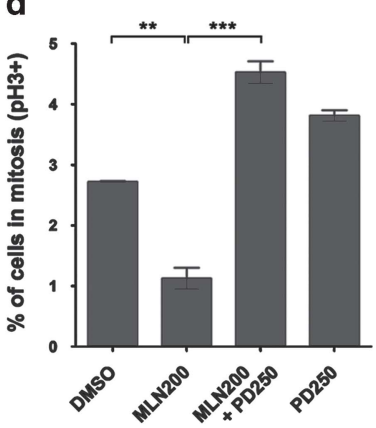

e

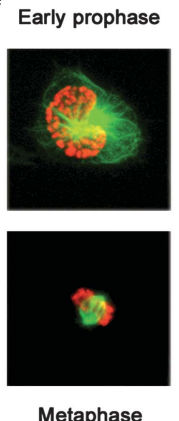

Late prophase
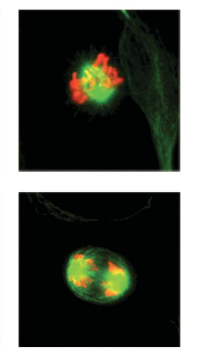

Anaphase f

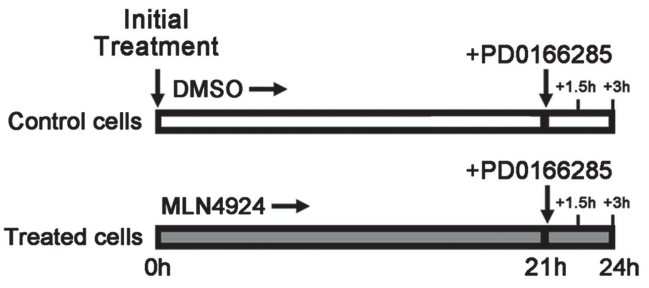

Figure 4. WEE1 inhibition reverts MLN4924-induced G2 arrest. PD0166285 (applied for $3 \mathrm{~h}$ to cells arrested by MLN4924 treatment) restored CDC2 phosphorylation at Y15 (a) and G2/M values (b) of MLN4924-treated cells to control levels. (c) MLN4924 was found to reduce the cell population undergoing mitosis ( $\mathrm{pH} 3+$ ) whereas PD0166285 restored mitosis (after 1.5 h) and G1 (after $3 \mathrm{~h}$ ). (d) Quantification of the mitotic population after $3 \mathrm{~h}$ of PD0166285 treatment. (e) Immunofluorescence confirmed the specific labeling of mitotic cells by the anti-pH3 antibody used ( $\times 40$ magnification micrographs of RDES cells at different mitotic stages: pH3, red; $\alpha$-tubulin, green). (f) Schematic representation of the experiment. In all cases, mean \pm s.d. of two independent replicates. Statistical tests: significant analysis of variance, Bonferroni post-hoc test $\left.<0.001{ }^{(* *}\right)$ and $0.01\left(^{* *}\right)$. MLN200, $200 \mathrm{~nm}$ MLN4924; PD250/500, $250 \mathrm{~nm} / 500 \mathrm{~nm}$ PD0166285.

detected. Indeed, WEE1 knockdown was found to elicit a higher basal (DMSO treatment) cleaved Caspase-3 population labeling when compared with cells transduced with the non-targeting control (NTC). Moreover, WEE1 knockdown-induced apoptosis was proportional to the silencing level achieved by each of the shRNA constructions (Figure 5c). The high value of shwee1-2-induced apoptosis indicates the dependence of ES cells on WEE1 and explains why this shRNA construction was less efficient in rescuing proliferation despite its better silencing ability.

Finally, both WEE 1 shRNA constructions demonstrated a potent effect preventing MLN4924-mediated G2 arrest, although the cell accumulation in S-phase that occurs at saturating concentrations was only partially affected (Figure $5 \mathrm{~d}$ ). The same results were obtained in WEE1-silenced RM82 cells (Supplementary Figure S1C).

Taken together, these results confirm the relevant role of WEE1 in MLN4924 cytostatic effect on ES cell lines, whereas no conclusions can be obtained regarding its contribution to induced apoptosis as WEE1 depletion triggered apoptosis by itself, probably through mitotic catastrophe.

MLN4924-induced S-phase delay is independent from WEE1 accumulation and simultaneous to depletion and loss of specific functions of CDK2-cyclin A.

WEE1 kinase has been shown to phosphorylate and inhibit CDK2 (the S-phase master regulator) in vitro. ${ }^{26}$ Although the data collected in our previous experiments indicated none or few implication of WEE1 in the S-phase delay detected in MLN4924treated ES cell lines, we assayed its potential contribution at saturating drug concentrations in synchronically growing RDES cells.

Cells synchronized at the G1-S boundary were MLN4924 pretreated $(500 \mathrm{~nm})$ for $2 \mathrm{~h}$ before thymidine withdrawal and released in medium with MLN4924 and nocodazole (added to avoid mitotic exit and G1 re-entering; Figure 6e). Treated cells, 


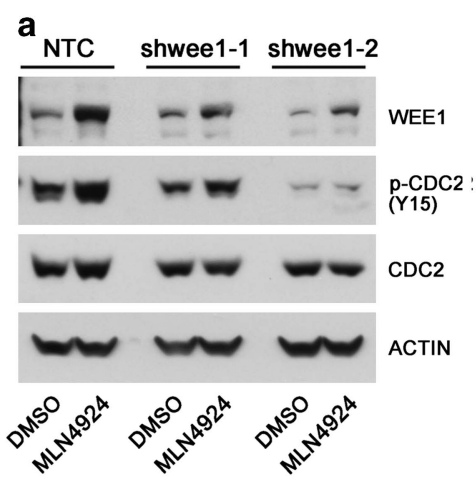

d

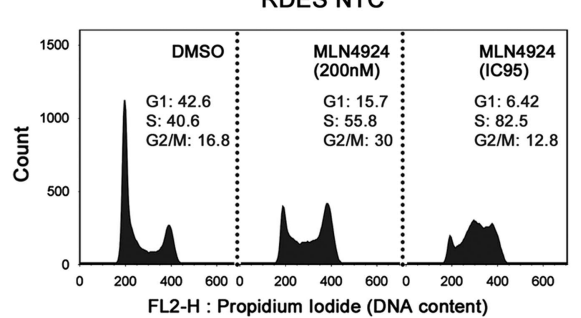

b

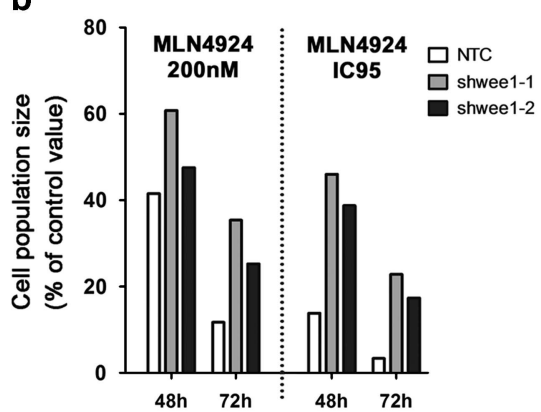

RDES shwee1-1
C

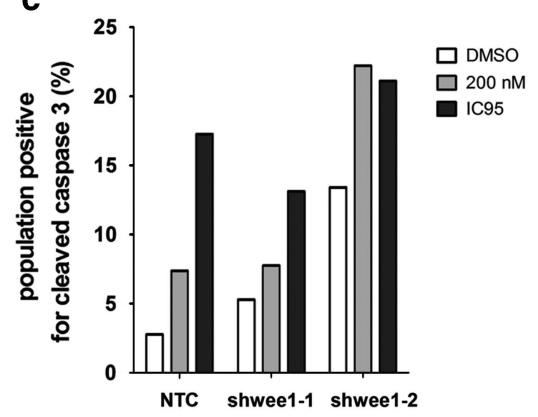

Figure 5. WEE1 knockdown substantially rescues proliferation and prevents MLN4924-induced cell cycle arrest. WEE1 knockdown with two different shRNAs impaired WEE1 protein accumulation after MLN4924 treatment of RDES cells (IC95) and also decreased CDC2-Y15 phosphorylation (a), partially rescuing the proliferation of the cultures at 48 and $72 \mathrm{~h}$ ( $y$ axis: cell population size of MLN4924-treated cells normalized to control, DMSO treated, values) (b), but was unable to further revert MLN4924 effect on proliferation probably because of the increased basal apoptosis detected in WEE1-silenced cells (c). Consistently, flow cytometry analysis revealed a marked effect of WEE1 knockdown preventing the MLN4924-induced G2/M peak (d). Representative experiment from two independent shRNA cell transductions with similar results.

subjected to 5-bromo-2-deoxyuridine (BrdU) pulses, were found to initiate the S-phase in a similar manner to control cells but were severely delayed thereafter (Figure 6a). At $12 \mathrm{~h}$ after thymidine withdrawal, a decrease in BrdU incorporation was detected in treated cells (Figure $6 \mathrm{~b}$ ). Consistently, most control cells reached a G2 DNA content at $15 \mathrm{~h}$ monitoring time point with few cells still incorporating BrdU, whereas DNA synthesis in MLN4924-treated cells did not progress during the last $6 \mathrm{~h}$, despite BrdU incorporation still taking place. After $24 \mathrm{~h}$, the entire control cell population displayed G2 DNA content whereas treated cells were still delayed and suffering from severe apoptosis (data not shown).

The protein levels of multiple key cell cycle activators and repressors were found dramatically accumulated (Figure 6c). Remarkably, enormous Cyclin E levels were observed during the entire S-phase progression in treated cells while in control cells its levels reduced and disappeared after the S-phase onset (3-6h). Consistently, high increases of pRB (Ser780) were detected at early time points and remained throughout the experiment, evidencing the active enzymatic status of CDK2. In addition, overall levels of Cyclin A were found diminished at the same time points in which treated cells were delayed with respect to control cells.

Immunoprecipitation of CDK2 showed a very slight increase in Y15 phosphorylation, again restricting WEE1 implication in the S-phase delay to few or none (Figure 6d). Strikingly, CDK2 from treated cells co-immunoprecipitated with Cyclin E at time points of advanced S-phase in which CDK2 from control cells did not partner with it, as expected. Conversely, Cyclin A was substantially reduced at the same time points in CDK2 immunoprecipitates of MLN4924-treated cells (Figures $6 \mathrm{~d}$ and c, respectively), strongly suggesting a displacement of Cyclin A from CDK2 complexes due to Cyclin E saturating protein levels.

CDK2-Cyclin E and CDK2-Cyclin A complexes can impinge different phosphorylation patterns upon CDK2 substrates. One of the best characterized examples of this differential action is CDC6, which is phosphorylated at S54 and S74 by CDK2-Cyclin E, a modification that is essential for the formation and DNA loading of the pre-replicative complex (pre-RC). Conversely, S106 phosphorylation is specifically exerted by CDK2-Cyclin A and triggers CDC6 relocation to the cytoplasm, a mechanism thought to assure that DNA replication is performed only once per cell cycle. ${ }^{27-29}$

We used CDC6 subcellular location to confirm the loss of CDK2Cyclin A-specific functions. As a result, MLN4924-treated cells displayed conspicuous nuclear labeling at late S-phase, 12 hours after thymidine release, whereas CDC6 presence in control ES cells was mainly cytoplasmatic, as expected (Figure 6f).

This same assay was carried out with WEE1-silenced cells. No significant effect of WEE1 knockdown on the S-phase delay was detected. Caffeine also failed in rescuing the delay under the same experimental conditions (data not shown).

Finally, RDES clones of inducible Cyclin A overexpression were established as an approach to rescue MLN4924-induced late S-phase delay (Supplementary Figure S4A). However, overexpression of Cyclin A was observed to also hamper DNA replication (Supplementary Figure S4B) and thus we could not evaluate its ability to rescue MLN4924-induced S-phase delay. Strikingly, the delay elicited by Cyclin A started in early S-phase, in sharp contrast to the one caused by MLN4924.

\section{DISCUSSION}

Here, we report an in-depth preclinical evaluation of MLN4924 in ES. Our results support a potential high sensitivity of this tumor entity to CRL inhibition and render a mechanistic explanation for its activity in ES cells, revealing WEE1 accumulation as a major effector of MLN4924 potent cytostatic activity. In addition, our data suggest that the induced $\mathrm{G} 2$ arrest could also be involved in MLN4924 cytotoxic action (Figure 1e). The contribution of other mechanisms, prevalent at saturating concentrations, was also 
explored. The evidences shown here point to CDK2-Cyclin A depletion as the most probable cause of the singular effect observed on S-phase, characterized by a huge CDK2 enzymatic activity (as proved by both the phosphorylated status of RB and the incorporation of BrdU) without completion of DNA synthesis. Consistent with this idea, aberrant location of CDC6 in the nucleus was detected in MLN4924-treated cells in late S-phase, confirming the loss of CDK2-cyclin A-specific functions.
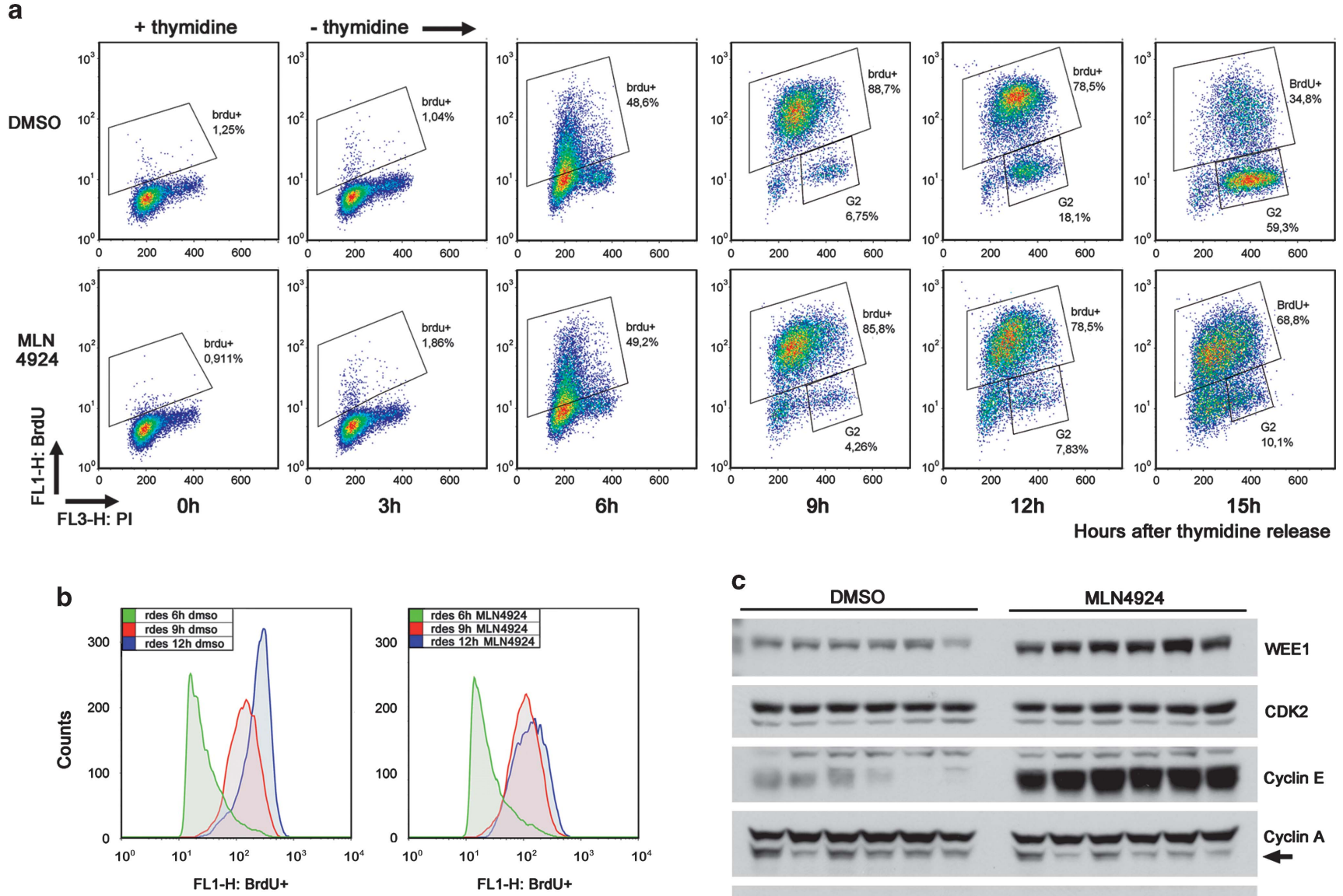

d

$$
\text { IP: CDK2 }
$$

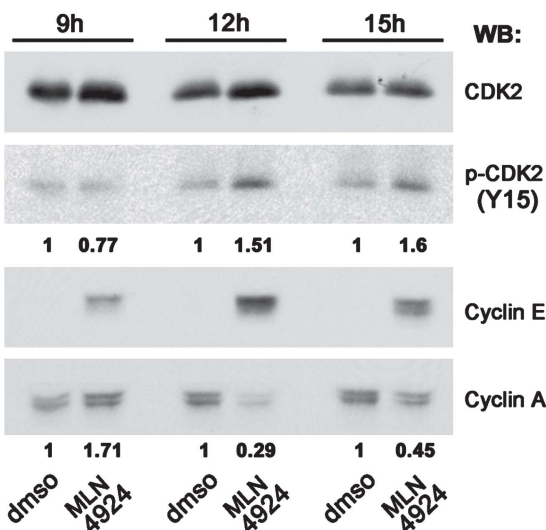

f
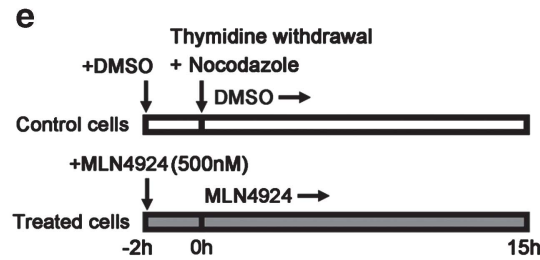

c

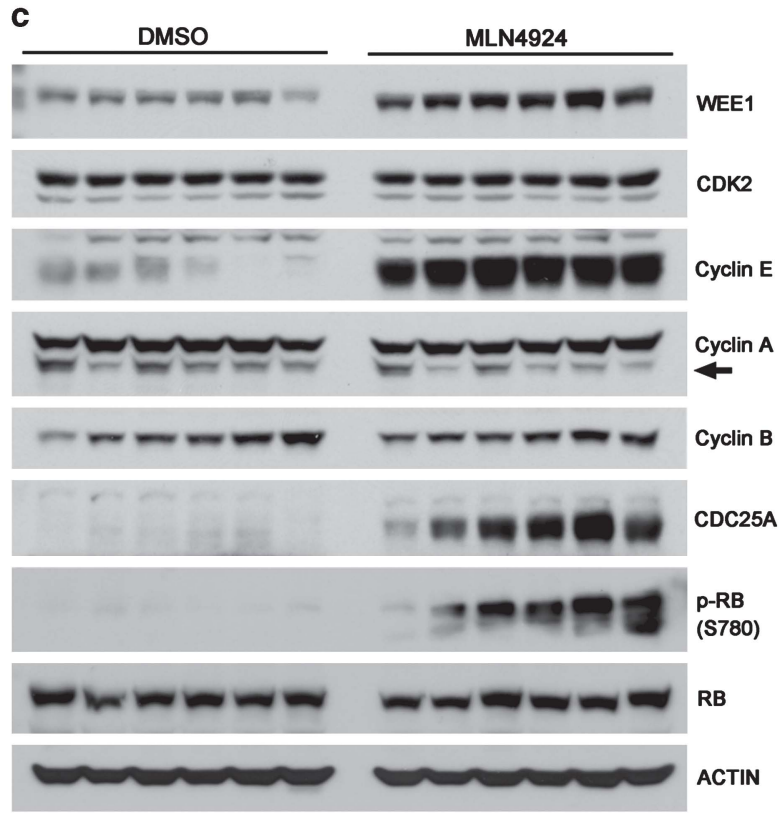

Oh $3 \mathrm{~h} \quad 6 \mathrm{~h} 9 \mathrm{~h} 12 \mathrm{~h} 15 \mathrm{~h} \quad$ Oh $3 \mathrm{~h}$ 6h $9 \mathrm{~h} 12 \mathrm{~h} 15 \mathrm{~h}$ hours after thymidine release
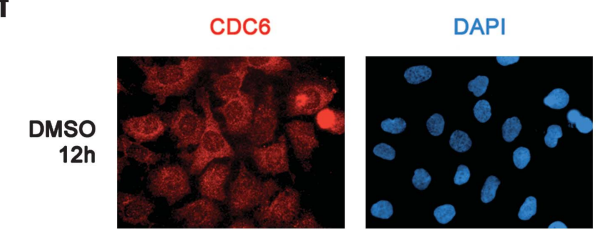

$\mathrm{CDC6}+\mathrm{DAPI}$

MLN4924
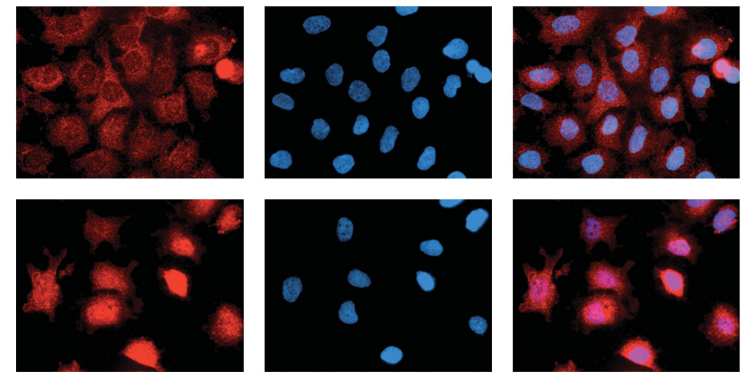
A previous study has evaluated the sensitivity of a set of pediatric tumors to MLN4924, including 6 ES cell lines, although not providing any further insight into the mechanism of action elicited. ${ }^{17}$ In this work, in spite of the acute in vitro response of ES cells to MLN4924 (the most sensitive among those tested), the treatment of tumors xenografted in mice was not found to induce any significant reduction in tumor size, an observation that was not restricted to ES cells but that affected most malignant cell types assayed. Apart from this internal inconsistence, the lack of in vivo effects in ES cells is in clear contrast with our data, especially when taking into account that the doses found effective in vivo in our study are considerably lower than those described in the said article. Remarkably, the authors mentioned that such high doses of the compound gave rise to a skin-hardening problem at the site of injection that led to a premature interruption of the assay. So, a suboptimal uptake of the drug due to this impediment might underlie the discrepancy between both studies.

Strikingly, MLN4924 arrests ES cells in G2 in sharp contrast with CDT2 knockdown, which halted the cells in $\mathrm{G}_{1}{ }^{3}$ and in accordance with the similar sensitivity and response of $1 \mathrm{q}$ gain and $1 \mathrm{q}$ normal ES cell lines to the said compound. Having discarded a molecular mechanism specific of 1q gain ES, the model proposed here could find a broader application not only to virtually all ES tumors but also to other tumor types that respond to MLN4924 treatment with G2 arrest/S-phase delay. In addition, this mechanism is triggered by a wide range of drug concentrations in cell culture, including levels easily attainable by in vivo dosing ( $<100 \mathrm{~nm}$ ).

The protein levels of CDT1, a substrate of both CUL4/DDB1 ${ }^{\text {CDT2 }}$ and SCF ${ }^{\text {SKP2 }}$ CRL complexes, ${ }^{30}$ were only slightly affected by MLN4924 in ES cells compared with HCT116. Consistently, the response of each of these cell types to $C R L$ inhibition differs greatly. ${ }^{7,19}$ However, deneddylation of CUL4 and CUL1 took place in ES cell lines to the same extent as in HCT116 (Figure 2b). These clearly dissimilar responses to CRL inhibition are not surprising as it is already known that despite the great selectivity of MLN4924 for its specific target $U B A 3^{7}$ its potent antitumoral action is exerted by different mechanisms depending on the cellular background, ${ }^{16,19-20,31-32}$ probably due to intercellular differences in the configuration of CRL substrates and CRL components and to celltype-specific ubiquitinomes. ${ }^{5,33}$ Most importantly, this phenomenon raises a relevant concern: the precise characterization of MLN4924 molecular mechanisms in each different malignant cell type is imperative for a better understanding of its clinical applications. Regarding this matter, a phase I clinical trial of MLN4924 in advanced nonhematologic malignancies is ongoing in the United States (ClinicalTrials.gov NCT00677170).

Besides, this report points out another interesting finding: the accumulation of some particular CRL substrates as a consequence of CRL inhibition might carry no functional manifestation in specific types of transformed cells. The results of the assays concerning P27 role in MLN4924 response suggest this conclusion. Also supporting this idea, it has been recently shown how several kinases (ABL, LYN and SRC) phosphorylate P27 at Tyr88 and Tyr74 during $\mathrm{G} 1$ to $S$ transition and how these phosphorylations cause the ejection of P27 from the catalytic cleft of the Cyclin E-CDK2 complexes, being a prerequisite for the phoshorylation at Thr187 exerted by Cyclin E-CDK2 itself. $^{34-36}$ Phosphorylation at Thr187 is the mark that enables recognition of P27 by the SCF complex and is the starting point for its ubiquitination and degradation. ${ }^{37}$ Therefore, MLN4924 could be inducing the accumulation of an inactive P27 form, which might explain why this tumor suppressor does not seem to have any significant role in MLN4924 effects on ES cells, despite its nuclear localization. In line with this idea, CDC25A and Cyclin E combined accumulation is expected to induce a premature entry in $\mathrm{G} 1{ }^{38}$ which was not observed neither in nocodazole nor in thymidine-synchronized ES cells subjected to MLN4924 treatment. Moreover, CDC25A did not seem to have any effect on accelerating $\mathrm{G} 2$ to $M$ progression either. So, both results suggest an also absence of function of the CDC25A protein accumulated in response to MLN4924 treatment. This point was not further explored as it has no relevance for the aims pursued in this study.

Alternatively, the ultimate effect of CRL inhibition could be the result of the net balance of opposed and/or overlapped deregulated protein activities, whose final outcome would be conditioned by the different, cell-type-dependent proteome and interactome configurations. According to this idea, WEE1 accumulation would represent the 'prevailing force' in ES cells subjected to CRL inhibition. However, the results reported in this study favor the hypothesis expressed in the former paragraph.

Finally, WEE1 provides an important advantage when considered as a therapeutic effector, as WEE1 loss drives the cells into mitotic catastrophe and, subsequently, into apoptosis. ${ }^{39}$ Hence, tumor cells could difficultly develop resistance by losing WEE1 function, in contrast to what could be expected of any therapy relying on other effectors frequently found lost in cancer such as P21 and P27. WEE1 is a ubiquitously expressed gene, key regulator of the cell cycle, and thus WEE 1 is present in virtually any malignant cell that could be considered as potentially treatable with this or similar compounds. In addition, WEE1 has recently been implicated in the radiosensitization of two human pancreatic cancer cell lines by MLN4924. ${ }^{40}$ So, WEE1 accumulation could be of further clinical use by empowering other antitumoral therapies. Regarding this issue, ongoing work in our laboratories is exploring the best drug combinations aiming an eventual inclusion of MLN4924 into traditional ES treatment schemes.

We have thus reported how MLN4924 inhibits ES cell growth and how its potent cytostatic effect depends on WEE1 accumulation.

\section{MATERIALS AND METHODS}

Cell lines and pharmaceutical compounds

A4573, A673, CADO-ES, RDES, RM82, SKES, SKNMC, STAET-1, STAET-2.1, STAET-10, TC71, TTC466, TC32 and WE68 were obtained from the EuroBoNet cell line panel that is maintained and regularly checked and characterized by Ottaviano et $a l^{41}$ in Heinrich-Heine-University at Düsseldorf, by the methods explained in reference. Cells were grown on gelatin-coated plates in RPMI 10-20\% except for A673 (DMEM 10\%).

MLN4924 was provided by Millennium Pharmaceuticals, Inc. (The Takeda Oncology Company, Cambridge, MA, USA). PD0166285 was purchased from Tocris Bioscience (Ellisville, MO, USA). Both were dissolved in DMSO for in vitro assays.

Figure 6. High MLN4924 concentrations cause a severe S-phase delay independent from WEE1 accumulation. Synchronized RDES cells were BrdU-pulsed and analyzed by flow cytometry (a) revealing a decrease in BrdU incorporation detectable $12 \mathrm{~h}$ after thymidine withdrawal (FL1- $\mathrm{H}$ histograms of the populations gated in $\mathrm{A}, \mathrm{BrdU}+)(\mathbf{b})$. Western blot of protein extracts at each monitoring time showed unscheduled presence of enormous Cyclin E amounts at late S-phase, correlating with diminished Cyclin A levels and huge phosphorylation of RB at Ser780 (arrow: Cyclin A-specific band) (c). CDK2 immunoprecipitation showed slight increase of CDK2-Y15 phosphorylation and aberrant coimmunoprecipitation of Cyclin E at late S time points. Cyclin A presence in the same immunoprecipitates was heavily reduced (d). Schematic representation of the experiment (e). Immunofluorescence study of CDC6 subcellular location revealed aberrant nuclear staining in cells subjected to MLN4924 treatment (f). Numbers below p-CDK2-Y15 and Cyclin A blots represent densitometric quantifications of MLN4924 bands, normalized to CDK2 and referred to their respective controls (DMSO band from the same time point). Representative experiment from several independent synchronization assays. PI: propidium iodide. 


\section{Cell viability assay}

Cells were seeded at 3000-4000 per well in 96-well culture plates. MLN4924 was added to complete growth medium at concentrations ranging from 0.001 to $10 \mu \mathrm{m}$. After $72 \mathrm{~h}$, cells were subjected to the ATPlite assay (PerkinElmer, Waltham, MA, USA) and inhibitory concentrations were calculated.

\section{Tumor xenografts in mice}

RDES cells were trypsinized and counted. Suspensions containing $4 \times 10^{6}$ living cells in a $0.2 \mathrm{ml}$ final volume composed of RPMI medium and Matrigel Matrix (Becton Dickinson, Franklin Lakes, NJ, USA) in a 1:1 proportion were injected subcutaneously in five-week-old CB.17 SCID female mice (Harlan, Indianapolis, IN, USA). Tumor size was measured with a caliper, and treatment was started when the mean volume reached $400 \mathrm{~mm}^{3}$. Animals were dosed subcutaneously with vehicle $(10 \%$ $\beta$-cyclodextrin) or MLN4924. At 16 days after injection, tumor volumes reached tolerable size limits and animals were euthanized by anesthetic overdose. All animals were housed and handled in accordance with the Guide for the Care and Use of Laboratory Animals, and the study was previously approved by the Bioethics Committee of the University of Salamanca.

\section{PH3, P27 and CDC6 immunofluorescence}

Cells were grown in gelatin-coated $6 \mathrm{~cm}$ plates, fixed with $3.6 \%$ paraformaldehyde for $8 \mathrm{~min}$ and permeabilized with ice-cold methanol applied for $3 \mathrm{~min}$. After phosphate-buffered saline (PBS) rehydration and washes, plates were blocked with $1 \%$ BSA in PBS and incubated overnight at $4{ }^{\circ} \mathrm{C}$ with 1:1000 anti-pH3 antibody (Cell Signalling, Danvers, MA, USA) and 1:500 anti- $\alpha$-tubulin (Calbiochem, Merck KGaA, Darmstadt, Germany) or 1:500 anti-P27 (BD, Franklin Lakes, NJ, USA) or 1:50 anti-CDC6 (Santa Cruz Biotechnology, Santa Cruz, CA, USA) under coverslips and inside humidified petri dishes. Cy3- (Jackson ImmunoResearch Laboratories, West Grove, PA, USA) and Alexa Fluor 488-labeled secondary antibodies (Invitrogen, Carlsbad, CA, USA) were applied under coverslips and incubated $1 \mathrm{~h}$ at room temperature. Finally, DAPI was added for 2 min to counterstain DNA.

Additional methods are described in Supplementary Material and Methods.

\section{CONFLICT OF INTEREST}

Peter G Smith was an employee of Millennium Pharmaceuticals, Inc. at the time of this study. There are no other competing financial interests.

\section{ACKNOWLEDGEMENTS}

We thank Cristina Teodosio and Martín Pérez de Andrés for their kind help in flow cytometry studies. Daniel J García-Domínguez is supported by a grant from the María García Estrada Foundation. Research in Enrique de Alava's lab is also supported by the Ministry of Economy and Competitiveness of Spain-FEDER (PI081828, RD06/0020/ 0059, PI1 100018, ISCIII_postdoc grant CD06/00001) and the European Commission (FP7-HEALTH-2011-two-stage, Project ID 278742 EUROSARC).

Author contributions: CM conceived the study and its design, analyzed the data and wrote the manuscript. The experimental work was accomplished by CM and DJGD. DJGD and JLO carried out the work with animals. AGP, PGS, MPS and EDA participated in conceptualization of the study and in critical discussion of data. All authors revised and edited the manuscript.

\section{REFERENCES}

1 Bernstein M, Kovar H, Paulussen M, Randall RL, Schuck A, Teot LA et al. Ewing's sarcoma family of tumors: current management. Oncologist 2006; 11: 503-519.

2 Haeusler J, Ranft A, Boelling T, Gosheger G, Braun-Munzinger G, Vieth V et al. The value of local treatment in patients with primary, disseminated, multifocal Ewing sarcoma (PDMES). Cancer 2010; 116: 443-450.

3 Mackintosh C, Ordonez JL, Garcia-Dominguez DJ, Sevillano V, Llombart-Bosch A, Szuhai $\mathrm{K}$ et al. 1q gain and CDT2 overexpression underlie an aggressive and highly proliferative form of Ewing sarcoma. Oncogene 2012; 31: 1287-1298.

4 Cardozo T, Pagano M. The SCF ubiquitin ligase: insights into a molecular machine. Nat Rev Mol Cell Biol 2004; 5: 739-751.

5 Bennett EJ, Rush J, Gygi SP, Harper JW. Dynamics of cullin-RING ubiquitin ligase network revealed by systematic quantitative proteomics. Cell 2010; 143 951-965.
6 Frescas D, Pagano M. Deregulated proteolysis by the F-box proteins SKP2 and beta-TrCP: tipping the scales of cancer. Nat Rev Cancer 2008; 8: 438-449.

7 Soucy TA, Smith PG, Milhollen MA, Berger AJ, Gavin JM, Adhikari S et al. An inhibitor of NEDD8-activating enzyme as a new approach to treat cancer. Nature 2009; 458: 732-736.

8 Duda DM, Borg LA, Scott DC, Hunt HW, Hammel M, Schulman BA et al. Structural insights into NEDD8 activation of cullin-RING ligases: conformational control of conjugation. Cell 2008; 134: 995-1006.

9 Liao H, Liu XJ, Blank JL, Bouck DC, Bernard H, Garcia K et al. Quantitative proteomic analysis of cellular protein modulation upon inhibition of the NEDD8activating enzyme by MLN4924. Mol Cell Proteomics. (e-pub ahead of print 2011 doi:10.1074/mcp.M111.009183).

10 Carrano AC, Eytan E, Hershko A, Pagano M. SKP2 is required for ubiquitin-mediated degradation of the CDK inhibitor p27. Nat Cell Biol 1999; 1: 193-199.

11 Yu ZK, Gervais JL, Zhang H. Human CUL-1 associates with the SKP1/SKP2 complex and regulates p21(CIP1/WAF1) and cyclin D proteins. Proc Natl Acad Sci USA 1998; 95: 11324-11329.

12 Tan P, Fuchs SY, Chen A, Wu K, Gomez C, Ronai Z et al. Recruitment of a ROC1CUL1 ubiquitin ligase by Skp1 and HOS to catalyze the ubiquitination of I kappa B alpha. Mol Cell 1999; 3: 527-533.

13 Watanabe N, Arai H, Nishihara Y, Taniguchi M, Hunter T, Osada H. M-phase kinases induce phospho-dependent ubiquitination of somatic Wee1 by SCFbeta-TrCP. Proc Natl Acad Sci USA 2004; 101: 4419-4424.

14 Busino L, Donzelli M, Chiesa M, Guardavaccaro D, Ganoth D, Dorrello NV et al. Degradation of Cdc25A by beta-TrCP during $S$ phase and in response to DNA damage. Nature 2003; 426: 87-91.

15 Singer JD, Gurian-West M, Clurman B, Roberts JM. Cullin-3 targets cyclin E for ubiquitination and controls $S$ phase in mammalian cells. Genes Dev 1999; 13 2375-2387.

16 Milhollen MA, Traore T, Adams-Duffy J, Thomas MP, Berger AJ, Dang L et al. MLN4924, a NEDD8-activating enzyme inhibitor, is active in diffuse large B-cell lymphoma models: rationale for treatment of NF-\{kappa\}B-dependent lymphoma. Blood 2010; 116: 1515-1523.

17 Smith MA, Maris JM, Gorlick R, Kolb EA, Lock R, Carol H et al. Initial testing of the investigational NEDD8-activating enzyme inhibitor MLN4924 by the pediatric preclinical testing program. Pediatr Blood Cancer (e-pub ahead of print 2011; doi: 10.1002/pbc.23357).

18 Ottaviano L, Schaefer KL, Gajewski M, Huckenbeck W, Baldus S, Rogel U et al. Molecular characterization of commonly used cell lines for bone tumor research: a trans-European EuroBoNet effort. Genes Chromosomes Cancer 2010; 49: 40-51.

19 Lin JJ, Milhollen MA, Smith PG, Narayanan U, Dutta A. NEDD8-targeting drug MLN4924 elicits DNA rereplication by stabilizing Cdt1 in $S$ phase, triggering checkpoint activation, apoptosis, and senescence in cancer cells. Cancer Res 2010; 70: 10310-10320.

20 Milhollen MA, Narayanan U, Soucy TA, Veiby PO, Smith PG, Amidon B et al. Inhibition of NEDD8-activating enzyme induces rereplication and apoptosis in human tumor cells consistent with deregulating CDT1 turnover. Cancer Res 2011; 71: 3042-3051.

21 Nakayama K, Nagahama H, Minamishima YA, Miyake S, Ishida N, Hatakeyama S et al. Skp2-mediated degradation of p27 regulates progression into mitosis. Dev Cell 2004; 6: 661-672.

22 Susaki E, Nakayama KI. Multiple mechanisms for p27(Kip1) translocation and degradation. Cell Cycle 2007; 6: 3015-3020.

23 Syljuasen RG, Jensen S, Bartek J, Lukas J. Adaptation to the ionizing radiationinduced G2 checkpoint occurs in human cells and depends on checkpoint kinase 1 and Polo-like kinase 1 kinases. Cancer Res 2006; 66: 10253-10257.

24 Bartek J, Lukas J. Chk1and Chk2 kinases in checkpoint control and cancer. Cancer Cell 2003; 3: 421-429.

25 McGowan $\mathrm{CH}$, Russell P. Human Wee1 kinase inhibits cell division by phosphorylating p34cdc2 exclusively on Tyr15. EMBO J 1993; 12: 75-85.

26 Watanabe N, Broome M, Hunter T. Regulation of the human WEE1Hu CDK tyrosine 15-kinase during the cell cycle. EMBO J 1995; 14: 1878-1891.

27 Jiang W, Wells NJ, Hunter T. Multistep regulation of DNA replication by Cdk phosphorylation of HsCdc6. Proc Natl Acad Sci USA 1999; 96: 6193-6198.

28 Petersen BO, Lukas J, Sorensen CS, Bartek J, Helin K. Phosphorylation of mammalian CDC6 by cyclin A/CDK2 regulates its subcellular localization. EMBO J 1999; 18: $396-410$.

29 Paolinelli R, Mendoza-Maldonado R, Cereseto A, Giacca M. Acetylation by GCN5 regulates $\mathrm{CDC} 6$ phosphorylation in the $\mathrm{S}$ phase of the cell cycle. Nat Struct $\mathrm{Mol}$ Biol 2009; 16: 412-420.

30 Nishitani H, Sugimoto N, Roukos V, Nakanishi Y, Saijo M, Obuse C et al. Two E3 ubiquitin ligases, SCF-Skp2 and DDB1-Cul4, target human Cdt1 for proteolysis. EMBO J 2006; 25: 1126-1136. 
31 Swords RT, Kelly KR, Smith PG, Garnsey JJ, Mahalingam D, Medina E et al. Inhibition of NEDD8-activating enzyme: a novel approach for the treatment of acute myeloid leukemia. Blood 2010; 115: 3796-3800.

32 Jia L, Li H, Sun Y. Induction of p21-dependent senescence by an NAE inhibitor, MLN4924, as a mechanism of growth suppression. Neoplasia 2011; 13: 561-569.

33 Kim W, Bennett EJ, Huttlin EL, Guo A, Li J, Possemato A et al. Systematic and quantitative assessment of the ubiquitin-modified proteome. Mol Cell 2011; 44: 325-340.

34 Grimmler M, Wang Y, Mund T, Cilensek Z, Keidel EM, Waddell MB et al. Cdk-inhibitory activity and stability of p27Kip1 are directly regulated by oncogenic tyrosine kinases. Cell 2007; 128: 269-280.

35 Chu I, Sun J, Arnaout A, Kahn H, Hanna W, Narod S et al. p27 phosphorylation by Src regulates inhibition of cyclin E-Cdk2. Cell 2007; 128: 281-294.

36 Russo AA, Jeffrey PD, Patten AK, Massague J, Pavletich NP et al. Crystal structure of the p27Kip1 cyclin-dependent-kinase inhibitor bound to the cyclin A-Cdk2 complex. Nature 1996; 382: 325-331.
37 Tsvetkov LM, Yeh $\mathrm{KH}$, Lee SJ, Sun $\mathrm{H}$, Zhang $\mathrm{H}$. p27(Kip1) ubiquitination and degradation is regulated by the SCF(Skp2) complex through phosphorylated Thr187 in p27. Curr Biol 1999; 9: 661-664.

38 Vigo E, Muller H, Prosperini E, Hateboer G, Cartwright P, Moroni MC et al. CDC25A phosphatase is a target of E2F and is required for efficient E2F-induced $\mathrm{S}$ phase. Mol Cell Biol 1999; 19: 6379-6395.

39 Mir SE, De Witt Hamer PC, Krawczyk PM, Balaj L, Claes A, Niers JM et al. In silico analysis of kinase expression identifies WEE1 as a gatekeeper against mitotic catastrophe in glioblastoma. Cancer Cell 2010; 18: 244-257.

40 Wei D, Li H, Yu J, Sebolt JT, Zhao L, Lawrence TS et al. Radiosensitization of human pancreatic cancer cells by MLN4924, an investigational NEDD8-activating enzyme inhibitor. Cancer Res 2012; 72: 282-293.

41 Ottaviano L, Schaefer KL, Gajewski M, Huckenbeck W, Baldus S, Rogel U et al. Molecular characterization of commonly used cell lines for bone tumor research: a trans-European EuroBoNet effort. Genes Chromosomes Cancer 2010; 49: $40-51$.

Supplementary Information accompanies the paper on the Oncogene website (http://www.nature.com/onc) 


\section{SUMMARY OF SUPPLEMENTARY INFORMATION}

1.- Supplementary Material and Methods: Cell synchronization, Flow cytometry analyses, Western blot, CDK2 immunoprecipitation, Production of shRNA containing lentiviral particles and cell transduction, Development of RDES clones with inducible Cyclin A overexpression, Statistics

\section{2.- Supplementary Figures:}

- Figure S1: Confirmation of MLN4924 mechanism of action in RM82 cell line

- Figure S2: Confirmation of the specificity of the anti-pH3 antibody used for the staining of mitotic cells.

- Figure S3: gamma-H2AX immunofluorescence revealing DNA damage at high drug concentrations only.

- Figure S4: Cyclin A inducible overexpression also delays cell cycle in early S-phase.

\section{3.- Supplementary Tables}

- Table S1: List of antibodies used in Western blot.

- Table S2: Detailed information on the shRNA constructions used. 


\section{SUPPLEMENTARY MATERIAL AND METHODS}

\section{Cell synchronization}

Synchronization in early mitosis: nocodazole was added to the growth medium of $60 \%$ confluent cultures to a final $80 \mathrm{ng} / \mathrm{ml}$ concentration. After 16 hours incubation mitotic cells were detached by tapping, PBS washed, counted, resuspended in nocodazole-free medium and reseeded $\left(4 \times 10^{5}\right.$ in wells of 6 well plates for FACS analyses; $2.4 \times 10^{6}$ in 10 $\mathrm{cm}$ plates for protein extracts).

Synchronization at the G1-S boundary: cells were maintained in confluence for $24-48$ hours, trypsinized, counted and reseeded at $4 \times 10^{5}$ (wells of 6-well plates) and $2.4 \times 10^{6}$ (10 $\mathrm{cm}$ plates) per well/plate. After 9 hours thymidine was added to a $2 \mathrm{mM}$ final concentration and cells were incubated for 15 additional hours before PBS washing and replacement with thymidine-free medium.

In both cases MLN4924 was added to the synchronization medium at the times indicated in the text.

\section{Flow cytometry analyses}

Non-confluent cultures of exponentially growing cells were trypsinized and ethanol fixed. BrdU pulsed cells (10 $\mu \mathrm{M}$ for 1 hour) were subjected to DNA denaturation (2N $\mathrm{HCl}$ ). Anti-pH3, Cleaved-Caspase 3 (both from Cell Signalling) and Alexa Fluor 488BrdU (Becton Dickinson) were added in 0.5\% BSA, 0.5\% Triton X-100 PBS at 1:1500, 1:200 and 1:10, respectively. Alexa Fluor 488-labeled secondary antibodies (Invitrogen) were applied after washing primaries, except for BrdU. All antibodies were incubated 
for 1 hour at room temperature and controls lacking primary antibodies were done in parallel. Next, cells were incubated in PBS containing propidium iodide and RNase A for 2 additional hours when DNA content study was added for combined analyses, being the only processing in those samples where DNA content was studied alone. After flow cytometry acquisition, data was processed and analyzed with FlowJo software (Tree Star). SubG1 population was gated out to improve the calculation of cell percentages at every cell cycle stage by built-in software algorithms.

\section{Western blot}

Protein extracts in RIPA were resolved in $8 \%$ to $12 \%$ polyacrylamide gels ( $40 \mu \mathrm{g}$ of protein per lane) and transferred to PVDF membranes (Millipore) following typical SDS-PAGE electrophoresis and wet transfer protocols. 1,10-orthophenathroline (Sigma) was added to RIPA lysis buffer ( $2 \mathrm{mM}$ final concentration) for cullin neddylation studies in order to inhibit deneddylation by COPS5 (5). 5\% dry-milk or BSA was used as blocking agents. Primary antibodies were incubated overnight at $4^{\circ} \mathrm{C}$. The antibodies and dilutions used are listed in Table S1. Image $\mathbf{J}$ software was applied for densitometric quantifications.

\section{CDK2 immunoprecipitation}

Whole protein extracts $(250 \mu \mathrm{g})$ in NP40 buffer $(150 \mathrm{mM} \mathrm{NaCl}, 20 \mathrm{mM}$ Tris pH 8.0, 1 mM DTT, $0.5 \%$ NP40) were incubated with $15 \mu$ of protein A-dynabeads (Invitrogen) coupled to $2 \mu \mathrm{g}$ of CDK2 (M2) antibody (Santa Cruz Biotechnology), 3 hours at $4^{\circ} \mathrm{C}$. 
After magnetic immunoprecipitation and washes, immunoprecipitates were resolved in a $10 \%$ polyacrilamyde SDS-PAGE gel, transferred and blotted as described above.

\section{Production of shRNA containing lentiviral particles and cell transduction}

pLKO.1-shRNA collections against WEE1 and P27 were obtained from Openbiosystems (Thermo) as detailed in Table S2. ShRNA identification codes and sequences can be found in Table S2. A pLKO.1-non targeting control (NTC) was included as an off-target effect control and pLKO.1-turboGFP was used for the evaluation of transduction efficiencies. ShRNA constructions, pMD.G and pCMVdR8.91 vectors (Addgene) were co-transfected in 293T, following a typical lipofectamine 2000 (Invitrogen) protocol. Forty-eight hours after transfection viral supernatants were collected, fresh medium added, filtered through a $0.44 \mu \mathrm{m}$ polysulfonate filter (PALL), polybrene-added to a final $8 \mu \mathrm{g} / \mathrm{ml}$ concentration (SIGMA Aldrich) and used to transduce target ES cells (seeded $4 \times 10^{5}$ cells per well of 6 -well plates). Plates were centrifuged at $2000 \mathrm{rpm}, 1$ hour, $32^{\circ} \mathrm{C}$.

\section{Development of RDES clones with inducible Cyclin A overexpression.}

RDES cells were first infected with the Tet-On vector (Retro-X Tet-On Advanced Inducible System, Clontech) with a moi=1 and selected with G418 (200 $\mu \mathrm{g} / \mathrm{ml})$. Independent clones were isolated and expanded, and tested with pTRE-tight-luciferase vector (Clontech) for inducibility and basal expression. pGL2C vector (which codes for constitutive firefly luciferase; Promega) was transfected in parallel and used for 
normalizing the basal/induced luciferase signal of each clone, assayed with Dual Luciferase Reporter Assay (Promega). The clone with the best basal/induced values was infected with p-RETRO-X-tight-pur-Cyclin A (subcloned from a cyclin A full cDNA plasmidic construction obtained from OpenBiosystems) with a moi=1. Clones were

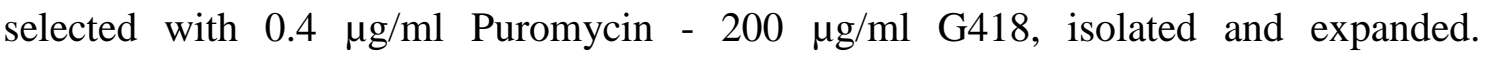
Inducibility was tested by Western blot using an anti-Cyclin A antibody after 24 hours induction with doxycycline $(0.5 \mu \mathrm{g} / \mathrm{ml})$.

\section{Statistics}

Statistical tests were computed with SPSS software. Normal distribution of data was assessed before application of parametric tests. All tests applied (described in each figure legend) were two-tailed. 


\section{SUPPLEMENTARY FIGURES}

Figure S1.

A

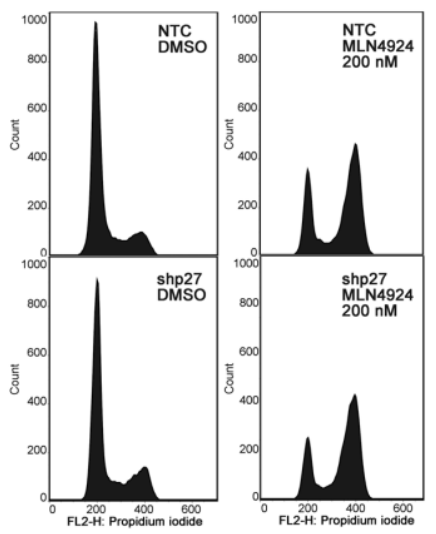

B

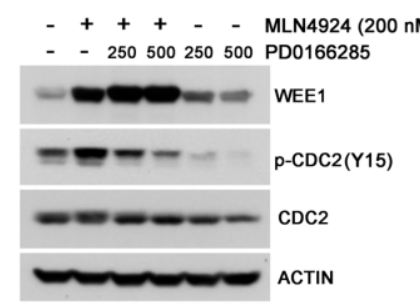

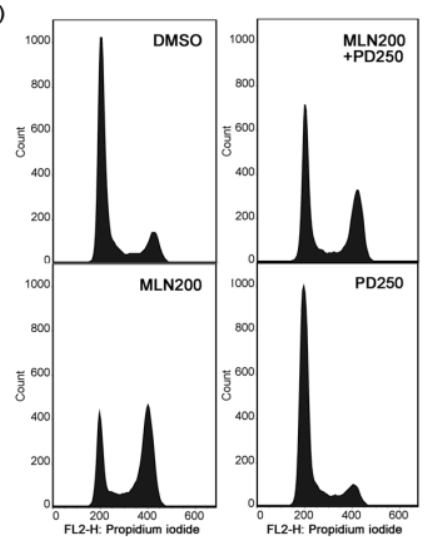

C
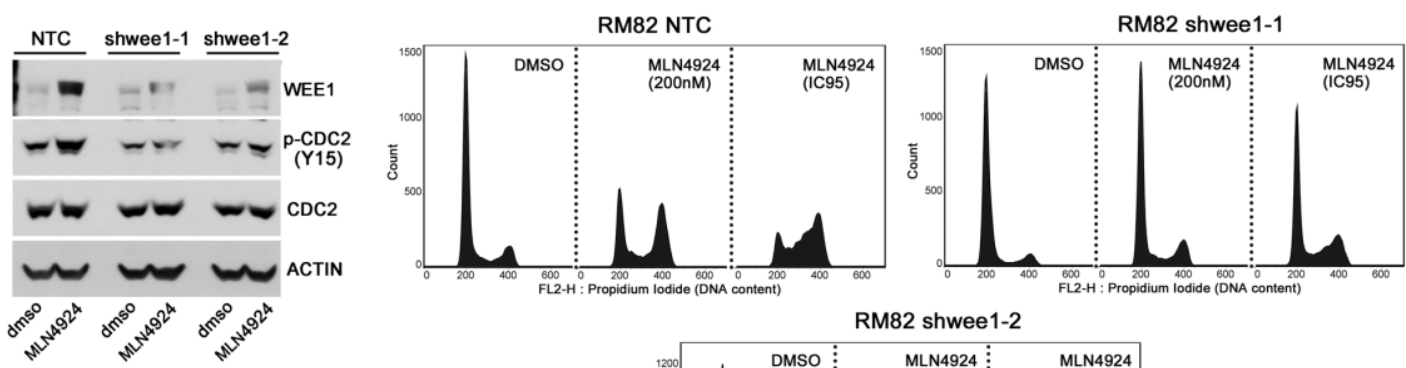

RM82 shwee1-2

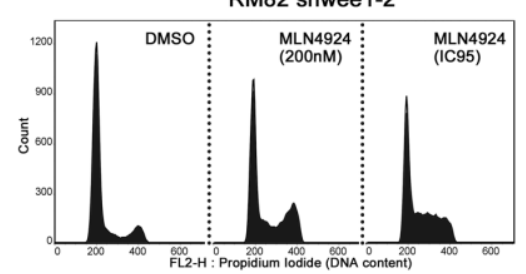

Figure S1. MLN4924 mechanism of action in RM82 cell line. (A) P27 knockdown did not revert MLN4924-induced G2 arrest. (B) PD0166285 WEE1 kinase inhibitor released cells from the MLN4924-imposed G2 arrest. (C) WEE1 knockdown prevented MLN4924-induced G2 peak. 
Figure S2.

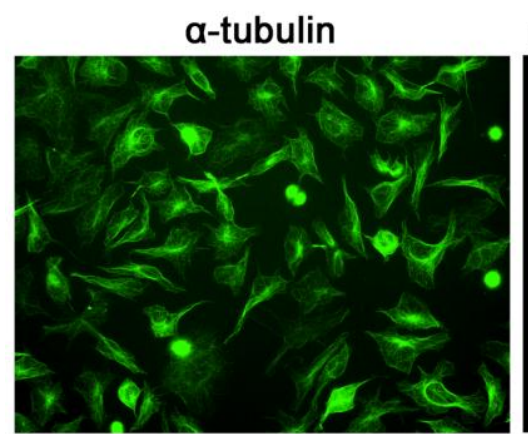

phospho histone H3 (Ser10)

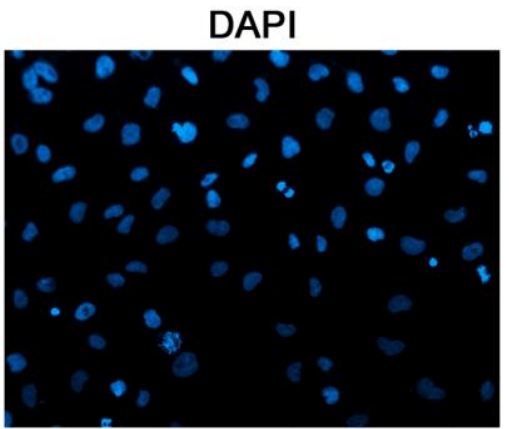

Overlay $\alpha$-tub. + pH3

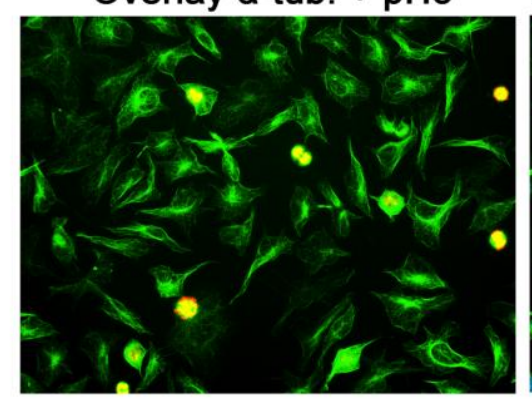

Overlay a-tub. + pH3 + DAPI

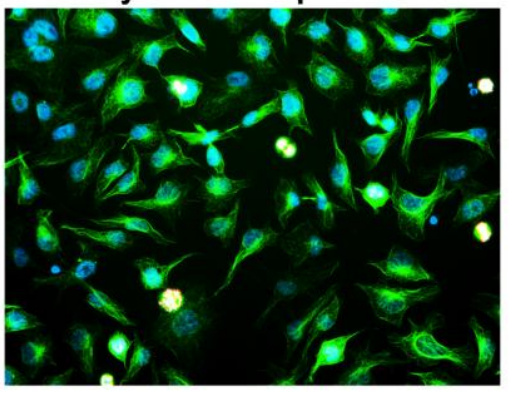

Figure S2. 20x magnification complete field micrograph of $\mathrm{pH} 3$ and $\alpha$-tubulin immunofluorescence of RDES showing the specific stain of mitotic cells with the antipH3 antibody used.

\section{Figure S3}

\section{A) DMSO}
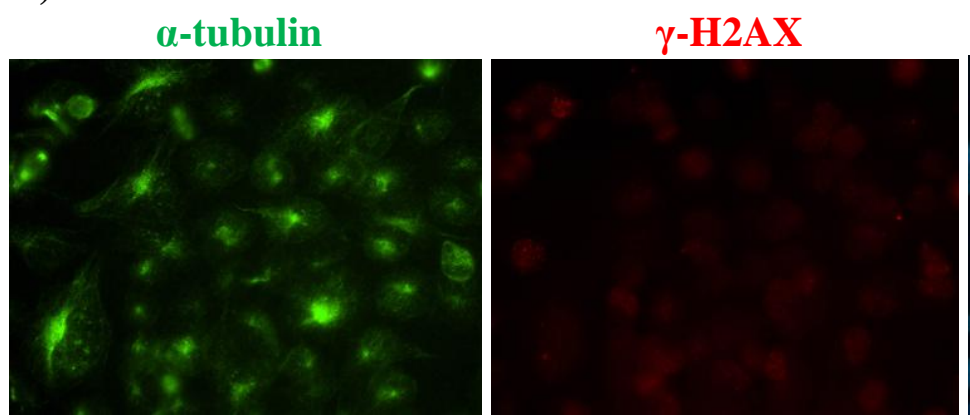

DAPI
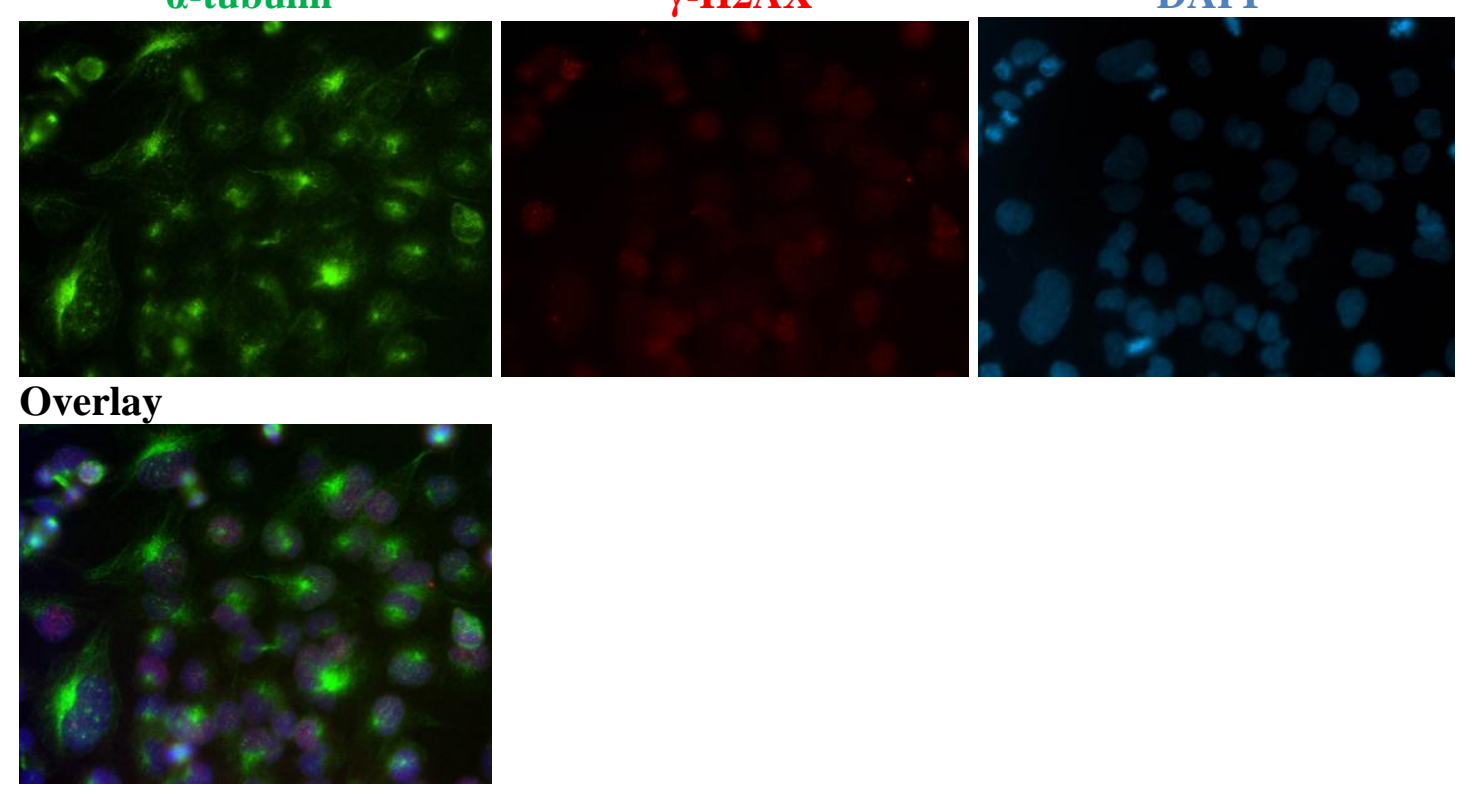
B) MLN4924 (IC75)

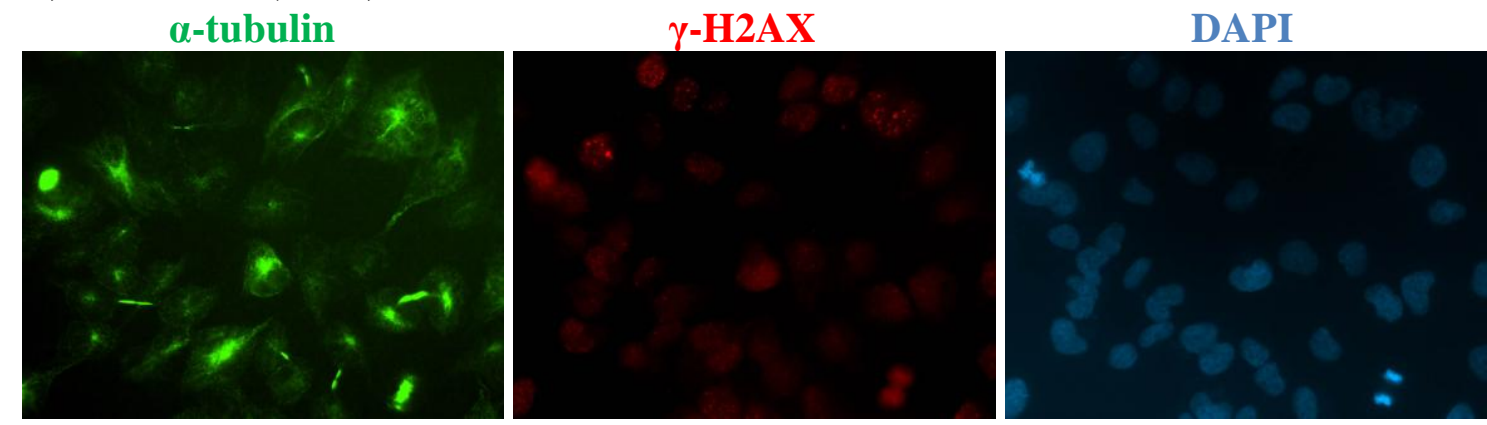

Overlay

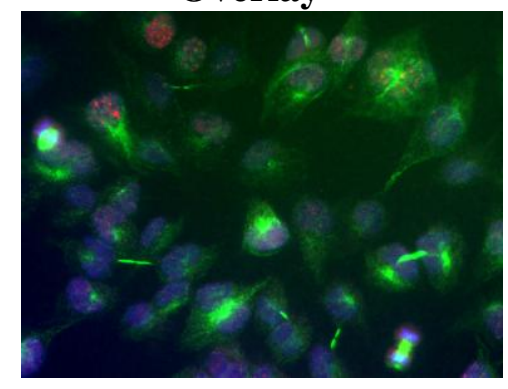

C) MLN4924 (IC95)

o-tubulin

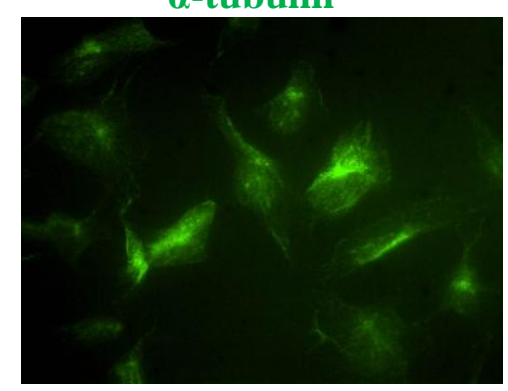

Overlay

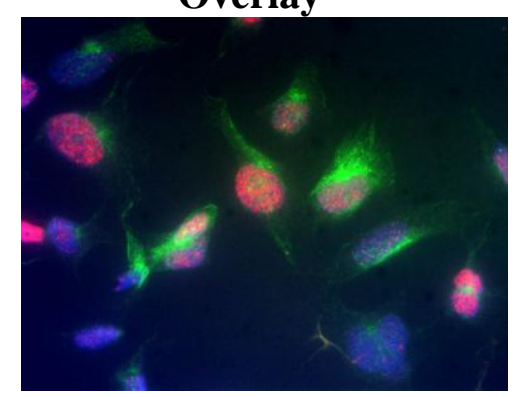

$\gamma-\mathrm{H} 2 \mathrm{AX}$

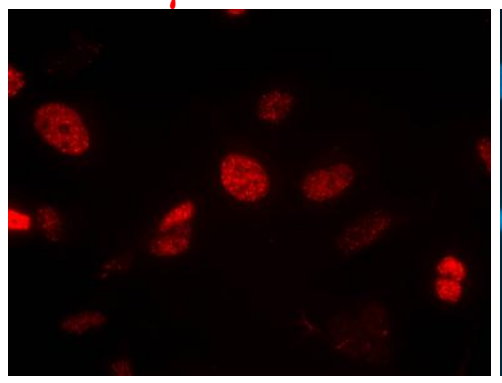

DAPI

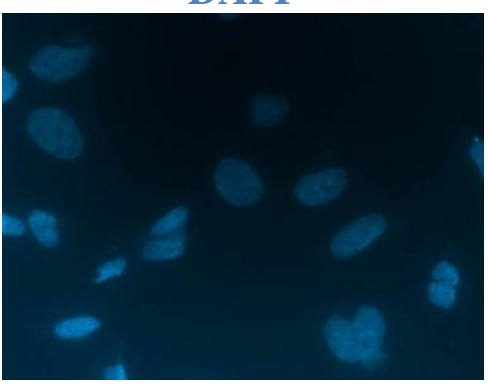

Figure S3. 40x magnification complete field micrographs of $\gamma-\mathrm{H} 2 \mathrm{AX}$ and $\alpha$-tubulin immunofluorescence demonstrating the slight and marked induction of DNA damage at MLN4924 IC75 (B) and MLN4924 IC95 (C), respectively. As expected, vehicle treatment did not induce detectable $\gamma$-H2AX immunostaining (A). 


\section{Figure S4}

A

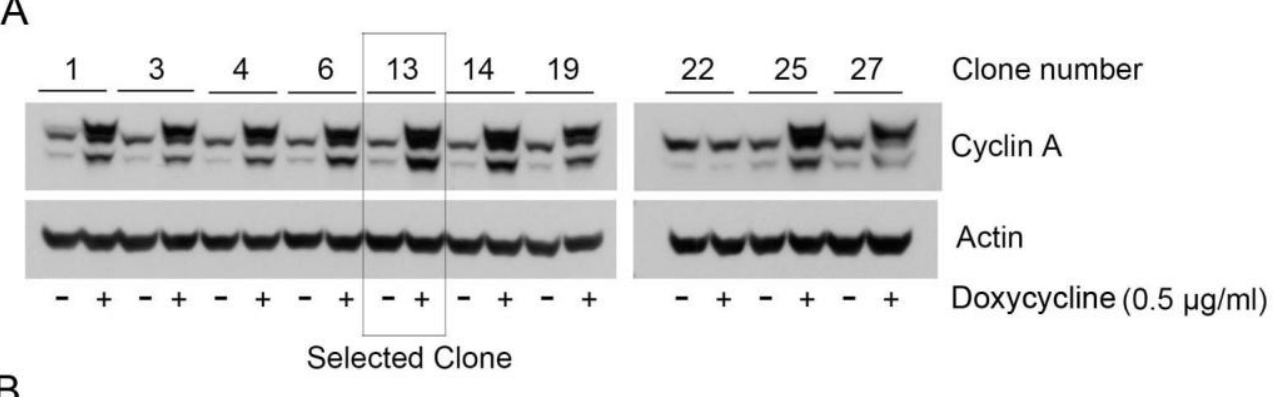

B
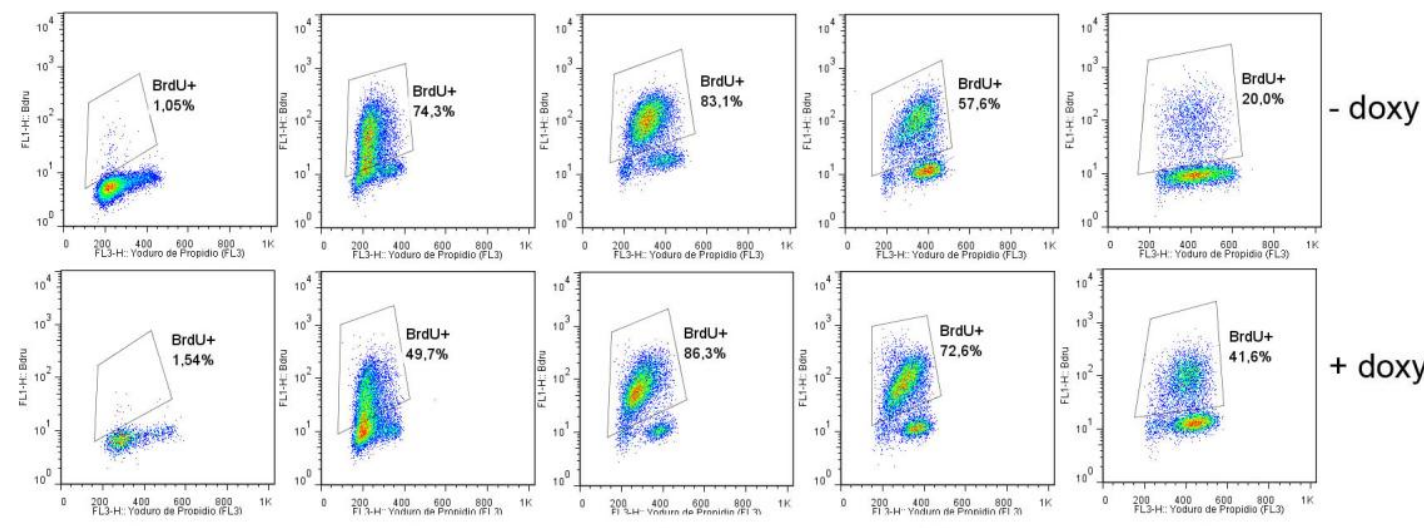

$6 \mathrm{~h}$

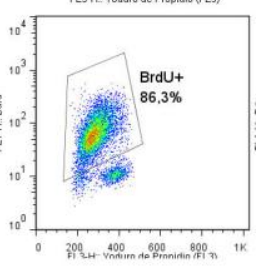

$9 \mathrm{~h}$

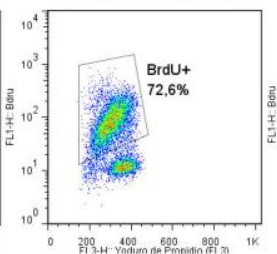

$12 \mathrm{~h}$

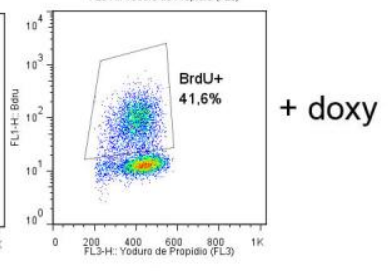

$15 \mathrm{~h}$

Time after thymydine release

\section{Figure S4}

(A) Inducibility testing of cyclin A Tet-On inducible clones established in RDES cell line. Cyclin A overexpression was elicited by adding doxycycline $(0.5 \mu \mathrm{g} / \mathrm{ml})$ to the cell culture medium. The clone selected (out of more than 20 clones established) presented the lowest basal expression (equal to endogenous cyclin A expression) and maximum inducibility levels.

(B) Induction of cyclin A (clone 13) caused a delay in early S-phase, as assayed by BrdU incorporation in thymidine synchronized cells (axes represent the same magnitudes depicted in Figure 6). Doxycycline treatment was discarded to be the cause of this delay. 


\section{SUPPLEMENTARY TABLES}

Table S1. Antibodies used in Western blot

\begin{tabular}{|c|c|c|c|}
\hline Antibody & Brand and reference & Source & Dilution \\
\hline$\beta$-TUBULIN & Sigma, T5293 & Mouse & $1: 10000$ \\
\hline Cl. Caspase-3 & CS, 9661 & Rabbit & $1: 1000$ \\
\hline CDC25A & SC, sc-7389 & Mouse & $1: 250$ \\
\hline p-CDC2-Y15 & CS, 9111 & Rabbit & $1: 1000$ \\
\hline CDC2 & $\mathrm{SC}, \mathrm{sc}-54$ & Mouse & 1:2000 \\
\hline $\mathrm{CDC} 2$ & CS, 9112 & Rabbit & 1:2000 \\
\hline $\mathrm{CDK} 2$ & SC, sc-163 & Rabbit & $1: 2000$ \\
\hline p-CDK (Y15) & $\mathrm{SC}, \mathrm{sc}-28435$ & Rabbit & 1:1000 \\
\hline CDT1 & Abcam, ab70829 & Rabbit & $1: 500$ \\
\hline Cyclin A2 & Sigma, C4710 & Mouse & $1: 500$ \\
\hline Cyclin B1 & $\mathrm{SC}, \mathrm{sc}-752$ & Rabbit & $1: 500$ \\
\hline Cyclin E & $\mathrm{SC}, \mathrm{sc}-247$ & Mouse & $1: 500$ \\
\hline CUL1 & Epitomics, 2436-1 & Rabbit & $1: 500$ \\
\hline CUL4 & Epitomics, 2527-1 & Rabbit & $1: 2500$ \\
\hline EMI1 & Invitrogen, 37-6600 & Mouse & $1: 100$ \\
\hline n-ACTIN & Sigma, A2103 & Rabbit & $1: 5000$ \\
\hline P21 & SC, sc-397 & Rabbit & $1: 500$ \\
\hline $\mathrm{P} 27$ & BD, 554069 & Mouse & $1: 1000$ \\
\hline CHK1 & SC, sc-8408 & Mouse & $1: 1000$ \\
\hline p-CHK1(S345) & CS, 2348 & Rabbit & $1: 500$ \\
\hline WEE1 & SC, sc-9037 & Rabbit & $1: 500$ \\
\hline $\mathrm{pRB}(\mathrm{S} 780)$ & CS, 9307 & Rabbit & $1: 500$ \\
\hline $\mathrm{RB}$ & Abcam, ab6075 & Rabbit & $1: 500$ \\
\hline
\end{tabular}

Brand name abbreviations: CS: Cell Signalling; SC: Santa Cruz Biotechnology

Table S2. ShRNA detailed information.

\begin{tabular}{lll}
\hline $\begin{array}{c}\text { shRNA } \\
\text { construction }\end{array}$ & mRNA sequence targeted (sense) & $\begin{array}{c}\text { mRNA targeted } \\
\text { (RefSeq) }\end{array}$ \\
\hline TRCN0000039930 & GCGCAAGTGGAATTTCGATTT & $\frac{\text { NM_004064.3 }}{(P 27)}$ \\
\hline $\begin{array}{l}\text { TRCN0000001703 } \\
\text { (shwee1-1) }\end{array}$ & AGATGAAACAAGACCTGCTAA & $\frac{\text { NM_003390.3 }}{(W E E 1)}$ \\
\hline $\begin{array}{l}\text { TRCN0000001704 } \\
\text { (shwee1-2) }\end{array}$ & GCCAGTGATTATGAGCTTGAA & $\frac{\text { NM_003390.3 }}{(W E E 1)}$ \\
\hline
\end{tabular}

Detailed information on the pLKO.1-shRNAs constructions used. 